\title{
Bundeling van omgevingsrecht $=$ Clustering of environmental law = Bündelung von Umweltrecht
}

Citation for published version (APA):

van den Broek, J. H. G. (2012). Bundeling van omgevingsrecht = Clustering of environmental law = Bündelung von Umweltrecht. [Doctoral Thesis, Maastricht University]. Maastricht University. https://doi.org/10.26481/dis.20121219jb

Document status and date:

Published: 01/01/2012

DOI:

10.26481/dis.20121219jb

Document Version:

Publisher's PDF, also known as Version of record

\section{Please check the document version of this publication:}

- A submitted manuscript is the version of the article upon submission and before peer-review. There can be important differences between the submitted version and the official published version of record.

People interested in the research are advised to contact the author for the final version of the publication, or visit the DOI to the publisher's website.

- The final author version and the galley proof are versions of the publication after peer review.

- The final published version features the final layout of the paper including the volume, issue and page numbers.

Link to publication

\footnotetext{
General rights rights.

- You may freely distribute the URL identifying the publication in the public portal. please follow below link for the End User Agreement:

www.umlib.nl/taverne-license

Take down policy

If you believe that this document breaches copyright please contact us at:

repository@maastrichtuniversity.nl

providing details and we will investigate your claim.
}

Copyright and moral rights for the publications made accessible in the public portal are retained by the authors and/or other copyright owners and it is a condition of accessing publications that users recognise and abide by the legal requirements associated with these

- Users may download and print one copy of any publication from the public portal for the purpose of private study or research.

- You may not further distribute the material or use it for any profit-making activity or commercial gain

If the publication is distributed under the terms of Article $25 \mathrm{fa}$ of the Dutch Copyright Act, indicated by the "Taverne" license above, 
Bundeling van omgevingsrecht 

Bundeling van omgevingsrecht

\section{Clustering of Environmental Law}

(with a summary in English)

\section{Bündelung von Umweltrecht}

(mit eine Zusammenfassung in Deutsch)

\section{PROEFSCHRIFT}

ter verkrijging van de graad van doctor aan de Universiteit Maastricht, op gezag van de Rector Magnificus

Prof. dr. L.L.G. Soete

volgens het besluit van het College van Decanen,

in het openbaar te verdedigen op

woensdag 19 december 2012 om 16.00 uur

$$
\text { door }
$$

\section{JOHANNES HENRICUS GERARDUS VAN DEN BROEK}

geboren op 3 november 1957

te Den Dungen 


\section{Promotor:}

Prof. dr. Ch.W. Backes, LL.M

\section{Beoordelingscommissie:}

Prof. dr. M.G. Faure LL.M (voorzitter)

Prof. dr. M.J. Jacobs

Prof. mr. drs. F.C.M.A. Michiels (Tilburg University)

Foto omslag: Laugnac (F) bij Bordo Basso Vormgeving omslag: Inge van den Broek 


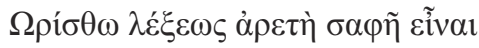

'De eerste eigenschap van stijl is helderheid'

Rhetorica, Aristoteles (384-322 BC)

'Non scolae sed vitae discimus.' Lucius Annaeus Seneca (ca. 4 BC-65 AD)

'A lot of times, people don't know what they want until you show it to them.'

Steve Jobs (1955-2011)

'Als de werkelijkheid er niet was, zou de wereld er geheel anders uitzien.'

Theo Maassen (1966)

'Man wird ohne viel Besinnen ein archäologisches oder literarhistorisches Buch auf den Geschenktisch legen, kaum je aber ein juristisches Buch.' Karl Engisch (1899-1990)

'Iedereen wil integreren, maar niemand wil geïntegreerd worden.' Luc Lavrijssen op 4 oktober 2012 



\section{Woord vooraf}

Het Nederlands omgevingsrecht bestaat uit honderden wetten, algemene maatregelen van bestuur en ministeriële regelingen op het gebied van milieu, ruimtelijke ordening, natuur en water. Dat is een van de oorzaken dat zelfs specialisten het overzicht zijn kwijtgeraakt. Het overzicht zou wellicht kunnen worden hersteld door met een schone lei, een tabula rasa, te beginnen en het omgevingsrecht opnieuw, maar nu aus einem Gu $\beta$ te herschrijven. Een andere benadering is om het omgevingsrecht daarbij niet geheel opnieuw uit te vinden, maar het bestaande omgevingsrecht anders te ordenen, te systematiseren. Die laatste benadering spreekt mij aan, aangezien ik het tamelijk onwaarschijnlijk acht dat de wetgever in het verleden gewoonlijk ondeugdelijke regels heeft geproduceerd. Wellicht gaat het veeleer om deugdelijke regels in een ondeugdelijk systeem. Ook Drupsteen twijfelt aan een tabula rasa-aanpak; hij meent dat uitgaande van bestaande regelingen een snellere en effectievere slag kan worden gemaakt. ${ }^{1}$ Maar hoe?

Een wetenschappelijk gefundeerd pasklaar antwoord heb ik niet gevonden. De door mij geraadpleegde literatuur inzake wetgevingsleer en -techniek van onder meer Eijlander, Van Gestel, Hill, Sebus en Voermans heeft gewoonlijk meer aandacht voor het tot stand brengen van nieuwe dan voor het bundelen van bestaande wetten. In de literatuur vond ik nauwelijks theoretische uitgangspunten die expliciet betrekking hebben op bundeling van omgevingsrecht. In elk geval vond ik geen bruikbare wegwijzer voor het bundelen van omgevingsrecht. Een eyeopener bleek Noll's Gesetzgebungslehre. Hoewel het boek van deze Zwitserse rechtsgeleerde is geschreven in 1973, niet specifiek het Nederlandse omgevingsrecht op het oog heeft en voorbeelden uit andere rechtsstelsels gebruikt, meen ik dat het op veel onderdelen inspiratie kan bieden voor het nadenken over het bundelen van Nederlands omgevingsrecht anno 2012.

De helaas veel te vroeg overleden Piet Gilhuis - leermeester, vriend en aanvankelijk mede promotor - vertelde me dat een proefschrift eigenlijk zoiets als een uitgebreid wetenschappelijk artikel is. Hij wist wel beter ... zoals Piet heel veel beter wist. Marleen van Rijswick drukte me op het hart dat een proefschrift geen levenswerk is, Herman Havekes dat ik na een jaar inlezen

1 Drupsteen, Een Omgevingswet 2011, p. 279. 
maar gewoon moest beginnen met schrijven en Rob van Gestel suggereerde dat ik me door de werkelijkheid moest laten verrassen. Als ik hun adviezen niet ter harte zou hebben genomen, zou ik nog aan het inlezen zijn.

Hans Woldendorp, Bert Rademaker, Tim Borman, Jaap Roording, Mandy Molenaars, Wilco de Vos, Wim Voermans en Thijs Drupsteen dank ik voor hun bereidheid om mij via interviews een kijkje in de wetgevingskeuken te geven en Jos Roosen voor het kritisch lezen van hoofdstuk 5. Mijn collega's bij VNO-NCW en MKB-Nederland dank ik voor de inspirerende werkomgeving en Jos Rijkhoff in het bijzonder voor zijn waardevolle suggesties. Franziska Grashof en Ineke Sijtsma-van der Kruk dank ik voor de vertaling van de samenvatting in het Duits respectievelijk het Engels. Hun gebleken interesse in het onderwerp van mijn onderzoek maakte dat hun opmerkingen over de vertaling ook tot verbeteringen van de oorspronkelijke tekst hebben geleid.

De leden van de leescommissie dank ik voor hun bereidheid om het manuscript te beoordelen. Hun weldoordachte tips gaven er niet alleen blijk van dat zij het goed hadden bestudeerd, maar hebben het manuscript ook verbeterd.

Zonder de jarenlange steun van mijn gezin zou dit proefschrift niet tot stand zijn gekomen. José las het met een managementblik wat soms tot andere inzichten heeft geleid. Zonder haar bereidheid tot vakanties die bestonden uit wandelen in de ochtend en proefschrijven in de middag, zou het proefschrift er zeker nog niet hebben gelegen. Het proefschrift is daarom hoofdzakelijk geschreven in Rosmalen, maar ook in Titmaringhausen (D), Schönstein (D), Loyers (B), Vijlen, Zeijen, Sleen, Strijbeek en Laugnac (F). Dochter Marleen dank ik voor haar redactionele correcties en inhoudelijke suggesties, dochter Inge voor het ontwerpen van het omslag en zoon Jaap voor zijn vele bezoeken aan de universiteitsbibliotheek voor weer een nauwelijks uitgeleend boek over wetgevingsleer.

Last but not least een welgemeend woord van dank aan Chris Backes. Het was elke keer weer een genoegen om met hem in Maastricht of Roermond van gedachten te kunnen wisselen. Geen moment wekte Chris de indruk gelijk te willen hebben, ook al had hij dat vaak; het ging hem altijd om de wetenschappelijke houdbaarheid van hetgeen ik schreef. Met zijn brede wetenschappelijke kennis wist hij fundamentele vragen zo vriendelijk en tegelijk gezaghebbend te stellen dat ik geen moment in de verleiding kwam er niets mee te doen. Suum cuique!

Ten slotte. Mijn onderzoek heeft ertoe geleid dat ik op een heel andere manier ben gaan aankijken tegen het omgevingsrecht, een rechtsgebied dat 
ik reeds enige decennia praktiseer. Seneca had gelijk: Non scolae sed vitae discimus.

Wetenschappelijke publicaties van na 1 april 2012 konden slechts summier worden meegenomen.

Jan van den Broek

's-Hertogenbosch, 5 oktober 2012 



\section{Inhoudsopgave}

Woord vooraf

1. AANLEIDING EN PROBLEEMSTELLING

1.1. Lappendeken van omgevingsrecht 1

1.2. Bundeling van omgevingsrecht 10

1.2.1. Algemeen 10

1.2.2. Bundeling in Vlaanderen, Duitsland en de Europese Unie 13 1.2.2.1. Algemeen 13

1.2.2.2. Vlaanderen: Voorontwerp Decreet Milieubeleid 14

1.2.2.3. Duitsland: Entwurf Umweltgesetzbuch $\quad 15$

1.2.2.4. Europese Unie: Richtlijn industriële emissies 16

$\begin{array}{ll}\text { 1.2.3. Bundeling in Nederland } & 17\end{array}$

1.3. Redenen voor bundeling van omgevingsrecht 22

1.3.1. Genoemde voordelen van bundeling 22

1.3.1.1. Algemeen 22

1.3.1.2. Activiteitenbesluit $\quad 22$

1.3.1.3. Waterwet 23

1.3.1.4. Wabo 24

1.3.1.5. Wet natuurbescherming $\quad 24$

1.3.1.6. Omgevingswet 25

1.3.1.7. Voorontwerp Decreet Milieubeleid 26

1.3.1.8. Entwurf Umweltgesetzbuch $\quad 27$

1.3.1.9. Richtlijn industriële emissies $\quad 29$

1.3.2. Ecologische en economische voordelen $\quad 29$

$\begin{array}{ll}\text { 1.3.3. Juridische voordelen } & 30\end{array}$

1.4. Onderzoeksvragen 32

1.5. Opzet en onderzoeksmethoden 34

2. BEGRIPPEN 37

2.1. Inleiding 37

2.2. Omgevingsrecht 38

2.3. Wetssystemen 44

2.3.1. Algemeen 44

2.3.2. Formele wetssystemen $\quad 47$

2.3.3. Materiële wetssystemen 50 
2.4. Wetssystematische tekorten 51

2.4.1. Algemeen 51

2.4.2. Coördinatie 52

2.4.3. Harmonisatie 55

2.4.4. Integratie $\quad 57$

2.4.5. Herschikking 58

2.4.6. Consolidatie 60

2.5. Bundeling 63

2.5.1. Algemeen 63

2.5.2. Bundelingsniveau 64

2.5.2.1. Algemeen 64

2.5.2.2. Horizontale bundeling 64

2.5.2.3. Verticale bundeling $\quad 65$

2.5.3. Codificatie en modificatie 66

$\begin{array}{lll}\text { 2.6. Samenvatting } & 67\end{array}$

3. WETSSYSTEMATISCH KADER VOOR BUNDELING VAN
OMGEVINGSRECHT

3.1. Inleiding $\quad 71$

3.2. Samenhang 72

$\begin{array}{ll}\text { 3.2.1. Algemeen } & 72\end{array}$

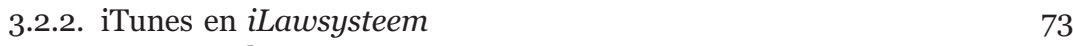

3.2.2.1. Algemeen 73

3.2.2.2. Samenhangcriteria in iTunes 75

3.2.2.3. Samenhangcriteria in een wetssysteem 77

3.2.3. iLawsysteem 80

3.2.3.1. Algemeen 80

$\begin{array}{ll}\text { 3.2.3.2. iLawsysteembesluit } & 81\end{array}$

3.2.3.3. iLawsysteembesluit Tankstations $\quad 85$

3.2.3.4. iLawsysteembesluit Bakkerij met winkel 86

3.2.4. Wetssystematische consequenties van samenhangcriteria $\quad 87$

$\begin{array}{ll}\text { 3.2.4.1. Algemeen } & 87\end{array}$

3.2.4.2. Samenhangcriteria bepalen het wetssysteem 88

3.2.4.3. Samenhangcriteria bepalen wetssystematische tekorten 89

$\begin{array}{ll}\text { 3.2.4.4. Samenhangcriteria bepalen problemen en oplossingen } & 89\end{array}$

$\begin{array}{ll}\text { 3.2.4.5. Uitgangspunt voor samenhangcriteria } & 92\end{array}$

3.2.5. Kenbaarheid en probleemgeoriënteerdheid 92

$\begin{array}{lll}\text { 3.2.5.1. Kenbaarheid } & 92\end{array}$

3.2.5.2. Probleemgeoriënteerdheid 97

3.2.5.3. De systematiek van de Wet bodembescherming als
voorbeeld

3.2.6. De echte werkelijkheid 101

3.2.6.1. Algemeen 101

3.2.6.2. Aanwijzingen voor de regelgeving 105

$\begin{array}{ll}3.2 .6 .3 \text {. Literatuur } & 107\end{array}$

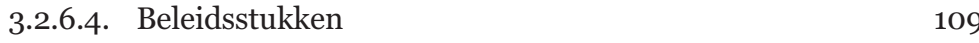

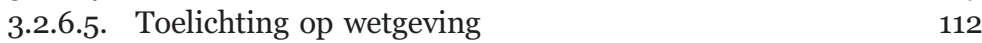

$\begin{array}{ll}\text { 3.2.6.6. Tussenconclusie } & 116\end{array}$ 
3.3. Zakelijke systeemordeningscriteria $\quad 117$

3.3.1. Algemeen 117

3.3.2. Subjecten 120

3.3.3. Objecten 122

3.3.4. Activiteiten 123

3.3.5. Fysieke leefomgeving als samenhangcriterium $\quad 124$

3.3.6. De fysieke leefomgeving als toetsingscriterium 130

3.3.6.1. Algemeen 130

3.3.6.2. Interne en externe integratie 131

3.3.6.3. Integrale afweging van omgevingsbelangen 133

3.3.6.4. Het specialiteitsbeginsel 134

3.3.6.5. Concretisering van integrale afweging van
omgevingsbelangen

3.3.6.6. Integrale afweging is geen uitruil $\quad 142$

3.3.7. Tussenconclusie 145

$\begin{array}{ll}\text { 3.4. Wetssystematisch(e) tekort(en) elders afwegen } & 148\end{array}$

$\begin{array}{lr}\text { 3.4.1. Algemeen } & 148\end{array}$

3.4.2. Bundeling handhaaft wetssystematisch tekort 149

3.4.3. Bundeling schept wetssystematisch tekort elders 150

3.4.4. Wetssystematisch tekort door gebruik typisch juridische
ordeningscriteria

$\begin{array}{ll}\text { 3.4.4.1. Algemeen } & 151\end{array}$

3.4.4.2. Algemeen en bijzonder $\quad 155$

3.4.4.3. Gelede normstelling $\quad 158$

3.4.4.4. Chronologische systeemordeningscriteria 161

3.4.4.5. Europese richtlijnen en verordeningen 161

$\begin{array}{ll}3.4 .5 \text {. Verdedigbare wetssystematische tekorten } & 164\end{array}$

3.4.5.1. Algemeen 164

3.4.5.2. Algemeen en bijzonder $\quad 165$

3.4.5.3. Gelede normstelling 165

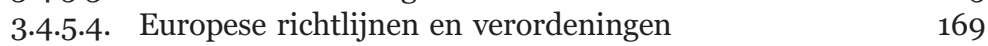

$\begin{array}{lr}\text { 3.4.6. Wetssystematische koekoekseibepalingen } & 171\end{array}$

3.4.7. Tussenconclusie 172

$\begin{array}{ll}\text { 3.5. } & \text { Nieuwe wettelijke oplossingen } \\ & 372\end{array}$

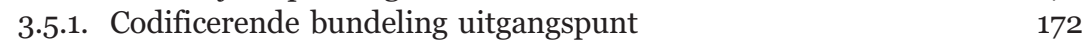

$\begin{array}{ll}\text { 3.5.2. Slimme aanpassingen } & 173\end{array}$

3.5.3. Modificerende bundeling 174

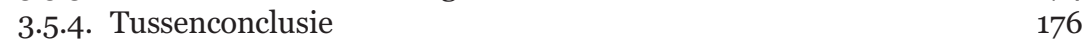

$\begin{array}{ll}\text { 3.6. Toekomstbestendig } & 176\end{array}$

3.6.1. Algemeen 176

3.6.2. Gericht op permanente verandering $\quad 177$

3.6.3. Toekomstbestendige samenhangcriteria 179

$\begin{array}{lr}\text { 3.6.4. Consequent wetssystematisch plaatsen } & 182\end{array}$

3.6.5. Aanbouwwetssysteem 183

$\begin{array}{lr}\text { 3.6.6. Tussenconclusie } & 184\end{array}$

$\begin{array}{ll}\text { 3.7. } & \text { Proeve van bundeling } \\ & 184\end{array}$

$\begin{array}{ll}\text { 3.8. Samenvatting en conclusie } & 188\end{array}$

3.9. Toetsing van de theorie aan de praktijk 191 
4. HERSCHIKKING: WET ALGEMENE BEPALINGEN

OMGEVINGSRECHT 193

4.1. Inleiding 193

4.2. De Wabo in het kort 194

4.3. Wetssystematische tekorten 196

4.3.1. Algemeen 196

4.3.2. Aanleiding voor bundeling 197

4.3.3. Samenhangcriteria 198

4.3.3.1. Algemeen 198

4.3.3.2. De fysieke leefomgeving 200

4.3.3.3. Verdere uitbouw van de Wabo 202

4.3.4. Wetssystematisch tekort 204

4.3.5. Antwoord op toetsvraag 1

4.4. Wetssystematische tekorten opgeheven of verminderd 205

4.4.1. Algemeen 205

4.4.2. Opgeheven wetssystematische tekorten 205

4.4.3. Niet opgeheven wetssystematische tekorten 206

4.4.3.1. Algemeen 206

4.4.3.2. Bundeling betreft niet alle regels ten aanzien van een project 206

4.4.3.3. Bundeling activiteiten in Wabo, andere wetten,

4.4.3.4. Bundeling betreft niet alle regels ten aanzien van toestemmingsbesluiten ten aanzien van projecten 212

4.4.4. Antwoord op toetsvraag $2 \quad 215$

4.5. Wetssystematische tekorten vanwege typische juridische
ordeningscriteria

4.5.1. Algemeen 216

4.5.2. Algemeen en bijzonder 216

4.5.2.1. Wetssystematische tekorten 216

4.5.2.2. Verdedigbaarheid wetssystematische tekorten 218

$\begin{array}{ll}\text { 4.5.3. Gelede normstelling } & 219\end{array}$

$\begin{array}{ll}\text { 4.5.3.1. Algemeen } & 219\end{array}$

4.5.3.2. Besluit omgevingsrecht 220

4.5.3.3. Regeling omgevingsrecht 220

4.5.3.4. Verdedigbaarheid gelede normstelling 221

4.5.4. Europese richtlijnen en verordeningen 223

4.5.4.1. Wetssystematische tekorten 223

4.5.4.2. Verdedigbaarheid wetssystematisch tekort 224

4.5.5. Antwoord op toetsvraag $3 \quad 224$

4.6. Wetssystematische tekorten in andere wetssystemen 224

4.6.1. Algemeen $\quad 224$

4.6.2. Wetssystematische tekorten 225

4.6.3. Verdedigbaarheid wetssystematische tekorten 226

$\begin{array}{ll}\text { 4.6.4. Antwoord op toetsvraag } 4 & 227\end{array}$

4.7. Wetssysteem toekomstbestendig $\quad 227$

$\begin{array}{ll}\text { 4.7.1. Algemeen } & 227\end{array}$

$\begin{array}{ll}\text { 4.7.2. Op permanente opschoning gericht } & 227\end{array}$ 
4.7.3. Aansluiten bij wetssystematische criteria en opbouw 228

$\begin{array}{ll}\text { 4.7.4. Geen aanbouwwet } & 229\end{array}$

4.7.5. Antwoord op toetsvraag $5 \quad 229$

$\begin{array}{ll}\text { 4.8. Samenvatting en conclusie } & 229\end{array}$

5. INTEGRATIE: WET MILIEUGEVAARLIJKE STOFFEN IN DE WET MILIEUBEHEER 231

5.1. Inleiding 231

5.2. Wms en Wet milieubeheer in het kort 232

5.2.1. Algemeen 232

5.2.2. De Wet milieugevaarlijke stoffen $\quad 232$

5.2.3. De Wet milieubeheer 234

5.3. Wetssystematische tekorten 239

5.3.1. Algemeen $\quad 239$

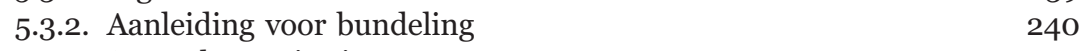

5.3.3. Samenhangcriterium 240

5.3.4. Wetssystematisch tekort $\quad 245$

$\begin{array}{ll}\text { 5.3.5. Antwoord op toetsvraag } 1 & 245\end{array}$

5.4. Wetssystematische tekorten opgeheven of verminderd 245

5.4.1. Algemeen 245

5.4.2. Opgeheven wetssystematische tekorten 248

5.4.3. Niet opgeheven wetssystematische tekorten 249

5.4.4. Antwoord op toetsvraag 2

5.5. Wetssystematische tekorten vanwege typisch juridische ordeningscriteria 252

5.5.1. Algemeen 252

5.5.2. Indeling 252

5.5.2.1. Interne wetssystematische tekorten $\quad 252$

5.5.2.2. Externe wetssystematische tekorten 253

5.5.2.3. Verdedigbaarheid wetssystematische tekorten $\quad 253$

$\begin{array}{ll}\text { 5.5.3. Algemeen en bijzonder } & 254\end{array}$

5.5.3.1. Algemeen 254

5.5.3.2. Wetssystematische tekorten 255

5.5.3.3. Verdedigbaarheid wetssystematische tekorten $\quad 255$

5.5.4. Gelede normstelling $\quad 256$

5.5.4.1. Algemeen $\quad 256$

5.5.4.2. Algemene maatregelen van bestuur $\quad 258$

5.5.4.3. Ministeriële regelingen 260

5.5.4.4. Verdedigbaarheid gelede normstelling 260

5.5.5. Antwoord op toetsvraag $3 \quad 261$

5.6. Wetssystematische tekorten in andere wetssystemen 262

5.6.1. Algemeen 262

5.6.2. Antwoord op toetsvraag $4 \quad 262$

5.7. Wetssysteem toekomstbestendig 262

$\begin{array}{ll}\text { 5.7.1. Algemeen } & 262\end{array}$

5.7.2. Op permanente opschoning gericht 263

5.7.3. Aansluiten bij wetssystematische criteria en opbouw 263 
5.7.4. Geen aanbouwwetssysteem 264

5.7.5. Antwoord op toetsvraag $5 \quad 264$

5.8. Samenvatting en conclusie 265

6. HERSCHIKKING: WET NATUURBESCHERMING 267

6.1. $\quad$ Inleiding $\quad 267$

6.2. De natuurwetgeving in het kort $\quad 269$

$\begin{array}{ll}\text { 6.2.1. Algemeen } & 269\end{array}$

6.2.2. Natuurbeschermingswet $1998 \quad 269$

6.2.3. Flora- en faunawet 271

6.2.4. Boswet 273

6.2.5. Ontwerp Wet natuurbescherming $\quad 274$

$\begin{array}{ll}\text { 6.3. Wetssystematisch tekort } & 277\end{array}$

$\begin{array}{ll}\text { 6.3.1. Algemeen } & 277\end{array}$

6.3.2. Aanleiding voor bundeling $\quad 278$

$\begin{array}{ll}\text { 6.3.3. Samenhangcriterium } & 281\end{array}$

6.3.4. Wetssystematisch tekort 283

6.3.5. Antwoord op toetsvraag $1 \quad 283$

6.4. Wetssystematisch tekorten opgeheven of verminderd 283

6.4.1. Algemeen 283

6.4.2. Wetssystematische tekorten gedeeltelijk opgeheven 283

6.4.3. Wetssystematisch tekorten gedeeltelijk niet opgeheven $\quad 284$

$\begin{array}{ll}\text { 6.4.3.1. Algemeen } & 284\end{array}$

6.4.3.2. Regimes van algemene aard $\quad 285$

6.4.3.3. Grondgebied BES-eilanden 286

$\begin{array}{ll}\text { 6.4.3.4. Wet inrichting landelijk gebied } & 287\end{array}$

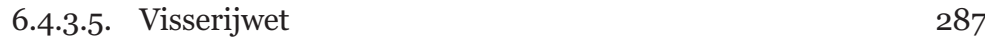

6.4.3.6. Waterwet 288

6.4.3.7. Natuurschoonwet $1928 \quad 289$

6.4.3.8. Wet luchtvaart 290

6.4.3.9. Gezondheids- en welzijnswet voor dieren 290

6.4.3.10. Omgevingswet 291

6.4.4. Antwoord op toetsvraag $2 \quad 292$

6.5. Andere samenhangcriteria 293

6.5.1. Algemeen 293

6.5.2. Typisch juridische begrippen 293

6.5.2.1. Interne wetssystematische tekorten 293

$\begin{array}{ll}\text { 6.5.2.2. Externe wetssystematische tekorten } & 297\end{array}$

6.5.2.3. Verdedigbaarheid wetssystematische tekorten 298

6.5.3. Gelede normstelling 298

6.5.3.1. Wetssystematische tekorten 298

6.5.3.2. Verdedigbaarheid gelede normstelling 299

6.5.4. Europese richtlijnen en verordeningen 299

$\begin{array}{ll}\text { 6.5.4.1. Wetssystematische tekorten } & 299\end{array}$

6.5.4.2. Verdedigbaarheid wetssystematische tekorten 300

6.5.5. Antwoord op toetsvraag $3 \quad 300$ 
6.6. Wetssystematische tekorten elders 300

$\begin{array}{ll}\text { 6.6.1. Algemeen } & 300\end{array}$

$\begin{array}{ll}\text { 6.6.2. Antwoord op toetsvraag } 4 & 301\end{array}$

$\begin{array}{ll}\text { 6.7. Toekomstbestendig } & 301\end{array}$

$\begin{array}{ll}\text { 6.7.1. Algemeen } & 301\end{array}$

$\begin{array}{ll}\text { 6.7.2. Op permanente opschoning gericht } & 301\end{array}$

6.7.3. Aansluiten bij wetssystematische criteria en opbouw 302

$\begin{array}{ll}\text { 6.7.4. Geen aanbouwwetssysteem } & 303\end{array}$

$\begin{array}{ll}\text { 6.7.5. Antwoord op toetsvraag } 5 & 303\end{array}$

$\begin{array}{ll}\text { 6.8. Samenvatting } & 303\end{array}$

7. HERSCHIKKING: OMGEVINGSWET 307

$\begin{array}{lll}\text { 7.1. } & \text { Inleiding } & 307\end{array}$

7.2. De Omgevingswet in het kort 310

7.2.1. Betrokken wetten 310

$\begin{array}{ll}\text { 7.2.2. Opbouw } & 310\end{array}$

7.2.3. Ontwerpprincipes van de Omgevingswet 311

7.2.4. Voorlopige inhoudsopgave $\quad 312$

7.3. Wetssystematische tekorten 316

7.4. Wetssystematische tekorten opgeheven of verminderd 317

7.5. Wetssystematische tekorten vanwege typisch juridische
ordeningscriteria

7.6. Wetssystematische tekorten in andere wetssystemen 319

$\begin{array}{ll}\text { 7.7. Wetssysteem toekomstbestendig } & 319\end{array}$

$\begin{array}{ll}\text { 7.8. Samenvatting en conclusie } & 320\end{array}$

8. SAMENVATTING, CONCLUSIES EN AANBEVELINGEN 323

8.1. Inleiding $\quad 323$

8.2. Samenvatting 324

8.3. Conclusies 334

8.4. Aanbevelingen $\quad 335$

8.4.1. Aanbevelingen aan de wetgever $\quad 335$

8.4.2. Aanbevelingen aan wetgevingsjuristen 336

8. Clustering of EnVironmental LaW 337

8.1. Introduction 337

$\begin{array}{lll}\text { 8.2. Summary } & 337\end{array}$

$\begin{array}{ll}\text { 8.3. Conclusions } & 347\end{array}$

$\begin{array}{ll}\text { 8.4. Recommendations } & 348\end{array}$

8.4.1. Recommendations to the legislator 348

8.4.2. Recommendations to legislative drafters 349

8. BüNDELUNG VON UMWELTRECHT 351

$\begin{array}{lll}\text { 8.1. } & \text { Einleitung } & 351\end{array}$

$\begin{array}{ll}\text { 8.2. Zusammenfassung } & 352\end{array}$ 
8.3. Ergebnisse $\quad 363$

8.4. Empfehlungen $\quad 365$

8.4.1. Empfehlungen an den Gesetzgeber 365

8.4.2. Empfehlungen für Juristen, die am Gesetzgebungsprozess
beteiligt sind 366

$\begin{array}{ll}\text { LITERATUUR } & 367\end{array}$

BIJLAGE 1: OMGEVINGSRECHT 2002-2012 395

BIJLAGE 2: INHOUDSTAFEL VOORONTWERP DECREET MILIEUBELEID VLAAMSE GEWEST $\quad 407$

BIJLAGE 3: INHALTSVERZEICHNIS UMWELTGESETZBUCH

(UGB-KOME) 411

BIJLAGE 4: BUNDELING IN DE HERIJKINGSBRIEF 2003

BIJLAGE 5: INTERVIEWS MET WETGEVINGSDESKUNDIGEN 419

5.1 Drs. H.E. Woldendorp 419

5.2 Mr. ing. B. Rademaker 446

5.3 Mr. T.C. Borman 454

5.4 Mr. J.F.L. Roording 454

5.5 Prof. dr. W.J.M. Voermans 463

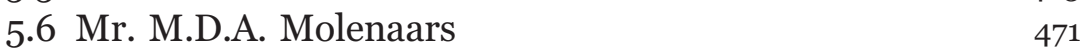

5.7 Mr. H.W. de Vos 471

5.8 Mr. Th.G. Drupsteen 479

$\begin{array}{ll}\text { NAMENREGISTER } & 487\end{array}$

TREFWOORDENREGISTER 493

$\begin{array}{ll}\text { CURriculum VitaE } & 501\end{array}$ 


\section{Lijst van gebruikte afkortingen}

\begin{tabular}{|c|c|}
\hline $\mathrm{ABl}$. & Amtsblatt der Europäischen Union \\
\hline ABRvS & Afdeling bestuursrechtspraak van de Raad van State \\
\hline Activiteitenbesluit & $\begin{array}{l}\text { Besluit algemene regels voor inrichtingen milieubeheer } \\
\text { (Stb. 2007, 415) }\end{array}$ \\
\hline a.D. & außer Dienst \\
\hline afd. & afdeling \\
\hline AIM & Activiteitenbesluit Internet Module \\
\hline amvb & algemene maatregel van bestuur \\
\hline art. & artikel(en) \\
\hline Awb & Algemene wet bestuursrecht \\
\hline BES & (de openbare lichamen) Bonaire, Sint-Eustasius en Saba \\
\hline Bevi & Besluit externe veiligheid inrichtingen \\
\hline BGB & Bürgerliches Gesetzbuch \\
\hline bijl. & bijlage \\
\hline Bor & Besluit omgevingsrecht \\
\hline BenW & college van burgemeester en wethouders \\
\hline $\mathrm{BR}$ & Bouwrecht \\
\hline Bro & Besluit ruimtelijke ordening \\
\hline BZK & $\begin{array}{l}\text { (Ministerie van) Binnenlandse Zaken en } \\
\text { Koninkrijksrelaties }\end{array}$ \\
\hline c.a. & cum annexis \\
\hline c.s. & cum suis \\
\hline cie. & commissie \\
\hline CITES & $\begin{array}{l}\text { Convention on International Trade in Endangered Species of } \\
\text { Wild Fauna and Flora (Trb. 1975, 23) }\end{array}$ \\
\hline $\begin{array}{l}\text { DG } \\
\text { diss. }\end{array}$ & $\begin{array}{l}\text { Directoraat-Generaal } \\
\text { dissertatie }\end{array}$ \\
\hline ECWM & Evaluatiecommissie Wet milieubeheer \\
\hline EEG & Europese Economische Gemeenschap \\
\hline EG & Europese Gemeenschappen \\
\hline EK & Eerste Kamer der Staten-Generaal \\
\hline ELenI & $\begin{array}{l}\text { (Ministerie van) Economische Zaken, Landbouw en } \\
\text { Innovatie }\end{array}$ \\
\hline EWG & Europäische Wirtschaftsgemeinschaft \\
\hline $\mathrm{EZ}$ & (Ministerie van) Economische Zaken \\
\hline
\end{tabular}


Ffw

ggo's

gpbv

GS

Gww

GWWD

hfds.

HGB

i.w.tr.

ICT

IED

IenM

IPO

ippc

Ivb

JM

jo.

Kamerstukken I

Kamerstukken II

Krw

LNV

LSP

m.nt.

$\mathrm{M}$ en $\mathrm{R}$

Monw 1988

Mor

MvT

Nb-wet 1998

NJB

$\mathrm{NtEr}$

NvT

OCW

OJ

OLO

p.

par.
Flora- en faunawet

genetisch gemodificeerde organismen

geïntegreerde preventie en bestrijding van verontreiniging

Gedeputeerde Staten

Grondwaterwet

Gezondheids- en welzijnswet voor dieren

hoofdstuk

Handelsgesetzbuch

inwerkingtreding

informatie- en comunicatietechnologie

Industrial Emissions Directive: Richtlijn 2010/75/EU van het

Europees Parlement en de Raad van 24 november 2010 inzake industriële emissies (geïntegreerde preventie en bestrijding van verontreiniging) (herschikking), ( $P b E U$ 2010 L 334)

(Ministerie van) Infrastructuur en Milieu

Interprovinciaal Overleg

integrated pollution prevention control

Inrichtingen- en vergunningenbesluit milieubeheer

Jurisprudentie Milieurecht

juncto

stukken van de Eerste Kamer der Staten-Generaal

stukken van de Tweede Kamer der Staten-Generaal

Kaderrichtlijn Water

(Ministerie van) Landbouw, Natuur en Voedselkwaliteit

Lex silencio positivo

met noot

Tijdschrift voor Milieu en Recht

Monumentenwet 1988

(ministeriële) Regeling omgevingsrecht

Memorie van Toelichting

Natuurbeschermingswet 1998

Nederlands Juristenblad

Nederlands tijdschrift voor Europees recht

Nota van Toelichting

(Ministerie van) Onderwijs, Cultuur en Wetenschappen

Official Journal of the European Union

Omgevingsloket Online

pagina/page

paragraaf 
PbEG

$\mathrm{PbEU}$

REACH

rechtbank

red.

r.o.

S.

SOMS

SPAW

Sr.

Stb.

Stcrt.

STEM

TBR

TK

TO

TOO

Trb.

UGB

UPR

VenJ

VenM

VenW

verv.

vgl.

VNG

VROM

vvgb

vzr.

Wabm

Wabo

Wbb

Wet luvo

Wgb

Wgh

Wm

Wms

ontwerp Wnb
Publicatieblad van de Europese Gemeenschappen

Publicatieblad van de Europese Unie

EG-verordening nr. 1907/2006) Registratie, Evaluatie en Autorisatie van Chemische stoffen ( $P b E U 2006$ L 396)

rechtbank

redactie

rechtsoverweging

Seite

Strategie Omgaan Met Stoffen

Specially Protected Areas and Wildlife

Wetboek van Strafrecht

Staatsblad

Staatscourant

Structurele Evaluatie Milieuwetgeving

Tijdschrift voor Bouwrecht

Tweede Kamer der Staten-Generaal

Tijdschrift voor Omgevingsrecht

Tijdschrift voor Omgevingsrecht en Omgevingsbeleid

Tractatenblad

Umweltgesetzbuch

Zeitschrift für Umwelt- und Planungsrecht

(Ministerie van) Veiligheid en Justitie

(Ministerie van) Volksgezondheid en Milieuhygiëne

(Ministerie van) Verkeer en Waterstaat

vervallen

vergelijk

Vereniging van Nederlandse Gemeenten

(Ministerie van) Volkshuisvesting, Ruimtelijke Ordening en Milieubeheer

verklaring van geen bedenkingen

voorzieningenrechter

Wet algemene bepalingen milieuhygiëne

Wet algemene bepalingen omgevingsrecht

Wet bodembescherming

Wet inzake de luchtverontreiniging

Wet gewasbeschermingsmiddelen en biociden

Wet geluidhinder

Wet milieubeheer

Wet milieugevaarlijke stoffen

ontwerp Wet natuurbescherming, versie o.2 d.d.

6 oktober 2011 
Wob

Wonw

WRO

Wro

Wtb

Wtw
Wet openbaarheid van bestuur

Woningwet

Wet op de Ruimtelijke Ordening

Wet ruimtelijke ordening

Waterbesluit

Waterwet 
'Wer Großes will, muß sich zusammenraffen;

In der Beschränkung zeigt sich erst der Meister,

Und das Gesetz nur kann uns Freiheit geben.'

Johann Wolfgang von Goethe ${ }^{1}$

\subsection{LAPPENDEKEN VAN OMGEVINGSRECHT}

Het Nederlandse omgevingsrecht vormt een lappendeken ${ }^{2}$ van vele tientallen wetten in formele zin, die de basis vormen voor honderden algemene maatregelen van bestuur en ministeriële regelingen. ${ }^{3}$ Het omgevingsrecht omvat wetgeving op het gebied van milieu, ruimtelijke ordening, natuur en water ${ }^{4}$ die in wezen is ontstaan in de laatste helft van de twintigste eeuw. Ter illustratie daarvan heb ik de thans nog bestaande wetten in formele zin $^{5}$

1 Johann Wolfgang von Goethe, gelegenheidssonnet Kunst und Natur 26 juni 1802 (http://mpg-trier. de/d7/read/goethe_naturundkunst.pdf).

Natur und Kunst, sie scheinen sich zu fliehen Und haben sich, eh man es denkt, gefunden;

Der Widerwille ist auch mir verschwunden, Und beide scheinen gleich mich anzuziehen.

Es gilt wohl nur ein redliches Bemühen! Und wenn wir erst in abgemeßnen Stunden

Mit Geist und Fleiß uns an die Kunst gebunden, Mag frei Natur im Herzen wieder glühen.

So ist's mit aller Bildung auch beschaffen. Vergebens werden ungebundne Geister

Nach der Vollendung reiner Höhe streben. Wer Großes will, muß sich zusammenraffen;

In der Beschränkung zeigt sich erst der Meister, Und das Gesetz nur kann uns Freiheit geben.

2 www.woorden.org/woord/lappendeken: deken uit allerlei stukjes gemaakt; figuurlijk bont, weinig samenhangend geheel (cursivering van mij, JvdB).

3 Hoewel het verschijnsel zich voordoet op het gehele terrein van het omgevingsrecht, zullen in par. 1.1 met name voorbeelden uit het milieuhygiënerecht worden genoemd, aangezien de lappendeken zich op dat terrein het sterkst voordoet.

4 In par. 2.2 is omschreven wat ik onder omgevingsrecht versta.

5 Daarbij is afgezien van het opnemen van wetten in formele zin die inmiddels zijn vervallen of opgenomen in bestaande omgevingswetten, zoals de Hinderwet $($ Stb. 1875, 95) die op 1 maart 1993 is vervallen als gevolg van de Wet milieubeheer (Stb. 1992, 414 en Stb. 1993, 59) en de Wet verontreiniging oppervlaktewateren $(S t b .1969,536)$, die op 22 december 2009 is opgenomen in de Waterwet (Stb. 2009, 489 en 549). Wie meer wil weten over - de ontstaansgeschiedenis van - het omgevingsrecht verwijs ik voor wat betreft het milieurecht bijvoorbeeld naar Biezeveld, Duurzame milieuwetgeving 2002, tabel 1.7, p. 36, alsmede hfds. 2-5, p. 41-195 en Tonnaer, Quo Vadis 2011, hfds. 2-4, p. 15-69. Voor wat betreft het waterrecht naar Havekes, Wetgeving op de waterkwaliteit 2006 en Havekes \& Van Rijswick, Waterrecht 2010, hfds. 4 en 5. Voor wat betreft het natuurrecht naar Backes, Natuurbeschermingsrecht 2006. Voor wat betreft het recht van de ruimtelijke ordening naar Van Buuren/De Gier/Nijmeijer \& Robbe, Hoofdlijnen ruimtelijk bestuursrecht 2010. 
op het gebied van het omgevingsrecht kort weergegeven in het achterin dit werk als uitklapblad opgenomen overzicht 1.1. ${ }^{6}$

Het overzicht bevat de wetten die in het algemeen tot het omgevingsrecht worden gerekend. Het gaat om 87 wetten die tot stand zijn gekomen tussen 1851 en 2012 en op enig moment in het decennium van 23 mei 2002 tot en met 2012 nog in werking waren. In rood zijn vervolgens 31 wetten aangegeven die in genoemde periode 2002-2012 zijn ingetrokken. In groen (langwerpige blokjes) zijn aangegeven de 56 wetten die op 23 mei 2012 - het moment van mijn inventarisatie - geldend waren. Het kabinet Rutte-Verhagen had het voornemen om 15 van die wetten te bundelen in een nieuwe Omgevingswet en twee wetten volledig in te trekken; die wetten zijn telkens per kolom aangegeven met een geel vierkant blokje rechts in elke relevante rij. Voor circa 25 wetten bestond het voornemen om die 'gedeeltelijk, later of mogelijk' te bundelen in die Omgevingswet; die wetten zijn telkens per kolom aangegeven met een oranje vierkant blokje rechts in elke relevante rij. ${ }^{7}$ Voorts heb ik nog 15 wetten geselecteerd die volgens mij ook tot het omgevingsrecht kunnen worden gerekend, maar geen deel uitmaken van de plannen om te komen tot een Omgevingswet; die wetten zijn telkens per kolom aangegeven met een blauw vierkant blokje rechts in elke relevante rij. Naar volledigheid is niet gestreefd. Het is mogelijk dat naast de 87 genoemde wetten in formele zin nog meer wetten tot het omgevingsrecht zouden kunnen worden gerekend.

De titels van de in het overzicht opgenomen wetten en het jaar van inwerkingtreding doen vermoeden dat de wetgever telkens een nieuwe wet heeft vastgesteld als zich een bepaald probleem voordeed of Europese regelgeving daartoe noopte. Van beide aanleidingen volgt hierna een voorbeeld.

Illustratief voor het eerste geval is de sectorale wetgeving inzake bodemsanering en -bescherming. Minister Stuyt ${ }^{8}$ stelde in april 1971 een Voorontwerp Wet inzake de Bodemverontreiniging op. Het voorontwerp haalde het niet, waarna voor de onderdelen afval en chemische stoffen aparte wetgeving werd opgesteld. ${ }^{9}$ In 1980 werd Nederland opgeschrikt door een gifschandaal in het ZuidHollandse Lekkerkerk. De nieuwbouwwijk Lekkerkerk West met 300 woningen bleek gebouwd op sterk verontreinigde grond. De verontreiniging kwam aan het licht toen een waterleidingbuis brak doordat het materiaal was aangetast door de verontreiniging. De kosten voor het verwijderen van deze bodemverontreiniging beliepen uiteindelijk 188 miljoen gulden. ${ }^{10}$ Om de verontreiniging met onder andere tolueen en xyleen te verwijderen moest de grond rondom en onder de huizen worden afgegraven. Er werden ongeveer 1.600 vaten met chemisch

\footnotetext{
In bijlage 1 zijn de in overzicht 1.1 opgenomen gegevens verantwoord.

Ministerie van IenM, Kabinetsbrief stelselherziening omgevingsrecht 2012, bijlage 1.

Louis Stuyt was de eerste minister met milieu in zijn portefeuille (1971-1973).

Dit voorbeeld is deels ontleend aan Evelien Verbauwen, Wet Bodembescherming (1987), NBV

Canon van de Nederlandse Bodemkunde, http://www.bodems.nl/canon/venster-31.php.

10 Circa $€ 85.310 .000$, $=$
} 
afval uit de bodem verwijderd. ${ }^{11}$ Pas naar aanleiding daarvan reageerde de wetgever met de inmiddels vervallen ${ }^{12}$ Interimwet bodemsanering, ${ }^{13}$ een tijdelijke wet, die bodemsanering van bestaande gevallen van bodemverontreiniging beoogde. Dat de Interimwet bodemsanering een reactie was op de actualiteit van 1980 blijkt niet alleen uit het moment van totstandkoming en de naam, maar ook uit het belangrijkste instrument dat was opgenomen in artikel 21 van die wet. Op basis daarvan kon de Staat der Nederlanden de kosten van voorbereiding en uitvoering van de sanering van een bestaand geval van bodemverontreiniging terugvorderen van degene door wiens onrechtmatige daad de verontreiniging van de bodem in het betrokken geval was veroorzaakt. ${ }^{14}$ Pas in 1987 bereikte de Wet bodembescherming het Staatsblad; ${ }^{15}$ deze wet richt zich door middel van een zorgplicht ${ }^{16}$ op bescherming tegen nieuwe gevallen van bodemverontreiniging. Op 15 mei 1994 is de zogeheten Inbouwwet ${ }^{17}$ grotendeels in werking getreden ${ }^{18}$ waarmee de Interimwet bodemsanering werd 'ingebouwd' (geïntegreerd) in de Wet bodembescherming. Die wet is in de jaren daarna nog een aantal malen ingrijpend gewijzigd. ${ }^{19,20}$ In 2011 bestonden er plannen om de Wet bodembescherming te integreren in de nieuwe Omgevingswet. ${ }^{21}$

Illustratief voor het tweede geval is het wetssysteem van hoofdstuk 9 Stoffen en producten van de Wet milieubeheer (Wm) dat op 1 januari 2012 bepalingen bevatte over stoffen, preparaten en producten, verdeeld over zeven titels. Op 1 januari 2012 is in Titel 9.1 Wm Algemeen een voor het gehele hoofdstuk 9 Wm

11 Pas in januari 2008 hebben de Staat der Nederlanden en de Gemeente Nederlek een vaststellingsovereenkomst gesloten met de bedrijven die betrokken waren bij het veroorzaken van de bodemverontreiniging (nl.wikipedia.org/wiki/Gifschandaal_Lekkerkerk).

12 Stb. 1994, 331 en 333

13 Stb. 1982, 763.

14 Het tweede lid van hetzelfde artikel maakte kostenverhaal mogelijk op de rechthebbende op verontreinigde grond, voor zover die rechthebbende door de sanering ongerechtvaardigd werd verrijkt.

15 Stb. 1986, 374, grotendeels in werking getreden op 1 januari 1987 (Stb. 1986, 404).

16 Art. 13 Wbb luidt: Ieder die op of in de bodem handelingen verricht als bedoeld in de artikelen 6 tot en met 11 en die weet of redelijkerwijs had kunnen vermoeden dat door die handelingen de bodem kan worden verontreinigd of aangetast, is verplicht alle maatregelen te nemen die redelijkerwijs van hem kunnen worden gevergd, teneinde die verontreiniging of aantasting te voorkomen, dan wel indien die verontreiniging of aantasting zich voordoet, de verontreiniging of de aantasting en de directe gevolgen daarvan te beperken en zoveel mogelijk ongedaan te maken. Indien de verontreiniging of aantasting het gevolg is van een ongewoon voorval, worden de maatregelen onverwijld genomen.

17 Stb. 1994, 331. In verband hiermee is ook een novelle relevant (Stb. 1995, 332).

18 Stb. 1994, 333.

19 wetten.overheid.nl/BWBR0003994/geldigheidsdatum_05-01-2012/informatie.

20 Zie uitgebreider Van den Broek/De Haas/De Kok \& Niezen, De Wet bodembescherming in bedrijf 1994, Von Meijenfeldt, De wettelijke regeling van de bodemsanering 1994 en Van den Broek, TઐC Wet bodembescherming 2012.

21 Kiela, Wet bodembescherming verdwijnt 2011, p. 6. Ministerie van IenM, Kabinetsbrief stelselherziening omgevingsrecht 2012, bijlage 1. 
geldende bepaling opgenomen. ${ }^{22}$ Titel $9.2 \mathrm{Wm}$ bevat met name een zorgplicht en de basis voor algemene maatregelen van bestuur die tot 1 juni 2008 in de Wet milieugevaarlijke stoffen (Wms) waren opgenomen. ${ }^{23}$ Titel $9.3 \mathrm{Wm}$ bevat de implementatiebepalingen van de op 1 juni 2007 in werking getreden EGverordening registratie, evaluatie en autorisatie van chemische stoffen $(\mathrm{REACH}){ }^{24}$ Titel $9.3 \mathrm{~A} \mathrm{Wm}$ is in werking getreden op 4 november 2009. ${ }^{25}$ Deze titel bevat de omzetting in Nederlands recht van de EG-verordening indeling, etikettering en verpakking van stoffen en mengsels. ${ }^{26}$ Titel $9.4 \mathrm{Wm}$ bevat per 20 november $2010^{27}$ de omzetting in Nederlands recht van de EG-richtlijn ecologisch ontwerp energieverbruikende producten (Ecodesign). ${ }^{28}$ Titel $9.5 \mathrm{Wm}$ Overige bepalingen met betrekking tot stoffen, preparaten en producten is in werking getreden op 1 januari 2012. ${ }^{29}$ Titel $9.6 \mathrm{Wm}$ is op 9 april 2011 in werking getreden. ${ }^{30}$ Deze titel geeft uitvoering aan de EG-richtlijn ter bevordering van schone en energiezuinige wegvoertuigen. ${ }^{31}$

Bocken schreef in 1991 dat zich in Vlaanderen een soortgelijke situatie had voorgedaan: 'Het milieurecht dat vandaag in Vlaanderen gelding vindt, werd, zoals het geval is in de meeste landen, niet opgebouwd op een systematische wijze, uitgaande van een duidelijk concept van wat een milieubeleid inhoudt. Het milieubeleid groeide organisch, sinds de industriële revolutie en vooral sinds de jaren '70. Dikwijls waren wetgevende initiatieven een reactie op een of ander concreet incident (de wet van 22 juli 1974 op de giftige afval bv.). Ook internationale verplichtingen en vooral de Europese richtlijnen bleken doorslaggevend om eerst de Belgische en nadien ook de Vlaamse wetgever tot een

22 Wet van 12 mei 2011 tot wijziging van de Wet milieubeheer en diverse aanverwante wetten (Verdere invulling van hoofdstuk 9) (Stb. 2011, 269 en 347). Tot de inwerkingtreding van deze wet was deze titel nog gereserveerd voor het initiatiefvoorstel Duurzaam geproduceerd hout (Kamerstukken II 1994/95, 23 982, nrs. 1-3 en Kamerstukken II 2002/03, 28 631, nrs. 1-3). Het initiatiefwetsvoorstel zal naar verluidt in een andere titel van hfds. $9 \mathrm{Wm}$ worden ondergebracht.

23 Zie par. 5.2.2.

24 Verordening (EG) nr. 1907/2006 van het Europees Parlement en de Raad van 18 december 2006 inzake de registratie en beoordeling van en de autorisatie en beperkingen ten aanzien van chemische stoffen (REACH), tot oprichting van een Europees Agentschap voor chemische stoffen, houdende wijziging van Richtlijn 1999/45/EG en houdende intrekking van Verordening (EEG) nr. 793/93 van de Raad en Verordening (EG) nr. 1488/94 van de Commissie alsmede Richtlijn 76/769/ EEG van de Raad en de Richtlijnen 91/155/EEG, 93/67/EEG, 93/105/EG en 2000/21/EG van de Commissie (PbEU 2006 L 396/1 met rectificatie in PbEU 2007 L 136/3). Zie ook art. 1.1 lid 1 Wm. Zie ook Stb. 2009, 440.

26 Verordening (EG) nr. 1272/2008 van het Europees Parlement en de Raad van de Europese Unie van 16 december 2008 betreffende de indeling, etikettering en verpakking van stoffen en mengsels tot wijziging en intrekking van de Richtlijnen 67/548/EEG en 1999/45/EG en tot wijziging van Verordening (EG) nr. 1907/2006 (PbEU 2008 L 353/1). Zie ook art. 1.1 lid 1 Wm.

27 Stb. 2007, 389 en Stb. 2010, 769.

28 Richtlijn 2009/125/EG van het Europees Parlement en de Raad van de Europese Unie van 21 oktober 2009 betreffende de totstandbrenging van een kader voor het vaststellen van eisen inzake ecologisch ontwerp voor energiegerelateerde producten (herschikking) (PbEU 2009 L 285/ 10). Zie ook art. 9.4.1 Wm.

29 Stb. 2011, 269 en 347.

30 Stb. 2011, 163.

31 Richtlijn 2009/33/EG van het Europees Parlement en de Raad van de Europese Unie van 23 april 2009 inzake de bevordering van schone en energiezuinige wegvoertuigen ( $P b E U 2009$ L 120/5). Zie ook art. 9.6 Wm. 
grotere activiteit op het vlak van het leefmilieu aan te zetten. Van een eigen systematische analyse van de milieuproblemen en van een geïntegreerde en planmatige aanpak door wetgever en bestuur was er tot voor enkele jaren echter geen sprake.' 32

Een omgevingswetgever staan veel manieren ter beschikking om omgevingswetten en hun onderlinge relaties te ordenen, anders gezegd: te systematiseren.

Onder wetgever versta ik in dit onderzoek 'een ambt dat bevoegd is algemeen verbindende voorschriften vast te stellen.'33 In het omgevingsrecht gaat het in het bijzonder om het ambt dat bevoegd is tot het vaststellen van wetten in formele zin, algemene maatregelen van bestuur en ministeriële regelingen.

In theorie zou de wetgever voor de meest adequate, ideale wetssystemen $^{34}$ kunnen kiezen, wetssystemen zonder wetssystematische tekorten. ${ }^{35}$ In praktijk zal een wetgever gewoonlijk echter in ieder geval zijn gebonden aan een vorm van systematisering, die niet per se tot de meest adequate, ideale wetssystemen behoeft te leiden. Een wetgever is immers niet alleen actief in de zin dat hij zich de luxe kan permitteren om een om het even welk wetssysteem te ontwerpen, maar in veel meer gevallen reactief in de zin dat hij bijvoorbeeld probeert bepaalde problemen ten aanzien van de fysieke leefomgeving op te lossen door middel van omgevingsrecht. Aangezien die problemen zich chronologisch aandienen, is het logisch, dat de wetgever dan ook gebonden is aan een chronologische aanpak als gevolg waarvan reeds een zekere ordening ontstaat.

Tot deze observatie kwam ook Noll al in 1973: 'Wie alles Handeln ist auch die Gesetzgebung selber dem Gesetz der Zeit unterworfen. Die Problemimpulse folgen sich in der Zeit, und der Gesetzgeber ist weitgehend gezwungen, Ihnen chronologisch zu folgen, Tag für Tag Gesetze zu produzieren, in einer zeitlichen Reihenfolge, die bereits ein primitives, serielles System darstellt. ${ }^{36}$ Ook volgens Hill is planning van wetgeving maar beperkt mogelijk: 'Wäre Gesetzgebung ein eindimensionales, lineares System, bei dem das Handeln seiner Akteure im voraus berechenbar wäre und das auf Umwelteinflusse nicht reagierte, ließen sich sowohl die Abfolge der Gesetze als auch ihre Durchführung im einzelnen genau planen. Da jedoch weder diese Vorstellung noch die Bezeichnung 'der'

Bocken, Naar een algemeen kaderdecreet inzake milieuhygiëne? 1991, p. 1399.

Munneke, De bevoegdheid tot wetgeving bij de centrale overheid 2012, p. 240.

Zie par. 2.3 .

Zie par. 2.4

6 Noll, Gesetzgebungslehre 1973, p. 212. Op deze plaats merk ik op dat Sebus voor wat betreft systematiek in de rechtsorde haar theoretische ondergrond voornamelijk aan Noll heeft ontleend. Ik heb er daarom van afgezien om steeds waar ik Noll noem te verwijzen naar Sebus. Met name hoofdstuk V van haar boek vormt echter op hoofdlijnen een adequate samenvatting voor wie kennis wil maken met het gedachtegoed van Noll (Sebus, Wetgevingstechniek en de toegankelijkheid van de wet voor de burger 1984, p. 57-81). 
Gesetzgeber der Realität entsprechen, vielmehr Gesetzgebung sich als Zusammenspiel verschiedener Interessen und Kräfteverhältnisse in einem komplexen politischen Umfeld darstellt, sind praktische Umwege bei der Entstehung von Gesetzen nicht zu vermeiden.'37

In 1968 werd het ontwerp ingediend voor een Wet inzake de luchtverontreiniging. ${ }^{38}$

Kleijs-Wijnnobel \& De Leeuw verklaren de aandacht voor water en lucht als volgt: 'In de tweede helft van de jaren zestig bestond veel publieke belangstelling voor de milieuproblematiek. Vooral de vervuiling van lucht en water baarde zorgen, terwijl de geluidsoverlast door vliegtuigen toenemende kritiek ondervond. Tot die tijd lag de nadruk in ons land vooral op economische groei, technologische ontwikkeling en expansie. De naoorlogse wederopbouwperiode liep door tot in de jaren zestig en had tot gevolg dat het particuliere autogebruik toenam, het energiegebruik steeg, er schaalvergroting en mechanisatie in de landbouw plaatsvond, etcetera. Aan het eind van de jaren zestig en in het begin van de jaren zeventig werd duidelijk dat de milieuproblematiek om een actief overheidsoptreden vroeg. Vooral door het ontbreken van een volwaardige milieuwetgever kon niet worden gesproken van een systematisch wetgevingsbeleid op dit terrein. Met de instelling van het Ministerie van Volksgezondheid en Milieuhygiëne in 1971 kwam een milieubeleid tot ontwikkeling en kwam in snel tempo een groot aantal milieuwetten tot stand.'39

De toenmalige staatssecretaris Kruisinga van Sociale Zaken en Volksgezondheid koos voor een aparte wet in plaats van voor het verbreden en aanpassen van de Hinderwet. Tijdens de behandeling van het wetsvoorstel werden opmerkingen gemaakt en vragen gesteld betreffende de sectorgewijze realisering van de wetgeving op het gebied van de milieuhygiëne en de coördinatie waartoe te zijner tijd zou moeten worden overgegaan, alsmede betreffende de noodzaak van coördinatie van de uitvoering van de verschillende wetten. De regering antwoordde dat inderdaad de voorkeur wordt gegeven aan sectorgewijze wetgeving op het gebied van milieuhygiëne. De hierna volgende passage uit de memorie van antwoord geeft aan waarom die keus is gemaakt.

37 Hill, Einführung in die Gesetzgebungslehre 1982, p. 53. Zie omtrent de vraag wie 'de wetgever' eigenlijk is ook Noll, Gesetzgebungslehre 1973, p. 15: 'Daß auch vom 'Gesetzgeber' heute höchstens noch in einem übertragenen Sinne einer vereinfachenden Fiktion gesprochen werden kann, da an der Gesetzgebung immer Zahlreiche Instanzen beteiligt sind, versteht sich am Rande: “Der Gesetzgeber ist heute ein pluriformes und heterogenes Gebilde."'

38 Kamerstukken II 1969/70, 9816, nrs. 1-3, Regelen in het belang van het voorkomen of beperken van luchtverontreiniging (Wet inzake de luchtverontreiniging). Drupsteen noemt deze wet na de Wet verontreiniging oppervlaktewateren de tweede moderne milieuwet, die volgens hem deel uitmaakt van de wetgevingsfamilie waarvan de Hinderwet de moeder is (Drupsteen, Twintig jaar milieuwetgeving 1990, p. 195).

39 Kleijs-Wijnnobel \& De Leeuw, Interne integratie 1998, p. 136-137. 
'De sectoren zijn onderling verscheiden en vragen ieder een eigen specifieke aanpak, waarmede kan worden begonnen zodra de urgentie zich aandient en inzichten in de problematiek zijn gerijpt. Het gevaar is niet denkbeeldig dat, indien men in het begin zou streven naar een het gehele terrein bestrijkende wettelijke regeling, het ontbreken van voldoende inzicht in het ene deelgebied belemmerend zal werken ten aanzien van de totstandkoming van een regeling op een ander deelgebied, dat veel dringender om een wettelijke voorziening vraagt. Niettemin zou ondergetekende zich zeer goed kunnen voorstellen dat later - indien op alle of de meeste deelgebieden wettelijke regelingen tot stand zijn gekomen - bezien zal moeten worden in hoeverre deze wettelijke regelingen zich tot één alomvattende regeling laten samenvoegen. De ondergetekende meent op dit moment zich te mogen wagen aan het uitspreken van de veronderstelling, dat het bij het overwegen van codificatie van de regelingen betreffende onderwerpen van milieuhygiëne niet onmogelijk zal blijken, dat deze regelingen zodanig verschillend van achtergrond en opzet zijn of zodanige uiteenlopende voorzieningen bevatten dat opneming in een uit verschillende regelingen samen te stellen algemene wet op de milieuhygiëne bijzonder moeilijk is. (...) De ondergetekende ziet een "codex milieu-hygiënicus" als een realiseerbare mogelijkheid in de verdere toekomst aanwezig. ${ }^{40}$

Uit deze passage volgt mijns inziens dat de wetgever destijds welbewust heeft gekozen voor een sectorale aanpak. De sectorale milieuwetgeving is de Nederlandse wetgever dus niet 'overkomen'.

Dit sluit aan bij één van de door Eijlander \& Voermans genoemde strategische redenen voor het verdelen van de stof over meer dan één regeling, te weten de complexiteit van het onderwerp. Als andere strategische redenen noemen zij de omvang van de regeling, de wens tot fasering en de relatie tussen de regeling en het mogelijk omvangrijke overgangsrecht. Dergelijke splitsingen hebben volgens de auteurs vaak het voordeel dat de behandeling van de voorstellen vlotter kan verlopen. Daartegenover staat echter wel eens het nadeel dat er voor de justitiabele voor kortere of langere tijd een wat onoverzichtelijke situatie ontstaat. ${ }^{41}$ In de nota Met recht verantwoordelijk! is voor de verdere uitbouw van de Wet milieubeheer ook gekozen voor een gefaseerde aanpak vanwege 'de complexiteit van de voorgestelde wijzigingen. ${ }^{42}$

Voorts is duidelijk dat de wetgever zich bewust is van de chronologische aanpak. Expliciet wordt immers aangegeven dat met de aanpak van een sectoraal probleem kan worden begonnen 'zodra de urgentie zich aandient'. Ten slotte volgt uit genoemde passage, dat de wetgever zich eveneens realiseerde dat sectorale wetgeving niet het einddoel zou behoeven te zijn. ${ }^{43}$

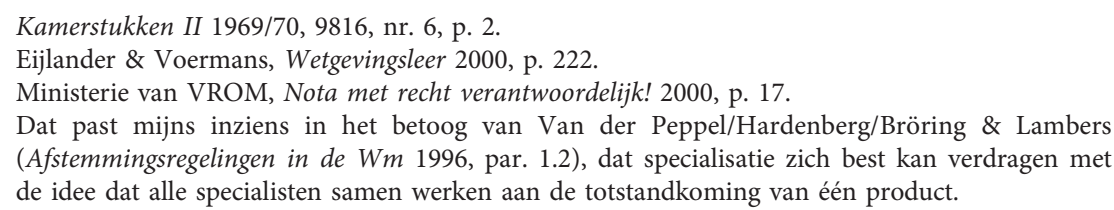


De wetgever heeft met de Wet inzake de luchtverontreiniging een principiële keuze gemaakt voor sectorale wetssystemen op het gebied van het milieurecht in plaats van voor het uitbouwen van het wetssysteem van de Hinderwet. Die principiële keuze is bevestigd in de Urgentienota Milieuhygiëne uit 1972. Biezeveld is van oordeel dat de Wet inzake de luchtverontreiniging de weg heeft vrijgemaakt voor een sectorgewijze benadering van de milieuproblematiek, die in de Urgentienota Milieuhygiëne nader inhoudelijk is onderbouwd en een impuls voor de toepassing daarvan heeft gegeven. ${ }^{44}$ Volgens Drupsteen werd met de totstandkoming van de Wet verontreiniging oppervlaktewateren in 1969 en de Wet inzake de luchtverontreiniging in 1970 een principiële keuze gemaakt voor de sectorale opzet van de milieuwetgeving, welke keuze volgens hem wordt bevestigd in de Urgentienota milieuhygiëne, waarin werd afgezien van een vernieuwing en aanpassing van de Hinderwet en van een integrale wettelijke regeling per bron of voor bepaalde bronnen. In plaats daarvan werd gekozen voor een effectieve aanpak per milieucomponent, die snel van de grond zou kunnen komen. ${ }^{45}$

In een algemeen deel van de Urgentienota milieuhygiëne worden in vier hoofdstukken de achtergronden en het ruimere verband van de milieuhygiëne geschetst. Het tweede deel omvat het urgentieprogramma. 'In hoofdstuk I.1 Het milieuvraagstuk wordt geschetst hoe sedert de tweede helft van de negentiende eeuw een aantal ontwikkelingen - de snelle bevolkingsgroei, de industrialisatie, de vergroting van productie en consumptie, de verstedelijking, de verhoging van de mobiliteit, de groei van de recreatie en de veranderingen in de agrarische bedrijfsvoering - geleid hebben tot toenemende aantasting van het milieu. Aan het einde van dat hoofdstuk wordt grote bezorgdheid geuit over de verstrekkende gevolgen van het groeiproces. In hoofdstuk I.2 Milieuhygiëne is aangegeven hoe de voortschrijdende aantasting van het milieu een nadelige uitwerking kan hebben op de volksgezondheid: lichamelijk, psychisch en sociaal welzijn. In hoofdstuk I.3 De ecologische samenhang wordt de samenhang behandeld die bestaat tussen de processen die plaatsvinden in de lucht, de bodem, het water en de organismen. Geconcludeerd wordt dat het moment is aangebroken dat de mens gedwongen is in zijn op zichzelf gerichte handelwijze naast waarden op sociaal en economisch gebied sterker dan ooit het milieu als grens stellende waarde op te nemen. Hoofdstuk I.4 Milieuhygiëne in wijder verband vestigt de aandacht op een antal algemene aspecten van de relatie tussen milieuhygiëne en de productie van goederen en diensten en tussen milieuhygiëne en verkeer. Vervolgens wordt gewezen op de samenhang van de milieuhygiëne met de sociaaleconomische ontwikkeling (waaronder structuurbeleid, energiebeleid), met ruimtelijke ordening en met natuur en landschapsbehoud. De belangrijke relaties tussen grote delen van het regeringsbeleid komen hier duidelijk naar voren: slechts door een onderling op elkaar afgestemde aanpak is verbetering van de situatie mogelijk.' Hoofdstuk II.1 Het milieuhygiënisch beleid bevat een inleiding op het Urgentieprogramma. 'De eerste

44 Biezeveld, Duurzame milieuwetgeving 2002, p. 87-88.

45 Drupsteen, Twintig jaar milieuwetgeving 1990, p. 195. 
ontwikkelingsfase waarin het corrigerend karakter van het beleid op de voorgrond heeft gestaan heeft reeds plaats gemaakt voor een overgangsfase met een meer actieve zorg voor de milieuhygiëne waarbij het wezenlijk ombuigen van de toenemende milieuverontreiniging centraal staat (sanering). Daarnaast wordt reeds waar mogelijk getracht nieuwe ontwikkelingen van het begin af aan in goede banen te leiden. Daarbij dient het ontwikkeling bepalend karakter van het beleid - dat het derde stadium kenmerkt - zich aan. ${ }^{46}$

In de Urgentienota Milieuhygiëne wordt aangegeven dat aan de uitbouw van de wettelijke maatregelen hoge prioriteit toekomt, waarbij 'steeds meer behoefte wordt gevoeld aan een zo groot mogelijke samenhang bij de opzet van de verschillende wettelijke regelingen in tegenstelling tot de nogal verbrokkelde situatie in het verleden. Al kunnen de belangrijkste maatregelen op de diverse gebieden van de milieuhygiëne moeilijk in één algemene milieuwet worden ondergebracht, toch zal meer dan voorheen naar een samenhangende basisfilosofie dienen te worden gestreefd in bovenomschreven zin.'47 De wetgever lijkt zich te realiseren dat er behoefte is aan een samenhangende aanpak van de milieuproblematiek, maar lijkt die aanpak op dat moment nog niet te kunnen vertalen in een samenhangend wetssysteem. De reden daarvoor lijkt te zijn dat de situatie van het milieu in Nederland tot urgente maatregelen noopte die een eerste aanzet vormden voor het doel van de binnen 5 tot 10 jaar te plegen sanering van de milieuverontreiniging. 'Op een latere termijn zou worden getracht een meer geïntegreerde visie en een meer systematisch geheel van beleidsplannen in een nota aan de Kamer voor te leggen. ${ }^{48}$

Volgens Drupsteen werd afgezien van vernieuwing en aanpassing van de Hinderwet, omdat de in 1972 moderne milieuproblemen van een bovengemeentelijke schaal waren en de Hinderwet werd beschouwd als zo sterk verbonden met het gemeentelijk bestuur, dat deze wet voor de aanpak van de moderne milieuproblematiek per definitie ontoereikend was. Ook werd afgezien van een integrale wettelijke regeling per bron of voor bepaalde bronnen, in welke benadering er een soort Inrichtingenwet zou kunnen komen. Doorslaggevend werd echter geacht een effectieve aanpak per milieucomponent, die snel van de grond zou kunnen komen. Het tot stand brengen van een geïntegreerde wettelijke regeling voor het gehele terrein van het milieubeleid zou te veel tijd vergen. Drupsteen vermoedt dat men in 1972 het gehele terrein ook nog moeilijk kon overzien. Acute milieuproblemen, zoals de luchtverontreiniging in Rijnmond, het vliegtuiglawaai rond Schiphol en de verontreiniging van het oppervlaktewater met zuurstofbindende stoffen vroegen om een oplossing. De gedachte was dat sectoraal opgedeelde wetgeving die oplossing het snelst dichterbij zou brengen. ${ }^{49}$

46 Ministerie van VenM, Urgentienota Milieuhygiëne 1972.

47 Ministerie van VenM, Urgentienota Milieuhygiëne 1972, p. 23.

48 Ministerie van VenM, Urgentienota Milieuhygiëne 1972, p. 25.

49 Drupsteen, Twintig jaar milieuwetgeving 1990, p. 195. In gelijke zin Kleijs-Wijnnobel \& De Leeuw, Interne integratie 1998, p. 137-138 en Drupsteen, Ontwikkelingen in het milieurecht gedurende de jaren zeventig 1981, p. 879-889. 
Biezeveld gaat een stap verder waar hij meent dat het ook verstandig is geweest om in de Urgentienota vast te houden aan de keuze voor afzonderlijke wetten in plaats van voor één algemene milieuwet.

Achteraf kan volgens hem wel worden geconstateerd dat de wetgever zich wellicht wat meer en wat eerder had moeten realiseren dat hij bezig was met de eerste fase van een wetgevingsproces, met alle onzekerheden en ook vergissingen die daarbij horen, en dat de afzonderlijke wetten naadloos op elkaar zouden moeten aansluiten. Biezeveld acht het zeer onwaarschijnlijk dat in dezelfde tijd net zo veel bereikt zou zijn - op het vlak van wetgeving en sturing - indien in één wettelijk kader voor alle milieuproblemen een goede regeling getroffen had moeten worden. De totstandkoming van een nieuwe milieuwet ging immers telkens gepaard met het opbouwen van een bijbehorende organisatie ten behoeve van beleidsvorming, uitvoering en handhaving op het niveau van het Rijk en de andere betrokken overheden, vooral provincies. De diverse milieuwetten maakten het mogelijk in betrekkelijk korte tijd resultaten te boeken, vooral bij de sanering van de meest urgente sectorale milieuproblemen..$^{5}$

Biezeveld geeft echter wel aan dat wat aanvankelijk de kracht van het stelsel van milieuwetten leek te zijn, gaandeweg steeds meer als zwakte van het stelsel werd ervaren. ${ }^{51}$ Eind 1989 schreef Biezeveld dat met de wetsvoorstellen Vergunningen en Algemene Regels (VAR), Dwangsom, Plannen en milieukwaliteitseisen en Afvalstoffen ter verandering van de Wabm een belangrijke stap was gezet in de richting van één, algemene wet voor het milieubeheer. In 2012 was het echter nog steeds niet zover. ${ }^{52}$

\subsection{BUNDELING VAN OMGEVINGSRECHT}

\subsubsection{Algemeen}

Drupsteen merkte al in 1983 op, dat vrijwel vanaf het moment dat er in ons land sprake is van milieubeleid, er wordt geklaagd over het gebrek aan samenhang in dit beleid, waarbij de klachten zich in eerste instantie richtten tegen de onoverzichtelijkheid en verbrokkeling in de snel groeiende milieuwetgeving. ${ }^{53}$ In 2011 merkte hij op dat juristen regelmatig geneigd zijn de bezwaren betreffende het omgevingsrecht (te gecompliceerd, te onoverzichtelijk, te onzeker, te star, te stroperig en te uitvoerig) te relativeren. Drupsteen denkt dat deze relativering terecht naar voren wordt gebracht, maar dat ze het centrale probleem niet wegneemt, want: 'Het omgevingsrecht is inderdaad gecompliceerd. ${ }^{54}$

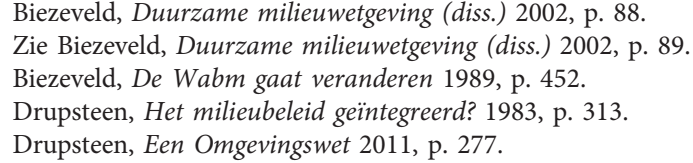


De Nederlandse wetgever heeft in de afgelopen decennia het aantal wetssystemen binnen het omgevingsrecht verminderd als gevolg van bundeling ${ }^{55}$ door integratie ${ }^{56}$ of herschikking. ${ }^{57}$ Hierna zal een aantal voorbeelden worden genoemd. ${ }^{5}$

Op 1 maart 1993 is het wetssysteem van de Hinderwet gebundeld in de Wet milieubeheer. ${ }^{59}$ In 1994 volgden de Wet chemische afvalstoffen en de Afvalstoffenwet. ${ }^{60}$ In 2001 is de discussienota Met recht verantwoordelijk! verschenen, die onder meer als doel had om duidelijkheid te scheppen over de systematiek van de milieuregelgeving. Voorgesteld werd onder meer om 'de milieuwetgeving waarvoor de minister van VROM eerstverantwoordelijk is, te bundelen in de Wet milieubeheer. Hierdoor kan de wetgeving worden vereenvoudigd en een samenhangende aanpak van milieuproblemen worden bevorderd. Wetgeving waarvoor andere ministers eerstverantwoordelijk zijn, kan in beginsel ook in de Wet milieubeheer worden opgenomen, voor zover die wetgeving de bescherming van het milieu of onderdelen daarvan centraal stelt. ${ }^{61}$ In 2008 is de Wet milieugevaarlijke stoffen geïntegreerd in de Wet milieubeheer. ${ }^{62}$

In 1998 zijn in de Flora- en faunawet ${ }^{63}$ gebundeld de Vogelwet 1936, de Jachtwet, de Nuttige Dierenwet 1914 en de Wet bedreigde uitheemse diersoorten, alsmede onderdelen van de toenmalige Natuurbeschermingswet.

55 Zie par. 2.5

56 Zie par. 2.4.4

57 Zie par. 2.4.5.

58 Ook Nijmeijer \& Soppe signaleren dat binnen het omgevingsrecht al langer de tendens bestaat om bestaande wet- en regelgeving te integreren om zo tot een vereenvoudiging van het wettelijke stelsel te komen. Zij noemen de Wabo (2009), de Waterwet (2009) en de plannen om te komen tot een Wet natuurbescherming en een Omgevingswet (Nijmeijer \& Soppe, Alles draait om eenvoud 2011, p. 427).

59 Art. XVII Wet milieubeheer (Stb. 1992, 414 en Stb. 1993, 59). Zie voor een toelichting op deze wet: Van den Broek/De Kok/Meulenberg \& Niezen, De Wet milieubeheer in bedrijf 1992 en Michiels, De Wet milieubeheer 2003.

60 Art. VI Wet van 2 juli 1992, tot uitbreiding en wijziging van de Wet algemene bepalingen milieuhygiëne (afvalstoffen) (Stb. 1993, 283 en 769).

61 Ministerie van VROM, Met recht verantwoordelijk! 2001, p. 10 en 11. In zijn bijdrage aan het themanummer van het Tijdschrift voor Milieu en Recht over deze nota bespreekt Eijlander de nota vanuit het perspectief van een modern en verantwoord wetgevingsbeleid. Hij besteedt met name aandacht aan de vraag hoe de toekomstige milieuwetgeving beter moet en kan aansluiten bij de eigen verantwoordelijkheid van de samenleving voor het milieu. Hij gaat onder meer in op de verhouding en verbinding tussen zelfregulering en wetgeving, de inzet van meer marktgerichte instrumenten en de betekenis van het opnemen van beginselen en zorgplichten in de wetgeving (Eijlander, De nota met recht verantwoordelijk! 2001). Gilhuis merkt naar aanleiding van de nota onder meer op, dat een goede wetgevingskoers oog heeft voor de kracht van de huidige wetgeving en van de nog ongebruikte potenties daarvan, maar ook moet bijsturen waar verandering is vereist (Gilhuis, Met recht verantwoordelijk! 2001, p. 180).

62 Art. IX van de Wet van 16 mei 2007 tot uitbreiding en wijziging van de Wet milieubeheer in verband met de uitvoering van EG-verordening registratie, evaluatie en autorisatie van chemische stoffen (REACH) en de overheveling van de bepalingen van de Wet milieugevaarlijke stoffen naar de Wet milieubeheer, alsmede daarmee samenhangende wijzigingen van andere wetten (Uitvoeringswet EG-verordening registratie, evaluatie en autorisatie van chemische stoffen (REACH)) (Stb. 2007, 181 en 182). Zie ook hfds. 5 van dit onderzoek.

63 Zie art. $123 \mathrm{Ffw}($ Stb. 1998, 402). 
Per 1 januari 2008 zijn in het Besluit algemene regels voor inrichtingen milieubeheer (het zogeheten Activiteitenbesluit) ${ }^{64}$ het Besluit bouwen houtbedrijven milieubeheer, het Besluit detailhandel en ambachtsbedrijven milieubeheer, het Besluit horeca-, sport- en recreatiebedrijven milieubeheer, het Besluit inrichtingen- en motorvoertuigen milieubeheer, het Besluit jachthavens, het Besluit opslaan in ondergrondse tanks 1998, het Besluit opslag- en transportbedrijven milieubeheer, het Besluit tankstations milieubeheer, het Besluit textielreinigingsbedrijven milieubeheer, het Besluit voorzieningen en installaties milieubeheer en het Besluit woon- en verblijfsgebouwen milieubeheer gebundeld.

In 2009 zijn in de Waterwet ${ }^{65}$ de Wet op de waterhuishouding, de Wet op de waterkering, de Grondwaterwet, de Wet verontreiniging oppervlaktewateren, de Wet verontreiniging zeewater, de Wet van 14 juli 1904 (droogmakerijen en indijkingen), de Wet beheer rijkswaterstaatswerken en de Waterstaatswet gebundeld. ${ }^{66}$ Volgens Havekes dateren de eerste pleidooien voor een integrale Waterwet niet uit $1985^{67}$ maar pleitte de Raad van State medio 1981 naar aanleiding van de ontwerp-Wet op de waterhuishouding reeds voor integratie: 'De Raad acht het niet vanzelfsprekend dat het ontwerp niet geïntegreerd behoeft te worden met kwaliteitsregelingen in de Wet verontreiniging oppervlaktewateren en de Grondwaterwet. ${ }^{68}$

Op 1 oktober 2010 is de Wet algemene bepalingen omgevingsrecht (Wabo) in werking getreden. Dit wetssysteem laat bestaande omgevingswetssystemen, waaronder de Wet milieubeheer, grotendeels in stand, maar heeft geleid tot herschikking van de regels die zien op de toestemming voor een plaatsgebonden project dat bestaat uit één of meer activiteiten die van invloed zijn op de fysieke leefomgeving. Als gevolg van de Wabo is voor het uitvoeren van een project vanaf 1 oktober 2010 nog slechts één toestemming nodig, de omgevingsvergunning, die in de plaats is gekomen van 26 tot die datum bestaande toestemmingen van bestuursorganen.

64 Stb. 2007, 415 en 472. Zie voor een beknopte toelichting Van den Broek \& Kortekaas, Wegwijzer Activiteitenbesluit en Landbouwbesluit 2011. Als art. AAA Besluit van 14 september 2012 tot wijziging van het Besluit algemene regels voor inrichtingen milieubeheer (agrarische activiteiten in het Besluit algemene regels voor inrichtingen milieubeheer) (Stb. 2012, 441) - naar verwachting op 1 januari 2013 - in werking is getreden, zal het Besluit algemene regels voor inrichtingen milieubeheer voortaan heten: Activiteitenbesluit milieubeheer (art. 6.45 Activiteitenbesluit). Het zal dan ook de algemene regels bevatten die tot 1 juli 2012 waren opgenomen in het Besluit glastuinbouw, het Besluit landbouw milieubeheer, het Besluit mestbassins milieubeheer, het Lozingenbesluit bodembescherming en het Lozingenbesluit open teelt en veehouderij (Stb. 2012, 441, art. VII). Aangezien over het Ontwerpbesluit houdende wijziging van het Besluit algemene regels voor inrichtingen milieubeheer (agrarische activiteiten in het Besluit algemene regels voor inrichtingen milieubeheer) en ontwerpregeling houdende wijziging van de Regeling algemene regels voor inrichtingen milieubeheer (agrarische activiteiten) (Stcrt. 2010, 21211) advies was gevraagd aan de Raad van State, was die in Nederland geheim, maar als genotificeerde wijziging in Brussel openbaar: ec.europa.eu/enterprise/tris/index_nl.htm.

65 Stb. 2009, 490 (Tekstplaatsing). Zie voor een beknopte toelichting Havekes \& De Putter, Wegwijzer Waterwet 2009.

66 Hfds. 2, art. 2.1 lid 2 Invoeringswet Waterwet (Stb. 2009, 489).

67 Regeringsnotitie Omgaan met water, Kamerstukken II 1984/85, 18 793, nr. 3.

68 Havekes, Het hete (hang)ijzer van de integrale Waterwet 1999, p. 104. 
De Wabo verplicht tot afstemming tussen de aan een omgevingsvergunning verbonden voorschriften ${ }^{69}$ en tussen de omgevingsvergunning en algemene regels, ${ }^{70}$ gelijkwaardige maatregelen ${ }^{71}$ en maatwerkvoorschriften. ${ }^{72}$ Voorts is de samenhang met de watervergunning geregeld. ${ }^{73}$

\subsubsection{Bundeling in Vlaanderen, Duitsland en de Europese Unie}

\subsubsection{Algemeen}

Er zijn ook voorbeelden van bundeling buiten Nederland. Zo werd in 1995 het Voorontwerp Decreet Milieubeleid ${ }^{74}$ gepubliceerd en is in Duitsland gepoogd om een Umweltgesetzbuch ${ }^{75}$ tot stand te brengen. Hierna is van beide ontwerpen een korte toelichting en een verkorte inhoudsopgave opgenomen teneinde een globale indruk te geven van de geregelde onderwerpen. Beide ontwerpen zijn tot stand gebracht onder leiding van vooraanstaande wetenschappers op het gebied van het omgevingsrecht. ${ }^{76}$ Ook binnen de Europese Unie zijn voorbeelden van bundeling te noemen.

De ECWM constateerde eind 2003 dat de integratie van de milieuwetgeving in Vlaanderen, Duitsland, Denemarken, Zweden en Engeland niet veel verder is ontwikkeld dan in Nederland. Alleen in Zweden is bijna alle milieuregelgeving in brede zin (dus inclusief bijvoorbeeld natuur, ontgrondingen, gmo's, waterwerken) in één milieuwetboek terechtgekomen. Maar ook hier is volgens de ECWM van materiële integratie nauwelijks sprake. De verschillende onderdelen staan betrekkelijk los van elkaar. Systematisering van de milieuregelgeving en (mede daardoor) vereenvoudiging van wetgeving is een van de belangrijkste motieven voor het vervangen van een groot aantal wetten en besluiten door een geringer aantal. In de meeste landen gaat het om de 'grijze' milieuwetten, maar natuur valt meestal onder het milieubegrip. In Zweden en het voorstel voor een Umweltgesetzbuch in Duitsland is natuurbeschermingswetgeving geheel geïntegreerd in de (brede) milieuwetgeving. ${ }^{77}$

Rehbinder schrijft: 'Seit den frühen Siebziger Jahren hat die Herausbildung der Umweltpolitik als separates Politikfeld zu intensiver Umweltgesetzgebung geführt. (...) Die Umweltrechtsentwicklung ist sowohl auf nationaler als auf EGEbene Schritt für Schritt und in recht unkoordinierter Form verlaufen. Die Folge ist, dass das Umweltrecht in der Regel eine reichlich amorphe und fragmentierte

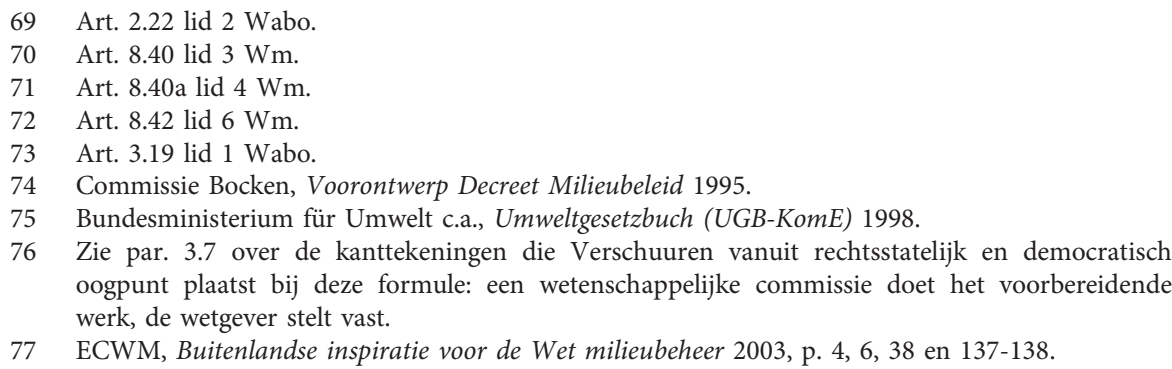

77 ECWM, Buitenlandse inspiratie voor de Wet milieubeheer 2003, p. 4, 6, 38 en 137-138. 
Ansammlung von Gesetzen, Verordnungen und Verwaltungsbestimmungen, EG-Verordnungen und Richtlinien sowie zugehörigem Fallrecht darstellt. (...) Als Reaktion auf die wenig zufrieden stellende Situation hat man in zahlreichen europäischen Staaten die Möglichkeit einer Kodifikation des Umweltrechts diskutiert und sie zum Teil auch verwirklicht. ${ }^{78}$

\subsubsection{Vlaanderen: Voorontwerp Decreet Milieubeleid}

De Vlaamse Regering besloot op 5 juli 1989 tot oprichting van de Interuniversitaire Commissie tot Herziening van het Milieurecht in het Vlaamse Gewest. ${ }^{79}$ Opdracht aan de commissie was 'een voorontwerp van kaderdecreet inzake milieuhygiëne uit te werken en aanbevelingen te doen om de doelmatigheid van het milieuhygiënerecht te vergroten.' Het voorontwerp dat de commissie opstelde tussen 1989 en 1995 is in de eerste plaats een poging tot inhoudelijke codificatie van het Vlaamse milieuhygiënerecht met als doel te komen tot een systematische uiteenzetting van het geheel van rechtsregelen uit het bestreken rechtsgebied, vertrekkende van een duidelijk concept over de doelstellingen en instrumenten van het milieubeleid. Het milieurecht in Vlaanderen nam in enkele decennia een grote vlucht, maar werd niet opgebouwd op een systematische wijze. Het ontwerp poogt de ontbrekende interne samenhang te geven aan het milieurecht. Waar mogelijk tracht het voorontwerp rechtszekerheid en voorspelbaarheid te verzekeren. ${ }^{80,81}$

Het voorontwerp bestaat uit de volgende hoofdstukken: ${ }^{82}$

Deel 1. Inleidende bepalingen

Deel 2. Besturen en adviesorganen betrokken bij het milieubeleid

Deel 3. Vrije toegang tot milieu-informatie

Deel 4. Besluitvorming

Deel 5. Economische en financiële maatregelen

Deel 6. Bedrijfsinterne milieuzorg

Deel 7. Handhaving

Deel 8. Veiligheidsmaatregelen

Deel 9. Herstel van schade door milieuverontreiniging

Deel 10. Water

78 Rehbinder, Kodifikation des Umweltrechts in Europa - Rechtsvergleichende Betrachtungen 2010 p. 89.

79 De Interuniversitaire Commissie tot Herziening van het Milieurecht in het Vlaamse Gewest bestond uit prof. dr. H. Bocken, prof. L. Lavrysen (R.U. Gent), prof. dr. A. de Nauw (V.U.B.), prof dr. M. Boes (K.U. Leuven), prof. dr. W. Lambrechts (U.I.A.) en prof. dr. M.G. Faure (Maastricht University), bijgestaan door een aantal wetenschappelijke medewerkers (Commissie Bocken, Voorontwerp Decreet Milieubeleid 1995, p. III).

80 Commissie Bocken, Voorontwerp Decreet Milieubeleid 1995, p. IX-X.

81 Zie onder meer Bocken, Naar een algemeen kaderdecreet inzake milieuhygiëne? 1991 en Verschuuren, Codificatie van het milieurecht in het Vlaamse Gewest 1996.

82 Commissie Bocken, Voorontwerp Decreet Milieubeleid 1995, p. XIX-XXIV. In bijlage 2 van dit onderzoek zijn per Deel ook Titels en/of Hoofdstukken vermeld om een indruk te geven van de in het ontwerp geregelde onderwerpen. 
Deel 11. Bodem

Deel 12. Afvalstoffen

Deel 13. Geluid

Dat het voorontwerp het niet geheel tot wet heeft gebracht, heeft volgens Lavrysen met name institutionele redenen. Sectorale wetgeving op het gebied van bijvoorbeeld water en bodem was begin oktober 2012 nog niet geïntegreerd. Voor het integreren van natuur-, erfgoed- of ruimtelijke ordeningswetgeving zijn bij zijn weten nimmer plannen geweest. ${ }^{83}$

\subsubsection{Duitsland: Entwurf Umweltgesetzbuch}

In 1998 publiceerde het Bundesministerium für Umwelt, Naturschutz und Reaktorsicherheit het Entwurf der Unabhängigen Sachverständigenkommission zum Umweltgesetzbuch. ${ }^{84}$ De onafhankelijke commissie beoogde met dit in de periode 1992-1997 geschreven ontwerp een aanzet te geven voor een wetsvoorstel. De commissie is overtuigd, 'daß es eine dringende Aufgabe unserer Zeit ist, ein solches Gesetzbuch zur gesamthaften und dauerhaften Sicherung der Umwelt zu schaffen., ${ }^{85}$

Het ontwerp bestaat uit de volgende hoofdstukken: ${ }^{86}$

\section{ALLGEMEINER TEIL}

1. Kapittel: Algemeine Vorschriften

2. Kapittel: Planung

3. Kapittel: Vorhaben

4. Kapittel: Produkte

5. Kapittel: Eingreifende Maßnahmen und Überwachung

6. Kapittel: Betrieblicher Umweltschutz, Umwelthaftung und sonstige ökonomische Instrumente

7. Kapittel: Umweltinformation

8. Kapittel: Grenzüberschreitender Umweltschutz

83 Prof. dr. L. Lavrysen, rechter bij het Belgische Grondwettelijk Hof, tijdens de workshop 'Europese aansluiting; een vergelijking met de Vlaamse aanpak', onderdeel van het Jubileumcongres ter gelegenheid van het 30-jarig bestaan van de Vereniging voor Milieurecht op 4 oktober 2012.

84 Voorzitter was Prof. Dr. Horst Sendler (Präsident des Bundesverwaltungsgerichts a. D.) en vice-voorzitter Prof. Dr. Michael Kloepfer. Leden waren Rechtsanwalt Dr. Manfred Bulling (Regierungspräsident a.D.), Vorsitzender Richter am Bundesverwaltungsgericht Dr. Günther Gaentzsch, Prof. Dr.-Ing. Hubert Peter Johann (Mannesmann AG), Rechtsanwalt Dr. Rüdiger Schweikl (Umweltreferent der Stadt München a.D.), Rechtsanwalt Dr. Dieter Sellner en Prof. Dr. Gerd Winter.

85 Bundesministerium für Umwelt c.a., Umweltgesetzbuch (UGB-KomE) 1998, p. 5-6.

86 Bundesministerium für Umwelt c.a., Umweltgesetzbuch (UGB-KomE) 1998. p. 10-31. In bijlage 3 van dit onderzoek zijn per Kapittel ook de Abschnitte vermeld om een indruk te geven van de in het ontwerp geregelde onderwerpen. 
BESONDERER TEIL

9. Kapittel: Naturschutz, Landschaftspflege und Waldschutz

10. Kapittel: Bodenschutz

11. Kapittel: Gewässerschutz

12. Kapittel: Immissionsschutz und Energieversorgung

13. Kapittel: Kernenergie und Strahlenschutz

14. Kapittel: Verkehrsanlagen und Leitungsanlagen

15. Kapittel: Gentechnik und sonstige Biotechnik

16. Kapittel: Gefährliche Stoffe

17. Kapittel: Abfallwirtschaft

Pogingen om een Umweltgesetzbuch daadwerkelijk tot stand te brengen hebben niet tot resultaat geleid.

In een persbericht van 1 februari 2009 heeft Bundesumweltminister Sigmar Gabriel verklaard: 'Das Umweltgesetzbuch (UGB) ist am Widerstand Bayerns und an mangelnder Kompromissbereitschaft auf Seiten der Union gescheitert.' 'Es wird in Deutschland weiterhin kein einfaches, transparentes und unbürokratisches Umweltrecht aus einem Guss geben; die bestehende Zersplitterung des Rechts bleibt bestehen. ${ }^{87}$

\subsubsection{Europese Unie: Richtlijn industriële emissies}

Ook ten aanzien van Europese wetgeving zijn er voorbeelden van bundeling. ${ }^{88}$ Recent zijn de zogeheten IPPC-richtlijn ${ }^{89}$ en zes andere richtlijnen ${ }^{90}$ met betrekking tot industriële emissies gebundeld in het wetssysteem dat wordt gevormd door de Richtlijn industriële emissies. ${ }^{91}$ In dit verband past

87 www.bmu.de/pressearchiv/16_legislaturperiode/pm/43013.php

88 Dat integratie van omgevingsrecht ook aandacht heeft buiten Europa blijkt onder meer uit: Peeters, Elaborating on integration of environmental legislation: the case of Indonesia 2006.

89 Richtlijn 2008/1/EG van het Europees Parlement en de Raad van 15 januari 2008 inzake geïntegreerde preventie en bestrijding van verontreiniging, ( $P b E U 2008 \mathrm{~L} \mathrm{24/8).} \mathrm{Het} \mathrm{gaat} \mathrm{hier}$ om de herziene versie van Richtlijn 96/61/EEG van de Raad van 24 september 1996 inzake geïntegreerde preventie en bestrijding van verontreiniging (PbEG 1996 L 257/26).

90 Richtlijn 78/176/EEG van de Raad van 20 februari 1978 betreffende de afvalstoffen afkomstig van de titaandioxide-industrie, (PbEG 1978 L 54/19), Richtlijn 82/883/EEG van de Raad van 3 december 1982 betreffende de voorschriften voor het toezicht op en de controle van de milieus die betrokken zijn bij lozingen van de titaandioxide-industrie, (PbEG 1982 L 378/1), Richtlijn 92/ 112/EEG van de Raad van 15 december 1992 tot vaststelling van de procedure voor de harmonisatie van de programma's tot vermindering en uiteindelijke algehele opheffing van de verontreiniging door afval van de titaandioxide-industrie, (PbEG 1992 L 409/11), Richtlijn 1999/13/EG van de Raad van 11 maart 1999 inzake de beperking van de emissie van vluchtige organische stoffen ten gevolge van het gebruik van organische oplosmiddelen bij bepaalde werkzaamheden en in installaties, (PbEG 1999 L 53/54), Richtlijn 2000/76/EG van het Europees Parlement en de Raad van 4 december 2000 betreffende de verbranding van afval, PbEG L 332/91 en Richtlijn 2001/80/EG van het Europees Parlement en de Raad van 23 oktober 2001 inzake beperking van de emissies van bepaalde verontreinigende stoffen in de lucht door grote stookinstallaties, (PbEG 2001 L 309/1).

91 Richtlijn 2010/75/EU van het Europees Parlement en de Raad van 24 november 2010 inzake industriële emissies (geïntegreerde preventie en bestrijding van verontreiniging) (herschikking), (PbEU 2008 L 334/17). 
een uitspraak van voormalig Eurocommissaris Verheugen van Ondernemingen en Industrie: "Om eerlijk te zijn ... het idee dat minder ook meer kan zijn, is voor veel ambtenaren moeilijk te begrijpen. President Barroso had gelijk toen hij over een culturele revolutie sprak. Ik heb grote moeite om Commissieambtenaren het begrip 'betere regelgeving' uit te leggen. Dan vragen ze: 'Betere regelgeving, hoezo beter, is de bestaande regelgeving dan niet goed?' Dan moet ik uitleggen dat - op zichzelf goede - regelgeving ook achterhaald kan zijn, of dat bepaalde regels beter gebundeld kunnen worden of beter afgestemd op burgers en bedrijven."92 Geelhoed meent dat net als dat op een gegeven moment bij de Nederlandse wetgeving het geval was, de Europese milieuwetgeving toe is aan harmonisatie, codificatie en consolidatie. Volgens hem 'kun je wel het een en ander verbeteren, maar nooit zo dat het volledig aansluit op nationale voorkeuren. ${ }^{93}$

\subsubsection{Bundeling in Nederland}

Hiervoor zijn het zogeheten Activiteitenbesluit en het opnemen van de Wet milieugevaarlijke stoffen in de Wet milieubeheer genoemd als recente voorbeelden van bundelen van regelingen op het gebied van omgevingsrecht. Beide wetgevingsoperaties zijn het gevolg van de Herijkingsbrief van 17 oktober $2003 \cdot{ }^{94}$

Daarin staat: 'De ongeveer 15 amvb's op grond van artikel 8.40 Wm (die voor categorieën bedrijven de vergunningplicht vervangen en exploitatievoorschriften bevatten) worden alle of groepsgewijs samengevoegd. Hierdoor kan een betere afstemming tussen de amvb's worden bereikt. Bekeken wordt in hoeverre de voorschriften voor het lozen in de bodem uit het Lozingenbesluit bodembescherming ook in de geïntegreerde amvb('s) kunnen worden opgenomen. In overleg met het Ministerie van VenW zullen algemene regels op grond van de Wet verontreiniging oppervlaktewateren waar mogelijk en doelmatig in de nieuwe algemene regels worden opgenomen, zodat de ondernemer met nog minder regelingen wordt geconfronteerd. Integratie met behoud van bevoegdheden (zoals reeds bijvoorbeeld in het Besluit glastuinbouw heeft plaatsgevonden) is daarbij uitgangspunt. ${ }^{.95}$

En verder: 'Er is een proeve van een nieuw hoofdstuk 9 van de Wet milieubeheer opgesteld ter vervanging van de Wms en van bepalingen over toestellen uit andere wetten zoals de Wet inzake de luchtverontreiniging en de Wet geluidhinder. 'Integratie van de Wms in de Wet milieubeheer wacht op de totstandkoming van de Europese wetgeving ... ${ }^{96}$

92 Eurocommissaris Verheugen, Teveel regelgeving hindert Europese integratie, Forum, 15 maart 2007, p. 13.

93 Geelhoed, Knopen zonder draden 2006, p. 595.

94 Ministerie van VROM, Herijkingsbrief 2003. Zie ook Van den Broek, Samenvatting herijkingsbrief 2003 en Van den Broek, Lex Dekker-Van Geel vergt politieke moed 2004

95 Ministerie van VROM, Herijkingsbrief 2003, p. 25.

96 Ministerie van VROM, Herijkingsbrief 2003, p. 17. 
In de Herijkingsbrief hebben de toenmalige bewindslieden van het toenmalige Ministerie van VROM, minister Dekker en staatssecretaris Van Geel, voorstellen gedaan om te komen tot vereenvoudiging en sanering van de VROM-regelgeving. Deze voorstellen moeten worden gezien in het licht van het Hoofdlijnenakkoord Meedoen, meer werk, minder regels ${ }^{97}$ van het kabinet-Balkenende II. ${ }^{98}$ Daarin wordt veel nadruk gelegd op het verminderen van regelzucht en bureaucratie. In dat kader werd onder meer aangekondigd dat de regelgeving van het Rijk kritisch tegen het licht zal worden gehouden en dat er een taakstelling zou komen voor de verlaging van de administratieve lasten voor bedrijven en burgers.

In de Herijkingsbrief wordt onder de noemer 'uitgangspunten en keuzen bij de samenstelling van de agenda' onder meer gesteld dat de ervaren ingewikkeldheid van en overmaat aan regels nog in de hand worden gewerkt doordat de regels voor een burger of bedrijf moeilijk kenbaar en beschikbaar zijn. Het in elkaar schuiven van meer regelingen over hetzelfde en - als dat niet verder lukt - het maximaal inzetten van ICT in zowel de voorlichting over als de uitvoering van regelgeving (registraties via internet) mogen, aldus de regering, misschien niet het aantal regels verminderen, maar zouden wel degelijk bijdragen aan het verminderen van de regeldruk. ${ }^{99}$

Het eindoordeel van Gilhuis over de gepresenteerde herijkingsplannen is niet gunstig, aangezien de herijking volgens hem plaats vindt zonder dat er een goede probleemanalyse is gemaakt en te breed is opgezet. Hij meent dat het beperken van administratieve lasten niet te veel als doel op zichzelf moet worden gezien. Met name het Activiteitenbesluit heeft geleerd, dat die nadruk op administratieve lasten er zijns inziens voor heeft gezorgd dat minder oog bestaat voor kenbaarheid van dat wetssysteem. ${ }^{100}$ Interessant voor mijn onderzoek is verder dat Gilhuis zich in een andere publicatie afvraagt waarom de herijking voorlopig blijft beperkt tot wetgeving van het Ministerie van VROM. 'Is de samenhang met bijvoorbeeld water- en natuurbeschermingswetgeving van andere ministeries voor de burger niet minstens zo relevant?'101

Onder de concrete voorstellen neemt de integratie van VROM-regelgeving een vooraanstaande plaats in. De genoemde bewindslieden schrijven: 'Binnen de VROM-wetgeving zou echter al duidelijke winst kunnen worden geboekt door een vergaande integratie van de grote VROM-wetten: de Woningwet, de Wet op de Ruimtelijke Ordening (WRO) en de Wet milieubeheer (Wm). Dat is echter iets dat niet op korte termijn kan worden bereikt. ${ }^{102}$ In dit verband wordt in het kader van de keus voor een integrale

97 Hoofdlijnenakkoord van het kabinet van CDA, VVD, D66 d.d. 16 mei 2003.

98 Beëdigd op 27 mei 2003. Op 30 juni 2006 diende dit kabinet zijn ontslag in.

99 Ministerie van VROM, Herijkingsbrief 2003, p. 10.

100 Gilhuis, Naar minder of naar betere regelgeving in het milieurecht? 2004, p. 203.

101 Gilhuis, Herijken 2004.

102 Ministerie van VROM, Herijkingsbrief 2003, p. 11. 
omgevingsvergunning opgemerkt, dat dit uiteindelijk zal leiden tot 'een vergaande integratie van de betrokken wetgevingscomplexen, te beginnen met de grote VROM-wetten.' Bij de integratie passen volgens de betrokken bewindslieden ook geïntegreerde regels over andere onderwerpen, zoals de subsidieverlening. Zo zou het onderbrengen van de gemeenschappelijke bepalingen over de VROM-subsidieregelingen in één regeling kunnen bijdragen aan een verdere uniformering. ${ }^{103}$

Rademaker merkt in dit verband op: "De stomste fout die de wetgever ooit heeft gemaakt is het lostrekken van de ruimtelijke ordening uit de Woningwet in 1965. Het bouwen is achtergebleven in de Woningwet terwijl de ontwikkeling van de ruimtelijke ordeningswetgeving in een aparte wet werd opgenomen. Daar is het denk ik fout gegaan." ${ }^{104}$ Ik kan niet beoordelen of de wetgever hier werkelijk 'de stomste fout' heeft gemaakt, maar interessant is wel dat Rademaker in feite zegt dat de wetgever in 1965 samenhangende regels niet over twee wetssystemen had moeten verdelen.

De Herijkingsbrief gebruikt een aantal omschrijvingen om het bundelen van regelingen aan te geven, zoals inbouwen, samenvoegen, overhevelen, bundelen, samenbrengen, opnemen in een andere regeling en in één besluit meenemen. In bijlage 4 bij dit onderzoek zijn de relevante passages weergegeven.

Op het moment dat dit onderzoek werd afgesloten, bestonden er twee initiatieven van het demissionaire kabinet Rutte-Verhagen ${ }^{105}$ op het gebied van bundeling van omgevingsrecht. De minister van Economische Zaken, Landbouw en Innovatie ${ }^{106}$ is voornemens om de Natuurbeschermingswet 1998, de Flora- en faunawet en de Boswet te herschikken tot een Wet Natuurbescherming. ${ }^{107}$ Dit voornemen zal in hoofdstuk 6 uitgebreid aan de orde komen. De minister van Infrastructuur en Milieu heeft aangekondigd in het voorjaar van 2013 een wetsvoorstel naar de Tweede Kamer te sturen dat de aanzet beoogt te zijn voor een Omgevingswet. ${ }^{108}$ Dit voornemen zal in hoofdstuk 7 worden besproken.

103 Ministerie van VROM, Herijkingsbrief 2003, p. 15

104 Rademaker, Interview 2011, bijl. 5.2, par. 1.1.

105 Beëdigd op 14 oktober 2010. Op 23 april 2012 werd het ontslag aangeboden.

106 De voormalige ministeries van LNV en van Economische Zaken (EZ) zijn samengevoegd tot het Ministerie van Economische Zaken, Landbouw en Innovatie (ELenI); zie Besluit opheffing Ministeries van Economische Zaken en Landbouw, Natuur en Voedselkwaliteit en instelling Ministerie van Economische Zaken, Landbouw en Innovatie, Stcrt. 2010, nr. 16584

107 Zie daarover hfds. 6 van dit onderzoek. Zie ook internetconsultatie.nl/wetnatuur voor de internetconsultatie d.d. 6 oktober 2011.

108 Ministerie van IenM, Kabinetsbrief stelselherziening omgevingsrecht 2012, p. 25. 
In 2010 zijn de toenmalige ministeries van Volkshuisvesting, Ruimtelijke Ordening en Milieubeheer (VROM), Landbouw, Natuur en Voedselkwaliteit (LNV) en Verkeer en Waterstaat (VenW) ${ }^{109}$ in afstemming met het toenmalige Ministerie van Justitie gestart met een bezinning op de gewenste toekomstige ontwikkeling van het omgevingsrecht. Daarbij staat de ontwikkeling van een stelsel van samenhangend en toekomstbestendig omgevingsrecht centraal. ${ }^{110}$ De aanleiding voor deze bezinning wordt gevormd door het in brede kring als te complex ervaren bestaande stelsel van omgevingsrecht. Die complexiteit leidt in de ogen van veel gebruikers van het omgevingsrecht tot lange doorlooptijden bij de ontwikkeling van gebieden, bestuurlijke onzekerheid, het onbenut laten van mogelijkheden voor integrale kwaliteit, juridisch getouwtrek, gebrek aan transparantie en ergernis en kosten voor burgers en bedrijven. ${ }^{111}$ Bij de start van de bezinning heeft de rijksoverheid een aantal deskundigen gevraagd om in een essay de contouren te ontwerpen van een realistisch stelsel van omgevingsrecht dat recht doet aan de wens in de maatschappij om de inrichting van de fysieke leefomgeving op een snellere, doorzichtigere en eenvoudigere wijze aan de maatschappelijk gewenste kwaliteit van de fysieke leefomgeving te kunnen aanpassen. ${ }^{112}$

In het Regeerakkoord VVD-CDA van het kabinet Rutte-Verhagen staat dat het kabinet met voorstellen komt om de milieuregelgeving te vereenvoudigen en te moderniseren. ${ }^{113}$ In lijn daarmee presenteerden de bewindslieden van Infrastructuur en Milieu namens het kabinet op 26 november 2010 in een beleidsbrief $^{114}$ drie hoofdlijnen van de agenda voor de kabinetsperiode. Voor deze studie is in het bijzonder relevant wat het kabinet samenvat als krachtige uitvoering: vereenvoudigen van regelgeving en procedures en sturen op voortgang van projecten. Onder het kopje 'Vereenvoudiging en bundeling omgevingsrecht' wordt aangegeven dat het van groot belang blijft om het omgevingsrecht te hervormen en verdergaand te vereenvoudigen. Daarbij wordt

109 Op 14 oktober 2010 zijn de voormalige ministeries van VROM en van VenW samengevoegd tot het Ministerie van Infrastructuur en Milieu (IenM); zie Besluit opheffing ministeries van Volkshuisvesting, Ruimtelijke Ordening en Milieubeheer en van Verkeer en Waterstaat en instelling Ministerie van Infrastructuur en Milieu, Stcrt. 2010, nr. 16525.

110 Ministerie van VROM, Opdracht essays 2010, p. 1. Zie ook Borgers \& Van der Heijden, Het recht op duurzame gebiedsexploitatie 2010, p. 32

111 Kortmann noemt - overigens in een andere context - nog een ander mogelijk gevolg van een ingewikkeld regelcomplex: 'Als het regelcomplex te ingewikkeld en ondoorgrondelijk is geworden, houdt men zich eenvoudig niet meer aan de regels.' Kortmann, Ontregeling 1993, p. 1376. Zie in gelijke zin ook Bundesministerium für Umwelt c.a., Umweltgesetzbuch (UGB-KomE) 1998, p. 74: 'Eine Kodifikation, die die Regelungsstrukturen strafft und vereinheitlicht, kann die Überschaubarkeit des Rechts beträchtlich erhöhen und seine instrumentelle Zielgenauigkeit steigern. Eine verbesserte Vollzugseignung des Rechts trägt auch dazu bei, seine Akzeptanz beim Bürger zu steigern und dessen Bereitschaft zu fördern, das Recht zu befolgen.' Van Gestel meent dat het vooral bij gedragsbeïnvloedende (modificerende) wetgeving van belang is dat de boodschap van de wetgever ook overkomt, omdat dit een elementaire voorwaarde voor naleving vormt (Van Gestel, Eenieder wordt geacht de wet te kennen 1998)

112 Aldus het voorwoord in Ministerie van IenM, Bezinning op het omgevingsrecht 2010. Op p. 259 van deze publicatie wordt ten onrechte aangegeven dat is gevraagd om een essay te schrijven over de relatie tussen het omgevingsrecht en gebiedsontwikkeling.

113 Vrijheid en verantwoordelijkheid, 30 september 2010, p. 30.

114 Ministerie van IenM, Beleidsbrief Infrastructuur en Milieu 2010, p. 5 en 6. 
onder meer genoemd het brengen van samenhang in sectorale regels, wetten en procedures.

In vervolg daarop heeft de minister van Infrastructuur en Milieu op 23 maart 2011 aangekondigd te streven naar een Raamwet omgevingsrecht, ${ }^{115}$ welk streven in haar beleidsbrief van 28 juni 2011 is omgezet in het plan om begin 2012 te komen met een wetsvoorstel voor een Omgevingswet, ${ }^{116}$ waarin 60 wetten op het gebied van het omgevingsrecht zouden moeten worden gebundeld. In haar brief van 9 maart 2012 aan de Tweede Kamer heeft de minister van Infrastructuur en Milieu aangegeven dat in de Omgevingswet in ieder geval 15 wetten $^{117}$ geheel worden geïntegreerd. Daarnaast worden twee wetten volledig ingetrokken ${ }^{118}$ en worden uit circa 25 andere wetten ${ }^{119}$ de omgevingsrechtelijke elementen overgenomen in de Omgevingswet. ${ }^{120}$

Zoals hiervoor is opgemerkt, is de Nederlandse wetgever in het recente verleden al een aantal malen overgegaan tot bundeling van omgevingsrecht (Waterwet, Wet algemene bepalingen omgevingsrecht en Activiteitenbesluit) of bestaat daartoe het voornemen (Wet natuurbescherming en Omgevingswet). Er bestaan dus kennelijk een politieke wens en politiek draagvlak $^{121}$ om omgevingswetten te bundelen. Hierna zal worden aangegeven welke redenen in de politiek onder meer worden genoemd om tot bundeling over te gaan.

115 Ministerie van IenM, Kabinetsbrief Raamwet Omgevingsrecht 2011.

116 Ministerie van IenM, Beleidsbrief Eenvoudig Beter 2011.

117 Belemmeringenwet Privaatrecht, Crisis- en herstelwet, Interimwet stad-en-milieubenadering, Ontgrondingenwet, Planwet verkeer en vervoer, Spoedwet wegverbreding, Tracéwet, Waterwet, We algemene bepalingen omgevingsrecht, Wet beheer rijkswaterstaatswerken, Wet bodembescherming, Wet geluidhinder, Wet inzake de luchtverontreiniging, Wet milieubeheer en Wet ruimtelijke ordening (Ministerie van IenM, Kabinetsbrief stelselherziening omgevingsrecht 2012, bijlage 1).

118 Wet ammoniak en veehouderij en Wet geurhinder en veehouderij (Ministerie van IenM, Kabinetsbrief stelselherziening omgevingsrecht 2012, bijlage 1).

119 Gaswet, Elektriciteitswet 1998, Lokaalspoor- en Tramwegwet/Wet lokaal spoor, Monumentenwet 1988, Mijnbouwwet, Onteigeningswet, Spoorwegwet, Spoorwegwet 1875, Waterstaatswet 1900 Woningwet, Wegenwet, Wet aanvullende regels wegtunnels, Wet bereikbaarheid en mobiliteit, Wet voorkeursrecht gemeenten, Wet herverdeling wegenbeheer, Wet kabelbaaninstallaties, Wet kenbaarheid publiekrechtelijke beperkingen onroerende zaken, Wet luchtvaart, Wet natuurbescherming (Boswet, Flora- en faunawet, Natuurbeschermingswet 1998), Wet voorkoming verontreiniging door schepen, Wrakkenwet en Zwemwaterwet (Wet hygiëne veiligheid badinrichtingen en zwemgelegenheden) (Ministerie van IenM, Kabinetsbrief stelselherziening omgevingsrecht 2012, bijlage 1).

120 Ministerie van IenM, Kabinetsbrief stelselherziening omgevingsrecht 2012, p. 1.

121 Op 21 april 2012 werd bekend dat het kabinet Rutte-Verhagen als gevolg van het mislukken van de Catshuisonderhandelingen in het najaar van 2012 nieuwe verkiezingen zou moeten uitschrijven. Het is nog niet duidelijk welke gevolgen dat heeft voor de Omgevingswet en het op 20 augustus 2012 ingediende wetsvoorstel Regels ter bescherming van de natuur (Wet natuurbescherming) (Kamerstukken II 2011/12, 33 348, nr. 1-3). Van der Velden merkt op dat ook bij wetgeving geldt dat sneller niet per definitie beter is. Hij acht het verstandig om voor de nieuwe Omgevingswet voldoende tijd te nemen (Van der Velden, Sneller is niet altijd beter 2012). 


\subsection{REDENEN VOOR BUNDELING VAN OMGEVINGSRECHT}

1.3.1. Genoemde voordelen van bundeling

\subsubsection{Algemeen}

Hiervoor zagen we dat de Herijkingsbrief een lans breekt voor het bundelen van omgevingsrecht. De opstellers van die brief zien een aantal mogelijke voordelen in bundeling zoals het vereenvoudigen van het omgevingsrecht, het verminderen van de regeldruk en het vergroten van de kenbaarheid van het omgevingsrecht. ${ }^{122}$ In het kader van de in paragraaf 1.2 genoemde bundelingswetgeving (Activiteitenbesluit, Waterwet, Wabo, Wet natuurbescherming en Omgevingswet) noemen de opstellers een aantal redenen voor en mogelijke voordelen van bundeling. Hetzelfde geldt ten aanzien van de Richtlijn industriële emissies, het Voorontwerp Vlaams Milieudecreet en het ontwerp-Umweltgesetzbuch. Het valt op dat genoemde opstellers eigenlijk nauwelijks mogelijke nadelen van bundeling naar voren brengen.

In de paragrafen 1.3.1.2-1.3.1.8 zal ik de belangrijkste genoemde voordelen van bundeling aanstippen. ${ }^{123}$ In paragraaf 1.3 .2 zal ik de gevonden ecologische en economische voordelen noemen. In paragraaf 1.3.3 komen de gevonden juridische voordelen aan de orde.

\subsubsection{Activiteitenbesluit}

In de nota van toelichting op het Activiteitenbesluit worden de vereenvoudiging en vermindering van de regelgeving als voordelen van deze bundeling genoemd, alsmede de reductie van administratieve lasten die uit de rijksregelgeving voortvloeien. De modernisering van de algemene regels levert volgens de nota van toelichting niet alleen effectievere en uniformere regels op. Door het laten vervallen van de vergunningplicht voor een groot aantal inrichtingen en het verminderen van de meet-, registratie- en onderzoeksverplichtingen, levert het Activiteitenbesluit ook een belangrijke bijdrage aan het voornemen om de administratieve lasten met $25 \%$ te reduceren. De nieuwe algemene regels en hun grotere toepassingsbereik leiden volgens de nota ook 'tot een verbeterde uitvoering en handhaving en daarmee tot een doeltreffender bescherming van het milieu. Tegelijk leveren zij een efficiencywinst op in de vorm van een aanzienlijke reductie van de administratieve lasten, waarbij de bestuurlijke lasten niet toenemen. Het bovenstaande leidt ertoe dat het logischer is om algemene regels op te stellen voor activiteiten, in plaats van per branche min of meer dezelfde regels te stellen. De 8.40besluiten ${ }^{124}$ kenden veelal gelijke regels voor verschillende branches. Het

122 Ministerie van VROM, Herijkingsbrief 2003, p. 10.

123 De cursiveringen in de citaten in par. 1.3 zijn grotendeels van mij, JvdB.

124 Algemene maatregelen van bestuur op basis van art. $8.40 \mathrm{Wm}$. 
reguleren van activiteiten is dan een logische vervolgstap. Uit de praktijk is bovendien gebleken dat bij toezicht en handhaving door het bevoegd gezag de activiteiten van inrichtingen centraal staan. Ook voor inrichtingen is deze insteek herkenbaar. Om in de toekomst meer inrichtingen onder de algemene (milieu)regels te kunnen brengen, is regulering op activiteiten een relatief eenvoudige wijze. ${ }^{125}$

Bij de formulering van de uitgangspunten voor modernisering van algemene regels noemt de nota van toelichting voorts een aantal eisen waaraan de te bundelen algemene regels zouden moeten voldoen. Zo moeten de nieuwe algemene regels relevante en herkenbare milieudoelen dienen. Activiteiten met een geringe milieubelasting worden niet of slechts globaal gereguleerd. ${ }^{126}$ 'De nieuwe algemene regels moeten goed uitvoerbaar en handhaafbaar zijn. Dit betekent voor de inhoud van de voorschriften onder meer dat ze helder, eenduidig en ook voor kleine inrichtingen hanteerbaar dienen te zijn.'127 'Dit besluit moet voorts het bevoegd gezag voldoende mogelijkheden bieden om effectief toezicht te kunnen houden en zo nodig te kunnen handhaven.' (...) 'De nieuwe algemene regels zijn zoveel mogelijk uniform, maar bieden ook ruimte voor flexibiliteit en innovatie. Waar nodig is er ruimte voor maatwerk en/of gebiedsgerichte normering. In beginsel worden dezelfde activiteiten die binnen verschillende bedrijfstakken plaatsvinden, gelijk geregeld met dezelfde voorschriften. Rechtszekerheid, rechtsgelijkheid en een effectieve uitvoering, naleving en handhaving zijn hierbij gebaat. Het bedrijfsleven en de overheden hebben op dit punt behoefte aan duidelijkheid en zekerheid. De regels laten waar mogelijk de vrijheid om andere middelen te gebruiken om de voorschriften na te leven, zodat innovatie wordt bevorderd. ${ }^{128}$ Uit de nieuwe algemene regels vloeien aanzienlijk minder administratieve lasten voort.' In dat verband wordt opgemerkt, dat is toegezegd om $€ 216$ miljoen te besparen zonder een toename van de bestuurlijke lasten. ${ }^{129}$

\subsubsection{Waterwet}

In de memorie van toelichting op de Waterwet $^{130}$ wordt opgemerkt dat naast een integrale aanpak per stroomgebied en een goede bestuurlijke

125 Activiteitenbesluit, NvT, p. 103-104

126 Voor een aantal activiteiten is daarom afgezien van het stellen van regels of zijn er ondergrenzen aangebracht, waardoor inrichtingen met een geringe milieurelevantie slechts met een beperkt aantal voorschriften te maken krijgt (Activiteitenbesluit, NvT, p. 104).

127 Daar waar dit lastig is, biedt ICT ondersteuning (Activiteitenbesluit, NvT, p. 104).

128 Voor de meeste inrichtingen kan volstaan worden met de algemene regels, maar in een aantal gevallen zijn specifieke voorschriften nodig. Dit heeft te maken met de omgeving waarin de inrichting zich bevindt, in combinatie met de specifieke activiteiten die in een inrichting worden verricht. Daarom bieden de algemene regels waar nodig mogelijkheden voor het bevoegd gezag om voorschriften verder te verbijzonderen met maatwerkvoorschriften of, met het oog op specifieke, plaatselijke of regionale milieuomstandigheden, een afwijkende normering in een gemeentelijke verordening op te nemen. Naar verwachting zal hier terughoudend gebruik van worden gemaakt (Activiteitenbesluit, NvT, p. 104).

129 Activiteitenbesluit, NvT, p. 104.

130 Regels met betrekking tot het beheer en gebruik van watersystemen (Waterwet), Kamerstukken II 2006/07, 30 818, nr. 3 . 
organisatie ook het wettelijke instrumentarium van groot belang is. De regering merkt op, dat al een aantal jaren wordt onderkend dat de waterwetgeving is achtergebleven bij de ontwikkelingen in het waterbeheer. De waterwetgeving is verbrokkeld en op diverse onderdelen verouderd en kenmerkt zich bovendien door het feit dat de afzonderlijke wetten doorgaans slechts betrekking hebben op één aspect van het waterbeheer. In dat verband wordt - kennelijk met instemming - verwezen naar de conclusie van de Commissie van Advies inzake de Waterstaatswetgeving ${ }^{131}$ 'dat de wetgeving niet meer voldoet aan algemene wetgevingseisen van transparantie, samenhang en consistentie en dat er voldoende aanleiding is om tot herziening en integratie van de waterwetgeving over te gaan. ${ }^{132}$ Kennelijk is de wetgever van oordeel dat een of meer van de genoemde juridische nadelen zullen worden verbeterd of opgelost met de bundeling van de hiervoor ${ }^{133}$ reeds genoemde acht wetten op het gebied van water. Het is echter opvallend dat dat niet expliciet in de memorie van toelichting is gemotiveerd.

\subsubsection{Wabo}

In de memorie van toelichting op de Wabo wordt onder meer aangegeven dat de Wabo circa 25 toestemmingen (vergunningen, ontheffingen en meldingen) integreert in één omgevingsvergunning. Als gevolg daarvan moet de dienstverlening aan burger en bedrijf verbeteren. De samenvoeging van deze toestemmingen moet ook leiden tot een omvangrijke vermindering van het aantal toestemmingen en een daarmee overeenkomende vermindering van administratieve lasten. ${ }^{134}$ De omgevingsvergunning biedt volgens de memorie van toelichting ook impulsen om te komen tot een organisatieverbetering en samenwerking binnen en tussen overheden. De omgevingsvergunning noodzaakt tot een goede organisatie van het omgevingsloket (frontoffice) en een goede organisatie en samenwerking tussen overheden achter dat loket (backoffice). ${ }^{135}$

\subsubsection{Wet natuurbescherming}

De minister van ELenI schrijft in de concept-memorie van toelichting op het ontwerp voor een Wet natuurbescherming onder meer: 'Het onderhavige wetsvoorstel strekt tot vervanging van het huidige wettelijke stelsel voor de natuurbescherming, als neergelegd in de Natuurbeschermingswet 1998, de

131 Commissie van Advies Waterstaatswetgeving, Die op water is, moet varen ... 2002, p. 2.

132 Kamerstukken II 2006/07, 30 818, nr. 3, p. 4.

133 Par. 1.2.1.

134 Onderzoek van SIRA Consulting (Nieuwegein, januari 2006) constateert dat omgevingsvergunning kan leiden tot 200.000 minder vergunningen per jaar voor burgers en bedrijven en een reductie van administratieve lasten van $€ 33$ miljoen.

135 Kamerstukken II 2006/07, 30 844, nr. 3, p. 3. Zie verder hfds. 4. 
Flora- en faunawet en de Boswet. Het nieuwe stelsel is eenvoudiger, sluit nauwkeurig en herkenbaar aan bij de internationale verplichtingen, legt taken en verantwoordelijkheden zoveel mogelijk decentraal, namelijk bij de provincies, bevordert - overeenkomstig de voornemens ten aanzien van het omgevingsrecht - ontwikkelingsgericht werken en integrale oplossingen en bevordert een goede balans tussen ecologie, economie en samenleving. ${ }^{136}$

\subsubsection{Omgevingswet}

Het Ministerie van IenM vraagt om een realistisch stelsel van samenhangend en toekomstbestendig omgevingsrecht dat volgens het Rijk recht doet aan de wens in de maatschappij om de inrichting van de fysieke leefomgeving op een snellere, doorzichtigere en eenvoudigere wijze aan de maatschappelijk gewenste kwaliteit van de fysieke leefomgeving te kunnen aanpassen. ${ }^{137}$ De minister van IenM is van oordeel dat een Omgevingswet ${ }^{138}$ onder meer zal leiden tot het inzichtelijker maken van de wettelijke kaders voor burgers, ondernemers en overheden, en het beter beheersbaar maken van ontwikkeling en beheer van de leefomgeving. Een eenvoudiger en beter samenhangend omgevingsrecht draagt er volgens de minister vervolgens aan bij om actiever en efficiënter aan een dynamische en duurzame leefomgeving te kunnen werken. Onderwerpen die in de nieuwe wet worden geregeld verdwijnen uit de bestaande wetgeving; daartoe worden (delen van) bestaande wetten ingetrokken. De nieuwe wet zal daarmee volgens de minister een aanzienlijke reductie van regels, wetten en regelingen op het terrein van de fysieke leefomgeving betekenen. ${ }^{139}$ In hoofdstuk 7 wordt ingegaan op de door het kabinet voorgestelde contouren van een Omgevingswet.

Eind 2011 brachten de vijf door de minister van IenM ingestelde Adviesgroepen Modernisering Omgevingsrecht elk een advies uit. ${ }^{140}$ Daarnaast brachten zij een gezamenlijk advies uit. ${ }^{111}$ In het gezamenlijk advies wordt als doel van de

136 Ontwerp Wnb, concept-MvT, p. 6. Zie daarover hfds. 6 en verder internetconsultatie.nl/wetnatuur voor de internetconsultatie d.d. 6 oktober 2011.

137 Ministerie van VROM, Opdracht essays 2010. Naar aanleiding van dit voornemen heb ik gepleit voor samenhang, eenvoud en een integrale benadering (Van den Broek, Omgevingswet eenvoudig beter 2011).

138 Op 19 januari 2010 hield de toenmalige premier Balkende in Zoetermeer tijdens het Bouwhuisdebat een pleidooi voor één omgevingswet en één instrument voor de leefomgeving (Verbraeken, Eén omgevingswet 2010).

139 Ministerie van IenM, Beleidsbrief Eenvoudig Beter 2011, p. 2.

140 Adviesgroep Natuur, Borging, beweging en betrokkenheid 2011. Adviesgroep Milieu, Energie en Duurzaamheid, Regels die helpen 2011, Adviesgroep Verkeer en Vervoer, Voor een beter Nederland 2011, Adviesgroep Water, Naar één ge(s)laagde Omgevingswet 2011, Adviesgroep Wonen en Cultuur, Naar een vereenvoudigd en gebundeld Omgevingsrecht 2011.

141 Adviesgroepen Modernisering Omgevingsrecht, Gezamenlijk advies 2011. 
Omgevingswet genoemd een duurzame bescherming van de fysieke leefomgeving en van de mensen die in deze omgeving leven. Verder zijn 10 uitgangspunten voor de Omgevingswet geformuleerd:

1. De wet moet, conform de doelstelling van het omgevingsrecht, zijn gestoeld op een algemene zorgplicht voor de bescherming van de leefomgeving. De Omgevingswet moet in principe bijdragen aan de verbetering van de kwaliteit van de fysieke leefomgeving en moet leiden tot grotere transparantie en tot grotere betrokkenheid van burgers en bedrijven.

2. In de Omgevingswet moet alle (inhoudelijke) regelgeving, die te maken heeft met de fysieke leefomgeving, worden ondergebracht.

3. Het Europees recht is uitgangspunt voor de Omgevingswet. Waar mogelijk worden de richtlijnen overgenomen zonder verdere vertaling of uitwerking. Er dient aangesloten te worden bij de terminologie van het Europese recht.

4. Waar mogelijk wordt een programmatische aanpak gehanteerd.

5. Integratie van toetsingskaders (zoals gezondheid, veiligheid, ecosysteem, leefbaarheid, natuur en culturele waarden) naar één afwegingskader: bij een beslissing over een project of gebied alle aspecten van de leefomgeving in samenhang afwegen.

6. Een heldere verdeling van verantwoordelijkheden, waarbij sprake is van een hiërarchie van bestuursorganen en waarbij per initiatief één bestuursorgaan verantwoordelijk is voor afwegingen en voor samenhangende besluitvorming (conform systematiek Wro).

7. Regels over voorbereiding van besluiten, bezwaar, (hoger) beroep, toezicht en handhaving moeten op één plek (in één wet) worden vastgelegd.

8. Verminderen van onderzoekslast, gegeven de enorme onzekerheidsmarges, en een regeling voor de houdbaarheid van onderzoeksuitkomsten. Alle bestaande onderzoeksverplichtingen zouden geharmoniseerd en geabstraheerd op één plek (in één wet) moeten worden opgenomen.

9. Voorkeur voor algemene regels boven individuele toestemming volgens de ladder (voorkeursvolgorde): zorgplicht, algemene regels en vergunningplicht.

10. Ruimte bieden voor verbetering om een duurzame leefomgeving te bereiken, onder meer door experimenteerruimte en flexibele toetsingskaders (bijvoorbeeld stand still, step forward).

Een voor mijn onderzoek belangrijk uitgangspunt is dat alle inhoudelijke regelgeving die te maken heeft met de fysieke leefomgeving in de Omgevingswet moet worden ondergebracht.

\subsubsection{Voorontwerp Decreet Milieubeleid}

Uit de opdracht aan de Interuniversitaire Commissie tot Herziening van het Milieurecht in het Vlaamse Gewest blijkt dat de Vlaamse Regering een voorontwerp van kaderdecreet inzake milieuhygiëne voorstaat om de doelmatigheid van het milieuhygiënerecht te vergroten. Meer bepaald betrof het 'een rationalisatie en vereenvoudiging van de milieuwetgeving' en 'een efficiënter gebruik van geëigende milieubeleidsinstrumenten zoals onder meer kwaliteitsdoelstellingen, controle op bronnen van verontreiniging, heffingen en andere economische maatregelen, veiligheidsmaatregelen en 
saneringswerken, integratie van milieuaspecten in andere beleidsdomeinen, milieubeleidsplanning.' Voorts vroeg de Vlaamse Regering naar 'verhoging van de doelmatigheid van de strafrechtelijke en andere middelen tot handhaving van het milieurecht.' ${ }^{142}$

De commissie gaat expliciet in op mogelijke voordelen van een Voorontwerp Decreet Milieubeleid. ${ }^{143}$

In de eerste plaats is het voorontwerp 'een poging tot inhoudelijke codificatie van het Vlaamse milieuhygiënerecht. Het doel daarbij is te komen tot een systematische uiteenzetting van het geheel van de rechtsregelen uit het bestreken rechtsgebied, vertrekkende van een duidelijk concept over de doelstellingen en instrumenten van het milieubeleid.'

In de tweede plaats poogt het voorontwerp 'de ontbrekende interne samenhang te geven aan het milieurecht.'

Dat was volgens de commissie nodig omdat 'het milieurecht in Vlaanderen niet op een systematische wijze werd opgebouwd', maar daarentegen veelal accidenteel groeide. 'Nieuwe wetgeving was dikwijls als reactie op een of ander concreet incident of op verplichtingen van internationale of Europeesrechtelijke aard. Van een globale en samenhangende aanpak van de verschillende deelproblemen was er zelden sprake. Het milieurecht werd dan ook sterk sectoraal uitgebouwd. Het ontbreken van eenvormigheid in de regelen betreffende de organisatie van de besluitvorming en de handhaving maakte het sectorale milieurecht overbodig complex.'

In de derde plaats wil de commissie 'het milieurecht meer doeltreffend maken en een grotere slagkracht geven, zonder de economische impact en de maatschappelijke aanvaardbaarheid ervan uit het oog te verliezen.'

In de vierde plaats zegt de commissie 'naast deze inhoudelijke doelstellingen ook de juridische kwaliteit van het milieurecht voor ogen te hebben gehad. Waar mogelijk tracht het voorontwerp rechtszekerheid en voorspelbaarheid te verzekeren.'

\subsubsection{Entwurf Umweltgesetzbuch}

De Sachverständigenkommission besteedt expliciet aandacht aan de mogelijke voordelen van een Umweltgesetzbuch in de paragraaf Zur Rechtfertigung einer Kodifikation. ${ }^{144}$ De zin van codificatie is met name gelegen in het antwoord op de vraag 'ob sie auch aus rechtlichen und ökologischen Gründen Vorteile bietet.' Naar de overtuiging van de commissie 'kann nur ein Umweltgesetzbuch das Umweltrecht harmonisieren, vereinfachen und auf eine dauerhafte Grundlage stellen (a) und dabei zugleich Impulse für

142 Commissie Bocken, Voorontwerp Decreet Milieubeleid 1995, p. IX.

143 Commissie Bocken, Voorontwerp Decreet Milieubeleid 1995, p. IX-X

144 Zie ook Bundesministerium für Umwelt c.a., 10 gute Gründe für ein Umweltgesetzbuch 2007 en Kloepfer, Sinn und Gestalt des kommenden Umweltgesetzbuchs 2007. 
eine Verbesserung des Umweltschutzes (b) geben.'145 'Eine Kodifikation, die die Regelungsstrukturen strafft und vereinheitlicht, kann die Überschaubarkeit des Rechts beträchtlich erhöhen und seine instrumentelle Zielgenauigkeit steigern. Eine verbesserte Vollzugseignung des Rechts trägt auch dazu bei, seine Akzeptanz beim Bürger zu steigern und dessen Bereitschaft zu fördern, das Recht zu befolgen.' 'In einer Kodifikation aus einem Guß können ältere Umweltfachgesetze wie das Wasserhaushaltsgesetz und das Atomgesetz begrifflich und systematisch an die modernen Umweltgesetze angepaßt werden. Dabei wird es möglich für gleichgelagerte Sachfragen einheitliche Regelungsebenen zu wählen. (...) Eine Reihe weniger bedeutender Fragen kann einheitlich an den Verordnungsgeber delegiert werden. Weiterhin bietet eine Kodifikation die Chance, Wertungs- und Regelungswiedersprüche zwischen den verschiedenen Fachgesetzen zu beseitigen. Auch können überflüssige Doppelregelungen entfallen, indem etwa eine einheitliche Regelung für die Genehmigungsverfahren im Allgemeinen Teil geschaffen wird.' De hoofdopgave van een moderne codificatie is volgens de commissie 'einen möglichst dauerhaften und auf Flexibilität angelegten Ordnungsrahmen für zukünftige Entwicklungen zu schaffen., ${ }^{146}$ De commissie meent voorts 'daß eine Kodifikation mit ihrem Zwang zu systematischer Geschlossenheit ungleich besser als spezialgesetzliche Regelungen in der Lage ist, den Gesetzgeber bei späteren Änderungen zu disziplinieren und einem Rechtsgebiet damit insgesamt zu größerer Kontinuität zu verhelfen.' Het gevaar op verstening acht de commissie niet groter of kleiner dan bij voortzetting van sectorwetten. 'Ein Umweltgesetzbuch auf Grund des mit ihm verbundenen Gewinns an Rechtsklarheit' kan 'eine wesentlich bessere Grundlage für den ... Vollzug bieten. Die Gefahr, daß Behörden und Bürger überfordert werden, is um so geringer, je stärker eine Kodifikation an gewachsene Strukturen anknüpft und diese behutsam fortentwickelt.' 'Die gegenwärtige Debatte über die Beschleuniging der Verwaltungsverfahren spricht ebenfalls eher für als gegen eine Kodifikation. Es ist unverkennbar, daß die heutigen Umweltschutzgesetze vollzugsunfreundlich sind und damit die Verwaltungsverfahren verzögern. Insofern hat die von der Bundesregierung eingesetzte Sachverständigenkommission 'Schlanker Staat' zutreffend festgestellt, daß nur eine Kodifikation des Umweltrechts, die den Leitmaximen des 'schlanken' Staates Rechnung trägt, Deregulierung und Harmonisierung aus einem $\mathrm{Gu}$ zu leisten vermag.' 147 'Festzuhalten bleibt, daß eine kodifikatorische Integration, Vereinfachung und Harmonisierung des Umweltrechts wesentliche Impulse für eine Vereinfachung auch der Verwaltungsverfahren geben kann.'148

145 Bundesministerium für Umwelt c.a., Umweltgesetzbuch (UGB-KomE) 1998, p. 73.

146 Bundesministerium für Umwelt c.a., Umweltgesetzbuch (UGB-KomE) 1998, p. 74.

147 Bundesministerium für Umwelt c.a., Umweltgesetzbuch (UGB-KomE) 1998, p. 75.

148 Bundesministerium für Umwelt c.a., Umweltgesetzbuch (UGB-KomE) 1998, p. 76. 


\subsubsection{Richtlijn industriële emissies}

In de overwegingen bij de Richtlijn industriële emissies wordt onder meer opgemerkt dat ter wille van de duidelijkheid tot herschikking van zeven richtlijnen moet worden overgegaan. ${ }^{149}$ Voorts wordt het passend genoemd 'de wetgeving met betrekking tot industriële installaties te herzien teneinde de bestaande bepalingen te vereenvoudigen en te verduidelijken, en de administratieve belasting te verminderen.'150

\subsubsection{Ecologische en economische voordelen}

In de paragrafen 1.3.2.2-1.3.2.8 is een aantal door wetgevers genoemde mogelijke ecologische en economische voordelen opgenomen.

Bij de ecologische voordelen lijkt het gewoonlijk met name te gaan om een integrale benadering van het te reguleren beleidsterrein. Zo vormt integraal waterbeheer een belangrijke, zo niet de belangrijkste aanleiding voor de Waterwet. De memorie van toelichting bij die wet vermeldt onder meer dat 'in het wetsvoorstel is gekozen voor een indeling in hoofdstukken die zoveel mogelijk recht doet aan het integrale karakter van het waterbeheer en die op een adequate manier de verschillende aspecten weergeeft. ${ }^{151}$ Integraal milieubeheer vormt in ieder geval ook een aanleiding voor het opnemen van sectorale wetten in het ontwerp-Umweltgesetzbuch ${ }^{152}$ en de Richtlijn industriële emissies.

In de overwegingen bij die laatste richtlijn wordt opgemerkt: 'Afzonderlijke initiatieven ter bestrijding van emissies in de lucht, het water of de bodem kunnen ertoe leiden dat verontreiniging van het ene milieucompartiment naar het andere wordt overgeheveld, in plaats van dat het milieu in zijn geheel wordt beschermd. Daarom is het passend te voorzien in een geïntegreerde benadering inzake preventie en beheersing van de emissies in lucht, water en bodem, afvalbeheer, energie-efficiëntie en preventie van ongevallen. Een dergelijke benadering zal eveneens bijdragen aan het scheppen van gelijke mededingingsvoorwaarden in de Unie door de eisen op het gebied van milieuprestaties voor industriële installaties te harmoniseren.'153

149 Richtlijn 2010/75/EU van het Europees Parlement en de Raad van 24 november 2010 inzake industriële emissies (geïntegreerde preventie en bestrijding van verontreiniging) (herschikking) (PbEU 2010 L 334/17), overweging 1.

150 Richtlijn 2010/75/EU van het Europees Parlement en de Raad van 24 november 2010 inzake industriële emissies (geïntegreerde preventie en bestrijding van verontreiniging) (herschikking) (PbEU 2010 L334/17), overweging 4.

151 Kamerstukken II 2006/07, 30 818, nr. 3, p. 6.

152 Bundesministerium für Umwelt c.a., Umweltgesetzbuch (UGB-KomE) 1998, p. 76.

153 Richtlijn 2010/75/EU van het Europees Parlement en de Raad van 24 november 2010 inzake industriële emissies (geïntegreerde preventie en bestrijding van verontreiniging) (herschikking) PbEG L334 van 17.12.2010, p. 17, overweging 3. 
Bij ecologische voordelen van bundeling lijkt met name te worden gedoeld op het feit dat een integrale benadering van de milieuproblematiek voorkomt dat milieuproblemen worden afgeschoven van het ene op het andere milieucompartiment.

Bij economische voordelen lijkt het met name te gaan om een reductie van administratieve lasten voor bedrijven. Dit voordeel wordt onder meer genoemd in de nota van toelichting bij het Activiteitenbesluit, waarin wordt opgemerkt, dat is toegezegd om $€ 216$ miljoen te besparen zonder een toename van de bestuurlijke lasten. ${ }^{154}$ In de rapportage van de Werkgroep Ruimte voor leven worden voorstellen gedaan voor vereenvoudiging en integratie van het omgevingsrecht. Tezamen met de verbetering van de besluitvormingsprocessen, de verbetering van de kwaliteit van de uitvoering en een eenduidig en samenhangend beleid zal dit volgens de werkgroep op termijn tot belangrijke besparingen leiden. Uiteindelijk kan het volgens de werkgroep gaan om besparingen c.q. maatschappelijke baten van enkele miljarden, maar een betere schatting vergt volgens de werkgroep nader onderzoek. ${ }^{155}$

In mijn onderzoek zal ik niet ingaan op mogelijke ecologische of economische voordelen van bundeling, maar zal ik mij beperken tot de hierna in paragraaf 1.3 .3 te noemen mogelijke juridische voordelen.

\subsubsection{Juridische voordelen}

In de paragrafen 1.3.2.2-1.3.2.8 noemen wetgevers ook regelmatig mogelijke voordelen van bundeling die van juridische aard zijn. In verschillende bewoordingen worden met name genoemd: systematisering, eenvoudiger regels, minder regels, effectiever regels, uniformer regels, duidelijker regels, transparanter regels, samenhang tussen regels, modernisering regels, consistentie tussen regels, minder toestemmingen, aansluiting bij internationale regels, toekomstbestendige regels, beter handhaafbare regels, flexibeler regels, meer rechtszekerheid en meer voorspelbaarheid.

Ook Rehbinder meent dat codificatie van omgevingsrecht door verschillende ideeën kan zijn ingegeven. 'Die bloße systematisch geordnete Sammlung des geltenden Rechts (formale Kodifikation), die Vereinfachung, Rechtsbereinigung und innere Harmonisierung, die Wahrung des umweltpolitischen Besitzstandes (umweltpolitisches Verschlechterungsverbot) oder reine Umweltrechtsreform könnten die primäre Ziele sein, die mit der Kodifikation verfolgt werden. Die meisten genannten Kodifikationsideen könnten auch neben einander verfolgt werden.' ${ }^{156}$

154 Activiteitenbesluit, NvT, p. 104.

155 Ministerie van Financiën, Ruimte voor leven 2010, p. 59

156 Rehbinder, Kodifikation des Umweltrechts in Europa - Rechtsvergleichende Betrachtungen 2010, p. 97. 
Het is echter de vraag of en zo ja in hoeverre dergelijke voordelen zich zullen voordoen als gevolg van bundeling. De genoemde wetgevers motiveren dat niet of nauwelijks, terwijl zulks bij een eerste beschouwing toch niet altijd voor zich lijkt te spreken.

Zo noemt de wetgever vereenvoudiging van regelgeving als voordeel van het Activiteitenbesluit. In de praktijk klagen bedrijven echter dat het Activiteitenbesluit juist ingewikkelder is geworden. Waar een horecaondernemer tot 2008 kon volstaan met het op zijn branche toegespitste Besluit horeca- sport- en recreatie-inrichtingen milieubeheer, moet hij de op zijn bedrijf toepasselijke regels sinds 1 januari 2008 zoeken in het Activiteitenbesluit, dat niet alleen regels bevat voor zijn bedrijf, maar eveneens voor bakkerijen, winkels en machinale timmerwerkplaatsen, en naar verwachting per 1 januari 2013 ook voor landbouwbedrijven, raffinaderijen en energiecentrales.

Een ander voorbeeld betreft uniformer regels die de wetgever als voordeel van het Activiteitenbesluit noemt. Dat het bundelen van soortgelijke regels tot uniformering kan leiden wil ik wel aannemen, maar de vraag is of bundeling noodzakelijk is voor uniformering en of bundeling altijd tot uniformering leidt. Zou uniformeren niet ook en wellicht eenvoudiger zijn bereikt door de gebundelde algemene maatregelen van bestuur als zelfstandige algemene maatregelen van bestuur te laten voortbestaan, maar aan elkaar aan te passen?

In de literatuur is door diverse auteurs ook gewezen op nadelen van bundeling. Zo meent Michiels dat een containerbegrip als duurzame leefomgeving leidt tot een schijnvoordeel van integratie van toetsingskaders vanwege het nadeel dat daarmee geen houvast meer wordt geboden, hetgeen wel het geval is met afzonderlijk geregelde en beschermde belangen. ${ }^{157}$ Blomberg c.s. noemen in hun onderzoek naar de noodzaak van en de mogelijkheden tot vereenvoudiging van VROM-uitvoeringsregelingen op het gebied van het milieubeheer hun belangrijkste conclusie 'dat er geen wezenlijke behoefte bestaat aan integratie, samenvoeging of harmonisatie van de milieu-uitvoeringsregelgeving. ${ }^{1158}$

In mijn onderzoek wil ik mij dan ook richten op de vraag of het bij bundeling van omgevingswetten vanuit wetssystematisch oogpunt om een politieke keuze gaat die nu eens in het voordeel dan weer in het nadeel van bundeling kan uitvallen, dan wel om een keuze die (ook) voldoet aan een wetenschappelijk te verantwoorden toetsingskader. Een soortgelijke vraag stelde Gilhuis zich in 1989 in zijn Tilburgse oratie in het kader van de toen naderende Wet milieubeheer Daarbij wees hij op de noodzaak van de ontwikkeling van criteria op basis waarvan al dan niet kon worden besloten

157 Michiels, Het schijnvoordeel van integrale wetgeving 2004.

158 In dit verband noem ik ook Blomberg/Jongma/van 't Lam \& Michiels, De milieu-uitvoeringsregelingen op een A4-tje 2002. Deze auteurs noemen als hun belangrijkste conclusie 'dat er geen wezenlijke behoefte bestaat aan integratie, samenvoeging of harmonisatie van de milieu-uitvoeringsregelgeving.' Zie ook Blomberg/Michiels \& Nijmeijer, Vergunningverlening in het omgevingsrecht 2005, waar de vraag naar stroomlijning of integratie wordt gesteld. 
tot integratie van bestaande wetgeving in de Wet algemene bepalingen milieuhygiëne. ${ }^{159}$

\subsection{ONDERZOEKSVRAGEN}

Het voorgaande doet de vraag rijzen of het bundelen van omgevingswetten niet alleen een politieke keus is, maar ook wetenschappelijke verantwoord is. Anders geformuleerd, bestaat er een wetenschappelijk gefundeerd kader of is een zodanig kader te ontwikkelen waaruit volgt in welk geval of in welke gevallen bundeling van omgevingsrecht al dan niet verantwoord is? Een vraag die daarbij aan de orde komt is voor welk probleem of welke problemen bundeling eigenlijk een oplossing zou kunnen zijn. Daarbij aansluitend kan de vraag worden gesteld aan welke criteria bundeling dan zou moeten voldoen. Is de wetgever bij bundeling van omgevingsrecht in bijvoorbeeld het Activiteitenbesluit, de Waterwet of de Wabo uitgegaan van een ordenende gedachte of slechts van de boekhoudkundige zekerheid dat één regeling minder is dan twee en dat elke vermindering van regels nastrevenswaardig is?

Ik noem dat om twee redenen boekhoudkundig. In de eerste plaats zijn regels van een geheel andere aard dan cijfers. In een begroting is het mogelijk en wellicht zelfs verstandig om pas uitgaven in te boeken als daartegenover ook inkomsten of bezuinigingen staan. Dat houdt de balans in evenwicht. In het recht is het niet zo maar mogelijk om de ene regel tegenover de andere te zetten. Wie dat wel doet, bezondigt zich al snel aan uitspraken als dat er pas een regel bij mag komen als er een andere regel verdwijnt. Het kan toch niet zo zijn dat bijvoorbeeld het Nederlandse equivalent van één van de Tien Geboden 'Gij zult niet stelen' (art. 310 $\mathrm{Sr}$ ) moet vervallen om de invoering mogelijk te maken van de regel dat het is verboden zonder omgevingsvergunning een bepaald project uit te voeren (art. 2.1 Wabo)? In de tweede plaats komt het op mij gewoonlijk merkwaardig over als wordt gezegd dat een regel verdwijnt, terwijl diezelfde regel in een andere wet weer opduikt. Een voorbeeld betreft de in de hoofdstuk 5 te bespreken integratie van de Wms in de Wet milieubeheer. Daarmee is weliswaar de Wms als zodanig vervallen, maar zijn veel artikelen uit die wet overgeheveld naar de Wet milieubeheer.

Borman lijkt dezelfde mening toegedaan. Hij noemt het terugdringen van het aantal regelingen door die te bundelen een schijnargument, omdat het voor de regeldruk niet uitmaakt over hoeveel regelingen de regels verspreid staan. Hij zoekt de verklaring in de Haagse werkelijkheid van de tucht van de regelgevingsmonitor. Het is voor een minister niet plezierig om in de hoogste regionen te prijken van ministeries met de meeste wetten, algemene maatregelen van bestuur en ministeriële regelingen. ${ }^{160}$ Hij noemt de Wet natuurbescherming een

159 Gilhuis, Milieurecht op weg naar de jaren negentig 1989, p. 14

160 Borman, Combineren van uitvoeringsregels 2010, p. 284. 
goed voorbeeld. "Als het alleen maar betekent dat drie wetten in drie hoofdstukken zijn weergegeven, dan is het eigenlijk slechts een cosmetische operatie. Maar toch zie je dat dat door de politiek wel als winst wordt gezien." "61 Roording meent echter dat eenvoudig in elkaar schuiven al kan leiden "tot een zekere stroomlijning. De operatie kan ertoe leiden dat je nog eens goed nadenkt over het systeem en dat je inconsistenties, die dan vanzelf aan het licht treden, wegneemt." ${ }^{162}$ Voermans/Moll/Florijn \& Van Lochem merken op dat 'The sheer volume of legislation has become a political item in itself.' Maar 'this has not always been the case', aldus deze auteurs. ${ }^{163}$

En zijn de mogelijke met bundeling beoogde resultaten in bepaalde gevallen wellicht ook of beter op een andere wijze te realiseren?

De centrale vraag in dit onderzoek is dan ook of bij de voornemens tot ordening van het omgevingsrecht door middel van bundeling sprake is van een louter politieke keuze, dan wel (ook) kan worden voldaan aan eisen die door middel van wetenschappelijk op te stellen criteria aan ordening van omgevingsrecht kunnen worden gesteld.

Om deze centrale vraag te beantwoorden is een antwoord gezocht op de volgende drie deelvragen:

1. Is er wetenschappelijk een toetsingskader (te ontwikkelen) waaruit volgt in welk geval of in welke gevallen bundeling van omgevingsrecht verantwoord is?

2. Hoe verhouden zich de bundeling door herschikking die in 2010 heeft geleid tot de Wet algemene bepalingen omgevingsrecht, de bundeling die in 2008 heeft geleid tot integratie van de Wet milieugevaarlijke stoffen in de Wet milieubeheer, de in 2010 voorgestelde bundeling door herschikking die moet leiden tot een Wet natuurbescherming en de contouren van de bundeling door herschikking die moet leiden tot een Omgevingswet tot dat (te ontwikkelen) toetsingskader?

De keus voor deze vier bundelingsprojecten is als volgt tot stand gekomen. Ik heb in de eerste plaats gezocht naar gerealiseerde, actuele bundelingsprojecten in het omgevingsrecht. Het lijkt mij gerechtvaardigd te veronderstellen dat de kans groter is dat het resultaat van die projecten nog niet onderhevig is geweest aan wetswijzigingen die het antwoord op de toetsvragen zouden kunnen beïnvloeden. In de tweede plaats heb ik gekozen voor een project dat bundeling door herschikking (Wabo) en een project dat bundeling door integratie (Wms in Wet milieubeheer) betreft. Vervolgens heb ik onderzocht of het toetsingskader ook

161 Borman, Interview 2011, bijl. 5.3, par. 1.6.

162 Roording, Interview 2012, bijl. 5.4, par. 1.6.

163 Voermans/Moll/Florijn \& Van Lochem, Codification and Consolidation in Europe as Means to Untie Red Tape 2008, par. 1. 
bruikbaar zou zijn voor toekomstige voornemens tot bundeling door herschikking (Wet natuurbescherming en Omgevingswet). Mij zijn geen voorbeelden bekend van bruikbare voornemens tot bundeling door integratie van omgevingsrecht.

3. Zijn er ten aanzien van de in deelvraag 2 genoemde bundelingsprojecten voorstellen te doen om de ordening van het omgevingsrecht beter te laten aansluiten bij de (te ontwikkelen) wetenschappelijke criteria voor bundeling van omgevingsrecht?

\subsection{OPZET EN ONDERZOEKSMETHODEN}

Teneinde de drie hiervoor genoemde vragen te kunnen beantwoorden heb ik in hoofdstuk 2 een begrippenkader ontwikkeld. In hoofdstuk 3 is vervolgens op wetenschappelijke wijze een kader ontwikkeld waaruit volgt in welk geval of in welke gevallen bundeling van omgevingsrecht verantwoord is. Daarmee wordt een antwoord gegeven op de eerste deelvraag. Daarbij heb ik mij beperkt tot mogelijke juridische criteria om over te gaan tot bundeling. Zoals hiervoor in paragraaf 1.3 aangegeven noemen wetgevers weliswaar mogelijke juridische, ecologische en economische voordelen van bundeling, maar mijn expertise ligt nu eenmaal op het juridische vlak. Ter ontwikkeling van het toetsingskader ter beantwoording van de eerste deelvraag van dit onderzoek zijn primair 'klassieke' juridische bronnen geanalyseerd, waaronder Nederlands-, Duits- en Engelstalige juridische literatuur en de geschiedenis van de totstandkoming van onderdelen van het omgevingsrecht waarbinnen bundeling van wetssystemen heeft plaatsgevonden.

Daarbij zal de lezer duidelijk worden, dat ik in belangrijke mate ben geïnspireerd door het boek Gesetzgebungslehre van de Zwitserse jurist Peter Noll (1926-1982). Uiteraard heb ik ook andere literatuur bestudeerd. De door mij geraadpleegde literatuur inzake wetgevingsleer en wetgevingstechniek besteedt gewoonlijk echter aanzienlijk meer aandacht aan het tot stand brengen van nieuwe wetten dan aan het bundelen van bestaande wetten. Een verhandeling over bundeling als zodanig vond ik zelfs niet in het in 2012 verschenen boek Wetgeven, dat overigens wel aandacht besteedt aan vermindering van regeldruk. ${ }^{164}$ Gesetzgebungslehre was voor mij een eyeopener. Hoewel het boek bijna 40 jaar geleden is geschreven, niet specifiek het Nederlands omgevingsrecht op het oog heeft en voorbeelden uit met name het Duitse en Zwitserse recht gebruikt, zijn de daarin verwoorde inzichten mijns inziens heden ten dage nog bruikbaar voor het nadenken over bundeling van omgevingsrecht.

164 Zijlstra/Borman/Munneke/Van Ommeren/Schilder \& Steyger, Wetgeven 2012. Par. 4.5 over vermindering van regeldruk is van de hand van Van Ommeren. 
Daarnaast zijn ook interviews met een aantal wetgevingsjuristen en wetenschappers als onderzoeksmethode ingezet. ${ }^{165}$ Het wetgevingsproces ten departemente is voor buitenstaanders immers tamelijk ondoorzichtig. Door middel van deze interviews is getracht meer in de keuken van de wetgever te kijken teneinde de bevindingen uit de literatuur te toetsen aan de werkelijkheid, waarvan ook de departementale activiteiten deel uitmaken.

In dat verband gelden mijns inziens ook heden ten dage nog de woorden van Van Eijkern, dat de ambtelijke wetgevingsjurist een vrij grote invloed kan uitoefenen op de inzichtelijkheid en overzichtelijkheid van ons rechtssysteem. 'In een tamelijk vroeg stadium van voorbereiding van een wet kunnen immers al principiële beslissingen worden genomen over zaken als het gebruik van bestaande organen en het toepassen van reeds bekende en beproefde juridische constructies, dan wel over de introductie van nieuwe instellingen of het bezigen van nieuwe rechtsfiguren. Ook waar geen nieuwe wegen worden ingeslagen, is de vraag welke bestaande worden gekozen niet zonder belang. Op de aldus gedane keuzen zal niet spoedig worden teruggekomen. ${ }^{166}$

In de hoofdstukken 4 en 5 zijn twee recente Nederlandse bundelingsoperaties getoetst aan het in hoofdstuk 3 ontwikkelde kader. Het gaat om de Wabo en de integratie van de Wet milieugevaarlijke stoffen in de Wet milieubeheer. In hoofdstuk 6 is hetzelfde gedaan voor de voorgenomen Wet natuurbescherming en in hoofdstuk 7 voor de contouren van de Omgevingswet. Doel van deze toetsing is om erachter te komen of bundeling in deze gevallen getoetst aan de ontwikkelde wetenschappelijke theorie, verantwoord is, alsmede of en zo ja in welke mate de wetgever rekening heeft gehouden met de geformuleerde aandachtspunten. Daarmee wordt een antwoord gegeven op de tweede deelvraag. Tevens is bezien of ten aanzien van elk van die vier bundelingsoperaties voorstellen kunnen worden gedaan om het resultaat daarvan beter te laten aansluiten bij de criteria die voor de ordening van samenhangende wetgevingscomplexen zijn ontwikkeld. Daarmee wordt een antwoord gegeven op de derde deelvraag.

In hoofdstuk 8 zijn conclusies getrokken uit hetgeen in de hoofdstukken 5, 6, 7 en 8 naar voren is gekomen. In dat hoofdstuk is ook de centrale vraag beantwoord en zijn aanbevelingen gedaan aan de wetgever en aan wetgevingsjuristen.

165 Zie bijlage 5.

166 Van Eijkern, De macht van de zwoegers in het vooronder 1977, p. 44-45. Die titel is tot de verbeelding blijven spreken, getuige onder meer een interview van Hans Woldendorp met Hans Bierman, Een werker in het vooronder 2006 en Van Gestel, Rol van de wetgevingsjurist 2011, p.3, die in noot 3 melding maakt van L.F.M. Verhey, De zwoegers uit het vooronder: over ambtelijke taakuitoefening, ministeriële verantwoordelijkheid en parlementaire controle, Deventer: WEJ Tjeenk Willink 2001, p. 12. 



\section{Begrippen}

'Een waar idee moet met het voorgestelde object overeenkomen.'

Baruch Spinoza ${ }^{1}$

\subsection{INLEIDING}

Als we de vraag willen beantwoorden of er een wetenschappelijk verantwoord toetsingskader bestaat of te ontwikkelen is waaruit volgt in welk geval of in welke gevallen bundeling van omgevingsrecht wetenschappelijk verantwoord is, dan dient allereerst duidelijkheid te bestaan over wat onder bundeling wordt verstaan.

Bij bundeling heb ik onder meer het oog op de wetgevingsoperatie die ertoe heeft geleid dat elf op artikel 8.40 van de Wet milieubeheer (Wm) gebaseerde algemene maatregelen van bestuur zijn samengevoegd tot één nieuw Besluit algemene regels voor inrichtingen milieubeheer (Activiteitenbesluit), ${ }^{2}$ het samenvoegen van wetten op het gebied van water in de Waterwet, ${ }^{3}$ het opnemen van de Wet milieugevaarlijke stoffen (Wms) in de Wet milieubeheer, ${ }^{4}$ alsmede het overhevelen van regels in de Woningwet inzake de bouwvergunning en regels in de Wet milieubeheer inzake de milieuvergunning naar de Wet algemene bepalingen omgevingsrecht (Wabo). ${ }^{5}$

Deze voorbeelden roepen de vraag op of er overeenkomsten tussen deze wetgevingsoperaties zijn aan te geven, die maken dat zij als bundeling kunnen worden aangemerkt. Een andere relevante vraag is of er wellicht verschillende varianten van bundeling kunnen of moeten worden onderscheiden die nopen tot een voor dit onderzoek bruikbare onderverdeling.

In dit hoofdstuk zal daarom eerst een begrippenkader worden ontwikkeld, dat is toegespitst op de beantwoording van de onderzoeksvragen. In dit

\footnotetext{
Aan Baruch Spinoza (1632-1677) toegeschreven tekst op een gebouw op de binnenplaats van de Raad van State in Den Haag.

Zie par. 1.2.

Stb. 2009, 490 (Tekstplaatsing). Zie voor een beknopte toelichting Havekes \& De Putter, Wegwijzer Waterwet 2009.

Zie hfds. 5 .

5 Zie hfds. 4
} 
verband zal ik regelmatig aansluiten bij Faure's nog steeds lezenswaardige 'attempt to formulate working definitions of the various notions used'6, waarbij hij - 'as a matter of convention and not of principle"7 - werkdefinities voorstelt voor integration, harmonization, codification en coordination.

Integration: 'When using the term integration it is proposed to refer to the internal integration of environmental law, meaning the ecological goal that, in the decision-making and balancing of interest with respect to the permitted amounts and quality of pollutants, the total effects of pollution emanating from the licensed activity on the various components of the environment are taken into account. The influence of environmental policy on other policy areas could then explicitly be called external integration.'

Harmonization: 'Harmonization is proposed for the legal situation where either various separate procedures are approximated (harmonization of procedures) and separate legal acts remain in existence; or various substantive environmental laws are approximated; or the number of licenses is reduced.'

Codification: 'This term is usually reserved for the legislative process whereby separate existing legal acts are brought together in one legal document.'

Coordination: 'This term is reserved for the situation where separate environmental legal acts remain in existence with separate licensing requirements (and hence no harmonization of licenses took place), but where the legislature has provided for legal rules which force the various authorities to take into account the separate procedures or licenses. ${ }^{8}$

\subsection{OMGEVINGSRECHT}

De centrale vraag in dit onderzoek ${ }^{9}$ heeft geen betrekking op bundeling van wetgeving in het algemeen, maar op bundeling van omgevingsrecht. Het is daarom belangrijk dat duidelijk is om welke regels het gaat. Dat komt ook naar voren in de inleiding van de Sachverständigenkommission op het ontwerpUmweltgesetzbuch, waar zij stelt dat 'Allgemeine Voraussetzung für die Kodifikation eines Rechtsgebietes ist dessen Abgrenzbarkeit gegenüber anderen Materien. ${ }^{10}$

6 Faure, The Harmonization, Codification and Integration of Environmental Law: A Search for Definitions 2000, p. 175. Daarbij verwijst hij onder meer ook naar eerdere publicaties waarin die termen worden gebezigd.

7 Faure, The Harmonization, Codification and Integration of Environmental Law: A Search for Definitions 2000, p. 181.

8 Faure, The Harmonization, Codification and Integration of Environmental Law: A Search for Definitions 2000, p. 181

9 Zie par. 1.4

10 Bundesministerium für Umwelt c.a., Umweltgesetzbuch (UGB-KomE) 1998, p. 73. 
Daarbij lijkt het mij overigens goed zich bij het lezen van dit onderzoek van meet af aan een aantal zaken voor ogen te blijven houden, die later nog verder zullen worden uitgewerkt en toegelicht.

In de eerste plaats betekent het feit dat bepaalde wetgeving als omgevingswetgeving wordt gekwalificeerd niet per se ook dat dat omgevingsrecht voldoet aan de in deze studie te ontwikkelen criteria voor het bundelen van omgevingsrecht. Zou er bijvoorbeeld overeenstemming bestaan dat de door de Wet bescherming Antarctica en de Kernenergiewet gevormde wetssystemen tot het omgevingsrecht moeten worden gerekend, dan wil dat nog niet per se zeggen dat deze wetssystemen op de een of andere wijze voor bundeling in aanmerking zouden moeten komen.

In de tweede plaats hoeft het oordeel dat verschillende omgevingswetssystemen voor bundeling in aanmerking komen niet per se te betekenen dat zulks dan voor de betreffende wetssystemen in hun geheel moet gelden. Zo zou men zich kunnen voorstellen dat bundeling van de Natuurbeschermingswet 1998 en de Flora- en faunawet, die allebei onder meer zien op de bescherming van dier- en plantensoorten, nog niet betekent dat dat ook geldt voor de in die laatste wet opgenomen regels inzake de jacht.

In de derde plaats is het voor deze studie weliswaar van belang om een zo precies mogelijke indicatie te hebben van wat onder omgevingsrecht wordt verstaan, maar dat betekent echter nog niet dat het voor het antwoord op de centrale vraag van dit onderzoek noodzakelijk is precies te weten welke wetten in formele en materiële zin wel en niet onder het omgevingsrecht zijn te begrijpen.

Voor een indicatief antwoord op de hiervoor gestelde vraag wat precies onder omgevingsrecht ware te begrijpen, kan ik mij wel vinden in de praktische invalshoek van de Sachverständigenkommission, die suggereert dat complete zekerheid over wat tot het - Duitse - omgevingsrecht (Umweltrecht) behoort niet te geven is, maar vaststelt: 'Mittlerweile besteht aber ein allgemeiner Konsens in der Beschreibung des Kernbereichs umweltspezifischer Rechtsnormen.' ${ }^{11}$

'Unmittelbar dem Schutz der Umwelt dienen insbesondere die Vorschriften des Naturschutzrechts, des Waldrechts, des Wasserrechts, des Immissionsschutzrechts, des Kreislaufwirtschafts- und Abfallrechts, des Chemikalienrechts, des Pflanzenschutzrechts, des Gentechnikrechts, des Bodenschutzrechts sowie

11 Bundesministerium für Umwelt c.a., Umweltgesetzbuch (UGB-KomE) 1998, p. 73. In gelijke zin versta ik Rehbinder, die aangeeft dat de reikwijdte van het omgevingsrecht moeilijke vragen opwerpt, maar vervolgens aangeeft dat het min of meer is geaccepteerd dat er een zeker 'Kernbereich des Umweltrechts' bestaat (Rehbinder, Kodifikation des Umweltrechts in Europa Rechtsvergleichende Betrachtungen 2010, p. 102). 
des Atom- und Strahlenschutzrechts. Ergänzt werden diese Vorschriften des Besonderen Umweltrechts durch eine wachsende Zahl allgemeiner Regelungen: $\mathrm{Zu}$ nennen sind insbesondere die Umweltverträglichkeitsprüfung, die Umweltinformation, die Umweltstatistik, das Umweltaudit, das Organisationsrecht der Umweltbehörden des Bundes sowie die privatrechtliche Umwelthaftung. ${ }^{12}$

Om erachter te komen wat onder Nederlands omgevingsrecht kan worden verstaan zou ik een soortgelijke aanpak willen volgen. Wie wetenschap en praktijk zou vragen wat onder Nederlands omgevingsrecht dient te worden begrepen zal naar mijn overtuiging gewoonlijk antwoorden krijgen die erop duiden dat de kern van het omgevingsrecht wordt gezien in wetgeving die relevant is voor de bestemming, de inrichting en het beheer van de fysieke ${ }^{13}$ leefomgeving. ${ }^{14}$ Het Nederlands omgevingsrecht wordt dan gewoonlijk verder onderscheiden in milieurecht, waterrecht, natuurrecht en recht van de ruimtelijke ordening.

In gelijke zin Drupsteen, die opmerkt dat er meer wetgeving bestaat die betrekking heeft op de fysieke leefomgeving, maar niet behoort tot de vier genoemde rechtsgebieden. Hij denkt daarbij aan wetgeving voor de inrichting van het landelijk gebied, de aanleg van infrastructuur en de bouw. ${ }^{15}$ Larmuseau, De Smedt en Roelandts noemen het uit Nederland geïmporteerde verzamelbegrip 'omgevingsrecht' de optelsom van het ruimtelijk bestuursrecht, het milieuhygiëne recht, het natuurbeschermingsrecht en het waterrecht. ${ }^{16}$ Volgens Van den Berg omvat het omgevingsrecht het totaal aan rechtsregels met betrekking tot de inrichting en het beheer van de fysieke leefomgeving. Het betreft een breed scala aan regels op met name de terreinen van de ruimtelijke ordening, het milieubeheer, het waterbeheer en het natuur- en landschapsbeheer. ${ }^{17}$ Koeman rekent tot het omgevingsrecht het ruimtelijk bestuursrecht, het milieuhygiënerecht en het natuurbeschermingsrecht, alles in de ruimste zin des woords. Het waterrecht laat hij in zijn essay buiten beschouwing vanwege de departementale indeling, de relatie tussen waterkwaliteit en -kwantiteit, recente nieuwe wetgeving (de Waterwet), de bijzondere positie van de waterschappen en

12 Bundesministerium für Umwelt c.a., Umweltgesetzbuch (UGB-KomE) 1998, p. 73.

13 In de zin van 'betrekking hebbend op de stoffelijke natuur', taaladvies.net/taal/advies/vraag/300/.

14 Het Planbureau voor de Leefomgeving verstaat onder fysieke leefomgeving de inrichting van de woonwijk/gemeente inclusief de wegen, parken, industrieterreinen. De kwaliteit van de fysieke leefomgeving wordt deels bepaald door de milieukwaliteit (www.planbureauvoordeleefomgeving.nl/ dossiers/leefomgeving/veelgestelde_vragen\#vraag1).

15 Drupsteen, Een Omgevingswet 2011, p. 274.

16 Larmuseau/De Smedt \& Roelandts, Vlaams omgevingsrecht 2010, p. 3. Zie ook Larmuseau/De Waele/Bernaert/Cabus \& De Smet, Wetboek Vlaams Omgevingsrecht, waarin zijn opgenomen de volgens de auteurs meest geconsulteerde wetteksten van het milieuhygiënerecht, ruimtelijk bestuursrecht, natuurbeschermingsrecht en waterrecht, aangevuld met 'algemene' en 'sectorale' omgevingsregelgeving. Larmuseau, Omgevingsrecht op z'n Vlaams 2011, p. 417, merkt op dat in Vlaanderen de klemtoon niet ligt op een verregaande samenhang tussen de verschillende onderdelen van het omgevingsrecht.

17 Van den Berg, Waterschappen en de integratie van het omgevingsrecht 2011, p. 243. 
de omstandigheid dat het onderwerp 'water' in de praktijk tot op heden redelijk goed sectoraal beoordeeld blijkt te kunnen worden. ${ }^{18}$ Het valt op dat hij eerder beleidsmatige dan wetssystematische argumenten bezigt. Met die laatste categorie bedoel ik argumenten die zijn gerelateerd aan de wetssystematiek. In zijn in hetzelfde jaar uitgesproken afscheidsrede rekent hij echter het ruimtelijk bestuursrecht, het milieuhygiënerecht, het natuurbeschermingsrecht én het waterrecht tot het omgevingsrecht, dat betrekking heeft op de fysieke leefomgeving. ${ }^{19}$ Verschuuren kwalificeert het recht van de ruimtelijke ordening, het milieurecht, het waterrecht en het natuurbeschermingsrecht als het omgevingsrecht in brede zin. ${ }^{20}$ Boeve c.s. verstaan onder omgevingsrecht het geheel aan rechtsgebieden dat betrekking heeft op de regulering van de fysieke leefomgeving en de samenhang tussen die rechtsgebieden. Daarbij leggen zij de nadruk op milieu, ruimte, natuur en water. $^{21}$

Deze rechtsgebieden zijn geregeld in een veelheid van wetssystemen: enige tientallen wetten in formele zin (zie bijlage 1) en honderden algemene maatregelen van bestuur en ministeriële regelingen. Bovendien geldt op het gebied van het omgevingsrecht een groot aantal Europese richtlijnen en verordeningen. Voor mijn onderzoek wil ik de term omgevingsrecht vooralsnog beperken tot wetssystemen die vallen binnen het milieurecht ${ }^{22}$ het waterrecht, het natuurrecht en het recht van de ruimtelijke ordening.

Het milieurecht heeft betrekking op aantasting, vervuiling en uitputting van het fysieke milieu (lucht, water, bodem) en vormen van hinder en bedreiging van de gezondheid en het leven van mensen (onveiligheid, geluid, straling, etcetera).

Het gaat met name om de volgende wetten: Wet algemene bepalingen omgevingsrecht (Wabo), Wet milieubeheer, Wet bodembescherming, Kernenergiewet, Interimwet stad- en milieubenadering, Luchtvaartwet, Wet luchtvaart, Meststoffenwet, Mijnbouwwet, Wet ammoniak en veehouderij, Wet belastingen op milieugrondslag, Wet hygiëne en veiligheid badinrichtingen en zwemgelegenheden, Wet inzake de luchtverontreiniging, Wet geluidhinder, Wet energiebesparing toestellen, Wet geurhinder en veehouderij en Wet gewasbeschermingsmiddelen en biociden.

Het waterrecht dat betrekking heeft op de kwaliteit van het water.

Het gaat met name om de Waterwet.

Het natuurrecht dat ziet op de bescherming van natuur, landschap, flora en fauna.

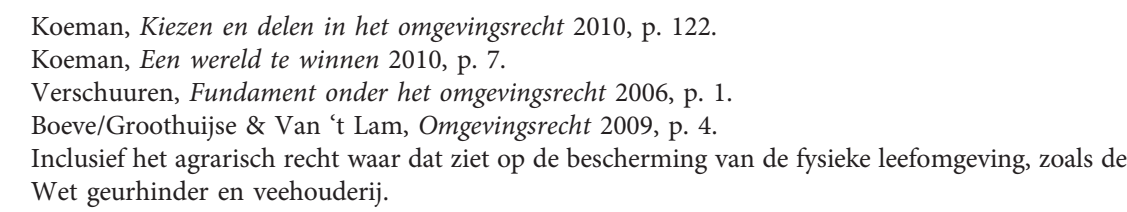


Het gaat met name om de Natuurbeschermingswet 1998, Flora- en faunawet, Boswet en Wet bescherming Antarctica.

Het recht dat ziet op de ruimtelijke ordening.

Het betreft met name de Wet algemene bepalingen omgevingsrecht (Wabo), Wet ruimtelijke ordening, Woningwet, Monumentenwet 1988, Ontgrondingenwet, Reconstructiewet concentratiegebieden, Spoedwet wegverbreding, Tracéwet, Wet inrichting landelijk gebied en Wet stads- en dorpsvernieuwing.

Zoals hiervoor opgemerkt, kies ik ervoor om datgene tot het omgevingsrecht te rekenen waarover consensus bestaat in praktijk en wetenschap. Voor wat betreft de wetenschap noem ik hier met name Michiels die in zijn oratie Kleur in het omgevingsrecht nadrukkelijk aandacht heeft besteed aan de term omgevingsrecht. ${ }^{23}$ Michiels maakt onderscheid tussen omgevingsrecht in ruime en in meer beperkte zin.

Onder omgevingsrecht in ruime zin verstaat hij het milieurecht in ruime zin, dus inclusief het recht inzake water en natuurbescherming, en het ruimtelijk bestuursrecht. 'Als onderwerpen waarop het omgevingsrecht ziet, kunnen onder meer ook nog de landbouw en het verkeer worden genoemd', aldus Michiels. ${ }^{24}$ Als ik het goed zie, komt wat Michiels omgevingsrecht in ruime zin noemt grosso modo overeen met wat ik in dit onderzoek omgevingsrecht noem. Het lijkt mij niet alleen belangrijk dat de optelsom van een groot, maatschappelijk belangrijk deel van het recht met één term 'omgevingsrecht' kan worden aangeduid, belangrijker is nog dat daarmee de samenhang tussen de vier genoemde rechtsgebieden wordt beklemtoond. ${ }^{25}$

Michiels noemt dat eerste wel 'handig', maar volgens hem gaat het daarbij slechts om 'een beperkte meerwaarde.' Als ik het juist zie heeft deze relativering te maken met het antwoord op de vraag of de term omgevingsrecht moet worden gereserveerd voor gevallen waarin de samenhang daadwerkelijk aan de orde is. Michiels wijst op een gevolg van het gebruik van de term omgevingsrecht in ruime zin, te weten dat bijvoorbeeld specifiek milieuhygiënische aspecten die niet in relatie staan met een of meer andere onderdelen van dit brede rechtsgebied, zoals een vergunningvoorschrift inzake de preventie van

23 Zie in dit verband Michiels, Kleur in het omgevingsrecht 2001, p. 5. Michiels merkt daar bescheiden op dat het omgevingsrecht niet door hem of zelfs in Utrecht is uitgevonden. Daarbij wijst hij onder meer op het op 14 mei 1980 verdedigde proefschrift van F.P.J. Otten getiteld 'Ruimtelijke Ordening en Milieubeheer (Bestuurlijke Verkenningen, Den Haag: VUGA 1980). De bescherming van het leefmilieu via het instrumentarium van de Wet op de Ruimtelijke Ordening', dat Michiels als omgevingsrechtelijk bestempelt.

24 Michiels, Kleur in het omgevingsrecht 2001, p. 4. Michiels geeft niet aan om welke onderdelen van het recht het nog meer kan gaan.

25 In gelijke zin Larmuseau/De Smedt \& Roelandts, Vlaams omgevingsrecht 2010, p. 3. 
afval, ook tot het omgevingsrecht behoren. Hetzelfde geldt voor puur planologische kwesties die geen directe milieurelevantie hebben, zoals het verzorgingsniveau in een woonwijk. Michiels stelt daarom voor om de term omgevingsrecht niet in de plaats te laten komen van milieurecht, milieuhygiënerecht of ruimtelijk bestuursrecht. De meerwaarde van het begrip zou volgens hem namelijk groter zijn wanneer het iets zou toevoegen aan het bestaande begrippenkader. Als de term omgevingsrecht is ontstaan uit een behoefte aan afstemming en integratie, is het volgens Michiels beter deze term slechts te gebruiken wanneer de (gewenste, bestaande of ontbrekende) samenhang tussen de onderdelen van het omgevingsrecht in ruime zin aan de orde is. In deze meer beperkte betekenis kan de term omgevingsrecht in enge zin de noodzaak van afstemming en integratie benadrukken, zonder termen als milieurecht en ruimtelijk bestuursrecht te vervangen. Daarom heeft hij een voorkeur voor die beperkte betekenis. ${ }^{26}$

Ik ben het met Michiels eens, dat de term omgevingsrecht de meeste meerwaarde zal hebben als het gaat om een samenhangend rechtsgebied dat betrekking heeft op de bescherming van milieu, natuur, water en ruimtelijke ordening. Dat strookt ook met de opvatting van Larmuseau c.s. ${ }^{27}$

Dat betekent naar mijn oordeel bijvoorbeeld dat onderdelen van de Woningwet die betrekking hebben op de financiering van woningcorporaties niet tot het omgevingsrecht gerekend behoeven te worden. Dat is onder meer van belang als een antwoord wordt gezocht op de vraag welke bestaande wettelijke regels in de door het Ministerie van Infrastructuur en Milieu voorgenomen Omgevingswet zouden moeten worden opgenomen. Als onderdelen van de Woningwet niet als omgevingsrecht kunnen worden gekwalificeerd, zouden zij ook geen plaats kunnen claimen in de Omgevingswet als dat een wetssysteem betreft met bescherming van de fysieke leefomgeving als samenhangcriterium.

Een kanttekening plaats ik echter bij de opvatting van Michiels om de term omgevingsrecht slechts te gebruiken als de gewenste, bestaande of ontbrekende samenhang tussen de onderdelen van het omgevingsrecht in ruime zin aan de orde is. In het geval van een ontbrekende, maar ook in geval van een gewenste - maar eveneens ontbrekende - samenhang is er mijns inziens geen verschil meer tussen het omgevingsrecht in ruime en in enge zin. Het heeft daarom mijn voorkeur om het door Michiels genoemde onderscheid achterwege te laten en de term omgevingsrecht in deze studie te gebruiken als aanduiding voor het milieurecht, het waterrecht, het natuurrecht en het recht van de ruimtelijke ordening los van de vraag of in concreto sprake is van daadwerkelijke - gewenste, bestaande of ontbrekende - samenhang; 'as a matter of convention, not of principle. ${ }^{28}$

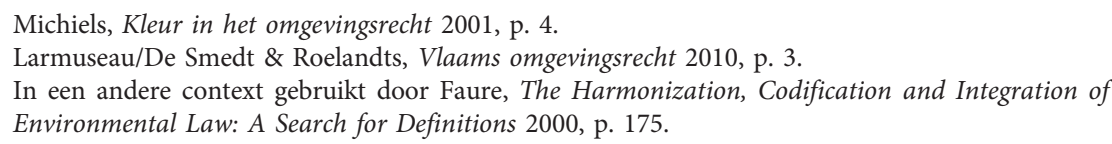




\subsection{WETSSYSTEMEN}

\subsubsection{Algemeen}

Het ontwikkelen van een begrippenkader kan mijns inziens niet los worden gezien van het in hoofdstuk 3 te ontwikkelen theoretisch wetssystematisch kader voor bundeling. Als uitgangspunt wil ik het definitieprobleem van de praktische kant benaderen. Bundeling betekent in wezen dat wettelijke regelingen worden samengevoegd. Zo algemeen gesteld zou bundeling dan echter betekenen dat elke wettelijke regeling of onderdeel daarvan met een willekeurige andere wettelijke regeling of deel daarvan kan worden samengevoegd. Het samenvoegen van de Wet milieubeheer met de Wet werk en inkomen naar arbeidsvermogen (Wia) ${ }^{29}$ lijkt op het eerste gezicht echter weinig zinvol. Ook zal men weinig of geen voorstanders vinden voor het samenvoegen van de Wet algemene bepalingen omgevingsrecht en de Werkloosheidswet. ${ }^{30}$ De verklaring daarvoor lijkt mij, dat inhoudelijke samenhang ontbreekt tussen hetgeen de ene en de andere wet van elk van de genoemde wettenparen regelt. Dat betekent niet per se dat deze wetten niets gemeen hebben. De Wet milieubeheer, de Wia en de Werkloosheidswet zijn alle drie wetten in formele zin in de Nederlandse taal. Een dergelijke formele samenhang lijkt mij op het eerste gezicht echter niet relevant voor het beoordelen of bundeling zinvol is.

Het vermoeden dat de Wet milieubeheer en de Wia geen, maar de Natuurbeschermingswet $1998^{31}$ en de Flora- en faunawet ${ }^{32}$ wel samenhang vertonen, valt mijns inziens te verklaren door de materiële samenhang die we in de werkelijkheid zien of menen te ontwaren. De beide laatste wetten hebben immers betrekking op flora en fauna of zo men wil op natuur. Bundeling heeft volgens mij dan ook betrekking op inhoudelijke samenhang.

In dit verband noem ik Havekes die in het licht van de voorgenomen opname van de Waterwet in de Omgevingswet niets lijkt te zien in het samenvoegen van 'een bonte schakering van regelingen die onderlinge samenhang nogal eens

29 De Wet Werk en Inkomen naar Arbeidsvermogen (WIA) regelt inkomen voor werknemers die arbeidsongeschikt raken. De wet is de opvolger van de Wet op de arbeidsongeschiktheidsverzekeringen (WAO), die overigens niet is afgeschaft. Iedereen met een WAO-uitkering behoudt deze uitkering. Afhankelijk van de mate van arbeidsongeschiktheid, heeft iemand recht op een WIAuitkering.

30 Bij ontslag kan een werknemer een beroep doen op een uitkering op grond van de Werkloosheidswet.

31 Wet van 25 mei 1998, houdende regels ter bescherming van in het wild levende planten- en diersoorten (Flora- en faunawet), Stb. 1998, 402. Art. 1, 83 lid 1 onderdeel d, 83 lid 3, 85-92, 97-100 Ffw zijn in werking getreden op 2 juli 1999 (Stb. 1999, 264).

32 Wet van 25 mei 1998, houdende nieuwe regelen ter bescherming van natuur en landschap (Natuurbeschermingswet 1998), Stb. 1998, 403. Met ingang van 1 oktober 2005 zijn art. 1 onderdelen b-f, 2, 10-26, 30-38, 39 lid 2, 40-46, 49, 57-75 Nb-wet 1998 in werking getreden (Stb. 2005, 473). 
ontberen' en zich afvraagt wat geluidsnormen te maken hebben met veilige dijken. ${ }^{33}$ Ik kan mij een dergelijke verzuchting voorstellen, maar de vraag zou moeten luiden of geluidsnormen en de veiligheid van dijken onder een gezamenlijke noemer, een samenhangcriterium, zijn te brengen. Is dat het geval, dan zou die samenhang ten grondslag kunnen liggen aan bundeling van regels inzake geluidsnormen en regels inzake de veiligheid van dijken in één wetssysteem. Ook Woldendorp lijkt te kiezen voor materiële samenhang. De Wet milieubeheer noemt hij een ballenbak van regels omdat alle onderwerpen die in die wet worden geregeld "als losse ballen in dezelfde bak zijn gegooid." De regels in de Flora- en faunawet hebben volgens hem weinig met elkaar te maken, behalve dat ze over dieren gaan. ${ }^{34}$ Ik zou zeggen dat die regels juist omdat ze over dieren - en planten - gaan wel met elkaar te maken hebben.

Als ik het juist zie, staan ook bij Faure de termen integratie, harmonisatie, codificatie en coördinatie in de sleutel van samenhang, maar spitst hij die samenhang toe op 'internal integration of environmental law, meaning the ecological goal that, in the decision-making and balancing of interests with the permitted amounts and quality of pollutants, the total effects of pollution emanating from the licensed activity on the various components of the environment are taken into account. ${ }^{35}$

In hoofdstuk 3 zal ik ingaan op de vraag wat naar mijn oordeel precies moet worden begrepen onder inhoudelijke, materiële samenhang in verband met bundeling. In hoofdstuk 2 worden de begrippen coördinatie, harmonisatie, integratie, herschikking, consolidatie, codificatie en modificatie hierna echter zo ruim mogelijk omschreven. Ik doe dat om mogelijke voordelen van bundeling niet al als gevolg van mijn begrippenkader uit te sluiten. Zou ik bijvoorbeeld samenhang 'slechts' zien als daarmee een ecologisch doel is gediend zoals ik begrijp dat Faure het ziet, dan zou dat wellicht betekenen dat niet van samenhang zou moeten worden gesproken als het enige of belangrijkste voordeel van een bepaalde bundeling is gelegen in bijvoorbeeld het vergroten van de kenbaarheid van het omgevingsrecht door bepaalde regelingen bij elkaar te plaatsen.

De relatie tussen bundeling van regelingen en inhoudelijke samenhang daartussen kan naar mijn oordeel goed worden bestudeerd aan de hand van het begrip wetssysteem. Daaronder versta ik in deze studie volgens bepaalde criteria geordende, onderling samenhangende regels. Daarbij sluit ik aan bij de door Noll gegeven definitie: 'Jeder Begriff ist ein System, indem er konkrete Dinge abstrakt als gleichartig zusammenfaßt. Systeme sind nach bestimmten Kriterien geordnete, untereinander zusammenhängende Begriffe. ${ }^{36}$ Door de

33 Havekes, Waterwet en Omgevingswet 2012, p. 159

34 Woldendorp, Interview 2011, bijl. 5.1, par. 4.1 en 4.2 .

35 Faure, The Harmonization, Codification and Integration of Environmental Law: A Search for Definitions 2000, p. 181.

36 Noll, Gesetzgebungslehre 1973, p. 205. 
wetssystematiek als uitgangspunt te nemen, richt deze studie zich dus niet op de inhoud van het omgevingsrecht, maar op de systematiek van dat recht. ${ }^{37}$ Anders gezegd gaat het niet in de eerste plaats om wat er is geregeld, maar hoe dat wetssystematisch is geregeld, hoe dat eventueel wetssystematisch beter zou kunnen en met name of en zo ja welke rol bundeling van omgevingsregelingen daarbij kan spelen. Concreet betekent dat bijvoorbeeld dat mijn studie geen antwoord beoogt te geven op de vraag welke voorschriften er precies moeten worden gesteld aan inrichtingen in een op artikel 8.40 Wm gebaseerde algemene maatregel van bestuur. Beoogd is wel een antwoord te kunnen geven op de vraag of het wetenschappelijk verantwoord is om die algemene regels samen te voegen in één algemene maatregel van bestuur (het Activiteitenbesluit ${ }^{38}$ ) in plaats van die te laten staan in elf op bepaalde branches van ondernemingen toegesneden algemene maatregelen van bestuur. ${ }^{39}$

Een wet kan een wetssysteem zijn, maar een wetssysteem is niet per se een wet. $^{40}$ Een wetssysteem bestaat zoals gezegd uit volgens bepaalde criteria geordende, onderling samenhangende regels. Binnen deze definitie kan bijvoorbeeld het gehele Europese recht of het gehele Nederlandse burgerlijk recht als één wetssysteem worden beschouwd. Daartoe is immers slechts nodig dat de juiste ordeningscriteria worden aangegeven. Als ik spreek over een wetssysteem bedoel ik in dit onderzoek dus niet uitsluitend een wetssysteem zoals dat is vormgegeven in bijvoorbeeld een Europese richtlijn, een wet in formele zin, een algemene maatregel van bestuur of een ministeriële regeling. Het kan ook gaan om wetssystemen die zich binnen dergelijke wetssystemen laten duiden. In dat geval zal ik om verwarring te voorkomen waar nodig de term subwetssysteem gebruiken. Ook binnen een subwetssysteem laten zich vaak weer verschillende wetssystemen onderscheiden, die dan kunnen worden aangeduid als subsubwetssystemen. ${ }^{41}$

37 Met Hirsch Ballin zou men ook van de architectuur van wetgeving kunnen spreken. Dit betreft het indelen als zodanig en de samenhang die tussen wettelijke bepalingen binnen een wet of over de grenzen van een wet heen moet bestaan (Hirsch Ballin, Architectuur van wetgeving 1984, p. 77).

38 Zie par. 1.2.

39 Het gaat om de volgende algemene maatregelen van bestuur: Besluit bouw- en houtbedrijven milieubeheer, Besluit detailhandel en ambachtsbedrijven milieubeheer, Besluit horeca-, sport- en recreatiebedrijven milieubeheer, Besluit inrichtingen- en motorvoertuigen milieubeheer, Besluit jachthavens, Besluit opslaan in ondergrondse tanks 1998, Besluit opslag- en transportbedrijven milieubeheer, Besluit tankstations milieubeheer, Besluit textielreinigingsbedrijven milieubeheer, Besluit voorzieningen en installaties milieubeheer en Besluit woon- en verblijfsgebouwen milieubeheer.

40 Munneke, Begrippen 2012, p. 28 geeft aan dat er twee mogelijkheden zijn om te bepalen of sprake is van een wet, een algemeen verbindend voorschrift of een verordening. In de formele benadering is iets te kwalificeren als wet, algemeen verbindend voorschrift of verordening, omdat een bepaalde procedure is gevolgd en een bepaald orgaan bij de totstandkoming betrokken is geweest. In de materiële benadering is iets te kwalificeren als wet, algemeen verbindend voorschrift of verordening, omdat de inhoud van dat document aan bepaalde inhoudeliike eisen voldoet, bijvoorbeeld algemene regels bevat.

41 Die ook weer kunnen bestaan uit een of meer subsubsubwetssystemen. 
Zo bevat het wetssysteem van de Flora- en faunawet onder meer een hoofdstuk over algemene bepalingen (hoofdstuk I), de aanwijzing van beschermde soorten (hoofdstuk II), algemene verbodsbepalingen (hoofdstuk III), de beschermde leefomgeving (hoofdstuk IV) en bijzondere bepalingen (hoofdstuk V). Die hoofdstukken kunnen worden gezien als even zovele subwetssystemen. Binnen het subwetssysteem van hoofdstuk $\mathrm{V}^{42}$ valt onder meer een subsubwetssysteem te onderscheiden waarin volgens bepaalde criteria geordende, onderling samenhangende regels staan over de jacht (Titel II).

Wetssystemen zijn te onderscheiden in formele en materiële wetssystemen. Dat wordt hierna toegelicht.

\subsubsection{Formele wetssystemen}

Een wetssysteem bestaat uit volgens bepaalde criteria geordende, onderling samenhangende regels. Vanuit een formele invalshoek ligt het accent daarbij op de uiterlijk zichtbare ordening, de vorm, de 'Außere Systematik'. ${ }^{43}$ Elk wetssysteem bestaat uit een uiterlijk zichtbare aaneenschakeling van regels in de vorm van bijvoorbeeld boeken, hoofdstukken, delen, paragrafen, titels en dergelijke, die telkens kleinere of grotere groepen van regels als onderling samenhangend omvatten.

In zijn elementaire vorm zal een formeel wetssysteem er in Nederland aldus uitzien:

Regelniveau 1: wet in materiële zin ${ }^{44}$

Regelniveau 2: hoofdstukken of paragrafen

Regelniveau 3: artikelen

Regelniveau 4: artikelleden.

Dit sluit aan bij aanwijzing 97 van de Aanwijzingen voor de regelgeving: 'Indien dit voor de toegankelijkheid van een regeling van belang is, wordt deze systematisch in Arabisch genummerde onderdelen verdeeld. Bij een verdeling op één niveau worden de onderdelen hoofdstuk of paragraaf genoemd.'45

42 Titel I betreft faunabeheereenheden en faunabeheerplannen. GS kunnen samenwerkingsverbanden van jachthouders erkennen als faunabeheereenheden ten behoeve van het beheer van diersoorten of de bestrijding van schade aangericht door dieren (art. $29 \mathrm{Ffw}$ ). Voor zover krachtens de art. 67 of 68 Ffw faunabeheerplannen worden geëist, behoeven deze de goedkeuring van GS, gehoord het Faunafonds (art. $30 \mathrm{Ffw}$ ). Titel II bevat regels inzake de jacht. Het gaat om regels inzake bejaagbare soorten (afd. 1), de jager (afd. 2), de jachtakten (afd. 3), het jagen (afd. 4), de verzekeringsplicht voor wie met een geweer jaagt (afd. 5) en eendenkooien (afd. 6). Titel III bevat regels inzake vrijstellingen, ontheffingen en vergunningen. Het gaat onder meer om ontheffing van het verbod van art. $12 \mathrm{Ffw}$ voor het zoeken en rapen van kievitseieren (art. $60 \mathrm{Ffw}$ ).

43 Noll, Gesetzgebungslehre 1973, p. 206-207.

44 Waaronder te verstaan een wet in formele zin: het document dat volgens de in de Grondwet omschreven procedure tot stand wordt gebracht door Regering en Staten-Generaal gezamenlijk (art. 81 Gw e.v.) (Munneke, Begrippen 2012, p. 59).

45 Minister-President, Aanwijzingen voor de regelgeving, wetten.overheid.nl/BWBR0005730/geldigheidsdatum 18-01-2012, p. 40. 
Deze elementaire uitwendige vorm van een wetssysteem kan nog worden uitgebreid door regelniveau 2 verder onder te verdelen.

Aanwijzing 97 vermeldt daarover: 'Bij een verdeling op twee niveaus worden de onderdelen van het eerste niveau hoofdstuk en de onderdelen van het tweede niveau paragraaf genoemd. Bij een verdeling op meer dan twee niveaus worden de onderdelen in volgorde van omvang deel, hoofdstuk, titel, afdeling en paragraaf genoemd, met dien verstande dat in ieder geval de aanduidingen hoofdstuk en paragraaf worden gebruikt. De benaming boek wordt alleen gebruikt voor een deel van een wetboek.'

Dat betekent dus, dat een formeel wetssysteem er dan als volgt uit kan zien: Regelniveau 1: wet in materiële zin

Regelniveau 2a: delen

Regelniveau 2b: hoofdstukken

Regelniveau 2c: titels

Regelniveau 2d: afdelingen

Regelniveau 2e: paragrafen

Regelniveau 3: artikelen

Regelniveau 4: artikelleden.

Ter illustratie worden in overzicht 2.1 regelniveaus in de Wet milieubeheer genoemd.

\section{Overzicht 2.1 Regelniveaus in de Wet milieubeheer}

\begin{tabular}{|l|l|}
\hline Regelniveau 1: & Wet milieubeheer \\
\hline Regelniveau 2a: & $\begin{array}{l}\text { hoofdstukken, zoals Hoofdstuk 16 Handel in emissierechten, onder- } \\
\text { verdeeld in: }\end{array}$ \\
\hline Regelniveau 2b: & $\begin{array}{l}\text { titels, zoals Titel 16.2 Broeikasgassen en broeikasgasemissierechten, } \\
\text { die in een aantal gevallen weer zijn onderverdeeld in: }\end{array}$ \\
\hline Regelniveau 2c: & $\begin{array}{l}\text { afdelingen, zoals Afdeling 16.2.3 Het toewijzen en verlenen van } \\
\text { broeikasgasemissierechten en het gebruik van emissiereductie-een- } \\
\text { heden en gecertificeerde emissierechten, welke in een aantal gevallen } \\
\text { weer zijn onderverdeeld in: }\end{array}$ \\
\hline Regelniveau 2d: & $\begin{array}{l}\text { paragrafen, zoals Paragraaf 16.2.3.1 Het nationale toewijzingsplan, } \\
\text { waarin: }\end{array}$ \\
\hline Regelniveau 3: & artikelen, die vaak zijn onderverdeeld in: \\
\hline Regelniveau 4: & leden \\
\hline
\end{tabular}


De Wet milieubeheer vormt een wetssysteem, waarbinnen subwetssystemen (hoofdstukken), subsubwetssystemen (titels), subsubsubwetssystemen (afdelingen) en subsubsubsubwetssystemen (paragrafen) kunnen worden onderscheiden.

Zoals gezegd vormt elke wettelijke regeling een formeel wetssysteem. Gewoonlijk zal die in het hiervoor genoemde stramien kunnen worden ondergebracht, reeds omdat van de wetgever mag worden verwacht dat Aanwijzing 97 van de Aanwijzingen voor de regelgeving wordt gerespecteerd. Een wetssysteem kan echter ook bestaan uit slechts een enkel artikel.

Een voorbeeld binnen het omgevingsrecht betreft het Besluit van 8 augustus 2011, houdende vaststelling van het tijdstip van inwerkingtreding van enkele onderdelen van de Aanpassingswet handel in emissierechten II. ${ }^{46}$ Dit wetssysteem kent als 'Enig artikel: Artikel I, onderdeel B, onder 1, onder a, 4, 5, 8, 13 , $14,15,16,17,17 \mathrm{a}, 18,19,20$ en 21, en artikel IIA van de Aanpassingswet handel in emissierechten II treden in werking met ingang van 1 september 2011.'

In theorie laat zich denken dat ook een wet als de Wet milieubeheer bestaat uit één artikel met even zoveel leden als die wet thans artikelleden kent; ook dan is sprake van een formele wetssystematiek, zij het dat regelniveau 2 dan afwezig is. In theorie zou zelfs het gehele Nederlandse recht in één wetboek kunnen worden ondergebracht met bijvoorbeeld evenzoveel delen of boeken als er thans wetten in formele zin zijn; ook dan is sprake van een formeel wetssysteem.

Een formeel wetssysteem vormt een hulpmiddel voor de toegankelijkheid van een wettelijke regeling. ${ }^{47}$ Dit formele wetssysteem $k a n$ een weerspiegeling zijn van het hierna ${ }^{48}$ te bespreken materiële wetssysteem, doch dat hoeft niet het geval te zijn. ${ }^{49}$ Eijlander \& Voermans merken terecht op dat formele indelingsstructuren bijdragen aan de toegankelijkheid van regelingen doordat zij als het ware herkenningspunten, of wegwijzers in een tekst aanbrengen die een gebruiker kan benutten als houvast bij het lezen van de wettekst. Een degelijk routeplan binnen een regeling moet er dan voor

\section{Stb. 2011, 389.}

47 Aanwijzing 97 geeft aan dat een regeling systematisch van Arabische cijfers wordt voorzien indien dat voor de toegankelijkheid van een regeling van belang is.

48 Zie par. 2.3.3.

49 Ook Noll lijkt die mening te zijn toegedaan waar hij - onder aanhaling van Engish, Sinn und Tragweite juristischer Systematik, in: Studium Generale 1957, p. 180 - schrijft: 'Das äußere System kann das innere nur «bis zu einem gewissen Grade widerspiegeln» die äußere Einteilung der Gesetzbücher in <Allgemeine $>$ und $<$ Besondere $>$ Teile mag unter Umständen $\ll$ den wesentlichen Unterschied allgemeiner Grundgedanken und untergeordneter besonderer Rechtsgedanken ausdrücken», dient aber «im wesentlichen nur gesetzestechnischen Absichten».' (Noll, Gesetzgebungslehre 1973, p. 207). 
zorgen dat de toegankelijke indeling ook een betrouwbare wegwijzer is naar betekenisvol samenhangende groepen van normen in een regeling..$^{5}$

Een voorbeeld betreft de Wet milieubeheer waarvan de formele wetssystematiek bestaat uit 22 hoofdstukken. Dat betekent echter nog niet, dat deze hoofdstukken materieel met elkaar samenhangen. Woldendorp spreekt in dit verband van een ballenbak. ${ }^{51}$

Noll spreekt van numerieke systeemordeningscriteria. ${ }^{52}$ Het gaat daarbij volgens hem om een bijzondere vorm van zakelijke systeemordeningscriteria. ${ }^{53}$ Een wettelijke regeling zal ook volgens Noll gewoonlijk bestaan uit genummerde hoofdstukken, paragrafen, titels, afdelingen, artikelen en leden van artikelen, maar die nummering betreft een strikt formeel registratiehulpmiddel.

\subsubsection{Materiële wetssystemen}

Een wetssysteem heb ik hiervoor gedefinieerd als volgens bepaalde criteria geordende, onderling samenhangende regels. Ligt bij formele wetssystemen het accent op de uiterlijk zichtbare ordening, bij materiële wetssystemen ligt het accent op de inhoudelijke systeemordeningscriteria en de onderlinge samenhang.

In beginsel heeft de wetgever een schier oneindig aantal mogelijkheden aan inhoudelijke criteria om onderlinge samenhang aan te brengen. ${ }^{54}$ Daarbij maak ik onderscheid tussen zakelijke en typisch juridische samenhangcriteria. In hoofdstuk 3 zullen deze systeemordeningscriteria worden toegelicht; op deze plaats worden zij slechts kort genoemd met een enkel voorbeeld.

Van zakelijke systeemordeningscriteria ${ }^{55}$ is sprake als de criteria aansluiten bij de echte werkelijkheid van het te beschermen belang (zoals milieu, natuur, ruimtelijke ordening), een activiteit (zoals het oprichten van een bedrijf), een object (zoals een stof of een inrichting) of een (rechts)subject (zoals de exploitant van een bedrijf). Deze criteria sluiten aan bij de gezichtspunten die Hill noemt om wetssystemen in te delen: beschermd rechtsgoed, rechtsvormen en rechtsbetrekkingen, chronologie en groepen

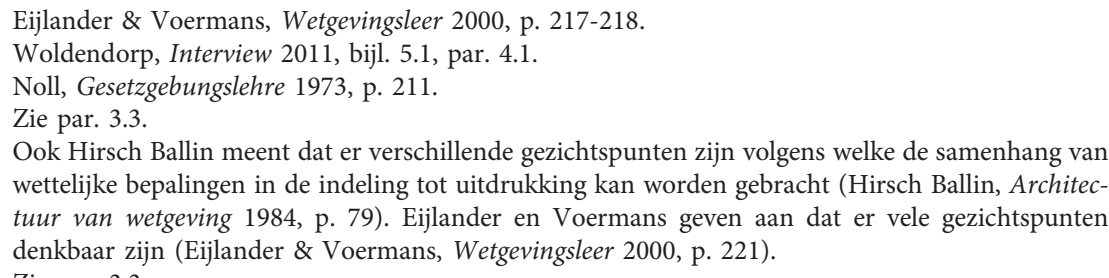


personen..$^{56}$ Eijlander \& Voermans geven voor elk van deze gezichtspunten een voorbeeld in het Nederlandse recht. ${ }^{57}$

Van typisch juridische systeemordeningscriteria ${ }^{58}$ is sprake bij criteria die gewoonlijk hun oorsprong vinden in de juridische wetenschap. Voorbeelden zijn het onderscheid tussen publiek- en privaatrecht, rechtsverhoudingen en de aard van een wettelijke regeling (wet in formele zin, algemene maatregel van bestuur, ministeriële regeling). Van typisch juridische systeemordeningscriteria is ook sprake als wettelijke regelingen worden geordend in categorieën zoals algemeen en bijzonder, of omvattend begrip en ondergeschikt begrip. Als voorbeeld van die laatste categorie noem ik hoofdstuk 3 Awb dat algemene bepalingen over besluiten bevat en hoofdstuk 4 van diezelfde wet waarin bijzondere bepalingen over besluiten, ${ }^{59}$ waaronder beschikkingen ${ }^{60}$ staan.

\subsection{WETSSYSTEMATISCHE TEKORTEN}

\subsubsection{Algemeen}

Uitgangspunt voor dit onderzoek zijn wetssystemen. Een wetssysteem bestaat per definitie uit volgens bepaalde criteria geordende, onderling samenhangende regels. In een wetssysteem dienen derhalve alle regels te worden opgenomen die beantwoorden aan het door de wetgever gekozen samenhangcriterium. Het samenhangcriterium bepaalt het systeem.

Volgens Hill moet een formeel wetssysteem het materiële wetssysteem volgen. Hill: 'Daraus ergibt sich die Forderung, sachlich zusammenhängende Materien auch zusammenhängend zu regeln. ${ }^{61}$ In dit verband noem ik ook Sebus die aanbeveelt om wat feitelijk bij elkaar hoort ook bij elkaar te regelen. ${ }^{62}$ Bij Sebus is het een van de vijf aanbevelingen in het kader van het logisch verdelen van de inhoud van een regeling. ${ }^{63}$ In het kader van het bundelen van regels gaat het hier mijns inziens om de kern.

56 Hill, Einführung in die Gesetzgebungslehre 1982, p. 103.

57 Eijlander \& Voermans, Wetgevingsleer 2000, p. 220-221.

58 Zie par. 3.4.4.

59 Onder besluit wordt verstaan: een schriftelijke beslissing van een bestuursorgaan, inhoudende een publiekrechtelijke rechtshandeling (art. 1:3 lid 1 Awb)

60 Onder beschikking wordt verstaan: een besluit dat niet van algemene strekking is, met inbegrip van de afwijzing van een aanvraag daarvan (art. 1:3 lid 2 Awb).

61 Hill, Einführung in die Gesetzgebungslehre 1982, p. 98-99.

62 Sebus, Wetgevingstechniek en de toegankelijkheid van de wet 1984, p. 65.

63 Eijlander \& Voermans noemen de aanbevelingen van Sebus zeer bruikbaar bij het logisch verdelen van de inhoud van een regeling over regelingsonderdelen (Eijlander \& Voermans, Wetgevingsleer 2000, p. 218). 
Voor dit onderzoek is verder de notie van het wetssystematisch tekort van wezenlijk belang. Van een wetssystematisch tekort is gelet op de definitie van een wetssysteem sprake als bepaalde regels volgens bepaalde samenhangcriteria onderling samenhangen maar desalniettemin geen deel uitmaken van hetzelfde wetssysteem. Ook Hill meent dat de wetgever een grote speelruimte toekomt 'bei der erstmaligen Einteilung rechtlicher Aussagen und Regelungen in ein bestimmtes gesetzliches System.' 'Hat er sich jedoch für eine bestimmte Einteilung entschieden, muß bei zeitlich späteren Regelungen, die in das System eingepaßt werden, der Grundsatz der Systemgerechtigkeit herrschen. ${ }^{64}$

In dit onderzoek beperk ik mij tot materiële wetssystemen, ${ }^{65}$ de inhoudelijke samenhang tussen wetssystemen of onderdelen daarvan. De formele wetssystematiek ${ }^{66}$ blijft daarbij buiten beschouwing.

In theorie laten zich verschillende mogelijkheden denken om ten onrechte ontbrekende samenhang tussen wetssystemen alsnog te realiseren: coördinatie, harmonisatie, integratie, herschikking en consolidatie. Deze verschillende manieren zullen hierna worden gedefinieerd. Bij het formuleren van het begrippenkader zal ik waar mogelijk steeds een voorbeeld noemen uit de Nederlandse omgevingsrechtpraktijk.

\subsubsection{Coördinatie}

Van coördinatie is sprake als tussen twee of meer wetssystemen samenhang wordt gebracht door een nieuwe wettelijke regeling waarbij de beide te coördineren wetssystemen blijven bestaan. In geval van coördinatie is geen sprake van bundeling. Zoals ik in paragraaf 2.3.1 heb aangegeven reserveer ik de term bundeling voor het geval wetssystemen worden samengevoegd. Bij coördinatie is dat niet het geval. De te coördineren wetssystemen veranderen niet als gevolg van coördinatie, zij het dat daaraan wel de coördinatieregeling kan worden toegevoegd.

Deze term sluit aan bij de terminologie van Faure: 'Coordination: this term is reserved for the situation where separate environmental legal acts remain in existence with separate licensing requirements (and hence no harmonization of licenses took place), but where the legislature has provided for legal rules which force the various authorities to take into account the separate procedures or licenses. ${ }^{67}$

\footnotetext{
64 Hill, Einführung in die Gesetzgebungslehre 1982, p. 102.

65 Zie par. 2.3.3.

66 Zie par. 2.3.2.

67 Faure, The Harmonization, Codification and Integration of Environmental Law: A Search for Definitions 2000, p. 181.
} 
In overzicht 2.2 is coördinatie schematisch weergegeven.

Overzicht 2.2 Schematische weergave coördinatie

\begin{tabular}{|l|l|}
\hline Voor coördinatie & Na coördinatie \\
\hline Wetssysteem A & Wetssysteem A \\
Wetssysteem B & Wetssysteem B \\
& Coördinatieregeling C \\
\hline
\end{tabular}

Een voorbeeld betreft de met de inwerkingtreding van de Wet algemene bepalingen omgevingsrecht op 1 oktober 2010 vervallen coördinatieregeling tussen de op die datum in de omgevingsvergunning geïntegreerde bouw- en milieuvergunning. ${ }^{68}$ Tot de inwerkingtreding van die wet waren voor het realiseren van een inrichting ${ }^{69}$ vaak een bouwvergunning ${ }^{70}$ en een milieuvergunning ${ }^{71}$ vereist.

Op grond van artikel 40 Woningwet $^{72}$ was het verboden te bouwen ${ }^{73}$ zonder of in afwijking van een door burgemeester en wethouders verleende bouwvergunning. Voor het bouwen van een inrichting was gewoonlijk ${ }^{74}$ een bouwvergunning nodig.

Op grond van artikel $8.1 \mathrm{Wm}^{75}$ was het in bepaalde gevallen ${ }^{76}$ verboden zonder milieuvergunning een inrichting op te richten, te veranderen of de werking daarvan te veranderen of in werking te hebben.

68 De afstemmingsregels stonden tot 1 oktober 2010 in art. 8.5, 20.1, 20.3 en $20.8 \mathrm{Wm}$, art. 8 en 52 Wonw en art. 5.3 Ivb. De desbetreffende artikelen in de Wm zijn vervallen als gevolg van art. 9.10, onder JJJ, K, LLL en OOO van de Invoeringswet Wabo (Stb. 2010, 142). De desbetreffende artikelen in de Wonw zijn vervallen als gevolg van art. 9.16, onder K en W van de Invoeringswet Wabo (Stb. 2010, 142). Het Ivb is vervallen als gevolg van art. 1.43 Invoeringsbesluit Wabo (Stb. 2010, 144). Zie ook VMR, Afstemmingsregelingen in de Wm 1996.

69 Inrichting: elke door de mens bedrijfsmatig of in een omvang alsof zij bedrijfsmatig was, ondernomen bedrijvigheid die binnen een zekere begrenzing pleegt te worden verricht (art. 1.1 lid $1 \mathrm{Wm}$ ).

70 Op grond van art. 40 Wonw zoals dat gold tot 1 oktober 2010.

71 Op grond van art. 8.1 Wm zoals dat gold tot 1 oktober 2010.

72 Op 1 oktober 2010 vervallen als gevolg van de inwerkingtreding van de Wabo.

73 Bouwen: het plaatsen, het geheel of gedeeltelijk oprichten, vernieuwen of veranderen en het vergroten van een bouwwerk, alsmede het geheel of gedeeltelijk oprichten, vernieuwen of veranderen en het vergroten van een standplaats (art. 40 Wonw). De Woningwet bevat(te) geen definitie van een bouwwerk, maar de jurisprudentie verstaat daaronder: elke constructie van enige omvang van hout, steen, metaal of ander materiaal, die op de plaats van bestemming hetzij direct hetzij indirect met de grond verbonden is, hetzij direct hetzij indirect steun vindt in of op de grond, bedoeld om ter plaatse te functioneren.

74 Voor bouwen was in bepaalde gevallen geen bouwvergunning nodig, maar dat was gewoonlijk niet het geval bij een inrichting van enige omvang.

75 Op 1 oktober 2010 vervallen als gevolg van de inwerkingtreding van de Wabo.

76 De vergunningplicht gold voor een inrichting waartoe een gpbv-installatie behoort (art. 8.1 lid 1 Wm zoals dat gold tot 1 oktober 2010) en bij amvb aangewezen andere categorieën van inrichtingen (artikel 8.1 lid $2 \mathrm{Wm}$ zoals dat gold tot 1 oktober 2010). Deze amvb was het per 1 oktober 2010 vervallen Inrichtingen- en vergunningenbesluit milieubeheer. 
Tot de inwerkingtreding van de Wet milieubeheer op 1 maart 1993 waren de bouwvergunning en de hinderwetvergunning, de voorganger van de milieuvergunning, niet op elkaar afgestemd. ${ }^{77}$ Dat kon tot gevolg hebben dat een bouwvergunning voor de inrichting vanwege het imperatief-limitatieve stelsel in artikel 40 Woningwet moest worden verleend, ${ }^{78}$ terwijl de hinderwetgunning als gevolg van de daarvoor geldende toetscriteria niet kon worden verleend of eisen bevatte die niet in overeenstemming waren met de verleende bouwvergunning.

Zo was het bijvoorbeeld mogelijk dat de hinderwetvergunning een schoorsteen van 30 meter hoogte eiste, terwijl daarvoor geen bouwvergunning kon worden verleend omdat zulks in strijd zou zijn met het bestemmingsplan. Dat kon ertoe leiden dat de inrichting niet mocht worden gebouwd als bouwwerk, maar - mits aan de voorschriften zou worden voldaan - wel mocht worden opgericht als inrichting. Dit voorbeeld laat zien, dat de wetgever geen samenhang had geregeld tussen het wetssysteem van de Woningwet voor wat betreft de bouwvergunning en het wetssysteem van de Hinderwet voor wat betreft de hinderwetvergunning, terwijl die samenhang in werkelijkheid wel bestond en relevant was of - in soortgelijke gevallen - zou kunnen zijn.

Michiels noemt een geval waarin BenW van Oudkarspel een milieuvergunning op grond van artikel $8.1 \mathrm{Wm}$ (zoals dat luidde tot 1 oktober 2010) hadden verleend aan een houthandel in Oudkarspel. In de milieuvergunning was voorgeschreven dat binnen vijf jaar een in- en uitrit moest zijn gerealiseerd. De aanleg van de in- en uitrit op de voorgeschreven plaats was echter op grond van het geldende bestemmingsplan niet mogelijk. Er waren ook geen pogingen ondernomen om het bestemmingsplan op dit punt aan te passen. Handhaving van het voorschrift was daarom niet mogelijk. ${ }^{79}$

Op 1 maart 1993 is de Wet milieubeheer in werking getreden. De Hinderwet verviel en de hinderwetvergunning werd vervangen door de milieuvergunning. ${ }^{80}$ In de Wet milieubeheer had de wetgever wel samenhang gerealiseerd tussen het wetssysteem van de Woningwet en het wetssysteem van de Wet milieubeheer of zo men wil tussen de bouwvergunning en de milieuvergunning door middel van een procedurele afstemmings- of coördinatieregeling. ${ }^{81}$ Die regeling kwam erop neer, dat de milieuvergunning en de bouwvergunning in beginsel $^{82}$ gelijktijdig moesten worden aangevraagd. Moest de bouwvergunning worden geweigerd, dan viel er niets af te

77 Van der Peppel/Hardenberg/Bröring \& Lambers, Afstemmingsregelingen in de Wm 1996, p. 10.

78 Samengevat betekende dat, dat de aanvraag om een bouwvergunning werd getoetst aan een limitatief aantal criteria. Werd aan de criteria, zoals het bestemmingsplan, het Bouwbesluit, de Bouwverordening en redelijke eisen van welstand voldaan, dan moest de bouwvergunning worden verleend; zo niet, dan moest de bouwvergunning worden geweigerd.

79 ABRvS 14 december 2000, nr. 200004247/1. Michiels, Kleur in het omgevingsrecht 2001, p. 12.

80 Stb. 1992, 414 en Stb. 1993, 59.

81 In de art. 8.5, 20.1, 20.3 en 20.8 Wm, art. 8 en 52 Wonw en art. 5.3 Ivb. Deze artikelen zijn vervallen op 1 oktober 2010 met de inwerkingtreding van de Wabo.

82 De milieuvergunningaanvraag mocht ook eerder worden ingediend. 
stemmen. Als er echter geen reden was om de bouwvergunning te weigeren, dan moest de beslissing op de bouwaanvraag worden aangehouden totdat de beslissing op de milieuaanvraag in een bepaald stadium verkeerde. De milieuvergunning trad vervolgens niet eerder in werking dan nadat de bouwvergunning was verleend. ${ }^{83}$ Gilhuis sprak van een ingewikkelde coördinatieregeling, die volgens hem een verbetering was ten opzichte van de daarvoor bestaande situatie, maar nogal wat zwakke plekken vertoonde, veroorzaakt door het compromiskarakter van de regeling. ${ }^{84}$

Het aldus gedefinieerde begrip coördinatie heeft in dit onderzoek betrekking op coördinatie van wetssystemen. Het moet - in het gegeven voorbeeld worden onderscheiden van de activiteit van het inhoudelijk coördineren van de bouw- en milieuvergunning zelf. In de Herijkingsbrief wordt gesteld dat coördinatie in de praktijk bijzonder moeilijk tot stand te brengen is. En waar zij tot stand komt, blijkt ze vaak onvoldoende soelaas te bieden. 'Regelingen over coördinatie zijn ook bijna per definitie ingewikkeld', aldus de Herijkingsbrief. ${ }^{85}$ Ook Rademaker is van oordeel dat coördinatieregelingen om diverse procedures op elkaar af te stemmen "nooit eenvoudig worden." 86

\subsubsection{Harmonisatie}

Van harmonisatie is sprake als tussen twee of meer wetssystemen samenhang wordt gebracht door die wetssystemen als zodanig te laten bestaan, maar aan elkaar aan te passen. Dat is mogelijk door wetssysteem A aan te passen aan wetssysteem B, door wetssysteem $B$ aan te passen aan wetssysteem A of door zowel wetssysteem A als wetssysteem B aan te passen.

Deze definitie sluit aan bij de definitie van Faure, die onder meer spreekt van harmonisatie als the legal situation where various separate procedures are approximated (harmonization of procedures) and separate legal acts remain in existence' of 'various substantive environmental laws are approximated. ${ }^{, 87}$ Mijn definitie lijkt ook aan te sluiten bij de Aanwijzingen voor de regelgeving die in paragraaf 2.6 vijf anwijzingen wijden aan harmonisatie. Zo bepaalt aanwijzing 47 dat in gevallen waarin soortgelijke onderwerpen worden geregeld, zoveel mogelijk wordt gestreefd naar harmonisatie van regelgeving. Aanwijzing 48 bepaalt dat bij wijziging van een regeling wordt nagegaan welke wijzigingen uit een oogpunt van harmonisatie kunnen worden meegenomen. De toelichting op die aanwijzing vermeldt dat 'wijziging van een regeling (...) soms een goede

\footnotetext{
Art. $20.8 \mathrm{Wm}$ zoals dat luidde tot 1 oktober 2010.

Gilhuis, Coördinatie bouw- en milieuvergunning 1992.

Ministerie van VROM, Herijkingsbrief 2003, p. 12

Rademaker, Interview 2011, bijl. 5.2, par. 1.1.

Faure, The Harmonization, Codification and Integration of Environmental Law: A Search for Definitions 2000, p. 181. Faure begrijpt onder harmonisatie ook het geval dat the number of licenses is reduced', maar dat kan in mijn optiek ook het gevolg zijn van bundeling, zoals ik in hfds. 4 aan de hand van de Wabo zal toelichten.
} 
aanleiding (kan) zijn om gelijktijdig de regeling zoveel mogelijk naar vorm en inhoud met vergelijkbare regelingen in overeenstemming te brengen. ${ }^{88}$

In overzicht 2.3 is harmonisatie schematisch weergegeven.

Overzicht 2.3 Schematische weergave harmonisatie

\begin{tabular}{|l|l|l|}
\hline & Voor harmonisatie & Na harmonisatie \\
\hline I & Wetssysteem A & Wetssysteem A \\
& Wetssysteem B1 & Wetssysteem B2 \\
\hline II & Wetssysteem A1 & Wetssysteem A2 \\
& Wetssysteem B & Wetssysteem B \\
\hline \multirow{2}{*}{ III } & Wetssysteem A1 & Wetssysteem A2 \\
& Wetssysteem B1 & Wetssysteem B2 \\
\hline
\end{tabular}

Een voorbeeld van harmonisatie biedt artikel 5.1 Wabo. Daarin wordt de handhaving van het bij of krachtens de Wabo bepaalde, alsmede met betrekking tot de handhaving van het bepaalde bij of krachtens de Floraen faunawet, de Kernenergiewet, de Monumentenwet 1988, de Natuurbeschermingswet 1998, de Ontgrondingenwet, de Wet bescherming Antarctica, de Wet bodembescherming, de Wet geluidhinder, de Wet inzake de luchtverontreiniging, de Wet milieubeheer, de Wet ruimtelijke ordening, de Waterwet en de Woningwet geharmoniseerd door hoofdstuk 5 Wabo Bestuursrechtelijke handhaving van de Wabo van toepassing te verklaren voor zover dit bij of krachtens de genoemde wetten is bepaald.

Als gevolg van deze bepaling geldt paragraaf 5.3 Wabo Aanwijzing ambtenaren met toezichthoudende of opsporingsbevoegdheden ${ }^{89}$ geheel of gedeeltelijk ten aanzien van de Flora- en faunawet, ${ }^{90}$ de Monumentenwet $1988,{ }^{91}$ hoofdstuk IX Natuurbeschermingswet 1998, ${ }^{92}$ de Ontgrondingenwet, ${ }^{93}$ de

http://wetten.overheid.nl/BWBR0005730/Hoofdstuk2/26/geldigheidsdatum_12-02-2012.

Art. 5.10-5.13 Wabo.

Art. 113a lid 2 Ffw: Met betrekking tot de handhaving van het bij of krachtens afdeling 2a bepaalde zijn de art. 5.3-5.25 Wabo van toepassing. Afd. 2a heeft betrekking op de omgevingsvergunning.

91 Art. 63 lid 3 Monw 1988: Met betrekking tot de handhaving van het bepaalde bij of krachtens deze wet is hoofdstuk 5 Wabo van toepassing, met uitzondering van art. 5.2 en par. 5.5 van die wet en, indien het een archeologisch monument betreft, met uitzondering van art. 5.11 van die wet. Art. 5.11 heeft betrekking op de aanwijzing van interbestuurlijke toezichthouders.

92 Art. 57a lid $1 \mathrm{Nb}$-wet 1998: Met betrekking tot de handhaving van het bij of krachtens hoofdstuk IX bepaalde zijn de art. 5.3-5.25 Wabo van toepassing.

93 Art. 22 Ontgrondingenwet: Met betrekking tot de handhaving van het bij of krachtens deze wet bepaalde zijn de art. 5.10, 5.13-5.16 en 5.18-5.25 Wabo van toepassing. 
Wet bescherming Antarctica, ${ }^{94}$ de Wet bodembescherming, ${ }^{95}$ de Wet geluidhinder, ${ }^{96}$ de Wet inzake de luchtverontreiniging, ${ }^{97}$ de Wet milieubeheer, ${ }^{98}$ de Wet ruimtelijke ordening ${ }^{99}$ en de Woningwet. ${ }^{100}$ Daarmee is ten aanzien van genoemde paragraaf 5.3 Wabo samenhang gebracht tussen de genoemde wetssystemen door die wetssystemen als zodanig te laten bestaan, maar aan elkaar aan te passen.

Toegegeven zij, dat de wetgevingstechniek waarmee deze harmonisatie is gerealiseerd niet zuiver in de door mij gegeven schematische voorstelling past. Mijns inziens betreft het hier echter in de kern variant III, aangezien elk van de wetssystemen a quo is aangepast. Die aanpassing heeft echter met uitzondering ten aanzien van de Wabo zelf - niet in elk wetssysteem zelf plaatsgevonden, maar door in elk van die wetssystemen te verwijzen naar paragraaf 5.3 Wabo. Aldus is in elk van die wetssystemen - met uitzondering van de Wabo - een wetssystematisch tekort geschapen aangezien de tot elk van die wetssystemen behorende regels niet daarin zijn opgenomen. ${ }^{101}$

\subsubsection{Integratie}

Het opheffen van wetssystematische tekorten door samenhang tussen wetssystemen te scheppen kan ook op een andere, verdergaande manier - dan coördinatie of harmonisatie - worden bewerkstelligd, namelijk door integratie $^{102}$ van een wetssysteem in een ander wetssysteem. Zie ik het juist, dan ziet Faure dit ook als harmonisatie, ${ }^{103}$ doch in het kader van mijn

94 Art. 28 Wet bescherming Antarctica: Met betrekking tot de handhaving van het bij of krachtens deze wet bepaalde zijn de art. 5.10, 5.13-5.16, 5.18, 5.19 lid 1 en lid 3, en 5.20-5.23 Wabo van toepassing. Art. 5.11 heeft betrekking op de aanwijzing van interbestuurlijke toezichthouders. Art. 5.12 heeft betrekking op de aanwijzing van opsporingsambtenaren.

95 Art. 95 lid $1 \mathrm{Wbb}$ : Met betrekking tot de handhaving van het bij of krachtens deze wet bepaalde zijn de art. 5.3-5.16 en 5.18-5.25 Wabo van toepassing.

96 Art. 148 lid 1 Wgh: Met betrekking tot de handhaving van het bij of krachtens deze wet bepaalde zijn de art. 5.3-5.16 en 5.18-5.25 Wabo van toepassing, met dien verstande dat met het toezicht op de naleving van het bij of krachtens deze wet bepaalde ten aanzien van inrichtingen als bedoeld in art. 170 lid 1, uitsluitend belast zijn de daartoe bij besluit van Onze Minister aangewezen ambtenaren.

97 Art. 90 lid 1 Wet luvo: Met betrekking tot de handhaving van het bij of krachtens deze wet bepaalde zijn de art. 5.3-5.16 en 5.18-5.25 Wabo van toepassing.

98 Art. 18.1a Wm: De art. 5.3-5.16 en 5.18-5.26 Wabo zijn van toepassing met betrekking tot de handhaving van het bepaalde bij of krachtens deze wet.

99 Art. 7.1 lid 3 Wro: Met betrekking tot de handhaving van het bepaalde bij of krachtens deze wet zijn de art. 5.3-5.25 Wabo van toepassing.

100 Art. 92 lid 2 Wonw: Met betrekking tot de handhaving van het bepaalde bij of krachtens de hoofdstukken I tot en met III zijn de art. 5.2 lid 2 en 5.3-5.25 Wabo van toepassing.

101 Zie verder par. 4.3.3, waarin in dit verband wordt gesproken van een wetssystematische koekoekseibepaling.

102 Opgemerkt zij dat integratie in verschillende kennisgebieden verschillende, specifieke betekenissen kan hebben.

103 Faure, The Harmonization, Codification and Integration of Environmental Law: A Search for Definitions 2000, p. 181 
onderzoek maak ik een duidelijk onderscheid, omdat ik meen dat dat een genuanceerder benadering van mijn onderzoeksvraag mogelijk maakt.

Van integratie is sprake als tussen twee of meer wetssystemen samenhang wordt gebracht door een wetssysteem geheel te laten opgaan in een ander wetssysteem, waarbij het geïntegreerde wetssysteem wordt ingetrokken. Het te integreren wetssysteem past zich aan het integrerende wetssysteem aan.

In overzicht 2.4 is integratie schematisch weergegeven.

\section{Overzicht 2.4 Schematische weergave integratie}

\begin{tabular}{|l|l|}
\hline Voor integratie & Na integratie \\
\hline Wetssysteem A & Wetssysteem A \\
& + \\
Wetssysteem B & Wetssysteem B
\end{tabular}

Een voorbeeld van integratie betreft de in hoofdstuk 5 te bespreken integratie van de Wet milieugevaarlijke stoffen ${ }^{104}$ in de Wet milieubeheer zoals die op 1 juni 2008 zijn beslag heeft gekregen. Als gevolg van deze integratie is het integrerende wetssysteem van de Wet milieubeheer aangevuld met bepalingen uit het geïntegreerde wetssysteem van de Wet milieugevaarlijke stoffen dat als gevolg van de integratie per 1 juni 2008 is komen te vervallen. ${ }^{105}$

\subsubsection{Herschikking}

Gaat bij integratie het geïntegreerde wetssysteem op in het integrerende wetssysteem, van herschikking is sprake als tussen twee of meer wetssystemen samenhang wordt gebracht door die wetssystemen geheel te laten opgaan in een nieuw of vernieuwd wetssysteem, waarbij de herschikte wetssystemen worden ingetrokken. Als ik het juist zie, spreekt Faure hier van codificatie: "this term is usually reserved for the legislative process whereby separate existing legal acts are brought together in one legal document.. ${ }^{106}$ Geheel hetzelfde lijkt het me echter niet, want in de definitie

104 Regelen ter bescherming van mens en milieu tegen gevaarlijke stoffen en preparaten (Wet milieugevaarlijke stoffen), Stb. 1985, 639 .

105 Art. IX van de Wet van 16 mei 2007 tot uitbreiding en wijziging van de Wet milieubeheer in verband met de uitvoering van EG-verordening registratie, evaluatie en autorisatie van chemische stoffen (REACH) en de overheveling van de bepalingen van de Wet milieugevaarlijke stoffen naar de Wet milieubeheer, alsmede daarmee samenhangende wijzigingen van andere wetten (Uitvoeringswet EG-verordening registratie, evaluatie en autorisatie van chemische stoffen (REACH)) (Stb. 2007, 181 en 182)

106 Faure, The Harmonization, Codification and Integration of Environmental Law: A Search for Definitions 2000, p. 181. 
van Faure staat niet - en daaruit volgt ook niet per se - dat de herschikte wetssystemen in een nieuw 'legal document' worden opgenomen en evenmin dat de herschikte wetssystemen worden ingetrokken. ${ }^{107}$

In overzicht 2.5 is herschikking schematisch weergegeven.

\section{Overzicht 2.5 Schematische weergave herschikking}

\begin{tabular}{|l|l|}
\hline Voor herschikking & Na herschikking \\
\hline Wetssysteem A & $\begin{array}{c}\text { Wetssysteem A } \\
+ \\
\text { Wetssysteem B }\end{array} \quad$ Wetssysteem B \\
\hline
\end{tabular}

Een voorbeeld van herschikking betreft het Activiteitenbesluit waarin per 1 januari 2008 elf op artikel 8.40 Wm gebaseerde algemene maatregelen van bestuur gebundeld, waarbij die elf algemene maatregelen van bestuur zijn vervallen. ${ }^{108}$ Een ander recent voorbeeld van herschikking, dat in hoofdstuk 4 zal worden toegelicht, betreft de Wabo. Als gevolg van die herschikking zijn regels van onder meer de Wet milieubeheer (wetssysteem A) en van de Woningwet (wetssysteem B) opgenomen in onder meer ${ }^{109}$ de Wabo (wetssysteem C).

Wat ik hiervoor als herschikking heb gedefinieerd, lijkt samen te vallen met hetgeen de Legal Service van de Europese Commissie kwalificeert als horizontal codification of als horizontal recast.

Codification is the process of bringing together a legislative act and all its amendments in a single new act. The new act passes through the full legislative process and replaces the acts being codified.' De Legal Service van de Europese Commissie maakt onderscheid tussen verticale en horizontale codificatie. In geval van vertical codification 'one original act and its amendments are incorporated in a single new act.' In geval van 'horizontal codification two or more original acts covering related subjects - and the amendments to them are incorporated in a single new act. ${ }^{110}$

Recasting is like codification in that it brings together in a single new act a legislative act and all the amendments made to it. The new act passes through the full legislative process and repeals all the acts being recast. But unlike codification, recasting involves new substantive changes, as amendments are made to the original act during preparation of the recast text.' De Legal Service

107 Voermans, Interview 2012, bijl. 5.5, par. 5.1, verstaat onder codificatie het in de wet formuleren van ongeschreven recht, zoals jurisprudentie. Als het gaat om het samenbrengen van wat reeds geschreven recht is, spreekt hij van assembleren.

108 Zie par. 1.2.

109 Een aantal regels is opgenomen in het Bor (Stb. 2010, 143) en de Mor (Stcrt. 2010, 5162).

110 ec.europa.eu/dgs/legal_service/codifica_en.htm, 12 februari 2012. Als voorbeeld wordt genoemd Directive 2006/12/EC of the European Parliament and of the Council of 5 April 2006 on waste. 
van de Europese Commissie maakt onderscheid tussen verticale en horizontale recasting. In geval van vertical recasting 'one original act and its amendments are incorporated in a single new act'. In geval van horizontal recasting 'two or more original acts covering related subjects - and the amendments to them are incorporated in a single new act.' ${ }^{111}$

Het onderscheid tussen horizontal codification en horizontal recasting valt mijns inziens nagenoeg samen met wat ik in paragraaf 2.5.3 zal omschrijven als codificerende en modificerende herschikking.

\subsubsection{Consolidatie}

In deze paragraaf wil ik nog stilstaan bij wat de Legal Service van de Europese Commissie aanduidt met legislative consolidation: 'combining in a single text the provisions of a basic instrument and all subsequent amendments.' Bij deze wettelijke consolidatie worden inhoud en vorm van de te consolideren wetteksten niet geamendeerd. Het gaat om een zuiver declaratoire, onofficiële vereenvoudiging van de wetgeving. Het doel van consolidatie is het dienen van de interests of citizens, administrative authorities and the business world by providing a more accessible and more transparent legislative framework and has the advantage of making the law more reader-friendly.' Er ontstaat, anders dan in geval van codification, ${ }^{112}$ geen nieuwe wetgeving. ${ }^{113}$

Het is van belang om consolidatie in hoofdstuk 2 toe te lichten aangezien ook bij consolidatie sprake is van het samenvoegen van met elkaar samenhangende wetgeving. Die samenhang is gelegen in het feit dat consolidatie uitgaat van een grondtekst en amendementen daarop.

In Nederland is het - uitzonderingen daargelaten ${ }^{114}$ - de gewoonte om wetten, algemene maatregelen van bestuur en ministeriële regelingen te wijzigen door middel van wijzigingswetgeving zonder dat de gewijzigde regeling opnieuw en in zijn geheel in het Staatsblad wordt gepubliceerd. Een voorbeeld betreft de Wet milieubeheer. Deze milieuwet heeft op 30 mei 2002 voor het laatst als complete wet in het Staatsblad gestaan. ${ }^{115}$ Daarna is

111 ec.europa.eu/dgs/legal_service/recasting_en.htm, 12 februari 2012. Als voorbeeld wordt genoemd Directive 2006/48/EC of the European Parliament and of the Council of 14 June 2006 relating to the taking up and pursuit of the business of credit institutions (recast).

112 Zie par. 2.4.5

113 ec.europa.eu/dgs/legal_service/consolida_en.htm, 12 februari 2012. Als voorbeeld noemt de Legal Service van de Europese Commissie de 'Council Directive of 15 July 1975 on waste, which has been amended several times and was consolidated on 20 November 2003, this consolidation then being used as a basis for the codified instrument.'

114 Als een wet in formele zin vaak is geamendeerd, wordt in bepaalde gevallen overgegaan tot een Tekstplaatsing. Het gaat dan om een beschikking van de Minister van Justitie, die de grondtekst en alle amendementen ongewijzigd consolideert.

115 Beschikking van de Minister van Justitie van 16 mei 2002, houdende plaatsing in het Staatsblad van de tekst van de Wet milieubeheer, zoals deze met ingang van 8 mei 2002 luidt (Stb. 2002, 239) 
de Wet milieubeheer meer dan honderd maal gewijzigd, hetgeen niet heeft geleid tot een nieuwe tekstplaatsing. Deze werkwijze heeft strikt genomen een aantal bezwaren.

Een eerste bezwaar is, dat het onevenredig veel tijd en energie kost om aan de hand van de officiële teksten in het Staatsblad de actuele, geldende tekst van een wetssysteem te achterhalen.

Ter illustratie noem ik de Wabo, die op 1 oktober 2010 in werking is getreden. Op het moment van inwerkingtreding is geen Tekstplaatsing in het Staatsblad gepubliceerd. De wetgever lijkt te verwachten, dat de justitiabele de op 1 oktober 2010 geldende tekst van de Wabo zelf zal (kunnen) samenstellen aan de hand van de door de Eerste Kamer aangenomen versie (Stb. 2008, 496), zoals die is gewijzigd als gevolg van de Invoeringswet Wabo (Staatsblad 2010, 142), de Crisis- en herstelwet (Stb. 2010, 135-137), de Aanpassingswet Dienstenrichtlijn (Stb. 2009, 616), de Wet bestuurlijke lus (Stb. 2009, 570) en de Wet van 29 april 2010 tot kleine wijzigingen en reparaties in diverse wetten op het terrein van VROM (Stb. 2010, 187).

Sedert 1 oktober 2010 is de Wabo verder aangepast als gevolg van de Wet van 7 april 2011 tot wijziging van de Algemene wet bestuursrecht, de Dienstenwet en enige andere wetten ter vastlegging van uitzonderingen op de toepasselijkheid van de positieve fictieve beschikking bij niet tijdig beslissen ingevolge de Dienstenwet (Stb. 2011, 201), de Wet van 6 juni 2011 tot wijziging van de Monumentenwet 1988 en de Wet algemene bepalingen omgevingsrecht in verband met de modernisering van de monumentenzorg (Stb. 2011, 330), de Wet van 6 juli 2011 tot wijziging van de Wet milieubeheer (verbeterde aansluiting van de Wet milieubeheer en de Wet algemene bepalingen omgevingsrecht op de kaderrichtlijn water) (Stb. 2011, 373), de Wet van 25 februari 2012 tot intrekking van de Invoeringswet Wet stedelijke vernieuwing en het redactioneel en wetstechnisch wijzigen van enkele wetten op het terrein van het wonen (Reparatiewet BZK op het terrein van het wonen) (Stb. 2012, 89) en de Wet van 22 februari 2012 tot herstel van wetstechnische gebreken alsmede andere wijzigingen van ondergeschikte aard in diverse wetten op of in verband met het terrein van infrastructuur en milieu (Stb. 2012, 114).

Een tweede bezwaar betreft het feit dat door de geschetste werkwijze van de wetgever wettelijke regelingen die inhoudelijk samenhangen niet zijn ondergebracht binnen één wetssysteem. Daardoor bestaat het gevaar dat het recht steeds onoverzichtelijker wordt, dat regels elkaar doorsnijden en tegen gaan spreken. ${ }^{116}$

Deze bezwaren zijn deels ondervangen door op www.overheid.nl de publicatie van Staatsblad, Staatscourant en Tractatenblad in pdf-formaat met een uitgiftedatum vanaf 1 juli 2009 te zien als een bekendmaking in de zin van

116 In 1973 constateerde Noll al dat 'auch die Wiedersprüche in dem großen Durcheinander der Rechtsunordnung schwer aufzufinden sind' (Noll, Gesetzgebungslehre 1973, p. 218). 
de Grondwet. Vóór die datum geldt dat alleen publicaties in de gedrukte bladen een officieel karakter hebben. Staatscourantpublicaties van vóór 1 juli 2009 zijn slechts gedeeltelijk elektronisch beschikbaar. ${ }^{117}$

Hiervoor schreef ik reeds dat de genoemde bezwaren slechts deels zijn ondervangen. Als ik het goed zie, zijn de teksten van wetssystemen zoals die zijn op te roepen op www.overheid.nl als zodanig in hun geheel immers geen bekendmaking in de zin van de Grondwet, zeker niet als daarin regels voorkomen, die voor 1 juli 2009 in Staatsblad of Staatscourant zijn gepubliceerd. Mij lijkt dat de wetgever alle betrokkenen dan ook een dienst zou bewijzen als hij jaarlijks rechtskracht zou verlenen aan het dan geldende omgevingsrecht. De justitiabele kan dan beschikken over een door de wetgever gecontroleerd en vastgesteld rechtssysteem. Bovendien worden digitale - wettenverzamelingen niet langer 'vervuild' met wetssystemen die voor de rechtspraktijk een slapend bestaan leiden, aangezien ze deel uitmaken van een groter wetssysteem.

Een voorbeeld is de Wet van 14 november 1991, houdende enige wijzigingen van de Grondwaterwet en van de Wet bodembescherming met betrekking tot infiltraties (Stb. 1991, 636). Art. I en III bevatten wijzigingen van de Wet bodembescherming en de Grondwaterwet. Art. II bevat overgangsrecht, waarvan op een gegeven moment vanwege tijdsverloop de waarde betwijfeld kan worden. Art. IV bevat de regeling van inwerkingtreding. De praktijk zal gewoonlijk niet genoemde wet raadplegen, doch de als gevolg van die wet gewijzigde Wet bodembescherming en Grondwaterwet.

De wetgever zou ook zichzelf met de voorgestelde opschoning een dienst bewijzen, aangezien hij door consolidatie voortdurend zicht houdt op en inzicht in de gevolgen van zijn wetgevende arbeid op de bestaande wetssystemen binnen het omgevingsrecht.

In dit verband merk ik op, dat de wetgever wellicht ook zijn voordeel zou kunnen doen met wat Voermans/Moll/Florijn \& Van Lochem als Sloveense best practice hebben opgetekend: 'Finally, we personally feel that the Slovenian procedure might qualify as a "best practice".' We refer back to paragraph 3.3, sub 1, of this paper, in which we mentioned the amended Official Journal Act (2006) of Slovenia. According to that Act, Acts of Parliament are promulgated in a consolidated form (both electronically and on paper) immediately after they have been amended by law. The remarkable point is that Parliament decides about the consolidated version of the amended Act. Thus problems of legal force and legal authenticity of a consolidated act are evaded, because the consolidated text truly represents 'the will of the legislator': the legislator has voted again on the effects its amendments had on the original Act. ${ }^{118}$

117 zoek.officielebekendmakingen.nl/zoeken.

118 Voermans/Moll/Florijn \& Van Lochem, Codification and Consolidation in Europe as Means to Untie Red Tape 2008. 


\subsection{BUNDELING}

\subsubsection{Algemeen}

In paragraaf 2.4 zijn coördinatie, harmonisatie, integratie, herschikking en consolidatie genoemd als manieren om in geval van een wetssystematisch tekort samenhang te scheppen tussen wetssystemen. Een wetssystematisch tekort bestaat immers als bepaalde regels volgens bepaalde samenhangcriteria onderling samenhangen maar desalniettemin geen deel uitmaken van hetzelfde wetssysteem. Coördinatie, harmonisatie, integratie, herschikking en consolidatie kunnen de ontbrekende samenhang alsnog realiseren. $\mathrm{Er}$ is echter wel een belangrijk verschil tussen deze vijf methoden om alsnog samenhang te realiseren. In geval van coördinatie en harmonisatie wordt afhankelijk van de concrete definitie van het wetssysteem - het wetssystematisch tekort namelijk niet, en in geval van integratie, herschikking en consolidatie wel opgelost.

In dit onderzoek wil ik mij om de in paragraaf 1.4 genoemde redenen beperken tot het bundelen van omgevingsrecht, waaronder ik wil verstaan het samenvoegen van wetssystemen als gevolg waarvan een nieuw of vernieuwd wetssysteem ontstaat. Dat is het geval bij integratie en herschikking. Onder bundeling wil ik niet verstaan consolidatie. Weliswaar is ook hier sprake van het samenvoegen van wetssystemen, maar het verschil met herschikking en integratie is dat geen nieuw of vernieuwd wetssysteem ontstaat. Het wetssysteem is voor en na consolidatie immers hetzelfde; er is slechts sprake van een administratieve handeling.

Onder bundeling begrijp ik evenmin coördinatie en harmonisatie, aangezien daar geen sprake is van het samenvoegen van wetssystemen; die instrumenten vallen dan ook buiten het kader van mijn onderzoek. Dat neemt echter niet weg, dat de wetgever die samenhang wil aanbrengen tussen wetssystemen er verstandig aan doet te onderzoeken of met coördinatie of harmonisatie wellicht beter zou kunnen worden bereikt wat met integratie of herschikking wordt beoogd. Dat is echter een andere vraag dan de vraag in hoeverre bundeling verantwoord is. Het is overigens niet uitgesloten dat bundeling verantwoord is, zelfs al zou hetzelfde resultaat kunnen worden bereikt door coördinatie of harmonisatie.

Op deze plaats verdient nog vermelding dat het voor het benoemen van de aard van bundeling - integratie of herschikking - van belang is van welk wetssysteem of van welke wetssystemen men uitgaat. Bij het bundelen van het subwetssysteem (grotendeels) van hoofdstuk $8 \mathrm{Wm}$ en het subwetssysteem van hoofdstuk IV Woningwet in het wetssysteem van de Wabo is sprake van herschikking, aangezien en voor zover beide subwetssystemen zijn opgegaan in het nieuw gevormde wetssysteem van de Wabo. Als de 
Wabo reeds zou hebben bestaan en dezelfde subwetssystemen daarin zouden zijn opgenomen, dan zou sprake zijn geweest van integratie.

2.5.2. Bundelingsniveau

\subsubsection{Algemeen}

In deze paragraaf wordt nader ingegaan op de verschillende niveaus waarop bundeling zich kan voordoen.

In de eerste plaats kan bundeling in het Nederlandse omgevingsrecht plaatsvinden tussen wetssystemen op hetzelfde niveau van een regeling: wet informele zin, algemene maatregel van bestuur of ministeriële regeling. Deze horizontale bundeling wordt toegelicht in paragraaf 2.5.2.2.

In de tweede plaats kan bundeling zich voordoen tussen wetssystemen van verschillende niveaus. Zo zouden twee wetten in formele zin bijvoorbeeld kunnen worden gebundeld in een algemene maatregel van bestuur of twee algemene maatregelen van bestuur in een ministeriële regeling of een wet in formele zin. Deze verticale bundeling wordt toegelicht in paragraaf 2.5.2.3.

In paragraaf 2.3.1 heb ik aangegeven dat ik onder wetssystemen begrijp (onderdelen van) een wet in formele zin, een algemene matregel van bestuur of een ministeriële regeling. Bundeling van wetssystemen kan dus betrekking hebben op - onderdelen van - deze drie wetssystemen. Daarbij dienen we ons wel te realiseren, dat bundeling zich de facto gewoonlijk zal voordoen op een of meer van de in paragraaf 2.3.2 genoemde regelingsniveaus: wet in materiële zin, ${ }^{119}$ delen, hoofdstukken, titels, afdelingen, paragrafen, artikelen of artikelleden.

Een voorbeeld moge zulks verduidelijken. Bij de bundeling door integratie van het wetssysteem van de Wet milieugevaarlijke stoffen in het wetssysteem van de Wet milieubeheer ${ }^{120}$ lijkt die bundeling zich op het eerste gezicht te voltrekken op regelingsniveau 1: wet in formele zin. In de praktijk heeft de bundeling echter haar beslag gekregen door hoofdstukken, artikelen en artikelleden van de Wet milieugevaarlijke stoffen op te nemen in hoofdstukken, artikelen en artikelleden van de Wet milieubeheer.

\subsubsection{Horizontale bundeling}

Als bundeling plaatsvindt tussen regelingen op hetzelfde niveau van wetgeving spreek ik van horizontale bundeling. Dus wetten in formele zin worden gebundeld met wetten in formele zin, algemene maatregelen van

119 Waaronder te verstaan een wet in formele zin

120 Zie hfds. 5. 
bestuur met algemene maatregelen van bestuur en ministeriële regelingen met ministeriële regelingen.

Een voorbeeld van een dergelijke horizontale bundeling door herschikking vinden we in het wetssysteem van het Activiteitenbesluit. Het gaat immers om elf algemene maatregelen van bestuur die als gevolg van herschikking hebben geleid tot een nieuwe algemene maatregel van bestuur: het Activiteitenbesluit.

Een voorbeeld van horizontale bundeling door integratie is de integratie van de Wet milieugevaarlijke stoffen in de Wet milieubeheer. Het gaat immers om een wet in formele zin (Wet milieugevaarlijke stoffen) die is geïntegreerd in een wet in formele zin (Wet milieubeheer).

In overzicht 2.6 is horizontale bundeling schematisch weergegeven.

\section{Overzicht 2.6 Schematische weergave horizontale bundeling}

\begin{tabular}{|l|l|}
\hline Voor integratie & Na integratie \\
\hline Wet A & $\begin{array}{c}\text { Wet A } \\
+\quad=\text { Wet A+ } \\
\text { Wet B B }\end{array}$ \\
\hline Amvb A & $\begin{array}{c}\text { Amvb A } \\
+\quad \text { Amvb B Amvb A+ }\end{array}$ \\
Amvb B & $\begin{array}{c}\text { Ministeriële regeling A } \\
+\quad \text { Ministeriële regeling A+ } \\
\text { Ministeriële regeling A }\end{array}$ \\
\hline
\end{tabular}

\begin{tabular}{|l|l|}
\hline Voor herschikking & Na herschikking \\
\hline Wet A + Wet B & Wet C \\
\hline Amvb A + Amvb B & Amvb C \\
\hline Ministeriële regeling A + B & Ministeriële regeling C \\
\hline
\end{tabular}

\subsubsection{Verticale bundeling}

Van verticale bundeling is sprake als daarbij wetssystemen van verschillende niveaus (wetten in formele zin, algemene maatregelen van bestuur en ministeriële regelingen of onderdelen daarvan) zijn betrokken. Bovendien moeten die wetssystemen dan na bundeling als gevolg van integratie of herschikking geheel of gedeeltelijk op een hoger of lager niveau zijn gekomen. 
Een voorbeeld betreft de herschikking van het subwetssysteem van hoofdstuk 8 Wm in het wetssysteem van de Wabo en het Besluit omgevingsrecht (Bor). Zo is artikel 8.19 Wm, zoals dat gold tot 1 oktober 2010, bijvoorbeeld in nagenoeg gelijke bewoordingen opgenomen in artikel 3.10 lid 3 Wabo (horizontale bundeling), doch artikel 8.1 lid $3 \mathrm{Wm}$ in artikel 2.4 lid 1 Bor (verticale bundeling). Uit dit voorbeeld blijkt, dat een bundelingsoperatie tegelijkertijd zowel horizontale als verticale bundeling kan betreffen.

Aangezien verticale bundeling vele vormen kan aannemen is afgezien van een schematische weergave.

Zo is van verticale bundeling onder meer sprake als een wet in formele zin met een algemene maatregel van bestuur wordt gebundeld in een wet in formele zin indien en zover als de regels in de algemene maatregel van bestuur promoveren naar de wet in formele zin. Een ander voorbeeld van verticale bundeling doet zich ook voor als een ministeriële regeling door middel van integratie wordt opgenomen in een wet in formele zin en een algemene maatregel van bestuur.

\subsubsection{Codificatie en modificatie}

Integratie en herschikking kunnen zich op verschillende manieren manifesteren. Het is van belang om onderscheid te maken tussen modificerende en codificerende bundeling. Bij modificerende integratie of herschikking worden een of meer van de bij integratie respectievelijk herschikking betrokken wetssystemen ook inhoudelijk (materieel) gewijzigd. Is dat niet het geval, dan spreek ik wel van codificerende integratie of herschikking.

Anders dan Voermans ${ }^{121}$ beperk ik de termen codificatie en codificerend niet om aan te geven dat in positief recht wordt vastgelegd wat daarin daarvoor niet was geregeld. Zoals in paragraaf 2.4.5 reeds is opgemerkt, sluit de door de Europese Commissie gebruikte term codification aan bij codificerende herschikking en de term recasting bij modificerende herschikking. ${ }^{122}$ Ook Faure spreekt in geval van codification over het bundelen van bestaand recht. ${ }^{123} \mathrm{Wel}$ breng ik een nuancering aan dat ik niet al van modificerende bundeling spreek als de te bundelen regels niet exact hetzelfde in het gebundelde wetssysteem terugkomen. Het zal nu eenmaal vaak zo zijn dat integratie of herschikking zal leiden tot enige puur tekstuele wijzigingen van de daarbij betrokken wetssystemen. In dergelijke gevallen wil ik toch spreken van codificerende herschikking of integratie. Van modificerende herschikking of integratie is

121 Voermans, Interview 2012, bijl. 5.5, par. 5.1.

122 De Europese Commissie hanteert niet het onderscheid tussen integratie en herschikking.

123 Faure, The Harmonization, Codification and Integration of Environmental Law: A Search for Definitions 2000, p. 181: 'The legislative process whereby separate existing (cursivering van mij, JvdB) legal acts are brought together in one legal document.' 
eerst dan sprake als door bundeling wordt beoogd om een geldende rechtsopvatting te wijzigen. Is dat niet het geval, dan spreek ik van codificerende bundeling. ${ }^{124}$

Een voorbeeld van codificerende herschikking betreft artikel 2.14 lid 1 aanhef en onder c Wabo, luidende:

'Voor zover de aanvraag betrekking heeft op een activiteit als bedoeld in artikel 2.1, eerste lid, onder $\mathrm{e}^{125}$ neemt het bevoegd gezag bij die beslissing in ieder geval in acht dat in de inrichting of het mijnbouwwerk ten minste de voor de inrichting of het mijnbouwwerk in aanmerking komende beste beschikbare technieken moeten worden toegepast.'

Deze op 1 oktober 2010 in werking getreden regel is feitelijk niet anders dan een voortzetting van het tot dat moment geldende artikel 8.10 lid 2 aanhef en onder a Wm, luidende:

'De vergunning ${ }^{126}$ wordt in ieder geval geweigerd indien door verlening daarvan niet kan worden bereikt dat in de inrichting ten minste de voor de inrichting in aanmerking komende beste beschikbare technieken worden toegepast.'

Weliswaar was hier en daar een redactionele aanpassing noodzakelijk, maar die was niet bedoeld om de onder vigeur van artikel $8.10 \mathrm{Wm}$ geldende rechtsopvatting inhoudelijk te veranderen.

Van modificerende herschikking zou wel sprake zijn geweest als de aanvraag om een omgevingsvergunning voor wat betreft de in artikel 2.14 Wabo genoemde activiteit niet langer zou worden getoetst aan de voor de inrichting in anmerking komende beste beschikbare technieken. In dat geval zou immers wel worden afgeweken van de in artikel $8.10 \mathrm{Wm}$ vastgelegde rechtsopvatting dat een aanvraag om milieuvergunning moet worden getoetst aan de beste beschikbare technieken.

Bij het in paragraaf 2.4.4 genoemde voorbeeld van de integratie van de Wet milieugevaarlijke stoffen in de Wet milieubeheer is sprake van codificerende integratie. Zoals nader zal worden toegelicht in hoofdstuk 5 had de wetgever namelijk niet de bedoeling om de geldende rechtsopvatting te veranderen.

\subsection{SAMENVATTING}

Hoofdstuk 2 bevat het begrippenkader dat in dit onderzoek zal worden gehanteerd. Centraal staat het wetssysteem: volgens bepaalde criteria geordende, onderling samenhangende regels. Bij elk wetssysteem kan een formeel en een materieel aspect worden onderscheiden. Bij formele wetssystemen

124 Zie in dit verband ook Van der Vlies, Handboek wetgeving 1991, p. 5, die aangeeft dat een wet die codificeert een geldende rechtsopvatting vastlegt. Een wet die modificeert is een wet die de geldende rechtsopvatting beoogt te veranderen.

125 Bedoeld is het oprichten, het veranderen of veranderen van de werking, of het in werking hebben van een inrichting of mijnbouwwerk.

126 Bedoeld is de milieuvergunning op basis van art. $8.1 \mathrm{Wm}$, zoals dat luidde vóór 1 oktober 2010 
ligt het accent op de uiterlijk zichtbare ordening. Bij materiële wetssystemen ligt het accent op de inhoudelijke systeemordeningscriteria en de onderlinge samenhang. Voor het antwoord op de vraag in welke gevallen bundeling van omgevingsrecht verantwoord is, is van belang de samenhang binnen een wetssysteem die aansluit bij de werkelijkheid zoals de gebruikers van dat wetssysteem die ervaren. Daarom zal ik mij in dit onderzoek richten op materiële wetssystemen.

Van een wetssystematisch tekort wordt gesproken als bepaalde regels wel onderling samenhangen maar desalniettemin geen deel uitmaken van hetzelfde wetssysteem. Om in geval van wetssystematische tekorten alsnog samenhang tussen wetssystemen te scheppen kan de wetgever gebruik maken van de instrumenten:

- coördinatie: tussen twee of meer wetssystemen wordt samenhang gebracht door een nieuwe wettelijke regeling waarbij de beide te coördineren wetssystemen blijven bestaan;

- harmonisatie: tussen twee of meer wetssystemen wordt samenhang gebracht door die wetssystemen als zodanig te laten bestaan, maar aan elkaar aan te passen;

- integratie: tussen twee of meer wetssystemen wordt samenhang gebracht door een wetssysteem geheel te laten opgaan in een ander wetssysteem, waarbij het geïntegreerde wetssysteem wordt ingetrokken;

- herschikking: tussen twee of meer wetssystemen wordt samenhang gebracht door die wetssystemen geheel te laten opgaan in een nieuw wetssysteem waarbij de herschikte wetssystemen worden ingetrokken;

- consolidatie: tussen een wetssysteem en alle daarop gevolgde in (deel) wetssystemen vervatte amendementen wordt samenhang gebracht door het oorspronkelijke wetssysteem en de amendementen ongewijzigd op te nemen in één wetssysteem.

In geval van coördinatie en harmonisatie wordt wel samenhang gebracht tussen wetssystemen, maar wordt het wetssystematisch tekort anders dan in geval van integratie en herschikking niet opgelost. In dit onderzoek wil ik mij beperken tot het bundelen van omgevingsrecht: het samenvoegen van wetssystemen als gevolg waarvan een nieuw of vernieuwd wetssysteem ontstaat. Dat is het geval bij integratie en herschikking. Onder bundeling wil ik niet verstaan consolidatie, aangezien daardoor geen nieuwe of vernieuwde wetssystemen ontstaan.

Bundeling kan plaatsvinden op verschillende regelingsniveaus: wet, algemene maatregel van bestuur of ministeriële regeling. Van horizontale bundeling is sprake als de bundeling beperkt blijft tot wetssystemen van hetzelfde regelingsniveau. Is dat (gedeeltelijk) niet het geval, dan is sprake van verticale bundeling. 
Bundeling kan modificerend of codificerend zijn. Bij codificerende bundeling is niet beoogd de geldende rechtsopvattingen te wijzigen. Bij modificerende bundeling is dat wel beoogd. Deze kwalificaties brengen met zich, dat van codificerende bundeling sprake kan zijn ook als de te bundelen regels niet exact hetzelfde in het gebundelde wetssysteem terugkomen. Het zal nu eenmaal vaak zo zijn dat integratie of herschikking zal leiden tot enige puur tekstuele wijzigingen van de daarbij betrokken wetssystemen. 



\section{$3 \quad$ Wetssystematisch kader voor bundeling van omgevingsrecht}

"Dat hele wetgevingsproces is een mengeling van rationaliteit en irrationaliteit. Een wetgevingsjurist die opstaat en zegt, wacht even want we moeten de leer van Noll toepassen, die wordt neergesabeld."

Thijs Drupsteen ${ }^{1}$

\subsection{INLEIDING}

In dit hoofdstuk wordt een antwoord gezocht op de eerste deelvraag van dit onderzoek: is er wetenschappelijk een kader (te ontwikkelen) waaruit volgt in welk geval of in welke gevallen bundeling van omgevingsrecht verantwoord is?

Voor het antwoord op die vraag neem ik materiële wetssystemen ${ }^{2}$ als uitgangspunt. Een wetssysteem bestaat uit volgens bepaalde criteria geordende, onderling samenhangende regels. ${ }^{3}$ Uit deze definitie volgt dat een wetssysteem en daarmee ook een wetssystematisch tekort worden bepaald door een of meer samenhangcriteria. Eerder heb ik al opgemerkt dat de wetgever in beginsel een schier oneindig aantal mogelijkheden heeft aan inhoudelijke criteria om samenhang aan te brengen tussen regels. ${ }^{4}$ De vraag is echter of het de wetgever geheel vrij staat om elk willekeurig samenhangcriterium te kiezen. Anders gesteld: is bij het kiezen van een samenhangcriterium sprake van een - willekeurige - politieke keuze of kan die keuze ook wetenschappelijk worden verantwoord?

Voor de beantwoording van de eerste deelvraag zal in paragraaf 3.2 eerst op basis van het computerprogramma iTunes, beleidsstukken, wetgeving en wetenschappelijke literatuur worden onderzocht welke criteria mogelijk bruikbaar zijn voor het antwoord op de vraag wat onder samenhang binnen

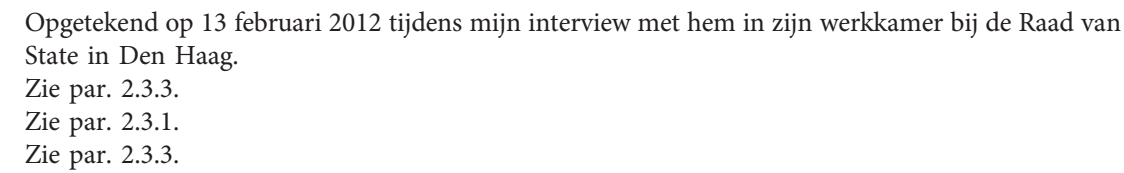


een wetssysteem kan worden verstaan. Naar aanleiding daarvan zal in paragraaf 3.3 vervolgens worden aangegeven wat ik onder samenhang in het kader van een wetssysteem wil verstaan. Daarbij zal ook aandacht worden besteed aan enige met samenhang samenhangende vraagstukken. Nadat in paragraaf 3.3 de zakelijke samenhangcriteria zijn besproken, zal in paragraaf 3.4 aandacht worden besteed aan het afwegen en de mogelijke verdedigbaarheid van na bundeling resterende wetssystematische tekorten. In paragraaf 3.5 gaat het om de vraag of bundeling ook tot nieuwe wettelijke oplossingen mag leiden. Paragraaf 3.6 behandelt de vraag of en zo ja hoe een door bundeling ontstaan wetssysteem toekomstbestendig kan worden vormgegeven. Paragraaf 3.7 noemt enige voordelen van een proeve van bundeling. Paragraaf 3.8 bevat een samenvatting en een vijftal toetscriteria als antwoord op de eerste deelvraag. ${ }^{5}$ In paragraaf 3.9 zal worden aangegeven op welke wijze vier praktijkvoorbeelden van bundeling zullen worden getoetst aan genoemde toetscriteria.

Op deze plaats roep ik in herinnering dat ik voor het beantwoorden van de eerste deelvraag niet alleen 'klassieke' juridische bronnen heb geanalyseerd, maar ook gebruik heb gemaakt van de resultaten van een aantal interviews ${ }^{6}$ met wetgevingsjuristen en wetenschappers. Door middel van deze interviews is getracht meer in de keuken van de wetgever te kijken.

\subsection{SAMENHANG}

\subsubsection{Algemeen}

Een wetssysteem bestaat uit volgens bepaalde criteria geordende, onderling samenhangende regels. Het is echter niet zo eenvoudig om aan te geven wat onder samenhang moet worden verstaan. Dat is niet het gevolg van het feit dat het lastig zou zijn om een samenhang te vinden, maar juist vanwege het feit dat er veelal zeer veel verschillende samenhangen denkbaar zijn.

5 Hfds. 3 beperkt zich tot het bundelen van omgevingsrecht en geeft geen antwoord op vragen hoe het recht binnen de te bundelen regels vorm kan of moet worden gegeven. Wie daarin is geïnteresseerd, verwijs ik onder meer naar de Aanwijzingen voor de regelgeving en de literatuur daaromtrent. Vragen als welk bestuursorgaan het beste als bevoegd gezag kan worden aangewezen voor het verlenen van een bepaalde vergunning, welke voorbereidingsprocedure het beste kan worden gevolgd of welke de beslistermijn zou moeten zijn komen dus niet aan de orde. Het antwoord op deze en dergelijke vragen is uiteraard wel van belang voor de invulling van wetssystemen, maar valt buiten de reikwijdte van mijn onderzoek. Dat heeft betrekking op de architectuur van het omgevingsrecht, niet op de keuze van bouwmaterialen.

6 Zie bijlage 5. 
Noll komt feitelijk tot dezelfde conclusie waar hij schrijft: 'Die sachlichen Systemkriterien lassen sich in der verschiedensten Weise einteilen; sie können auf Personen und ihre sozialen Verhältnisse und Funktionen (Mutter, Kinder, Rentner, Berufsangehörige usw.), auf Institutionen und soziale Aufgaben (Schule, Universität, Kirche, Sozialversicherung usw.), auf bestimmte Unternehmungen und Tätigkeiten (Handel, Industrie, Landwirtschaft, Straßenverkehr usw.) bezogen sein.'

Alvorens mij verder te verdiepen in de samenhangen zoals die binnen een wetssysteem kunnen worden geduid, zal ik in paragraaf 3.2.2 ter illustratie een voorbeeld buiten het recht toelichten. Daarbij heb ik gezocht naar bruikbare kenmerken en criteria binnen een systeem van muziekopnamen dat is gegenereerd door iTunes, een computerprogramma dat het onder meer mogelijk maakt om muziekopnamen op te nemen in een digitale muziekbibliotheek, die opnamen te ordenen en af te spelen. ${ }^{8}$

\subsection{2. iTunes en iLawsysteem}

\subsubsection{Algemeen}

Een door het computerprogramma iTunes samengestelde digitale muziekbibliotheek kan worden gezien als een muzieksysteem dat bestaat uit volgens bepaalde criteria geordende, onderling samenhangende muziekopnamen.

De muziekopnamen in dit muzieksysteem zijn door de gebruiker aan het programma aangeboden. De gebruiker kan elke willekeurige muziekopname aan het programma aanbieden. Het is niet nodig dat de gebruiker daarbij enig systeem of enige volgorde in acht neemt. Hij kan de opnamen die hij wenst op te nemen ook op elk willekeurig moment opnemen. ${ }^{9}$ Voor mijn onderzoek is het niet nodig dat wij ons verdiepen in de wijze waarop die informatie technisch wordt opgeslagen. Het is voldoende te weten dat iTunes alle aangeboden muziekopnamen bevat. Van een systeem in de zin van volgens bepaalde criteria geordende, onderling samenhangende muziekopnamen is echter pas sprake als iTunes volgens een of meer door de gebruiker gekozen samenhangcriteria een bepaalde ordening heeft aangebracht in de aangeboden muziekopnamen. Zonder een dergelijke ordening is immers geen sprake van volgens bepaalde criteria geordende, onderling samenhangende muziekopnamen.

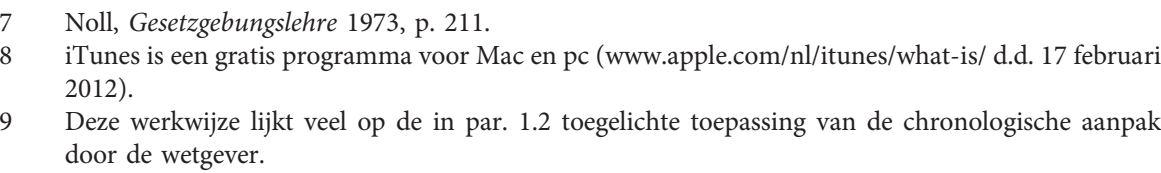


De gebruiker kan op het moment van toevoegen van muziekopnamen of daarna aan elk van de aan iTunes aangeboden muziekopnamen of onderdelen daarvan automatisch of handmatig een of meer samenhangcriteria verbinden. Voorbeelden van samenhangcriteria zijn: album, artiest, genre, componist en opnamejaar. iTunes biedt de gebruiker vervolgens de mogelijkheid om aan de hand van een of meer door de gebruiker gekozen samenhangcriteria muziekopnamen op te roepen in een muzieksysteem dat bestaat uit volgens bepaalde criteria geordende, onderling samenhangende muziekopnamen. Daarbij kan de gebruiker kiezen tussen diverse soorten samenhang al naar gelang hij die criteria in iTunes - handmatig of automatisch - heeft ingebracht.

Als de gebruiker bijvoorbeeld kiest voor 'genre' als samenhangcriterium, dan ordent iTunes de muziekopnamen zodanig, dat alle muziekopnamen binnen een door iTunes herkend genre ${ }^{10}$ bij elkaar staan; te denken is aan klassieke muziek, popmuziek, jazz, etcetera. Als de gebruiker om ordening vraagt volgens het door hem of haar gekozen samenhangcriterium, dan zal het programma de aan dat samenhangcriterium beantwoordende onderdelen automatisch alfabetisch of numeriek rangschikken.

Als de gebruiker kiest voor 'opera' als samenhangcriterium, dan ordent iTunes de muziekopnamen zodanig dat alle opera's bij elkaar staan.

Combinaties van samenhangcriteria die een nieuw samenhangcriterium opleveren, zijn ook mogelijk. Als de gebruiker bijvoorbeeld kiest voor het samenhangcriterium 'opera's van Richard Wagner', dan ordent iTunes de muziekopnamen zodanig dat alle opera's van deze componist worden getoond. Als de gebruiker de juiste procedures heeft gevolgd, zal iTunes ervoor zorgen dat geen systematisch tekort binnen de muziekverzameling ontstaat, aangezien alle muziekopnamen die beantwoorden aan een of meer samenhangcriteria binnen het op basis van die criteria geordende muzieksysteem zullen worden opgenomen.

De vraag kan worden gesteld of sprake is van een systematisch tekort als zich - bij wijze van voorbeeld - in de verzameling muziekopnamen niet alle opnamen van opera's van Richard Wagner bevinden. Dat zal immers logischerwijs gebeuren als de gebruiker niet alle opera's van Richard Wagner in iTunes heeft ingevoerd. Het oproepen van de opera's van Richard Wagner volgens het samenhangcriterium 'opera's van Richard Wagner' zal dan immers een systeem opleveren dat niet alle opera's van Richard Wagner omvat, maar de opera's van Richard Wagner voor zover die zich in de verzameling bevinden. Ik beantwoord die vraag ontkennend. Van een systematisch tekort is slechts sprake als door de gebruiker aan iTunes aangeboden muziekopnamen volgens bepaalde samenhangcriteria

10 iTunes kent reeds een aantal genres, maar de gebruiker kan die lijst van genres aanvullen. 
onderling samenhangen, maar desalniettemin geen deel uitmaken van het door iTunes gegenereerde muzieksysteem. Niet aan iTunes aangeboden muziekopnamen zijn voor het programma non existent. ${ }^{11}$

Van de vorenstaande situatie moet worden onderscheiden het geval dat een gebruiker twee - of meer - muziekverzamelingen heeft gegenereerd in iTunes. ${ }^{12}$ Gesteld dat als gevolg van welke oorzaak dan ook de muziekopnamen van deze gebruiker zijn verspreid over deze muziekverzamelingen. ${ }^{13}$ Gesteld verder dat in beide muziekverzamelingen onder meer verschillende opera's van Richard Wagner zijn opgenomen. Als dan 'opera's van Richard Wagner' als samenhangcriterium wordt gebruikt, zal iTunes per muziekverzameling een systeem van muziekopnamen produceren. Gesteld dat in de ene verzameling de opera's Lohengrin en Der Ring des Nibelungen zijn opgenomen, dan zullen die opnamen het systeem vormen van samenhangende muziekopnamen als gevolg van het gebruik van het genoemde samenhangcriterium. Als in de tweede verzameling de opera's Die Meistersinger von Nürnberg, Rienzi en Tristan und Isolde zijn opgenomen, dan vormen die drie opera's samen een systeem als gevolg van het samenhangcriterium. Anders dan in het in de vorige alinea geschetste geval is hier echter wel sprake van een systematisch tekort, aangezien alle door de gebruiker aan iTunes aangeboden muziekopnamen ${ }^{14}$ volgens de samenhangcriteria 'opera's van Richard Wagner' onderling samenhangen, maar desalniettemin geen deel uitmaken van het door iTunes op basis van die samenhangcriteria gegenereerde muzieksysteem.

Het systematisch tekort wordt ook in dit geval niet veroorzaakt door het feit dat de beide verzamelingen elk voor zich en in combinatie niet compleet zijn aangezien daarin niet alle opera's van Richard Wagner voorkomen. ${ }^{15}$

\subsubsection{Samenhangcriteria in iTunes}

Uit het voorbeeld van iTunes valt naar mijn oordeel een aantal lessen te trekken over samenhang binnen een systeem zoals door mij gedefinieerd.

In de eerste plaats vormen alle aan iTunes aangeboden muziekopnamen samen nog geen systeem in de zin van volgens bepaalde criteria geordende,

11 De vergelijking met een wetssysteem bestaat hierin, dat geen sprake is van een wetssystematisch tekort als in een wetssysteem geen regels zijn opgenomen die de wetgever (nog) niet in het leven heeft geroepen. Dergelijke regels zijn eveneens non existent.

12 De vergelijking met een wetssysteem is, dat hier - anders dan in het hiervoor gegeven voorbeeld wel sprake is van regels die de wetgever in het leven heeft geroepen, maar ondergebracht in een ander wetssysteem

13 Dat kan zich bijvoorbeeld voordoen als een gebruiker op zijn iMac (desktopcomputer) een muziekbibliotheek heeft aangemaakt en een tweede op zijn MacBook (laptop).

14 Lohengrin, Der Ring des Nibelungen, Die Meistersinger von Nürnberg, Rienzi en Tristan und Isolde.

15 Das Liebesverbot, Die Feeën, Der Fliegende Hollander, Parsifal en Tannhäuser ontbreken. 
onderling samenhangende muziekopnamen. Er is immers (nog) geen sprake van enige ordening volgens een of meer door de gebruiker gekozen samenhangcriteria. Per definitie kan pas worden gesproken van een systeem als de gebruiker heeft gekozen voor een of meer samenhangcriteria.

In de tweede plaats maakt het voorbeeld van iTunes duidelijk dat er binnen een verzameling veel verschillende soorten van samenhang kunnen bestaan. Dat leidt tot veel mogelijke samenhangcriteria. Ik noemde het 'muziekgenre', 'opera' of 'opera's van Richard Wagner'. Dat zijn slechts drie willekeurige voorbeelden, die schier oneindig kunnen worden aangevuld, bijvoorbeeld met samenhangcriteria als 'alle opnamen van de Wiener Philharmoniker' of 'alle opnamen uit 1964.'

In de derde plaats wordt een systeem bepaald door het gekozen samenhangcriterium. Dat criterium kan ruim zijn zoals: alle muziekopnamen van een bepaalde gebruiker, of beperkt zoals: alle opnamen van de Wiener Philharmoniker uit 1964. Dat betekent dat zich binnen een verzameling van elementen een schier oneindig aantal verschillende systemen laat denken, afhankelijk van de samenhangcriteria die worden gekozen. ${ }^{16}$

In de vierde plaats sluit de ene samenhang een andere niet uit in die zin dat één opname kan beantwoorden aan meer dan één samenhangcriterium. Zo past een opname van Lohengrin uit 1964 van de Wiener Philharmoniker ${ }^{17}$ zowel in het samenhangend criterium 'klassieke muziek', als 'opera', als 'opera's van Richard Wagner', als 'alle opnamen van de Wiener Philharmoniker', als 'alle opnamen uit 1964'. Hier past echter wel een belangrijke kanttekening. Het moge zo zijn dat het programma iTunes elke samenhang en dus elk systeem mogelijk maakt, het is voor de gebruiker slechts mogelijk om één of een beperkt aantal samenhangcriteria tegelijk op te roepen. Als iTunes een muzieksysteem genereert op basis van het samenhangcriterium 'opera's van Richard Wagner', dan worden de opera's van andere componisten niet getoond, ook al bevinden die zich wel in een of meer muziekbibliotheken binnen iTunes. De gebruiker dient derhalve wel een keus te maken tussen de vele mogelijke samenhangcriteria. Hij is echter niet gebonden aan een eenmaal gemaakte keus.

In de vijfde plaats gaat het bij de kwalificatie van een systematisch tekort steeds om een tekort binnen een bestaande verzameling van muziekopnamen. Het gaat daarbij niet om de vraag of een verzameling compleet is, maar of binnen een op basis van een bepaald samenhangcriterium gevormd systeem alle aan dat criterium beantwoordende elementen van die verzameling deel uitmaken van het aldus gevormde systeem.

16 Zie ook par. 2.3.3

17 EMI Classics, Lohengrin, dirigent Rudolf Kempe, met Jess Thomas als Lohengrin en Elisabeth Grümmer als Elsa von Brabant, 1964. 


\subsubsection{Samenhangcriteria in een wetssysteem}

Mij lijkt dat de hiervoor uit iTunes getrokken lessen voor muzieksystemen ook bruikbaar zijn voor het denken over - de samenhang binnen - wetssystemen.

In de eerste plaats vormen omgevingsregels in de door mij gebruikte definitie pas een systeem als de wetgever heeft gekozen voor een of meer samenhangcriteria die dienen om die regels te ordenen. Alle tot het omgevingsrecht behorende wetten, algemene maatregelen van bestuur en ministeriële regelingen vormen als zodanig nog geen systeem in de zin van volgens bepaalde criteria geordende, onderling samenhangende regels zolang geen sprake is van enige ordening volgens een of meer door de wetgever gekozen samenhangcriteria.

In de tweede plaats kunnen er binnen de verzameling van regels die het omgevingsrecht uitmaken vele verschillende soorten van samenhang bestaan. Zo zien we bijvoorbeeld in de Wabo, dat de samenhang onder meer ${ }^{18}$ is gezocht in 'plaatsgebonden projecten die bestaan uit een of meer activiteiten die van invloed zijn op de fysieke leefomgeving' ${ }^{19}$ in het Activiteitenbesluit in 'activiteiten van inrichtingen die van invloed zijn op de fysieke leefomgeving' en in de Waterwet (Wtw) in 'watersystemen'. Ook buiten het omgevingsrecht laten zich veel verschillende samenhangcriteria denken. Het centrale samenhangcriterium in de Wet op de economische delicten (Wed) is de regulering van 'economische delicten'. De Algemene wet bestuursrecht (Awb) kent als een belangrijk - maar niet enig - samenhangcriterium dat daarin bestuursrechtelijke procedures zijn gereguleerd.

In de derde plaats wordt ook in het omgevingsrecht een wetssysteem bepaald door het samenhangcriterium. Dat kan ruim zijn, zoals het belang van de fysieke leefomgeving of beperkter zoals het belang van een integraal beheer van watersystemen, dat een belangrijk samenhangcriterium vormt voor het wetssysteem van de Waterwet ${ }^{20}$ of het belang van de bescherming van de bodem dat een belangrijk samenhangcriterium vormt voor het wetssysteem van de Wet bodembescherming (Wbb). ${ }^{21}$

18 Onder meer, want het project is niet het enige samenhangcriterium binnen de Wabo. Zo wordt bijvoorbeeld in hfds. 3 ook een chronologisch ordeningscriterium gehanteerd. Ook in het Activiteitenbesluit en de Waterwet is sprake van verschillende samenhangcriteria.

19 Zie uitgebreider par. 4.3.3

20 De aanhef van de Waterwet (Stb. 2009, 107) vermeldt in dit verband: 'Alzo Wij in overweging genomen hebben, dat de overheid zich bij de zorg voor de bewoonbaarheid van het land alsmede de bescherming en verbetering van het milieu, waar die zorg gestalte krijgt in het waterbeheer, voor grote opgaven gesteld ziet, en dat het met het oog op een doeltreffende en doelmatige aanpak van het waterbeheer wenselijk is om het wettelijke instrumentarium te stroomlijnen en te moderniseren en daarbij het integraal beheer van watersystemen centraal te stellen.'

21 De aanhef van de Wbb (Stb. 1986, 374) vermeldt in dit verband: 'Alzo Wij in overweging genomen hebben, dat het noodzakelijk is in het belang van de bescherming van het milieu regels te stellen ten einde de bodem te beschermen.' 
In de vierde plaats sluit ook in het omgevingsrecht de ene samenhang een andere niet per se uit in die zin dat een regel kan beantwoorden aan meer dan één samenhangcriterium. Zo past bijvoorbeeld de bouw van een fabriek zowel in het samenhangcriterium 'bouwen van een bouwwerk', ${ }^{22}$ als in 'oprichten van een inrichting. ${ }^{, 23,} 24$ Hier doet zich echter een belangrijk verschil voor tussen een wetssysteem en door iTunes te genereren muzieksystemen. iTunes maakt zoals hiervoor aangegeven het voor de gebruiker mogelijk om de muziekopnamen op te roepen in elk door hem gewenst muzieksysteem. Het enige wat daarvoor nodig is, is dat de gebruiker zijn muziekopnamen zodanig heeft gelabeld, dat het programma dat systeem kan genereren. Het is voor de gebruiker echter wel slechts mogelijk om één of meer samenhangcriteria tegelijk te gebruiken om een systeem op te roepen. De gebruiker van een wetssysteem heeft die keus niet. Hij is gebonden aan de keuzes die de wetgever heeft gemaakt ten aanzien van één of meer samenhangcriteria.

Een voorbeeld om het verschil tussen beide systemen te illustreren. Stel dat de gebruiker van iTunes de beschikking heeft over een muziekbibliotheek (systeem 1) waarin onderdelen van opera's zijn geordend via het samenhangcriterium 'opera vocaal' en over een tweede muziekbibliotheek (systeem 2) waarin onderdelen van opera's zijn geordend via het samenhangcriterium 'opera instrumentaal'. Stel dat deze gebruiker een muziekbibliotheek (systeem 3) wil samenstellen met volledige opera's (vocale en instrumentale onderdelen). Als hij de onderdelen 'opera vocaal' en 'opera instrumentaal' ook heeft gelabeld met het samenhangcriterium 'opera' dan is het eenvoudig om die muziekbibliotheek te genereren door te kiezen voor het samenhangcriterium 'opera'. De beide eerstgenoemde muziekbibliotheken (systeem 1 en systeem 2) kunnen dan echter nog steeds worden opgeroepen door het samenhangcriterium aan te passen.

In het omgevingsrecht bestaat voor de hierboven geschetste mogelijkheid (nog) geen equivalent. Als de wetgever heeft besloten dat voor één project (vergelijk: opera) zowel een omgevingsvergunning (vergelijk: opera vocaal) op basis van de Wabo als een watervergunning (vergelijk: opera instrumentaal) op basis van de Waterwet nodig is, kan de gebruiker niet een eigen wetssysteem genereren dat is gebaseerd op het samenhangcriterium 'project' en waarin voor een project slechts één vergunning nodig is die de omgevingsvergunning en de watervergunning omvat. De gebruiker is in het omgevingsrecht immers afhankelijk van de keus die de wetgever heeft gemaakt ten aanzien van de samenhangcriteria.

Art. 2.1 lid 1 aanhef en onder a Wabo.

Art. 2.1 lid 1 aanhef en onder e Wabo.

Het gaat hier om een geval waarin gewoonlijk sprake zal zijn van onlosmakelijk verbonden activiteiten (art. 2.7 Wabo). Een aanvraag die betrekking heeft op een handeling die is te kwalificeren als meer dan één aangewezen activiteit heeft van rechtswege betrekking op elk van die activiteiten. Zie uitgebreider Van den Broek, Wegwijzer Wabo 2012, p. 41. Zie over onlosmakelijke samenhang ook ABRvS 12 oktober 2011, M en R 2012/6, nr. 86 m.nt. Van den Broek. 
Anders dan in het programma iTunes biedt de wetgever de gebruiker dus niet de mogelijkheid om zelf voor een bepaald systeem met een of meer bepaald samenhangcriteria te kiezen. Het zou interessant zijn te onderzoeken of omgevingsrecht nu of in de toekomst zodanig zou kunnen worden vorm gegeven dat de gebruiker via een computerprogramma wel als het ware zijn eigen wetssysteem in de vorm van een iLawsysteem zou kunnen genereren op basis van een door hem zelf te kiezen, op dat moment voor hem relevant samenhangcriterium. Wie een woning wil bouwen en zich afvraagt welke regels in het omgevingsrecht daarop van toepassing zijn, zou dan bijvoorbeeld alle op het bouwen van een huis toepasselijke regels met een druk op de knop van zijn toetsenbord kunnen genereren als wetssysteem.

Gevraagd of de wetgever wel aan de gebruiker heeft gedacht, noemt Voermans ${ }^{25}$ in dit verband de belastingwetgeving. Het gaat volgens hem om een lappendeken van wetten die stuk voor stuk ontzettend ingewikkeld zijn. De Belastingdienst heeft niet gekozen voor een integratie van al die wetten in een belastingwetboek, maar een ICT-tool ontwikkeld. Daarbij wordt helemaal vanuit gebruikers gedacht. Die zeer diverse groep van gebruikers kan door het beantwoorden van vragen die te maken hebben met zijn persoonlijke situatie een antwoord krijgen op vragen die hij anders zou moeten proberen te vinden door het bestuderen van de belastingwetgeving zelf. Het gaat hier mijns inziens om het ontsluiten van wetssystemen. ${ }^{26}$ De gebruiker kan niet zelf een wetssysteem op maat laten genereren.

Van ontsluiting is ook sprake bij de Activiteitenbesluit Internet Module (AIM) $(2008)^{27}$ en het Omgevingsloket Online (OLO) (2010). ${ }^{28}$ Als gevolg van het Activiteitenbesluit is de AIM gerealiseerd. Met deze module is het mogelijk om de voorschriften en toelichting uit het Activiteitenbesluit te genereren voor een of meer vooraf ingegeven activiteiten. De AIM is slechts een manier om het Activiteitenbesluit te ontsluiten. De gebruiker krijgt daarmee niet de mogelijkheid

25 Voermans, Interview 2012, bijl. 5.5, par. 4.2.

26 Zie ook Voermans, Het ontwerpen van wetten en systeemontwikkeling 1998. Voermans geeft hier een interessant betoog over hoe om te gaan met het steeds vaker voorkomende probleem van gelijktijdig verlopende processen van wetgeving en informatiesysteemontwikkeling. Voermans beschrijft de volgens hem bestaande verschillen tussen wetgevers en systeemontwikkelaars ('een apart slag volk'). Als ik Voermans goed begrijp ziet hij zich wel als pleitbezorger van een nieuwe doordenking van onze wetgevingsprocessen tegen de achtergrond van de huidige ICT-ontwikkelingen, maar laat hij in het midden of dat ook moet leiden tot andere wetten. Ik kan mij voorstellen dat voor een iLawsysteem geheel andere wetssystemen nodig zijn. Zie verder over de symbolische weergave van regelingen met het oog op geautomatiseerde uitvoering: Eijlander \& Voermans, Wetgevingsleer 2000, p. 196-198. Voermans/Van Wijk \& Fokkema, Free the Legislative Process of its Paper Chains 2011 'argues that it is now time we took the next step and redesign the legislative process by tailoring it to the information needs of the 21 st century.' Kramer vraagt aandacht voor de juridische status van de door deze ICT-voorzieningen gegenereerde voorschriften, meldingen en vergunningaanvragen. Hij concludeert dat in elk geval bij de melding en de vergunningaanvraag mits juist en volledig ingevuld - de verantwoordelijkheid voor de juiste uitkomsten niet bij de aanvrager respectievelijk gebruiker ligt. Hetzelfde lijkt verdedigbaar bij het voorschriftenpakket (Kramer, ICT en Milieuregelgeving: moet de ondernemer de wet nog kennen? 2009).

27 aim.vrom.nl/

28 www.omgevingsloket.nl/ 
om het Activiteitenbesluit te raadplegen volgens een of meer door hem aan te geven wetssystematische samenhangen. Dat geldt ook voor het OLO waarmee een omgevingsvergunning kan worden aangevraagd en de app Vergunningcheck van het Ministerie van Binnenlandse Zaken en Koninkrijksrelaties, die aangeeft of voor een bepaald project al dan niet een omgevingsvergunning is vereist.

In mijn voorstel voor een iLawsysteem gaat het niet om het ontsluiten van omgevingsrecht door middel van digitale technieken, maar om het vorm geven aan omgevingsrecht in een naar de wens van de gebruiker te genereren wetssysteem op een wijze die verschillende samenhangen eenvoudig mogelijk maakt. In paragraaf 3.2.3 zal ik het iLawsysteem aan de hand van een eenvoudig voorbeeld toelichten. De vraag of een dergelijk systeem thans technisch al mogelijk is of zou kunnen worden, kan ik op dit moment niet beantwoorden, maar is ook niet het onderwerp van mijn onderzoek. Voor mijn onderzoek is het wel van belang te constateren dat de wetgever bij het genereren van een wetssysteem een keus moet maken voor één of meer samenhangcriteria. Mij komt het voor dat het voor het via ICT-tools ontsluiten van wetssystemen noodzakelijk is om die wetssystemen zo kenbaar en leesbaar mogelijk te laten zijn. In dit verband vind ik bijval bij Noll waar hij schrijft: 'Eine Bereiniging der Rechtsordnung, durch welche diese wieder lesbar und nicht etwa nur im Computer aufrufbar wird, setzt den Einsatz des Computers gerade voraus. ${ }^{29}$

In de vijfde plaats kunnen na vergelijking met iTunes voor het omgevingsrecht de les trekken dat het ook binnen het omgevingsrecht bij de kwalificatie van een wetssystematisch tekort gaat om een tekort binnen een bestaande verzameling van regels. Het gaat daarbij niet om de vraag of de verzameling compleet is, dat wil zeggen of de wetgever wel 'alles' heeft geregeld. Het gaat erom of binnen een op basis van een of meer samenhangcriteria gevormd wetssysteem alle aan die criteria beantwoordende regels binnen het geldende recht deel uitmaken van het aldus gevormde wetssysteem.

\subsection{3. iLawsysteem}

\subsubsection{Algemeen}

Hiervoor heb ik het voorstel gedaan om een wetssysteem via een iLawsysteem beter aan de wens van gebruikers tegemoet te kunnen komen. Hierna zal ik dat voorstel aan de hand van een eenvoudig, realistisch voorbeeld toelichten en het verschil aangeven met het digitaal ontsluiten van een wetssysteem.

29 Noll, Gesetzgebungslehre 1973, p. 30. 


\subsubsection{2. iLawsysteembesluit}

Bij wijze van voorbeeld is de algemene maatregel van bestuur iLawsysteembesluit hierna omwille van de eenvoud beperkt tot vier hoofdstukken waarin in totaal elf artikelen voorkomen, die zijn ontleend aan het Activiteitenbesluit milieubeheer. Dit iLawsysteembesluit wordt bepaald door het samenhangcriterium 'activiteiten van inrichtingen'.

\section{Hoofdstuk 1 Algemeen}

\section{Artikel $1.1^{30}$}

In dit besluit en de daarop berustende bepalingen wordt verstaan onder: bevoegd gezag: burgemeester en wethouders van de gemeente waarin de inrichting zich geheel of grotendeels bevindt;

$N R B$ : door InfoMil uitgegeven Nederlandse richtlijn bodembescherming bedrijfsmatige activiteiten;

verwaarloosbaar bodemrisico: een situatie als bedoeld in de NRB waarin door een goede afstemming van bodembeschermende voorzieningen en bodembeschermende maatregelen de kans op een verandering van de bodemkwaliteit, ten gevolge van een immissie van een stof, verwaarloosbaar is gemaakt;

vloeibare brandstof: lichte olie, halfzware olie of gasolie als bedoeld in de artikelen 26 en 28 van de Wet op de accijns.

\section{Artikel 1.2 ${ }^{31}$}

Degene die een inrichting opricht, meldt dit ten minste vier weken voor de oprichting aan het bevoegd gezag.

\section{Artikel 1.3 ${ }^{32}$}

Indien bij of krachtens dit besluit is bepaald dat een daarbij aangegeven maatregel ter bescherming van het milieu moet worden toegepast kan een andere maatregel worden toegepast indien het bevoegd gezag heeft beslist dat met die maatregel ten minste een gelijkwaardig niveau van bescherming van het milieu wordt bereikt.

\section{Hoofdstuk 2 Algemene regels ten aanzien van alle activiteiten}

Artikel 2.13

Degene die een inrichting drijft en weet of redelijkerwijs had kunnen weten dat door het in werking zijn dan wel het al dan niet tijdelijk buiten werking stellen van de inrichting nadelige gevolgen voor het milieu ontstaan of kunnen ontstaan, die niet of onvoldoende worden voorkomen of beperkt door naleving van de bij of krachtens dit besluit gestelde regels, voorkomt die gevolgen of beperkt die voor zover voorkomen niet mogelijk is en voor zover dit redelijkerwijs van hem kan worden gevergd.

\footnotetext{
Vgl. art. 1.1 lid 1 Activiteitenbesluit.

Vgl. art. 1.10 lid 1 Activiteitenbesluit.

Vgl. art. 1.8 Activiteitenbesluit.

Vgl. art. 2.1 lid 1 Activiteitenbesluit.
} 
Artikel 2.2 ${ }^{34}$

Degene die de inrichting drijft neemt alle bekende energiebesparende maatregelen met een terugverdientijd van vijf jaar of minder of die een positieve netto contante waarde hebben bij een interne rentevoet van $15 \%$.

\section{Artikel 2.3}

1. Degene die een inrichting drijft waarin vloeibare brandstof of afgewerkte olie in een ondergrondse tank wordt opgeslagen stelt door verzekering of anderszins financiële zekerheid ter dekking van de aansprakelijkheid die voortvloeit uit verontreiniging van de bodem als gevolg van dat opslaan of het drijven van het tankstation.

2. De zekerheid bedraagt $€ 225.000$ per ondergrondse tank. Bij meer dan zes ondergrondse tanks bedraagt de zekerheid in totaal $€$ 1.361.340, 65 .

\section{Hoofdstuk 3 Voorschriften voor bepaalde activiteiten}

\section{Artikel $\mathbf{3 . 1}^{36}$}

Bij het lozen van grondwater vanuit een proefbronnering, die plaatsvindt in het kader van een saneringsonderzoek in de zin van de Wet bodembescherming, of vanuit een bodemsanering in de zin van de Wet bodembescherming wordt ten minste voldaan aan het tweede tot en met het negende lid.

Artikel $3.2^{37}$

Bij het in werking hebben van een acculader wordt ten behoeve van het realiseren van een verwaarloosbaar bodemrisico, voldaan aan de bij ministeriële regeling te stellen eisen.

\section{Hoofdstuk 4 Overgangs- en slotbepalingen}

Artikel 4.1 $^{38}$

Voor een tankstation waarvoor onmiddellijk voorafgaand aan het tijdstip van inwerkingtreding van artikel 1.2 een melding is gedaan, wordt voor de toepassing van artikel 1.2 een termijn van zes weken aangehouden.

Artikel $4.2^{39}$

Dit besluit treedt in werking met ingang van een bij koninklijk besluit te bepalen tijdstip, dat voor verschillende artikelen of onderdelen en voor verschillende soorten inrichtingen verschillend kan worden vastgesteld.

Artikel $4 \cdot 3^{40}$

Dit besluit wordt aangehaald als: iLawsysteembesluit.

\footnotetext{
Vgl. Art. 2.15 lid 1 Activiteitenbesluit.

Vgl. art. 2.24 lid 1 en 2 Activiteitenbesluit.

Vgl. art. 3.1 lid 1 Activiteitenbesluit.

Vgl. art. 4.114 Activiteitenbesluit.

Vgl. art. 6.1 lid 1 Activiteitenbesluit.

Vgl. art. 6.44 Activiteitenbesluit.

Vgl. art. 6.45 Activiteitenbesluit.
} 
Gesteld dat dit besluit alle milieuregels bevat voor de activiteiten van een tankstation en die van een bakkerij met winkel in het centrum, zij het dat niet alle artikelen onder alle omstandigheden op elk van die inrichtingen van toepassing zijn. De exploitant van elk van beide inrichtingen heeft geen andere keus dan het gehele iLawsysteembesluit te lezen om te weten welke regels op zijn inrichting van toepassing zijn. Dat valt in het geval van het iLawsysteembesluit nog wel mee, maar we dienen daarbij te bedenken dat het hier slechts een vereenvoudigd voorbeeld betreft; het Activiteitenbesluit milieubeheer bevat honderden artikelen, die bovendien niet allemaal eenvoudig te doorgronden zijn.

Gesteld voorts dat aan de hand van een digitale vragenlijst (input) kan worden vastgesteld dat uitsluitend de artikelen 1.1, 1.2, 1.3, 2.1, 2.2, 2.3, 3.1, 4.1, 4.2 en 4.3 van het iLawsysteembesluit gelden voor een tankstation en uitsluitend de artikelen 1.1, 1.2, 1.3, 2.1, 2.2, 4.2 en 4.3 voor de bakkerij met winkel. Digitale ontsluiting, zoals de Activiteitenbesluit Internet Module levert als output een lijst met toepasselijke artikelen, die niet als wetssysteem worden gepresenteerd.

Zo zal digitale ontsluiting voor de bakkerij met winkel als output de volgende opsomming van toepasselijke artikelen opleveren:

\section{Artikel 1.1 ${ }^{41}$}

In dit besluit en de daarop berustende bepalingen wordt verstaan onder:

bevoegd gezag: burgemeester en wethouders van de gemeente waarin de inrichting zich geheel of grotendeels bevindt;

NRB: door InfoMil uitgegeven Nederlandse richtlijn bodembescherming bedrijfsmatige activiteiten;

verwaarloosbaar bodemrisico: een situatie als bedoeld in de NRB waarin door een goede afstemming van bodembeschermende voorzieningen en bodembeschermende maatregelen de kans op een verandering van de bodemkwaliteit, ten gevolge van een immissie van een stof, verwaarloosbaar is gemaakt; vloeibare brandstof: lichte olie, halfzware olie of gasolie als bedoeld in de artikelen 26 en 28 van de Wet op de accijns.

\section{Artikel 1.2.2}

Degene die een inrichting opricht, meldt dit ten minste vier weken voor de oprichting aan het bevoegd gezag.

\section{Artikel 1.3 $3^{43}$}

Indien bij of krachtens dit besluit is bepaald dat een daarbij aangegeven maatregel ter bescherming van het milieu moet worden toegepast kan een andere maatregel worden toegepast indien het bevoegd gezag heeft beslist dat met die maatregel ten minste een gelijkwaardig niveau van bescherming van het milieu wordt bereikt.

41 Vgl. art. 1.1 lid 1Activiteitenbesluit.

Vgl. art. 1.10 lid 1 Activiteitenbesluit.

Vgl. art. 1.8 Activiteitenbesluit. 


\begin{abstract}
Artikel 2.144
Degene die een inrichting drijft en weet of redelijkerwijs had kunnen weten dat door het in werking zijn dan wel het al dan niet tijdelijk buiten werking stellen van de inrichting nadelige gevolgen voor het milieu ontstaan of kunnen ontstaan, die niet of onvoldoende worden voorkomen of beperkt door naleving van de bij of krachtens dit besluit gestelde regels, voorkomt die gevolgen of beperkt die voor zover voorkomen niet mogelijk is en voor zover dit redelijkerwijs van hem kan worden gevergd.
\end{abstract}

Artikel 2.2 ${ }^{45}$

Degene die de inrichting drijft neemt alle bekende energiebesparende maatregelen met een terugverdientijd van vijf jaar of minder of die een positieve netto contante waarde hebben bij een interne rentevoet van $15 \%$.

\title{
Artikel $4.2^{46}$
}

Dit besluit treedt in werking met ingang van een bij koninklijk besluit te bepalen tijdstip, dat voor verschillende artikelen of onderdelen en voor verschillende soorten inrichtingen verschillend kan worden vastgesteld.

\section{Artikel $4 \cdot 3^{47}$}

Dit besluit wordt aangehaald als: iLawsysteembesluit.

Een belangrijk nadeel van deze digitale ontsluiting is, dat de op de exploitant van de bakkerij met winkel daarmee wel de beschikking krijgt over de toepasselijke regels, maar niet over een wetssysteem: volgens bepaalde criteria geordende, onderling samenhangende regels. Het ontbreken van een geheel van onderling samenhangende regels zal zich nog ernstiger doen voelen als de regels die vallen binnen het samenhangcriterium 'bakkerij met winkel' niet slechts in het iLawsysteembesluit staan, maar in een aantal wetten, algemene maatregelen van bestuur en/of ministeriële regelingen.

Een iLawsysteem kan dergelijke nadelen aanzienlijk verminderen en wellicht zelfs voorkomen. Dat levert als output namelijk geen lijst met toepasselijke artikelen, maar een op de desbetreffende inrichting toegespitst en voor de exploitant van de desbetreffende inrichting relevant wetssysteem dat uitsluitend de toepasselijke artikelen in samenhang bevat. In paragraaf 3.2.3.3 is het resultaat opgenomen voor het tankstation en in paragraaf 3.2.3.4 voor de bakkerij met winkel. De exploitant van elk van beide inrichtingen behoeft niet het gehele iLawsysteembesluit te lezen, maar slechts een op zijn inrichting toegespits wetssysteem: het iLawsysteembesluit Tankstations dan wel het iLawsysteembesluit Bakkerij met winkel. Opgemerkt zij, dat het beide inrichtingen omvattende iLawsysteembesluit blijft bestaan.

\footnotetext{
Vgl. art. 2.1 lid 1 Activiteitenbesluit.

Vgl. art. 2.15 lid 1 Activiteitenbesluit.

Vgl. art. 6.44 Activiteitenbesluit.

Vgl. art. 6.45 Activiteitenbesluit.
} 


\title{
3.2.3.3. iLawsysteembesluit Tankstations
}

\section{Hoofdstuk 1 Algemeen}

\begin{abstract}
Artikel $1.1^{48}$
In dit besluit en de daarop berustende bepalingen wordt verstaan onder: bevoegd gezag: burgemeester en wethouders van de gemeente waarin de inrichting zich geheel of grotendeels bevindt;

$N R B$ : door InfoMil uitgegeven Nederlandse richtlijn bodembescherming bedrijfsmatige activiteiten;

verwaarloosbaarbodemrisico: een situatie als bedoeld in de NRB waarin door een goede afstemming van bodembeschermende voorzieningen en bodembeschermende maatregelen de kans op een verandering van de bodemkwaliteit, ten gevolge van een immissie van een stof, verwaarloosbaar is gemaakt; vloeibare brandstof: lichte olie, halfzware olie of gasolie als bedoeld in de artikelen 26 en 28 van de Wet op de accijns.
\end{abstract}

Artikel 1.2 ${ }^{49}$

Degene die een inrichting opricht, meldt dit ten minste vier weken voor de oprichting aan het bevoegd gezag.

\section{Artikel 1.3 ${ }^{50}$}

Indien bij of krachtens dit besluit is bepaald dat een daarbij aangegeven maatregel ter bescherming van het milieu moet worden toegepast kan een andere maatregel worden toegepast indien het bevoegd gezag heeft beslist dat met die maatregel ten minste een gelijkwaardig niveau van bescherming van het milieu wordt bereikt.

\section{Hoofdstuk 2 Algemene regels ten aanzien van alle activiteiten}

\section{Artikel 2.1 ${ }^{51}$}

Degene die een inrichting drijft en weet of redelijkerwijs had kunnen weten dat door het in werking zijn dan wel het al dan niet tijdelijk buiten werking stellen van de inrichting nadelige gevolgen voor het milieu ontstaan of kunnen ontstaan, die niet of onvoldoende worden voorkomen of beperkt door naleving van de bij of krachtens dit besluit gestelde regels, voorkomt die gevolgen of beperkt die voor zover voorkomen niet mogelijk is en voor zover dit redelijkerwijs van hem kan worden gevergd.

\section{Artikel 2.2 ${ }^{52}$}

Degene die de inrichting drijft neemt alle bekende energiebesparende maatregelen met een terugverdientijd van vijf jaar of minder of die een positieve netto contante waarde hebben bij een interne rentevoet van $15 \%$.

\footnotetext{
Vgl. art. 1.1 lid 1Activiteitenbesluit.

Vgl. art. 1.10 lid 1 Activiteitenbesluit.

Vgl. art. 1.8 Activiteitenbesluit.

Vgl. art. 2.1 lid 1 Activiteitenbesluit.

Vgl. art. 2.15 lid 1 Activiteitenbesluit.
} 
Artikel 2.3 ${ }^{53}$

1. Degene die een inrichting drijft waarin vloeibare brandstof of afgewerkte olie in een ondergrondse tank wordt opgeslagen stelt door verzekering of anderszins financiële zekerheid ter dekking van de aansprakelijkheid die voortvloeit uit verontreiniging van de bodem als gevolg van dat opslaan of het drijven van het tankstation.

2. De zekerheid bedraagt $€$ 225.00o per ondergrondse tank. Bij meer dan zes ondergrondse tanks bedraagt de zekerheid in totaal $€ 1.361 .340,65$.

\title{
Hoofdstuk 3 Voorschriften voor bepaalde activiteiten
}

Artikel 3.1 ${ }^{54}$

Bij het in werking hebben van een acculader wordt ten behoeve van het realiseren van een verwaarloosbaar bodemrisico, voldaan aan de bij ministeriële regeling te stellen eisen.

\section{Hoofdstuk 4 Overgangs- en slotbepalingen}

Artikel 4.1 ${ }^{55}$

Voor een tankstation waarvoor onmiddellijk voorafgaand aan het tijdstip van inwerkingtreding van artikel 1.2 een melding is gedaan, wordt voor de toepassing van artikel 1.2 een termijn van zes weken aangehouden.

Artikel $4.2^{56}$

Dit besluit treedt in werking met ingang van een bij koninklijk besluit te bepalen tijdstip, dat voor verschillende artikelen of onderdelen en voor verschillende soorten inrichtingen verschillend kan worden vastgesteld.

Artikel $4 \cdot 3^{57}$

Dit besluit wordt aangehaald als: iLawsysteembesluit.

\subsubsection{4. iLawsysteembesluit Bakkerij met winkel}

\section{Hoofdstuk 1 Algemeen}

\author{
Artikel $1.1^{58}$

\footnotetext{
Vgl. art. 2.24 lid 1 en 2 Activiteitenbesluit

Vgl. art. 4.114 Activiteitenbesluit.

Vgl. art. 6.1 lid 1 Activiteitenbesluit.

Vgl. art. 6.44 Activiteitenbesluit.

Vgl. art. 6.45 Activiteitenbesluit.

Vgl. art. 1.1 lid 1Activiteitenbesluit.
}

In dit besluit en de daarop berustende bepalingen wordt verstaan onder:

bevoegd gezag: burgemeester en wethouders van de gemeente waarin de inrichting zich geheel of grotendeels bevindt; 
Artikel 1.2 $2^{59}$

Degene die een inrichting opricht, meldt dit ten minste vier weken voor de oprichting aan het bevoegd gezag.

\begin{abstract}
Artikel 1.3 ${ }^{60}$
Indien bij of krachtens dit besluit is bepaald dat een daarbij aangegeven maatregel ter bescherming van het milieu moet worden toegepast kan een andere maatregel worden toegepast indien het bevoegd gezag heeft beslist dat met die maatregel ten minste een gelijkwaardig niveau van bescherming van het milieu wordt bereikt.
\end{abstract}

\title{
Hoofdstuk 2 Algemene regels ten aanzien van alle activiteiten
}

\begin{abstract}
Artikel 2.1 ${ }^{61}$
Degene die een inrichting drijft en weet of redelijkerwijs had kunnen weten dat door het in werking zijn dan wel het al dan niet tijdelijk buiten werking stellen van de inrichting nadelige gevolgen voor het milieu ontstaan of kunnen ontstaan, die niet of onvoldoende worden voorkomen of beperkt door naleving van de bij of krachtens dit besluit gestelde regels, voorkomt die gevolgen of beperkt die voor zover voorkomen niet mogelijk is en voor zover dit redelijkerwijs van hem kan worden gevergd.
\end{abstract}

Artikel 2.2 ${ }^{62}$

Degene die de inrichting drijft neemt alle bekende energiebesparende maatregelen met een terugverdientijd van vijf jaar of minder of die een positieve netto contante waarde hebben bij een interne rentevoet van $15 \%$.

\section{Hoofdstuk 3 Overgangs- en slotbepalingen}

\section{Artikel $\mathbf{3 . 1}^{63}$}

Dit besluit treedt in werking met ingang van een bij koninklijk besluit te bepalen tijdstip, dat voor verschillende artikelen of onderdelen en voor verschillende soorten inrichtingen verschillend kan worden vastgesteld.

Artikel $3.2^{64}$

Dit besluit wordt aangehaald als: iLawsysteembesluit.

\subsubsection{Wetssystematische consequenties van samenhangcriteria}

\subsubsection{Algemeen}

Hiervoor zagen we dat de wetgever bij het ordenen van het omgevingsrecht niet alleen kan kiezen tussen vele samenhangcriteria, maar dat hij daartussen

\footnotetext{
Vgl. art. 1.10 lid 1 Activiteitenbesluit.

Vgl. art. 1.8 Activiteitenbesluit.

Vgl. art. 2.1 lid 1 Activiteitenbesluit.

Vgl. art. 2.15 lid 1 Activiteitenbesluit.

Vgl. art. 6.44 Activiteitenbesluit.

Vgl. art. 6.45 Activiteitenbesluit
} 
ook een keus moet maken zolang de mogelijkheid van een iLawsysteem niet realiseerbaar is. Als de wetgever eenmaal voor een of meer samenhangcriteria $^{65}$ heeft gekozen, bepalen die samenhangcriteria het wetssysteem. Daarmee zijn andere, niet door de wetgever gekozen samenhangcriteria expliciet of impliciet uitgesloten en daarmee ook andere, wellicht meer wenselijke wetssystemen. De door de wetgever gemaakte keus voor een of meer samenhangcriteria heeft drie voor mijn onderzoek belangrijke consequenties die hierna zullen worden genoemd en toegelicht.

\subsubsection{Samenhangcriteria bepalen het wetssysteem}

In de eerste plaats brengt de keus van de wetgever voor een of meer samenhangcriteria mee dat de wetgever niet kiest voor een of meer andere samenhangcriteria. Dat betekent dat de wetgever aldus per definitie een of meer wetssystematische tekorten in wetssystemen of tussen wetssystemen laat bestaan of in het leven roept.

In dit verband zij opgemerkt dat een wetssysteem een relatief begrip is. Indien en in zoverre het gekozen samenhangcriterium bijvoorbeeld "natuurbescherming' betreft, dienen alle regels die betrekking hebben op natuurbescherming in het wetssysteem te zijn opgenomen. In zoverre niet alle regels zijn opgenomen die betrekking hebben op natuurbescherming is dan sprake van een wetssystematisch tekort. Maar als als samenhangcriterium 'natuurbescherming van soorten' of 'natuurbescherming van gebieden' zou zijn gekozen, dan zou daarmee ook de reikwijdte van het systeem worden bepaald; hetzelfde zou dan gelden voor wetssystematische tekorten.

Ook Biezeveld gaat ervan uit dat het niet mogelijk is eenzelfde regeling in haar geheel in twee verschillende kaders te integreren. 'Als een regeling bij twee integratieprocessen wordt betrokken (...) moet onvermijdelijk een keus worden gemaakt. Dit is ook volgens hem meer dan louter een kwestie van systematiek, aangezien het wettelijk kader immers de toekomstige beslissingsgrondslag en reikwijdte van de desbetreffende regeling bepaalt. ${ }^{36}$

Een bijzonderheid van het omgevingsrecht is overigens dat het een doorsnijdend karakter heeft. Zo behoort het omgevingsrecht niet slechts tot het bestuursrecht, maar ook tot rechtsgebieden als het burgerlijk recht (zoals milieuaansprakelijkheidsrecht), het strafrecht (overtreding van omgevingsrecht levert vaak een economisch delict op), het belastingrecht en het algemeen bestuursrecht. Gilhuis wees er in 1991 reeds op dat niet alle onderwerpen die voor het milieuvraagstuk van belang zijn in de tot 1 maart 1993 geldende Wet algemene bepalingen milieuhygiëne kunnen worden geregeld, aangezien andere

65 Als ik spreek van een of meer samenhangcriteria, dan doel ik gewoonlijk op een combinatie van samenhangcriteria, die in combinatie een wetssysteem bepalen

66 Biezeveld, Omgaan met samenhang bij integratie van milieuwetgeving en waterwetgeving 1990 p. 232. 
integratiekaders voor bepaalde onderwerpen geschikter kunnen zijn. ${ }^{67}$ In gelijke zin merkt Drupsteen op, dat uit een oogpunt van codificatie winst wordt geboekt met een Omgevingswet, maar dat 'we ons hierbij moeten realiseren dat het tot stand brengen van een Raamwet omgevingsrecht op andere plaatsen ten koste zal gaan van de codificatie. Zo zullen delen van het milieurecht, die nu samen met de ruimtelijke delen zijn opgenomen in de Wet milieubeheer, op zichzelf blijven staan.' Drupsteen meent ook dat uit codificatieoogpunt het paard achter de wagen zou worden gespannen als onderwerpen uit de Awb zouden worden overgebracht naar de Raamwet omgevingsrecht. ${ }^{98}$

Kleijs \& De Leeuw noemen in dit verband de relatie van de Wet milieubeheer en de Awb: 'Met de Wet milieubeheer is indertijd gekozen voor een algemene milieukaderwet, waarin op termijn zo veel mogelijk onderwerpen algemeen worden geregeld. (...) De geldende rechtsregels behoeven niet meer te worden opgespoord in verschillende en qua systematiek uiteenlopende regelingen wat belangrijke voordelen heeft voor degenen die bij de uitvoering van de wet zijn betrokken. Het streven naar een algemene milieukaderwet waarin zoveel mogelijk onderwerpen worden geïntegreerd wordt doorkruist door de Awb. Met de Awb worden bepaalde onderwerpen die over het brede terrein van het bestuursrecht voorkomen algemeen geregeld.' ${ }^{39}$

\subsubsection{Samenhangcriteria bepalen wetssystematische tekorten}

In de tweede plaats genereert de wetgever een wetssystematisch tekort of laat hij een dergelijk tekort in stand, als hij niet alle regels die volgens de gekozen samenhangcriteria tot het wetssysteem behoren, daarin een plaats geeft.

Heeft de wetgever dus bijvoorbeeld in de Wabo voor het samenhangcriterium 'plaatsgebonden project dat bestaat uit een of meer activiteiten die van invloed zijn op de fysieke leefomgeving' gekozen, ${ }^{70}$ dan is sprake van een wetssystematisch tekort als daarin bijvoorbeeld niet ook de watervergunning voor lozen een plaats krijgt voor die plaatsgebonden projecten van waaruit lozingen op het oppervlaktewater, onderdeel van de fysieke leefomgeving, plaatsvinden. ${ }^{71}$

\subsubsection{Samenhangcriteria bepalen problemen en oplossingen}

In de derde plaats bepalen samenhangcriteria het wetssysteem en daardoor in meer of mindere mate de oplossing voor het probleem dat de wetgever wil regelen. Zo zal de oplossing van een aan de rechter voorgelegd probleem

67 Gilhuis, De integratie van de milieuwetgeving in de Wabm 1991, p. 39. Zie ook Gilhuis, Over de verhouding van Wabm tot Awb 1990.

68 Drupsteen, Een Omgevingswet 2011, p. 285.

69 Kleijs-Wijnnobel \& De Leeuw, Relatie Awb-Wm 1998, p. 186.

70 Zie par. 4.3.3.

71 In par. $3.4 .5 \mathrm{zal} \mathrm{ik}$ aandacht besteden aan het kiezen tussen verschillende wetssystematische tekorten. Op deze plaats is het voorlopig voldoende om aan te geven dát in het hier genoemde geval sprake is van een wetssystematisch tekort. 
sterk afhankelijk kunnen zijn van het wetssystematisch kader waarbinnen dat probleem aan de orde kan of moet worden gesteld. Dat betekent naar mijn opvatting dat de wetgever zich bij het kiezen voor een wetssysteem door bundeling in elk geval ook moet afvragen welke problemen hij daarmee wenst op te lossen en welke probleemoplossingen hij uitsluit of bemoeilijkt. Het gevaar dat problemen over het hoofd worden gezien, wordt daardoor verminderd..$^{72}$

Een voorbeeld dat illustreert dat de keus voor een bepaalde wetssystematiek gevolgen heeft voor de praktijk ontleen ik aan de Utrechtse oratie van Michiels. ${ }^{73}$ In 1977 verleenden burgemeester en wethouders (BenW) van Enschede aan het bedrijf SE Fireworks een revisievergunning. ${ }^{74}$ Omwonende Slot schreef aan BenW: 'Het lijkt mij dat je midden in een woonwijk een dergelijke inrichting juist zou moeten weren. Hoe het überhaupt in deze tijd nog mogelijk is dat in een woonwijk als deze een dergelijke onderneming nog steeds gehuisvest is, is me een raadsel. Waarom niet verhuizen naar een andere locatie buiten de stad op het industriegebied? Dergelijke opslagplaatsen behoren niet in woonwijken te worden gesitueerd.' BenW wezen de bedenking van Slot resoluut van de hand. Die betrof volgens hen namelijk een planologisch aspect dat als zodanig niet behoort tot het toetsingskader van de Wet milieubeheer, te weten de bescherming van het milieubelang. Daarmee volgden BenW volgens Michiels de jurisprudentie van de Afdeling bestuursrechtspraak van de Raad van State. ${ }^{75}$ De Afdeling vindt dat een argument als aangevoerd door Slot uitsluitend de verenigbaarheid van planologische functies betreft. Zij eist dat hetgeen naar voren wordt gebracht betrekking heeft op de inrichting in kwestie. ${ }^{76}$

Dit voorbeeld laat zien dat de wetgever zich ten minste de vraag zou moeten stellen of het milieubelang en het belang van een goede ruimtelijke ordening wel zouden moeten worden gescheiden als in het voorbeeld het geval is. ${ }^{77}$ In feite is dat een vraag naar de te hanteren samenhangcriteria.

Art. 6a lid 1 eerste volzin Hinderwet luidde: 'Wanneer een vergunning wordt verzocht of zou moeten worden verzocht voor de uitbreiding of wijziging van een inrichting, ten opzichte waarvan reeds een of meer vergunningen werden verleend, dan wel voor de verandering van een in een zodanige inrichting gebezigde werkwijze, kan het gemeentebestuur toestaan of verlangen, dat door de betrokkene een verzoek wordt ingediend voor een nieuwe, de gehele inrichting omvattende, vergunning.'

75 Zie bijvoorbeeld ABRvS 13 oktober 1997, JM 1997, 65

76 Zie bijvoorbeeld ABRvS 17 juni 1999, JM 1999, 116.

77 Idem Michiels, Kleur in het omgevingsrecht 2001, p. 3. Overigens is dit probleem na de oratie van Michiels opgelost doordat strijd met het bestemmingsplan op 1 juli 2008 werd opgenomen in de Wet milieubeheer als weigeringsgrond voor de milieuvergunning. Die weigeringsgrond is op 1 oktober 2010 als zodanig niet teruggekomen in art. 2.14 Wabo. 
Een ander voorbeeld betreft de in de Wabo geregelde omgevingsvergunning en de in de Waterwet geregelde watervergunning. Een project als bedoeld in de Wabo, zoals de bouw van een fabriek, heeft vaak ook gevolgen voor de waterkwaliteit. In dat geval is zowel een omgevingsvergunning ${ }^{78}$ als een watervergunning ${ }^{79}$ nodig. Bij de beoordeling van een aanvraag om een omgevingsvergunning worden onder meer de gevolgen voor het milieu betrokken. ${ }^{80}$ De gevolgen voor de waterkwaliteit kunnen onder die noemer echter niet aan de orde komen. Zou de wetgever in de Wabo hebben gekozen voor 'de fysieke leefomgeving als geheel' als samenhangcriterium, dan zou dat criterium uit wetssystematisch oogpunt leidend dienen te zijn. Het gevolg daarvan zou zijn, dat de omgevingsvergunning ook zou dienen te gelden voor de activiteiten van de fabriek waarvoor thans een watervergunning nodig is. Probleemoplossingen zouden in dat geval ook gezocht kunnen worden in een afweging tussen milieu- en waterkwaliteit.

In dit verband noem ik graag Noll, waar hij stelt: 'Die Gesetzessystematik dient der Erleichterung der Information. Darüber hinaus hat sie Nebenwirkungen, die oft gar nicht in den Blick gelangen. Da sie immer zugleich Themen begrenzt und Probleme definiert, kann sie ganz ungewollt und dem Adressaten unbewußt Problemsicht, Erkenntnis- und Forschungsinteresse vorbestimmen. ${ }^{, 81}$ Volgens Noll bepaalt het systeem het probleem en niet andersom het probleem het systeem. ${ }^{82}$ Noll toont met twee voorbeelden overtuigend belangrijke mogelijke bijwerkingen van een wetssysteem aan. De wetgever dient naar mijn oordeel oog te hebben voor dergelijke bijwerkingen bij het ordenen van het omgevingsrecht.

Het eerste voorbeeld dat Noll noemt betreft het strafrecht. Als strafrecht betekent dat het gaat om het thema 'straf', dan zal strafrecht in eerste instantie om het probleem 'straf' gaan en maar gedeeltelijk om het probleem 'bestrijding van de criminaliteit'. Als daarentegen 'criminaliteit' als systematiseringsthema zou zijn gekozen, dan is straf slechts een van de vele mogelijkheden om te reageren op criminaliteit naast bijvoorbeeld maatschappelijk werk, opvoeding en opleiding en de afbouw van criminogene wetten. Elke mogelijke oorzaak van criminaliteit en elk mogelijk middel daartegen wordt voorwerp van onderzoek. De keus voor straf als systematiseringscriterium betekent volgens Noll zelfs dat oplossingen worden verhinderd: 'Das Systematisieringskriterium der Straf ist also geeignet, strafrechtliche Problemlösungen zu verhindern. ${ }^{83}$

Het tweede voorbeeld ontleent Noll aan de Zwitserse rechtspraktijk. Het toont aan dat de keuze voor de oplossing van een bepaald probleem afhangt van het wetssysteem waarbinnen die oplossing moet worden gevonden. Aan de orde was een tariefswijziging in het Postverkehrsgesetz. De eidgenössischen Räten discussieerden in dat verband over de vraag of en hoe de verscheidenheid van de

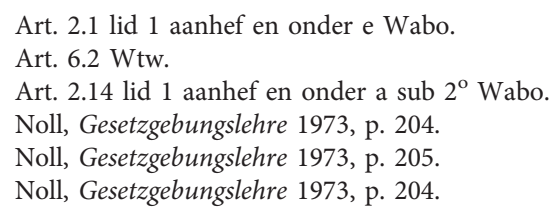


Zwitserse pers kon worden behouden. Commercieel succesvolle kranten met veel advertenties zouden worden benadeeld als gevolg van het feit dat het posttarief sterk zou stijgen boven een bepaald gewicht. Omdat de krantenbezorging voor de post toch al een verliesgevende afdeling was, zouden daardoor de indirecte subsidies ten gunste van de zwakkere persorganen herverdeeld worden. Deze wetgevingsdiscussie doorbrak het systeem en het thema van het Postverkehrsgesetz. 'Was von Systematisierungskriterium 'Postverkehr' und 'Finanzierung der Post' nur Nebenwirkung war, wurde vom Systematisierungskriterium 'Pressefreiheit' und Erhaltung der Meinungsvielfalt vorrangiger Zweck.' Daardoor kwam voor het probleem 'pers' maar een enkel wetgevingsmiddel in aanmerking, namelijk het posttarief. Zou de wetgever de discussie hebben gevoerd binnen de systeemordeningscriteria persvrijheid en persverscheidenheid, dan zouden volgens Noll vermoedelijk ook andere oplossingen voor het probleem zijn bekeken. De uitwerkingen voor de post zouden dan niet als wetgevingsdoel, maar als louter bijwerking zijn gezien met vanzelfsprekend een ander gewicht in de discussie. ${ }^{84}$

\subsubsection{Uitgangspunt voor samenhangcriteria}

Hiervoor zagen we dat de keus voor een of meer samenhangcriteria drie belangrijke consequenties heeft:

a. samenhangcriteria bepalen het wetssysteem;

b. samenhangcriteria bepalen het wetssystematisch tekort;

c. samenhangcriteria bepalen probleemstelling en oplossingen.

Gelet op dit belang is de vraag relevant of er in wetenschappelijke zin iets te zeggen valt over de keus die de wetgever dient te maken. Is elke - politieke keus een kwestie van smaak waarover - niet - te twisten valt? Of is er wetenschappelijk een kader (te ontwikkelen) dat de wetgever een leidraad geeft bij het kiezen van een samenhang voor het ordenen van omgevingsrecht? Op deze vragen zal hierna een antwoord worden gezocht.

\subsubsection{Kenbaarheid en probleemgeoriënteerdheid}

\subsubsection{Kenbaarheid}

De belangrijkste functie van een wetssysteem ligt naar mijn oordeel in het vergemakkelijken van in het geschreven recht opgenomen informatie. ${ }^{85}$ Wetssystematiek is met andere woorden - los van de inhoud van de daarvan deel uitmakende regels - van belang voor de kenbaarheid van het recht. In dit verband citeer ik met instemming Noll, waar hij schrijft: 'auch die

Noll, Gesetzgebungslehre 1973, p. 204-205.

85 Vergelijk Noll, Gesetzgebungslehre 1973, p. 204. Hill noemt 'Adressatengerechtigkeit' als een belangrijke eigenschap van wetgeving. Daarbij gaat het om 'die Verständlichkeit des Gesetzes beim betroffenen Bürger' (Hill, Einführung in die Gesetzgebungslehre 1982, p. 96). 
Gesetzessystematik muß auf die möglichst adressengerechte Information ausgerichtet sein. ${ }^{86}$ Noll schrijft verder: 'Das Prinzip der Erkennbarkeit verlangt, daß der Gesetzgeber die Normen in einen systematischen Zusammenhang stellt. ${ }^{87}$ Hill schrijft dat het doel van wetten meestal is 'eine große Anzahl von Sachverhalten und persönlichen Betroffenheiten zu regeln. Der Umfang der Regelungsgegenstände und die Allgemeinheit der Regelung machen es daher erforderlich, die vorhandene Regelungsmaterie zu ordnen und nach bestimmten Kriterien zu systematisieren. Erst diese Einteilung vermag eine gewisse geistige Beherrschung des Rechtsstoffes zu gewährleisten (....).88

De vraag is echter wat onder kenbaarheid dient te worden verstaan. Volgens Visser houdt het kenbaarheidsbeginsel in dat een regel door een ieder voor wie hij van belang kan zijn moet kunnen worden gekend. ${ }^{89}$ Hoewel Visser dit beginsel behandelt als een materieel beginsel van behoorlijke wetgeving komt het beginsel op die wijze geformuleerd mij eerder voor als een formeel beginsel. Het richt zich immers op het feit dat de gebruiker van het recht bekend kan zijn met de desbetreffende regel. Dat betekent echter nog niet dat die gebruiker uit een verzameling van wettelijke regels zijn rechten en plichten ook kan begrijpen. Ik zou een wetssysteem kenbaar willen noemen als een gebruiker daaruit zijn rechten en plichten kan kennen. Dat sluit aan bij Voermans: 'De rechtzoekende moet snel kunnen vinden wat hij zoekt en vervolgens eenvoudig vast kunnen stellen waar hij aan toe is, i.e. weten welke norm geldt. ${ }^{90}$

De mate van kenbaarheid van het omgevingsrecht zal niet voor iedere gebruiker hetzelfde zijn. Hoewel ik het een nobel streven vind, lijkt het mij dan ook niet mogelijk om, zoals Heuving \& Boere bepleiten, in het algemeen de regelgeving zo goed mogelijk kenbaar en toegankelijk te maken voor 'de klant' in de zin van alle personen en instellingen tot welke de wetgever zich richt: de samenleving als geheel, uitvoerders, handhavers, rechters, instellingen, bedrijven, burgers. ${ }^{91}$ Of een wetssysteem kenbaar is voor een gebruiker zal immers onder meer afhankelijk zijn van voorkennis, intelligentie en analytisch vermogen. Hetzelfde geldt overigens voor de kenbaarheid van de relativiteitstheorie van Albert Einstein ${ }^{92}$ of voor de gebruiksaanwijzing van een elektronisch apparaat. Die laten zich ook niet door iedereen overzien en begrijpen. Het heeft mijns inziens dan ook weinig

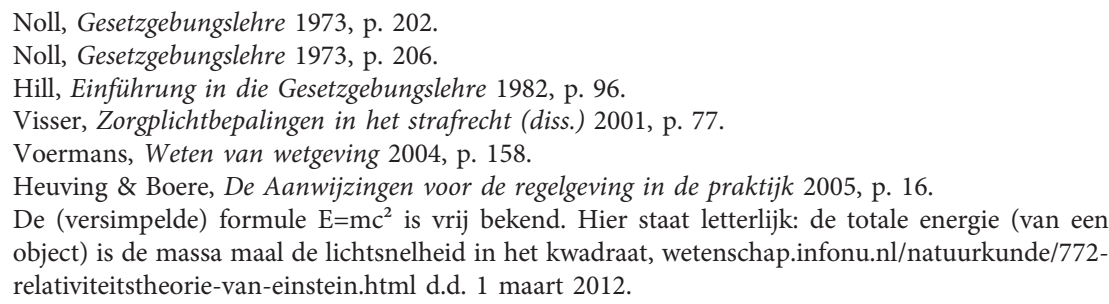


zin om de kenbaarheid van een wetssysteem te laten afhangen van de vraag of het al dan niet in Jip-en-Janneketermen ${ }^{93}$ is geformuleerd.

Sebus noemt een wet toegankelijk als men zonder aanzienlijke inspanning of vertraging kennis kan nemen van de wet. Als een van de oorzaken voor die inspanning of vertraging noemt zij het feit dat de gebruiker de wet niet begrijpt. ${ }^{94}$ Volgens Voermans is de realiteit: 'de meeste rechtsgenoten kennen de letterlijke inhoud van wetgeving die hen aangaat meestal niet, en zeker niet vooraf; dat wil zeggen alvorens ze het genormeerde gedrag ontplooien. Sterker nog: de meeste rechtsgenoten gedragen zich volgens mij volgens de normen die in wetgeving zijn neergelegd zonder ze ook maar ooit in hun leven letterlijk te raadplegen. Wetgeving is het boek in cellofaan in de kast.95 Ook Van Gestel gaat ervan uit dat burgers geen wetten lezen. ${ }^{96}$ Zijlstra meent dat geen enkele wet door iedere willekeurige burger kan worden gebruikt. De wetgever doet soms wel pogingen om een wettelijke regeling zo op te stellen dat zij meer voor particuliere consumptie geschikt is, maar kan daar volgens Zijlstra niet in slagen. Dergelijke wetgeving zou de burger zelfs op het verkeerde been kunnen zetten. ${ }^{97}$ Hij meent dat we ons er maar bij neer moeten leggen, dat wetten niet worden geschreven om door burgers begrepen te worden. Het uiteindelijk doel van wettelijke regelingen is volgens hem weliswaar het dienen van burgers, maar dat betekent nog niet dat de burgers de regeling ook moeten kunnen begrijpen..$^{98}$

Drupsteen meent dat meer kenbaarheid of voorspelbaarheid van wetssystemen voor burgers en ondernemers niet de eerste insteek zal zijn van de wetgevingsjurist, "als het al een aandachtspunt is. ${ }^{99}$ Ondernemers hebben wel wat anders te doen dan wetten te lezen. Burgers en ondernemers lezen de wetssystemen niet. Maar als een gebruiker, zoals een ondernemer, aanloopt tegen problemen die te maken hebben met de inrichting van wetssystemen, dan moet je kijken of daaraan iets te doen is. Zo liepen ondernemers voor de Wabo aan tegen het probleem dat ze veel verschillende vergunningen moesten aanvragen voor een activiteit. Daaraan is wat gedaan met de Wabo. Dat wordt meer geredeneerd vanuit het voorkomen van onnodige verschillen, valkuilen en moeilijkheden. Er wordt dus niet beredeneerd vanuit de gedachte dat wetssystemen voor iedereen leesbaar moeten zijn, zodat de ondernemer na zijn dagtaak denkt: 'Kom, ik ga nog eens een stukje wetgeving lezen."'100

93 Annie M.G. Schmidt, Jip en Janneke, Querido 2005. Zie ook Simo Goddijn, Floor van Horen, Inge Leenders, e.a., De taal van mr. Jip van Harten en dr. Janneke Bavelinck, Sdu 2011.

94 Sebus, Wetgevingstechniek en de toegankelijkheid van de wet voor de burger 1984, p. 2-3.

95 Voermans, Weten van wetgeving 2004, p. 158.

96 Van Gestel, Eenieder wordt geacht de wet te kennen 1998.

97 Zijlstra illustreert dat aan de hand van art. 74 Reglement verkeersregels en verkeerstekens: 'Groen licht betekent oversteken.' Hier is volgens Zijlstra duidelijk gekozen voor spreektaal boven wetgeverstaal. Maar, zo constateert hij, de lezer van het Reglement zal zich te allen tijde de derogerende werking van art. 5 Wegenverkeerswet 1994 dienen te realiseren: 'Het is een ieder verboden zich zodanig te gedragen dat gevaar op de weg wordt veroorzaakt of kan worden veroorzaakt of dat het verkeer op de weg wordt gehinderd of kan worden gehinderd.' Volgens dat artikel moet men soms bij groen licht blijven staan als dat een ongeluk voorkomt. 
De door een wetssysteem beschreven werkelijkheid is vaak ingewikkeld en dientengevolge zal dat, alle pogingen om wetgeving te vereenvoudigen ten spijt, vaak ook gelden voor het wetssysteem zelf. Uiteraard valt er altijd wel iets te verbeteren, maar zolang de bedoelde werkelijkheid complex blijft, zal dat naar verwachting ook blijven gelden voor het wetssysteem dat die werkelijkheid beoogt te reguleren. Ik leg de lat van de kenbaarheid daarom lager; de kenbaarheid van een wetssysteem is in mijn optiek afhankelijk van het antwoord op de vraag of het voor gebruikers met enige kennis op het gebied van dat wetssysteem mogelijk is uit het desbetreffende wetssysteem rechten en verplichtingen in hun geheel te overzien en te begrïpen.

Ook Zijlstra meent dat een regeling wel duidelijk en toegankelijk moet zijn voor de gebruiker. Dat is volgens hem echter niet de burger, maar de rechtspraktijk. Juristen dienen de regeling met enige snelheid te kunnen doorgronden en ermee te kunnen werken. Wetten die voor geschoolde juristen niet te begrijpen zijn, die inconsistent of te 'open' zijn, leveren rechtsstatelijk wel grote problemen op, aldus Zijlstra. ${ }^{101}$ In gelijke zin Woldendorp die zich wel erin kan vinden dat kenbaarheid wordt afgemeten aan de personen die enige kennis van de wetgeving hebben. ${ }^{102}$ Backes noemt een milieurechtelijk stelsel waarvan zelfs specialisten en de meest betrokken wetgevingsambtenaren aangeven dat zij het niet meer in hun geheel kunnen overzien en begrijpen te complex. Backes noemt die complexiteit het voornaamste bezwaar tegen het omgevingsrecht. ${ }^{103}$ Ook Bregman stelt de gebruikers van het omgevingsrecht centraal. Hij doelt daarbij op overheden die binnen het door de wetgever vastgestelde normenkader omgevingsbeleid maken en omgevingsrechtelijk relevante investeringsbeslissingen nemen, maar ook op marktpartijen die investeringsbeslissingen nemen. ${ }^{104}$

Een gebrek aan kenbaarheid van een wetssysteem in het omgevingsrecht leidt tot rechtsonzekerheid, aangezien het voor specialisten op het gebied van het omgevingsrecht dan onmogelijk is om rechtszekerheid te verschaffen omtrent de impact van een omgevingsregel, zowel op zichzelf als bezien in samenhang met andere omgevingsregels. Gebrek aan kenbaarheid kan

101 Zijlstra, Aanpak bij het opstellen van een wettelijke regeling 2012, p. 388.

102 Woldendorp, Interview 2011.

103 Vergelijk Backes, Naar een integrale omgevingswet? 2010, p. 3. 'Er zijn veel en zeer gedetailleerd uitgewerkte materiële normen die bij besluiten omtrent de inrichting van de fysieke leefomgeving in acht moeten worden genomen, en er is ook een grote hoeveelheid procedures die doorlopen, en het liefst zonder fouten toegepast moeten worden. De omvang van dit probleem is aanzienlijk en sinds inwerkingtreding van de Wet milieubeheer in 1993 beduidend toegenomen. Een robuuste besluitvorming over iets complexere infrastructuurmaatregelen lijkt alleen nog mogelijk met begeleiding van een team van interne en externe juristen. De inschatting en vermijding van juridische procesrisico's is een prioritaire taak van projectteams, (...).' Ik ben het met hem eens (Van den Broek, Omgevingswet, Offer you can't refuse 2011).

104 Bregman, Naar een gebruikersvriendelijk omgevingsrecht 2010, p. 49. Bregman noemt ook belanghebbenden die zelf niet investeren, maar die wel anderszins belanghebbende zijn bij de mogelijkheden en belemmeringen die het gevolg zijn van planologische maatregelen en omgevingsrechtelijke toestemmingen. Die laatste groep lijkt mij niet, althans niet uitsluitend, te bestaan uit specialisten. 
om dezelfde reden ook leiden tot vertraging in procedures of extra beroepsprocedures.

Gebrek aan kenbaarheid kan mijns inziens slechts ten dele worden ondervangen door een ICT-toepassing, die hooguit een juiste interpretatie van de wettelijke werkelijkheid kan vormen. ${ }^{105}$ De praktijk leert dat de bouwers van dergelijke systemen de neiging hebben om de wettekst en -systematiek tot een soort journalistieke Jip-en-Janneketaal te vereenvoudigen, terwijl Jip en Janneke vanwege hun leeftijd nu juist niet tot de gebruikers van het recht zullen behoren. De taal van de wetgever onderscheidt zich niet van die van Jip en Janneke omdat de wetgever het de gebruiker per se moeilijk wil maken, maar omdat de taal van het recht naar haar aard tot grotere zorgvuldigheid en genuanceerdheid noopt. De geschetste 'vereenvoudiging' heeft soms tot gevolg dat degene die de ICT-tool gebruikt dat eigenlijk alleen adequaat kan doen als hij het wetssysteem voldoende kent, zodat hij de ICT-verwoording in de juiste context kan plaatsen, terwijl degene die het wetssysteem kent de wettelijke voorzieningen soms niet adequaat terugvindt in de ICT-tool.

Een voorbeeld betreft artikel 2.21 Wabo, dat een zogeheten rompvergunning mogelijk maakt. Een aanvraag om een omgevingsvergunning kan betrekking hebben op een project dat bestaat uit meer activiteiten. Als de vergunning moet worden geweigerd voor een of meer activiteiten, brengt het systeem van de Wabo mee dat de omgevingsvergunning voor het gehele project moet worden geweigerd. ${ }^{106}$ De aanvrager kan dat echter voorkomen door te vragen om een rompvergunning. Artikel 2.21 Wabo bepaalt namelijk dat het bevoegd gezag op verzoek van de aanvrager de omgevingsvergunning kan verlenen voor de activiteiten waarvoor zij niet behoeft te worden geweigerd.

In het Omgevingsloket online wordt deze mogelijkheid echter als volgt geformuleerd: 'Als blijkt dat voor één van de aangevraagde onderdelen geen vergunning verleend kan worden, wilt $\mathrm{u}$ dan voor de overige aangevraagde onderdelen wel een vergunning ontvangen?'107 Deze vraag is onvolledig, aangezien de aanvrager niet in de ICT-tool kan aangeven voor welke activiteit of activiteiten hij de rompvergunning precies wenst. Stel dat iemand een omgevingsvergunning vraagt voor het bouwen van een garage, het kappen van een boom en het maken van een uitweg. Het is mogelijk dat hij de omgevingsvergunning in elk geval wil hebben voor bouwen en uitwegen en zo mogelijk voor kappen. Als hij de genoemde vraag positief beantwoordt, loopt hij het risico dat hem een rompvergunning wordt verleend voor bouwen en kappen. Dat risico is niet aanwezig als het digitale aanvraagformulier de aanvrager in de gelegenheid zou hebben gesteld aan te geven voor welke activiteiten hij met een rompvergunning genoegen wil nemen.

105 Zie in dit verband ook hetgeen ik daarover heb opgemerkt in par. 3.2.2.3.

106 Dat volgt uit de art. 2.10-2.20a Wabo. Zie ook Van den Broek \& Dresden, De Wabo in de praktijk 2011, p. 104.

107 www.omgevingsloket.nl/Zakelijk/zakelijk/formulier.pdf?id=aec175f9-8576-418b-a8807c59d3eb6e391137, d.d. 28 februari 2012. 


\subsubsection{Probleemgeoriënteerdheid}

Bij de eis van kenbaarheid sluit aan de eis dat een wetssysteem probleemgeoriënteerd dient te zijn. Wie een wetssysteem in het omgevingsrecht raadpleegt zal zulks gewoonlijk doen om helderheid te verkrijgen omtrent bepaalde rechten en verplichtingen van hemzelf of anderen. Hij heeft met andere woorden een vraag, vermoedt het antwoord in het desbetreffende wetssysteem en wil - bij voorkeur zo snel mogelijk en zonder onnodige omwegen - in dat wetssysteem het antwoord op zijn vraag vinden. De vraag kan bijvoorbeeld worden gesteld door een burger of een bedrijf, maar ook door een rechter, een handhaver of vergunningverlener. Mogelijke vragen zijn 'bij wie moet ik mijn aanvraag om omgevingsvergunning indienen?', 'hoe lang duurt het voordat op die aanvraag is beslist?', 'welke rechter is bevoegd?' of 'in welke gevallen mag ik een bepaalde vogel vangen?'108

Teneinde de gebruiker zo goed mogelijk van dienst te kunnen zijn, dient een wetssysteem daarom probleemgeoriënteerd te zijn. Dat is het geval als een wetssysteem zelf reeds - los van de inhoud van de daarin opgenomen regels tot het vinden van een antwoord op de gestelde (rechts)vraag leidt en niet eerst - op een groot aantal andere vragen, die voor de vraagsteller - op dat moment - niet interessant zijn. Wetssystemen moeten bij voorkeur uitgaan van hetgeen de gebruiker al weet en zonder onnodige omwegen leiden naar hetgeen hij wil weten. In gelijke zin merkt Noll daarover op: 'Die Systematik innerhalb der Gesetze soll so aufgebaut sein, daß sie Antwort gibt auf die Rechtsfrage des Sachverhalts und nicht auf irgendwelche andere Fragen. Sie muß ausgehen von dem, was der Rechtsuchende schon weiß, und hinführen zu dem, was er noch nicht weiß, aber wissen möchte, nicht umgekehrt.'109 Daarbij sluit aan de mening van Voermans, dat 'de rechtzoekende snel moet kunnen vinden wat hij zoekt ...110

Er zijn echter veel voorbeelden te noemen in het omgevingsrecht waar het omgekeerde het geval is. De gebruiker vindt het antwoord op tal van vragen, maar kan slechts met veel moeite of zelfs in het geheel niet achter het antwoord op zijn vraag komen.

Een voorbeeld betreft de gebruiker die een antwoord zoekt op de vraag of en zo ja in welke gevallen een bestuursorgaan bij de beoordeling van een aanvraag om omgevingsvergunning voor het oprichten van een inrichting ${ }^{111}$ rekening moet houden met een nationaal milieubeleidsplan. Het wetssysteem van het

108 Zie hierover par. 6.5.2.1.

109 Noll, Gesetzgebungslehre 1973, p. 222, overgenomen door Sebus, Wetgevingstechniek en de toegankelijkheid van de wet 1984, p. 65: 'De wetssystematiek moet uitgaan van wat de lezer weet en hem leiden tot wat hij nog niet weet, maar te weten wil komen (en niet omgekeerd)', ook opgenomen in Eijlander \& Voermans, Wetgevingsleer 2000, p. 218.

110 Voermans, Weten van wetgeving 2004, p. 158.

111 Art. 2.1 lid 1 aanhef en onder e Wabo. 
omgevingsrecht nodigt uit om te zoeken in het wetssysteem van de Wabo, dat regels bevat over de omgevingsvergunning, maar ook in het wetssysteem van de Wet milieubeheer, dat regels bevat over plannen.

Het wetssysteem van de Wet milieubeheer nodigt uit om te zoeken in paragraaf 4.2 Het nationale milieubeleidsplan van hoofdstuk 4 Plannen. De desbetreffende paragraaf bestaat uit vier artikelen (artikel 4.3-4.6 Wm), die de vraagsteller zal moeten lezen om een antwoord op zijn vraag te vinden. De artikelen 4.3, 4.4 en 4.5 Wm geven een antwoord op de vraag wat de inhoud is van het plan en hoe het wordt vastgesteld. Die artikelen geven dus antwoorden op vragen die de vraagsteller - op dat moment - niet interesseren. Pas in artikel 4.6 lid $3 \mathrm{Wm}$ wordt een begin van antwoord gevonden op zijn vraag: 'de organen van het Rijk houden in elk geval rekening met het geldende nationale milieubeleidsplan bij het nemen van een besluit dat daartoe is aangewezen in deze wet, en bij het nemen van een besluit krachtens een wet, genoemd in bijlage 1, voor zover daarbij het belang van de bescherming van het milieu in beschouwing moet of kan worden genomen.' Bijlage 1, waarnaar wordt verwezen, noemt onder meer de Wabo. Artikel 2.14 lid 1 onder b onder $1^{\circ}$ Wabo bepaalt dat het bevoegd gezag bij een beslissing op de aanvraag voor het oprichten van een inrichting in ieder geval rekening moet houden met het voor hem geldende milieubeleidsplan.

Als de gebruiker het wetssysteem van de Wet milieubeheer als uitgangspunt kiest, wordt hij daardoor slecht geholpen om het antwoord op zijn vraag te krijgen. In de eerste plaats is genoemd wetssysteem niet op voorhand duidelijk. Een verduidelijking zou kunnen worden bewerkstelligd door bijvoorbeeld het gebruik van tussenkopjes als inhoud (art. 4.3 Wm), totstandkoming (art. 4.4 Wm), bekendmaking (art. 4.5 Wm), geldingsduur (art. 4.6 lid 1 en lid $2 \mathrm{Wm}$ ), toepassing bij besluiten (art. 4.6 lid 3 en lid $4 \mathrm{Wm}$ ) en inhoud (art. 4.6 lid $5 \mathrm{Wm}$ ). Het is waarschijnlijk dat de aandacht van de gebruiker dan reeds bij het lezen van de inhoudsopgave zou worden getrokken door artikel 4.6 lid $3 \mathrm{Wm}$. In de tweede plaats geeft artikel 4.6 lid 3 Wm de gebruiker slechts een antwoord op de vraag dat organen van het Rijk ten aanzien van aangewezen besluiten rekening moeten houden met het nationale milieubeleidsplan. Het wetssysteem van de Wet milieubeheer geeft hem echter nog geen antwoord op de vraag welke besluiten zijn aangewezen of hoe hij erachter kan komen welke besluiten zijn aangewezen. ${ }^{112}$

De gebruiker kan ook het wetssysteem van de Wabo kiezen om een antwoord te vinden op zijn vraag. De Wabo nodigt uit om te zoeken binnen paragraaf 2.3 De beoordeling van de aanvraag. Artikel 2.14 lid 1 onder b onder $1^{\circ}$ Wabo bepaalt dat het bevoegd gezag bij een beslissing op een aanvraag om omgevingsvergunning voor een inrichting in ieder geval rekening moet houden met het voor hem geldende milieubeleidsplan.

Als de gebruiker deze weg kiest zal hij naar verwachting sneller een antwoord op zijn vraag vinden. Een kanttekening daarbij is, dat van hem wel de voorkennis wordt verwacht dat 'het voor hem geldende milieubeleidsplan' in het kader van

112 Daarvoor moet hij in casu art. 2.14 Wabo raadplegen. 
zijn vraag slechts het nationaal milieubeleidsplan betreft als het bevoegd gezag een orgaan van het Rijk is. De gebruiker die in de Wabo zoekt naar 'nationaal milieubeleidsplan' weet zich door het wetssysteem van de Wabo niet geholpen. Ook niet bij het zoeken van de woorden 'nationaal milieubeleidsplan' in de Wabo; die woordcombinatie komt namelijk niet voor in de Wabo.

Maar waarom is dit zo? Ik neem aan dat de wetgever niet uit alle macht probeert het de burger zo moeilijk mogelijk te maken. Het lijkt mij veeleer een kwestie van wetssystematiek waarbij de wetgever nu eenmaal een keus moet maken tussen verschillende mogelijke, vaak te verdedigen samenhangcriteria. ${ }^{113}$ De probleemgeoriënteerdheid van een wetssysteem zal mijns inziens sterk afhangen van de gekozen samenhangcriteria. Als dat juist is, dan komt het mij voor dat de wetgever zich bij het kiezen van een of meer samenhangcriteria bewust moet zijn van deze afhankelijkheid.

Als voorbeeld om aan te geven dat de probleemgeoriënteerdheid van een wetssysteem sterk zal afhangen van de gekozen samenhangcriteria noem ik het Activiteitenbesluit. In hoofdstuk 4 daarvan is uitdrukkelijk gekozen voor bepaalde activiteiten als samenhangcriteria. Zo wordt het subwetssysteem van paragraaf 4.1.2 bepaald door de activiteit Opslaan van vuurwerk en andere ontplofbare stoffen en van paragraaf 4.6.2 door de activiteit Bieden van parkeergelegenheid in een parkeergarage. Met de probleemgeoriënteerdheid lijkt het dus wel goed te zitten als het probleem is: 'Welke regels gelden voor het opslaan van vuurwerk' of 'Welke regels gelden voor het bieden van parkeergelegenheid in een parkeergarage.' Voor het probleem van de ambtenaar die zich afvraagt in welke gevallen het Activiteitenbesluit maatwerkvoorschriften mogelijk maakt, is deze probleemgeoriënteerdheid echter ver te zoeken. Die regels staan namelijk niet ergens bij elkaar in een subwetssysteem 'Maatwerkvoorschriften', aangezien het Activiteitenbesluit dat samenhangcriterium niet kent. Digitale ontsluiting of een iLawsysteem ${ }^{114}$ zouden hier soelaas kunnen bieden, aangezien daarmee een wetssysteem met daarin alle regels inzake maatwerkvoorschriften kan worden gegenereerd.

\subsubsection{De systematiek van de Wet bodembescherming als voorbeeld}

Aan de hand van de systematiek van de Wet bodembescherming zal ik illustreren op welke wijze een wetssysteem op zichzelf reeds - dus los van de inhoud van de daarin opgenomen regels - behulpzaam kan zijn bij het bevorderen van de kenbaarheid van de daarin opgenomen regels. Daarbij zal tevens worden toegelicht wat het betekent dat een wetssysteem probleemgeoriënteerd is.

113 Zie par. 3.2.4.4

114 Par. 3.2.3.2. 
Het wetssysteem van de Wet bodembescherming bestond op 12 juli 2011 uit 117 artikelen die handelen over de bescherming van de bodem. ${ }^{115}$ Stellen we ons voor dat al die artikelen zouden zijn geordend op de wijze zoals dat bij een telefoonboek gebruikelijk is, te weten alfabetisch. Het zal duidelijk zijn dat zulks tot weinig overzicht zou leiden. Wie wil weten hoe hij een bodemsanering moet uitvoeren, zou dan immers net zolang moeten lezen totdat hij de regel tegenkomt die thans in artikel 38 lid $1 \mathrm{Wbb}$ is opgenomen: 'Degene die de bodem saneert, voert de sanering zodanig uit dat: a. de bodem ten minste geschikt wordt gemaakt voor de functie die hij na de sanering krijgt waarbij het risico voor mens, plant of dier als gevolg van blootstelling aan de verontreiniging zoveel mogelijk wordt beperkt; $b$. het risico van de verspreiding van verontreinigende stoffen zoveel mogelijk wordt beperkt; c. de noodzaak tot het nemen van maatregelen en beperkingen in het gebruik van de bodem als bedoeld in artikel 39d zoveel mogelijk wordt beperkt (...).' Hij zal ook daarna verder moeten lezen om er zeker van te zijn dat hij geen regel mist die over de uitvoering van bodemsanering gaat. Naarmate het om omvangrijker regelcomplexen gaat is het des te meer van belang dat een wetssysteem overzicht biedt. ${ }^{116}$ In de Wet bodembescherming is in het licht van de gestelde vraag sprake van een dergelijke systematiek.

De eerste via de formele wetssystematiek kenbaar gemaakte materiële systematiek die opvalt is dat de Wet bodembescherming bestaat uit 11 hoofdstukken. ${ }^{117}$ Deze systematiek geeft de gebruiker op zichzelf reeds enig houvast ten aanzien van wat hij aan regels in elk hoofdstuk mag verwachten. Wie regels zoekt over verontreiniging van de bodem, zal ook zonder juridische voorkennis - waarschijnlijk hoofdstuk IV Algemene bepalingen in geval van verontreiniging van de bodem opslaan. Wie een antwoord zoekt op de vraag hoe hij de bodem mag of moet saneren, zal op basis van de hoofdstukindeling wellicht niet meteen naar dit hoofdstuk gaan, maar waarschijnlijk in elk geval niet naar hoofdstuk VIII Beroep op de administratieve rechter.

115 Zie ook Van den Broek, T\&C Wet bodembescherming 2012. Op 12 juli 2011, het moment waarop ik par. 3.2.5.3 schreef, waren de op dat moment geldende artikelen van de Wet bodembescherming genummerd 1 tot en met 106. In de genoemde 117 artikelen zijn niet meegerekend de artikelen 100-104, die wijzigingen bevatten in andere regelgeving. Van de overige artikelen zijn er 16 vervallen. Voorts zijn er 32 artikelen toegevoegd met een letteraanduiding, zoals art. 2a.

116 Neem bijvoorbeeld een gebruiker die op basis van de Awb zou willen weten of en zo ja hoeveel reiskosten hij vergoed krijgt als hij als getuige moet verschijnen voor een zitting bij de bestuursrechter. Het antwoord op die vraag staat in art. 8:36 Awb.

117 I Algemeen, II Technische commissie bodembescherming, III Algemene bepalingen ter bescherming van de bodem, IV Algemene bepalingen in geval van verontreiniging van de bodem, V Vrijstelling en ontheffing, VI Onderzoek in het belang van de bescherming van de bodem, VII Financiële bepalingen, VIII Beroep op de administratieve rechter, IX Verdere bepalingen, $\mathrm{X}$ Handhaving en XI Overgangs- en slotbepalingen. 
Genoemde gebruiker wordt waarschijnlijk wel goed bediend doordat binnen elk hoofdstuk weer is gekozen voor een zekere systematiek. Zo kent hoofdstuk IV een paragraaf 1 Algemeen, paragraaf 2 Bevoegdheden bij ernstige verontreiniging of aantasting van de bodem ten gevolge van een ongewoon voorval, paragraaf 3 Sanering, paragraaf 3a Bijzondere bepalingen inzake sanering van bedrijfsterreinen, paragraaf 4 Verplichte aankoop door gemeenten bij ernstige verontreiniging en paragraaf 5 Bijzondere regels inzake sanering van de waterbodem. Het ligt voor de hand dat degene die een antwoord zoekt op de vraag hoe hij een bodemsanering moet uitvoeren gaat lezen in paragraaf 3. Dat antwoord zal hij, zoals eerder opgemerkt, vinden in artikel 38 van die paragraaf.

Bij dit alles dienen wij ons te realiseren dat de desbetreffende gebruiker om bij paragraaf 3 uit te komen nog geen enkel wetsartikel heeft hoeven te lezen. Hij heeft 'slechts' de opschriften van de hoofdstukken en de daaronder ressorterende paragrafen behoeven te lezen. Daaruit valt af te leiden dat een goed vormgegeven wetssysteem als zodanig reeds van essentieel belang is voor de kenbaarheid van het systeem. Dat is in het geschetste voorbeeld mede te danken aan de formele wetssystematiek, ${ }^{118}$ maar zeker ook door de materiële wetssystematiek die ertoe heeft geleid dat de onderling samenhangende regels inzake sanering van de bodem zijn opgenomen in het subwetssysteem van paragraaf 3 van hoofdstuk IV van de Wet bodembescherming.

\subsubsection{De echte werkelijkheid}

\subsubsection{Algemeen}

Zoekend naar een antwoord op de vraag welke samenhangcriteria voor een wetssysteem wetenschappelijk verdedigbaar zijn, heb ik hiervoor aangegeven dat de belangrijkste functie van een wetssysteem - los van de inhoud van de daarvan deel uitmakende regels - de kenbaarheid van het recht betreft. Dat geldt ook voor het omgevingsrecht. Omwille van de kenbaarheid is het daarbij van belang dat een wetssysteem probleemgeoriënteerd is vormgegeven. Daaruit volgt mijns inziens dat de wetgever moet kiezen voor samenhangcriteria die waar mogelijk recht doen aan deze kenbaarheid en probleemgeoriënteerdheid. Dit uitgangspunt wordt naar mijn overtuiging nog versterkt door het in Nederland geldende postulaat dat ieder wordt geacht de wet te kennen. Dat betekent vanzelfsprekend niet dat juristen veronderstellen dat rechtssubjecten 
'de' wet ook daadwerkelijk kennen, maar dat rechtssubjecten zich niet op onbekendheid daarmee kunnen beroepen. ${ }^{119}$

Het kennen van alle wetten is alleen al vanwege hun omvang onbegonnen werk. Zo meldt Jurofoon ${ }^{120}$ dat er volgens onderzoek van het Nederlands Juristenblad op 1 december 2003138.764 wettelijke bepalingen in Nederland van kracht waren: 1.790 wetten (46.472 wetsartikelen), 2680 algemene maatregelen van bestuur (35.695 artikelen) en 7.664 ministeriële regelingen (56.597 artikelen). Een wet telde in 2003 gemiddeld 26 bepalingen, een algemene maatregel van bestuur 13 en een ministeriële regeling ruim 7. Daarnaast bestaan er nog beleidsregels, internationale verdragen, Europese regels, regels van zelfstandige bestuursorganen, waterschappen, gemeenten en provincies. Volgens Veerman stonden in 2004 in de wettenbank van de Sdu ongeveer 1750 wetten, 2750 algemene maatregelen van bestuur en 7800 ministeriële regelingen. In totaal 12.300 regelingen die samen 140.000 artikelen telden. ${ }^{121}$

Op 23 mei 2002 telde ik op www.overheid.nl 1598 wetten in formele zin. Op 23 mei 2012 was dat aantal opgelopen tot 1878 wetten in formele zin, 2287 algemene maatregelen van bestuur en andere koninklijke besluiten, alsmede 5471 ministeriële regelingen.

Deze juridische fictie brengt naar mijn oordeel echter wel met zich dat van de wetgever mag worden verwacht dat hij zich alle mogelijke moeite zal getroosten om wetssystemen op het gebied van het omgevingsrecht zodanig in te richten dat het voor gebruikers van het omgevingsrecht niet onnodig moeilijk wordt gemaakt om de voor hen relevante wetssystemen te kunnen kennen. Een op de juiste wijze vormgegeven wetssysteem zou daaraan een belangrijke bijdrage kunnen leveren.

Lokin meent terecht dat de wetgever het aan zijn stand verplicht is om de fictie dat de burger nog steeds wordt geacht de wet te kennen dichter bij de werkelijkheid te brengen. ${ }^{122}$ In dit verband is ook interessant Witteveen waar hij schrijft dat in de utopische traditie een ideaalbeeld van de wetgeving van Utopia ontstond, waartoe behoorde een volmaakte wetskennis bij iedereen die van de gemeenschap deel uitmaakt. Hij citeert onder meer Thomas Mores Utopia: 'Dit keuren zij dan ook in de eerste plaats bij andere volken af, dat daar ontelbare boekdelen met wetten en uitleggingen nog niet voldoende zijn. Zelf

119 Zie Drupsteen, Interview 2012, bijl. 5.8, par. 2.3. Zie ook Voermans, Het ontwerpen van wetten en systeemontwikkeling 1998: 'De realiteit in een complexe samenleving als de onze is dat al lang niet meer iedereen alle relevante wettelijke regelingen kan kennen.' Van Gestel schrijft dat het om een juridische fictie gaat en niet om een opdracht aan de burger om wetteksten van buiten te leren of om anderszins actief informatie over bestaande regelgeving in te winnen. De fictie beoogt volgens Van Gestel tot uitdrukking te brengen dat 'je als burger van het bestaan van wettelijke regels moet kunnen weten en kennis van de inhoud dient te kunnen nemen, alvorens je eraan gehouden mag worden.' (Van Gestel, Eenieder wordt geacht de wet te kennen 1998, p. 78)

120 www.jurofoon.nl/jurofoonjournaal/200401/wetten_en_regels.asp.

121 Veerman, De wet als zinsbegoochelingstoestel 2004, p. 9.

122 Lokin, Het op orde houden van het wettenbestand 2005, p. 156 
achten zij het echter in hoge mate onbillijk iemand, wie ook maar, te binden aan zulke wetten, die of te talrijk zijn, dan dat men ze zou kunnen doorlezen, of te duister, dan dat een willekeurig mens ze zou kunnen begrijpen. ${ }^{123}$ Ook Van Gestel begint zijn rede Wetgeven is vooruitzien met een verwijzing naar Utopia, Interessanter voor mijn onderzoek is echter dat Van Gestel meent dat op de wetgever de plicht rust om wettelijke regels zoveel mogelijk zo in te richten dat ze voldoende duidelijk, kenbaar en voorzienbaar zijn om te voorkomen dat er reeds op wetsniveau strijd met het rechtszekerheidsbeginsel ontstaat. ${ }^{124}$

Mij lijkt dat een wetssysteem op het gebied van het omgevingsrecht aan kenbaarheid zal winnen naarmate het beter aansluit bij de samenhangen en de problemen die door gebruikers reeds als werkelijkheid worden ervaren. Het gaat dan bijvoorbeeld om de samenhang 'bouwen van een fabriek' of om het probleem 'welke vergunningen heb ik nodig voor het bouwen van een fabriek?' Omwille van de kenbaarheid en de probleemgeoriënteerdheid moet de wetgever de samenhang in een wetssysteem daarom bij voorkeur niet zoeken in de door hemzelf geschapen wereld van het (omgevings)recht, maar juist in de werkelijkheid, zoals die door de gebruikers van wetssystemen wordt ervaren. Ik noem dat de echte werkelijkheid, de werkelijke wereld, the real world. ${ }^{125}$ Op wie van oordeel is dat er slechts één werkelijkheid bestaat, zal 'de echte werkelijkheid' wellicht overkomen als een pleonasme. Toch gebruik ik dit begrip om duidelijk aan te geven dat er een verschil bestaat tussen de (echte) werkelijkheid zoals die door gebruikers van wetssystemen wordt ervaren en de (juridische) werkelijkheid die door wetgevingsjuristen in wetteksten wordt geschapen. Die juridische werkelijkheid is tot op zekere hoogte evenmin te vermijden als formules in de wiskunde, maar heeft wel gevolgen voor de kenbaarheid van een wetssysteem.

Het risico dat een wetssysteem aan kenbaarheid en probleemgeoriënteerdheid inboet neemt toe in de mate dat de wetgever datgene wat in de werkelijkheid samenhangt niet samenhangend heeft geregeld.

Noll noemt in dit verband het voorbeeld van de wetgever die de samenhang zoekt in het criterium 'straf' en vervolgens het Wetboek van Strafrecht niet systematiseert volgens delictsomschrijvingen maar volgens de verschillende strafbedreigingen. Een voorbeeld zou dan zijn: 'Met levenslange gevangenisstraf wordt gestraft hij die a) een moord pleegt, b) volkerenmoord pleegt etcetera.' Op die manier zou de systematiek, 'ins Extrem geführt, einem Telefonbuch gleichen, das nicht nach den Namen der Inhaber von Telefonanschlüssen und ihre alphabetischen Reihenfolge geordnet wäre, sondern nach der arithmetischen Reihenfolge der Telefonnummern. ${ }^{126}$ Bij deze voorbeelden past wel de relativering, dat

123 Witteveen, Utopia en de volmaakte wetskennis 2004, p. 191 en 193.

124 Van Gestel, Wetgeven is vooruitzien, 2008, p. 2 en 30.

125 Zie Explanatory Memorandum bij Richtlijn 96/61/EEG van de Raad van 24 september 1996 inzake geïntegreerde preventie en bestrijding van verontreiniging, (PbEG 1996 L 257/26).

126 Noll, Gesetzgebungslehre 1973, p. 223. 
dergelijke samenhangcriteria wel nuttig kunnen blijken voor degene die wil weten op welke strafbare feiten levenslange gevangenisstraf staat of degene die een telefoonnummer heeft en de daarbij behorende naam zoekt. Inmiddels zijn er ook digitale telefoonboeken op de markt die het mogelijk maken om bij een telefoonnummer een naam en adres te zoeken. ${ }^{127}$

Deze voorbeelden illustreren dat een (wets)systeem voor bepaalde gebruikers aan kenbaarheid inboet (voorbeeld van het strafrecht) of zelfs praktisch geheel onbruikbaar wordt (voorbeeld van het telefoonboek als men tenminste op naam zoekt) als wordt gekozen voor een samenhangcriterium dat niet aansluit bij de door gebruikers van het wetssysteem ervaren in de werkelijkheid bestaande samenhang(en). Deze voorbeelden geven en passant ook aan dat niet elke politieke - keus voor een samenhangcriterium op goede gronden verdedigbaar is. $^{128}$

In het kader van de door mij gehouden interviews heb ik het punt van de kenbaarheid en de echte werkelijkheid uitdrukkelijk aan de orde gesteld.

Een deel van de geïnterviewden is gecharmeerd van het idee om de kenbaarheid van een wetssysteem te vergroten door samenhang te zoeken in de echte werkelijkheid. Woldendorp vraagt zich af "of de wetgever wel een eenvoudige en voor iedereen kenbare wet wil en moet willen”, maar hij is het met mij eens dat de wetgever de wetgeving zou moeten maken "voor de werkelijkheid van de mensen waarvoor de wetgeving is bedoeld. En niet zoals vroeger, toen de wetten in elkaar zaten overeenkomstig de organisatie van de ministeries. Dat is niet het goede uitgangspunt." Aan de hand van een aantal praktijkvoorbeelden - mestboekhouding (MINAS), $\mathrm{CO}_{2}$ - en $\mathrm{NO}_{\mathrm{x}}$-emissiehandel en natuurwetgeving - geeft hij vervolgens aan, dat het uitgangspunt van kenbaarheid en eenvoud in de wetgevingspraktijk soms sneuvelt om tegemoet te komen aan in de maatschappij levende wensen, die daar vaak haaks op staan. $^{129}$ Rademaker is er "heilig van overtuigd dat de wetgever moet aansluiten bij de echte werkelijkheid van burgers en bedrijven." ${ }^{\text {"130 }} \mathrm{Hij}$ zegt dit in het licht van de Wabo, waar de werkelijkheid voor burgers en bedrijven is dat zij iets op een bepaalde plaats willen realiseren en gebruiken. In het kader van de Omgevingswet stellen Molenaars en De Vos dat zij bij het vormgeven van de Omgevingswet wel bezig zijn met het zoeken van een betere aansluiting bij de echte werkelijkheid van burgers en ondernemers. Daarbij is

127 Zoals www.zoekopnummer.nl/.

128 Dat het probleem van het gebrek aan kenbaarheid van het omgevingsrecht overigens niet veel vaker wordt gesignaleerd - en geattaqueerd - is misschien voor een belangrijk deel het gevolg van het feit dat degenen die zich bezig houden met het omgevingsrecht daarin veelal goed zijn ingevoerd en de juridische werkelijkheid ook als een eigen werkelijkheid, misschien wel als de echte werkelijkheid, zijn gaan ervaren. Om een vergelijking te maken. Wie nooit moeite heeft gehad met de uitgang van een voltooid deelwoord in het Nederlands zal niet snel een noodzaak gevoelen in te stemmen met een vereenvoudiging van deze voor veel mensen lastige taalregel.

129 Woldendorp, Interview 2011, bijl. 5.1, par. 3.1.

130 Rademaker, Interview 2011, bijl. 5.2, par. 3.3. 
de vraag gesteld of moet worden uitgegaan van het begrip inrichting, dan wel van activiteiten waarmee iemand daadwerkelijk bezig is. De Vos zegt: "We zijn nadrukkelijk op zoek naar terminologie en aangrijpingspunt voor de normstelling om beter aan te sluiten bij de fysieke wereld en wie zich daarin bezighouden." ${ }^{131}$

Een ander deel van de geïnterviewden lijkt niet tegen het zoeken van samenhang in de echte werkelijkheid, maar operationaliseert dat niet. Voor Borman lijkt de kenbaarheid voor burgers en bedrijven geen prioriteit te hebben: "Wetgeving blijft natuurlijk een juridisch document, dat niet kan worden opgesteld in Jip-en-Janneketaal." "De geadresseerde is wel vaak een burger of bedrijf, maar het gaat om juridische documenten. Die worden eerder geschreven voor de rechter dan voor de burger." ${ }^{32}$ Voermans sluit aan bij dit van binnen naar buiten-denken ${ }^{133}$ waar hij zegt dat de wetgevingsjurist de kenbaarheid eerder zoekt voor juridische gebruikers. Het gaat immers om wetgeving. ${ }^{134}$ Drupsteen ten slotte meent dat kenbaarheid en voorspelbaarheid voor burgers en ondernemers niet de eerste insteek zal zijn van een wetgevingsjurist. Er wordt volgens hem niet geredeneerd vanuit de gedachte dat wetssystemen voor iedereen leesbaar moeten zijn. ${ }^{135}$

Zoals ik hiervoor al heb gemotiveerd, moet de (omgevings)wetgever de samenhang in een wetssysteem niet zoeken in de wereld van het recht, maar juist in de werkelijke wereld. Mijn oordeel dienaangaande wordt gedeeld door een deel van de geïnterviewden. Voor dat oordeel valt eveneens steun te vinden in de Aanwijzingen voor de regelgeving, literatuur, beleidsstukken en (toelichting op) wetgeving. Dat zal ik hierna toelichten.

\subsubsection{Aanwijzingen voor de regelgeving}

De Aanwijzingen voor de regelgeving ${ }^{136}$ hebben betrekking op regelingen die onder ministeriële verantwoordelijkheid tot stand komen en, voor zover uitdrukkelijk aangegeven, op verdragen, bindende besluiten van instellingen van de Europese Unie en andere besluiten van volkenrechtelijke organisaties. ${ }^{137}$ Aanwijzing 54 bepaalt dat het normale spraakgebruik zoveel mogelijk moet worden gevolgd en dat geen woorden worden gebruikt waarvan de betekenis te weinig bepaald of onduidelijk is. Aanwijzing 121 bepaalt dat termen die een te weinig bepaalde of een van het spraakgebruik afwijkende

131 Molenaars en De Vos, Interview 2012, bijl. 5.6 en 5.7, par. 2.1.

132 Borman, Interview 2012, bijl. 5.3, par. 3.2.

133 Zie hierover ook par. 3.2.6.3.

134 Voermans, Interview 2012, bijl. 5.5, p.2.1.

135 Drupsteen, Interview 2012, bijl. 5.8, p. 2.1

136 Circulaire van de Minister-President van 18 november 1992, Stcrt. 1992, 230. Deze circulaire is sindsdien een aantal malen gewijzigd. Ik gebruik de tekst van 2 maart 2012, wetten.overheid.nl/ BWBR0005730/geldigheidsdatum_02-03-2012.

137 Zie Aanwijzing 1. 
betekenis hebben, worden gedefinieerd. In een begripsbepaling mag aan een term geen sterk van het normale spraakgebruik afwijkende betekenis worden gegeven. De toelichting op Aanwijzing 121 vermeldt dat op zichzelf duidelijke termen uit juridisch oogpunt soms nadere definiëring zullen behoeven, bijvoorbeeld ambtenaar en bouwen. Het is volgens genoemde toelichting aanvaardbaar om in een begripsbepaling onder landbouw mede te verstaan tuinbouw, maar onjuist is het om daaronder ook visserij te begrijpen.

Toch lijkt de wetgever nog wel tegen deze regel te zondigen. Zo bepaalt art. 1 Wbb onder meer dat onder bodem wordt verstaan het vaste deel van de aarde met de zich daarin bevindende vloeibare en gasvormige bestanddelen en organismen. Het is echter de vraag of in het normale spraakgebruik ook grondwater en organismen onder bodem worden begrepen. In art. $1 \mathrm{Ffw}$ wordt onder grond mede verstaan: wateren. Ook worden onder 'veld' onder meer mede verstaan 'stranden', 'wadden', 'binnenwateren en territoriale wateren' en 'wegen en paden'. Mij lijkt dat een gebruiker gewoonlijk niet deze uitleg zal geven aan de begrippen grond en veld.

Bedoelde aanwijzingen ondersteunen mijn oordeel dat de wetgever de samenhang in een wetssysteem vanwege de kenbaarheid daarvan moet zoeken in de echte werkelijkheid. Juist van het normale spraakgebruik mag immers worden verwacht dat het de door gebruikers van het (omgevings)recht ervaren echte werkelijkheid en de door hen in die werkelijkheid ervaren samenhang weerspiegelt.

Een voorbeeld moge zulks verduidelijken. De ondernemer die een fabriek exploiteert zal in de Wabo niet gemakkelijk zijn uit die wet voorvloeiende rechten en verplichtingen kunnen kennen. Dat heeft voor een deel te maken met het feit, dat die wet zijn fabriek aanduidt met de 'inrichting' en hem aanduidt met de 'vergunninghouder.'138 Beide termen wijken af van die in het gewone spraakgebruik. De ondernemer heeft dus juridische voorkennis nodig om zijn rechten en verplichtingen in de Wabo te kunnen kennen. De kenbaarheid voor de ondernemer zou worden vergroot als de wetgever zou hebben aangesloten bij het spraakgebruik en termen als onderneming of fabriek, en ondernemer of exploitant zou hebben gebezigd.

De wetgever neemt regelmatig zijn toevlucht tot een uitleg in de toelichting op de relevante wettelijke regeling. Mij lijkt dat gewoonlijk geen acceptabele weg. In de eerste plaats dient een gebruiker van het recht zijn rechten en verplichtingen waar mogelijk uit de wettekst zelf te kunnen kennen. In de tweede plaats mag de wetgever er toch niet op vertrouwen dat een gebruiker de - vaak zeer uitgebreide - toelichting op een wettelijke regeling van A tot Z leest om erachter te komen of de wetgever ook werkelijk bedoelt wat hij heeft opgeschreven in de wettekst. In de derde plaats is niet zonder meer duidelijk 
of hetgeen in de toelichting op een wettelijke regeling is opgenomen ook het oordeel van 'de wetgever' is. Daarop dient men met name bedacht te zijn bij wetten in formele zin. De wetsgeschiedenis die dient ter toelichting op een dergelijk wetgevingsproduct bestaat gewoonlijk immers uit een memorie van toelichting van de regering, een of meer verslagen van Tweede en Eerste Kamer, een of meer nota's naar aanleiding van die verslagen van de regering en de mondelinge behandeling. Er bestaat geen zekerheid dat de meerderheid van het parlement die een wet in formele zin vaststelt het daarmee ook eens is met al hetgeen ter toelichting in genoemde stukken is opgenomen. Zo is het niet ondenkbeeldig dat een voorstemmer het wellicht niet eens is met een bepaalde uitleg van een onderdeel van de wet door de regering maar om politieke redenen toch voor het wetsvoorstel als geheel stemt.

\subsubsection{Literatuur}

Ook in de juridische literatuur valt steun te vinden voor mijn oordeel dat de wetgever de samenhang in een wetssysteem vanwege de kenbaarheid daarvan moet zoeken in de echte werkelijkheid. Uitgesproken is Biezeveld die evenals ikzelf - uitgaat van de idee 'dat de meest logische inrichting van wetgeving en beleid die is welke het beste aansluit bij in de werkelijkheid te herkennen systemen die om beheer vragen.' Hij meent dat de effectiviteit en efficiëntie van wetgeving groter zullen zijn naarmate wetgeving en beleid meer aan deze eis voldoen. Volgens Biezeveld schuilt het grote belang van integratie-activiteiten in het stapje voor stapje steeds beter benaderen van de werkelijkheid. Daarbij moet heel zorgvuldig te werk worden gegaan. 'Als niet geprobeerd wordt zo goed mogelijk aansluiting te zoeken bij in de werkelijkheid aanwezige of ervaren verbanden en patronen, zal de meerwaarde ervan gering blijken te zijn of zal zelfs verlies kunnen optreden.'139 Biezeveld zoekt de oorzaak van de structurele tekortkomingen in het milieurecht in het feit dat de wetgever bij het maken van de verschillende wetten en bij de opbouw van het stelsel als geheel - in de woorden van Geelhoed ${ }^{140}-$ te weinig 'van buiten naar binnen' heeft gekeken in die zin dat de wetgever te weinig aansluiting heeft gezocht bij relevante vormen van samenhang die zich in het milieu of de maatschappij manifesteren. Leidend daarentegen waren veeleer overwegingen van intern belang binnen de overheid, meer in het bijzonder van het betrokken departement. Biezeveld noemt in dit verband ook Tjeenk Willink die constateerde dat burgers nogal eens stuiten op een verbrokkelde en vaak tegenstrijdige overheidsorganisatie, die geen rekening houdt met de samenhangen die zij in hun dagelijks leven ondervinden. ${ }^{141}$

139 Biezeveld, Omgaan met samenhang bij integratie van milieuwetgeving en waterwetgeving 1990, p. 239. Hij illustreert het risico van verlies aan de hand van de lozingsvergunning voor inrichtingen. De plaats van de wettelijke regeling is bepalend voor de beslissingsgrondslag en de reikwijdte van die vergunning.

140 Geelhoed, Wetgeving en bestuur in de semi-soevereine rechtstaat 1996, p. 11.

141 Tjeenk Willink, De mythe van het samenhangend overheidsbeleid 1984, p. 16 
Hoewel Biezeveld deze woorden niet gebruikt, leid ik uit zijn betoog af dat ook hij van oordeel is dat in elk geval het milieurecht zou moeten aansluiten bij de echte werkelijkheid. ${ }^{142}$

Noll stelt: 'Wer in einem bestimmten, durch äußere Merkmale gekennzeichneten Sozialbezug steht, etwa im Straßenverkehr, und sein Verhalten normgemäß einrichten wird, wird eben unter dem Stichwort Straßenverkehr oder einem verwandten Begriff aus dem gegebenen Sachkomplex die für ihn geltenden gesetzlichen Normen suchen.' ${ }^{143}$

Daarbij sluit mijns inziens aan het door Visser genoemde beginsel van duidelijke terminologie en duidelijke systematiek, één van de materiële beginselen van behoorlijke regelgeving. ${ }^{144}$ Ingevolge het beginsel van duidelijke terminologie en systematiek ${ }^{145}$ dienen regels volgens Visser begrijpelijk en helder te zijn, zowel voor wat betreft de gebruikte termen als voor wat betreft de structuur. Niet alleen vage termen, maar ook bijvoorbeeld zeer gecompliceerde zinsconstructies, gebrek aan eenheid in terminologie, ondoorzichtige gelede normstellingen en onduidelijke rubriceringen dienen te worden vermeden. Volgens Visser worden hierdoor de rechtszekerheid en rechtsgelijkheid gediend.

Ook Backes lijkt wetssystematische samenhang te zoeken in de echte werkelijkheid waar hij pleit voor een 'werkelijk integraal stelsel van omgevingsrecht.' Een robuust Natura 2000-netwerk 'kan volgens hem niet worden gerealiseerd zonder ruimtelijke ordening, milieu- en waterbeleid, een goede waterkwaliteit kan niet worden nagestreefd zonder afstemming met het natuur- en milieubeleid en de ruimtelijke ordening. Een integrale benadering van het omgevingsrecht is dus om inhoudelijke redenen aangeraden. Bovendien heeft de burger, niet alleen de ondernemende burger, een bepaalde vraag of een wens die doorgaans niet is beperkt tot een bepaalde sector. $^{146}$

Volgens Scheltema leidt de legaliteitseis tot een benadering waarin het normaal is om sterk vanuit individuele bevoegdheden van de overheid te denken, zonder rekening te houden met de verbanden die er voor de burger bestaan. De overheid wordt ten opzichte van de burger in partjes gedeeld, terwijl de burger die overheid als één geheel ziet. De burger moet de partjes die de overheid eerst gemaakt heeft, weer aan elkaar zetten. ${ }^{147}$

\footnotetext{
42 Biezeveld, Duurzame milieuwetgeving 2002, p. 27.

143 Noll, Gesetzgebungslehre 1973, p. 211.

144 Visser, Zorgplichtbepalingen in het strafrecht (diss.) 2001, p. 77.

145 Visser geeft niet aan wat nu precies onder een duidelijke terminologie en systematiek dient te worden begrepen.

146 Backes, Naar een integrale omgevingswet? 2010, p. 15.

147 Scheltema, Van rechtsbescherming naar een volwaardig bestuursrecht 1996, p. 1355 e.v.
} 


\subsubsection{Beleidsstukken}

Een aantal beleidsstukken lijkt eveneens ervan uit te gaan dat de wetgever de samenhang in een wetssysteem vanwege de kenbaarheid daarvan moet zoeken in de echte werkelijkheid.

De nota Zicht op wetgeving ${ }^{148}$ van het voormalige Ministerie van Justitie formuleert zes kwaliteitseisen ${ }^{149}$ voor het overheidsoptreden, waaronder de kwaliteitseis van 'onderlinge afstemming'. Als de onderlinge afstemming van regels binnen een rechtsstelsel tekort schiet, ontstaan er volgens de nota inconsistenties en onnodige fricties bij lagere regelgevers, uitvoerders, handhavers, de consument en de rechter. Onderlinge afstemming is volgens de nota onder meer noodzakelijk wanneer regelingen weliswaar een verschillend onderwerp betreffen, maar door hun effecten sterk op elkaar inwerken. Dat kan bijvoorbeeld het geval zijn doordat ze vanuit een verschillende invalshoek aan een en dezelfde gedraging van de burger eisen stellen, die soms haaks op elkaar staan. Dan zal door het gebrek aan onderlinge samenhang niet zelden de werking van de ene of de andere wet of van allebei, geheel of gedeeltelijk worden gefrustreerd. Dit kan volgens de nota in beginsel worden verholpen door coördinatie of integratie van regelgeving of bestuurlijk optreden. ${ }^{150}$ De nota kiest dus niet alleen voor onderlinge samenhang van regels, maar lijkt die samenhang ook te zoeken in een en dezelfde gedraging van burgers in de echte werkelijkheid.

Ten tijde van de Herijkingsbrief ${ }^{41}$ van het voormalige Ministerie van VROM reguleerde de wetgever activiteiten van onder meer burgers en bedrijven, zoals het bouwen van een fabriek, het oprichten van een inrichting, het slopen van een woning of het kappen van een boom elk in afzonderlijke wetssystemen. ${ }^{152}$ Die activiteiten waren opgeknipt zonder rekening te houden met de samenhang die er voor de burger of het bedrijf bestaan. Volgens de Herijkingsbrief heeft een ondernemer, die op een bepaalde plaats iets wil gaan (ver)bouwen, oprichten of aanleggen en dat

148 Ministerie van Justitie, Zicht op wetgeving 1990.

149 Deze eisen zijn: rechtmatigheid en verwerkelijking van rechtsbeginselen, doeltreffendheid en doelmatigheid, subsidiariteit en evenredigheid, uitvoerbaarheid en handhaafbaarheid, onderlinge afstemming, alsmede eenvoud, duidelijkheid en toegankelijkheid. Deze eisen zijn steeds op ten minste twee niveaus van belang. Eerst voor de vraag of wetgeving wel noodzakelijk is en vervolgens bij het bepalen van de inhoud van de eventuele wet. Ten slotte zijn de kwaliteitseisen eveneens van belang bij het achteraf evalueren van de wet.

150 Ministerie van Justitie, Zicht op wetgeving 1991, p. 29

151 Ministerie van VROM, Herijkingsbrief 2003. Zie onder meer par. 1.2 van dit onderzoek.

152 Het betrof een bouwvergunning op basis van de Wonw, een milieuvergunning op basis van de Wm, een sloopvergunning op basis van de gemeentelijke Bouwverordening en een kapvergunning op basis van de gemeentelijke Algemene Plaatselijke Verordening of Kapverordening. Dat had tot gevolg dat voor elk van die activiteiten gewoonlijk een vergunning was vereist, die was gebaseerd op dat afzonderlijke wetssysteem. Elk wetssysteem bevatte regels over bijvoorbeeld de aanvraag, het bevoegd gezag, de toetsingsgronden en de rechtsbescherming. 
vervolgens in gebruik wil nemen voor de uitoefening van een bepaalde activiteit, een tamelijk eenvoudige vraag aan de overheid: 'Mag dat?' Idealiter zou het daarop snel en zonder al te veel bureaucratische rompslomp en kosten een helder antwoord krijgen: 'Ja', 'Nee' of 'Ja, mits'. ${ }^{153}$ In wezen geeft de Herijkingsbrief aan dat het omgevingsrecht niet aansluit bij de echte werkelijkheid van een ondernemer of burger die op een bepaalde plaats bepaalde activiteiten wil ontplooien. Het is dan ook niet verwonderlijk dat in twee in de Herijkingsbrief aangekondigde wetssystemen, te weten het Activiteitenbesluit ${ }^{154}$ en de Wabo ${ }^{155}$ is aangesloten bij de echte werkelijkheid van respectievelijk activiteiten en projecten. Het Activiteitenbesluit bevat milieuregels voor inrichtingen waarin bepaalde activiteiten worden ontplooid, zoals lassen, ${ }^{156} \operatorname{lozen}^{157}$ en solderen, ${ }^{158}$ activiteiten die de exploitant van een inrichting waarin activiteiten met betrekking tot metalen plaatsvinden zonder juridische vooropleiding aanstonds zal herkennen. De Wabo bevat regels over een plaatsgebonden project dat bestaat uit één of meer activiteiten die van invloed zijn op de fysieke leefomgeving. ${ }^{159}$ Ook hier gaat het om activiteiten die voor burgers en ondernemers gewoonlijk zonder juridische vooropleiding duidelijk zullen zijn, zoals bouwen, ${ }^{160}$ vellen van een houtopstand ${ }^{161}$ of het maken van handelsreclame. ${ }^{162}$ Daarmee heeft de wetgever de samenhang die bestaat in de echte werkelijkheid van een project voor burgers en ondernemers beter ${ }^{163}$ in overeenstemming gebracht met de juridische werkelijkheid.

153 Ministerie van VROM, Herijkingsbrief 2003, p. 11.

154 Zie par. 1.2 en 1.3.2

155 Stb. 2008, 496

156 Art. 4.39 lid 1 Activiteitenbesluit bepaalt: Het is verboden om in de buitenlucht laswerkzaamheden te verrichten. De term laswerkzaamheden is niet gedefinieerd. Dat is wel het geval bij 'lassen van textiel': het door middel van warmteopwekking of warmtetoevoer aaneenhechten van textiel (art. 1.1 lid 1 Activiteitenbesluit).

157 Art. 1.1 lid 1 Activiteitenbesluit: lozen: het brengen van: $1^{\circ}$. afvalwater of andere afvalstoffen, verontreinigende of schadelijke stoffen in een oppervlaktewaterlichaam; $2^{\circ}$. afvalwater of overige vloeistoffen op of in de bodem; $3^{\circ}$. afvalwater of andere afvalstoffen in een openbaar hemelwaterstelsel; $4^{\circ}$. afvalwater of andere afvalstoffen in een openbaar ontwateringstelsel; $5^{\circ}$. afvalwater of andere afvalstoffen in een openbaar vuilwaterriool; $6^{\circ}$. afvalwater of andere afvalstoffen in een andere voorziening voor de inzameling en het transport van afvalwater, of $7^{\circ}$. afvalwater of andere afvalstoffen met behulp van een werk niet zijnde een voorziening voor de inzameling en het transport van afvalwater op een zuiveringtechnisch werk.

158 De term 'solderen' wordt gebruikt in de art. 4.44-4.48 Activiteitenbesluit, maar is in het Activiteitenbesluit niet gedefinieerd.

159 Zie onder meer art. 2.1 en 2.2 Wabo. Zie verder par. 4.3.3 van dit onderzoek.

160 Onder bouwen verstaat de Wabo bouwen als bedoeld in artikel 1 van de Woningwet: het plaatsen, het geheel of gedeeltelijk oprichten, vernieuwen of veranderen en het vergroten van een bouwwerk (art. 1.1 lid 1 Wabo).

161 Art. 2.2 lid 1 aanhef en onder g Wabo.

162 Art. 2.2 lid 1 anhef en onder i Wabo.

163 Een aantal vergunningen, zoals de exploitatievergunning en de terrasvergunning, maakt geen deel uit van de omgevingsvergunning. 
In het rapport Ruimte voor leven wordt onder meer gesteld, dat de afgelopen decennia door verschillende oorzaken een complex en kostbaar bouwwerk van regels is ontstaan om een duurzaam gebruik van de schaarse ruimte in Nederland in goede banen te leiden. Onder meer door de Europeanisering van belangrijke delen van het beleid voor de fysieke leefomgeving, is een situatie gegroeid, waarin het nationale gefragmenteerde stelsel van het omgevingsrecht niet langer is aangepast aan de eisen van de $21^{\mathrm{e}}$ eeuw. (...) Verdere verfijningen en aanvullende instrumenten om een betere aansluiting op de praktijk te bereiken, zoals in het verleden steeds is gezocht, bieden nauwelijks nog een oplossing en beginnen steeds meer onderdeel van het probleem te worden. De werkgroep komt tot de conclusie dat een redesign van het omgevingsrecht nodig is. ${ }^{164}$

In het voorwoord bij de bundeling van essays over de toekomst van het omgevingsrecht wordt gesteld dat er behoefte bestaat aan een eenduidig, overzichtelijk en samenhangend stelsel van regels. ${ }^{165}$ De opdracht luidt onder meer om de contouren te ontwerpen van een realistisch stelsel van omgevingsrecht dat recht doet aan de wens in de maatschappij om de inrichting van de fysieke leefomgeving op een snellere, doorzichtigere en eenvoudigere wijze aan de maatschappelijk gewenste kwaliteit van de fysieke leefomgeving te kunnen aanpassen. In de opdracht zijn enige aanwijzingen te vinden voor het feit dat het ministerie bij de inrichting van het stelsel van omgevingsrecht zoekt naar wat in de werkelijkheid samenhangt. De aandacht van de essayisten wordt namelijk gevraagd voor een aantal uitgangspunten of inrichtingsprincipes. Een van die inrichtingsprincipes is: gebiedsgericht (integraal) versus sectoraal. Gevraagd wordt wat het vertrekpunt zou moeten zijn: de ruimte of het project waar alles samenkomt (het optimale integrale resultaat) of het samenstel van alle deelbelangen (waarbij elke sector ten minste de minimale norm haalt). De ruimte of het project zijn samenhangen die zich in de werkelijkheid voordoen. Het lijkt er dus op dat het ministerie voor wat betreft de gewenste samenhang wenst aan te sluiten bij de echte werkelijkheid. ${ }^{166}$

In de beleidsbrief Eenvoudig Beter kondigt de minister van IenM een nieuwe Omgevingswet aan. De minister schrijft dat burgers, ondernemers en overheden worstelen met de steeds complexer wordende samenhang tussen de verschillende wettelijke kaders. Die complexiteit leidt tot onduidelijkheid en onzekerheid rond voorgenomen ruimtelijke projecten als de aanleg van (spoor)wegen, stedelijke herstructurering, plattelandsontwikkeling, waterveiligheid, energietransitie en natuurprojecten. ${ }^{167}$ Voor mijn

164 Ministerie van Financiën, Ruimte voor leven 2010, p. 56

165 Ministerie van IenM, Bezinning op het omgevingsrecht 2010, p. 1.

166 Ministerie van VROM, Opdracht essays 2010.

167 Ministerie van IenM, Beleidsbrief Eenvoudig Beter 2011, p. 1. 
betoog is de aandacht voor de genoemde concrete projecten, de echte werkelijkheid van belang.

\subsubsection{Toelichting op wetgeving}

\section{Algemeen}

In de toelichting op wetgeving vinden we soms een indicatie dat de wetgever de samenhang in een wetssysteem vanwege de kenbaarheid daarvan zoekt in de echte werkelijkheid.

\section{IPPC-richtlijn}

In het Explanatory Memorandum (1993) bij de IPPC-richtlijn ${ }^{168}$ wordt onder meer het volgende opgemerkt: 'Increasingly, throughout the Community it has come to be recognized that no one part of the environment is separate from any other. It functions as an integrated whole. Yet, pollution control was until recently usually based on an approach which considers emissions to air, water and land separately. That has begun to change, particularly since the 1987 report on sustainable development, which stated in the section entitled 'The Institutional Gaps' in the overview: "the integrated and interdependent nature of the new challenges and issues contrasts sharply with the nature of the institutions which exist today. The institutions tend to be independent, fragmented and working to relatively narrow mandates with closed decision processes. The real world ${ }^{169}$ of interlocked economic and ecological systems will not change; the policies and institutions must." Mij komt deze passage voor als een duidelijk pleidooi voor het feit dat het (omgevings)recht zich moet aanpassen aan de werkelijkheid, niet andersom. Sterker nog, de werkelijkheid waarover het in deze passage gaat kan zich volgens de opstellers van het Memorandum niet aanpassen.

\section{Wabo}

In de memorie van toelichting bij de Wabo wordt opgemerkt, dat het project (bestaande uit de in de artikelen 2.1 en 2.2 Wabo genoemde activiteiten) dat de burger of het bedrijf wil gaan realiseren, centraal staat. De dienstverlening door de overheid zal daaraan zo veel mogelijk moeten worden aangepast. ${ }^{170} \mathrm{In}$

168 Proposal for a Council Directive on integrated pollution prevention and control, COM(93) 423 final, Brussels, 14 September 1993, Explanatory memorandum, p. 3.

169 Cursief van mij, JvdB

170 Regels inzake een vergunningstelsel met betrekking tot activiteiten die van invloed zijn op de fysieke leefomgeving en inzake handhaving van regelingen op het gebied van de fysieke leefomgeving (Wet algemene bepalingen omgevingsrecht), Kamerstukken II 2006/07, 30 844, nr. 3, p. 8. 
de Wabo wordt dus aangesloten bij de echte werkelijkheid van een burger of ondernemer die een bepaald tastbaar project wil realiseren.

\section{Activiteitenbesluit}

In de nota van toelichting op het Besluit algemene regels voor inrichtingen milieubeheer ${ }^{171}$ wordt het als logischer gezien om algemene regels op te stellen voor activiteiten, in plaats van per branche min of meer dezelfde regels te stellen. De vóór het Activiteitenbesluit geldende algemene maatregelen van bestuur ${ }^{172}$ kenden veelal gelijke regels voor verschillende branches. Het reguleren van activiteiten is volgens de toelichting dan een logische vervolgstap. Uit de praktijk is bovendien gebleken dat bij toezicht en handhaving door het bevoegd gezag de activiteiten van inrichtingen centraal staan. Ook voor inrichtingen is deze insteek herkenbaar. Om in de toekomst meer inrichtingen onder de algemene (milieu)regels te kunnen brengen, is regulering op activiteiten een relatief eenvoudige wijze. In de praktijk wordt dit besluit daarom ook wel het Activiteitenbesluit genoemd. ${ }^{173}$ In het Activiteitenbesluit is dus beoogd aan te sluiten bij de echte werkelijkheid van een burger of ondernemer die bepaalde activiteiten wil uitvoeren.

\section{Richtlijn industriële emissies}

Een recent illustratief voorbeeld van dat kenbaarheid een rol speelt voor de wetgever en hoe gedachten over kenbaarheid in de loop der tijd kunnen veranderen biedt het wetsvoorstel tot Wijziging van de Wet algemene bepalingen omgevingsrecht, de Wet milieubeheer en enkele andere wetten ten behoeve van de implementatie van richtlijn nr. 2010/75/EU van het Europees Parlement en de Raad van 24 november 2010 inzake industriële emissies (geïntegreerde preventie en bestrijding van verontreiniging; herschikking; PbEU L 334). ${ }^{174}$ Daarin wordt van de gelegenheid gebruik gemaakt om de term 'gpbv-installatie' ${ }^{175}$ te vervangen door de term 'IPPC-installatie'. ${ }^{176}$ Met beide acroniemen wordt een installatie aangeduid als bedoeld in bijlage 1 van de Richtlijn 2010/75/EU inzake industriële emissies (IED). ${ }^{177}$

171 Zie par. 1.2 en 1.3.2.

172 Zie par. 1.2.

173 Activiteitenbesluit, NvT, p. 104.

174 Kamerstukken II 2011/12, 33 197, nr. 2, art. I, onderdelen A en B.

175 gpbv: geïntegreerde preventie en bestrijding van verontreiniging.

176 IPPC: Integrated Pollution Prevention Control.

177 Richtlijn 2010/75/EU van het Europees Parlement en de Raad van 24 november 2010 inzake industriële emissies (geïntegreerde preventie en bestrijding van verontreiniging) (herschikking) (PbEU 2010 L 334/17). In Nederland wordt deze richtlijn gewoonlijk afgekort met IED (Industrial Emissions Directive). 
De term gpbv-installatie is op 1 december 2005 in de Wet milieubeheer geïntroduceerd ${ }^{178}$ en per 1 oktober 2010 'overgeheveld' naar de Wabo. ${ }^{179}$ In de memorie van toelichting wordt opgemerkt dat destijds bewust is gekozen voor het Nederlandstalige acroniem, gelet op Aanwijzing voor de regelgeving 57 , die bepaalt dat vreemde woorden of daarvan afgeleide woorden worden vermeden, uitgezonderd wanneer het vreemde woord of een afgeleide daarvan ingang heeft gevonden in de Nederlandse taal.

De regering noemt in de memorie van toelichting een aantal redenen om in 2012 toch voor IPPC-installatie te kiezen. Bij elk van die redenen zijn kanttekeningen te plaatsen.

In de eerste plaats werd volgens de regering reeds in de toelichting bij de introductie van de term 'gpbv-installatie' onderkend dat het Engelstalige acroniem eigenlijk al was ingeburgerd in het gangbare taalgebruik. ${ }^{180}$

Kanttekening: als zulks in 2005 reeds werd onderkend wordt niet helder waarom dan in 2005 niet reeds gebruik was gemaakt van de uitzondering die Aanwijzing 57 biedt.

In de tweede plaats heeft introductie van de vervangende Nederlandstalige term door de wetgever het tij volgens de regering niet kunnen keren. Zo meldt bijvoorbeeld Infomil op de website dat gpbv-installaties veelal meer bekend zijn als IPPC-installaties. Reeds de enkele omstandigheid dat een dergelijke, het bedrijfsleven en publiek informerende, website onmiddellijk naast de officiële term voor alle duidelijkheid het gangbaarder Engelse acroniem meent te moeten vermelden, is volgens de regering voldoende aanleiding ook in de wetgeving te kiezen voor het spraakgebruik.

Kanttekening: mij lijkt dat de vermelding op de Infomil-website een indicatie kan zijn voor het feit dat de term IPPC-installatie ingang heeft gevonden in de Nederlandse taal, maar ik vraag mij af of de enkele omstandigheid dat een het bedrijfsleven en publiek informerende website de IPPC-installatie 'meent te moeten vermelden' 'reeds voldoende aanleiding' moet vormen voor de wetgever om de wet aan te passen. Als deze redenering werkelijk valide is, kan men zich afvragen of dat geen nieuwe, ongekende mogelijkheden zou openen voor andere het bedrijfsleven en publiek informerende websites, zoals bijvoorbeeld die van VNO-NCW en MKB-Nederland.

178 Art. I onder A Wet van 16 juli 2005, houdende wijziging van de Wet milieubeheer en de Wet verontreiniging oppervlaktewateren (verduidelijking in verband met de EG-richtlijn inzake geïntegreerde preventie en bestrijding van verontreiniging; vergunning op hoofdzaken/vergunning op maat) (Stb. 2005, 432). De inwerkingtreding is geregeld in art. II Besluit van 8 oktober 2005, houdende wijziging van het Inrichtingen- en vergunningenbesluit milieubeheer (implementatie IPPC-richtlijn en EG-inspraakrichtlijn) (Stb. 2005, 527).

179 Art. 1.1 Wabo (Stb. 2008, 496 en Stb. 2010, 231) en art. 9.10 onder A Invoeringswet Wabo (Stb. 2010, 142).

180 Kamerstukken II 2004/05, 29 711, nr. 6, p. 5-6, en nr. 7. 
In de derde plaats is het Engelse acroniem 'IPPC' volgens de regering ook gemakkelijker uit te spreken dan het Nederlandse equivalent 'gpbv'.

Kanttekening: ik ben het daarmee eens, maar neem aan dat dat in 2005 ook reeds het geval was.

In de vierde plaats handhaaft de nieuwe richtlijn volgens de regering uitdrukkelijk de oorspronkelijke aanduiding 'Integrated Pollution Prevention and Control' (geïntegreerde preventie en bestrijding van verontreiniging) in het opschrift als ondertitel, zodat naar verwachting het ingeburgerde acroniem IPPC in de uitvoeringspraktijk gangbaar en herkenbaar zal blijven.

Kanttekening: het moge zo zijn dat de woorden 'integrated pollution prevention control' terugkomen in het opschrift als ondertitel van de Richtlijn industriële emissies, maar de inmiddels reeds gangbare aanduiding voor deze richtlijn is IED. ${ }^{181}$

Ten slotte is het gebruik van een Engelstalig acroniem volgens de regering niet nieuw in de nationale milieuwetgeving. In de Wet milieubeheer wordt reeds gebruik gemaakt van de term 'PRTR' (titel 12.3), een acroniem voor 'Pollutant Release and Transfer Register', hoewel een goede Nederlandse vertaling voor handen is: register inzake de emissie en overbrenging van verontreinigende stoffen.

Kanttekening: het feit dat het gebruik van een Engelstalig acroniem niet nieuw is in de nationale milieuwetgeving vormt op zichzelf geen legitimatie om van Aanwijzing 57 af te wijken. Zo zou het best kunnen dat PRTR voldeed aan de uitzondering in Aanwijzing 57.

Om aansluiting met nationale regelgeving te vereenvoudigen en interpretatiegeschillen te voorkomen adviseert de (Afdeling advisering van de) Raad van State om de terminologie en systematiek van de Richtlijn industriële emissies als uitgangspunt te nemen en slechts om klemmende redenen hiervan af te wijken. Daarbij wijst hij in het bijzonder op het begrip 'installatie', dat in artikel 3, aanhef en onder 3 van de richtlijn wordt gedefinieerd. Aangezien de term 'IPPC-installatie' niet voorkomt in de richtlijn en de IPPC-richtlijn vanaf 7 januari 2014 niet meer geldig is, wekt het voorstel om voortaan te verwijzen naar een 'IPPC-installatie' verwarring. De Raad adviseert in de nationale regelgeving te verwijzen naar een installatie als bedoeld in de richtlijn. ${ }^{182}$

181 Zie onder meer Roos, Implementatie Richtlijn industriële emissies stroomlijnt emissieregelgeving 2012, François, De BBT in Richtlijn IED 2012 en François, De Europese Richtlijn industriële emissies 2012.

182 Kamerstukken II 2011/12, 33 197, nr. 4, p. 2. 
De regering blijft echter bij haar voorstel om 'gpbv-installatie' te vervangen door 'IPPC-installatie' dat met name wordt ingegeven 'door de overweging dat de Engelse term 'IPPC' beter 'bekt' en belangrijker, ook meer is ingeburgerd.' Dat onder IPPC-installaties slechts wordt gedoeld op de installaties die behoren tot de in bijlage I van de richtlijn genoemde categorieën installaties en niet op alle installaties waarop de richtlijn van toepassing is, leidt volgens de regering niet tot verwarring, '... integendeel, de uitvoeringspraktijk heeft altijd wat 'aangehikt' tegen de term 'gpbv-installatie' als een typisch 'Haags' bedenksel.' Nijmeijer is het van harte met de Raad van State eens. Een wettekst moet volgens hem duidelijk en rechtszeker zijn en daarbij helpt het niet om te refereren aan begrippen uit niet langer geldende richtlijnen. ${ }^{183} \mathrm{Ik}$ ben het met hem eens met name ook op basis van het door hem gebezigde argument dat de term IPPC-installatie slechts is ingeburgerd voor hen die in het verleden met de IPPC-richtlijn van doen hebben gehad. Teneinde beter aan te sluiten bij de echte werkelijkheid zou het wellicht te overwegen zijn om een onderscheid te maken tussen industriële installaties (art. 10 IED) en oplosmiddeleninstallaties (art. 56 IED) als dat in de Nederlandse context meerwaarde heeft. ${ }^{184}$

\subsubsection{Tussenconclusie}

In dit onderzoek heb ik een wetssysteem gedefinieerd als volgens bepaalde criteria geordende, onderling samenhangende regels. Gegeven deze definitie is sprake van een wetssystematisch tekort als bepaalde regels volgens bepaalde wetenschappelijke samenhangcriteria onderling samenhangen maar desalniettemin geen deel uitmaken van hetzelfde wetssysteem.

$\mathrm{Na}$ een vergelijking met het computerprogramma iTunes heb ik geconcludeerd dat de wetgever binnen het geldende recht tussen veel verschillende samenhangcriteria kan kiezen. Anders dan de gebruiker van iTunes is de wetgever echter gedwongen een keus te maken voor een bepaald systeem. Die keus is om drie redenen van groot belang voor de rechtspraktijk. In de eerste plaats bepaalt het door de wetgever gekozen samenhangcriterium het wetssysteem in die zin dat alle regels die beantwoorden aan het gekozen samenhangcriterium ook in het als gevolg van dat criterium geschapen wetssysteem een plaats dienen te krijgen. In de tweede plaats sluit de keus voor een of meer samenhangcriteria uit dat het systeem tegelijkertijd is geordend volgens een of meer andere samenhangcriteria. De keus voor een of meer samenhangcriteria betekent daarom welhaast automatisch dat er wetssystematische tekorten ontstaan of blijven voortbestaan als gevolg van het feit dat niet voor een of meer andere criteria is gekozen. In de derde plaats betekent de keus voor een of meer samenhangcriteria bovendien dat het risico bestaat dat bepaalde problemen of oplossingen worden uitgesloten

183 Nijmeijer, IPPC-inrichting of -installatie? 2012.

184 Kamerstukken II 2011/12, 33 197, nr. 4, p. 3-4 
of over het hoofd gezien. Reeds om de genoemde redenen is het cruciaal dat de wetgever een wetenschappelijk te verantwoorden keus maakt voor een of meer samenhangcriteria die het wetssysteem bepalen. Daarbij is echter niet elke - politieke - keus ook wetenschappelijk verdedigbaar.

Bij het zoeken naar wetenschappelijk verantwoorde samenhangcriteria wordt mijn vertrekpunt gevormd door de kenbaarheid van het recht, mijns inziens de belangrijkste functie van een wetssysteem los van de inhoud van de daarvan deel uitmakende regels, de probleemgeoriënteerd van een wetssysteem en het in Nederland geldende postulaat dat ieder wordt geacht de wet te kennen. Dit vertrekpunt betekent naar mijn oordeel dat de wetgever bij voorkeur naar samenhangcriteria moet zoeken buiten de wereld van het recht, in de echte werkelijkheid. Op die wijze zullen wetssystematische tekorten naar verwachting zoveel mogelijk kunnen worden vermeden. In de door mij gehouden interviews, de Aanwijzingen voor de regelgeving, literatuur, beleidsstukken en toelichting op wetgeving zijn aanwijzingen te vinden die steun bieden aan de gedachte dat de samenhang die een wetssysteem bepaalt in eerste instantie moet worden gezocht in de door gebruikers van het omgevingsrecht ervaren en begrepen echte werkelijkheid. Uit genoemde Aanwijzingen voor de regelgeving, literatuur, beleidsstukken en toelichting op wetgeving volgt echter geen duidelijk antwoord op de vraag om welke samenhang of samenhangen in de echte werkelijkheid het dan precies gaat. Op die vraag zal hierna in paragraaf 3.3 een antwoord worden gezocht.

\subsection{ZAKELIJKE SYSTEEMORDENINGSCRITERIA}

\subsubsection{Algemeen}

Hiervoor heb ik betoogd dat een wetssysteem moet worden bepaald door samenhangcriteria die de wetgever niet moet zoeken binnen de wereld van het omgevingsrecht, maar daarbuiten, in de echte werkelijkheid zoals gebruikers van het omgevingsrecht die ervaren en zonder specialistische juridische voorkennis begrijpen. De vraag is echter wat in de echte werkelijkheid onderling zodanig samenhangt dat het kan dienen als samenhangcriterium voor wetssystemen in het omgevingsrecht. Om een antwoord op deze vraag te geven heb ik gezocht naar zo eenvoudig mogelijke samenhangen. Het is immers logisch te veronderstellen dat eenvoudige samenhangen eerder kunnen leiden tot een eenvoudig wetssysteem dat de kenbaarheid en probleemgeoriënteerdheid van het omgevingsrecht ten goede komt. ${ }^{185}$ Ook Woldendorp adviseert vanuit zijn ervaring als wetgevingsjurist om eenvoudig te beginnen: "Een gemakkelijk begin wordt altijd

185 In dit verband schrijft Noll: 'Eine geniale Erfindung ist die Weiterführung dieser Rationalisierung im metrischen System, in welchem alle Maße und Gewichte auf zwei Einheiten reduziert werden können, nämlich den Erdumfang und das Wasser.', Noll, Gesetzgebungslehre 1973, p. 206. 
moeilijker, maar een moeilijk begin wordt nooit gemakkelijk. Dus begin niet meteen moeilijk te doen, want dan wordt het alleen nóg moeilijker." ${ }^{186}$

Als we de in omgevingswetten te reguleren echte werkelijkheid heel eenvoudig weergeven, dan bestaat die volgens mij uit subjecten, objecten, activiteiten en de fysieke leefomgeving. In meer juridische termen en toegespitst op dit onderzoek gaat het dan in geval van subjecten om (rechts)personen. Onder objecten kan een veelheid van in de werkelijkheid voorkomende verschijnselen worden begrepen, zoals producten, inrichtingen en stoffen. De vier genoemde categorieën van in de echte werkelijkheid voorkomende samenhangen zullen in de paragrafen 3.3.2 tot en met 3.3.5 nader worden toegelicht.

Teneinde de kenbaarheid en de probleemgeoriënteerdheid van een wetssysteem te optimaliseren, moeten zakelijke systeemordeningscriteria dan wel aansluiten bij wat in het algemeen spraakgebruik door de gebruikers van het omgevingsrecht ook zonder specialistische juridische voorkennis als onderdeel van hun werkelijkheid wordt ervaren. ${ }^{187,188}$ Dat is helaas niet altijd het geval, zoals de hierna te noemen voorbeelden laten zien.

Zo dient de bestuurder van wat in het normale spraakgebruik een auto heet de regels die daarop van toepassing zijn te zoeken in de categorie motorrijtuigen: alle voertuigen, bestemd om anders dan langs spoorstaven te worden voortbewogen uitsluitend of mede door een mechanische kracht, op of aan het voertuig zelf aanwezig dan wel door elektrische tractie met stroomtoevoer van elders, met uitzondering van fietsen met trapondersteuning. ${ }^{189}$ Een wetssysteem waarin de echte werkelijkheid van de auto wordt omschreven met een door de gebruiker niet als zodanig ervaren begrip motorrijtuig zal voor die gebruiker niet aanstonds en zonder voorkennis kenbaar zijn. Persoonlijk heb ik nooit iemand horen zeggen: "Kijk daar eens, dat is een mooi motorrijtuig!" of "Morgen ga ik een fiets met trapondersteuning kopen."

Een voorbeeld van een zakelijk systeemordeningscriterium dat niet aansluit bij de door gebruikers van het omgevingsrecht ervaren werkelijkheid, is het begrip inrichting in de Wet milieubeheer. Onder een inrichting wordt verstaan: elke door de mens bedrijfsmatig of in een omvang alsof zij bedrijfsmatig was, ondernomen bedrijvigheid die binnen een zekere begrenzing pleegt te worden verricht. ${ }^{190}$ Het begrip inrichting zal - hoewel het ruimer is - door ondernemers vaak worden gezien als een synoniem voor een bedrijf of onderneming.

186 Woldendorp, Interview 2011, bijl. 5.1, par. 6.1

187 Noll, Gesetzgebungslehre 1973, p. 211.

188 Aanwijzing 54 van de Aanwijzingen voor de regelgeving bepaalt dat het normale spraakgebruik zoveel mogelijk moet worden gevolgd. Aanwijzing 121 bepaalt dat termen die een te weinig bepaalde of van het spraakgebruik afwijkende betekenis hebben, worden gedefinieerd. Zie in dit verband ook par. 3.2.6.2

189 Art. 1 Wegenverkeerswet 1994.

190 Art. 1.1 lid $1 \mathrm{Wm}$. 
Deze laatste twee begrippen sluiten wel aan bij het normale spraakgebruik van ondernemers en burgers. Onder het begrip inrichting zullen gebruikers van het omgevingsrecht slechts met de noodzakelijke specialistische juridische voorkennis een bedrijf of onderneming verstaan. Stel dat een advertentie in een gemeentelijk verschijnend blad slechts zou laten weten dat er een aanvraag is binnengekomen om op een bepaalde plek in een dorp een inrichting te bouwen. Hoewel ik daarnaar geen onderzoek heb gedaan, lijkt mij de kans groot dat de lezers van de advertentie niet onmiddellijk en vermoedelijk zelfs in het geheel niet zullen denken aan een bedrijf, onderneming of fabriek. De kans lijkt me groter dat zij zullen denken aan een psychiatrische of penitentiaire inrichting.

Voorbeelden van zakelijke systeemordeningscriteria die wel aansluiten bij het normale spraakgebruik zijn bouwen en bouwwerk. De Wabo verstaat onder bouwen: het plaatsen, geheel of gedeeltelijk oprichten, vernieuwen, veranderen of vergroten (van een bouwwerk). ${ }^{191}$ Het begrip bouwwerk is niet wettelijk gedefinieerd, maar in de jurisprudentie verduidelijkt: 'elke constructie van enige omvang van hout, steen, metaal of ander materiaal, die op de plaats van bestemming hetzij direct hetzij indirect met de grond verbonden is, hetzij direct of indirect steun vindt in of op de grond, bedoeld om ter plaatse te functioneren.' Hoewel deze uit de modelverordeningen van de VNG afkomstige definitie tot veel jurisprudentie aanleiding heeft gegeven, sluit deze definitie, evenals die voor bouwen nog steeds aan bij het normale spraakgebruik. Er bestaat in de praktijk geen enkele twijfel over dat het bouwen van een woning juridisch kan worden gekwalificeerd als het bouwen van een bouwwerk. De jurisprudentie heeft met name betrekking op zaken die in het normale spraakgebruik niet zonder meer als bouwen van een bouwwerk worden gezien, zoals het schilderen of stucen van een woning. ${ }^{192}$

Drupsteen $^{193}$ is van mening dat je in theorie wel kunt uitgaan van rechtssubjecten en objecten, maar hij werpt terecht de vraag op dat er bij het kiezen van samenhangcriteria gebaseerd op de echte werkelijkheid wel overeenstemming dient te zijn met wat iemand in de werkelijkheid als eenheid ervaart. En zelfs als dat lukt, dan gelooft Drupsteen hier niet in. Hij illustreert dat met het voorbeeld van de vraag of een wetssysteem kan worden gevormd op basis van het samenhangcriterium 'invalide'. In dat systeem zouden dan onder meer regels moeten worden opgenomen over de invaliditeitsuitkering, een invalideparkeerplaats, een aangepaste auto, omscholing en herhuisvesting.

191 Art. 1.1 lid 1 Wabo

192 Zie onder meer $A B R v S 19$ juli 2006, $A B$ 2006, 305 (erfverharding is geen constructie dus geen bouwwerk), ABRvS 11 maart 1999, BR 1999, p. 789 (het schilderen van een gevel is geen bouwen) $A B R v S 19$ juni 2002, $A B$ 2002, 376 (stucen van een gevel is bouwen; omdat de bouwkundige staat van de gevel als gevolg van het stucen werd gewijzigd, was sprake van een constructieve voorziening) en ABRvS 4 april 2007, BR 2007, p. 596 (op grasveld geplaatste vrachtwagen is bouwwerk). Zie ook Nijmeijer/Hillegers \& Lam, Bouwen en ontwikkelen met de Wabo 2010, p. 15-17.

193 Drupsteen, Interview 2012, bijl. 5.8, par. 3.1. 
Dat het niet 'ongelofelijk' is, illustreert Konijnenbelt: 'Er is een sterke neiging, de wetboeken 'compleet' te laten zijn, dat wil zeggen dat ze alle relevante wettelijke bepalingen over een bepaalde bevolkingsgroep bevatten (code rural, de l'artisanat) of betreffende een bepaalde materie (fiscale wetboeken, code du vin, enz.). Gevolg is dat de wetboeken omvangrijk zijn, 2.000 artikelen per wetboek is geen uitzondering. Bepalingen die worden ontleend aan andere wetboeken of aan andere wetten die ook afzonderlijk blijven bestaan, krijgen dan de vorm van een citaat (...). Om te voorkomen dat verschillende teksten die identiek moeten blijven, bij wijziging gaan uiteenlopen, wordt dan sedert enkele jaren de 'moederbepaling' soms uitdrukkelijk aangeduid als hoofdtekst (code pilote, aldus de te ruime benaming), terwijl de afgeleide teksten 'code suiveur' heten; wijziging van de moedertekst brengt dan automatisch wijziging van de afgeleide teksten mee.'194

Drupsteen ziet meer in een juridische indeling en opbouw die naar zijn oordeel langer beklijven. Hij wil het in het door hem gegeven voorbeeld wel gemakkelijker maken voor de invalide om zijn rechten en plichten te kunnen kennen, maar vraagt zich af of dat in de wet zelf moet gebeuren. Ik ben van mening dat de wetgever waar mogelijk moeite moet doen om wetssystemen zelf zo kenbaar mogelijk in te richten. Het door Drupsteen gegeven voorbeeld illustreert echter wel dat de keuze voor een bepaald samenhangcriterium elders wetssystematische tekorten kan veroorzaken. Als bijvoorbeeld wetssystemen op het gebied van belastingrecht regels kennen inzake invaliden, dan worden die regels uit die wetssystemen overgeheveld naar het wetssysteem dat wordt bepaald door het samenhangcriterium invalide. Die regels staan dan dus niet meer in de wetssystemen op het gebied van belastingrecht.

\subsubsection{Subjecten}

Een eerste samenhang die gebruikers van het recht als werkelijkheid zullen ervaren is de aanwezigheid van subjecten: ${ }^{195}$ natuurlijke personen en rechtspersonen. Als de wetgever een (rechts)persoon als samenhangcriterium voor een wetssysteem gebruikt zal het voor gebruikers van het omgevingsrecht aanstonds en zonder specialistische juridische voorkennis duidelijk zijn waarop de wetgever doelt. Daarbij kan het ook gaan om een persoon qualitate qua, zoals een moeder, een kind, een pensioengerechtigde, de beoefenaar van een bepaald beroep etcetera. Hetzelfde geldt voor een rechtspersoon, zoals de exploitant van een fabriek. Daarbij verdient vermelding dat een (rechts)persoon meer dan één kwaliteit kan hebben.

194 Konijnenbelt, Wetgevingskwaliteit in Frankrijk 2000, p. 242-243.

195 Hirsch Ballin ziet er in navolging van Achterberg vanaf om deze subjecten als rechtssubjecten aan te duiden, omdat een subject slechts door het feit zelf dat het in een of meer rechtsbetrekkingen staat een rechtssubject is. Dat geldt zowel voor natuurlijke personen als voor rechtspersonen en overheidsorganen (Hirsch Ballin, Architectuur van wetgeving 1984, p. 77). 
Een wetssysteem bestaat uit volgens bepaalde criteria geordende, onderling samenhangende regels. Als het wetssysteem wordt bepaald door een (rechts-) persoon als samenhangcriterium, dan is van een wetssystematisch tekort sprake als binnen dat wetssysteem niet alle voor die (rechts)persoon relevante regels zijn opgenomen. Het omgevingsrecht zal meer kenbaar worden voor een bepaalde (rechts)persoon naarmate de wetgever meer aansluiting heeft gezocht bij die (rechts)persoon. In het omgevingsrecht maakt de wetgever gebruik van een (rechts)persoon als samenhangcriterium, zoals hierna zal worden geillustreerd.

Een voorbeeld van een (rechts)persoon als samenhangcriterium is te vinden in hoofdstuk 2 van het Besluit bodemkwaliteit. Deze mede op hoofdstuk $11 \mathrm{Wm}$ gebaseerde algemene maatregel van bestuur bevat regels over de erkenning dat een persoon of een instelling voor een werkzaamheid voldoet aan de bij of krachtens het Besluit bodemkwaliteit geldende voorwaarden. ${ }^{196}$ De erkenningsbeschikking vermeldt ten minste 'de naam van de persoon of instelling, de werkzaamheid, de vestigingsplaats en, indien van toepassing, de naam van de natuurlijk persoon die werkzaam is voor de erkende persoon of instelling en die een van de bij regeling van Onze Ministers aangewezen handelingen uitvoert. ${ }^{\text {'197 }}$

In het genoemde voorbeeld is het, vooropgesteld dat de gebruikte termen aansluiten bij het spraakgebruik, voor de te erkennen persoon of instelling aanstonds en zonder veel juridische voorkennis kenbaar dat het genoemde wetssysteem op dat subject betrekking heeft.

Opgemerkt zij overigens, dat niet overal waar in het omgevingsrecht een (rechts)persoon wordt genoemd ook sprake is van het gebruik van die (rechts-) persoon als samenhangcriterium. In de voorbeelden die hierna volgen bevat het relevante wetssysteem weliswaar regels ten aanzien van (rechts-) personen, maar de (rechts)persoon is niet het samenhangcriterium dat het desbetreffende wetssysteem bepaalt.

Een voorbeeld biedt artikel 9.2.1.2 Wm: 'Een ieder die beroepshalve een stof, preparaat of genetisch gemodificeerd organisme vervaardigt, in Nederland invoert, toepast, bewerkt, verwerkt of aan een ander ter beschikking stelt, en die weet of redelijkerwijs had kunnen vermoeden dat door zijn handelingen met die stof of dat preparaat of organisme gevaren kunnen optreden voor de gezondheid van de mens of voor het milieu, is verplicht alle maatregelen te nemen die redelijkerwijs van hem kunnen worden gevergd, teneinde die gevaren zoveel mogelijk te voorkomen of te beperken.' Artikel 9.2.1.3 Wm sluit daarbij aan door te bepalen dat de desbetreffende (rechts)persoon desgevraagd aan Onze Minister gegevens moet verstrekken over die stof of dat preparaat of organisme waarover hij beschikt of redelijkerwijs kan beschikken. Het samenhangcriterium is hier niet de genoemde (rechts)persoon maar 'een stof, preparaat of genetisch 
gemodificeerd organisme'. In dit geval is niet het subject, doch de stof, het preparaat of het genetisch gemodificeerd organisme het samenhangcriterium dat het subwetssysteem van Titel $9.2 \mathrm{Wm}$ bepaalt. ${ }^{198}$

Een tweede voorbeeld betreft artikel $13 \mathrm{Wbb}$ : 'Ieder die op of in de bodem handelingen verricht als bedoeld in de artikelen 6 tot en met 11 en die weet of redelijkerwijs had kunnen vermoeden dat door die handelingen de bodem kan worden verontreinigd of aangetast, is verplicht alle maatregelen te nemen die redelijkerwijs van hem kunnen worden gevergd, teneinde die verontreiniging of aantasting te voorkomen, dan wel indien die verontreiniging of aantasting zich voordoet, de verontreiniging of de aantasting en de directe gevolgen daarvan te beperken en zoveel mogelijk ongedaan te maken. Indien de verontreiniging of aantasting het gevolg is van een ongewoon voorval, worden de maatregelen onverwijld genomen.' In dit geval is niet het subject, doch bodembescherming en bodemsanering als samenhangcriterium voor het wetssysteem van de Wet bodembescherming gebruikt. Dat geldt ook voor artikel $28 \mathrm{Wbb}$, dat onder meer bepaalt dat degene die voornemens is de bodem te saneren van dat voornemen melding moet doen bij Gedeputeerde Staten van de betrokken provincie.

\subsubsection{Objecten}

Een tweede samenhang die gebruikers van het recht als werkelijkheid zullen ervaren is de aanwezigheid van objecten. Als de wetgever een object als samenhangcriterium voor een wetssysteem gebruikt zal het voor gebruikers van het omgevingsrecht aanstonds en zonder specialistische juridische voorkennis duidelijk zijn waarop de wetgever doelt.

Een wetssysteem bestaat uit volgens bepaalde criteria geordende, onderling samenhangende regels. Als een wetssysteem wordt bepaald door een object als samenhangcriterium, is van een wetssystematisch tekort sprake als binnen het door dat samenhangcriterium bepaalde wetssysteem niet alle voor dat object relevante regels zijn opgenomen. Het omgevingsrecht zal meer kenbaar worden naarmate de wetgever meer aansluiting heeft gezocht bij duidelijke objecten. In het omgevingsrecht maakt de wetgever op verschillende plaatsen gebruik van een object als samenhangcriterium, zoals hierna zal worden geillustreerd.

Een voorbeeld van een object als samenhangcriterium betreft stoffen: 'chemische elementen en de verbindingen ervan, zoals deze voorkomen in natuurlijke toestand of bij de vervaardiging ontstaan, met inbegrip van alle additieven die nodig zijn voor het behoud van de stabiliteit ervan en alle onzuiverheden ten gevolge van het toegepaste procedé, doch met uitzondering van elk oplosmiddel dat kan worden afgescheiden zonder dat de stabiliteit van de stof wordt aangetast of de samenstelling ervan wordt gewijzigd. ${ }^{, 199}$ Het samenhangcriterium stoffen wordt onder meer gebruikt als samenhangcriterium voor het

198 Titel 9.2 Wm Stoffen, preparaten en genetisch gemodificeerde producten. Zie ook hfds. 5.

199 Art. 1.1 lid $1 \mathrm{Wm}$. 
wetssysteem dat Titel 9.2 Wm Stoffen, preparaten en genetisch gemodificeerde organismen vormt.

Een ander voorbeeld betreft een project als bedoeld in artikel 2.1 lid 1 en artikel 2.2 Wabo. Het gaat hier om een project dat bestaat uit één of meer in de genoemde artikelen genoemde activiteiten. Het begrip plaatsgebonden project dat bestaat uit één of meer activiteiten die van invloed zijn op de fysieke leefomgeving wordt als samenhangcriterium gebruikt voor het wetssysteem van de Wabo. ${ }^{200}$

In de genoemde voorbeelden is het, vooropgesteld dat de gebruikte termen aansluiten bij het spraakgebruik, voor respectievelijk de gebruiker van stoffen of de initiatiefnemer van een project aanstonds en zonder veel specialistische juridische voorkennis kenbaar dat de genoemde regels op dat object betrekking hebben.

\subsubsection{Activiteiten}

Een derde samenhang die gebruikers van het recht als werkelijkheid zullen ervaren is de uitvoering van activiteiten. Als de wetgever een activiteit als samenhangcriterium voor een wetssysteem gebruikt zal het voor gebruikers van het omgevingsrecht aanstonds en zonder juridische voorkennis duidelijk zijn waarop de wetgever doelt.

Een wetssysteem bestaat uit volgens bepaalde criteria geordende, onderling samenhangende regels. Als een wetssysteem wordt bepaald door een activiteit als samenhangcriterium, is van een wetssystematisch tekort sprake als binnen het door dat samenhangcriterium bepaalde wetssysteem niet alle voor die activiteit relevante regels zijn opgenomen. Het omgevingsrecht zal meer kenbaar worden voor een gebruiker naarmate de wetgever meer aansluiting heeft gezocht bij een activiteit. In het omgevingsrecht maakt de wetgever op verschillende plaatsen gebruik van een activiteit als samenhangcriterium, zoals hierna zal worden geïllustreerd.

Het Besluit algemene regels voor inrichtingen milieubeheer bevat algemene regels voor inrichtingen. Het wetssysteem van dit zogeheten Activiteitenbesluit wordt in eerste instantie bepaald door de samenhangcriteria 'inrichting'201 en 'bescherming van het milieu'. ${ }^{202}$ Dat betekent dat alle regels die nodig zijn ter bescherming van het milieu tegen de nadelige gevolgen die inrichtingen daarvoor kunnen veroorzaken dienen te zijn opgenomen in het Activiteitenbesluit. De meeste onderdelen van het Activiteitenbesluit bestaan uit subwetssystemen

200 Zie ook hfds. 4

201 Het betreft inrichtingen als bedoeld in art. 1.1 lid 1, 3 en 4, en art. $8.40 \mathrm{Wm}$. In art. 1.2 Activiteitenbesluit zijn de inrichting type A, type B en type C, waarop het Activiteitenbesluit betrekking heeft, nader gedefinieerd.

202 Art. 8.40 lid $1 \mathrm{Wm}$. 
die worden gevormd door een bepaalde activiteit als samenhangcriterium. Zo wordt het subwetssysteem van paragraaf 3.1.1 Lozen van grondwater bij bodemsanering of proefbronnering bepaald door het samenhangcriterium 'lozen vanuit een proefbronnering'. Andere activiteiten zijn bijvoorbeeld het lozen van grondwater bij ontwatering, ${ }^{203}$ snijden van koper $^{204}$ en het afleveren van vloeibare brandstoffen aan vaartuigen. ${ }^{205}$

In genoemd voorbeeld is het voor degene die een met name omschreven activiteit wil uitvoeren aanstonds en zonder veel specialistische juridische voorkennis kenbaar dat de genoemde regels op die activiteit betrekking hebben.

\subsubsection{Fysieke leefomgeving als samenhangcriterium}

Een vierde samenhang die gebruikers van het recht als werkelijkheid zullen ervaren is de fysieke leefomgeving. Als de wetgever de fysieke leefomgeving als samenhangcriterium voor een wetssysteem gebruikt zal het voor gebruikers van het omgevingsrecht aanstonds en zonder specialistische juridische voorkennis duidelijk zijn waarop de wetgever doelt. Milieu, ruimte, water en natuur hangen samen en zullen door burgers en bedrijven ook als zodanig worden ervaren. Zo zal de ondernemer die een fabriek wil bouwen of uitbreiden zich realiseren dat zulks niet alleen gevolgen heeft voor de ruimte, maar dat de emissies van die fabriek gevolgen kunnen hebben voor milieu, natuur en water. Het gaat hier om de samenhang van de te beschermen belangen van milieu, ruimtelijke ordening, water en natuur.

Het omgevingsrecht kent op dit moment geen wetssysteem dat wordt bepaald door de fysieke leefomgeving als samenhangcriterium.

In de geplande Omgevingswet zal dat naar verwachting anders zijn in zoverre daarin de bescherming van milieu, ruimtelijke ordening, water en natuur wordt geregeld. De hoofddoelstelling van die wet is 'een veilige, gezonde en duurzame leefomgeving te bewerkstelligen en deze op een duurzame en doelmatige wijze te behouden, beheren, gebruiken en ontwikkelen.' ${ }^{\text {,206 }}$ De Omgevingswet zal onder meer een integrale omgevingsvisie mogelijk maken, een strategisch plan waarin een bestuursorgaan keuzes in de fysieke leefomgeving in samenhang beschrijft. Deze integrale gebiedsdekkende visie zal de huidige vijf wettelijke sectorale visiedocumenten vervangen: de (gebiedsdekkende) structuurvisie voor de ruimtelijke ordening, het waterplan, het milieubeleidsplan, het verkeers- en vervoerplan en de gebiedsgerichte delen van het natuurbeleidsplan. ${ }^{207}$

\footnotetext{
203 Par. 3.1.2 Activiteitenbesluit.

204 Art. 4.35 Activiteitenbesluit.

205 Art. 4.79 Activiteitenbesluit.

206 Minister van IenM, Kabinetsbrief stelselherziening omgevingsrecht, p. 7.

207 Minister van IenM, Kabinetsbrief stelselherziening omgevingsrecht, p. 10-11.
} 
In het geldende omgevingsrecht maakt de wetgever voor verschillende wetssystemen wel gebruik van onderdelen van de fysieke leefomgeving als samenhangcriterium. Te denken is aan de Wet milieubeheer en de Waterwet. Hierna zullen beide voorbeelden kort worden toegelicht.

De Wet milieubeheer bevat regels met betrekking tot een aantal algemene onderwerpen op het gebied van de milieuhygiëne. ${ }^{208}$ Het begrip milieuhygiëne wordt in de Wet milieubeheer niet gedefinieerd. Wel bepaalt de wet dat onder gevolgen voor het milieu in ieder geval worden verstaan gevolgen voor het fysieke milieu, gezien vanuit het belang van de bescherming van mensen, dieren, planten en goederen, van water, bodem en lucht en van landschappelijke, natuurwetenschappelijke en cultuurhistorische waarden en van de beheersing van het klimaat, alsmede van de relaties daartussen. ${ }^{209}$ Onder gevolgen voor het milieu worden mede verstaan gevolgen die verband houden met een doelmatig beheer van afvalstoffen of een doelmatig beheer van afvalwater, gevolgen die verband houden met het gebruik van energie en grondstoffen, alsmede gevolgen die verband houden met het verkeer van personen of goederen van en naar de inrichting. ${ }^{210}$ Onder bescherming van het milieu worden mede verstaan de verbetering van het milieu, de zorg voor een doelmatig beheer van afvalstoffen of een doelmatig beheer van afvalwater, de zorg voor een zuinig gebruik van energie en grondstoffen, alsmede de zorg voor de beperking van de nadelige gevolgen voor het milieu van het verkeer van personen of goederen van en naar de inrichting. ${ }^{211,212}$

De Waterwet $^{213}$ bevat regels met betrekking tot het beheer en gebruik van watersystemen. Daarbij staat het integraal beheer van watersystemen centraal. ${ }^{214}$ Onder beheer verstaat de Waterwet de overheidszorg met betrekking tot een of meer afzonderlijke watersystemen of onderdelen daarvan, gericht op de in artikel $2.1 \mathrm{Wtw}$ genoemde doelstellingen. ${ }^{215}$ Onder een watersysteem verstaat de Waterwet een samenhangend geheel van een of meer oppervlaktewaterlichamen en grondwaterlichamen, met bijbehorende bergingsgebieden, waterkeringen

208 Wet van 13 juni 1979, houdende regelen met betrekking tot een aantal algemene onderwerpen op het gebied van de milieuhygiëne (Stb. 1979, 442). Zie ook de aanhef bij de Wet milieubeheer: 'Alzo Wij in overweging genomen hebben, dat het wenselijk is, naast de wettelijke regelingen, geldende voor de onderscheidene onderdelen van het gebied van de milieuhygiëne, regelen te stellen met betrekking tot een aantal algemene onderwerpen op dat gebied.'

209 Art. 1.1 lid 2 aanhef en onder a Wm.

210 Art. 1.1 lid 2 aanhef en onder b Wm.

211 Art. 1.1 lid 2 aanhef en onder c Wm.

212 Zie ook Van den Broek, Wegwijzer omgevingsrecht 2011, p. 155-230.

213 Wet van 29 januari 2009, houdende regels met betrekking tot het beheer en gebruik van watersystemen (Waterwet), Stb. 2009, 107. Deze wet is op 22 december 2009 in werking getreden (Stb. 2009, 549).

214 Aldus de aanhef bij de Waterwet: 'Alzo Wij in overweging genomen hebben, dat de overheid zich bij de zorg voor de bewoonbaarheid van het land alsmede de bescherming en verbetering van het milieu, waar die zorg gestalte krijgt in het waterbeheer, voor grote opgaven gesteld ziet, en dat het met het oog op een doeltreffende en doelmatige aanpak van het waterbeheer wenselijk is om het wettelijke instrumentarium te stroomlijnen en te moderniseren en daarbij het integraal beheer van watersystemen centraal te stellen.'

215 Art. 1.1 lid 1 Wtw. 
en ondersteunende kunstwerken. ${ }^{216}$ De hiervoor genoemde doelstellingen zijn gericht op de voorkoming en waar nodig beperking van overstromingen, wateroverlast en waterschaarste, in samenhang met bescherming en verbetering van de chemische en ecologische kwaliteit van watersystemen en vervulling van maatschappelijke functies door watersystemen. ${ }^{217}, 218$

Het samenhangcriterium 'de gevolgen voor het fysieke milieu' bepaalt het wetssysteem van de Wet milieubeheer en het samenhangcriterium 'integraal beheer van watersystemen' bepaalt het wetssysteem van de Waterwet. Binnen de als gevolg van deze koepelcriteria bepaalde wetssystemen zijn verschillende subwetssystemen te onderkennen, die worden bepaald door andere samenhangcriteria. Zo bepaalt het samenhangcriterium 'inrichting' het subwetssysteem van paragraaf 8.1 Wm Algemene regels. Molenaars geeft in dit verband terecht aan dat bij de Waterwet integraal waterbeheer de kerngedachte is, maar dat dit criterium binnen die wet uiteenvalt in onder meer waterveiligheid, chemische en ecologische kwaliteit en maatschappelijke functies. $^{219}$

In de Wabo wordt het belang van de fysieke leefomgeving als zodanig weliswaar niet als samenhangcriterium gebruikt, maar artikel 2.22 lid 2 Wabo bepaalt dat de aan een omgevingsvergunning verbonden voorschriften op elkaar moeten zijn afgestemd. Het gaat hier om voorschriften op het gebied van milieu, ${ }^{220}$ ruimtelijke ordening en natuur, als de natuurbeschermingsvergunning ${ }^{221}$ of de ontheffing op basis van artikel 75 Flora- en faunawet ${ }^{222}$ zijn aangehaakt. Artikel 2.22 lid 2 Wabo heeft geen betrekking op voorschriften met betrekking tot beschikkingen krachtens artikel 6.2 Wtw, maar paragraaf 3.5 Wabo bevat wel coördinatiebepalingen

216 Art. 1.1 lid $1 \mathrm{Wtw}$.

217 Art. 2.1 lid $1 \mathrm{Wtw}$. Volgens het tweede lid is de toepassing van de Waterwet mede gericht op andere doelstellingen dan genoemd in het eerste lid, voor zover dat elders in de Waterwet is bepaald.

218 Zie Havekes \& De Putter, Wegwijzer Waterwet 2009 en Van den Broek, Wegwijzer omgevingsrecht 2011, p. 129-137.

219 Molenaars, Interview 2012, bijl. 5.6, par. 3.1.

220 Met betrekking tot de betekenis van de begrippen 'gevolgen voor het milieu' en 'bescherming van het milieu' in de Wabo is art. 1.1 lid $2 \mathrm{Wm}$ van overeenkomstige toepassing.

221 De aanvrager van een omgevingsvergunning draagt er zorg voor dat de aanvraag tevens betrekking heeft op de handelingen die voldoen aan de criteria, bedoeld in art. 47 lid 1 Nb-wet 1998 (art. 47a $\mathrm{Nb}$-wet 1998). Het gaat om handelingen waarvoor een omgevingsvergunning is vereist en die tevens zijn aan te merken als projecten of andere handelingen waarvoor het verbod, bedoeld in art. 19d lid 1 Nb-wet 1998 geldt. Een uitzondering geldt als het gaat om projecten of andere handelingen die zijn toegestaan krachtens een vergunning als bedoeld in artikel 19d, eerste lid, of waarvoor een zodanige vergunning is aangevraagd (art. $47 \mathrm{Nb}$-wet 1998).

222 De aanvrager van een omgevingsvergunning draagt er zorg voor dat de aanvraag tevens betrekking heeft op de handelingen die voldoen aan de criteria, bedoeld in art. 75b lid 1 Flora- en faunawet (art. 75c Ffw). Het gaat om handelingen waarvoor een omgevingsvergunning is vereist en die tevens zijn aan te merken als handelingen waarvoor een of meer van de bij of krachtens de artikelen 8 tot en met 13, eerste lid, 17 en 18 gestelde verboden gelden en ten aanzien waarvan Onze Minister op grond van art. 75 lid 3, bevoegd is ontheffing te verlenen. Een uitzondering geldt als het gaat om handelingen die zijn toegestaan krachtens een ontheffing als bedoeld in art. 75 lid 3, of waarvoor een zodanige ontheffing is aangevraagd (art. 75b Ffw). 
als het gaat om een omgevingsvergunning die betrekking heeft op een inrichting waarbij tevens sprake is van het lozen van stoffen als bedoeld in artikel $6.1 \mathrm{Wtw}^{223}$

Een wetssysteem bestaat uit volgens bepaalde criteria geordende, onderling samenhangende regels. Als een wetssysteem wordt bepaald door de fysieke leefomgeving als samenhangcriterium, is van een wetssystematisch tekort sprake als binnen het door dat samenhangcriterium bepaalde wetssysteem niet alle voor de bescherming van de fysieke leefomgeving relevante belangen kunnen worden afgewogen bij regelgeving en besluitvorming door bestuursorganen. Bij besluitvorming denk ik dan met name aan vergunningverlening en handhaving. ${ }^{224}$

Gelet op hetgeen ik hiervoor heb opgemerkt, zal duidelijk zijn dat ik het belang van de fysieke leefomgeving als een verdedigbaar samenhangcriterium beschouw aangezien de fysieke leefomgeving - naast criteria als subject, object en activiteit - aansluit bij de echte werkelijkheid.

In dit verband merk ik op, dat de keus voor een wetssysteem waarin de belangen van de fysieke leefomgeving kunnen worden afgewogen wellicht ook kan worden verdedigd op basis van politieke, beleidsmatige of natuurwetenschappelijke argumenten. Zo wordt in het voorstel voor de IPPC-richtlijn onder meer het volgende opgemerkt: 'From the North Sea tot the Great Lakes in America, air emissions and run-off from land have been recognized as major contributors to water pollution. And on land too, dioxin emissions into the atmosphere, for example, have led to the contamination of farming land and water. There have even been cases of attempts to address pollution in one medium alone leading to disproportionate pollution problems in another medium (for example, in order to reduce gaseous fluoride emissions wet scrubbing took place. The scrubbing liquor was discharged to water as an industrial wastewater and found its way into sewage sludge. That was then spread on grazing land and the cattle developed fluorosis through eating fluoride contaminated grass). By requiring the use of Best Available Techniques, and defining it in such a way as to ensure that environmental problems can be estimated and compared on a common basis, IPC ${ }^{225}$ provides for a further step - that the technology chosen or the method of operating an installation should be the best for the environment as a whole. ${ }^{226}$ Mijn onderzoek heeft zoals gezegd ${ }^{227}$ geen betrekking op de vraag of het in dit citaat gestelde juist is en of de genoemde voorbeelden een integrale benadering van het milieu als geheel rechtvaardigen. Als de (Europese) wetgever politiek of beleidsmatig kiest voor een dergelijke benadering op basis van natuurwetenschappelijke argumenten, dan zou die naar mijn oordeel echter ook juridisch vorm moeten (kunnen) krijgen.

223 Art. 3.16 Wabo.

224 Van Hall, Belangenafweging in de wet op de fysieke leefomgeving 2000, p. 140. Van Hall noemt ook nog beleidsvorming, maar dat valt buiten de reikwijdte van mijn onderzoek.

225 Integrated pollution prevention and control.

226 Proposal for a Council Directive on integrated pollution prevention and control, COM(93) 423 final, Brussels, 14 september 1993, Explanatory memorandum, p. 3.

227 Zie par. 1.5 
In dezelfde zin versta ik Kleijs-Wijnnobel \& De Leeuw. Zij memoreren dat het streven naar harmonisatie en coördinatie in de loop van de jaren tachtig is overgegaan in een streven naar integratie. De aanleiding hiertoe vormde volgens hen het besef dat de inmiddels beleidsmatig uitgewerkte integrale aanpak van de milieuproblemen, zoals die in gang werd gezet naar aanleiding van het Plan Integratie Milieubeleid, ${ }^{228}$ ook juridisch vorm zou moeten krijgen. ${ }^{229}$ Hordijk verwijst naar het beleid van begin jaren tachtig waarin een integrale aanpak van de milieuproblematiek wordt bepleit. Hordijk weidt niet uit over de vraag of een integrale aanpak meerwaarde heeft ten opzichte van een sectorale aanpak, maar stelt dat voor het realiseren van een integrale aanpak nodig is over instrumenten te beschikken die zo'n aanpak mogelijk maken. ${ }^{230}$

Interessant is in dit verband het voorstel van Fleurke \& Michiels voor een digitale structuur voor het omgevingsrecht. ${ }^{231} \mathrm{Zij}$ onderscheiden de natuur als object en de natuur als subject en menen dat dit onderscheid logisch kan worden omgezet in het onderscheid tussen de fysieke leefomgeving van de mens enerzijds en de natuur anderzijds. Voor het gebied waarop het begrip fysieke leefomgeving betrekking heeft, heeft de invulling van het begrip milieu niet de betekenis van de bescherming van de natuur in de ecocentrische zin van het woord, maar draagt het bij aan een ordening van de ruimtelijke structuur van ons dichtbevolkte land. De ontwikkeling van een geïntegreerd omgevingsrecht valt te begrijpen in het licht van de behoefte om ruimtelijke en milieuwensen in de directe omgeving van de mens op elkaar af te stemmen. Daarnaast heeft zich volgens Fleurke \& Michiels de afgelopen decennia in het omgevingsrecht een gebiedsgewijze benadering ontwikkeld die niet een algemeen geldende werking voor het gehele land heeft, maar waarvan de werking zich beperkt tot specifieke aangewezen gebieden. Een deel hiervan is niet primair bedoeld om bij te dragen aan de ordening van de leefomgeving van de mens, maar heeft betrekking op de bescherming van de natuur. Daarin staat niet de mens centraal, maar de natuur. ${ }^{232}$

Op basis van deze analyse komen Fleurke \& Michiels op een nieuw stelsel voor omgevingsrecht, dat bestaat uit twee regimes. Het ene regime geldt de directe leefomgeving waarvoor een te maken Leefomgevingswet zou kunnen gelden. De doelstelling is het reguleren van aanspraken op ruimte zodanig dat een adequaat leefmilieu ontstaat respectievelijk wordt beschermd. Het welbevinden van de mens staat hier centraal. Het andere regime geldt de bescherming van natuur (Ecologische hoofdstructuur, Natura 2000 en aangewezen natuurmonumenten). Het eerste regime bevat de Wet ruimtelijke ordening, de Wet

228 Kamerstukken II 1982/83, 18 010, nr. 1.

229 Kleijs-Wijnnobel \& De Leeuw, Interne integratie 1998, p. 139.

230 Hordijk, Een nieuwe wet voor het milieubeheer 1993, p. 68.

231 Fleurke \& Michiels, Een digitale structuur voor het omgevingsrecht 2010.

232 Fleurke \& Michiels, Een digitale structuur voor het omgevingsrecht 2010, p. 107-108. 
milieubeheer en andere deelterreinen van het milieurecht (zoals stoffen, producten, afvalstoffen en bestrijdingsmiddelen). Ook gelden hier de regels van het Europeesrechtelijk soortenbeschermingsrecht. Het tweede regime omvat met name de Natuurbeschermingswet 1998, de Flora- en faunawet en de Boswet. De gebieden waarvoor het leefomgevings- of het natuurregime geldt, worden ruimtelijk gescheiden door bufferzones die tot het natuurregime behoren. ${ }^{233}$

Volgens Fleurke \& Michiels heeft dit stelsel twee aanzienlijke voordelen. In de eerste plaats zijn de centrale begrippen in het milieurecht veel beter te plaatsen en te definiëren dan bij de huidige wetgeving of wanneer men uitgaat van één allesomvattende Omgevingswet. 'In de tweede plaats heeft het stelsel het voordeel dat het criterium 'samenhang', dat beslissend is om te bepalen welke wetten of delen van de regelgeving met vrucht kunnen/ moeten worden geïntegreerd, veel beter kan worden toegepast op elk van de twee terreinen afzonderlijk (leefomgeving en natuur) dan voor het gehele terrein. ${ }^{234}$ Met name het tweede door Fleurke \& Michiels genoemde voordeel is interessant voor mijn onderzoek. Van belang is dat ook zij samenhang centraal stellen om te bepalen welke regels binnen het omgevingsrecht in aanmerking komen voor bundeling. Dat er samenhang bestaat binnen leefomgeving en binnen natuur in de door Fleurke \& Michiels geschetste zin valt moeilijk te betwisten, maar de wetssystematische vraag die hier moet worden beantwoord is mijns inziens niet of zich binnen het belang van de fysieke leefomgeving verschillende samenhangen laten onderscheiden, maar of dergelijke samenhangen beter overeenkomen met de echte werkelijkheid dan het belang van de fysieke leefomgeving als geheel. Ik meen dat zulks in het geval van leefomgeving en natuur niet het geval is. Dat volgt eigenlijk reeds uit het betoog van Fleurke \& Michiels zelf, zodat wellicht het vermoeden gerechtvaardigd is dat het hebben van twee afzonderlijke wetten voor hen geen halszaak is. In de eerste plaats omdat binnen het regime voor de directe leefomgeving volgens hen immers ook rekening moet worden gehouden met soortenbescherming. Maar soortenbescherming is nu juist bij uitstek een onderdeel van het regime voor de bescherming van de natuur. In de tweede plaats betekent het instellen van bufferzones dat een echte scheiding tussen de twee voorgestelde regimes niet goed mogelijk is. Waarom die zones tot het natuurregime zouden moeten behoren wordt niet uitgelegd. Met Fleurke \& Michiels ben ik het eens, dat er samenhang bestaat tussen leefomgeving en natuur. In feite meen ik dat zulks zelfs de echte werkelijkheid is, maar daaruit volgt mijns inziens dat beide aspecten beter in één wetssysteem kunnen worden opgenomen. In dit verband noem ik ook Driessen \& Schueler die stellen dat het inzicht dat bij het bevorderen van de kwaliteit van de leefomgeving de beleidsterreinen ruimtelijke ordening,

233 Fleurke \& Michiels, Een digitale structuur voor het omgevingsrecht 2010, p. 109-110.

234 Fleurke \& Michiels, Een digitale structuur voor het omgevingsrecht 2010, p. 110. 
milieubeleid, waterbeleid, natuurbeleid en infrastructuurbeleid in samenhang moeten worden bezien inmiddels algemeen is aanvaard. ${ }^{235}$ Dat neemt overigens niet weg, dat binnen dat wetssysteem verschillende regels kunnen gelden voor aangewezen natuurgebieden.

\subsubsection{De fysieke leefomgeving als toetsingscriterium}

\subsubsection{Algemeen}

Hiervoor is de fysieke leefomgeving als samenhangcriterium aan de orde gekomen. Als de fysieke leefomgeving als samenhangcriterium wordt gehanteerd, ligt het echter wel voor de hand dat de wetgever ook nadenkt over de vraag of - het belang van - de fysieke leefomgeving ook kan worden gebruikt als toetsingscriterium voor het verlenen van een omgevingsvergunning die - anders dan de huidige omgevingsvergunning op basis van de Wabo - betrekking heeft op milieu, ruimtelijke ordening, water en natuur.

In de Wabo is een keus gemaakt tussen de toetsingskaders, die bekend zijn als model 3 en 4 . In de Wabo is gekozen voor model 3, waarin de verschillende toestemmingsstelsels procedureel zijn geïntegreerd, terwijl de inhoudelijke beoordeling nog gecoördineerd plaats vindt. Voor wat betreft de inhoudelijke beoordeling van een aanvraag om omgevingsvergunning betekent dit dat de toetsingskaders niet zijn geïntegreerd. Een omgevingsvergunningaanvraag wordt dus niet aan een integraal toetsingskader getoetst. Dat kan pas na realisatie van model 4, waarin ook de toetsingskaders zullen zijn geïntegreerd. ${ }^{236}$ In de motie Koopmans-Vermeij ${ }^{237}$ wordt de regering verzocht om nog in de lopende kabinetsperiode met voorstellen te komen voor integratie van toetsingskaders tot één toetsingskader, maar ten tijde van het afsluiten van dit onderzoek was deze motie nog niet uitgevoerd.

In deze paragraaf zal met name een antwoord worden gezocht op de vraag of het belang van de fysieke leefomgeving als algemene wettelijke taakomschrijving niet dusdanig ruim is geformuleerd dat daaraan geen specifieke bevoegdheidsgrondslag kan worden ontleend. Daarbij zal ik mij dan beperken tot de bevoegdheid van bestuursorganen om op basis van het toetsingscriterium 'belang van de fysieke leefomgeving' een vergunning al dan niet - onder voorvoorwaarden - te verlenen.

Integratie kan bijvoorbeeld ook betrekking hebben op plannen. Op dat gebied lijkt volgens Kramer de stap naar verdergaande integratie 'nu eindelijk gezet'. Hij doelt daarbij op de beleidsbrief Eenvoudig Beter, ${ }^{238}$ waarin de regering een integratie van zes planvormen overweegt (structuurvisie, milieubeleidsplan,

235 Driessen \& Schueler, Naar een integraler omgevingsbeleid 2011, p. 257.

236 Kamerstukken II 2006/07, 30 844, nr. 3, p. 20

237 Kamerstukken II 2007/08, 30 844, nr. 23,

238 Ministerie van IenM, Kabinetsbrief Eenvoudig Beter 2011. 
natuurbeleidsplan, waterplan, verkeers- en vervoersplan en eventueel het afvalbeheerplan). Kramer noemt dat een enorme stap in de goede richting voor de integrale benadering van de omgevingskwaliteit. ${ }^{239}$

\title{
3.3.6.2. Interne en externe integratie
}

\begin{abstract}
Algemeen
Alvorens in te gaan op integrale afweging van omgevingsbelangen (milieu, ruimtelijke ordening, natuur en water) zal ik enige woorden wijden aan interne en externe integratie van milieubelangen, waaraan in de juridische literatuur en in beleidsstukken in de afgelopen jaren veel aandacht is besteed. De gedachtevorming op dit terrein kan dienen als inspiratiebron voor het denken over integrale afweging van omgevingsbelangen.
\end{abstract}

\section{Interne integratie}

De gedachte achter de interne integratie van milieubelangen is dat alle milieubelangen met elkaar samenhangen en dus ook vragen om een samenhangende aanpak. Doel van zo'n samenhangende aanpak van de milieuproblematiek is een verbetering van het milieu als geheel. ${ }^{240}$ Die opvatting meen ik ook terug te vinden in de definitie die Faure geeft van (interne) integratie: "When using the term integration it is proposed to refer to the internal integration of environmental law, meaning the ecological goal that, in the decision-making and balancing of interests with respect to the permitted amounts and quality of pollutants, the total effects of pollution emanating from the licensed activity on the various components of the environment are taken into account. ${ }^{241}$

Interne integratie van milieubelangen wordt gewoonlijk geplaatst tegenover een sectorale benadering van milieubescherming, waarbij in verschillende wetssystemen de afweging van een bepaald milieubelang centraal staat, zoals het belang van de bescherming van de bodem in de Wet bodembescherming ${ }^{242}$ of het belang van het bestrijden en voorkomen van geluidhinder als gevolg van wegverkeer, ${ }^{243}$ railverkeer ${ }^{244}$ en industrie ${ }^{245}$ in de Wet geluidhinder (Wgh). Een sectorale benadering kan het risico inhouden van afwenteling van milieuproblemen van de ene naar de andere sector. Dat

239 Kramer, Op naar een integrale benadering van het milieubeleid 2011

240 Zie ook Kleijs-Wijnnobel \& De Leeuw, Interne integratie 1998, p. 140.

241 Faure, The Harmonization, Codification and Integration of Environmental Law: A Search for Definitions 2000, p. 181.

242 Zo kunnen GS bepalen dat een sanering in fasen wordt uitgevoerd als het belang van de bescherming van de bodem zich daartegen niet verzet (art. 38 lid $3 \mathrm{Wbb}$ ).

243 Zie art. 68-104 Wgh.

244 Zie art. 105-107 Wgh

245 Zo bepaalt art. 40 lid 1 Wgh: 'Indien bij de vaststelling van een bestemmingsplan aan gronden een zodanige bestemming wordt gegeven dat daardoor een industrieterrein ontstaat, wordt daarbij tevens een rond het betrokken terrein gelegen zone vastgesteld, waarbuiten de geluidsbelasting vanwege dat terrein de waarde van $50 \mathrm{~dB}(\mathrm{~A})$ niet te boven mag gaan.' 
laat zich illustreren aan de hand van het plaatsen van een installatie die dient om verontreiniging van de lucht te verminderen, maar wel meer energie verbruikt. De milieuvoordelen voor de sector lucht worden dan afgewenteld op de sector energie. ${ }^{246,247}$

Met interne integratie op het terrein van het milieu wordt zoals gezegd een milieudoel gediend. Interne integratie van milieubelangen is volgens Faure zelfs 'crucial, to guarantee optimal reduction of environmental harm, that the administrative authorities can examine the total effects of the overall pollution caused by an entity. ${ }^{248} \mathrm{Mij}$ lijkt het een juist uitgangspunt om alle sectorale belangen in de integrale afweging te betrekken om het milieu als geheel daarvan te laten profiteren. Dit betekent mijns inziens echter nog niet per se, dat elk sectoraal belang bij een integrale afweging steeds optimaal zal profiteren.

Het hiervoor gegeven voorbeeld van de nageschakelde installatie illustreert dat. Als die wordt voorgeschreven vanuit het sectorale belang van een goede luchtkwaliteit, dan wordt binnen de sector luchtkwaliteit het nadeel voor de sector energie- of $\mathrm{CO}_{2}$-besparing als het ware op de koop toegenomen. $\mathrm{Er}$ wordt dus een keus gemaakt. Het voordeel van de interne integratie van milieubelangen zal gewoonlijk zijn en moet mijns inziens ook zijn, dat een sectoraal belang - hoe belangrijk ook - niet wordt verabsoluteerd. Die verabsolutering kan immers leiden tot afwenteling op een ander, binnen de afwentelende sector op dat moment als minder prioritair geziene sector.

Drupsteen wijst er overigens terecht op dat een sectorale aanpak zeker voordelen kan hebben en integratie geen doel op zichzelf moet worden. Aan de vooravond van de Wet milieubeheer noemde hij integratie van milieuwetgeving en de ontwikkeling van die wet 'nuttig en noodzakelijk'. Hij waardeerde dit proces positief en noemde het een moeilijk proces dat veel energie, denkkracht en doorzettingsvermogen vergt. Hij plaatste daarbij wel de kanttekening dat er iets te snel de indruk wordt gewekt dat sectoraal milieubeleid niet veel meer oplevert dan het verschuiven van de problemen. Volgens Drupsteen is met de sectorale wetgeving en het sectorale beleid veel bereikt en ook voor de toekomst verwachtte hij dat op onderdelen van het milieubeleid met een sectorale aanpak nog een stuk verder kan worden gekomen. Niet alle milieuproblemen vragen per definitie om een geïntegreerde aanpak, dus moet zorgvuldig worden afgewogen 'voor welke problemen we ons de extra inspanning van het totstandbrengen van geïntegreerd

246 Zie in dit verband ook het in par. 3.3.5 genoemde voorbeeld in het Explanatory Memorandum bij de IPPC-richtlijn.

247 Zie in dit verband ook De Putter, Verdroging van natuurgebieden vraagt integrale aanpak 1995 Koeman, Integratie van milieudoelstellingen in de ruimtelijke ordening 1994.

248 Faure, The Harmonization, Codification and Integration of Environmental Law: A Search for Definitions 2000, p. 181 
beleid en geïntegreerde wetgeving moeten getroosten en voor welke dat niet per se hoeft.' Deze afweging ontbreekt wel eens, aldus Drupsteen, waardoor integratie van wetgeving dan een doel op zichzelf wordt, terwijl het in zijn ogen een middel is om te komen tot beter hanteerbare wetgeving en beter beleid. ${ }^{249}$ Ik deel die opvatting.

\section{Externe integratie}

Speelt interne integratie van milieubelangen zich af binnen de sfeer van milieubelangen, van externe integratie van milieubelangen wordt in de literatuur gesproken als het gaat om integratie van milieubelangen binnen de besluitvorming op andere beleidsterreinen dan het milieubeleid. ${ }^{250}$ Bij externe integratie gaat het volgens Faure om 'the influence of environmental policy on other policy areas. ${ }^{, 251}$ In gelijke zin bedoelen Dhondt \& Uylenburg met externe integratie de integratie binnen de besluitvorming op andere terreinen dan het milieubeleid. Milieuoverwegingen zouden bij toepassing van dit beginsel een rol moeten spelen op terreinen als ruimtelijke ordening, ontwikkelingssamenwerking, landbouw, vervoer, handel, enzovoort. ${ }^{252} \mathrm{Bij}$ externe integratie is sprake van eenrichtingsverkeer. Het gaat erom dat in andere wetssystemen dan op het terrein van milieuwetgeving rekening wordt gehouden met milieubelangen, niet per se andersom.

\subsubsection{Integrale afweging van omgevingsbelangen}

De gedachte achter de integrale afweging van omgevingsbelangen is dat alle omgevingsbelangen met elkaar samenhangen en dus ook vragen om een samenhangende aanpak. Doel van zo'n samenhangende aanpak is een verbetering van de omgeving als geheel. Gaat het bij interne integratie van milieubelangen om het afwegen van milieubelangen, een integrale afweging van omgevingsbelangen is meeromvattend. Het gaat er namelijk om dat alle omgevingsbelangen, dus de belangen van milieu, ruimtelijke ordening, natuur en water integraal worden afgewogen.

249 Drupsteen, Relativiteit van integratie 1991, p. 63.

250 Verschuuren, Externe integratie 1998, p. 167. Zie ook het Themanummer: externe integratie van M en R met bijdragen van J.H. Jans over externe integratie in het Gemeenschapsrecht, R. Uylenburg over een milieugericht produktenbeleid, H.P.A.M. van Arendonk over ecologisering van het belastingstelsel en N.S.J. Koeman over de ruimte die de WRO biedt tot integratie van milieudoelstellingen in de ruimtelijke ordening. Volgens de redactie van $\mathrm{M}$ en $\mathrm{R}$ geeft het streven naar duurzame ontwikkeling een krachtige impuls aan externe integratie ( $\mathrm{M}$ en $\mathrm{R}$, Externe integratie 1994). Dhondt, Integration of Environmental Protection into other EC Policies 2003 heeft onderzocht in hoeverre art. 6 EG-Verdrag dwingt tot het aanpassen van Europees beleid in het belang van Europees milieubeleid.

251 Faure, The Harmonization, Codification and Integration of Environmental Law: A Search for Definitions 2000, p. 189.

252 Dhondt \& Uylenburg, Het beginsel van externe integratie 2001, p. 89. 
De roep om een integrale aanpak van omgevingsvraagstukken bestaat al lang. Zo schrijft Menninga in 1997 een integraler aanpak van omgevingsvraagstukken toe te juichen. Hij denkt daarbij onder meer aan onderwerpen als mobiliteit, duurzaam landelijk gebied, duurzame stedelijke ontwikkeling en grote infrastructurele werken. ${ }^{253}$ In hetzelfde jaar heb ik in mijn preadvies voor de Vereniging voor wetgeving en wetgevingsbeleid aangegeven dat sinds het begin van de jaren tachtig in het bedrijfsleven ontwikkelingen op gang zijn gekomen die gemeen hebben dat ze uitgaan van een integrale benadering van de milieuproblematiek: duurzame ontwikkeling, bedrijfsmilieuzorg, milieuconvenanten en integratie van economie en milieu. ${ }^{254}$

In een door het samenhangcriterium fysieke leefomgeving bepaald wetssysteem zou een dergelijke afweging tot uitdrukking kunnen komen door het belang van de fysieke leefomgeving als toetsingskader te introduceren voor het beslissen omtrent een omgevingsvergunning voor een project dat bestaat uit één of meer activiteiten. Anders dan bij externe integratie van milieubelangen is er geen sprake van eenrichtingsverkeer. Er dient niet alleen op het gebied van ruimtelijke ordening, natuur en water rekening te worden gehouden met milieubelangen, maar er moet op de terreinen van milieu, ruimtelijke ordening, natuur en water over en weer rekening gehouden worden met die belangen.

Een niet onbelangrijke, maar buiten mijn onderzoek vallende vraag is de vraag die Gilhuis zich in 2004 al stelde: hoe integraal kunnen wij denken? Hij maakt gewag van een onderzoek waarbij het heel opvallend was dat er ondanks alle discussie onder politici, beleidsmakers en wetenschappers over 'integratie' en 'omgevingsbeleid' in de praktijk op alle fronten nog altijd erg sectoraal of verkokerd wordt gedacht. Zo wordt meestal een van de drie sporen, ruimtelijke ordening, natuurbescherming of milieubeheer, dominant geacht voor de bescherming van natuurwaarden. Gilhuis pleit dan ook terecht voor het in het vizier houden van de spankracht van de uitvoerders. ${ }^{255}$ Uylenburg stelt voor om te onderzoeken of het uitvoeren van een integrale toets praktisch uitvoerbaar is. ${ }^{256}$

\subsubsection{Het specialiteitsbeginsel}

De vraag kan worden gesteld of een integrale afweging van omgevingsbelangen niet te ruim is als kader voor besluitvorming. Mij lijkt dat die vraag adequaat kan worden benaderd via het specialiteitsbeginsel. ${ }^{257}$ Daarbij zal

253 Menninga, Integraal omgevingsbeleid? 1997, p. 1.

254 Van den Broek, Integrale benadering verdient integrale milieuvergunning 1997.

255 Gilhuis, Over integraal besluiten 2004, p. 205-206 en Gilhuis \& Van Gestel, Hoe groen is de Wm? 2002, p. 386

256 Uylenburg, Het omgevingsrecht van de toekomst: kiezen en delen 2010, p. 212.

257 Schlössels meent dat het rechtsstatelijke leerstuk van het specialiteitsbeginsel op deze plaats de juridisch-technische discussies over de coördinatie en/of integratie van vergunningstelsels raakt (Schlössels, Het Specialiteitsbeginsel 1998, p. 132). 
ik uitgaan van de definitie die Schlössels daaraan heeft gegeven. ${ }^{258}$ Volgens Schlössels brengt het specialiteitsbeginsel met zich dat een administratieve wet uitsluitend op haar eigen afgebakende terrein mag worden toegepast en bijgevolg niet mag dienen tot het bereiken van daarbuiten gelegen doeleinden. ${ }^{259}$ Bovendien mogen de in die wet neergelegde bestuursbevoegdheden niet voor een ander doel worden aangewend dan voor het doel dat de wetgever bij de toekenning van deze bevoegdheden voor ogen stond. ${ }^{260}$ Scheltema meent dat het specialiteitsbeginsel is verbonden met de legaliteitseis. Het beginsel brengt volgens hem mee, dat bij het hanteren van een bevoegdheid in de afweging geen andere belangen mogen worden betrokken dan de belangen met het oog waarop de bevoegdheid is verleend. ${ }^{261}$

Schlössels noemt vijf perspectieven van waaruit zijns inziens het belang van 'specialiteit' van bestuursbevoegdheid kan worden verdedigd. ${ }^{262}$ Die zal ik hierna kort toelichten in het licht van de vraag die mij bezig houdt.

Het democratisch perspectief brengt mee dat de wetgever bestuursbevoegdheden die hij toedeelt aan een bestuurlijke organisatie zo nauwkeurig als mogelijk inhoudelijk zal dienen af te bakenen. Doordat het specialiteitsbeginsel eist dat bestuursbevoegdheden door de wetgever enkel worden toebedeeld ter behartiging van specifieke publiekrechtelijke belangen (de eis van publieke doelbinding), ondersteunt dit beginsel het democratisch postulaat. Bij de wetgever berust binnen de democratische rechtsstaat immers het primaat inzake de eenzijdig gerichte publieke rechtsvorming binnen de staat. ${ }^{263}$

Het legitimiteitsperspectief in ruime zin betekent dat de mate van specialiteit van een (wettelijke) bevoegdheidsnorm volgens Schlössels mede bepalend is voor de kenbaarheid, voorzienbaarheid en voorspelbaarheid van de publieke rechtsvorming voor de rechtssubjecten. Naarmate de toepassingscondities van een competentie concreter zijn omschreven kunnen rechtssubjecten zich een beter beeld vormen van hun rechtspositie zoals die kan ontstaan, of ontstaat, nadat bevoegdheidsuitoefening heeft plaatsgevonden. ${ }^{264}$

258 Ik volg hier Schlössels, aangezien zijn opvattingen een goed licht werpen op de vraag die mij hier bezighoudt. Dat neemt niet weg, dat er veel nuances bestaan in de benadering van het specialiteitsbeginsel. Daarvoor verwijs ik naar Schlössels, Het Specialiteitsbeginsel 1998. Van Hall besteedt aandacht aan de opvattingen van Stroink, Scheltema en Drupsteen ten aanzien van het specialiteitsbeginsel (Van Hall, Belangenafweging in de wet op de fysieke leefomgeving 2009, p. 141-144).

259 Schlössels, Het Specialiteitsbeginsel 1998, p. 1. Hij ontleent deze algemene definitie naar eigen zeggen aan Van der Burg/Cartigny/Overkleeft-Verburg, Rechtsbescherming tegen de overheid, Nijmegen 1985, vijfde druk, p. 109-110.

260 Ten aanzien van dit onderdeel verwijst Schlössels naar F.A.M. Stroink, Algemeen bestuursrecht. Een inleiding, tweede druk, Zwolle 1996, p. 13

261 Scheltema, Van rechtsbescherming naar een volwaardig bestuursrecht 1996, p. 1359

262 Schlössels, Het Specialiteitsbeginsel 1998, p. 127.

263 Schlössels, Het Specialiteitsbeginsel 1998, p. 127-128.

264 Schlössels, Het Specialiteitsbeginsel 1998, p. 128-129. 
Het rechtsbeschermingsperspectief houdt in dat de waarborgfunctie van bevoegdheidsnormen toeneemt naarmate deze normen in een hogere mate inhoudelijk zijn gespecificeerd. De bevoegdheidsnorm is volgens Schlössels immers het referentiekader waaraan de bevoegdheidsuitoefening primair op geldigheid getoetst dient te worden. De bevoegdheidsnorm vervult deze functie voor de (administratieve) rechter. Een bevoegdheid die onvoldoende geconditioneerd is kan deze functie niet op een adequate wijze vervullen. ${ }^{265}$

Het organisatieperspectief heeft te maken met het feit dat de werking van het specialiteitsbeginsel zijn neerslag ook vindt in het bestuurlijke organisatierecht. Ieder bestuursorgaan heeft binnen de statelijke structuur van organen een eigen afgebakende werkkring waarbinnen het zijn bestuursactiviteit dient te ontplooien. Deze werkkring zal volgens Schlössels primair moeten worden afgeleid uit de context van de wet op grond waarvan het betreffende bestuursorgaan in het leven is geroepen. Een duidelijke afbakening van bestuursverantwoordelijkheid (de ambtsplicht) vormt tevens een duidelijke instructie aan het bestuur om niet te treden in de behartiging van publiekrechtelijke belangen die door de wetgever aan andere onderdelen van de bestuursorganisatie zijn toevertrouwd. ${ }^{266}$

Het doelmatigheids- en besluitvormingsperspectief vloeit volgens Schlössels voort uit het organisatieperspectief. Door de werking van het specialiteitsbeginsel wordt de bestuurlijke belangenafweging ingekaderd en gestructureerd. Doordat het bestuur deze 'afweging van rechtsbelangen' opzet vanuit de door de wetgever gedetermineerde speciale publiekrechtelijke belangen, wordt voorkomen dat de administratie, die een bepaalde maatschappelijke activiteit wil tegenhouden, van argument naar argument kan verspringen. Dit perspectief is gunstig voor de burger. Voor de bestuursorganisatie voorkomt het overbelasting doordat de te behartigen publiekrechtelijke belangen vooraf door de wetgever zijn vastgesteld en niet meer in algemene zin tegen elkaar behoeven te worden afgewogen. De bestuurlijke afweging van belangen is daarom gespecificeerd, doorzichtig en juist daarom doelmatig. ${ }^{267}$

In de weinige passages die Schlössels in zijn dissertatie wijdt aan coördinatie en integratie constateert hij dat niet kan worden ontkend dat de gefragmenteerde structuur van bestuursbevoegdheden voor burger en bestuur bepaalde ongemakken voor de besluitvorming met zich brengt. ${ }^{268}$ Hij is echter van oordeel dat dergelijke besluitvormingsproblemen niet moeten worden ondervangen door het specialiteitsbeginsel te relativeren of zelfs helemaal overboord te zetten. Hij adviseert om te kiezen voor vanuit rechtsstatelijk oogpunt minder bedenkelijke wegen. 
Evenals Schlössels meen ik, dat het specialiteitsbeginsel in het omgevingsrecht onverkort van toepassing kan en moet blijven. De belangrijkste reden daarvoor lijkt mij het door hem genoemde legitimiteitsperspectief van het specialiteitsbeginsel. Zoals ik eerder in deze studie heb laten zien, zijn kenbaarheid, voorzienbaarheid en voorspelbaarheid van de publieke rechtsvorming van cruciaal belang voor de gebruikers van het omgevingsrecht. Het specialiteitsbeginsel kan daaraan een belangrijke bijdrage leveren naarmate 'de toepassingscondities van een competentie concreter zijn omschreven.'269 Dit standpunt vindt bijval in de literatuur. Zo stelt Geelhoed dat de functie van het milieurecht slechts goed tot zijn recht kan komen als de normen voldoende houvast bieden, zowel voor het bestuur als voor de justitiabele. ${ }^{270}$ Gilhuis meent dat het specialiteitsbeginsel vraagt om specifieke en begrensde toedelingen van bevoegdheden aan het bestuur. Hij vraagt zich af of de burger niet moet en wil worden beschermd tegen een overheid die over te algemene bevoegdheden beschikt en daardoor als het ware zelf de norm kan stellen. ${ }^{271}$ Eijlander vraagt zich af hoe het is gesteld met de kenbaarheid van open, meer globale normen die nader invulling krijgen in het maatschappelijk verkeer. De schaduwzijde van de flexibiliteit is volgens hem onder meer de beperkte voorspelbaarheid van het overheidsoptreden. ${ }^{272}$

\subsubsection{Concretisering van integrale afweging van omgevingsbelangen}

Met name het legitimiteitsperspectief van het specialiteitsbeginsel brengt mijns inziens met zich dat een wetssysteem na bundeling duidelijk moet aangeven met welke belangen van de fysieke leefomgeving in welke gevallen rekening moet worden gehouden en in welke mate dat het geval moet zijn. Daaraan staat mijns inziens niet in de weg een breed afwegingskader zoals het belang van de fysieke leefomgeving. Met een dergelijk breed afwegingskader brengt de wetgever expliciet tot uitdrukking dat een volledig integrale afweging van omgevingsbelangen is toegestaan. In 2003 stelde ik mij nog op het standpunt dat zulks noodzakelijk is om het specialiteitsbeginsel te doorbreken, doch thans ben ik van oordeel dat het hier gaat om een invulling van het specialiteitsbeginsel. ${ }^{273}$ Ook Van Hall meent dat het specialiteitsbeginsel geen geweld wordt aangedaan wanneer in een Wet op de fysieke omgeving een breed belangenkader wordt opgenomen. ${ }^{274}$ Als ik hem goed begrijp, zou het specialiteitsbeginsel anders een gewenste brede belangenafweging in de weg kunnen staan. Dat volgt mijns inziens uit het feit dat hij zijn conclusies trekt naar aanleiding van het waterrecht waar de praktijk een

269 Schlössels, Het Specialiteitsbeginsel 1998, p. 128.

270 Geelhoed, Knopen zonder draden 2006, p. 592.

271 Gilhuis, Over integraal besluiten 2004, p. 205.

272 Eijlander, De verbindende wetgever 2000, p. 16.

273 Van den Broek, De kroonjuwelen van VROM 2005, p. 582.

274 Van Hall, Belangenafweging in de wet op de fysieke leefomgeving 2000, p. 152. Zie ook Van Hall, Het specialiteitsbeginsel in het waterstaatsrecht (oratie) 1995. 
breed toetsingskader nodig had, maar de wetgever dat niet had gereguleerd. ${ }^{275}$ Hij noemt in dit verband belangen als het milieu, een goede ruimtelijke ordening, een duurzame ontwikkeling, integraal waterbeheer en een duurzaam natuur- en landschapsbeheer. ${ }^{276}$ In zijn afscheidsrede noemt hij art. 2.1 Wtw één van de mooiste artikelen - gezien vanuit het perspectief van zijn betoog - dat de doelstellingen van de Waterwet regelt en daarmee inhoud geeft aan het specialiteitsbeginsel - het onderwerp van zijn oratie in $1995 .{ }^{277}$

Het belang van de fysieke leefomgeving integreert alle belangen die bij een volledige afweging van omgevingsbelangen volgens de wetgever moeten worden afgewogen. Nijmeijer \& Soppe spreken hier van materiële integratie: normen die thans afzonderlijk bestaan, gaan op in de nieuwe norm 'belang van de fysieke leefomgeving,. ${ }^{278}$ Dat neemt echter niet weg, dat ik meen dat louter een dergelijke algemene en weinig bepaalde omschrijving geen recht doet aan de door het specialiteitsbeginsel in het legitimiteitsperspectief in het vooruitzicht gestelde kenbaarheid, voorzienbaarheid en voorspelbaarheid van de besluitvorming. Mij lijkt het reeds om die reden beter om het belang van de fysieke leefomgeving verder te concretiseren.

Deze gedachte vindt bijval in de literatuur. Volgens Struiksma is een verdere integratie van toetsingskaders op vergunningenniveau onhaalbaar. Eén criterium zou zo vaag en veelomvattend zijn dat het voor een aanvrager volstrekt onvoorspelbaar zou worden of hij een vergunning zou kunnen krijgen. ${ }^{279} \mathrm{Nij}$ meijer \& Soppe hebben het idee dat materiële integratie alleen te bereiken is door de kwantitatieve normen te vervangen door een kwalitatieve norm, iets wat de wetgever volgens hen beslist niet zou moeten willen. ${ }^{280}$ Schueler schrijft dat een vage overkoepelende norm de onvoorspelbaarheid vergroot. Zo laat de norm 'een goede ruimtelijke ordening' volgens hem zien dat de rechter concrete belangen en daarop toepasselijke deelnormen nodig heeft om te kunnen oordelen of de vage overkoepelende norm geschonden is. ${ }^{281}$ Michiels meent dat een containerbegrip als duurzame leefomgeving leidt tot een schijnvoordeel van integratie van toetsingskaders vanwege het nadeel dat daarmee geen houvast meer wordt geboden, hetgeen wel het geval is met afzonderlijk geregelde en beschermde belangen. ${ }^{282}$

Om de afweging van alle door hem aangewezen belangen van de fysieke leefomgeving in te kaderen stel ik voor dat de wetgever een aantal uitgangspunten hanteert.

275 Van Hall, Belangenafweging in de wet op de fysieke leefomgeving 2000, p. 152.

276 Van Hall, Belangenafweging in de wet op de fysieke leefomgeving 2000, p. 153.

277 Van Hall, Het recht als waterdrager 2007, alinea 12. Zie ook Drupsteen, Het specialiteitsbeginsel en de Waterwet 2006.

278 Nijmeijer \& Soppe, Alles draait om eenvoud 2011, p. 429.

279 Struiksma, Simpel toch? 2010, p. 182 en 186.

280 Nijmeijer \& Soppe, Alles draait om eenvoud 2011, p. 432.

281 Schueler, Of heeft u liever negatieve evenredigheid? 2012, p. 241.

282 Michiels, Het schijnvoordeel van integrale wetgeving 2004. 
In de eerste plaats moet de wetgever zelf aangeven met welke belangen in geval van welke activiteiten bij een volledig integrale afweging van omgevingsbelangen rekening moet worden gehouden. Daarbij dient ten minste rekening te worden gehouden met de grenzen die Europeesrechtelijke regels stellen. ${ }^{283}$

Dat zou kunnen door een limitatieve opsomming op te nemen van onder meer hetgeen thans in de artikelen 2.10 tot en met 2.20 Wabo is opgenomen als toetsingskader voor een omgevingsvergunning. Voor de activiteit 'bouwen' betekent dat bijvoorbeeld dat - samengevat - moet worden voldaan aan het geldende bestemmingsplan, het Bouwbesluit, de gemeentelijke Bouwverordening en het belang van redelijke eisen van welstand. ${ }^{284}$ Ook Schueler geeft aan niet te geloven in een algemene overkoepelende norm in de nieuwe omgevingswet. Hij vraagt zich af wat de rechter ermee kan. De rechterlijke toetsing krijgt volgens hem meer betekenis als zij wordt toegespitst op de beoordeling van deelbelangen, zoals geluid, externe veiligheid en bepaalde milieukwaliteitseisen. ${ }^{285}$

Dit uitgangspunt biedt twee belangrijke voordelen. Een eerste voordeel is, dat zo kan worden voorkomen, dat een verschuiving plaatsvindt van wettelijke normen naar pseudo-regelgeving, waarvoor Struiksma, Nijmeijer \& Soppe, ${ }^{286}$ alsmede Driessen \& Schueler terecht waarschuwen.

Struiksma meent dat een verdere integratie van toetsingskaders op vergunningenniveau onhaalbaar is. Volgens hem is één criterium zo vaag en veelomvattend dat het voor een aanvrager volstrekt onvoorspelbaar zou worden of hij een vergunning zou kunnen krijgen. Het ligt dan voor de hand dat dit criterium zou worden ingevuld door richtlijnen en beleidsregels, waarin naar alle waarschijnlijkheid de nu nog in wettelijke voorschriften vastgelegde regels in al dan niet aangepaste vorm zouden terugkeren. Het resultaat zou een conglomeraat aan regels zijn met beduidend minder democratische legitimatie en slechtere controleerbaarheid. ${ }^{287}$ Driessen \& Schueler menen dat het beleid moet zijn gericht op integrale bescherming en verbetering van de leefomgevingskwaliteit. Het centrale uitgangspunt, de leefomgevingskwaliteit, behoort volgens hen geen juridisch criterium te zijn, maar richtinggevend voor het beleid. Als de wetgever

283 Zie ook Backes, Naar een integrale omgevingswet 2010, p. 5. Anders dan Uylenburg meen ik dat deze Europeesrechtelijke eisen een volledig integrale toetsing van vergunningaanvragen niet belemmeren, doch beperken. Uylenburg noemt als voorbeeld de eis dat een vergunning voor een IPPC-inrichting niet mag worden verleend als daarmee niet kan worden bereikt dat de beste beschikbare technieken worden toegepast. Ik zou hier niet willen spreken van een belemmering, maar van een uit het Europese recht voortvloeiende beperking (Uylenburg, Het omgevingsrecht van de toekomst: kiezen en delen 2010, p. 212). Zie ook Uylenburg, De richtlijn industriële emissies 2011. Uylenburg bespreekt daarin de gevolgen van deze richtlijn voor de mogelijkheden om flexibel met het instrument vergunning om te gaan.

284 Art. 2.10 Wabo.

285 Schueler, Of heeft u liever negatieve onevenredigheid? 2012, p. 241.

286 Nijmeijer \& Soppe, Alles draait om eenvoud 2011, p. 432.

287 Struiksma, Simpel toch? 2010, p. 182 en 186. 
er wel een rechtsnorm van zou willen maken, dan doemt volgens de auteurs het grote probleem op dat de rechter er niet goed aan kan toetsen zonder die toetsing op deelbelangen toe te spitsen. ${ }^{288}$

Door de deelbelangen te koppelen aan activiteiten wordt bovendien voorkomen dat één ruim geformuleerd integraal toetsingskader ertoe kan leiden dat activiteiten op veel meer aspecten beoordeeld moeten worden dan nu het geval is. Dat is het tweede voordeel.

De voorgenomen Omgevingswet zal uitgaan van toetsingskaders die per activiteit verschillen. Er wordt geen alomvattende materiële integratie van de toetsingskaders beoogd omdat één ruim geformuleerd integraal toetsingskader er volgens het kabinet toe kan leiden dat activiteiten op veel meer aspecten beoordeeld moeten worden dan nu het geval is. Een ruim en veelomvattend toetsingskader voor alle gevallen zou volgens het kabinet ten koste gaan van de rechtszekerheid van de initiatiefnemers en belanghebbenden en een gerichte toetsing door de rechter. ${ }^{289}$

In de tweede plaats moeten alle door de wetgever aangewezen omgevingsbelangen vrij kunnen worden afgewogen mits wordt gebleven binnen vooraf bepaalde randvoorwaarden. ${ }^{290}$ Daarbij zijn alle omgevingsbelangen in beginsel gelijkwaardig. Ik acht het niet juist om van een of meer bepaalde belangen reeds op voorhand aan te geven dat die minder zwaar zouden moeten wegen, zoals Van Hall \& Van Rijswick lijken te doen als het gaat om economische belangen. ${ }^{291}$ Als bijvoorbeeld economische belangen binnen het belang van de fysieke leefomgeving door de wetgever als af te wegen belangen gelden, dan dienen die belangen in beginsel gelijkwaardig te zijn aan andere belangen. ${ }^{292}$ Wil de wetgever dat niet, dan dient hij aan een dergelijk belang restricties te verbinden. Dergelijke restricties moeten het resultaat zijn van een politieke discussie. Daarbij moet worden voorkomen dat spanning ontstaat met duurzaamheid, waarbij rekening wordt gehouden met ecologische, economische en sociale aspecten. ${ }^{293}$ Welke belangen in concreto de boventoon voeren binnen de door de wetgever

288 Driessen \& Schueler, Naar een integraler omgevingsbeleid 2011, p. 272.

289 Ministerie van IenM, Kabinetsbrief stelselherziening omgevingsrecht 2012, bijlage 3, par. 5.2

290 Zie ook Van den Broek, De Kroonjuwelen van VROM 2003.

291 Zie ook Van Wijmen, Water en natuur 2006, p. 368 waar hij stelt dat de waarde natuur vóór gaat op het belang water, zeker als er andere mogelijkheden bestaan om ruimte voor de rivier te maken.

292 Geelhoed acht kenmerkend voor het milieurecht dat het in sterke mate arbitreert tussen enerzijds de bescherming van het milieu als bijzonder publiek belang en anderzijds andere, over het algemeen positief beoordeelde, economische of andere activiteiten. Er wordt met milieuwetgeving paal en perk gesteld aan op zichzelf niet negatief te beoordelen vrijheden, ten behoeve van de bescherming van het algemene milieubelang (Geelhoed, Knopen zonder draden 2006, p. 592).

293 Duurzame ontwikkeling is ontwikkeling die aansluit op de behoeften van het heden zonder het vermogen van toekomstige generaties om in hun eigen behoeften te voorzien in gevaar te brengen, aldus de definitie van de VN-commissie Brundtland uit 1987 (World Commission on Environment and Development, Our Common Future, Oxford: Oxford University Press 1987). 
gestelde grenzen zal gewoonlijk een kwestie van politieke afweging zijn. Hiermee kan mijns inziens ook worden voorkomen dat het belang dat de zwakste pleitbezorgers kent om die reden het onderspit delft, waartegen Uylenburg terecht waarschuwt. ${ }^{294}$

Zo spelen economische belangen uitdrukkelijk een rol bij de vaststelling van beste beschikbare technieken. Het gaat daarbij immers om 'voor het bereiken van een hoog niveau van bescherming van het milieu meest doeltreffende technieken om de emissies en andere nadelige gevolgen voor het milieu, die een inrichting kan veroorzaken, te voorkomen of, indien dat niet mogelijk is, zoveel mogelijk te beperken, die - kosten en baten in aanmerking genomen economische en technisch haalbaar in de bedrijfstak waartoe de inrichting behoort, kunnen worden toegepast, en die voor degene die de inrichting drijft, redelijkerwijs in Nederland of daarbuiten verkrijgbaar zijn.' ${ }^{295}$ Bij de aanwijzing van Natura 2000-gebieden mogen juist uitsluitend wetenschappelijke, ornithologische en andere ecologische criteria worden gehanteerd. Dwingende redenen van openbaar belang, waaronder sociaal-economische belangen, zijn bij de aanwijzing niet aan de orde. ${ }^{296}$ Schueler wijst in dit verband nog op de sinds 1994 in de Awb neergelegde evenredigheidsnorm. ${ }^{297}$ Die evenredigheidsnorm betekent onder meer de verplichting om alle rechtstreeks bij een besluit betrokken belangen af te wegen, tenzij de wetgever anders heeft beslist.

In de derde plaats zou aandacht moeten worden besteed aan de inflexibiliteit die zou ontstaan als een besluit nimmer mag afwijken van concrete normen, zelfs niet als dat het belang van de fysieke leefomgeving als geheel ten goede zou komen. Van Hall \& Van Rijswick pleiten ervoor om in zulke gevallen afwijking van grenswaarden toch toe te staan als elders compensatie in natura wordt geboden. Ook mij komt het voor dat de wetgever waar mogelijk een dergelijke voorziening zou kunnen overwegen, mits hij daarbij aangeeft onder welke condities een dergelijke compensabele afwijking is toegestaan.

De door Borgers \& Van der Heijden voorgestelde algemene hardheidsclausule acht ik te algemeen in het kader van de kenbaarheid, voorzienbaarheid en voorspelbaarheid van de besluitvorming. Zij stellen voor om een hardheidsclausule en een regel inzake voordeelsaansprakelijkheid op te nemen in artikel 3:4 Awb. ${ }^{298}$ Als hardheidsclausule stellen zij voor: 'Het bestuursorgaan weegt de rechtstreeks bij het besluit betrokken belangen af, en de beperkingen die

294 Uylenburg, Het omgevingsrecht van de toekomst: kiezen en delen 2010, p. 212.

295 Art. 1.1 lid 1 Wabo.

296 Woldendorp, Teksten en toelichting Wetgeving natuurbescherming 2011, p. 158 en de daar genoemde jurisprudentie van het Hof van Justitie van de Europese Gemeenschappen (na 1 december 2009: Europese Unie).

297 Schueler, Of heeft u liever negatieve evenredigheid? 2012, p. 241. Art. 3:4 Awb: 1. Het bestuursorgaan weegt de rechtstreeks bij het besluit betrokken belangen af, voor zover niet uit een wettelijk voorschrift of uit de aard van de uit te oefenen bevoegdheid een beperking voortvloeit. 2. De voor een of meer belanghebbenden nadelige gevolgen van een besluit mogen niet onevenredig zijn in verhouding tot de met het besluit te dienen doel.

298 Borgers \& Van der Heijden, Het recht op duurzame gebiedsexploitatie 2010, p. 44. 
voortvloeien uit wettelijke voorschriften of uit de aard van de uit te oefenen bevoegdheden.'299 De voordeelsaansprakelijkheid willen zij als volgt vorm geven: 'De gevolgen van een besluit voor een of meer belanghebbenden mogen niet onevenredig nadelig of voordelig zijn in verhouding tot de met het besluit te dienen doelen.' ${ }^{300}$ Een dergelijke algemene regeling zou mijns inziens verkeerde verwachtingen wekken, aangezien met name Europeesrechtelijke randvoorwaarden tot een systeem zullen leiden van strikte deelbelangen waaraan niet kan worden getornd en belangen die zich binnen een bepaalde bandbreedte mogen bewegen. ${ }^{301}$

Als ik me niet vergis werken zij hetzelfde concept elders uit tot een nieuwe juridische maatstaf van positieve evenredigheid. Daarmee kan de Omgevingswet volgens hen evenredig de ruimte bieden aan realisatie van creatieve en duurzame projecten, waarvoor het omgevingsrecht geen onnodige hindernis mag zijn. ${ }^{302}$ De regering heeft de introductie van het uitgangspunt van positieve evenredigheid aangekondigd om bestuurlijke afwegingsruimte te scheppen voor projecten die kunnen bijdragen aan de gewenste kwaliteit van de leefomgeving maar thans niet door kunnen gaan, omdat aan één of meerdere sectorale normen niet wordt voldaan. Hierbij wordt een brede integrale afweging per project of gebied gemaakt. Indien het belang van de leefomgeving zich er niet tegen verzet, kan van individuele normen worden afgeweken, mits bepaalde belangen hierdoor niet onevenredig benadeeld worden. Niet alle normen komen hiervoor in aanmerking. Bij of krachtens de wet zal worden aangegeven welke normen niet afweegbaar zijn. Dwingende Europese normen, zoals bijvoorbeeld die voor luchtkwaliteit, zijn in ieder geval uitgezonderd van toepassing van het beginsel. ${ }^{303}$ Volgens Schueler is hier sprake van een misleidende term. Als de evenredigheidsnorm (art. 3:4 Awb) goed wordt toegepast, pakt die volgens hem positief uit. Hij ziet in de nieuwe figuur dan ook - terecht, lijkt mij - een extra afwijkingsmogelijkheid. ${ }^{304}$

\subsubsection{Integrale afweging is geen uitruil}

Hiervoor is gesteld dat de wetgever zo concreet mogelijk moet aangeven met welke omgevingsbelangen in welke gevallen in welke mate rekening moet worden gehouden. Daarbij dient nog een belangrijke vraag te worden beantwoord, te weten hoe kan worden voorkomen dat uitruil plaatsvindt van af te wegen belangen op een zodanige manier dat een door de wetgever als zodanig aangewezen beschermenswaardig omgevingsbelang als gevolg van een werkelijk integrale afweging het onderspit delft?

Die omgevingsbelangen behoren naar mijn mening uitgangspunt te zijn. Met Koeman ben ik van mening dat normen ooit niet zonder reden zijn vastgesteld en vaak al flexibiliseringsmogelijkheden kennen, bijvoorbeeld waar het

299 Borgers \& Van der Heijden, Het recht op duurzame gebiedsexploitatie 2010, p. 38.

300 Borgers \& Van der Heijden, Het recht op duurzame gebiedsexploitatie 2010, p. 41.

301 Zie ook Van den Broek, Kroonjuwelen met scherpe randjes 2006, p. 138.

302 Borgers \& Van der Heijden, Evenredig de ruimte 2011.

303 Ministerie van IenM, Kabinetsbrief stelselherziening omgevingsrecht 2012, p. 9 en 18.

304 Schueler, Of heeft u liever negatieve onevenredigheid? 2012, p. 241. 
gaat om de mogelijkheid tot het vaststellen van hogere waarden voor geluid. ${ }^{305}$ Blijkt die reden niet langer te gelden, dan is het aan de wetgever om de normen aan te passen en niet aan bestuursorganen of de rechter om die normen naast zich neer te leggen. Zou dat anders zijn, dan lijkt mij de kenbaarheid en voorspelbaarheid van wetssystemen in gevaar te komen.

Robesin benoemt die zorg reeds ten aanzien van het voorontwerp Wet algemene bepalingen omgevingsrecht van 3 mei 2005. ${ }^{306}$ Robesin meent dat 'vooral in de artikelen 2.22 en 2.23 lid 1 van het voorontwerp' ${ }^{307}$ het gevaar schuilt 'dat het bevoegd gezag bij het stellen van voorschriften tot een zodanige 'afstemming' komt dat een door een van die toetsingskaders te beschermen belang het onderspit delft. Het bevoegd gezag heeft immers geen enkel ander afwegingskader dan het in artikel 2.22 van het voorontwerp genoemde criterium 'de bescherming van de fysieke leefomgeving." ${ }^{08}$ Enerzijds ben ik het met Robesin eens dat door de wetgever als beschermenswaardig aangegeven milieubelangen, en ik breid dat uit naar door de wetgever als beschermenswaardig aangegeven omgevingsbelangen, niet het onderspit mogen delven. Anderzijds volg ik ook Schueler waar die stelt dat men soms als nuttig effect van een overkoepelende norm ziet dat de ene milieuwaarde tegen de andere kan worden afgewogen, zodat je aan de ene kant wat water bij de wijn kunt doen om aan de andere kant betere wijn te kunnen serveren. Als de kwaliteit van de leefomgeving over het geheel maar verbetert. Met Schueler acht ik het heel goed voorstelbaar dat meer flexibiliteit soms leidt tot betere resultaten. ${ }^{309}$

Mij lijkt dat de betere wijn van Schueler te serveren valt zonder dat het gevaar waarvoor Robesin terecht waarschuwt zich zal hoeven voordoen. De

305 Koeman, Een wereld te winnen 2010, p. 10-11. Als meer gebruiksruimte nodig is, dan zoekt Koeman die niet in een afwijking van milieunormen, maar in herverdeling van milieugebruiksruimte.

306 Zie www.ibr.nl/files_content/docs/Wabo\%20mei\%202005.pdf d.d. 29 mei 2012. Zie voor een samenvatting van het voorontwerp Van den Broek, Samenvatting Voorontwerp Wabo 2005.

307 Artikel 2.22 1. In een vergunning wordt de activiteit waarop zij betrekking heeft, duidelijk beschreven. 2. Aan een vergunning worden de voorschriften verbonden, die nodig zijn met het oog op de bescherming van de fysieke leefomgeving. 3. In elk geval worden aan de vergunning de voorschriften verbonden, bedoeld in de artikelen 8.11, derde, vierde en vijfde lid, en 8.12 tot en met 8.14 van de Wet milieubeheer. 4 . Voor zover met betrekking tot de activiteit algemeen verbindende voorschriften gelden, kunnen de voorschriften daarvan alleen afwijken voor zover dat bij die regels is toegestaan.

Artikel 2.23 1. Indien de vergunning voor meer dan een activiteit is aangevraagd en er geen grond is voor het weigeren van de vergunning, draagt het bevoegd gezag ervoor zorg dat de beschrijving van de vergunde activiteit in de vergunning duidelijk en eenduidig is, en dat de aan de vergunning verbonden voorschriften op elkaar zijn afgestemd. 2. Het eerste lid is niet van toepassing met betrekking tot voorschriften als bedoeld in artikel 2.28 , vierde en vijfde lid.

308 Robesin, Moderne milieuregels 2005, p. 190. Zie ook Van den Broek \& Rutteman, Bedrijfsleven en milieubeweging steunen Wabo 2005. Daarin betoont VNO-NCW zich voorstander van een integrale omgevingsvergunning die het bedrijven mogelijk maakt om met één bestuursorgaan een integraal oordeel te krijgen over de gevolgen van een fysiek project voor het milieu als geheel. De ZuidHollandse Milieufederatie noemt de totstandkoming van een integrale omgevingsvergunning een positieve ontwikkeling, die de rechtsbescherming 'een stuk overzichtelijker' maakt.

309 Schueler, Of heeft u liever negatieve onevenredigheid? 2012, p. 241. 
crux lijkt mij te zitten in het antwoord op de vraag wat men onder een integrale afweging en wat onder uitruil wil verstaan.

Ik versta onder een integrale afweging van omgevingsbelangen, dat een besluit wordt genomen waarbij voor elk relevant belang wordt gebleven binnen de daarvoor door de wetgever aangegeven concrete bandbreedte, waarbij geen enkel belang wordt verabsoluteerd of geprioriteerd, tenzij de wetgever zulks heeft aangegeven. ${ }^{310}$ Dat zou de wetgever bijvoorbeeld kunnen doen door de uitstoot van een bepaalde stof aan grenswaarden ${ }^{311}$ te binden, ook al zou dat meer energie kosten. Bij integrale afweging gaat het erom een zo optimaal mogelijk resultaat te bereiken voor de fysieke leefomgeving als geheel.

Van uitruil is in mijn ogen sprake als een besluit wordt genomen waarbij voor een of meer bepaalde relevante omgevingsbelangen niet wordt gebleven binnen de door de wetgever aangegeven concrete bandbreedte teneinde te kunnen voldoen aan een ander relevant belang.

Een voorbeeld moge zulks verduidelijken. Stel dat de norm door de overheid voor luchtkwaliteit is vastgesteld tussen 75 en 100 eenheden en voor waterkwaliteit tussen 500 en 600 eenheden. Het resultaat van een integrale afweging moet zijn dat de eisen ten aanzien van luchtkwaliteit blijven tussen 75 en 100 eenheden en voor waterkwaliteit tussen 500 en 600 eenheden. De integrale afweging zou dan kunnen betekenen dat een norm van 95 eenheden voor luchtkwaliteit wordt voorgeschreven teneinde een norm van 500 eenheden voor waterkwaliteit te kunnen realiseren. Maar stel dat een bestuursorgaan voor luchtkwaliteit een norm van 75 wil voorschrijven, die slechts haalbaar is als de norm ten aanzien van de waterkwaliteit wordt overschreden met 25. Als dat wordt toegestaan, is sprake van uitruil.

Ik ben wel een voorstander van een integrale benadering van omgevingsbelangen, maar niet van uitruil daarvan. De reden daarvoor is eenvoudig. Als de wetgever de grenzen heeft vastgesteld van de normen ter bescherming van de relevante belangen die samen het belang van de fysieke leefomgeving uitmaken, dan dienen die grenzen te worden geëerbiedigd zolang die normen gelden.

Een niet te onderschatten voordeel van mijn benadering lijkt mij niet alleen, dat alle door de wetgever relevant geachte omgevingsbelangen steeds in de afweging worden betrokken, maar ook, dat het niet noodzakelijk is om een gemeenschappelijke noemer te ontwikkelen voor alle mogelijke omgevingsaspecten. In de literatuur wordt de (on)mogelijkheid om een dergelijke

310 Zie ook art. 3:4 lid 1 Awb.

311 Een grenswaarde geeft de kwaliteit aan die op een bepaald tijdstip ten minste moet zijn bereikt en die, waar zij aanwezig is, ten minste in stand moet worden gehouden (vglk. art. 5.1 lid $3 \mathrm{Wm}$ ). 
gemeenschappelijke noemer te ontwikkelen regelmatig genoemd als argument tegen een integrale afweging van omgevingsbelangen. Drupsteen noemt het probleem van integratie van toetsingskaders dat 'we geen gemeenschappelijke noemer hebben waarop we de verschillende omgevingsaspecten kunnen terugvoeren en tot elkaar herleiden. ${ }^{312}$ Brans merkt op dat verschillende milieucompartimenten of aspecten daarbuiten zich lastig laten vergelijken, zodat het niet eenvoudig zal zijn om vast te stellen of de overkoepelende effecten daarvan ten minste gelijk zijn. ${ }^{313}$ Tolsma vraagt zich af of de regering er wel in slaagt om een voor de praktijk uitvoerbare methode te vinden om de diverse omgevingsrechtelijke deelbelangen tegen elkaar te kunnen afwegen. ${ }^{314}$ In mijn visie op een integrale afweging is het vinden van een gemeenschappelijke noemer om onvergelijkbare grootheden, zoals geluid tegen geur of tegen uitzicht, met elkaar te kunnen vergelijken echter niet noodzakelijk. ${ }^{315}$

\subsubsection{Tussenconclusie}

In paragraaf 2.3.3 heb ik opgemerkt dat de wetgever in beginsel uit een schier oneindig aantal systeemordeningscriteria kan kiezen. Dergelijke systeemordeningscriteria ordenen een wetssysteem. Zij brengen daarin samenhang, reden waarom ik hiervoor heb gesproken over samenhangcriteria. Die systeemordeningscriteria heb ik onderscheiden in zakelijke en typisch juridische systeemordeningscriteria. De door de wetgever gekozen samenhangcriteria bepalen het wetssysteem, het wetssystematisch tekort, alsmede probleemstelling en oplossingen. ${ }^{316}$

Een wetssysteem bestaat uit volgens bepaalde criteria geordende, onderling samenhangende regels. De kenbaarheid van het recht, de belangrijkste functie van een wetssysteem los van de inhoud van de daarvan deel uitmakende regels, de probleemgeoriënteerd van een wetssysteem en het in Nederland geldende postulaat dat ieder wordt geacht de wet te kennen, betekenen dat de wetgever naar samenhangcriteria moet zoeken buiten de wereld van het recht, in de echte werkelijkheid. Die samenhang betreft dan subjecten, objecten, activiteiten en de fysieke leefomgeving. Het gaat daarbij om zakelijke systeemordeningscriteria.

312 Drupsteen, Een Omgevingswet 2011, p. 281.

313 Brans, Het gebiedsontwikkelingsplan 2011, p. 36.

314 Tolsma, Omgevingsvergunning model 4 een stap dichterbij met de Omgevingswet? 2012, p. 87. Haar publicatie is zeer lezenswaardig voor wie een overzicht op hoofdlijnen wil hebben van de discussie inzake een integrale omgevingsvergunning.

315 Het voorbeeld is van Schueler, Of heeft u liever negatieve onevenredigheid? 2012 p. 241

316 Zie par. 3.2.4 
Hierna zal nader worden aangegeven waarom juist zakelijke systeemordeningscriteria zich bij uitstek lenen als samenhangcriteria voor het bundelen van wetssystemen op het gebied van het omgevingsrecht.

In de eerste plaats komt het gebruik van zakelijke systeemordeningscriteria de kenbaarheid van het omgevingsrecht ten goede.

De Wabo wordt bepaald door het zakelijk samenhangcriterium plaatsgebonden project dat bestaat uit één of meer activiteiten die van invloed zijn op de fysieke leefomgeving. ${ }^{317}$ Een van die activiteiten is het bouwen van een bouwwerk. Een aannemer die een huis wil bouwen zal er vermoedelijk zonder specialistische juridische voorkennis in slagen in de Wabo de regel te vinden dat het is verboden om een huis (bouwwerk) te bouwen zonder omgevingsvergunning. ${ }^{318}$ Die voorkennis is evenmin vereist voor degene die voornemens is een raffinaderij te exploiteren, aangezien het hier ook een plaatsgebonden project betreft dat bestaat uit één of meer activiteiten die van invloed zijn op de fysieke leefomgeving. Van hem of haar wordt iets meer voorkennis gevraagd, aangezien hij moet weten dat de wetgever voor het exploiteren van een raffinaderij de van het normale spraakgebruik afwijkende begrippen 'oprichten van een inrichting' gebruikt. $^{319}$ Deze voorbeelden laten overigens zien, dat de kenbaarheid niet in het gedrang behoeft te komen als de wetgever een overkoepelend samenhangcriterium hanteert als een plaatsgebonden project, in plaats van samenhangcriteria als woning, raffinaderij, etcetera. Op zichzelf zal de kenbaarheid groter zijn, naarmate het samenhangcriterium specifieker is, maar dat kan tot onnodig uitgebreide wetssystemen leiden.

In de tweede plaats vormt het gebruik van zakelijke systeemordeningscriteria een uitstekende manier om de in paragraaf 3.2.6 bepleite samenhang zoals die bestaat in de echte werkelijkheid te realiseren.

Een wetssysteem bestaat uit volgens bepaalde criteria geordende, onderling samenhangende regels. Het per 1 januari 2008 vervallen $^{320}$ Besluit horeca-, sport- en recreatie-inrichtingen ${ }^{321}$ werd bepaald door het samenhangcriterium 'horeca-, sport- en recreatie-inrichtingen voor zover van invloed op de fysieke leefomgeving', nader uitgewerkt in artikel 2 van dat Besluit. ${ }^{322}$ Voor de exploitant van een hotel, restaurant of café (horeca) was het aanstonds duidelijk dat dit wetssysteem op zijn bedrijf van toepassing was. De wetgever heeft dit

317 Zie par. 4.3.3.

318 Zie art. 2.1 lid 1 aanhef en onder a Wabo.

319 Art. 2.1 lid 1 aanhef en onder e Wabo.

320 Art. 6.43 Activiteitenbesluit.

321 Stb. 1998, 322, in werking getreden op 1 oktober 1998

322 Zo was het besluit onder meer van toepassing op een inrichting waarbij uitsluitend of in hoofdzaak sprake is van een hotel, restaurant, pension, café, cafetaria, snackbar, discotheek, buurthuis, clubhuis of daaraan verwante inrichting waar tegen vergoeding logies wordt verstrekt, dranken worden geschonken of spijzen voor directe consumptie worden bereid of verstrekt (art. 2 lid 1 aanhef en onder a sub $1^{\circ}$ Besluit horeca-, sport- en recreatie-inrichtingen). Art. 3 van het Besluit bevatte uitzonderingen. 
Besluit per 1 januari 2008 vervangen door het Activiteitenbesluit, onder meer teneinde administratieve lasten te reduceren. ${ }^{323}$ In het Activiteitenbesluit zijn de samenhangcriteria niet langer inrichtingen, maar bedrijfsmatige activiteiten die van invloed zijn op de fysieke leefomgeving.' Door de samenhang niet langer te zoeken in inrichtingen, maar in activiteiten binnen die inrichtingen mag worden aangenomen dat de kenbaarheid voor de horeca- sport- en recreatieondernemer is verminderd. Had hij tot 1 januari 2008 te maken met een Besluit dat - uitzonderingen daargelaten - geheel op zijn inrichting van toepassing was, per 1 januari 2008 heeft hij te maken met een Activiteitenbesluit dat slechts op zijn inrichting van toepassing is voor zover daarin de in het Activiteitenbesluit geregelde activiteiten worden uitgevoerd. Om te weten welke regels dat zijn, dient hij eigenlijk nagenoeg het gehele Activiteitenbesluit door te nemen.

In de derde plaats zijn zakelijke systeemordeningscriteria geschikt voor het realiseren van een probleemgeoriënteerd wetssysteem.

Zo gebruikt het Activiteitenbesluit de zakelijke systeemordeningscriteria 'activiteiten met betrekking tot metaal'324 en nog specifieker 'lassen van metalen'325 en 'solderen van metalen'326 om subwetssystemen binnen het Activiteitenbesluit te bepalen. Wie vragen heeft over wat rechtens is in geval van het lassen of solderen van metalen zal als gevolg van het gebruik van de genoemde zakelijke systeemordeningscriterium tamelijk gemakkelijk geraken tot de voor hem relevante bepalingen in het Activiteitenbesluit.

In de vierde plaats helpt het gebruik van zakelijke systeemordeningscriteria de wetgever om wetssystemen binnen het omgevingsrecht toekomstbestendig te maken en te houden. Onder toekomstbestendig versta ik een wetssysteem dat niet wordt verstoord doordat de wetgever genoodzaakt is en blijft om een chronologische aanpak te gebruiken bij het tot stand brengen van omgevingsrecht.

Als bijvoorbeeld een 'inrichting' of 'installatie' als samenhangcriterium wordt gehanteerd, is de wetgever - op straffe van het realiseren van wetssystematische tekorten - verplicht om toekomstige omgevingsregels ten aanzien van een inrichting of installatie eveneens in het door dergelijke samenhangcriteria bepaalde wetssysteem op te nemen.

Woldendorp noemt een wetssysteem toekomstbestendig als je de juiste kapstokken kunt vinden om nieuwe regels aan op te hangen. Hij wil daartoe de naar verwachting permanente Europese richtlijnen als uitgangspunt gebruiken. Het is echter niet duidelijk of Woldendorp daarbij naar zakelijke ordeningscriteria wil kijken. ${ }^{327}$ Ook Molenaars zoekt toekomstbestendigheid in

\footnotetext{
323 Activiteitenbesluit, NvT, Algemeen deel, par. 2.

324 Afd. 4.5 Activiteitenbesluit.

325 Par. 4.5.2 Activiteitenbesluit

326 Par. 4.5.3 Activiteitenbesluit

327 Woldendorp, Interview 2011, bijl. 5.1, par. 6.1-6.2
} 
wat zij noemt 'haakjes', aangrijpingspunten, in wetssystemen, maar meent dat die haakjes ook kunnen worden gezocht in het instrumentarium. ${ }^{328}$

In de vijfde plaats kan het gebruik van zakelijke systeemordeningscriteria zorgen voor een eenvoudiger omzetting van Europese richtlijnen op het gebied van het omgevingsrecht. Dergelijke Europese richtlijnen zijn nog steeds erg sectoraal ingericht. ${ }^{329}$ Dat maakt de kans groter dat het Europese wetssysteem van richtlijnen op het gebied van het omgevingsrecht wetssystematische tekorten bevat of zou kunnen bevatten. Dergelijke tekorten kunnen echter worden opgevangen als bij de omzetting van Europese richtlijnen wordt aangesloten bij in nationale wetssystemen op het gebied van het omgevingsrecht gehanteerde zakelijke samenhangcriteria. ${ }^{330}$

Als bijvoorbeeld 'installatie'331 als bedoeld in de Richtlijn industriële emis$\operatorname{sies}^{332}$ als samenhangcriterium wordt gebezigd voor een nationaal (sub)wetssysteem, dan zouden Europese richtlijnen die zien op een dergelijke installatie in het op basis van dat samenhangcriterium gevormde nationale (sub)wetssysteem behoren te worden geregeld.

\subsection{WETSSYSTEMATISCH(E) TEKORT(EN) ELDERS AFWEGEN}

\subsubsection{Algemeen}

Van een wetssystematisch tekort is sprake als bepaalde regels volgens bepaalde samenhangcriteria onderling samenhangen maar desalniettemin geen deel uitmaken van hetzelfde wetssysteem. Bundeling van omgevingsrecht biedt een mogelijkheid om dergelijke wetssystematische tekorten op te heffen. ${ }^{333}$ Idealiter zorgt bundeling immers voor (meer) samenhang door ten onrechte over meer wetssystemen verspreid staande regels een plaats te geven in hetzelfde wetssysteem.

328 Molenaars, Interview 2012, bijl. 5.6, par. 6.1

329 In de inleiding op het Umweltgesetzbuch (UGB-KomE) merkt de Sachverständigenkommission in dit verband op: 'Noch ist nicht absehbar, ob es zukünftig zu einem weiteren Ausbau des Gemeinschaftsrechts zu einem umfassenden System kommen wird.' (Bundesministerium für Umwelt c.a., Umweltgesetzbuch (UGB-KomE) 1998, p. 75).

330 Zie voor een voorbeeld van de gevolgen van een afwijkende implementatie Van den Broek, IPPC in werking getreden 1997 en Van den Broek, Europese installatieproblemen 2003.

331 Installatie: een vaste technische eenheid waarin een of meer van de in bijlage I of in deel 1 van bijlage VII vermelde activiteiten en processen alsmede andere op dezelfde locatie ten uitvoer gebrachte en daarmee rechtstreeks samenhangende activiteiten plaatsvinden die technisch in verband staan met de in die bijlagen vermelde activiteiten en die gevolgen kunnen hebben voor de emissies en de verontreiniging (art. 3 onder 3 IED).

332 Richtlijn 2010/75/EU van het Europees Parlement en de Raad van 24 november 2010 inzake industriële emissies (geïntegreerde preventie en bestrijding van verontreiniging) (herschikking) (PbEU 2010 L 334/17). In Nederland wordt deze richtlijn gewoonlijk afgekort met IED (Industrial Emissions Directive).

333 Zie par. 2.5 
Zolang er nog geen sprake is van een iLawsysteem, dient de wetgever echter een keus te maken welke wetssystematische tekorten hij precies wil opheffen en welke hij wil laten voortbestaan. De keus voor een bepaald samenhangcriterium betekent immers per definitie dat bundeling elders in het omgevingsrecht wetssystematische tekorten laat bestaan of zelfs creëert. Daarbij laat zich een aantal categorieën onderscheiden.

In de eerste plaats kan bundeling op basis van zakelijke samenhangcriteria betekenen dat bepaalde wetssystematische tekorten slechts gedeeltelijk worden opgeheven. Een voorbeeld betreft het niet opnemen van de watervergunning in de omgevingsvergunning als gevolg van de Wabo (zie par. 3.4.2). ${ }^{334}$

In de tweede plaats kan bundeling op basis van zakelijke samenhangcriteria betekenen dat bepaalde wetssystematische tekorten geheel of gedeeltelijk worden opgeheven, doch dat daardoor wetssystematische tekorten in andere wetssystemen worden gecreëerd. Een voorbeeld betreft het grotendeels schrappen van hoofdstuk $8 \mathrm{Wm}$ als gevolg van de Wabo (zie par. 3.4.3).

In de derde plaats kan bundeling op basis van typisch juridische samenhangcriteria betekenen dat wetssystematische tekorten worden gehandhaafd of gecreëerd in een door bundeling op basis van zakelijke samenhangcriteria bepaald wetssysteem (zie par. 3.4.4). Het kan hier gaan om interne en externe wetssystematische tekorten. Een intern tekort kan zich voordoen als typisch juridische samenhangcriteria worden gebruikt binnen genoemd wetssysteem. Een voorbeeld is het gebruik van algemene en bijzondere bepalingen voor installaties in de Richtlijn industriële emissies (zie par. 3.4.4.1). Een extern tekort kan zich voordoen als typisch juridische samenhangcriteria tot gevolg hebben dat bepaalde regels geen deel uitmaken van dat wetssysteem. Een voorbeeld betreft het in de Wet op de economische delicten opnemen van de strafbedreiging van een aantal artikelen in de Waterwet (zie par. 3.4.4.1).

Hierna zullen deze categorieën worden uitgewerkt en toegelicht. In paragraaf 3.4.5 zal aandacht worden besteed aan de verdedigbaarheid van het in het kader van bundeling laten voortbestaan of scheppen van wetssystematische tekorten.

\subsubsection{Bundeling handhaaft wetssystematisch tekort}

Bundeling op basis van zakelijke samenhangcriteria kan betekenen dat bepaalde wetssystematische tekorten slechts gedeeltelijk worden opgeheven. In het gebundelde wetssysteem blijven dan wetssystematische tekorten bestaan. 
Een voorbeeld betreft de Wabo. Dit wetssysteem wordt bepaald door het samenhangcriterium 'plaatsgebonden project dat bestaat uit één of meer activiteiten die van invloed zijn op de fysieke leefomgeving. ${ }^{335}$ Het is verboden een dergelijk project uit te voeren zonder omgevingsvergunning. ${ }^{336}$ Die omgevingsvergunning voor genoemde projecten geldt echter niet voor van het project deel uitmakende activiteiten waarvoor een in de Waterwet geregelde watervergunning is vereist, zoals de activiteit 'lozen op oppervlaktewater.' ${ }^{337}$ Voor die activiteit is een watervergunning nodig die ten onrechte geen deel uitmaakt van het wetssysteem van de Wabo maar van het wetssysteem van de Waterwet. Hier is sprake van een wetssystematisch tekort, aangezien niet alle van een 'plaatsgebonden project' deel uitmakende 'activiteiten die van invloed zijn op de fysieke leefomgeving' in hetzelfde wetssysteem van de Wabo zijn geregeld.

\subsubsection{Bundeling schept wetssystematisch tekort elders}

Bundeling op basis van zakelijke samenhangcriteria kan betekenen dat bepaalde wetssystematische tekorten in andere wetssystemen worden geschapen. Rehbinder merkt op: 'Bei jeder Kodifikation des Umweltrechts muss dessen Verhältnis zu bestehenden oder geplanten Kodifikationen auf anderen Gebieten, wie z.B. zum Strafgesetzbuch, Zivilgesetzbuch, Verwaltungsverfahrensgesetz oder Informationsfreiheitsgesetz bedacht werden. ${ }^{338}$ Anders dan in de in paragraaf 3.4.2 geschetste situatie gaat het niet om wetssystematische tekorten in het gebundelde wetssysteem, maar in andere wetssystemen als gevolg van de bundeling.

Ook hier biedt de Wabo een goed voorbeeld. Deze wet herschikt onder meer de tot 1 oktober 2010 bestaande bouwvergunning en milieuvergunning in de omgevingsvergunning. De bouwvergunning was geregeld in hoofdstuk IV Woningwet De bouwvergunning. De milieuvergunning was geregeld in hoofdstuk 8 Wm Inrichtingen. Met de inwerkingtreding van de Wabo en de omgevingsvergunning op 1 oktober 2010 is hoofdstuk IV Woningwet geheel ingetrokken en hoofdstuk 8 Wm grotendeels. Met het bundelen van de bouwvergunning en de milieuvergunning in de omgevingsvergunning is het wetssystematisch tekort opgeheven dat was ontstaan omdat de voor een project benodigde bouw- en milieuvergunning in verschillende wetssystemen (Woningwet en Wet milieubeheer) was geregeld. Tegelijkertijd zijn echter twee nieuwe wetssystematische tekorten ontstaan. De Woningwet bevat namelijk niet meer alle regels over bouwen en de Wet milieubeheer mist in hoofdstuk 8 belangrijke regels die gelden voor vergunningplichtige inrichtingen.

335 Zie par. 4.3.2.

336 Art. 2.1 lid 1 aanhef Wabo.

337 Art. $6.2 \mathrm{Wtw}$.

338 Rehbinder, Kodifikation des Umweltrechts in Europa - Rechtsvergleichende Betrachtungen 2010, p. 104. 
3.4.4. Wetssystematisch tekort door gebruik typisch juridische ordeningscriteria

\subsubsection{Algemeen}

In de hiervoor beschreven voorbeelden ging het om wetssystematische tekorten, die na bundeling op basis van zakelijke samenhangcriteria ontstaan in ${ }^{339}$ of buiten ${ }^{340}$ het na bundeling gevormde wetssysteem.

Een geheel andere situatie doet zich voor indien bundeling op basis van typisch juridische samenhangcriteria wetssystematische tekorten handhaaft of schept in een door bundeling op basis van zakelijke samenhangcriteria bepaald wetssysteem.

Een intern tekort kan zich voordoen als typisch juridische samenhangcriteria worden gebruikt binnen een door bundeling op basis van zakelijke samenhangcriteria bepaald wetssysteem.

Een voorbeeld van het gebruik van een typisch juridisch systeemordeningscriterium, dat leidt tot een intern wetssystematisch tekort biedt het wetssysteem van de Europese Richtlijn industriële emissies. Een belangrijk samenhangcriterium wordt gevormd door het zakelijke samenhangcriterium van 'industriële activiteiten (art. 1 IED).' Binnen het aldus bepaalde wetssysteem is echter ook gebruik gemaakt van typisch juridische samenhangcriteria, te weten algemene en bijzondere regels. ${ }^{341}$ Hoofdstuk I bevat gemeenschappelijke bepalingen. Hoofdstuk II bevat algemene bepalingen ${ }^{342}$ voor de in bijlage I genoemde activiteiten. De hoofdstukken III, IV, V en VI bevatten bijzondere bepalingen betreffende respectievelijk stookinstallaties, afvalverbrandingsinstallaties en afvalmeeverbrandingsinstallaties, installaties waarin en activiteiten waarbij organische oplosmiddelen worden gebruikt, en installaties die titaandioxide produceren. Voor de exploitant van een stookinstallatie betekent het gebruik van deze typisch juridische systeemordeningscriteria dat hij in elk geval de hoofdstukken I, II en III moet raadplegen.

Met een intern wetssystematisch tekort moet rekening worden gehouden bij de voorstellen van Koeman voor een gedifferentieerd omgevingsrecht. Hij meent dat het zeer onverstandig zou zijn om te zoeken naar één algemeen geldende oplossing voor een probleem dat zich niet in het algemeen voordoet. Hij pleit daarom voor een standaardregime 'dat op een goede manier de doorsnee omgevingsrechtelijke activiteiten reguleert. Als zo'n stelsel duidelijk is, kan vervolgens worden nagedacht over een regime voor de grote en/of ingewikkelde gevallen enerzijds en de

339 Zie par. 3.4.2

340 Zie par. 3.4.3.

341 Zie par. 3.5.4.2

342 Het gaat hier om een soort algemene regels in het kwadraat: gemeenschappelijke regels en algemene regels. 
nog veel simpeler gevallen anderzijds.' ${ }^{343}$ Het lijkt mij de moeite waard om na te denken over een dergelijke driedeling, mits men zich daarbij realiseert dat een dergelijke driedeling niet zou moeten leiden tot een situatie waarin de gebruiker voor soortgelijke projecten of activiteiten drie verschillende (sub)wetssystemen moet raadplegen teneinde te weten welk wetssysteem voor zijn project of activiteit geldt. Ook Drupsteen vraagt zich naar aanleiding van de voorstellen van Koeman af of er onderscheid moet worden gemaakt tussen eenvoudige en gecompliceerde situaties. Hij waarschuwt voor een nieuw stelsel dat complicaties zou kunnen opleveren voor eenvoudige gevallen. Tegelijkertijd is volgens Drupsteen wel een geïntegreerd en gestroomlijnd één-besluitmodel voor gebiedsontwikkeling en de aanleg van infrastructuur gewenst. ${ }^{344}$

Een extern wetssystematisch tekort kan zich voordoen als typisch juridische samenhangcriteria tot gevolg hebben dat bepaalde regels geen deel uitmaken van een door bundeling op basis van zakelijke samenhangcriteria bepaald wetssysteem.

Een voorbeeld van het gebruik van een typisch juridisch systeemordeningscriterium dat leidt tot een extern wetssystematisch tekort vinden we in artikel 1a Wed. Dat artikel benoemt de economische delicten op het gebied van het omgevingsrecht. Zo wordt overtreding van met name genoemde voorschriften, gesteld bij of krachtens de Waterwet als economisch delict aangemerkt. ${ }^{345}$ Het gaat hier om het typisch juridische samenhangcriterium van de strafbedreiging. Het gebruik van dit criterium brengt met zich dat de samenhang van de regels in het wetssysteem van de Wet op de economische delicten wordt bepaald door het antwoord op de vraag of overtreding daarvan met straf in strafrechtelijke zin wordt bedreigd. Een voor mijn onderzoek relevant gevolg van het gebruik van dit criterium is, dat de samenhang in het wetssysteem van de Waterwet daardoor wordt doorbroken. Zoals eerder opgemerkt wordt de samenhang in dat wetssysteem immers bepaald door het zakelijke ordeningscriterium integraal beheer van watersystemen. ${ }^{346}$ De gebruiker van dat wetssysteem moet echter voor de strafbedreiging het wetssysteem van de Wet op de economische delicten raadplegen.

Hierna zal worden toegelicht wat onder typisch juridische ordeningscriteria wordt verstaan, waarbij steeds een aantal belangrijke mogelijke voordelen van het gebruik van dergelijke criteria wordt genoemd. ${ }^{347}$ Vervolgens zal worden aangegeven in welke situaties het gebruik van dergelijke criteria

343 Koeman, Kiezen en delen in het omgevingsrecht 2010, p. 123-124.

344 Drupsteen, Een Omgevingswet 2011, p. 279).

345 Het gaat om art. 6.2, 6.3, 6.4, 6.5, 6.6 lid 1 en 2, 6.7, 6.8, 6.10 lid 1, 6.20 lid 3 Wtw, tenzij de desbetreffende vergunning uitsluitend berust op een verordening van een waterschap, en $10.1 \mathrm{Wtw}$ (art. 1a onder $1^{\circ} \mathrm{Wed}$ ), art. $6.9 \mathrm{Wtw}$ (art. 1a onder $2^{\circ} \mathrm{Wed}$ ) en art. 6.24 lid $2 \mathrm{Wtw}$, tenzij de desbetreffende vergunning uitsluitend berust op een verordening van een waterschap (art. 1a onder $3^{\circ}$ Wed).

346 Zie par. 3.3.5.

347 Zie par. 3.4.4 
ondanks het scheppen of handhaven van wetssystematische tekorten verdedigbaar is. ${ }^{348}$

In paragraaf 2.3.3 heb ik opgemerkt dat de wetgever in beginsel uit een schier oneindig aantal systeemordeningscriteria kan kiezen. Dergelijke systeemordeningscriteria ordenen een wetssysteem. Zij brengen daarin samenhang, reden waarom ik hiervoor heb gesproken over samenhangcriteria. Die systeemordeningscriteria heb ik onderscheiden in zakelijke en typisch juridische systeemordeningscriteria. De door de wetgever gekozen samenhangcriteria bepalen het wetssysteem, het wetssystematisch tekort, alsmede probleemstelling en oplossingen. ${ }^{349}$ In de paragrafen 3.2 en 3.3 heb ik betoogd dat een wetssysteem vanwege de kenbaarheid en de probleemgeoriënteerdheid bij voorkeur wordt bepaald door zakelijke samenhangcriteria die per definitie aansluiten bij de echte werkelijkheid.

Dat neemt echter niet weg dat de wetgever verdedigbare argumenten kan hebben om niet te kiezen voor bundeling op basis van zakelijke samenhangcriteria, maar voor typisch juridische systeemordeningscriteria, die dan een (sub)wetssysteem bepalen. Van typisch juridische systeemordeningscriteria is sprake bij criteria die niet aansluiten bij de echte werkelijkheid, maar gewoonlijk hun oorsprong vinden daarbuiten, in de juridische wetenschap. Daarmee wordt bedoeld, dat die criteria zijn geschapen door de juridische wetenschap zonder welke zij niet zouden bestaan. Noll zegt daarover, dat 'Normative Kriterien in einer Rechtsordnung um so häufiger und konsequenter Verwendung finden, je mehr juristenrechtliche Einflußnahme und dogmatische Durchdringung die Rechtsordnung erfahren hat. ${ }^{350}$ Dergelijke typisch juridische systeemordeningscriteria oriënteren zich volgens hem overwegend op normatieve gezichtspunten, op de manier waarop rechtsverhoudingen, -instituten en -instituties zijn geregeld, op de juridische status en op juridische sancties. Hij noemt als voorbeelden van de toepassing van typisch juridische systeemordeningscriteria het onderscheid tussen publiekrecht en privaatrecht, rechtsverhoudingen en de aard van een wettelijke regeling (wet in formele zin, algemene maatregel van bestuur, ministeriële regeling). ${ }^{351}$ Timmer spreekt van een kloof tussen de juridische wereld en die van de beleidsvorming en politiek. Hij noemt een minder sterk punt van de rechtsgeleerdheid het tamelijk zelfreferentiële karakter ervan. 'Dat wil zeggen dat de juristerij een societas perfecta, een gesloten wereld, vormt. Zij ontleent haar waarde aan zichzelf, en haar argumentatie 
kan alleen begrepen worden vanuit de juridische context. Bijgevolg lopen juridische oplossingen het gevaar in het juridische te blijven hangen: ze zullen daarbuiten geen medestanders vinden. ${ }^{352}$ Engisch merkt in dit verband op: 'Die üblichen Einführungen in die Rechtswissenschaft scheinen mit seltenen Ausnahmen nur dem angehenden Juristen, nicht aber dem Laien etwas zu bieten. Wie oft findet man wohl auch in der Bibliothek des Nichtjuristen ein Gesetzbuch?’353

Te denken is verder aan chronologische systeemordeningscriteria, die met name worden toegepast om activiteiten - procedureel - te reguleren die elkaar in de tijd opvolgen. ${ }^{354}$ Ook logische systeemordeningscriteria zijn typisch juridische systeemordeningscriteria. ${ }^{355}$ Hierna zal een aantal in het omgevingsrecht - en daarbuiten - veelvuldig gebruikte typisch juridische systeemordeningscriteria worden toegelicht. Daarbij wordt niet beoogd volledig te zijn. Het gaat er mij om aan te geven wat het gevolg is van het gebruik van typisch juridische systeemordeningscriteria in het kader van bundeling van omgevingsrecht.

In de echte werkelijkheid bestaan strikt genomen geen typisch juridische begrippen als omgevingsvisie, programma's, algemene regels, omgevingsvergunning, omgevingsverordening en projectbesluit. ${ }^{356}$ Dergelijke begrippen zijn ontsproten aan het brein van wetgevingsjuristen.

Een voorbeeld betreft de Wabo. Het zakelijk samenhangcriterium betreft een plaatsgebonden project dat bestaat uit één of meer activiteiten die van invloed zijn op de fysieke leefomgeving. Binnen het door dat criterium bepaalde wetssysteem is echter gebruik gemaakt van typisch juridische ordeningscriteria: begripsbepalingen, de omgevingsvergunning, voorbereidingsprocedures, financiële bepalingen, bestuursrechtelijke handhaving, inwerkingtreding beschikkingen en rechtsbescherming, verdere bepalingen, alsmede overgangs- en slotbepalingen.

Het gebruik van dergelijke typisch juridische ordeningscriteria heeft een aantal voordelen.

352 Timmer, Wetgevingskwaliteit: een wereld te winnen 2005, p. 38.

353 Engish, Einführung in das juristische Denken 1956, p. 2.

354 Een voorbeeld is de uniforme uitgebreide voorbereidingsprocedure die wordt beschreven in de Awb (afd. $3.4 \mathrm{Awb}$ ).

355 Daarvan is bijvoorbeeld sprake als wettelijke regelingen worden geordend in categorieën zoals algemeen en bijzonder, of omvattend begrip en ondergeschikt begrip. Als voorbeeld noem ik hoofdstuk 3 van de Awb dat algemene bepalingen over besluiten bevat en hoofdstuk 4 van diezelfde wet waarin bijzondere bepalingen over besluiten, waaronder beschikkingen, staan.

356 De regering stelt zich volgens een brief van 9 maart 2012 aan de Tweede Kamer voor om een nieuwe Omgevingswet op te bouwen door gebruik te maken van onder meer deze typisch juridische ordeningscriteria (Ministerie van IenM, Kabinetsbrief stelselherziening omgevingsrecht 2012). 
In de eerste plaats komt het gebruik van typisch juridische systeemordeningscriteria de kenbaarheid en probleemgeoriënteerdheid van een wetssysteem voor - gewoonlijk gespecialiseerde - juristen ten goede. Bij hen mag immers de voorkennis worden verondersteld om de betekenis van dergelijke criteria te begrijpen. Voor een gewone gebruiker van de Awb moge het onderscheid tussen besluiten en beschikkingen, alsmede de daarmee verband houdende rechtsgevolgen niet zonder voorkennis - vaak daarna overigens evenmin - duidelijk zijn, voor de in het bestuursrecht gespecialiseerde jurist zal dat gesneden koek - moeten - zijn. In de praktijk blijkt overigens niet elke meester in de rechten het recht meester. Borman merkt in dit verband dan ook op: "Laten we wel zijn, het gaat bij wetgeving om juridische documenten. Die zullen in de praktijk in de voorlichting vertaald moeten worden. Het is een illusie te denken dat burgers en ondernemers die teksten zonder gedegen voorkennis zouden kunnen begrijpen.”357

In de tweede plaats vormt het gebruik van typisch juridische systeemordeningscriteria een uitstekende manier om samenhang zoals die bestaat in de juridische werkelijkheid te realiseren.

In de derde plaats kan het gebruik van typisch juridische systeemordeningscriteria de wetgever helpen om het wetssysteem van het omgevingsrecht toekomstbestendig te maken en te houden. Onder toekomstbestendig versta ik een wetssysteem dat niet wordt verstoord doordat de wetgever genoodzaakt is en blijft om de chronologische aanpak te gebruiken bij het tot stand brengen van omgevingsrecht. Molenaars zoekt toekomstbestendigheid zoals hiervoor reeds opgemerkt in 'haakjes' in wetssystemen, maar meent dat die haakjes ook kunnen worden gezocht in het instrumentarium..$^{358}$

\subsubsection{Algemeen en bijzonder}

Een typisch juridisch systeemordeningscriterium ${ }^{359}$ is de ordening binnen een wetssysteem in categorieën zoals algemeen en bijzonder, of omvattend begrip en ondergeschikt begrip.

Een voorbeeld is te vinden in de Awb waarin in hoofdstuk 3 algemene bepalingen over besluiten ${ }^{360}$ en in hoofdstuk 4 bijzondere bepalingen over besluiten staan.

357 Borman, Interview 2012, bijl. 5.3, par. 3.1.

358 Molenaars, Interview 2012, bijl. 5.6, par. 6.1.

359 Noll, Gesetzgebungslehre 1973, p. 210, spreekt hier van logische systeemordeningscriteria

360 Art. 1:3 lid 1 Awb: Onder besluit wordt verstaan: een schriftelijke beslissing van een bestuursorgaan, inhoudende een publiekrechtelijke rechtshandeling. 
Voor mijn onderzoek is het van belang te constateren dat de wetgever regels die in de echte werkelijkheid op een bepaald geval van toepassing zijn, verdeelt over verschillende (sub)wetssystemen. Aldus schept de wetgever een wetssystematisch tekort, aangezien niet alle met elkaar samenhangende regels zijn ondergebracht in hetzelfde (sub)wetssysteem.

In het omgevingsrecht worden ook regelmatig dergelijke typisch juridische systeemordeningscriteria gebruikt. Een voorbeeld betreft de Wet bodembescherming. Het subwetssysteem van paragraaf 3 Wbb Sanering ${ }^{361}$ van hoofdstuk IV Algemene bepalingen in geval van bescherming van de bodem bevat

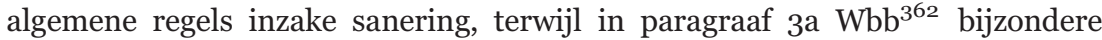
bepalingen inzake sanering van bedrijfsterreinen staan.

Een ander voorbeeld vinden we in de Regeling omgevingsrecht (Mor). ${ }^{363}$ Hoofdstuk 1 Mor bevat regels inzake algemene indieningsvereisten voor de aanvraag van een omgevingsvergunning. De hoofdstukken 2 tot en met 8 Mor bevatten vervolgens bijzondere regels inzake indieningsvereisten vanwege bepaalde activiteiten. Zo bevat hoofdstuk 2 Mor indieningsvereisten vanwege bouwactiviteiten.

Een belangrijk voordeel van het gebruik van juridische systeemordeningscriteria als algemeen-bijzonder lijkt mij dat het voor juristen en andere gespecialiseerde gebruikers van het wetssysteem waarin die criteria worden toegepast duidelijk is welke regels gelijkelijk voor welke gevallen gelden. ${ }^{364}$ Dat geldt bijvoorbeeld voor de regels inzake besluiten ${ }^{365}$ en beschikkingen $^{366}$ (bijzondere besluiten) in de Awb. Het gebruik van typisch juridische systeemordeningscriteria als algemeen-bijzonder lijkt mij ook voor de wetgever voordelen te bieden. Het betekent immers dat de wetgever regels die op dezelfde gevallen betrekking hebben maar één keer behoeft uit te schrijven. Borman lijkt dit te onderschrijven waar hij opmerkt, dat het bij wetssystemen gaat om juridische documenten "die eerder worden geschreven voor een rechter dan voor een burger."367 Ook Drupsteen stelt dat met

361 Art. 36-55 Wbb.

362 Art. 55a-55b Wbb.

363 Stcrt. 2010, 5162.

364 Zie voor de mogelijke voordelen van een algemeen deel ook Hirsch Ballin, Architectuur van wetgeving 1984, p. 82-84. Als nadeel van algemene regels, althans voor zover zij een grote verscheidenheid binnen het bijzonder deel bestrijken, geldt volgens hem dat zij een hoog abstractieniveau bezitten en dat hun draagwijdte moeilijk is te overzien.

365 Art. 1:3 lid 1Awb: Onder besluit wordt verstaan: een schriftelijke beslissing van een bestuursorgaan, inhoudende een publiekrechtelijke rechtshandeling.

366 Art. 1:3 lid 2 Awb: Onder beschikking wordt verstaan: een besluit dat niet van algemene strekking is, met inbegrip van de afwijzing van een aanvraag daarvan.

367 Borman, Interview 2012, bijl. 5.3, par. 3.2. 
wetgeving wordt geprobeerd regels te stellen en normen te geven, hetgeen een juridische bezigheid is. ${ }^{368}$ Voermans onderschrijft dat het handig is om een algemeen en een bijzonder deel te hebben, zodat de wetgever niet in de bijzondere delen hoeft te herhalen wat hij al heeft geregeld in het algemeen deel. Anders dan Borman meent hij echter dat dit ook handig is voor andere gebruikers dan juristen. De gemiddelde burger zal wel weten dat het verschil maakt of er sprake is van een besluit of een beschikking en welke voorbereidingsprocedure geldt. ${ }^{369}$ Ik betwijfel of de gemiddelde burger of ondernemer zich daarvan werkelijk bewust zal zijn.

Typisch juridische systeemcriteria als algemeen-bijzonder worden overigens niet altijd juist toegepast. Mij komt het voor dat de bijzondere regels een aanvulling of uitzondering op de algemene regels dienen te vormen. Het lijkt mij wetssystematisch onjuist als op de gevallen waarop een bijzondere regel ziet de algemene regels in het geheel niet van toepassing zijn. In een dergelijk geval dient de bijzondere regeling uit wetssystematisch oogpunt niet als een uitzondering op de algemene regel te worden geformuleerd maar als een op zichzelf staande regeling. ${ }^{370}$

Een voorbeeld van een onjuiste toepassing betreft hoofdstuk 5 Wm Milieukwaliteitseisen. Titel $5.1 \mathrm{Wm}$ bevat Algemene bepalingen ten aanzien van milieukwaliteitseisen. Titel $5.2 \mathrm{Wm}$ bevat regels ten aanzien van luchtkwaliteitseisen. Artikel 5.6 lid $1 \mathrm{Wm}$ bepaalt dat ten aanzien van de kwaliteit van de buitenlucht uitsluitend Titel 5.2, bijlage 2 en de op deze Titel 5.2 berustende bepalingen gelden. Dat betekent dat de wetssystematisch in Titel $5.1 \mathrm{Wm}$ als algemene bepalingen voorgestelde regels inzake milieukwaliteitseisen niet van toepassing zijn ten aanzien van de kwaliteit van de buitenlucht. Ten aanzien van de kwaliteit van de buitenlucht is dus geen sprake van algemene regels in Titel $5.1 \mathrm{Wm}$, waarop in de bijzondere regels van Titel 5.2 Wm een uitzondering is gemaakt. De wetgever zou er beter aan hebben gedaan om niet de indruk te wekken dat het in Titel $5.1 \mathrm{Wm}$ gaat om 'algemene' bepalingen ten aanzien van milieukwaliteitseisen.

Deze indruk kan eenvoudig worden weggenomen door de inhoud van de huidige Titel 5.2 Wm op te nemen in een Titel 5.1 Wm Luchtkwaliteitseisen en daarna de inhoud van de huidige Titel 5.1 Wm op te nemen in een Titel 5.2 Wm Overige milieukwaliteitseisen. Alsdan zou aanstonds duidelijk zijn, dat het niet gaat om algemene en bijzondere bepalingen. 


\subsubsection{Gelede normstelling}

\section{Algemeen}

In deze paragraaf wil ik aandacht besteden aan een in het omgevingsrecht frequent toegepaste ${ }^{371}$ categorie van typisch juridische systeemcriteria. Het gaat daarbij om het principe van hiërarchie van wetgeving ${ }^{372}$ of de gelede normstelling ${ }^{373}$ :

- wet in formele zin. Een wet in formele zin is het document dat volgens de in de Grondwet omschreven procedure tot stand wordt gebracht door Regering en Staten-Generaal gezamenlijk; ${ }^{374}$

- algemene maatregel van bestuur. Artikel 89 lid 1 Grondwet noemt de algemene maatregel van bestuur als algemene regeling. Deze wordt vastgesteld bij koninklijk besluit. In het algemeen berust een algemene maatregel van bestuur op een wet, maar dat hoeft niet. Dan is sprake van een zelfstandige algemene maatregel van bestuur; ${ }^{375}$

- ministeriële regeling. Ministeriële regelingen zijn algemeen verbindende voorschriften die zijn vastgesteld door een minister of staatssecretaris. Veerman noemt een beleidsmatig voordeel van ministeriële regelingen dat er weinig externe controle op is; ook de rechter kan weinig meer dan de regeling toetsen aan de grondslag. Vanuit een juridische invalshoek en de waarden die daaraan verbonden zijn, zijn deze regelingen er volgens Veerman echt voor de details. ${ }^{376}$

Een recent voorbeeld in het omgevingsrecht moge zulks verduidelijken. De op 1 oktober 2010 in werking getreden Wabo is verder uitgewerkt in het Besluit omgevingsrecht (Bor), dat weer is uitgewerkt ${ }^{377}$ in de ministeriële Regeling omgevingsrecht (Mor). Daarnaast bevat deze Regeling ook regels die een directe uitwerking vormen van de Wabo. ${ }^{378}$

Zo bepaalt artikel 2.4 lid 2 Wabo dat bij algemene maatregel van bestuur kan worden bepaald dat Gedeputeerde Staten bevoegd gezag zijn om op een aanvraag om omgevingsvergunning te beslissen als het gaat om een project

371 Ik heb de indruk dat de wetgever bij voorkeur wetten ontwerpt met drie lagen, maar niet altijd voldoende aandacht heeft besteed aan de vraag of dat in het gegeven geval aangewezen is.

372 Zie uitgebreider doch voor mijn onderzoek niet direct relevant: Veerman \& Hendriks-de Lange, Over wetgeving 2007, p. 51: internationaal recht/recht van de Europese Unie, Statuut, Grondwet, Rijkswet/wet in formele zin, algemene maatregel van rijksbestuur/algemene maatregel van bestuur, (klein $\mathrm{KB}$ ) en ministeriële regeling

373 De gelede normstelling is beschreven door Van Wijk/Konijnenbelt \& Van Male, Hoofdstukken van bestuursrecht 2008, p. 140-147.

374 Munneke, Begrippen 2012, p. 59. Art. 81 Gw e.v.

375 Veerman \& Hendriks-de Lange, Over wetgeving 2007, p. 49

376 Veerman \& Hendriks-de Lange, Over wetgeving 2007, p. 51.

377 Art. 4.3 lid 3, 4.4 lid 1 en 5.4 lid 2 Bor.

378 Art. 5.11 lid 3 Wabo geeft de minister van IenM de bevoegdheid om bij ministeriële regeling te bepalen dat bestuursorganen die met de uitvoering of de handhaving van het bij of krachtens de betrokken wet bepaalde zijn belast, daarbij aan te geven gegevens te verstrekken aan de krachtens art. 5.11 lid 1 Wabo aangewezen ambtenaren. Van deze mogelijkheid is gebruik gemaakt in art. 9.1 Mor. 
dat in hun provincie in hoofdzaak zal worden uitgevoerd. Het betreft hier een uitzondering op de hoofdregel in artikel 2.4 lid 1 Wabo dat BenW bevoegd gezag zijn. Artikel 2.4 lid 2 Wabo is uitgewerkt in het Besluit omgevingsrecht. Artikel 3.3 lid 1 Bor bepaalt in welke gevallen Gedeputeerde Staten bevoegd gezag zijn.

Een ander voorbeeld van gelede normstelling in het omgevingsrecht betreft het op de Wet milieubeheer gebaseerde ${ }^{379}$ Besluit algemene regels voor inrichtingen milieubeheer, ${ }^{380}$ dat is uitgewerkt in de ministeriële Regeling algemene regels voor inrichtingen milieubeheer. ${ }^{381}$

\section{Bestuurlijke overwegingen}

Het gebruik van gelede normstelling kan een aantal voordelen hebben. Met name Veerman noemt een aantal voordelen voor de wetgever.

Volgens Veerman is delegatie onder meer een bestuurlijke kwestie omdat het primair verband houdt met het bestuur van het land. ${ }^{382}$ Hij noemt vijf bestuurlijke overwegingen voor delegatie:

- De eerste reden is dat de organen van de wetgevende macht zoveel te doen hebben dat eenvoudigweg niet alles bij wet kan worden vastgesteld. ${ }^{383} \mathrm{Er}$ is te weinig capaciteit. Delegatie bevordert een doelmatige werkverdeling tussen regering en parlement.

- Een tweede reden is de behoefte aan flexibiliteit en slagvaardigheid, waarbij moet worden gedacht aan de aanpassing van regels aan snel veranderende omstandigheden. De slagvaardigheid kan ook een financiële achtergrond hebben; bezuinigingen zijn bijvoorbeeld moeilijker te realiseren als de bekostiging is vastgelegd in de wet.

- Een derde reden is wat Veerman de verplaatsingsreden noemt. De verschillen van mening over de inhoud van wetgeving kunnen zo groot zijn dat de ministers en departementen het onderling niet eens worden. Om voortgang in het wetgevingsproces te houden, wordt het litigieuze onderwerp verplaatst naar een algemene maatregel van bestuur en dus naar de toekomst. ${ }^{384}$

- Een vierde reden voor delegatie is het machtsmotief: bewindslieden willen de vinger aan de pols houden.

- Ten slotte kan men volgens Veerman willen experimenteren.

379 Art. $8.40 \mathrm{Wm}$

380 Stb. 2007, 472 (Activiteitenbesluit).

381 Stcrt. 2007, 223 (Activiteitenregeling).

382 Veerman \& Hendriks-de Lange, Over wetgeving 2007, p. 60.

383 Aldus ook de Commissie Wetgevingsvraagstukken, Orde in de regelgeving 1985.

384 Een voorbeeld van deze situatie is de implementatie van de Richtlijn milieuaansprakelijkheid in hoofdstuk 17 Wm (Stb. 2008, 166). De Tweede Kamer wilde meer activiteiten onder de regeling laten vallen dan waartoe de richtlijn verplichtte. Uiteindelijk werd ervoor gekozen om bedoelde uitbreiding mogelijk te maken door aanwijzing in een amvb (art. 17.7 onder a onder $2^{\circ} \mathrm{Wm}$ ). Toen deze delegatiebepaling op bezwaren bij de Eerste Kamer stuitte werd besloten te onderzoeken of een dergelijke amvb nuttig zou zijn (Kamerstukken II 2007/08, 30 920, nr. 19). Op basis van de resultaten van dat onderzoek heeft de regering op 19 mei 2010 besloten om een wetsvoorstel voor te bereiden waarmee de amvb-grondslag zou vervallen (Kamerstukken II 2009/10, 30 920, nr. G). Op 30 april 2012 stond die grondslag nog steeds in art. $17.7 \mathrm{Wm}$. 


\section{Juridische overwegingen}

Veerman noemt verder een drietal principiële juridische overwegingen bij delegatie: ${ }^{385}$

- Het democratisch beginsel brengt mee dat de wetgever zoveel mogelijk de inhoudelijke onderwerpen in de wet regelt. ${ }^{386}$

- De leer der machtenscheiding brengt mee dat regelgeving en uitvoering niet in één hand zijn ondergebracht.

- Het rechtszekerheidsargument: door de gelede normstelling raakt het overzicht mogelijk zoek. Hierbij merk ik op, dat het overzicht ook zoek kan raken als niet wordt overgegaan tot gelede normstelling. Dat zou mijns inziens het geval zijn geweest als de bepalingen in het Besluit omgevingsrecht en de Regeling omgevingsrecht integraal in de Wabo zouden zijn opgenomen. ${ }^{387}$

\section{Relevantie wetssystematische plaats}

Ten slotte vraag ik in dit verband nog aandacht voor een aspect waarvan ik de indruk heb dat daarmee niet altijd rekening wordt gehouden. Het gaat om het punt dat louter reeds de wetssystematische plaats van een wettelijke bepaling de feitelijke werkzaamheid daarvan kan verhogen of daaraan juist afbreuk kan doen. ${ }^{388}$ Daarbij gaat het niet alleen om de opzoekbaarheid en kenbaarheid van een norm, die zoals hiervoor in paragraaf 3.2.5 reeds is opgemerkt, afhankelijk is van de plaats van een norm in een wetssysteem. Noll schrijft in dit verband dat 'auch der Zugang zum allgemeinen Rechtsbewußtsein und dessen Beeinflussung vom systematischen Zusammenhang und gesetzlichen Kontext bestimmt werden, in welchem die Norm sich befindet. Schon der Ausdruck 'Nebengesetz' läßt auf die Tatsache schließen, daß zumindest im Bewußtsein der Juristen die darunter eingeordneten Normen weniger zentrale Stellung einnehmen als die in de Hauptkodifikationen enthaltenen Rechtssätze. ${ }^{389}$ Naar mijn oordeel wijst hij daar op een belangrijk punt. Normen die in een algemene maatregel van bestuur of een ministeriële regeling zijn neergelegd kunnen in de praktijk vanwege die wetssystematische plaats al snel worden beschouwd als van minder gewicht. Een belangrijke aanleiding voor die gedachte lijkt mij, dat dergelijke normen vaak juist op die plaatsen zijn terechtgekomen vanwege het feit dat ze dan sneller en eenvoudiger kunnen worden aangepast. Door normen vast te leggen op een wetssystematische plaats waarin wijzigingen moeilijker kunnen worden gerealiseerd, lijkt de wetgever ook te kennen te geven dat hij die normen van groter gewicht acht. Illustratief voor die gedachte zijn

385 Veerman \& Hendriks-de Lange, Over wetgeving 2007, p. 61.

386 Zie in dit verband ook Rademaker, Interview 2011, bijl. 5.2, par. 4.2, die aangeeft dat we "niet op alle fronten slim genoeg" zijn "om een kort en eenvoudig criterium te bedenken wat wel en niet met vergunning mag worden gebouwd. Dus is op die onderdelen vaak een uitwerking nodig, zoals bij vergunningvrije bouwwerken. Dit kan beter op amvb-niveau. Dat is flexibeler."

387 Zie par. 4.5.3.4.

388 Zie Noll, Gesetzgebungslehre 1973, p. 205.

389 Noll, Gesetzgebungslehre 1973, p. 205. 
grondwettelijke normen, die slechts via een zware procedure kunnen worden gewijzigd. ${ }^{390}$

\subsubsection{Chronologische systeemordeningscriteria}

Chronologische systeemordeningscriteria vervullen een nuttige functie bij het reguleren van zaken die in de tijd opvolgen. Om die reden worden dergelijke systeemordeningscriteria met name toegepast waar processen worden beschreven. ${ }^{391}$ De chronologie kan echter als zodanig niet dienen als samenhangcriterium voor het bepalen van een wetssysteem.

In dit verband past overigens een waarschuwing van Noll, dat het gebruik van chronologische systeemordeningscriteria ook als neveneffect kan hebben dat de indruk wordt gewekt alsof een bepaalde procedure dwingend moet worden afgewikkeld. Hij noemt het voorbeeld van een strafprocesrechtelijke regeling, waarin voorschriften zijn opgenomen over de opname en behandeling van een gedetineerde, en zijn ontslag uit een strafinrichting. Het gebruik van chronologische systeemordeningscriteria suggereert hier volgens Noll eerder dat de gevangene object is van een bijna automatisch aflopende reeks van gebeurtenissen en niet subject van rechten en verplichtingen. ${ }^{392}$

\subsubsection{Europese richtlijnen en verordeningen}

Het milieurecht in Nederland is voor een aanzienlijk deel een implementatie van Europese richtlijnen.

Volgens Drupsteen mocht in 1998 al worden aangenomen dat meer dan de helft van de nieuwe wet- en regelgeving op het terrein van het milieu uit implementatiewetgeving van Europese richtlijnen en verdragen bestaat, terwijl ook de Europese verordeningen, hoewel ze uit zichzelf werken - toch vaak om aanvullende wetgeving vragen bijvoorbeeld op het gebied van de handhaving. ${ }^{393}$ Ook het natuur- en waterrecht bestaat voor een belangrijk deel uit de implementatie van Europese richtlijnen, zoals de Vogelrichtlijn, ${ }^{394}$ de Habitatrichtlijn ${ }^{395}$ en de Kaderrichtlijn water. ${ }^{396}$

Het ligt dan ook voor de hand om bij het ordenen van het Nederlandse omgevingsrecht samenhang te realiseren tussen het Europese recht en het

390 Zie hfds. $8 \mathrm{Gw}$

391 Sebus, Wetgevingstechniek en de toegankelijkheid van de wet voor de burger 1984, p. 61.

392 Noll, Gesetzgebungslehre 1973, p. 212.

393 Zie Drupsteen, De toekomst van de Wm 1998, p. 24.

394 Richtlijn 2009/147/EG van het Europees Parlement en de Raad van de Europese Unie van 30 november 2009 inzake het behoud van de vogelstand (PbEU 2010, L 20/7).

395 Richtlijn 92/43/EEG van de Raad van de Europese Gemeenschappen van 21 mei 1992 inzake de instandhouding van de natuurlijke habitats en de wilde flora en fauna (PbEG 1992 L 206/7).

396 Richtlijn 2000/60/EG van het Europees Parlement en de Raad van 23 oktober 2000 tot vaststelling van een kader voor communautaire maatregelen betreffende het waterbeleid (PbEG 2000 L 327/1). 
nationale recht. Aangezien het Europese recht leidend is, dient het nationale recht volgend te zijn voor wat betreft zakelijke systeemordeningscriteria. Dat is bijvoorbeeld mogelijk door in het kader van omzetting van Europese richtlijnen zakelijke systeemordeningscriteria in dergelijke richtlijnen over te nemen in Nederlandse wetssystemen. ${ }^{397,} 398$ Als dat niet gebeurt, is nog geen sprake van een wetssystematisch tekort. In een wetssysteem behoeven immers niet zowel de implementatieregels als de regels van de richtlijn zelf een plaats te krijgen.

Interessant is in dit verband de waarschuwing van Uylenburg c.s. ${ }^{399}$ dat het ontwerpen van een nieuwe, of een aangepaste structuur voor de Wet milieubeheer, de Wabo of een Omgevingswet met veronachtzaming van de taak om de Europese regelgeving in de Nederlandse rechtsorde te integreren en te handhaven, kortzichtig en contraproductief zou zijn. Vanuit wetssystematisch oogpunt zijn met name twee door hen genoemde noties inzake de ontwikkelingen in de Europese milieuwetgeving van belang.

In de eerste plaats de notie dat op EU-niveau, anders dan in Nederland, vrijwel geen wetgeving tot stand wordt gebracht waarbij verschillende sectoren van het milieu geïntegreerd worden gereguleerd. Wel is in de Europese Unie een ontwikkeling merkbaar naar een geïntegreerde benadering per milieu-onderdeel. Voorbeelden daarvan zijn de Kaderrrichtlijn water, ${ }^{400}$ de IPPC-richtlijn ${ }^{401}$ en de Richtlijn industriële emissies. ${ }^{402}$

In de tweede plaats is er een tendens om specifieke milieubeleidsterreinen in een kaderrichtlijn te regelen, zoals bij water, lucht en mariene omgeving, waarbij alleen essentiële onderdelen in een dergelijke richtlijn worden neergelegd. Nadere

397 Zie ook par. 3.3.7

398 Uylenburg c.s. menen dat Europeesrechtelijke kaders en begrippen in beginsel overgenomen dienen te worden. Zij denken daarbij aan het vervangen van het begrip 'inrichting' door het begrip 'installatie' of 'activiteit', het beter aansluiten bij Europeesrechtelijke termen zoals 'grenswaarde' en bij Europeesrechtelijke instrumenten, zoals plan- en programmaverplichtingen (Uylenburg/Vogelezang-Stoute/Boeve/van der Grijp/Groothuijse/Koeman/Smorenburg-van Middelkoop \& Peeters, De Wm als kader voor implementatie van Europese wetgeving 2010, p. 424). Voor verdere lezing: Vogelezang-Stoute/Boeve/van der Grijp/Groothuijse/Koeman/van Middelkoop/Peeters \& Uylenburg, De Wm als kader voor implementatie van Europese wetgeving 2009. Zie in dit verband ook par. 3.6.3.

399 Uylenburg/Vogelezang-Stoute/Boeve/van der Grijp/Groothuijse/Koeman/Smorenburg-van Middelkoop \& Peeters, De Wm als kader voor implementatie van Europese wetgeving 2010, p. 418.

400 Richtlijn 2000/60/EG van het Europees Parlement en de Raad van 23 oktober 2000 tot vaststelling van een kader voor communautaire maatregelen betreffende het waterbeleid (PbEG $2000 \mathrm{~L}$ 327/1).

401 Richtlijn 2008/1/EG van het Europees Parlement en de Raad van 15 januari 2008 inzake geïntegreerde preventie en bestrijding van verontreiniging, (PbEU 2008 L 24/8).

402 Richtlijn 2010/75/EU van het Europees Parlement en de Raad van 24 november 2010 inzake industriële emissies (geïntegreerde preventie en bestrijding van verontreiniging) (herschikking) (PbEU 2010 L 334/17). In Nederland wordt deze richtlijn gewoonlijk afgekort met IED (Industrial Emissions Directive). 
normen worden dan soms door middel van dochterrichtlijnen, maar ook door middel van comitologiebesluiten of via co-regulering ${ }^{403}$ tot stand gebracht. ${ }^{404}$

Woldendorp meent dat het van realiteitszin zou getuigen om de Europese invalshoek bij de integratie van het omgevingsrecht vaker als uitgangspunt te hanteren. Hij wijst er daarbij op dat integrerende processen in Europa langs andere breuklijnen verlopen dan in Nederland. De invalshoek is vaak niet 'bedrijven', maar 'maatschappelijke problemen'. Dat verschil in invalshoeken betekent dat Europese regels moeten worden opgeknipt en nationaal herverkaveld, hetgeen volgens Woldendorp een vlotte implementatie bemoeilijkt. ${ }^{405}$

Van een wetssystematisch tekort is wel sprake als in een Nederlands wetssysteem ter implementatie van een Europese richtlijn wordt verwezen naar die richtlijn op zodanige wijze dat de gebruiker van het wetssysteem ook die richtlijn moet raadplegen om zijn rechten en verplichtingen te kunnen kennen. In dat geval hangen de regels in het wetssysteem en de richtlijn immers wel onderling samen, maar maken zij geen deel uit van hetzelfde wetssysteem. ${ }^{406}$

Een voorbeeld in het Nederlandse omgevingsrecht treffen we aan in artikel 12.20 Wm. Het eerste lid bepaalt dat indien degene die een inrichting drijft, ingevolge artikel 5 lid 1 EG-verordening PRTR $^{407}$ met betrekking tot een kalenderjaar rapportageplichtig is, hij uiterlijk op 31 maart van het kalenderjaar volgend op het verslagjaar aan de op grond van artikel 12.21 Wm bevoegde instantie langs elektronische weg een verslag moet zenden bevattende de in artikel 5 lid 1 en 2 EG-verordening PRTR bedoelde gegevens. Het tweede lid bepaalt dat het PRTR-verslag moet voldoen aan de in artikel 9 lid 2 EG-verordening PRTR genoemde kwaliteitseisen. Het subwetssysteem van Titel 12.3 Wm De EG-verordening PRTR en het PRTR-protocol kent dientengevolge een aantal wetssystematische tekorten, aangezien de rapportageplichtige niet in dit subwetssysteem, maar in de EG-verordening PRTR moet opzoeken of hij rapportageplichtig is, welke gegevens hij moet rapporteren en aan welke kwaliteitseisen het PRTR-verslag moet voldoen.

403 Een vorm van regulering waarbij, binnen het kader van communautaire regels, partijen een bepaalde ruimte hebben voor zelfregulering.

404 Uylenburg/Vogelezang-Stoute/Boeve/van der Grijp/Groothuijse/Koeman/Smorenburg-van Middelkoop \& Peeters, De Wm als kader voor implementatie van Europese wetgeving 2010, p. 419.

405 Woldendorp, Makkelijker kunnen we het niet maken, wel leuker? 2010.

406 Aanwijzing 78 lid 1 Aanwijzingen voor de regelgeving bepaalt: Verwijzing naar andere bepalingen wordt vermeden, indien de toegankelijkheid van de regeling daardoor onnodig wordt geschaad. Onduidelijk is echter op welke schadelijkheid wordt gedoeld. Ook is niet helder wat deze aanwijzing inhoudt ten aanzien van verwijzing naar Europese wetgeving (idem Uylenburg/Vogelezang-Stoute/ Boeve/van der Grijp/Groothuijse/Koeman/Smorenburg-van Middelkoop \& Peeters, De Wm als kader voor implementatie van Europese wetgeving 2010, p. 420).

407 Art. 1.1 lid 1 Wm bepaalt: EG-verordening PRTR: verordening (EG) nr. 166/2006 van het Europees Parlement en de Raad van de Europese Unie van 18 januari 2006 betreffende de instelling van een Europees register inzake de uitstoot en overbrenging van verontreinigende stoffen en tot wijziging van de Richtlijnen 91/689/EEG en 96/61/EG van de Raad (PbEU 2006 L 33/1). 
Een belangrijk voordeel van het gebruik van een dergelijk typisch juridisch systeemordeningscriterium als een verwijzing naar Europese richtlijnen of verordeningen is dat de richtlijn of verordening niet behoeft te worden overgeschreven in Nederlandse wetssystemen. Dat brengt met zich dat er geen licht kan zitten tussen de Europese en de nationale regels. Voor de wetgever is een voordeel dat hij de desbetreffende Europese regel niet behoeft over te schrijven, hetgeen in het algemeen zal leiden tot minder omvangrijke nationale wetssystemen. Een belangrijk nadeel is, dat onduidelijke Europese regels door implementatie niet opeens aan duidelijkheid winnen, maar een onduidelijkheid scheppen in het nationale recht.

Volgens Uylenburg c.s. is niet duidelijk in hoeverre de omzettingstechniek via verwijzing voldoet aan de vereiste nauwkeurigheid en duidelijkheid. Het Hof lijkt soms toe te staan dat in nationale wetgeving ter implementatie van richtlijnen wordt verwezen naar andere, meer gedetailleerde normen. ${ }^{408}$

In het licht van de implementatie van Europese regels hanteert de Nederlandse wetgever nog een ander typisch juridisch ordeningscriterium dat kan leiden tot wetssystematische tekorten. Het gaat dan om het gebruik van een richtlijn of verordening als samenhangcriterium. Het (sub)wetssysteem wordt dan bepaald door regels die dienen ter implementatie van een bepaalde verordening of richtlijn.

Voorbeelden in de Wet milieubeheer zijn:

- titel 9.3 Wm De EG-verordening registratie, evaluatie en autorisatie van chemische stoffen;

- titel 9.3a Wm De EG-verordening indeling, etikettering en verpakking van stoffen en mengsels;

- titel 9.4 Wm De EG-richtlijn ecologisch ontwerp energiegerelateerde producten;

- titel 12.3 Wm De EG-verordening PRTR en het PRTR-protocol.

Een belangrijk voordeel van het gebruik van een dergelijk typisch juridisch systeemordeningscriterium is, dat de gebruiker aanstonds weet waar hij de regels ter implementatie van de desbetreffende Europese regels kan vinden, vooropgesteld dat die regels niet ook elders in een ander (sub)wetssysteem een plaats hebben gekregen.

3.4.5. Verdedigbare wetssystematische tekorten

\subsubsection{Algemeen}

Hiervoor is een aantal mogelijke belangrijke voordelen besproken van een aantal in het huidige omgevingsrecht veel gebruikte typisch juridische

408 Commissie/Duitsland, zaak C-108/85. 
ordeningscriteria. ${ }^{409}$ Tegenover de mogelijke voordelen van het gebruik van dergelijke systeemordeningscriteria staat een belangrijk nadeel. Dat nadeel is dat het gebruik van dergelijke criteria de samenhang op basis van zakelijke samenhangcriteria eerder zal doorbreken dan bevorderen. De regels die gelden voor wat in de echte werkelijkheid samenhangt staan als gevolg van het gebruik van genoemde typisch juridische samenhangcriteria immers verspreid over meer (sub)wetssystemen. De wetgever zal dan ook van geval tot geval moeten onderbouwen waarom de voordelen van het gebruik van typisch juridische systeemordeningscriteria opwegen tegen het scheppen of handhaven van wetssystematische tekorten. Hierna zal ik van elk van de in paragraaf 3.4.4 genoemde categorieën van typisch juridische systeemcriteria met een voorbeeld aangeven hoe een wetssystematisch tekort zou kunnen worden opgeheven. Daarbij zal ik aangeven of dat tot een verbetering leidt. Zo niet, dan is het wetssystematisch tekort verdedigbaar.

\title{
3.4.5.2. Algemeen en bijzonder
}

Als voorbeeld van een wetssystematisch tekort als gevolg van het gebruik van het typisch juridisch ordeningscriterium algemeen-bijzonder heb ik het voorbeeld genoemd van de Richtlijn industriële emissies. ${ }^{410}$

Hier lijkt mij het gebruik van algemene en bijzondere bepalingen voor bepaalde installaties verdedigbaar. Het alternatief zou immers zijn, dat de algemene regels per categorie van installaties in het desbetreffende subwetssysteem zou moeten worden overgeschreven. Dat betekent niet alleen een onnodige belasting voor de wetgever en een onnodig omvangrijk wetssysteem, maar zou ook betekenen dat de exploitant die meer bijzondere installaties exploiteert zelf zou moeten uitzoeken in hoeverre bij elke installatie sprake is van algemeen geldende en bijzondere regels.

\subsubsection{Gelede normstelling}

\begin{abstract}
Algemeen
Als voorbeeld van een wetssystematisch tekort als gevolg van het gebruik van het typisch juridisch ordeningscriterium van de gelede normstelling kan artikel 8.40 Wm gelden. Dat bepaalt dat bij of krachtens algemene maatregel van bestuur regels worden gesteld, die nodig zijn ter bescherming van het milieu tegen de nadelige gevolgen die inrichtingen daarvoor kunnen veroorzaken. De belangrijkste algemene maatregel van bestuur is het Activiteitenbesluit dat algemene regels bevat voor circa 281.500 inrichtingen. De Regeling algemene regels voor inrichtingen (Activiteitenregeling) werkt een aantal algemene regels voor inrichtingen verder uit. Inrichtingen
\end{abstract}

409 De chronologische systeemordeningscriteria blijven hierna verder buiten beschouwing.

410 Zie par. 3.4.4.1. 
die te maken hebben met algemene regels, dienen dus de Wet milieubeheer, het Activiteitenbesluit en de Activiteitenregeling te raadplegen. Veerman is op dit punt niet helder. Hij lijkt het met mij eens te zijn, waar hij meent dat door de gelede normstelling het overzicht mogelijk zoek raakt. Maar hij merkt ook op dat wetten niet te gedetailleerd moeten zijn en dat het subsidiariteitsvereiste vereist dat een regeling zo dicht mogelijk tegen de werkelijkheid moet aanzitten en dus moet worden getroffen op een zo laag mogelijk niveau. Direct betrokkenen kunnen dan directer worden ingeschakeld. ${ }^{411}$

Het Activiteitenbesluit bevatte op 1 januari 2008238 artikelen en een bijlage, de Regeling algemene regels voor inrichtingen 176 artikelen en twee bijlagen. Door het opnemen van besluit en regeling aansluitend aan artikel $8.40 \mathrm{Wm}$ zou de Wet milieubeheer vermoedelijk aan kenbaarheid inboeten. Gelede normstelling acht ik in dit geval dan ook verdedigbaar. Daarbij plaats ik hierna twee kanttekeningen.

\section{Normstelling op drie niveaus}

De eerste kanttekening betreft de vraag of gelede normstelling op drie niveaus hier verdedigbaar is. Zou er vanuit wetssystematisch oogpunt niet iets voor te zeggen zijn om de gelede normstelling waar mogelijk te beperken tot zo min mogelijk niveaus? Waarom zouden de regels van de Activiteitenregeling niet kunnen worden opgenomen in het Activiteitenbesluit? Alsdan zou de gebruiker bepalingen inzake algemene regels voor inrichtingen vinden in de Wet milieubeheer en het Activiteitenbesluit.

Woldendorp is van mening dat gelaagdheid wetgeving 'echt ingewikkeld' maakt. Hij noemt een voorbeeld waar een soortgelijke wetgevende activiteit op vier niveaus wordt geregeld. Het gaat om de aanwijzing van beschermde diersoorten. Woldendorp: “Als je ziet hoeveel lijsten met dieren er zijn. In de eerste plaats zijn er de richtlijnen waarnaar rechtstreeks wordt verwezen bij ministeriële regeling. Maar dan heb je verder nog aanwijzingen bij wet, bij algemene maatregel van bestuur en nog een keer bij ministeriële regeling en daar komen dan nog verduidelijkende handleidingen met hun eigen lijsten bovenop om invulling te geven aan algemene aanduidingen in de regelgeving, zoals 'alle in Europa in het wild voorkomende vogelsoorten." 412 Arentz waarschuwt dat 'de Omgevingswet is gedoemd te mislukken als er niet iets gedaan wordt aan de 'lijstjesterreur'. De voornaamste bezigheid van de omgevingsrechtelijke werkvloer is volgens hem het doorakkeren van de lijstjes waar het omgevingsrecht van wemelt: lijstjes met milieurelevante inrichtingen, lijstjes met algemeen geregelde activiteiten en uitzonderingen daarop, lijstjes met vergunningplichtige inrichtingen (inclusief doorverwijzingen naar lijstjes in andere algemene maatregelen van bestuur, inclusief doorverwijzingen naar lijstjes in ministeriële regelingen), lijstjes met m.e.r.plichtige of m.e.r.-beoordelingsplichtige gevallen, bevoegd gezag- en vvgb-lijstjes

411 Veerman \& Hendriks-de Lange, Over wetgeving 2007, p. 60-61.

412 Woldendorp, Interview 2011, bijl. 5.1, par. 5.1. 
en last but not least, als jongste telg van de immer uitdijende lijstjesfamilie, de Crisis- en herstellijstjes. ${ }^{413}$

Illustratief in dit verband is hetgeen de Raad van State opmerkt naar aanleiding van de implementatie van de Richtlijn industriële emissies. ${ }^{414}$ De Raad overweegt: 'De implementatie van de richtlijn maakt zichtbaar dat de geldende Nederlandse systematiek van milieueisen zeer complex is. Naast de in het wetsvoorstel voorgestelde implementatie van een aantal artikelen van de richtlijn in de Wet milieubeheer (Wm), de Wet algemene bepalingen omgevingsrecht (Wabo) en enkele andere wetten, zullen de overige richtlijnartikelen worden geïmplementeerd in bijvoorbeeld het Besluit algemene regels voor inrichtingen milieubeheer (het Activiteitenbesluit), het Besluit omgevingsrecht (het Bor) en de regeling omgevingsrecht. Een burger zal steeds de diverse wettelijke regelingen moeten raadplegen om zijn rechten en plichten te kennen. Deze gelaagdheid van de regelgeving, alsmede de omstandigheid dat de regelingen niet altijd volledig op elkaar zijn afgestemd en de gelding van de Wm naast de Wabo maken het systeem onoverzichtelijk en complex. ${ }^{415}$ Opvallend is dat de regering de kritiek van de Raad van State kenschetst als een 'korte schets van de complexe en gelaagde systematiek van de Nederlandse milieuwetgeving, ${ }^{416}$ terwijl de Raad die complexiteit juist onder meer ziet als gevolg van die gelaagde systematiek. Verder valt op dat de regering zich deze kritiek eigenlijk niet aantrekt, daartegen in elk geval geen verweer voert en geen oplossing aandraagt. Deze opstelling lijkt mij te stroken met de beperkte aandacht die de door mij geïnterviewde wetgevingsjuristen aangeven te hebben voor wetssystematiek. ${ }^{417}$

Mij lijkt niet op voorhand te zeggen of een regeling op één (wet in formele zin), twee (wet in formele zin en amvb) of drie niveaus (wet in formele zin, amvb en ministeriële regeling) wenselijk is. Een algemene maatregel van bestuur en een ministeriële regeling hoeven - tenzij er sprake is van voor- of nahang ${ }^{418}$ niet langs de Tweede en de Eerste Kamer. Een algemene maatregel van bestuur wordt wel besproken in de ministerraad en van een advies voorzien door de Raad van State. In volgorde van democratische controle zou dus moeten worden gekozen voor wet, algemene maatregel van bestuur, ministeriële regeling. In termen van snelheid zou wellicht de omgekeerde volgorde moeten worden aangehouden. Ik pleit ervoor dat de wetgever daarnaast ook de door gelede normstelling veroorzaakte - mogelijk onverdedigbare - wetssystematische tekorten afweegt. Zo zou de wetgever tot de conclusie kunnen

413 Arentz, De kop moet er (juist) op! 2012, 398

414 Richtlijn 2010/75/EU van het Europees Parlement en de Raad van 24 november 2010 inzake industriële emissies (geïntegreerde preventie en bestrijding van verontreiniging) (herschikking) (PbEU 2010 L 334/17).

415 Kamerstukken II 33 197, nr. 4, p. 2.

416 Kamerstukken II 33 197, nr. 4, p. 3.

417 Bijl. 5.

418 Bij nahang krijgen de beide Kamers der Staten-Generaal de gelegenheid te reageren op een amvb na de vaststelling ervan. Bij voorhang krijgen de beide Kamers de gelegenheid te reageren op het ontwerp van een amvb (Kamerstukken II 2006/07, 30 930, nr. 3, p. 1 (Wijziging van diverse wetten in verband met vereenvoudiging en harmonisatie van de totstandkomingsprocedures voor algemene maatregelen van bestuur op het gebied van wonen, ruimte en milieu (voor- en nahangprocedures)). 
komen dat de snelheid waarmee de Activiteitenregeling kan worden aangepast niet opweegt tegen het wetssystematisch tekort en de zwaardere procedure die geldt voor aanpassing van het Activiteitenbesluit. Alsdan zou het wellicht geraden zijn om de Activiteitenregeling op te nemen in het Activiteitenbesluit.

\section{Het combineren van uitvoeringsregels}

De tweede kanttekening betreft de opmerking van Borman dat er de laatste jaren sprake lijkt te zijn van een tendens om uitvoeringsregels van een nieuwe wet zo veel mogelijk samen te brengen in één algemene maatregel van bestuur en één ministeriële regeling. ${ }^{419}$ Heuving \& Boere hebben in 2005 voorgesteld om in de Aanwijzingen voor de regelgeving op te nemen om op één wet maar één algemene maatregel van bestuur en één ministeriële regeling te baseren. Als voordelen noemen zij dat nooit meer hoeft te worden gezocht in welke besluiten en regelingen (allemaal) nadere regels zijn gesteld (als ze niet in die ene algemene maatregel van bestuur of ministeriële regeling staan zijn ze er eenvoudig niet), kenbaarheid, toegankelijkheid, de dwang tot inhoudelijke consistentie en het feit dat minder vaak wijzigingen nodig zijn. ${ }^{420}$ Als voordeel van deze aanpak noemt Borman dat het onderlinge verband tussen de uitvoeringsregels duidelijker wordt, dat er minder kans bestaat op inconsistenties en dat herhalingen worden vermeden. Het nadeel van een groot aantal artikelen in één regeling kan volgens hem worden ondervangen via een overzichtelijke indeling van de artikelen in hoofdstukken en paragrafen.

Borman meent dat de hoofdstukken van een omvangrijk uitvoeringsbesluit in feite elk een soort mini-amvb vormen. Het Activiteitenbesluit laat dat mijns inziens juist niet zien. Deze algemene maatregel van bestuur is oorspronkelijk ontstaan door bundeling van elf amvb's waarin algemene regels stonden ten aanzien van specifieke inrichtingen, zoals winkels, garage's en horecabedrijven. Deze algemene regels zijn verspreid over het Activiteitenbesluit en vormen geen herkenbare sets van mini-amvb's voor bijvoorbeeld winkels, garage's en horecabedrijven. $^{421}$

Voor mijn onderzoek is met name genoemd onderling verband van belang. Daarbij sluit het door Borman genoemde advies van de Raad van State aan, toen hem in 2004 zeven algemene maatregelen van bestuur ter uitvoering van de wet op de jeugdzorg werden voorgelegd. Volgens de Raad wordt door bundeling in één algemene maatregel van bestuur 'de onderlinge samenhang veel duidelijker, kan volstaan worden met het eenmalig vermelden van definities en behoeft niet steeds naar andere besluiten te worden verwezen.'422

419 Borman, Combineren van uitvoeringsregels 2010.

420 Heuving \& Boere, De Aanwijzingen voor de regelgeving in de praktijk 2005, p. 16.

421 Borman, Combineren van uitvoeringsregels 2010.

422 Zie onder meer Advies van 24 november 2003, nr. W13.03.0396/III, punt 1, inzake het Besluit jeugdzorgaanspraken. 
Interessant is ook het door Borman genoemde voorbeeld van het advies van de Raad van State over een voorgenomen aanvulling van het Besluit videoconferentie. De Raad van State adviseerde hier tegen bundeling omdat hij het geen goed idee vond de regels inzake de videoconferentie in het vreemdelingenrecht uit te breiden met regels over de videoconferentie in het strafrecht. ${ }^{423}$ Minister Hirsch Ballin vond het echter overzichtelijker als alle regels inzake de videoconferentie in dezelfde algemene maatregel van bestuur zouden staan. Later zouden immers ook aanvullingen komen met betrekking tot de videoconferentie in het civiele recht en het bestuursrecht. Interessant is hier dat de minister mijns inziens kiest voor het op de echte werkelijkheid gebaseerde samenhangcriterium van de videoconferentie in plaats van voor typisch juridische ordeningscriteria.

Op 11 mei 2011 is Aanwijzing 104 opgenomen in de Aanwijzingen voor de regelgeving. Indien een regeling voorziet in de verplichting of de bevoegdheid tot het vaststellen van uitvoeringsregelingen, wordt ter uitvoering van de hogere regeling zo mogelijk één algemene maatregel van bestuur of ministeriële regeling vastgesteld. In een uitvoeringsregeling worden zo mogelijk de indeling en volgorde van de onderdelen, de opschriften van die onderdelen, de wijze van nummering van de artikelen en de volgorde van de artikelen van de hogere regeling in acht genomen.

Als voorbeelden worden genoemd de Vreemdelingenwet 2000 en het Vreemdelingenbesluit 2000. ${ }^{424}$ Op het gebied van het omgevingsrecht zijn het Bor en de Mor goede voorbeelden.

De toelichting op deze aanwijzing vermeldt, dat de regelgeving overzichtelijker en toegankelijker wordt 'door per wet zo veel mogelijk met één algemene maatregel van bestuur of één ministeriële regeling te werken. (...) Bij een goed doordachte delegatiesystematiek kan ook een zekere besparing worden bereikt op de totale omvang van het wetgevingscorpus, omdat niet steeds hoeft te worden herhaald wat onder 'wet' of andere te herhalen begrippen moet worden verstaan. (...) Niet alleen de volgorde van de artikelen, maar de hele structuur van de hogere regeling wordt zo veel mogelijk gevolgd. Ook hierdoor worden de overzichtelijkheid en toegankelijkheid van de regelgeving gediend. ${ }^{425}$

\subsubsection{Europese richtlijnen en verordeningen}

Als voorbeeld van een wetssystematisch tekort als gevolg van het gebruik van het typisch juridisch ordeningscriterium van verwijzing naar Europese richtlijnen en verordeningen heb ik artikel $12.20 \mathrm{Wm}$ genoemd. ${ }^{426}$

423 Adviezen van 13 maart 2006, nr. W03.06.0013, punt 4 en van 9 juni 2006, nr. W03.06.142/1, punt 1

424 Stcrt. 2011, 6602, p. 11-12. Zie ook Roording, Interview 2011, bijl. 5.4, par. 4.1

425 Stcrt. 2011, 6602, p. 54.

426 Zie par. 3.4.4.5. 
De verwijzing naar een richtlijn ${ }^{427}$ acht ik in beginsel wetssystematisch niet verdedigbaar, aangezien de gebruiker daardoor een extra wetssysteem moet raadplegen om zijn rechten en verplichtingen te kunnen kennen. Dat lijkt een voordeel, met name als richtlijnen vaak veranderen. Dan kan de wetgever door middel van een dynamische verwijzing ervoor zorgen dat het verwijzende nationale wetssysteem niet behoeft te worden veranderd. Dat is echter met name een voordeel voor de wetgever. De gebruiker wordt door deze wetgevingstechniek niet alleen gedwongen om voor het kennen van zijn rechten en plichten meer wetssystemen te raadplegen, hij dient er zich ook elke keer dat hij de verwijzing leest van te vergewissen of de richtlijn waarnaar wordt verwezen inmiddels niet is gewijzigd. In het hierna gegeven voorbeeld is de gebruiker bovendien gedwongen de Staatscourant te raadplegen om te weten te komen of er een ministerieel besluit geldt.

Als voorbeeld noem ik artikel 1.1 lid 4 Wabo: Een wijziging van bijlage 1 bij richtlijn nr. 2008/1/EG van het Europees Parlement en de Raad van de Europese Unie van 15 januari 2008 inzake geïntegreerde preventie en bestrijding van verontreiniging ( $P b E U$ L 24) gaat voor de toepassing van de in het eerste lid gegeven omschrijving van 'gpbv-installatie' gelden met ingang van de dag waarop aan de betrokken wijzigingsrichtlijn uitvoering moet zijn gegeven, tenzij bij ministerieel besluit, dat in de Staatscourant wordt bekendgemaakt, een ander tijdstip wordt vastgesteld.

Als het gaat om een verwijzing naar een richtlijn, kan de wetgever een einde maken aan het wetssystematische tekort door de regelingen waarnaar wordt verwezen op te nemen in het - dan overigens niet meer - verwijzende wetssysteem. Daardoor kunnen gebruikers hun rechten en verplichtingen in hetzelfde wetssysteem lezen. Vermelding verdient overigens wel, dat de regels waarnaar wordt verwezen tamelijk ingewikkeld en omvangrijk kunnen zijn, zodat de wetgever omwille van de kenbaarheid waarschijnlijk niet zal kunnen ontkomen aan gelede normstelling of een bijlage bij de Wet milieubeheer. ${ }^{428}$

Een uitzondering moet worden gemaakt voor een verwijzing naar een Europese verordening. Verordeningen zijn volgens artikel 249 EG immers maatregelen met een algemene strekking die verbindend zijn in al hun onderdelen en rechtstreeks toepasselijk in elke lidstaat. Richtlijnen moeten in nationale wetssystemen worden omgezet. Voor verordeningen geldt dat zij niet in nationale wetssystemen mogen worden omgezet. Verordeningen dienen als verordening plaats te nemen in de rechtsorde van lidstaten. Lidstaten mogen of moeten wel uitvoeringsmaatregelen nemen op grond

427 Zie voor twee voorbeelden par. 4.5.4.2 en par. 6.5.4.2.

428 Zijlstra, Opzet en indeling van een wettelijke regeling 2012, p. 550 meent dat het, om een regeling enigszins 'schoon' te houden, nuttig kan zijn haar te voorzien van een bijlage. Dat geldt met name als men wel op hetzelfde regelingsniveau wil blijven, maar opneming in het lichaam van de regeling ten koste zou gaan van de toegankelijkheid. 
van de verordening, als die daarin voorziet. ${ }^{429}$ Als een verwijzing naar een verordening derhalve noodzakelijk is, acht ik zulks verdedigbaar.

\subsubsection{Wetssystematische koekoekseibepalingen}

Als de wetgever eenmaal heeft gekozen voor een samenhangcriterium, dan bepaalt dat criterium niet alleen het wetssysteem, maar dienen in beginsel ook alle regels die aan dat criterium voldoen in dat wetssysteem te worden opgenomen. Als dat niet het geval is, is sprake van een wetssystematisch tekort. Daarvan dient te worden onderscheiden het geval dat in een wetssysteem geen wetssystematische tekorten bestaan, omdat daarin alle regels zijn opgenomen die aan het gekozen samenhangcriterium voldoen, doch waarin zich regels bevinden die daarin op basis van dat samenhangcriterium niet thuis horen. Dergelijke regels noem ik wetssystematische koekoekseibepalingen. Voor een voorbeeld verwijs ik naar paragraaf 4.3.3.3.

De aanwezigheid van wetssystematische koekoekseibepalingen is in de eerste plaats onwenselijk, omdat zij een wetssysteem vervuilen met bepalingen die daarin niet thuis horen en daar derhalve ook niet snel zullen worden gezocht, hetgeen de kenbaarheid van de desbetreffende bepalingen niet ten goed komt. In de tweede plaats zijn wetssystematische koekoekseibepalingen onwenselijk, omdat zij eigenlijk thuis horen in een ander wetssysteem, wat voor dat wetssysteem tot een onwenselijk wetssystematisch tekort leidt.

Drupsteen waarschuwt overigens dat wetssystematische koekoekseibepalingen niet altijd zijn te voorkomen. Hij meent dat de wetgever wel kan beginnen met een systematisch ontwerp, maar dat er soms toch een kleinigheidje moet worden geregeld, dat niet past in het systeem, maar daarin toch wordt opgenomen. ${ }^{430}$ Woldendorp is dezelfde mening toegedaan en gebruikt in dat verband de metafoor van het opruimen van een kamer. Driekwart van de spullen past in kasten met planken en vakken, maar er blijft altijd wat over wat nergens past. Dat komt dan terecht in een systeem waarin het eigenlijk niet thuishoort. ${ }^{431}$

Uit deze ervaringen blijkt dat de praktijk soms wellicht weerbarstiger is dan de leer, maar mijns inziens mag van de wetgever ten minste worden verwacht dat hij bij het bundelen van wetgeving zich de moeite getroost om wetssystematische koekoekseibepalingen te voorkomen.

429 Amtenbrink en Vedder, Recht van de Europese Unie 2008, p. 188. Zie ook Hof van Justitie van de Europese Gemeenschappen zaak nr. $34 / 73$ r.o. 10-11, zaak nr. 50/76 r.o. 4 en zaak nr. 94/77 r.o. 26 Zie verder Bonnes \& Florijn, Uitvoering van EG-verordeningen: overschrijven verboden 1995 en Steyger, Implementatie van Europees recht 2012, p. 636-641.

430 Drupsteen, Interview 2012, bijl. 5.8, par. 2.6.

431 Woldendorp, Interview 2011, bijl. 5.1, par. 6.2. 


\subsubsection{Tussenconclusie}

De wetgever zal gewoonlijk naast zakelijke systeemordeningscriteria ook gebruik maken van typisch juridische ordeningscriteria. Hoewel het gebruik van zakelijke samenhangcriteria de voorkeur geniet, heeft het gebruik van diverse veel gebruikte typisch juridische ordeningscriteria een aantal belangrijke mogelijke voordelen. Aangezien het gebruik van dergelijke criteria vaak zal leiden tot wetssystematische tekorten, is de wetgever gehouden om te motiveren waarom dergelijke tekorten voor lief worden genomen. Als een wetssystematisch tekort niet verdedigbaar is, moet de wetgever het voorkomen of oplossen.

In dit verband moet de wetgever wel opletten dat hij niet frequent en zonder noodzaak van wetssystematisch gezichtspunt wijzigt door zonder strikte noodzaak verschillende samenhangcriteria te gebruiken. ${ }^{42}$ Voermans lijkt het daarmee eens te zijn waar hij stelt dat het slechtste wat je kunt hebben is, dat de wetgever een indelingscriterium kiest en dat verlaat voor een ander. ${ }^{433}$ Dan is de wet volgens hem niet meer te volgen. Ik ben dat met hem eens, met name omdat een ander samenhangcriterium per definitie tot een ander door dat criterium bepaald wetssysteem leidt en dus logischerwijs tot een wetssystematisch tekort in het door het eerste samenhangcriterium bepaalde wetssysteem.

\subsection{NIEUWE WETTELIJKE OPLOSSINGEN}

\subsubsection{Codificerende bundeling uitgangspunt}

Bundeling door integratie of herschikking is in deze studie gepresenteerd als een mogelijkheid om wetssystematische tekorten op te heffen. ${ }^{434}$ De aandacht van de wetgever moet zich daarbij logischerwijs in de eerste plaats richten op de te bundelen wetssystemen en niet op de daarvan deel uitmakende regels. Het gaat er bij bundeling immers om dat bestaande, samenhangende regels ook samenhangend een plaats krijgen in hetzelfde wetssysteem. Dat betekent dat de wetgever in beginsel zou moeten kiezen voor codificerende integratie of herschikking. Eerder heb ik opgemerkt dat daarvan mijns inziens ook sprake is als de te bundelen regels niet exact hetzelfde in het gebundelde wetssysteem terugkomen. Het zal nu eenmaal vaak zo zijn dat integratie of herschikking zal leiden tot enige puur tekstuele wijzigingen van de daarbij betrokken wetssystemen. In dergelijke gevallen wil ik toch spreken van codificerende herschikking of integratie. Van

432 Zie Noll, Gesetzgebungslehre 1973, p. 223 en Hill, Einführung in die Gesetzgebungslehre 1982, p. 98-99.

433 Voermans, Interview 2012, bijl. 5.5, par. 3.6

434 Zie par. 2.4.1 
modificerende herschikking of integratie is eerst dan sprake als door bundeling wordt beoogd om een geldende rechtsopvatting te wijzigen. Is dat niet het geval, dan spreek ik van codificerende bundeling. ${ }^{435}$

Bundeling is daarmee in de eerste plaats een geheel of gedeeltelijke opschoning van de regels waarop zij betrekking heeft. Dat sluit aan bij Noll, die stelt dat de 'Verdienst der Kodifikationen liegt in der Vereinheitlichung, Systematisierung und gesetzgebungstechnischen Rationalisierung des von Rechtswissenschaft, Rechtsprechung und Einzelgesetzgebung schon bewältigten Rechtsstoffes; die Erprobung im sozialen Experiment ist ihnen jeweils schon vorausgegangen. Kodifikation bedeutet somit nichts anderes als Teilbereinigung der Rechtsordnung. ${ }^{.436}$

Hierna zal ik aangeven dat bundeling niet meer behoeft te omvatten dan een dergelijke opschoning. Er lijken echter geen steekhoudende wetenschappelijke argumenten te zijn om en passant niet ook tot modificatie over te gaan. ${ }^{437}$

\subsubsection{Slimme aanpassingen}

Kiezen voor bundeling betekent dat de wetgever niet uitgaat van het tamelijk onwaarschijnlijke geval dat in het verleden gewoonlijk ondeugdelijke regels zijn geproduceerd, maar dat die regels volgens andere criteria moeten worden geordend. ${ }^{438}$ Deze codificerende bundeling betekent echter niet, dat de wetgever niet en passant slimme aanpassingen zou mogen plegen en overbodige regels mag schrappen. In dezelfde zin versta ik Noll: 'Wahrhaftig begründeten Ruhm könnte ein heutiger Gesetzgeber ernten, wenn er daranginge, neu z.B. das gesamte Zivilrecht, das seit Erlaß des BGB sich wieder in weithin verstreute Einzelgesetze zersplittert hat, im Sinne einer Rationalisierung und Vereinfachung zusammenzufassen, dabei pandektistischen Ballast sowohl wie auch modernen Gesetzesperfektionismus (immer ein Produkt der Bürokratie) mutig, aber auch überlegt über Bord zu werfen.'439 Voor Rademaker is het vanzelfsprekend dat de wetgever oog moet hebben voor dingen die beter en eenvoudiger kunnen worden geregeld. Hij waarschuwt echter voor ingewikkeld makende compromissen. ${ }^{440}$ Ook Borman acht slimme modificaties mogelijk. Hij noemt het voorbeeld van het in de Awb integreren van de uitgebreide openbare voorbereidingsprocedure, die in de Wet algemene bepalingen milieuhygiëne (Wabm ${ }^{441}$ stond. Die regeling was volgens Borman nog veel uitgebreider dan de uitgebreide

435 Zie par. 2.5.3.

436 Noll, Gesetzgebungslehre 1973, p. 215.

437 Zie par. 3.5.2 en 3.5.3.

438 Zie ook Van den Broek, Omgevingswet doet recht aan integrale omgevingsbescherming 2010, p. 69.

439 Noll, Gesetzgebungslehre 1973, p. 217.

440 Rademaker, Interview 2011, bijl. 5.2, par. 5.1.

441 Wet algemene bepalingen milieuhygiëne, Wet van 13 juni 1979, houdende regelen met betrekking tot een aantal algemene onderwerpen op het gebied van de milieuhygiëne (Stb. 1979, 442). 
procedure die uiteindelijk in de Awb is gekomen. "Justitie wilde, anders dan VROM, dat de uitgebreide procedure niet zou worden bevuild met allerlei details uit de Wabm en heeft zich er toen sterk voor gemaakt de procedure te ontdoen van allerlei details." ${ }^{42}$ Drupsteen denkt dat het een goed idee is om nieuwe wettelijke oplossingen te creëren bij het bundelen van omgevingsrecht. "Ik denk dat je als je bezig bent toch veranderingen aanbrengt. Het zou ook jammer zijn om de gelegenheid niet te baat te nemen. Je weet van bepaalde regelingen dat ze niet goed functioneren. Of dat het beter zou kunnen. Daarover bestaan soms ook wel ideeën. Neem dat meteen mee. Je moet wel oppassen dat je het wetsvoorstel wel overzichtelijk houdt. Je moet aangeven wat je gaat doen. Als je te veel modificaties aanbrengt kan dat ertoe leiden dat het overzicht verdwijnt. Maar als je al weet dat een regeling niet optimaal is en je hebt een idee hoe het beter kan, dan zou ik het onverstandig vinden om dat niet mee te nemen bij een bundelingsoperatie." 443

\subsubsection{Modificerende bundeling}

Hiervoor is codificerende bundeling als uitgangspunt genomen. Daarbij is niet beoogd de geldende rechtsopvatting te veranderen. Daarmee is aangegeven, dat het mijns inziens verantwoord is als bundeling zich beperkt tot codificatie. Hiervoor heb ik aangegeven, dat slimme aanpassingen in het kader van bundeling mogelijk zijn. Ik had daarbij het oog op minder majeure wijzigingen. De vraag is echter of ook meer majeure wijzigingen in het kader van bundeling zijn toegestaan, wijzigingen bijvoorbeeld die wel beogen de geldende rechtsopvatting te veranderen. ${ }^{444}$

Mij lijkt dat bundeling eveneens verantwoord kan zijn als sprake is van meer majeure wijzigingen. Het zou immers onlogisch zijn om kleine onvolkomenheden in het omgevingsrecht wel te willen oplossen in het kader van bundeling, maar majeure problemen te laten voortbestaan. Bundeling is echter niet in de eerste plaats gericht op het oplossen van dergelijke problemen.

Ook Voermans meent dat het de wetgever vrij staat om nieuwe wettelijke oplossingen te scheppen in het kader van bundeling van omgevingsrecht. "Er is niets op tegen om tegelijk te assembleren ${ }^{445}$ en te modificeren." De politieke beslissing om het recht te veranderen kan volgens hem niet afhankelijk zijn van het vehikel, de wet. ${ }^{446}$ Dat lijkt mij een juist uitgangspunt. Molenaars heeft evenmin problemen met nieuwe wettelijke oplossingen: "Bij het opstellen van een nieuwe wet kom je gewoonlijk ook tot wijzigingen van bestaande systemen en tot nieuwe oplossingen. Dat kan het gevolg zijn van politieke wensen of wensen vanuit het beleid. Soms wil je ook vanuit wetgevingstechnisch oogpunt

\footnotetext{
442 Borman, Interview 2012, bijl. 5.3, par. 5.1.

443 Drupsteen, Interview 2012, bijl. 5.8, par. 5.1.

444 In dat geval is sprake van modificerende bundeling (zie par. 2.5.3)

445 Voermans bedoelt daarmee het bijeenbrengen van wat is geschreven.

446 Voermans, Interview 2012, bijl. 5.5, par. 5.1.
} 
zaken anders regelen. Uitgangspunt bij de Omgevingswet is het ontwerpen van een nieuw systeem, waarbij ook oog is voor het behoud van het 'goede' uit de bestaande systemen." ${ }^{447}$ Drupsteen meent dat de wetgever bij de Wet natuurbescherming welhaast moet modificeren. "De bestaande wet is zo ingewikkeld en moeilijk leesbaar, dat er sprake zou zijn van een halfbakken operatie als je niet ook zou modificeren. Maar of je het zo ingrijpend zou moeten doen dat je beschermde natuurmonumenten weghaalt, dat weet ik niet. Men gaat van het ene uiterste in het andere. We gaan alleen doen wat Europa voorstelt. Dat is geen gekke benadering. Als je in korte tijd kans ziet om de Europese richtlijnen om te zetten in Nederlands recht, dan hebben we heel wat bereikt. Die omzetting gaat nog steeds niet heel goed. Men heeft de omzettingstermijn vaak heel hard nodig en dan is er vaak nog wel iets fout. Maar je krijgt niet de indruk dat er een inventarisatie heeft plaatsgevonden waarbij is gekeken of bepaalde natuurmonumenten tot Natura 2000-gebied zouden moeten worden verheven. Ik weet niet of dat zo is. We moeten natuurlijk ook oppassen, dat niet alleen wordt geklaagd dat er zoveel biodiversiteit verdwijnt, terwijl er de afgelopen jaren ook heel veel natuur is bijgekomen." ${ }^{48}$ Backes meent dat een vergaande, veel radicalere integratie dan de Wabo theoretisch mogelijk is. Dat kan volgens hem echter alleen, "indien de bestaande verdeling van bevoegdheden mag worden veranderd, en de wetgeving op het terrein van het omgevingsrecht geheel nieuw kan worden doordacht en ontworpen." Dat betekent volgens Backes echter niet dat alle bestaande omgevingsrechtelijke wetgeving moet verdwijnen en opnieuw moet worden geschreven. ${ }^{449}$

Drupsteen snijdt hierbij overigens wel een belangrijk punt aan. Als de wetgever naar de opvattingen van sommigen te ver gaat met modificatie dan kan dat de aandacht afleiden van de voordelen van bundeling. Zo heeft het schrappen van nationale koppen in de voorgenomen Wet natuurbescherming ${ }^{450}$ met - kort gezegd - als gevolg dat de natuur in Nederland niet langer verder wordt beschermd dan Europeesrechtelijk is vereist, alle aandacht gekregen van natuurbeschermingsorganisaties, terwijl de bundeling op zichzelf vermoedelijk niet tot een dergelijke weerstand zou hebben geleid.

De Vereniging Natuurmonumenten stelt onder meer dat de nieuwe wet oorspronkelijk is bedoeld om drie bestaande, goede natuurwetten samen te voegen tot één duidelijkere en eenvoudigere wet. De groene organisaties zijn altijd voorstander van dit principe geweest, onder de voorwaarde dat die wet ook goed is voor natuur en landschap. Aan die voorwaarde wordt echter niet voldaan. De aangepaste voorstellen van staatssecretaris Bleker beschermen volgens de natuur-, landschaps- en dierenwelzijnsorganisaties natuur en landschap nog onvoldoende. Zo wordt een aantal natuurgebieden straks niet meer beschermd tegen verstoring, en kan er straks op meer diersoorten worden

447 Molenaars, Interview 2012, bijl. 5.6, par. 5.1

448 Drupsteen, Interview 2012, bijl. 5.8, par. 5.2

449 Backes, Naar een integrale omgevingswet? 2010, p. 9.

450 Zie hfds. 5 . 
gejaagd. Das\&Boom spreekt in een persbericht onder meer van 'een 'kookboek' voor uitsterven' en van een 'kwaadaardige wet die de basis van de natuurbescherming in Nederland aantast en probeert draconische bezuinigingen op natuurbeheer te legaliseren en te legitimeren.'451, 452

In dit verband is overigens nog interessant de opmerking van Noll dat het ook onder juristen een wijd verbreid misverstand is dat de wetgever zijn grootste wetgevingsdaden heeft verricht in de vroegere monumentale codificaties. De echte vernieuwingen waren volgens hem reeds gerealiseerd in daaraan voorafgaande wetgeving. De wetgever zou volgens Noll ook een bewijs van onvermogen afgeven als hij allerlei misstanden zou laten voortbestaan in afwachting van een komende codificatie: 'Der Gesetzgeber stellt sich selber ein schlechtes Zeugnis aus, wenn er in einer Kodifikation in großem Umfang inhaltlich neues Recht setzt; denn dies bedeutet, daß er in entsprechendem Maße und auf vermutlich längere Dauer die Probleme ungelöst hat anstehen lassen.'453

\subsubsection{Tussenconclusie}

Codificerende bundeling behoort uitgangspunt te zijn, aangezien bundeling zich in de eerste plaats moet richten op het opheffen of verminderen van wetssystematische tekorten in plaats van op de te bundelen regels zelf. Bundeling is echter ook dan verantwoord als kleine, maar ook als majeure modificaties worden aangebracht. In het laatste geval dient de wetgever zich er wel van te vergewissen, dat zulks kan betekenen dat de mogelijke voordelen van bundeling worden beperkt als gevolg van de modificatie. De wetgever loopt het risico dat de maatschappelijke acceptatie van bundeling wordt verminderd of zelfs opgeheven door maatschappelijke weerstand tegen een of meer modificaties.

\subsection{TOEKOMSTBESTENDIG}

\subsubsection{Algemeen}

Bundeling van omgevingsrecht betekent dat wetssystematische tekorten worden opgeheven die zijn ontstaan als gevolg van het feit dat de wetgever steeds weer is gedwongen nieuwe wetgeving te ontwerpen om zich voordoende problemen het hoofd te bieden. ${ }^{454}$ Het is echter geenszins uit te sluiten dat de wetgever ook na bundeling van wetssystemen regelmatig zal worden geconfronteerd met nieuwe problemen die hem dwingen daarop te

\footnotetext{
451 Zie onder meer de reacties op www.natuurmonumenten.nl en www.dasenboom.nl.

452 Zie ook Nijmeijer, De Wet natuur versnippert 2012.

453 Noll, Gesetzgebungslehre 1973, p. 215-216.

454 Zie par. 1.2
} 
reageren met nieuwe wetgeving. De vraag is echter of en zo ja hoe de wetgever kan voorkomen dat zich daarbij steeds opnieuw - onverdedigbare wetssystematische tekorten zullen voordoen, die door bundeling moeten worden opgeheven of verminderd. In andere woorden luidt deze vraag of en zo ja hoe de wetgever ervoor kan zorgen dat een door bundeling ontstaan wetssysteem toekomstbestendig is. ${ }^{455}$

Ik noem een wetssysteem toekomstbestendig als daarbinnen geen nieuwe onverdedigbare - wetssystematische tekorten ontstaan als gevolg van het feit dat de wetgever in belangrijke mate is gedwongen om een chronologische aanpak te hanteren. Ook bij de vraag naar de toekomstbestendigheid van een wetssysteem gaat het om de wetssystematiek. Die moet toekomstbestendig zijn.

Ook Hirsch Ballin wijst op het belang van een juiste keuze voor de wetssystematiek, die hij aanduidt met de architectuur van de wetgeving. 'Als eenmaal de architectuur van een wettelijke regeling is vastgelegd, dan staat daarmee in feite vrijwel vast dat latere wijzigingen of aanvullingen binnen dit kader zullen blijven, en aldus het eenmaal gekozen soort wetgeving slechts zullen reproduceren - ook als de oorspronkelijke keuze een minder gelukkige blijkt te zijn. ${ }^{456}$ Zelfs bij ingrijpende wijzigingen in de materiële inhoud (zoals toevoeging van veel andere bepalingen dan de in het oorspronkelijke concept voorziene) pleegt de architectuur in wezen onveranderd te blijven. ${ }^{457}$ Volgens Eijlander is het wezenlijk voor de hedendaagse wetgever dat hij onder meer robuuste en slijtvaste regels maakt, die niet te vaak wijziging behoeven..$^{458}$

Met toekomstbestendigheid laat zich naar mijn oordeel wel verenigen dat aan het wetssysteem nieuwe regels worden toegevoegd, regels worden ingetrokken of regels worden gewijzigd. Hierna zal ik een aantal wetgevingstechnieken noemen die al dan niet in samenhang gebruikt kunnen leiden tot een - meer - toekomstbestendig wetssysteem.

\subsubsection{Gericht op permanente verandering}

Het komt mij voor dat de wetgever met bundeling niet moet streven naar een wetssystematiek die de pretentie heeft het omgevingsrecht voor eens en altijd te codificeren. De reden daarvoor is, dat de wetgever in het verleden niet alle denkbare situaties heeft kunnen of willen regelen, en dat de kans groot is dat zulks zich in de toekomst ook voor zal doen. Zulks temeer daar

455 Zie ook Aanwijzing 10 van de Aanwijzingen voor de regelgeving: Gestreefd wordt naar duidelijkheid en eenvoud van regelingen en naar een bestendig karakter daarvan. De toelichting vermeld dat een regeling bestendig is indien zij niet frequent behoeft te worden gewijzigd. Het verdient aanbeveling naar zo groot mogelijke bestendigheid van regelingen te streven. Dit betekent dat het beleid in beginsel duidelijk moet zijn alvorens tot het treffen van een regeling wordt overgegaan.

456 Hirsch Ballin, Architectuur van wetgeving 1984, p. 91.

457 Hirsch Ballin, Architectuur van wetgeving 1984, p. 92.

458 Eijlander, De verbindende wetgever 2000, p. 25. 
de maatschappelijke ontwikkelingen elkaar steeds sneller opvolgen, ook waar het de belangen van de fysieke leefomgeving betreft. Bij het vorm geven van de Omgevingswet wordt volgens Molenaars en De Vos rekening gehouden met deze onvoorspelbaarheden. Molenaars merkt op dat de Omgevingswet bij voorkeur decennia mee moet kunnen. "Dat betekent dat er een voldoende robuust maar ook flexibel wetssysteem moet worden ontworpen met een instrumentarium dat daarop is berekend." ${ }^{459}$ De Vos geeft aan dat het "de kunst is om flexibiliteit in te bouwen in het systeem, aangezien je weet dat er zich situaties gaan voordoen die je niet kunt voorspellen." 460

Het doel van bundeling moet daarom niet zijn te komen tot een wetssystematiek van gelijke orde als ten grondslag lag aan het Burgerlijk Wetboek of het Wetboek van Strafrecht, die wetboek heten omdat zij de bedoeling hadden al het bestaande recht op die rechtsgebieden vast te leggen. Bundeling zou daarentegen moeten leiden tot een opschoning van het omgevingsrecht in de vorm van een op permanente verandering of ontwikkeling toegesneden wetssystematiek, waarin nieuwe omgevingsregels van nationale of Europese oorsprong een plaats kunnen krijgen zonder nieuwe wetssystematische tekorten te veroorzaken.

In dezelfde zin noem ik Noll, die in 1973 reeds schreef: 'Um sich mit der Arbeit des Kodifizierens Verdienste zu erwerben, kann sich heute der Gesetzgeber nicht mehr damit begnügen, die alten Kodifikationen durch thematisch in derselben Weise umgrenzte neue Kodifikationen zu ersetzen, also beispielsweise ein neues Strafgesetzbuch, ein neues BGB, ein neues HGB zu schaffen. '461 Volgens Noll kon de burger, 'wenn er das 'Gesetzbuch' las, erkennen, was Rechtens war, und sicher sein, daß keine Vorschriften außerhalb des Gesetzbuches bestanden, die dessen Regeln durchbrachen. ${ }^{462}$ In feite komt dat overeen met mijn betoog dat gebruikers van een wetssysteem daarin alle regels moet aantreffen die nodig zijn om zijn rechten en verplichtingen te kunnen kennen. ${ }^{463}$ Maar het doel van een opschoning van het recht 'muß eine Gesamtkodifikation der Rechtsordnung sein, die allerdings nicht in der größten aller bisherigen Monumentalkodifikationen gipfeln darf, sondern vielmehr die ... Form einer systematischen, auf permanenten Änderung angelegten Gesamtdarstellung des geltenden gesetzten Rechts annehmen sollte. ${ }^{364}$

\footnotetext{
459 Molenaars, Interview 2012, bijl. 5.6, par. 6.1

460 De Vos, Interview 2012, bijl. 5.7, par. 6.1.

461 Noll, Gesetzgebungslehre 1973, p. 216.

462 Noll, Gesetzgebungslehre 1973, p. 217.

463 Zie onder meer par. 3.2.5.1.

464 Noll, Gesetzgebungslehre 1973, p. 218.
} 
Interessant in dit verband is hetgeen Van den Berg schrijft dat voorstanders van codificatie fixatie van het recht als een voordeel zien, omdat volgens hen daarmee de houdbaarheid van het recht en dus de kenbaarheid en de rechtszekerheid gewaarborgd wordt. Tegenstanders van codificatie vrezen juist dat het recht als gevolg van de fixatie geen gelijke tred zal houden met de maatschappelijke ontwikkelingen, waarmee de maatschappij wordt opgescheept met verouderd recht dat 'over de datum' is (par. 1). Van den Berg komt tot de conclusie dat voor- en tegenstanders ongelijk hadden. De codificaties waren volgens hem niet gericht op fixatie van het recht en hebben die ook niet tot stand gebracht. 'Men liet noodgedwongen, omdat anders over veel kwesties moeizame compromissen gesloten zouden moeten worden, de concrete oplossing eenvoudig in het midden. De rechter die opereert in een dergelijk rechtsstelsel is weliswaar formeel gebonden aan de wet, maar krijgt omdat de wetsbepaling abstract is geformuleerd toch veel ruimte ten opzichte van de wet. De formele binding aan de wet zorgt er tegelijkertijd voor, dat de rechter zich niet strikt gebonden acht aan de eigen uitspraken. Een en ander heeft anders dan de intuïtie doet vermoeden tot gevolg, dat het recht in de gecodificeerde stelsels flexibel en dus niet erg houdbaar is. In ieder geval is het meer flexibel en dus minder houdbaar dan het niet-gecodificeerde Engelse recht. Er kan worden gesproken van de paradox van de codificatie (par. 5). ${ }^{365}$

Ten slotte merk ik op dat de eis dat het omgevingsrecht moet zijn gericht op permanente verandering mijns inziens ook met zich brengt, dat de wetgever er reeds thans over moet nadenken dat bundeling leidt tot wetssystemen die in de nabije of verre toekomst zo eenvoudig mogelijk kunnen worden gebruikt als basis voor een iLawsysteem. ${ }^{466}$

\subsubsection{Toekomstbestendige samenhangcriteria}

De wetgever zal eerder een toekomstbestendig wetssysteem realiseren naarmate in de wetssystematische opbouw wordt gekozen voor het gebruik van toekomstbestendige systeemordeningscriteria. Daarbij bedoel ik ordeningscriteria waarvan mag worden verwacht, dat die niet alleen op dit moment, maar ook in de toekomst valide zijn.

Dat kunnen in de eerste plaats zakelijke systeemordeningscriteria zijn, die aansluiten bij de echte werkelijkheid. ${ }^{467}$ Aangenomen mag immers worden dat voor het reguleren van nieuwe problemen die zich voordoen in de echte werkelijkheid dan kan worden aangesloten bij de gekozen zakelijke systeemordeningscriteria. In zoverre als dat gebeurt, zullen geen nieuwe wetssystematische tekorten ontstaan.

465 Van den Berg, De paradox van de codificatie 2002.

466 Zie par. 3.2.3.

467 Zie ook par. 3.3.7. 
Stel bij wijze van voorbeeld dat een bepaald wetssysteem wordt bepaald door het in de Europese Richtlijn industriële emissies ${ }^{468}$ gebruikte samenhangcriterium 'installatie'.469 Als de wetgever vervolgens alle toekomstige, wellicht thans nog niet denkbare, regels inzake installaties opneemt in het aldus bepaalde wetssysteem, dan ontstaan geen wetssystematische tekorten. Alle regels die betrekking hebben op een installatie vinden immers een plaats in genoemd wetssysteem.

Deze gedachte wordt gesteund door Molenaars, die flexibiliteit in een wetssysteem onder meer zoekt "door op onderdelen in de wet haakjes op te nemen om daaraan in de toekomst nieuwe wetgeving op te hangen." Het is daarvoor volgens haar niet per se nodig dat je precies weet welk probleem zich gaat voordoen en welk nieuw beleid er komt. Zij noemt als voorbeeld verwachte klimaatveranderingen, die ertoe zouden moeten leiden dat de opslag van $\mathrm{CO}_{2}$ in elk geval kan worden geregeld in de Omgevingswet. ${ }^{470}$

Maar ook typisch juridische systeemordeningscriteria kunnen zorgen voor een toekomstbestendig wetssysteem. Aangenomen mag immers worden dat voor het reguleren van nieuwe problemen die aansluiten bij de juridische werkelijkheid dan kan worden aangesloten bij de gekozen typische juridische systeemordeningscriteria. In zoverre als dat gebeurt, zullen geen nieuwe wetssystematische tekorten ontstaan.

Zo bevat de Waterwet een paragraaf 'Watervergunning en algemene regels'. Dit subwetssysteem bevat regels over de watervergunning en algemene regels met betrekking tot handelingen in watersystemen. Als de wetgever vervolgens alle toekomstige, wellicht thans nog niet denkbare, regels inzake vergunningen en algemene regels met betrekking tot handelingen in watersystemen opneemt in dit subwetssysteem, dan ontstaan daarin geen wetssystematische tekorten. Alle regels die betrekking hebben op een vergunning of algemene regels met betrekking tot handelingen in watersystemen vinden immers een plaats in genoemd subwetssysteem.

Ik heb de indruk dat Molenaars en met name De Vos de toekomstbestendigheid van de Omgevingswet zoeken in het gebruik van typisch juridische systeemordeningscriteria. Molenaars: "Je kunt het ook zoeken in het instrumentarium dat je ontwerpt. Bijvoorbeeld een omgevingsvergunning kun je algemeen regelen. Als in een latere fase blijkt dat het noodzakelijk is om een

468 Richtlijn 2010/75/EU van het Europees Parlement en de Raad van 24 november 2010 inzake industriële emissies (geïntegreerde preventie en bestrijding van verontreiniging) (herschikking) (PbEU 2010 L 334/17).

469 Installatie: een vaste technische eenheid waarin een of meer van de in bijlage I of in deel 1 van bijlage VII vermelde activiteiten en processen alsmede andere op dezelfde locatie ten uitvoer gebrachte en daarmee rechtstreeks samenhangende activiteiten plaats vinden die technisch in verband staan met de in die bijlagen vermelde activiteiten en die gevolgen kunnen hebben voor de emissies en de verontreiniging (art. 3 onder 3 IED).

470 Molenaars, Interview 2012, bijl. 5.6, par. 6.1. 
vergunning te eisen voor een bepaalde activiteit, dan kun je dat instrument ook daarvoor gebruiken. Het is dan een kwestie van een nieuwe activiteit opnemen in het lijstje van activiteiten waarvoor al een omgevingsvergunning is vereist." ${ }^{471}$ De Vos sluit hierbij aan: "Bestendigheid creëer je ook door de basisinstrumenten te verankeren. Die kunnen voor verschillende onderwerpen worden ingezet. Een vergunning kan zo'n basisinstrument zijn. Die rechtsfiguur gaat al lang mee. Het is redelijk te veronderstellen dat je ook in de toekomst een vergunningstelsel nodig hebt. Dat kan ook gelden voor beginselen, zoals de vervuiler betaalt. Die kunnen betekenis hebben voor toekomstige zaken die je nu nog niet kunt voorspellen. De Omgevingswet regelt de basisinstrumenten om de doelen van de wet te kunnen bereiken." ${ }^{472}$

In het kader van de Omgevingswet wordt op verschillende wijzen gebruik gemaakt van de door mij genoemde wetgevingstechnieken om de toekomstbestendigheid van dat wetssysteem te bevorderen.

In de eerste plaats zal de Omgevingswet onder meer voor wat betreft doelen, terminologie en instrumentarium nauw aansluiten bij de EU-regelgeving. Zulks draagt volgens de regering bij aan de toegankelijkheid en eenduidigheid van de regelgeving. Als voorbeeld wordt het in het Nederlands omgevingsrecht gebruikte begrip 'inrichting' genoemd, terwijl de meeste Europese regelgeving het begrip 'installatie' hanteert. ${ }^{473}$ Het gaat hier om een zakelijk ordeningscriterium, dat aansluit bij de echte werkelijkheid. Aangenomen mag worden dat er ook in de toekomst te reguleren installaties zullen bestaan, zodat het hanteren van dit criterium bijdraagt tot toekomstbestendigheid van de Omgevingswet. Ook Gilhuis \& Verschuuren menen dat er geen verschil moet en mag zijn tussen het nationale recht en het Europese milieurecht als het gaat om onderwerpen waarover de EG regels heeft gesteld of wil stellen. Zij menen dat het daarom van belang is om discussies over (nieuwe) milieuregelgeving op Europees niveau aan te gaan, zodat de specifieke Nederlandse wensen zoveel mogelijk op dat niveau moeten worden bepleit. De uitkomst van die dialoog bepaalt sterk de ontwikkeling van het nationale milieurecht. ${ }^{474}$

In de tweede plaats worden de tientallen rechtsfiguren die het omgevingsrecht thans volgens de regering kent vervangen door zes rechtsfiguren die in de Omgevingswet centraal komen te staan: omgevingsvisie, programma, algemene regels voor activiteiten in de leefomgeving, omgevingsverordening, omgevingsvergunning en projectbesluit. Het gaat volgens de regering om deels bestaande, deels nieuwe en alle gebaseerd op bestaande, werkende instrumenten. ${ }^{475}$ Het betreft hier typisch juridische ordeningscriteria, waarvan mag worden aangenomen dat die ook in de toekomst nodig zullen zijn, zodat het hanteren van deze criteria bijdraagt tot toekomstbestendigheid van de Omgevingswet.

471 Molenaars, Interview 2012, bijl. 5.6, par. 6.1

472 De Vos, Interview 2012, bijl. 5.7, par. 6.1.

473 IenM, Kabinetsbrief stelselwijziging omgevingsrecht 2012, p. 19

474 Gilhuis \& Verschuuren, Is er nog verschil en moet er nog verschil zijn? 2003, p. 254.

475 IenM, Kabinetsbrief stelselwijziging omgevingsrecht 2012, p. 10 


\subsubsection{Consequent wetssystematisch plaatsen}

De wetgever moet ervoor zorgen dat nieuwe omgevingsregels die een bepaald probleem beogen te regelen aansluiten bij de gekozen wetssystematische ordeningscriteria waarop zij anders een inbreuk zouden vormen. Noll merkt in dit verband op dat het systematische principe van de chronologie $^{476}$ van de elkaar opvolgende problemen, waaraan de wetgever is gebonden, geen bevredigend systeem oplevert, maar bestaande systemen doorbreekt en onorde ${ }^{477}$ schept. Om die onorde binnen draaglijke grenzen te houden moet de wetgever volgens hem van drie mogelijkheden gebruik maken. Twee van die drie mogelijkheden sluiten aan bij hetgeen ik hiervoor heb opgemerkt: 'Die Normen, die ein bestimmtes Problem neu regeln, sollen wenigstens unter sich systematisch geordnet sein, und zwar, wenn immer möglich, nach systematischen Gesichtspunkten, die der bestehenden Rechtsordnung zugrunde liegen und sich bewährt haben. (...) Der Gesetzgeber soll, wenn immer möglich, die neuen Rechtssätze in das System der bestehenden Rechtsordnung so einfügen, daß sie dieses nicht sprengen. ${ }^{478}$

Dat betekent bijvoorbeeld dat als de wetgever heeft gekozen voor het wetssystematische samenhangcriterium van een project zoals dat is gebeurd in de Wabo, ${ }^{479}$ hij nieuwe omgevingsregels die betrekking hebben op een project ook volgens hetzelfde criterium moet regelen. De wetgever moet regels inzake inrichtingen of installaties, die onderdeel vormen van een project, dan niet gaan regelen volgens afwijkende samenhangcriteria. Dat neemt overigens niet weg, dat dergelijke criteria wel kunnen worden benut om samenhang te brengen in subwetssystemen. ${ }^{480}$

In dit verband is interessant hetgeen Woldendorp zegt als hij als wetgevingsjurist de opdracht krijgt om nieuwe wettelijke bepalingen te schrijven. Het gaat Woldendorp met name om het bereiken van een duidelijk geformuleerd beleidsdoel. De opdracht is volgens hem echter niet "om alle wetgeving in de gaten te houden en te kijken hoe de hele wetssystematiek er uit zou moeten zien nadat het nieuwe onderwerp geregeld is. Het ontbreekt gewoonlijk aan tijd om dat te doen. (...) Je gaat niet de hele wereld er steeds bijhalen en ook niet het wiel opnieuw proberen uit te vinden." ${ }^{481}$ Ook zegt hij dat er meestal weinig tijd is om de aanvliegroute te bepalen, zodat

Zie par. 1.1

477 'Unordnung' lijkt mij iets anders dan wanorde. In het geval van wanorde is er geen orde, terwijl er bij Unordnung wel ordening is, maar een ondeugdelijke.

478 Noll, Gesetzgebungslehre 1973, p. 202.

479 Zie hfds. 4.

480 Dat is bijvoorbeeld gedaan in hfds. 4 Mor, dat indieningsvereisten bevat vanwege het oprichten, veranderen of in werking hebben van een inrichting of mijnbouwwerk.

481 Woldendorp, Interview 2011, bijl. 5.5, par. 4.4. Deze ervaringen herhaalt Woldendorp in soortgelijke bewoordingen in par. 4.7 en 4.8 . 
het zijn indruk is dat er eigenlijk in het wilde weg wordt begonnen met wetgeven. ${ }^{482}$ Daarbij sluiten de woorden van Borman aan: "Als er een probleem moet worden aangepakt en er is wetgeving nodig, dan moet er gewoon iets geregeld worden. De eerste reflex is dan niet om te kijken of er samenhang bestaat met andere onderdelen van het recht." 483

Deze ervaringen van deze ervaren wetgevingsjuristen versterken de noodzaak voor mijn aanbeveling aan de wetgever om nieuwe omgevingsregels consequent wetssystematisch te plaatsen. Wetgevingsjuristen lijken eigenlijk veeleer te kiezen voor een chronologische aanpak, die eerder tot onorde leidt.

Drupsteen geeft daarvoor de verklaring dat wie een proefschrift schrijft, naar houvast zoekt. "De wetgevingsleer van Peter Noll levert dat houvast. Maar als je een wetgevingsjurist vraagt of hij daaraan denkt, mag je het antwoord verwachten: 'Hoe bedoelt u?"” 484 Hij vindt dat niet vreemd, want "wetgevingsjuristen zijn over het algemeen cynische lieden, die al veel hebben meegemaakt. Die hebben al veel opgeschreven, waarvan ze denken: 'Als ik het zelf voor het zeggen had, dan was dit het laatste wat ik zou hebben opgeschreven. Maar laten we maar kijken hoe we de schade zo beperkt mogelijk kunnen houden.' Dat moet je wel in de gaten houden. Je moet je realiseren dat initiatieven voor wetgeving op allerlei wonderlijke manieren tot stand komen. De politiek roept wat en de minister heeft het zwaar voor zijn kiezen gehad in de Tweede Kamer; hij roept dan dat het afgelopen moet zijn. Jullie moeten aan de slag en dit en dat doen." ${ }^{485}$

\subsubsection{Aanbouwwetssysteem}

De wetgever kan de toekomstbestendigheid van een wetssysteem ook bevorderen door te werken met aanbouwwetgeving die voldoet aan de eisen die in dit hoofdstuk zijn gesteld aan de keuze voor wetssystematische ordeningscriteria. Aanbouwwetgeving betekent dat eerst de wetssystematiek wordt geschapen, waarna de diverse onderdelen van de wet weliswaar chronologisch tot stand komen, maar wel meteen op hun wetssystematisch juiste plaats kunnen worden gezet. Een belangrijk voorbeeld van aanbouwwetgeving treffen we binnen het omgevingsrecht aan in de Wet milieubeheer. ${ }^{486}$ Uiteraard dient de wetgever bij aanbouwwetgeving wel in staat te zijn een zo mogelijk toekomstbestendig wetssysteem te ontwerpen dat later

482 Woldendorp, Interview 2011, bijl. 5.1, par. 4.5

483 Borman, Interview 2012, bijl. 5.3, par. 1.1.

484 Drupsteen, Interview 2012, bijl. 5.8, par. 5.1

485 Drupsteen, Interview 2012, bijl. 5.8, par. 5.2

486 Zie Gilhuis, Over de verhouding van Wabm tot Awb 1990, p. 213: 'Evenals bij de Wabm wordt bij de Awb met het systeem van de zogenaamde aanbouwwetgeving gewerkt. Dit betekent dat de eerste versie van de Awb niet als eindversie is bedoeld. In een latere fase zullen nieuwe onderwerpen in de wet worden opgenomen. In de MvT is echter een indeling voor een meer volledige wetgeving opgenomen. Uit die indeling blijkt welke onderwerpen de regering in elk geval in een latere fase in de wet wil opnemen.' Verder Michiels, De Wet milieubeheer 2003. 
daaraan toe te voegen aanbouwen daarmee verenigbaar zijn. ${ }^{487} \mathrm{Als}$ de wetgever daartoe niet in staat is, riskeert hij het verwijt van nota bene een van zijn door mij zeer gewaardeerde wetgevingsjuristen, dat zijn wetssysteem feitelijk een ballenbak is. ${ }^{488}$

\subsubsection{Tussenconclusie}

Een door bundeling ontstaan wetssysteem noem ik toekomstbestendig als daarbinnen geen - onverdedigbare - wetssystematische tekorten ontstaan als gevolg van het feit dat de wetgever in belangrijke mate is gedwongen om de chronologische aanpak te hanteren. De wetgever heeft vier mogelijkheden om toekomstbestendigheid van door bundeling ontstane wetssystemen te bevorderen. In de eerste plaats moet hij niet streven naar een wetssystematiek die de pretentie heeft het omgevingsrecht voor eens en altijd te codificeren, maar naar een op verandering en zo mogelijk op een iLawsysteem gericht wetssysteem. In de tweede plaats zal de wetgever eerder een toekomstbestendig wetssysteem realiseren naarmate in de wetssystematische opbouw wordt gekozen voor het gebruik van toekomstbestendige systeemordeningscriteria, waarvan mag worden verwacht, dat die niet alleen op dit moment, maar ook in de toekomst valide zijn. Dat kunnen zowel zakelijke als typisch juridische systeemordeningscriteria zijn. In de derde plaats moet de wetgever ervoor zorgen dat nieuwe omgevingsregels die een bepaald probleem beogen te regelen aansluiten bij de gekozen wetssystematische ordeningscriteria waarop zij anders een inbreuk zouden vormen. Ten slotte kan de wetgever de toekomstbestendigheid van een wetssysteem ook bevorderen door te werken met aanbouwwetgeving die voldoet aan de eisen die in dit hoofdstuk zijn gesteld aan de keuze voor wetssystematische ordeningscriteria.

\subsection{PROEVE VAN BUNDELING}

In hoofdstuk 3 is duidelijk geworden, dat het bundelen van omgevingsrecht geen automatisme kan zijn, maar vaak een groot aantal afwegingen van de wetgever vereist met betrekking tot de bij bundeling betrokken en te betrekken wetssystemen. Maar zelfs als de daaruit voortvloeiende keuzes verantwoord zijn op basis van het hierna in paragraaf 3.8 te noemen toetsingskader, kan vaak niet van tevoren worden bepaald tot welk resultaat die keuzes op zichzelf of in combinatie met andere keuzes leiden. Het is wellicht vanwege die onzekerheid dat politiek en ambtenaren naar mijn ervaring gewoonlijk wat huiverig staan tegenover veelomvattende wetgevingsprojecten die tot bundeling van wetssystemen moeten leiden. In de

487 In gelijke zin Hirsch Ballin, Architectuur van wetgeving 1984, p. 95.

488 Woldendorp, Interview 2011, bijl. 5.1, par. 4.1. 
literatuur wordt regelmatig de vraag aan de orde gesteld wat de meerwaarde is van bundeling: voor welk probleem is het een oplossing en is bundeling de juiste oplossing?

Backes schrijft: 'Voordat enkele gedachten over de toekomst aan het omgevingsrecht gewijd kunnen worden, lijkt het noodzakelijk kort te memoreren welke knelpunten thans worden ondervonden en welke van deze knelpunten mogelijkerwijs door een wijziging van de toepasselijke wetgeving oplosbaar zouden zijn. Niet elk ondervonden knelpunt is ook een knelpunt, niet elk knelpunt is oplosbaar en voor niet elk oplosbaar knelpunt ligt de sleutel voor verbetering in een wijziging van het wettelijke en organisatorische stelsel van het omgevingsrecht.'489 Fleurke \& Michiels menen: 'Voor een heldere probleemanalyse is het daarom verstandig eerst na te gaan wat precies onder 'complexiteit' wordt verstaan. ${ }^{390}$ Koeman relativeert: 'Het omgevingsrecht is te complex, zo wordt vaak geklaagd. (...) Bij die probleemanalyse passen enkele relativerende opmerkingen. In de eerste plaats moet de betekenis van wetgeving niet worden overschat. Een nieuwe wet hoeft helemaal niet te betekenen dat alle problemen uit het verleden als sneeuw voor de zon verdwijnen. ${ }^{491}$

Ook de Raad van State kan genoemde vraag stellen.

In zijn voorlichtingsadvies met betrekking tot de herziening van het omgevingsrecht merkt de Raad van State in dit verband onder meer het volgende op: 'Al geruime tijd en in toenemende mate wordt het omgevingsrecht als een complex rechtsgebied ervaren. Als daarmee samenhangende nadelen worden de langdurige en stroperige procedures en de onvoorspelbaarheid genoemd. Het voornemen van de Minister om een integrale Omgevingswet te maken, vormt zoals uit het vorige hoofdstuk bleek, niet de eerste poging om deze problemen aan te pakken. Het gaat echter wel om de meest verstrekkende poging. Om te kunnen vaststellen of en in welke mate de nieuwe Omgevingswet, op basis van de door de Minister genoemde uitgangspunten en doelstellingen, een bijdrage kan leveren aan de vermindering van de complexiteit, de duur van de procedures en de onvoorspelbaarheid in het omgevingsrecht, is het noodzakelijk dat de belangrijkste oorzaken van die problemen voldoende worden onderzocht. De Minister heeft veel partijen hierover gehoord. Op basis van de aldus verkregen gegevens dient een nadere analyse te volgen van de oorzaken van de problemen. De Afdeling beveelt aan deze analyse met voorrang te maken. ${ }^{492}$

In dit verband citeer ik met instemming Noll, die de wetgever in dit verband voorhoudt wat hij noemt het Prinzip des ökonomischen Konservatismus: ‘̈̈ndernde Neuordnungen sind erst berechtigt, wenn ein minimales Wertgefälle

489 Backes, Naar een integrale omgevingswet? 2010, p. 3.

490 Fleurke \& Michiels, Een digitale structuur voor het omgevingsrecht 2010, p. 105.

491 Koeman, Kiezen en delen in het omgevingsrecht 2010, p. 123.

492 Voorlichtingsadvies Raad van State, 25 januari 2012, nr. W14.11.0341/V, p. 12-13. De brief van de regering inzake de stelselherziening van het omgevingsrecht van 9 maart 2012 (Ministerie van IenM, Kabinetsbrief stelselherziening omgevingsrecht 2012, par. 1) beoogt onder meer tegemoet te komen aan de door de Raad van State gevraagde analyse. 
zwischen dem erstrebten und dem gegebenen Zustand nachweislich vorhanden ist.' ${ }^{493}$ De vraag is echter hoe daar achter is te komen.

Mij lijkt dat ook hier geldt: the proof of the pudding is in the eating. De wetgever zou er bij het constateren van een of meer wetssystematische tekorten mijns inziens goed aan doen om aan deskundigen uit wetenschap en praktijk opdracht te geven om op korte termijn met een overtuigende proef te komen voor een wetssystematiek die het gevolg is van bundeling. ${ }^{494}$ Wordt de wetgever niet overtuigd van de meerwaarde daarvan, dan kan hij van bundeling afzien of het door bundeling verkregen wetssysteem aanpassen. ${ }^{495}$ Ook Backes adviseert deze methode. Hij doet voorstellen voor een Omgevingswet die de wettelijke basis zou moeten vormen voor een integrale omgevingsverordening, een integraal omgevingsplan en een integrale omgevingsvergunning. Een voorwaarde om een kans te scheppen een dergelijk voornemen te realiseren is volgens hem 'het kunnen presenteren van een overtuigende proef die bewijst dat omgevingsrechtelijke regelgeving meer integraal, eenvoudiger, helderder en efficiënter kan. Geef daarom een opdracht om binnen twee jaar een overtuigende maquette van de ideale Omgevingswet te vervaardigen. Het Europese recht is hiervoor de enige harde randvoorwaarde. ${ }^{496}$ In dezelfde zin noem ik nog Van Hall, die de wetgever adviseert: 'toon moed en neem uw verantwoordelijkheid. Benoem een soort 'Commissie Scheltema'497 (Awb-traject) voor de ontwikkeling van een fundamenteel anders ingerichte leefomgevingswet. U mag er tien jaren over doen. Dan kunt u aansluiten op onvermoede ontwikkelingen betreffende de landsdelen. ${ }^{498}$

Ten slotte noem ik nog de motie-Van Velzen/Duyvendak om een commissie van wetgevingsjuristen in te stellen met de opdracht de voor- en nadelen te inventariseren en eventueel een voorstel te ontwikkelen voor het integreren van milieu- en natuurwetgeving in één wet. ${ }^{499}$ Die op 7 februari 2004 aangenomen motie heeft echter niet tot een dergelijke wet geleid, aangezien een

493 Noll, Gesetzgebungslehre 1973, p. 214.

494 Een dergelijke proeve zal niet zo eenvoudig te realiseren zijn als het door mij samengestelde Wetboek omgevingsrecht, door Michiels tijdens presentaties menigmaal als Lex Van den Broek aangeduid (Van den Broek, Die Unvollendete 2005).

495 Van den Broek, Omgevingsrecht doet recht aan integrale omgevingsbescherming 2010, p. 64

496 Backes, Naar een integrale omgevingswet? 2010, p. 16.

497 Commissie wetgeving algemene regels bestuursrecht, naar haar voorzitter de regeringscommissaris Michiel Scheltema genoemd. De Commissie is ingesteld bij besluit van 23 augustus 1983 (Stb. 1983, 417). Haar taak is het uitbrengen van voorstellen aan de ministers van Justitie en Binnenlandse Zaken en Koninkrijksrelaties met betrekking tot de wettelijke regeling van algemene regels van bestuursrecht. Deze voorstellen worden zoveel mogelijk gegoten in de vorm van ontwerpvoorstellen van wet, voorzien van ontwerp-memorie van toelichting (almanak.overheid.nl/13615/Veiligheid en_Justitie/Commissies_en_Raden/Commissie_wetgeving_algemene_regels_bestuursrecht/).

498 Van Hall, Belangenafweging in de wet op de fysieke leefomgeving 2000, p. 146.

499 Motie-Van Velzen/Duyvendak over het instellen van een commissie van wetgevingsjuristen (Kamerstukken II 2002/03, 29 383, nr.8). Zie ook Van den Broek, Leden der Staten-Generaal! 2004. 
informele commissie van beleids- en wetgevingsjuristen tot de conclusie was gekomen dat er onvoldoende basis bestond voor een dergelijke stap. ${ }^{500}$

Verschuuren ${ }^{501}$ meent dat er vanuit rechtsstatelijk en democratisch oogpunt wel wat kanttekeningen zijn te plaatsen bij de formule die is gehanteerd bij het Vlaamse Voorontwerp Decreet Milieubeleid en het Umweltgesetzbuch (UGB-KomE): een wetenschappelijke commissie doet het voorbereidende werk, de wetgever stelt vast. ${ }^{502}$ Aan de wetenschappers wordt niet gevraagd om een deskundigenadvies te geven over een door de regering voorgesteld wetsontwerp, maar om 'een soort van particulier intitiatief-wetsvoorstel'. Daarmee wordt volgens Verschuuren het fundament van nieuwe regelgeving niet door de wetgever, maar door wetenschappers gelegd, waarbij de representativiteit 'natuurlijk' ver is te zoeken. Bij nadere beschouwing van beide genoemde wetsontwerpen blijkt volgens Verschuuren echter dat de voorbereiding van een ingewikkeld conglomeraat van regelgeving goed kan geschieden door deskundigen. De wet zelf wordt uiteindelijk gemaakt door de democratisch gelegitimeerde wetgever. Aangezien de wetgever daarbij naar eigen inzichten geheel kan afwijken van een commissievoorstel adviseert Verschuuren de commissie zich bij zijn werkzaamheden rekenschap te geven van mogelijke politieke gevoeligheden. Ik ben het in zoverre eens met Verschuuren dat de voorbereiding van een wetsontwerp goed kan geschieden door deskundigen. Juist om politieke en andere gevoeligheden te adresseren, meen ik echter dat het verstandig zou zijn om wetenschap en praktijk te betrekken bij de vormgeving van het wetsvoorstel. Daarmee bedoel ik onder meer wetgevingsjuristen, maar ook gebruikers van het op te stellen wetsontwerp, zoals burgers, bedrijven, ambtenaren, rechters en advocaten. Van hen mag daarbij wel een zekere onthechte houding worden verwacht in die zin dat een mogelijke lobby pas wordt gevoerd na totstandkoming van het ontwerp.

Ten slotte noem ik in dit verband nog Hirsch Ballin, die opmerkt dat verbetering van wetgeving, en van haar architectuur in het bijzonder, slechts mogelijk is als men het wetgevingsproces daar aangrijpt, waar de zaak nog of weer voldoende openligt. Dit is het geval bij de totstandkoming van het eerste concept van een nieuwe wet, en verder bij het opzetten van een algemene wet die alsnog codificeert wat eerst in vele bijzondere wetten apart en vaak ook gevarieerd regeling heeft gevonden. ${ }^{503}$ De eerste klap is dus een daalder waard.

500 Stcrt. 7 juli 2004.

501 Verschuuren, Codificatie van het milieurecht in het Vlaamse Gewest 1996, p. 19.

502 Zie par. 1.2.2.2 en 1.2.2.3

503 Hirsch Ballin, Architectuur van wetgeving 1984, p. 93. 


\subsection{SAMENVATTING EN CONClUSIE}

Als antwoord op de eerste deelvraag van dit onderzoek is in hoofdstuk 3 wetenschappelijk een kader ontwikkeld waaruit volgt in welke gevallen bundeling van omgevingsrecht al dan niet verantwoord is.

Voor het antwoord op die vraag heb ik de materiële wetssystematiek ${ }^{504}$ als uitgangspunt genomen. Een wetssysteem bestaat uit volgens bepaalde criteria geordende, onderling samenhangende regels. ${ }^{505}$ Van een wetssystematisch tekort is gelet op deze definitie sprake als bepaalde regels volgens bepaalde samenhangcriteria onderling samenhangen maar desalniettemin geen deel uitmaken van hetzelfde wetssysteem. ${ }^{506}$ Daarbij gaat het om bestaande wetssystemen. Coördinatie, harmonisatie, consolidatie, integratie en herschikking vormen mogelijkheden om de ten onrechte ontbrekende samenhang tussen wetssystemen te verminderen of op te heffen. Mijn onderzoek heeft betrekking op bundeling van wetssystemen door integratie of herschikking.

Van een wetssysteem is pas sprake als er samenhangcriteria zijn. Die samenhangcriteria bepalen het wetssysteem, wetssystematische tekorten en de oplossingen voor het probleem dat de wetgever met een wetssysteem wil regelen. De wetgever moet een keus maken uit een in beginsel schier oneindig aantal ordeningscriteria om samenhang aan te brengen tussen regels in het omgevingsrecht. ${ }^{507}$ Daarbij kan het gaan om zakelijke ordeningscriteria en typisch juridische ordeningscriteria.

De keus voor een of meer samenhangcriteria wordt weliswaar politiek bepaald, maar niet elke politieke keuze is ook wetenschappelijk verantwoord. De keus voor samenhangcriteria kan echter wetenschappelijk worden onderbouwd.

Daarvoor dient in de eerste plaats te worden gekeken naar de belangrijkste functie van een wetssysteem, die naar mijn oordeel is gelegen in het vergemakkelijken van in het geschreven recht opgenomen informatie. Een wetssysteem is los van de inhoud van de daarvan deel uitmakende regels van belang voor de kenbaarheid van het omgevingsrecht. Een wetssysteem behoort bovendien probleemgeoriënteerd te zijn, waaronder ik versta dat degene die het omgevingsrecht raadpleegt om een antwoord te vinden omtrent rechten en verplichtingen in het wetssysteem zelf al naar de plaats wordt geleid waar het antwoord is te vinden. Als gevolg van de kenbaarheid en de probleemgeoriënteerdheid heeft het daarom de voorkeur dat de

504 Zie par. 2.3.3.

505 Zie par. 2.3.1

506 Zie par. 2.4.1.

507 Zie par. 2.3.3. 
wetgever kiest voor samenhangcriteria die aansluiten bij de samenhangen die gebruikers van het omgevingsrecht in de echte werkelijkheid ervaren en zonder specialistische juridische voorkennis begrijpen. Dat betekent dat de wetgever bij voorkeur moet kiezen voor zakelijke samenhangcriteria als subjecten, objecten, activiteiten en de fysieke leefomgeving. Indien en voor zover de wetgever zulks doet, is bundeling in beginsel verantwoord.

In beginsel, want bundeling van wetssystemen in het omgevingsrecht biedt weliswaar een mogelijkheid om wetssystematische tekorten op te heffen door ten onrechte over meer wetssystemen verspreid staande regels een plaats te geven in hetzelfde wetssysteem, maar de keus voor een bepaald samenhangcriterium betekent per definitie dat bundeling elders in het omgevingsrecht wetssystematische tekorten laat bestaan of zelfs creëert. Daarbij laat zich een aantal categorieën onderscheiden. Ten eerste kan bundeling op basis van zakelijke samenhangcriteria betekenen dat bepaalde wetssystematische tekorten slechts gedeeltelijk worden opgeheven. Ten tweede kan bundeling op basis van zakelijke samenhangcriteria betekenen dat bepaalde wetssystematische tekorten geheel of gedeeltelijk worden opgeheven, doch dat daardoor wetssystematische tekorten in andere wetssystemen worden gecreëerd. Tot slot kan bundeling op basis van typisch juridische samenhangcriteria betekenen dat wetssystematische tekorten worden gehandhaafd of gecreëerd in een door bundeling op basis van zakelijke samenhangcriteria bepaald wetssysteem. Het kan hier gaan om interne en externe wetssystematische tekorten. Een intern tekort kan zich voordoen als typisch juridische samenhangcriteria worden gebruikt binnen genoemd wetssysteem. Een extern tekort kan zich voordoen als typisch juridische samenhangcriteria tot gevolg hebben dat bepaalde regels geen deel uitmaken van dat wetssysteem. Bundeling is niet verantwoord als het ontstaan of voortbestaan van deze wetssystematische tekorten niet verdedigbaar is.

Codificerende bundeling behoort uitgangspunt te zijn, aangezien bundeling zich in de eerste plaats moet richten op het opheffen of verminderen van wetssystematische tekorten in plaats van op de te bundelen regels zelf. Bundeling is echter ook dan verantwoord als kleine, maar ook als majeure modificaties worden aangebracht. In het laatste geval dient de wetgever zich er wel van te vergewissen, dat zulks kan betekenen dat de mogelijke voordelen van bundeling worden beperkt als gevolg van de modificatie. De wetgever loopt voorts het risico dat de maatschappelijke acceptatie van bundeling wordt verminderd of zelfs opgeheven door maatschappelijke weerstand tegen een of meer modificaties.

Ten slotte moet de wetgever zich ervan vergewissen of een door bundeling ontstaan wetssysteem toekomstbestendig is. Daarmee bedoel ik dat daarbinnen geen - onverdedigbare - wetssystematische tekorten ontstaan als gevolg van het feit dat de wetgever in belangrijke mate is gedwongen om een 
chronologische aanpak te hanteren. De wetgever kan deze toekomstbestendigheid bevorderen door niet te streven naar een wetssystematiek die de pretentie heeft het omgevingsrecht voor eens en altijd te codificeren, maar naar een op verandering en zo mogelijk op een iLawsysteem gericht wetssysteem. Voorts kan de toekomstbestendigheid worden vergroot door het gebruik van toekomstbestendige zakelijke of typisch juridische systeemordeningscriteria, waarvan mag worden verwacht, dat die niet alleen op dit moment, maar ook in de toekomst valide zijn. De wetgever moet ervoor zorgen dat nieuwe omgevingsregels die een bepaald probleem beogen te regelen aansluiten bij de gekozen wetssystematische ordeningscriteria waarop zij anders een inbreuk zouden vormen. Het gebruik van aanbouwwetgeving die voldoet aan de eisen die in dit hoofdstuk zijn gesteld aan de keuze voor wetssystematische ordeningscriteria kan eveneens bijdragen aan toekomstbestendigheid.

Gelet op het bovenstaande zou de wetgever zich bij een voornemen tot bundeling van omgevingsrecht de volgende vragen moeten stellen om te komen tot een wetenschappelijk verantwoorde bundeling:

1. Is er binnen het omgevingsrecht sprake van een wetssystematisch tekort omdat niet alle regels die volgens een op de echte werkelijkheid gebaseerd zakelijk samenhangcriterium onderling samenhangen, desalniettemin geen deel uitmaken van hetzelfde wetssysteem? ${ }^{508}$

2. Zo ja, kan dat wetssystematisch tekort worden opgeheven of verminderd door middel van bundeling van wetssystemen door herschikking of integratie?509

3. Leidt het gebruik van typisch juridische ordeningscriteria tot het ontstaan of voortbestaan van wetssystematische tekorten? Zo ja, zijn dergelijke tekorten verdedigbaar? ${ }^{510}$

4. Leidt bundeling tot het ontstaan of voortbestaan van wetssystematische tekorten in andere wetssystemen? Zo ja, zijn dergelijke tekorten verdedigbaar? ${ }^{511}$

5. Leidt de bundeling tot een toekomstbestendig wetssysteem? ${ }^{512}$

Als het antwoord op de vragen 1, 2 en 5 bevestigend en op de vragen 3 en 4 ontkennend luidt, noem ik bundeling verantwoord. Als het antwoord op de vragen 3 en 4 bevestigend luidt, maar het antwoord ten aanzien van de verdedigbaarheid van de geconstateerde wetssystematische tekorten bevestigend, dan is bundeling eveneens verantwoord. Naar aanleiding van het antwoord op genoemde vragen kan bundeling ook deels verantwoord worden genoemd.

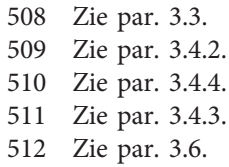


Per onderwerp zal moeten worden bekeken tot welke resultaten het toepassen van de genoemde toetsingscriteria leidt. De criteria zullen niet voor alle gevallen scherp omlijnd kunnen worden. Bij toepassing ervan kunnen de meningen mogelijk uiteenlopen. Maar we hebben nu tenminste een kompas, zodat we niet bij voorbaat het spoor bijster behoeven te raken. ${ }^{513}$

\subsection{TOETSING VAN DE THEORIE AAN DE PRAKTIJK}

In hoofdstuk 3 zijn wetenschappelijk criteria ontwikkeld waaraan een verantwoorde bundeling van omgevingsrecht moet voldoen. In de hoofdstukken 4, 5, 6 en 7 is onderzocht of en zo ja in welke mate dit theoretisch kader bruikbaar is in de praktijk. Daartoe is in hoofdstuk 4 de bundeling door herschikking die heeft geleid tot de Wabo getoetst aan het theoretisch kader, meer in het bijzonder aan de in paragraaf 3.8 genoemde vragen. In hoofdstuk 5 is hetzelfde gebeurd ten aanzien van de bundeling door integratie waarbij de Wet milieugevaarlijke stoffen is opgenomen in hoofdstuk $9 \mathrm{Wm}$. In hoofdstuk 6 is de voorgenomen bundeling door herschikking van de Natuurbeschermingswet 1998, de Flora- en faunawet en de Boswet in een nieuwe Wet Natuurbescherming getoetst aan het theoretisch kader. In hoofdstuk 7 is hetzelfde gedaan ten aanzien van de voorgenomen bundeling door herschikking van tientallen wetssystemen in een Omgevingswet.

Daarbij is in de hoofdstukken 4, 5, 6 en 7 steeds als volgt te werk gegaan. Eerst is een korte indruk gegeven van de desbetreffende bundeling; daarbij is met name ook aandacht besteed aan de motieven die de wetgever voor ogen stonden om te bundelen. Vervolgens zijn de vijf vragen beantwoord die zijn geformuleerd in paragraaf 3.8. Steeds is afgesloten met een korte samenvatting.

Het gaat het bestek van deze studie te buiten om volledig en uitputtend te beschrijven of en zo ja in welke mate de in de hoofdstukken 4, 5, 6 en 7 genoemde voorbeelden van bundeling voldoen aan de ontwikkelde criteria. Doel van de toetsing in die hoofdstukken is om erachter te komen of de vier besproken bundelingsoperaties aspecten bevatten die getoetst aan de ontwikkelde theorie tot het oordeel moeten leiden dat bundeling ten aanzien van die aspecten al dan niet verantwoord is. Daarmee wordt een antwoord gegeven op de tweede deelvraag van dit onderzoek.

Daarbij zal ik waar nodig ook suggesties doen om te komen tot vermindering of opheffing van geconstateerde wetssystematische tekorten. Daarmee wordt een antwoord gegeven op de derde deelvraag van dit onderzoek.

513 De formulering ontleen ik aan Gilhuis, Over de verhouding van Wabm tot Awb 1990, p. 215. 



\section{$4 \quad$ Herschikking: Wet algemene bepalingen omgevingsrecht}

'Door het betrekkelijk grote aantal afwijkende en aanvullende bepalingen dat in de Wabm nodig is, wordt het probleem van de twee dienstregelingen, die van de Awb en de Wabm, die men beide beurtelings moet raadplegen om achter de route van één treinverbinding te komen, groter. De toegankelijkheid en gebruikersuriendelijkheid van deze wetgeving neemt daardoor af.'

Piet Gilhuis ${ }^{1}$

\subsection{INLEIDING}

Op 1 oktober 2010 is de Wet algemene bepalingen omgevingsrecht (Wabo) in werking getreden. ${ }^{2}$ Hier is sprake van bundeling door herschikking. ${ }^{3}$ In hoofdstuk 4 zal aan de hand van de in paragraaf 3.8 genoemde vijf toetsvragen worden onderzocht hoe deze bundeling van diverse regels in het omgevingsrecht in het wetssysteem van de Wabo zich verhoudt tot de in hoofdstuk 3 opgenomen criteria.

In paragraaf 4.2 zal een korte indruk worden gegeven van de Wabo. Vervolgens worden in de paragrafen 4.3 tot en met 4.7 de vijf genoemde toetsvragen beantwoord. Afgesloten zal worden met een korte samenvatting en conclusie in paragraaf 4.8 .

\footnotetext{
Gilhuis, Over de verhouding van Wabm tot Awb 1990, p. 219.
}

Regels inzake een vergunningstelsel met betrekking tot activiteiten die van invloed zijn op de fysieke leefomgeving en inzake handhaving van regelingen op het gebied van de fysieke leefomgeving (Wet algemene bepalingen omgevingsrecht), Stb. 2008, 496 en Stb. 2010, 231. Zie ook Van den Broek, Dag van de Wabo 2008, waarin hij de Wabo ziet als een opstap naar verdere verbeteringen in het omgevingsrecht. Zie voor de parlementaire geschiedenis van wetsvoorstel 30844 (Wabo) en wetsvoorstel 31953 (Invoeringswet Wabo) Van den Broek \& Dresden, Parlementaire geschiedenis Wabo en omgevingsvergunning 2011. Voor een toelichting op de Wabo verwijs ik naar Van den Broek, Wegwijzer Wabo 2012, Van den Broek \& Dresden, De Wabo in de praktijk 2011, Van den Broek, Aan de slag met de Wabo 2010, Nijmeijer/Hillegers \& Lam, Bouwen en ontwikkelen met de Wabo 2010, Koeman/Nijmeijer \& Uylenburg (red.), T\&C Wabo 2010, en Van den Broek, De bouw maakt het met Wabo en omgevingsvergunning 2008. In hun preadviezen voor de Vereniging voor Bouwrecht beschrijven en analyseren Michiels c.s. enige huns inziens belangrijke thema's uit het wetsvoorstel Wabo. Hun wijzigingsvoorstellen lijken mij een nuttige bijdrage geweest te zijn aan de parlementaire behandeling (Michiels/Nijmeijer \& Van der Velden, Het wetsvoorstel Wabo 2007).

3 Zie par. 2.4 .5 


\subsection{DE WABO IN HET KORT}

Het wetssysteem van de Wabo bevat acht hoofdstukken. De kern van de Wabo wordt gevormd door de omgevingsvergunning. Het is verboden zonder omgevingsvergunning een project uit te voeren voor zover dat geheel of gedeeltelijk bestaat uit een aantal met name genoemde activiteiten, zoals het bouwen van een bouwwerk, ${ }^{4}$ het oprichten van een inrichting of mijnbouwwerk, ${ }^{5}$ en het vellen of doen vellen van een houtopstand. ${ }^{6}$

Na hoofdstuk 1 Begripsbepalingen volgt hoofdstuk 2 De omgevingsvergunning dat onder meer het genoemde verbod bevat om zonder omgevingsvergunning een project uit te voeren voor zover dat geheel of gedeeltelijk bestaat uit een aantal met name genoemde activiteiten. Die activiteiten zijn opgesomd in artikel 2.1 lid 1 en artikel 2.2 lid 1 Wabo. Daarnaast voorziet de Wabo in de mogelijkheid om een omgevingsvergunning verplicht te stellen voor categorieën activiteiten die zijn aangewezen in een algemene maatregel van bestuur ${ }^{7}$ dan wel een provinciale, gemeentelijke of waterschapsverordening. ${ }^{8}$ Voorts kunnen ook andere wetten dan de Wabo activiteiten aanwijzen waarvoor in bepaalde gevallen een omgevingsvergunning is vereist. Voorbeelden van vergunningen voor deze zogeheten aangehaakte activiteiten ${ }^{9}$ zijn de natuurbeschermingsvergunning ${ }^{10}$ en de ontheffing op grond van artikel 75 Flora- en faunawet $(\mathrm{Ffw}) .{ }^{11}$

In hoofdstuk 2 vinden we onder meer ook de bepalingen inzake de aanwijzing van het bevoegd gezag, de wijze van aanvragen, de beoordeling daarvan, alsmede de wijziging en intrekking van de omgevingsvergunning. Als bevoegd gezag zijn aangewezen burgemeester en wethouders van de gemeente waar het betrokken project in hoofdzaak zal worden of wordt uitgevoerd. ${ }^{12}$ Bij algemene maatregel van bestuur kunnen echter ook Gedeputeerde Staten of een minister als bevoegd gezag worden aangewezen. ${ }^{13} \mathrm{Er}$ kan maar één bestuursorgaan bevoegd gezag zijn. ${ }^{14}$ Ten aanzien van de beoordeling van een aanvraag om een omgevingsvergunning voor een project dat bestaat uit een of meer aangewezen activiteiten kent de Wabo voor elke activiteit een eigen beoordelingskader. ${ }^{15}$ De toetsingskaders zijn immers nog niet inhoudelijk geïntegreerd. De aan de

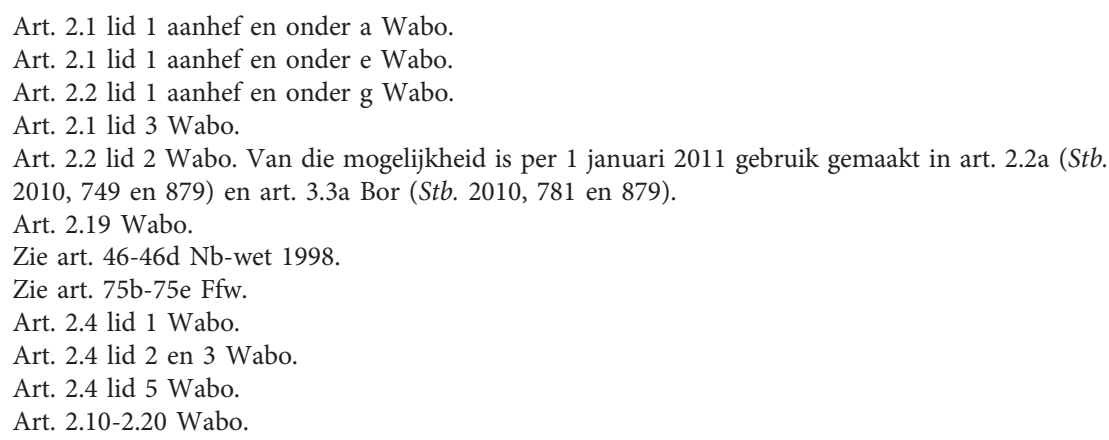


omgevingsvergunning verbonden voorschriften moeten wel op elkaar worden afgestemd. ${ }^{16}$

Hoofdstuk 3 bevat regels over de voorbereiding van een omgevingsvergunning voor een project. Daarbij wordt onder meer vaak verwezen naar de relevante bepalingen in de Awb. Hoofdregel is dat de in de Awb geregelde reguliere voorbereidingsprocedure ${ }^{17}$ van toepassing is op de voorbereiding van een omgevingsvergunning. ${ }^{18}$ Als het project echter met name genoemde activiteiten omvat, ${ }^{19}$ geldt de eveneens in de Awb geregelde uitgebreide voorbereidingsprocedure. ${ }^{20}$ Hoofdstuk 3 regelt voorts de procedures voor wijziging en intrekking van de omgevingsvergunning, alsmede coördinatie van de voorbereiding van een omgevingsvergunning en een watervergunning als bedoeld in artikel 6.2 Waterwet (Wtw). ${ }^{21}$

Hoofdstuk 4 bevat bepalingen inzake financiële zekerheid en vergoeding van kosten en schade. Bij algemene maatregel van bestuur kunnen categorieën gevallen worden aangewezen waarin een omgevingsvergunning betrekking heeft op een activiteit die ernstige nadelige gevolgen voor de fysieke leefomgeving kan hebben. Degene die die activiteit verricht kan dan worden verplicht om financiële zekerheid te stellen voor het nakomen van krachtens de omgevingsvergunning voor hem geldende verplichtingen. Ook kan financiële zekerheid worden verlangd ter dekking van zijn aansprakelijkheid voor schade die voortvloeit uit de door de activiteit veroorzaakte nadelige gevolgen voor de fysieke leefomgeving. ${ }^{22}$ Het bevoegd gezag kan degene tot wie een omgevingsvergunning of andere met name genoemde beschikking op basis van de Wabo is gericht een vergoeding van kosten en schade toekennen die hij als gevolg van die beschikking maakt. ${ }^{23}$

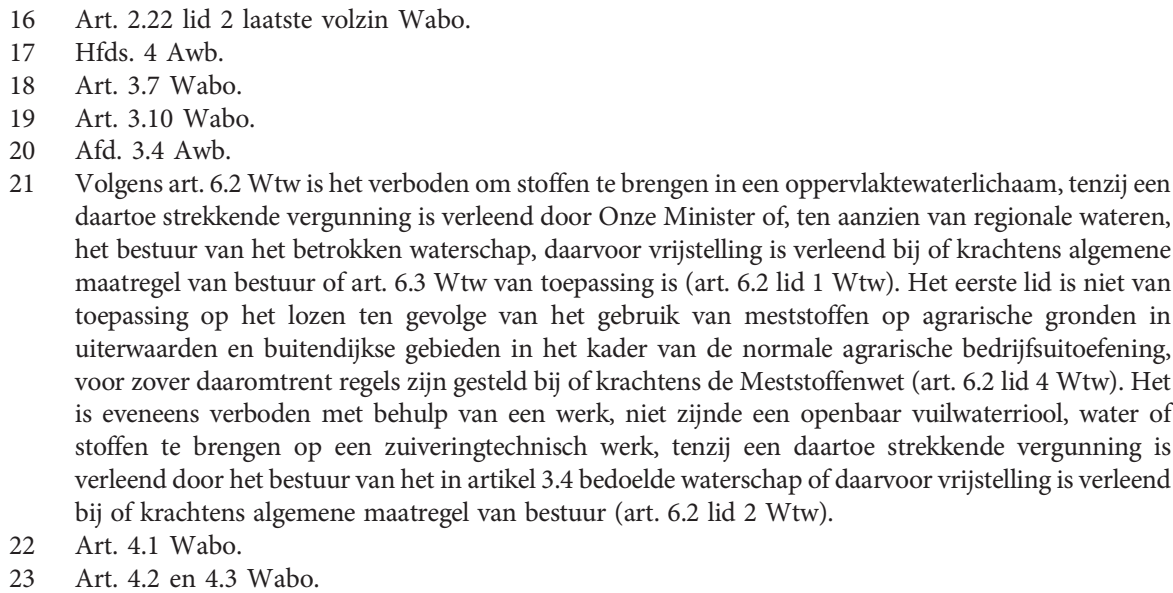


Hoofdstuk 5 bevat aanvullingen op de bepalingen van hoofdstuk 5 Awb inzake toezicht en handhaving van het bij of krachtens de Wabo ${ }^{24}$ bepaalde. Te denken is aan afstemming en coördinatie in verband met een doelmatige handhaving, de aanwijzing van toezichthouders en opsporingsambtenaren, de last onder dwangsom, de last onder bestuursdwang en de intrekking van de omgevingsvergunning. Ook kostenverhaal met betrekking tot het beheer van afvalstoffen ${ }^{25}$ is geregeld in hoofdstuk 5 .

Hoofdstuk 6 kent onder meer regels over de inwerkingtreding van de omgevingsvergunning en andere beschikkingen krachtens de Wabo. Het gaat hier om een aanvulling op de bepalingen van de Awb. Hetzelfde geldt voor de in hoofdstuk 6 van de Wabo opgenomen regels inzake rechtsbescherming. De hoofdstukken 7 en 8 bevatten 'verdere bepalingen', alsmede overgangs- en slotbepalingen. ${ }^{26}$

De Wabo kent in een groot aantal bepalingen de verplichting of de mogelijkheid om het onderwerp van die bepalingen nader uit te werken in een algemene maatregel van bestuur of een ministeriële regeling. Dat is gebeurd in het Besluit omgevingsrecht ${ }^{27}$ (Bor) en de ministeriële Regeling omgevingsrecht (Mor). ${ }^{28}$

In geval van de Wabo kan worden gesproken van codificerende herschikking. ${ }^{29}$ Bij vergelijking van de Wabo met de daarin door herschikking opgenomen regels van omgevingsrecht blijkt dat die regels mutatis mutandis grotendeels overeenkomen met de regels die tot 1 oktober 2010 waren opgenomen in andere wetssystemen, zoals de Wet milieubeheer (Wm) en de Woningwet. De beperkte wijzigingen die zijn aangebracht zijn gewoonlijk veeleer van tekstuele en redactionele aard dan dat zij beogen de geldende rechtsopvattingen te veranderen.

\subsection{WETSSYSTEMATISCHE TEKORTEN}

\subsubsection{Algemeen}

In deze paragraaf zal de eerste toetsuraag worden beantwoord: is er binnen het omgevingsrecht sprake van een wetssystematisch tekort omdat niet alle regels die volgens een op de echte werkelijkheid gebaseerd zakelijk

\footnotetext{
24 Hetzelfde geldt met betrekking tot de handhaving van het bepaalde bij of krachtens een aantal genoemde wetten voor zover dit bij of krachtens de genoemde wetten is bepaald (art. 5.1 Wabo). Art. 5.26 Wabo.

Overgangsbepalingen staan ook in art. 1.2-1.10 Invoeringswet Wabo (Stb. 2010, 142).

Stb. 2010, 143

Stcrt. 2010, 5162. Het is mij overigens een raadsel waarom deze regeling niet wordt afgekort met Ror.

29 Zie par. 2.5.3.
} 
samenhangcriterium onderling samenhangen desalniettemin geen deel uitmaken van hetzelfde wetssysteem?

Om die vraag te beantwoorden zal ik in paragraaf 4.3.2 eerst nagaan welke aanleiding de regering noemt voor de bundeling die per 1 oktober 2010 heeft geleid tot het wetssysteem van de Wabo.

In paragraaf 4.3.3 zal worden onderzocht of en zo ja welk samenhangcriterium de regering in de memorie van toelichting op het wetsvoorstel Wabo noemt dat voor haar de aanleiding vormde tot bundeling. Daarbij neem ik het door de regering gekozen samenhangcriterium als uitgangspunt. Niet vanwege het feit dat dit het enige of beste criterium zou zijn - zoals eerder aangegeven kan een wetgever kiezen uit een schier oneindig aantal samenhangcriteria ${ }^{30}$ - maar vanwege het feit dat ik de vraag wil beantwoorden in hoeverre de herschikking die heeft geleid tot de Wabo beantwoordt aan de in hoofdstuk 3 door mij ontwikkelde criteria voor bundeling. In paragraaf 4.3.3 zal ook worden aangegeven of het aldus gevonden samenhangcriterium een op de echte werkelijkheid gebaseerd zakelijk samenhangcriterium betreft.

Mocht de vorige vraag bevestigend worden beantwoord, dan zal ik in paragraaf 4.3.4 vervolgens nagaan of sprake is van een of meer wetssystematische tekorten omdat niet alle regels die passen binnen het gevonden samenhangcriterium deel uitmaken van hetzelfde wetssysteem.

In paragraaf 4.3.5 zal de eerste toetsvraag worden beantwoord.

\subsubsection{Aanleiding voor bundeling}

De aanleiding voor de Wabo was het feit dat voor één project meer toestemmingen van de overheid nodig konden zijn. Dat blijkt met name uit de volgende passage in de memorie van toelichting: 'Het huidige stelsel van wetten en regels op het terrein van bouwen, ruimte, natuur, monumenten en milieu is niet zozeer opgebouwd vanuit de positie van de burger, het bedrijf en hun activiteiten ('van buiten naar binnen'), maar vanuit de organisatie van de overheid en de behartiging van de in diverse wetten neergelegde publieke belangen. Het vragen van toestemming voor een voorgenomen project door een burger of een bedrijf aan de overheid (alsook het bezwaar en beroep tegen die toestemming) is één van de momenten waarop burgers en bedrijven zeer direct met de consequenties van dat stelsel worden geconfronteerd. Er is veelal sprake van een cumulatie van deelbesluiten van de overheid op basis van een betrokkenheid van deelaspecten van dat project.'31

30 Par. 2.3.3

31 Kamerstukken II 2006/07, 30 844, nr. 3, p. 3. De cursiveringen zijn van mij, JvdB. 
Als voorbeeld noemt de memorie van toelichting een project dat bestaat uit de bouw van een uitbouw aan een woning die is aangewezen als beschermd monument op grond van de Monumentenwet. Voor dit project waren tot 1 oktober 2010 een bouwvergunning nodig op basis van de Woningwet en een monumentenvergunning op basis van de Monumentenwet. In het kader van de bouwvergunning werden onder meer de planologische en bouwtechnische aanvaardbaarheid beoordeeld, terwijl in het kader van de monumentenvergunning de aanvaardbaarheid werd getoetst vanuit het oogpunt van een goede monumentenzorg. ${ }^{32}$

\subsubsection{Samenhangcriteria}

\subsubsection{Algemeen}

Hoewel de memorie van toelichting bij de Wabo $^{33}$ de samenhangcriteria niet als zodanig benoemt, blijken die daaruit toch wel waar wordt opgemerkt dat in de Wabo de dienstverlening door de overheid aan burgers en het bedrijfsleven centraal staat. In de Wabo 'worden daartoe de toestemmingen samengevoegd die nodig zijn als een burger of een bedrijf op een bepaalde plek iets wil gaan slopen, (ver)bouwen, oprichten of gaan gebruiken. De Wet algemene bepalingen omgevingsrecht integreert een groot aantal (circa 25) vergunningen, ontheffingen en meldingen (verder te noemen toestemmingen) tot één omgevingsvergunning. De dienstverlening aan burger en bedrijf verbetert als gevolg van de introductie van de omgevingsvergunning voor de betreffende toestemmingsstelsels. Eén omgevingsvergunning leidt tot de invoering van één loket, één (digitaal) aanvraagformulier, één bevoegd gezag (één aanspreekpunt), één uniforme en in het algemeen ook kortere procedure, één procedure voor bezwaar en beroep en één handhavend bestuursorgaan.'34

De omgevingsvergunning beoogt volgens de memorie van toelichting dus de diverse toestemmingsstelsels die nodig zijn voor het realiseren van een fysiek project (bouw, aanleg, oprichten, gebruik, sloop) zodanig te bundelen dat één besluit overblijft. Het moet daarbij gaan om projecten - die kunnen bestaan uit een of meer activiteiten zoals bouwen, kappen en slopen - die plaatsgebonden zijn en die op een of andere manier van invloed zijn op de fysieke leefomgeving. ${ }^{35}$ De regering realiseert zich daarbij dat de voor 1 oktober 2010 geldende wetgeving niet aansluit bij de echte werkelijkheid van de burger, het bedrijf en hun activiteiten.

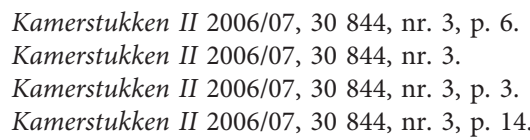


Uit het voorgaande leid ik af dat het wetssysteem van de Wabo wordt bepaald door het samenhangcriterium van een plaatsgebonden project dat bestaat uit één of meer activiteiten die van invloed zijn op de fysieke leefomgeving. Dit samenhangcriterium zal ik hierna kortheidshalve aanduiden als project.

De tekst van de Wabo bevestigt dat het project als samenhangcriterium centraal staat in de Wabo.

Kern van de Wabo zijn de artikelen 2.1 lid 1 en 2.2 lid 1, waarin staat dat het is verboden zonder omgevingsvergunning een project uit te voeren. Hoofdstuk 2 bevat een aantal bepalingen over de omgevingsvergunning, zoals het verbod om te handelen in strijd met de aan een omgevingsvergunning verbonden voorschriften (art. 2.3 Wabo), het bevoegd gezag dat de omgevingsvergunning verleent (art. 2.4 Wabo), de verschillende varianten van omgevingsvergunningen (art. 2.5 en 2.6 Wabo), de aanvraag (art. 2.7-2.9a Wabo), de beoordeling van de aanvraag (art. 2.10-2.21 Wabo), de aard, inhoud en geldingsduur van de omgevingsvergunning (art. 2.22-2.25 Wabo), adviezen en verklaringen van geen bedenkingen (art. 2.26-2.28 Wabo), de wijziging en intrekking van een omgevingsvergunning (art. 2.29-2.33a Wabo) en aanwijzingen in het algemeen belang over het nemen van een besluit ten aanzien van een aanvraag om een omgevingsvergunning of een al verleende omgevingsvergunning (art. 2.34 Wabo). Hoofdstuk 3 bevat regels over de voorbereiding van een beschikking op de aanvraag om een omgevingsvergunning (art. 3.1-3.22 Wabo). Hoofdstuk 4 regelt financiële zekerheid als de omgevingsvergunning betrekking heeft op activiteiten die ernstige nadelige gevolgen voor de fysieke leefomgeving kunnen hebben (art. 4.1 Wabo) en de vergoeding van kosten en schade als gevolg van een omgevingsvergunning, de wijziging of intrekking daarvan (art. 4.2 en 4.3 Wabo). Hoofdstuk 5 bevat regels over de handhaving van de omgevingsvergunning en hetgeen verder bij of krachtens de Wabo is bepaald. Hoofdstuk 6 Wabo bevat de Awb aanvullende bepalingen over de inwerkingtreding van de omgevingsvergunning en andere beschikkingen krachtens de Wabo. De hoofdstukken 7 en 8 zijn nodig voor een juiste uitvoering van de Wabo.

Gelet op het feit dat de regering met de Wabo het wetssystematisch tekort waarover meer in paragraaf 4.4 - heeft willen oplossen dat bestaat omdat voor een project een groot aantal deeltoestemmingsbesluiten nodig is, zou de indruk kunnen bestaan dat het samenhangcriterium niet een project is, maar een 'toestemmingsbesluit voor een project'. Mij lijkt die indruk niet juist. Het is nuttig om hier onderscheid te maken tussen een samenhangcriterium en instrumenten die ten aanzien van een dergelijk criterium worden toegepast. Het toestemmingsbesluit is niet het ordeningscriterium voor het wetssysteem Wabo, maar een instrument dat wordt gebruikt in verband met een project. Daaraan doet niet af dat de regering - waarover meer in paragraaf 4.4 - het wetssystematisch tekort dat bestaat omdat niet alle regels ten aanzien van een project in één wetssysteem zijn opgenomen, slechts heeft willen oplossen door bundeling van de regels inzake toestemmingsbesluiten die nodig zijn voor het uitvoeren van een project. 
Het samenhangcriterium project kan worden gekwalificeerd als een op de echte werkelijkheid gebaseerd samenhangcriterium. Dit samenhangcriterium combineert in wezen drie zakelijke systeemcriteria (zie paragraaf 3.3): object (project), activiteit (de met name genoemde activiteiten waaruit een project kan bestaan) en fysieke leefomgeving. Voor burgers, ondernemers en andere gebruikers van het omgevingsrecht zal aanstonds duidelijk zijn wat wordt bedoeld met een project dat bestaat uit met name genoemde activiteiten, zoals bouwen, aanleggen, oprichten, gebruiken en slopen. Die duidelijkheid wordt met name geschapen door het gebruik van op de echte werkelijkheid gebaseerde activiteiten om een project nader te duiden zoals bouwen, slopen en kappen. ${ }^{36}$ Minder duidelijk is de wetgever ten aanzien van het onderdeel 'fysieke leefomgeving'.

De regering benoemt de samenhangcriteria zoals gezegd niet als zodanig. Dat is uit een oogpunt van wetssystematiek onverstandig. Eerder in dit onderzoek heb ik het grote belang geschetst van samenhangcriteria voor een wetssysteem. Mijn aanbeveling aan de wetgever is dan ook om niet eerder tot bundeling van omgevingsrecht over te gaan dan nadat glashelder is welke samenhangcriteria het te bundelen wetssysteem bepalen. In paragraaf 4.3.3.2 zal ik aandacht besteden aan het feit dat de wetgever het samenhangcriterium fysieke leefomgeving niet glashelder heeft geformuleerd.

Als de wetgever het samenhangcriterium niet duidelijk voor ogen heeft, loopt hij het risico dat in het wetssysteem van de Wabo regels zijn of worden opgenomen, die daarin niet thuis horen, dan wel wetssystematische tekorten zijn ontstaan of ontstaan omdat regels die wel in het wetssysteem van de Wabo thuis horen daarin niet zijn opgenomen. ${ }^{37}$ In paragraaf 4.3.3.3 zal ik aangeven tot welke gevolgen dit kan leiden bij een mogelijke uitbouw van de Wabo.

\subsubsection{De fysieke leefomgeving}

Het samenhangcriterium 'fysieke leefomgeving' speelt een belangrijke rol in de Wabo. De Wabo heet voluit de wet 'Regels inzake een vergunningstelsel met betrekking tot activiteiten die van invloed zijn op de fysieke leefomgeving en inzake handhaving van regelingen op het gebied van de fysieke leefomgeving (Wet algemene bepalingen omgevingsrecht).' Zoals hiervoor aan de orde kwam, wordt het wetssysteem van de Wabo bepaald door het samenhangcriterium van een project: een plaatsgebonden project dat bestaat uit één of meer activiteiten die van invloed zijn op de fysieke leefomgeving.

\footnotetext{
36 Daaraan doet niet af, dat de Wabo een aantal activiteiten nader preciseert, aangezien daarmee niet of nauwelijks van het normale spraakgebruik wordt afgeweken.

37 Zie onder meer par. 4.4.3
} 
Het begrip fysieke leefomgeving ${ }^{38}$ is desondanks niet gedefinieerd in de Wabo. In de memorie van toelichting wordt opgemerkt dat er 'vooralsnog van af is gezien het begrip 'fysieke leefomgeving' nader te definiëren in de Wabo. Dit heeft te maken met de voorlopige keuze voor model 3, de 'integrale omgevingsvergunning met schotten'. In dit model worden, (...) de toetsingskaders immers nog niet inhoudelijk geïntegreerd. Overigens zijn op dit moment ${ }^{39}$ twee belangrijke samenstellende onderdelen van het begrip fysieke leefomgeving, te weten een goede ruimtelijke ordening en bescherming van het milieu, evenmin uitputtend gedefinieerd in de wet.' ${ }^{\prime 0}$ Deze motivering overtuigt mij niet. Het moge juist zijn dat de wetgever een definitie van het begrip fysieke leefomgeving niet per se nodig heeft als toetsingskader voor het beoordelen van een aanvraag om omgevingsvergunning. De toetsingskaders voor elke activiteit zijn immers nog niet inhoudelijk geïntegreerd. ${ }^{41}$ Dat ontslaat de wetgever echter nog niet van de verplichting om de vraag te beantwoorden wat hij daaronder precies verstaat waar hij het begrip wel gebruikt: als samenhangcriterium. Als onderdeel van het samenhangcriterium project is 'de fysieke leefomgeving' immers mede bepalend voor het wetssysteem van de Wabo en dientengevolge ook voor wetssystematische tekorten, probleemstelling en oplossingen van dat wetssysteem. ${ }^{42}$ Als de wetgever de contouren van dit samenhangcriterium niet duidelijk voor ogen heeft, loopt hij onder meer het niet onaanzienlijke risico dat in het wetssysteem van de Wabo regels zijn of worden opgenomen, die daarin niet thuis horen, ${ }^{43}$ dan wel wetssystematische tekorten bevat ${ }^{44}$ omdat regels die wel in het wetssysteem van de Wabo thuis horen daarin niet zijn opgenomen.

Ondanks het ontbreken van een definitie noemt de memorie van toelichting fysieke leefomgeving 'een breed begrip dat ziet op alle fysieke waarden in de leefomgeving ${ }^{45}$ zoals milieu, natuur, landschappelijke of cultuurhistorische waarden. Het dekt in elk geval datgene wat $\mathrm{nu}^{46}$ valt onder de reikwijdte van het wetsvoorstel voor de Wro, ${ }^{47}$ de hoofdstukken I tot en met IV van de $\mathrm{Ww},{ }^{48}$ de $\mathrm{Mw},{ }^{49}$ de Mijnbouwwet (Mbw) en de Wm. ${ }^{50}$ De reikwijdte van de

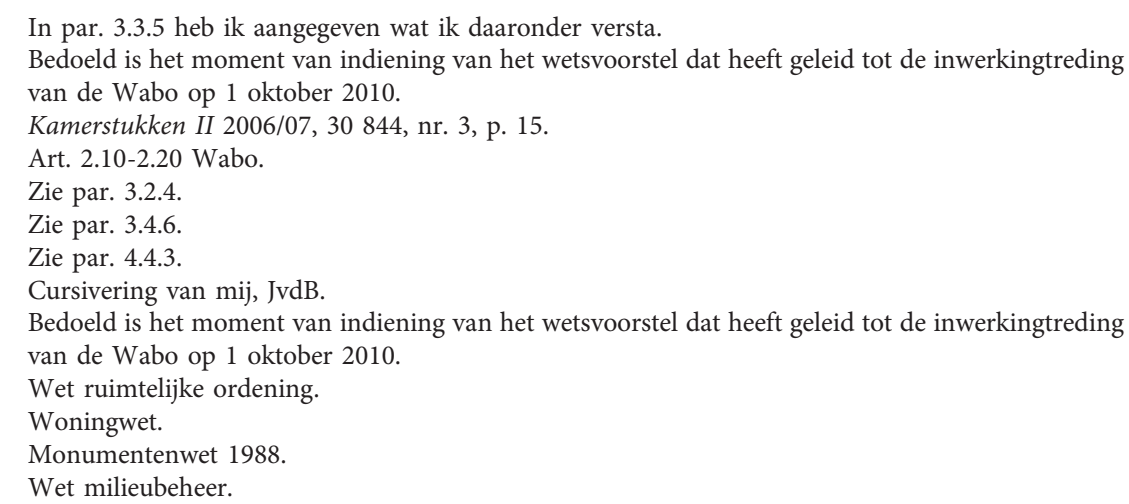


omgevingsvergunning zal (...) breder zijn. ${ }^{51}$ Robesin noemt de term fysieke leefomgeving rijkelijk vaag en vraagt zich af hoe kan worden voorkomen dat een onjuiste uitruil van normen leidt tot een vermindering van het beschermingsniveau..$^{52}$

Bij gebrek aan een wettelijke definitie zal ik het samenhangcriterium fysieke leefomgeving verstaan in de brede betekenis die daaraan in de memorie van toelichting wordt toegekend, te weten alle fysieke waarden in de leefomgeving.

\subsubsection{Verdere uitbouw van de Wabo}

Uit de memorie van toelichting blijkt dat de regering heeft nagedacht over een verdere uitbouw van de Wabo.

Daarbij wordt onderscheid gemaakt tussen de reikwijdte en de werkingssfeer. De reikwijdte heeft betrekking op de vraag op welke wettelijke regelingen de Wabo betrekking heeft. De werkingssfeer heeft betrekking op welke onderwerpen in de Wabo worden geregeld. ${ }^{53}$

De in de memorie van toelichting gegeven voorbeelden doen echter vermoeden dat de regering daarbij niet per se denkt aan een uitbouw op basis van het samenhangcriterium project. Het is echter onduidelijk welke samenhangcriteria volgens de regering dan wel leidend zouden moeten zijn voor uitbouw van de Wabo. Zoals hiervoor reeds aangegeven, loopt de wetgever daardoor onder meer het risico dat in het wetssysteem van de Wabo regels worden opgenomen, die daarin niet thuis horen, ${ }^{54}$ dan wel wetssystematische tekorten bevat ${ }^{55}$ omdat regels die wel in het wetssysteem van de Wabo thuis horen daarin niet zijn opgenomen.

Het eerste voorbeeld van mogelijke uitbouw van de Wabo dat de memorie van toelichting noemt betreft de vraag of en in hoeverre bepaalde wetten in de Wabo worden geïntegreerd. Als voorbeeld wordt de Ontgrondingenwet genoemd. Ook moet de uitbouw volgens de regering bezien worden in het licht van de ontwikkeling van andere wetgeving zoals de Waterwet. ${ }^{56}$ Een dergelijke uitbouw past binnen het samenhangcriterium project als bijvoorbeeld wordt gedacht aan het opnemen van activiteiten in een project waarvoor thans nog een vergunning

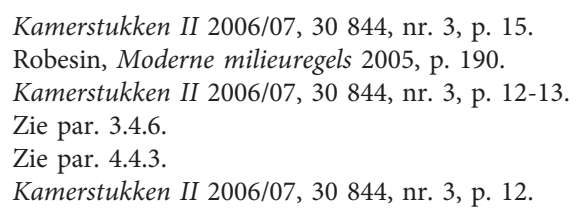


nodig is op grond van de Waterwet ${ }^{57}$ of de Ontgrondingenwet. ${ }^{8}$ Als echter wordt gedacht aan uitbouw buiten dat samenhangcriterium zal de wetgever moeten aangeven welk samenhangcriterium het uit te bouwen wetssysteem zal moeten bepalen. In dit verband breng ik in herinnering de woorden van de Sachverständigenkommission zum Umwelgesetzbuch: 'Allgemeine Voraussetzung für die Kodifikation eines Rechtsgebietes ist dessen Abgrenzbarkeit gegenüber anderen Materien. 59

Het tweede voorbeeld van mogelijke uitbouw van de Wabo betreft de werkingssfeer. Hoofdstuk 5 Wabo $^{60}$ bevat bepalingen inzake de handhaving van de omgevingsvergunning en het verder bij of krachtens de Wabo bepaalde. Voor zover dergelijke handhavingsregels betrekking hebben op een project, passen deze regels binnen het samenhangcriterium project. Hoofdstuk 5 heeft echter ook betrekking op de handhaving van het bepaalde bij of krachtens 13 met name aangewezen wetten ${ }^{61}$ voor zover dit bij of krachtens die wetten is bepaald. ${ }^{62}$ De memorie van toelichting vermeldt dat het aanvankelijk de bedoeling was dat de Wabo alleen betrekking zou hebben op het overhevelen van de toestemmingsstelsels van de diverse wetten en deze wetten voor het overige volledig intact zou laten. De bepalingen omtrent de handhaving van de omgevingsvergunning hangen echter zozeer samen met de bepalingen van het nieuwe vergunningenstelsel dat deze bepalingen eveneens zijn opgenomen in de Wabo. Er is echter besloten om de in de diverse wetten resterende overige bepalingen omtrent handhaving ook over te nemen in de Wabo. Dit heeft ertoe geleid dat deze bepalingen in een afzonderlijk hoofdstuk zijn opgenomen en in de diverse betrokken wetten een verwijzing naar dit hoofdstuk plaatsvindt. ${ }^{63}$ Het gaat hier mijns inziens om wetssystematische koekoekseibepalingen, in een wetssysteem opgenomen regels die daarin op grond van de gekozen samenhangcriteria niet thuis horen. ${ }^{64}$ In hoofdstuk 5 Wabo zijn immers regels opgenomen die volgens het samenhangcriterium project niet in de Wabo thuis horen, maar in de 13 genoemde wetssystemen. Bovendien is daarmee en passant een wetssystematisch tekort geschapen in elk van de wetten waarin nu moet worden verwezen naar hoofdstuk 5 Wabo.

Het derde voorbeeld van mogelijke uitbouw van de Wabo betreft de bedoeling van de regering om de Wabo verder uit te bouwen met die onderwerpen die de diverse wetten gemeenschappelijk hebben of die nog in geen van deze wetten

57 Art. $6.2 \mathrm{Wtw}$.

58 Op grond van art. 3 lid 1 Ontgrondingenwet is het verboden zonder ontgrondingenvergunning te ontgronden dan wel als eigenaar, erfpachter, vruchtgebruiker, opstalhouder, beklemde meier of gebruiker van enige onroerende zaak toe te laten, dat aldaar zonder vergunning ontgronding plaats heeft. In artikel 2.1 lid 1 Wabo zou als activiteit kunnen worden opgenomen het ontgronden dan wel als eigenaar, erfpachter, vruchtgebruiker, opstalhouder, beklemde meier of gebruiker van enige onroerende zaak toe te laten, dat aldaar ontgronding plaats heeft.'

59 Bundesministerium für Umwelt c.a., Umweltgesetzbuch (UGB-KomE) 1998, p. 73

60 Zie uitgebreider Van den Broek, Wegwijzer toezicht en handhaving omgevingsrecht 2011, p. 15-18.

61 Flora- en faunawet, Kernenergiewet, Monumentenwet 1988, Natuurbeschermingswet 1998, Ontgrondingenwet, Wet bescherming Antarctica, Wet bodembescherming, Wet geluidhinder, Wet inzake de luchtverontreiniging, Wet milieubeheer, Wet ruimtelijke ordening, Waterwet en Woningwet.

62 Art. 5.1 Wabo.

63 Kamerstukken II 2006/07, 30 844, nr. 3, p. 12-13.

64 Zie par. 3.4.6 
zijn opgenomen. ${ }^{65}$ De laatste categorie laat wederom zien dat de regering geen vastomlijnd - ordeningsprincipe voor ogen staat bij de uitbouw van de Wabo. Het is immers onmogelijk om nu reeds te zeggen of de onderwerpen die nog in geen van deze wetten zijn opgenomen zullen beantwoorden aan het gekozen samenhangcriterium dat bepalend is voor de inhoud van het wetssysteem. Ook ten aanzien van de eerste categorie noemt de memorie van toelichting geen samenhangcriterium waaraan die onderwerpen zouden moeten beantwoorden. Er worden slechts twee voorbeelden genoemd: het opnemen van een uniform stelsel voor algemene regels voor activiteiten en een regeling van de milieueffectrapportage. Voor zover het hier regels betreft die betrekking hebben op een project, lijkt het opnemen daarvan in de Wabo wetssystematisch juist. Voor zover het niet om projecten gaat is echter de vraag op basis van welk samenhangcriterium die regels dan in het wetssysteem van de Wabo zouden dienen te worden opgenomen.

Het ontbreken van een duidelijke definitie van fysieke leefomgeving en hetgeen in de memorie van toelichting is opgemerkt over de uitbouw van de Wabo geven aan dat de wetgever geen duidelijke samenhangcriteria voor ogen hebben gestaan bij de bundeling die heeft geleid tot de Wabo. Tekenend is in dit verband wel de opmerking in de memorie van toelichting dat 'de naam Wet algemene bepalingen omgevingsrecht er in ieder geval niet aan in de weg staat dat gefaseerd diverse onderwerpen uit de betrokken wettelijke regelingen (Woningwet, Wro, Wet milieubeheer, etc.) worden overgenomen in de Wabo. ${ }^{96}$ Vanzelfsprekend staat de citeertitel van een wet niet in de weg aan het opnemen van regels daarin. Rubrica non est lex. Maar het gaat niet om een citeertitel; bij bundeling van omgevingsrecht moet het samenhangcriterium de wetgever helder voor ogen staan.

\subsubsection{Wetssystematisch tekort}

De regels inzake - toestemmingsbesluiten voor wat betreft - een project waren tot 1 oktober 2010 opgenomen in verschillende wetssystemen. Reeds om die reden was sprake van een wetssystematisch tekort, aangezien niet alle regels die zien op een project waren opgenomen in hetzelfde wetssysteem.

\subsubsection{Antwoord op toetsvraag 1}

Voor de inwerkingtreding van de Wabo was binnen het omgevingsrecht sprake van een wetssystematisch tekort omdat niet alle regels die volgens het op de echte werkelijkheid gebaseerde zakelijk samenhangcriterium project onderling samenhangen, deel uitmaakten van hetzelfde wetssysteem. Onder een project wordt verstaan een plaatsgebonden project dat bestaat uit één of meer activiteiten die van invloed zijn op de fysieke leefomgeving. Daarmee is de eerste toetsvraag ${ }^{67}$ positief beantwoord. 


\subsection{WETSSYSTEMATISCHE TEKORTEN OPGEHEVEN OF VERMINDERD}

\subsubsection{Algemeen}

In deze paragraaf zal de vraag worden beantwoord of de bundeling die heeft geleid tot het wetssysteem van de Wabo het wetssystematisch tekort heeft opgeheven of verminderd dat tot de inwerkingtreding van die wet bestond omdat niet alle regels inzake een project in hetzelfde wetssysteem waren opgenomen.

\subsubsection{Opgeheven wetssystematische tekorten}

De regering heeft met bundeling door herschikking in de Wabo niet het oogmerk gehad om in dat wetssysteem alle regels van het omgevingsrecht op te nemen die betrekking hebben op een project. ${ }^{68}$ De regering heeft met de Wabo met name een einde willen maken aan de tot 1 oktober 2010 bestaande situatie dat voor een project verschillende toestemmingsbesluiten noodzakelijk waren. ${ }^{69}$ De regels ten aanzien van die toestemmingsbesluiten stonden tot die datum in verschillende wetssystemen, ${ }^{70}$ te weten de Wet ruimtelijke ordening, ${ }^{71}$ de Woningwet, ${ }^{72}$ de Wet milieubeheer, ${ }^{73}$ de Monumentenwet $1988,{ }^{74}$ de Mijnbouwwet $^{75}$ en het Besluit brandveilig gebruik bouwwerken. ${ }^{76}$

De Wabo heeft het wetssystematisch tekort dat niet alle regels in het omgevingsrecht ten aanzien van een project in één wetssysteem waren opgenomen verminderd door het bundelen door herschikking van regels

68 Zie par. 4.3.

69 Aanvankelijk was het de bedoeling dat de Wabo alleen betrekking zou hebben op het overhevelen van de toestemmingsstelsels van de diverse wetten en deze wetten voor het overige volledig intact zou laten. Aangezien de bepalingen omtrent de handhaving van de omgevingsvergunning zozeer samenhangen met de bepalingen van het vergunningstelsel in de Wabo zijn deze bepalingen echter eveneens opgenomen in de Wabo (Kamerstukken II 2006/07, 30 844, nr. 3, p. 12). Zie ook par. 4.3.3.3.

70 Kamerstukken 2006/07, 30 844, nr. 3, p. 17-18.

71 Het gaat om de aanlegvergunning (art. 3.3 onder a), de sloopvergunning (art. 3.3 onder b), de binnenplanse ontheffing (art. 3.6 lid 1 onder c), het projectbesluit (art. 3.8b lid 1), de tijdelijke ontheffing van het bestemmingsplan (art. 3.15 lid 1), de ontheffing van het bestemmingsplan in bij algemene maatregel van bestuur aangegeven gevallen (art. 3.16 lid 1), de ontheffing binnen de beheersverordening (art. 3.29 lid 4) en de buitenwerkingstelling van de beheersverordening voor een project (art. 3.31 lid 1).

72 Het gaat om de ontheffing Bouwbesluit 2003 (art. 6), de bouwvergunning (art. 40 lid 1) en de ontheffing van voorschrift bouwverordening (art. 11 en de Modelbouwverordening).

73 Het gaat om de milieuvergunning (artikel 8.1 lid 1) en de meldingsplicht veranderen van de inrichting of van de werking daarvan (art. 8.19 lid 2)

74 Het gaat om de monumentenvergunning (art. 11 lid 2) en de sloopvergunning in beschermd stadsof dorpsgezicht (art. 37 lid 1).

75 Het gaat om de mijnbouwmilieuvergunning (art. 40).

76 Het gaat om de gebruiksvergunning (par. 2.11). Het Besluit brandveilig gebruik bouwwerken (Stb. 2008, 327 en 373) is op 1 april 2012 ingetrokken als gevolg van het Bouwbesluit 2012 (Stb. 2011, 416 en 2012, 125). 
in de Wabo die betrekking hebben op toestemmingsbesluiten die nodig zijn voor het mogen uitvoeren van een project. De regels inzake die toestemmingsbesluiten in de wetssystemen waarin zij tot 1 oktober 2010 stonden, zijn daarbij ingetrokken. Zo is hoofdstuk IV Woningwet inzake de bouwvergunning ingetrokken ${ }^{77}$ en bevat hoofdstuk $8 \mathrm{Wm}$ per 1 oktober geen regels meer inzake de milieuvergunning. ${ }^{78}$ Hierna zal ik aantonen dat de Wabo bedoeld wetssystematisch tekort weliswaar heeft verminderd, maar nog niet opgeheven.

\subsubsection{Niet opgeheven wetssystematische tekorten}

\subsubsection{Algemeen}

De Wabo heeft een aantal wetssystematische tekorten ten aanzien van een project verminderd, maar niet opgeheven. Dat is het gevolg van het feit dat het wetssysteem van de Wabo niet voldoet aan het wetssystematische uitgangspunt dat het samenhangcriterium bepalend is voor de regels die in een wetssysteem moeten worden opgenomen. ${ }^{79}$ Hierna zal ik de volgende in het oog springende voorbeelden toelichten:

a. de Wabo bevat niet alle regels ten aanzien van een project (zie paragraaf 4.4.3.2);

b. de Wabo noemt niet alle activiteiten binnen een project waarvoor een omgevingsvergunning is vereist (zie paragraaf 4.4.3.3);

c. de Wabo eist geen omgevingsvergunning voor bepaalde activiteiten binnen een project (zie paragraaf 4.4.3.4).

\subsubsection{Bundeling betreft niet alle regels ten aanzien van een project}

Een wetssystematisch tekort van de Wabo is dat dit wetssysteem niet alle regels bevat die gelden voor een project. De regering heeft met bundeling door herschikking in de Wabo niet het oogmerk gehad om in dat wetssysteem alle regels in het omgevingsrecht op te nemen die betrekking hebben op een project. ${ }^{80}$ De regering heeft met de Wabo met name een einde willen maken aan de tot 1 oktober 2010 bestaande situatie dat voor een project verschillende toestemmingsbesluiten noodzakelijk waren. Het feit dat de wetgever veel regels ten aanzien van een project niet in de Wabo heeft opgenomen, leidt soms tot ernstige problemen ten aanzien van de kenbaarheid van het recht ten aanzien van een project, zoals de volgende voorbeelden illustreren.

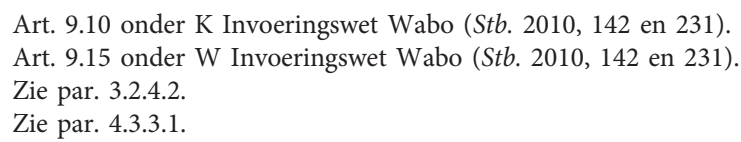


Een project kan onder meer bestaan uit het oprichten, het veranderen of veranderen van de werking of het in werking hebben van een inrichting of mijnbouwwerk. ${ }^{81}$ Belangrijke regels ten aanzien van inrichtingen staan echter niet in het wetssysteem van de Wabo, maar in dat van de Wet milieubeheer.

In de eerste plaats gaat het om het begrip omgevingsvergunningplichtige inrichting. Onder inrichting wordt verstaan elke door de mens bedrijfsmatig of in een omvang alsof zij bedrijfsmatig was, ondernomen bedrijvigheid die binnen een zekere begrenzing pleegt te worden verricht. ${ }^{82}$ Van een omgevingsvergunningplichtige inrichting is volgens de Wabo sprake als het gaat om een inrichting, behorende tot een categorie die is aangewezen als omgevingsvergunningplichtig krachtens het derde lid van artikel 1.1 van de Wabo. ${ }^{83}$ Genoemd derde lid bepaalt dat de aanwijzing categorieën inrichtingen betreft, die zijn aangewezen in artikel 1.1 lid 4 Wm. ${ }^{84}$ In genoemd vierde lid staat dat onder een inrichting wordt verstaan een inrichting behorende tot een categorie die krachtens het derde lid van artikel 1.1 Wm is aangewezen. De aanwijzing van omgevingsvergunningplichtige inrichtingen heeft plaatsgevonden in artikel 2.1 lid 2 Bor. Om te weten of sprake is van een omgevingsvergunningplichtige inrichting als bedoeld in de Wabo, dient men dus niet alleen het wetssysteem van de Wabo te raadplegen, maar eveneens het wetssysteem van de Wet milieubeheer en het wetssysteem van het Besluit omgevingsrecht.

In de tweede plaats kent het wetssysteem van de Wet milieubeheer de hoofdregel, ${ }^{85}$ dat bij of krachtens algemene maatregel van bestuur algemene regels worden gesteld die nodig zijn ter bescherming van het milieu tegen de nadelige gevolgen die inrichtingen daarvoor kunnen veroorzaken. Een uitzondering op deze hoofdregel geldt als voor een inrichting een omgevingsvergunning is vereist. Tot 1 oktober 2010 stonden hoofdregel en uitzondering in hoofdstuk 8 Wm. Met de inwerkingtreding van de Wabo staat de hoofdregel nog steeds in hoofdstuk $8 \mathrm{Wm},{ }^{86}$ maar staat de uitzondering in de Wabo. ${ }^{87}$ Om te weten dat voor een inrichting algemene regels gelden tenzij een omgevingsvergunning is vereist, dient men dus niet alleen het wetssysteem van de Wabo te raadplegen, maar eveneens het wetssysteem van de Wet milieubeheer. Waarbij nog komt, dat de algemene regels zelf in het wetssysteem van het Activiteitenbesluit staan en het wetssysteem van het Besluit omgevingsrecht moet worden geraadpleegd om erachter te komen voor welke inrichtingen een omgevingsvergunningplicht geldt.

Het feit dat een aantal belangrijke regels inzake inrichtingen niet is opgenomen in de Wabo strookt niet met het wetssystematische uitgangspunt dat het samenhangcriterium bepalend is voor de regels die in een wetssysteem

81 Art. 2.1 lid 1 aanhef en onder e Wabo.

82 Elke door de mens bedrijfsmatig of in een omvang alsof zij bedrijfsmatig was, ondernomen bedrijvigheid die binnen een zekere begrenzing pleegt te worden verricht (art. 1.1 lid $1 \mathrm{Wm}$ ).

83 Art. 1.1 lid 1 Wabo.

84 Dat is gebeurd in art. 2.1 lid 1 Bor.

85 Art. $8.40 \mathrm{Wm}$.

86 Par. 8.1 Algemene regels.

87 Art. 2.1 lid 1 aanhef en onder e Wabo. 
moeten worden opgenomen, en heeft er in de praktijk toe geleid dat de Wabo de kenbaarheid van regels inzake inrichtingen complexer heeft gemaakt dan onder de Wet milieubeheer tot 1 oktober 2010 het geval was. Dit is het gevolg van het feit dat de wetgever zich voornamelijk heeft beperkt tot het bundelen van regels die betrekking hebben op toestemmingsbesluiten. Dit wetssystematisch tekort - en de daaruit voortvloeiende complexiteit en verminderde kenbaarheid - is niet gerechtvaardigd. De wetgever kan dit tekort eenvoudig opheffen door de regels inzake inrichtingen die in de Wet milieubeheer zijn achtergebleven alsnog op te nemen in de $\mathrm{Wabo}^{88}$ dan wel in de nog op te stellen Omgevingswet. ${ }^{89}$

\subsubsection{Bundeling activiteiten in Wabo, andere wetten, amvb's en verordeningen}

Een ander wetssystematisch tekort van de Wabo is dat dit wetssysteem niet alle activiteiten binnen een project omvat waarvoor een omgevingsvergunning is vereist. Een omgevingsvergunning is vereist voor een project dat bestaat uit met name genoemde activiteiten. ${ }^{90}$ Het is echter niet mogelijk om in het wetssysteem van de Wabo te lezen om welke activiteiten het gaat. Dat is het gevolg van het feit dat slechts een gedeelte van de omgevingsvergunningplichtige activiteiten in de Wabo staat. Het betreft hier de activiteiten, die zijn genoemd in artikel 2.1 lid 1 aanhef en onder a-h en artikel 2.2 lid 1 Wabo.

Het is echter ook mogelijk dat een project geheel of gedeeltelijk bestaat uit activiteiten die niet zijn opgenomen in het wetssysteem van de Wabo, maar in andere wetssystemen op het niveau van een wet in formele zin, een algemene maatregel van bestuur of een verordening van provincie, gemeente of waterschap. Dit zal hierna worden toegelicht.

Een omgevingsvergunningplichtig project kan betrekking hebben op handelingen die tevens zijn aan te merken als handelingen waarvoor een of meer van de bij of krachtens de artikelen 8-13 lid 1, 17 en 18 Ffwet gestelde verboden ${ }^{91}$ gelden en ten aanzien waarvan de minister van ELenI op grond van artikel 75

88 De memorie van toelichting bij de Wabo vermeldt dat met het overbrengen van een uniform stelsel voor algemene regels voor activiteiten van de Wet milieubeheer en andere wetten naar de Wabo kan worden bereikt dat deze regels beter op elkaar en op het stelsel van de omgevingsvergunning kunnen worden afgestemd (Kamerstukken II 2006/07, 30 844, nr. 3, p. 13).

89 In de Omgevingswet vormen algemene regels en de omgevingsvergunning twee van de zes voorgestelde instrumenten (Ministerie van IenM, Kabinetsbrief stelselherziening omgevingsrecht 2012, par. 4.2). Zie ook hfds. 7.

90 Art. 2.1 lid 1 Wabo.

91 Het gaat onder meer om het verbod om dieren, behorende tot een beschermde inheemse diersoort, te doden, te verwonden, te vangen, te bemachtigen of met het oog daarop op te sporen (art. $9 \mathrm{Ffw}$ ) of opzettelijk te verontrusten (art. $10 \mathrm{Ffw})$. 
lid 3 Ffwet bevoegd is ontheffing te verlenen. In dat geval komt de omgevingsvergunning in de plaats van die ontheffing. ${ }^{92}$ Een soortgelijke situatie doet zich voor als een omgevingsvergunningplichtig project betrekking heeft op handelingen waarvoor het verbod, bedoeld in artikel 16 lid $1^{93}$ of artikel 19d lid $1^{94}$ Natuurbeschermingsvergunning 1998 (Nb-wet 1998) geldt. In dat geval komt de omgevingsvergunning in plaats van de natuurbeschermingsvergunning. ${ }^{95}$

Op basis van artikel 2.1 lid 1 aanhef en onder i Wabo kunnen bij algemene maatregel van bestuur categorieën van activiteiten worden aangewezen die van invloed zijn op de fysieke leefomgeving. Voor het verrichten van dergelijke aangewezen activiteiten is dan een omgevingsvergunning vereist. Van die mogelijkheid is per 1 januari 2011 gebruik gemaakt in artikel $2.2 \mathrm{a}^{96}$ en artikel $3.3 \mathrm{a}^{97}$ Bor.

Hetzelfde geldt als bij een verordening van provincie, gemeente of waterschap is bepaald dat het in daarbij aangewezen categorieën van gevallen verboden is projecten die geheel of gedeeltelijk bestaan uit andere activiteiten die behoren tot een daarbij aangewezen categorie activiteiten die van invloed kunnen zijn op de fysieke leefomgeving, uit te voeren zonder omgevingsvergunning. ${ }^{98}$

In alle genoemde gevallen staan de van een omgevingsvergunningplichtig project deel uitmakende activiteiten dus niet in het wetssysteem van de Wabo, maar in een ander wetssystemen: de Natuurbeschermingswet 1998, de Flora- en faunawet, het Besluit omgevingsrecht of een verordening van provincie, gemeente of waterschap. Het feit dat de activiteiten die onderdeel kunnen uitmaken van een omgevingsvergunningplichtig project niet zijn

92 Art. 75b en 75 c Ffw.

93 Art. 16 lid $1 \mathrm{Nb}$-wet 1998 luidt als volgt: 'Het is verboden zonder vergunning van gedeputeerde staten of, ten aanzien van handelingen als bedoeld in het zesde lid, van Onze Minister, in een beschermd natuurmonument handelingen te verrichten, te doen verrichten of te gedogen, die schadelijk kunnen zijn voor het natuurschoon, voor de natuurwetenschappelijke betekenis van het beschermd natuurmonument of voor dieren of planten in het beschermd natuurmonument of die het beschermd natuurmonument ontsieren, dan wel in strijd met de bij een vergunning gestelde voorschriften of beperkingen handelingen te verrichten, te doen verrichten of te gedogen.'

94 Art. 19d lid $1 \mathrm{Nb}$-wet 1998 luidt als volgt: 'Het is verboden zonder vergunning, of in strijd met aan die vergunning verbonden voorschriften of beperkingen, van gedeputeerde staten of, ten aanzien van projecten of andere handelingen als bedoeld in het vierde lid, van Onze Minister, projecten of andere handelingen te realiseren onderscheidenlijk te verrichten die gelet op de instandhoudingsdoelstelling, met uitzondering van de doelstellingen, bedoeld in artikel 10a, derde lid, de kwaliteit van de natuurlijke habitats en de habitats van soorten in een Natura 2000-gebied kunnen verslechteren of een significant verstorend effect kunnen hebben op de soorten waarvoor het gebied is aangewezen. Zodanige projecten of andere handelingen zijn in ieder geval projecten of handelingen die de natuurlijke kenmerken van het desbetreffende gebied kunnen aantasten.

95 Art. 46, 46a, 47 en 47a Nb-wet 1998.

96 Stb. 2010, 749 en 879 .

97 Stb. 2010, 781 en 879.

98 Art. 2.2 lid 2 Wabo. 
opgenomen in de Wabo strookt niet met het wetssystematische uitgangspunt dat het samenhangcriterium bepalend moet zijn voor de regels die in een wetssysteem moeten worden opgenomen.

Daarbij komt nog, dat bij algemene maatregel van bestuur kan worden bepaald dat met betrekking tot daarbij aangewezen activiteiten als bedoeld in artikel 2.1 lid 1 Wabo in daarbij aangegeven categorieën gevallen geen omgevingsvergunning is vereist. ${ }^{99}$ Van die mogelijkheid is gebruik gemaakt in het Besluit omgevingsrecht. ${ }^{100}$ In deze gevallen staan de van een omgevingsvergunningplichtig project deel uitmakende activiteiten dus in het wetssysteem van de Wabo, maar de uitzonderingen daarop in een ander wetssysteem: het Besluit omgevingsrecht. Ook dat strookt niet met het wetssystematische uitgangspunt dat het samenhangcriterium bepalend is voor de regels die in een wetssysteem moeten worden opgenomen.

De gebruiker die wil weten voor welke activiteiten binnen een project al dan niet een omgevingsvergunning is vereist, is aldus gedwongen verschillende wetssystemen te raadplegen. Deze situatie komt de kenbaarheid van het omgevingsrecht niet ten goede en is om die reden niet verdedigbaar. De wetgever kan deze wetssystematische tekorten eenvoudig opheffen door alle activiteiten die onderdeel kunnen uitmaken van een omgevingsvergunningplichtig project - en alle uitzonderingen daarop - waar mogelijk op te nemen in hetzelfde wetssysteem. Er zijn goede argumenten aan te voeren om daarvoor de Wabo zelf te kiezen. Het gaat immers om een zeer belangrijk onderwerp, te weten de regeling van de activiteiten waarvoor al dan niet een omgevingsvergunning is vereist. ${ }^{101}$ Mij lijkt echter ook verdedigbaar, dat deze regeling een plaats krijgt in het Besluit omgevingsrecht. ${ }^{102}$ In de eerste plaats omdat de aanwijzing van activiteiten en alle uitzonderingen daarop thans in de Wabo en het Besluit omgevingsrecht tamelijk omvangrijk en gedetailleerd zijn. In de tweede plaats omdat zulks voorkomt dat voor elke toevoeging van een activiteit een wijziging van de Wabo noodzakelijk is.

De hiervoor geschetste oplossing is niet mogelijk als de wetgever vast wil houden aan de keus om decentrale wetgevers de mogelijkheid te geven om omgevingsvergunningplichtige activiteiten of uitzonderingen daarop aan te wijzen in verordeningen van provincie, gemeente- of waterschap. ${ }^{103}$ Voor

99 Art. 2.1 lid 3 Wabo.

100 Art. 2.3 (bouwen en planologische gebruiksactiviteiten), 2.4 (veranderen van een inrichting), 2.5 (mijnbouwwerken), 2.5a (monumenten) en 2.6 (slopen) Bor.

101 Dat sluit aan bij Aanwijzing 24 van de Aanwijzingen voor de regelgeving. Daarin staat onder meer dat zoveel mogelijk in de wet worden opgenomen voorschriften die de grondslag vormen van een stelsel van vergunningen of een stelsel waarbij anderszins de toelaatbaarheid van handelen afhankelijk wordt gesteld van verlof van de overheid.

102 In gelijke zin versta ik De Vos, Interview 2012, bijl. 5.7, par. 4.3.

103 Art. 2.2 lid 2 Wabo. De in het eerste lid van dat artikel aangewezen activiteiten zijn weliswaar in het leven geroepen in verordeningen van provincie, gemeente of waterschap, maar zijn door die aanwijzing verankerd in de Wabo. 
die keus valt veel te zeggen, aangezien daarmee niet onnodig van de omgevingsvergunning afwijkende vergunningen voor een project in verordeningen van decentrale wetgevers worden geschapen. Wellicht kan het effect van de wetssystematische tekorten wel worden verzacht als ten aanzien van artikel 2.2 lid 2 Wabo een soort van notificatieprocedure zou worden ingevoerd.

Ik ontleen dit idee aan de notificatieprocedure op basis van Richtlijn 98/34/EG betreffende een informatieprocedure op het gebied van normen en technische voorschriften en regels betreffende de diensten van de informatiemaatschappij. ${ }^{104}$ Deze notificatierichtlijn strekt ertoe, dat wanneer een lidstaat - uit een oogpunt van bescherming van bepaalde, op zichzelf wellicht gerechtvaardigde, belangen - een maatregel wil nemen die een beperking van het vrij goederenverkeer of het vrij verrichten van elektronische diensten kan inhouden, het voornemen hiertoe wordt gemeld aan de Europese Commissie. Dit om die Commissie en de andere lidstaten in de gelegenheid te stellen de ontwerpmaatregel te bezien en eventueel opmerkingen te maken. Notificatie is een instrument om ongerechtvaardigde belemmeringen voor het functioneren van de interne markt op te sporen. ${ }^{105}$

In artikel 2.2 lid 1 Wabo zijn reeds de activiteiten opgenomen waarvoor veelvuldig in verordeningen van decentrale wetgevers een vergunning is vereist. Het voordeel daarvan is dat die activiteiten in de Wabo zijn opgenomen, hetgeen het wetssystematisch tekort wat hier aan de orde is verzacht heeft. De gebruiker kan immers in de Wabo zelf lezen voor welke in artikel 2.2 lid 1 Wabo genoemde activiteiten de decentrale wetgever mogelijk een omgevingsvergunningplicht in het leven heeft geroepen. De notificatieprocedure zou dan inhouden dat de decentrale wetgever die gebruik wenst te maken van de in artikel 2.2 lid 2 Wabo geboden mogelijkheid om een activiteit in een verordening omgevingsvergunningplichtig te maken zulks zou moeten notificeren bij de centrale overheid. Die wordt dan in de gelegenheid gesteld om de Wabo - dan wel het Besluit omgevingsrecht als wordt gekozen voor het opnemen van alle activiteiten in het Bor - aan te vullen met de activiteit waarvoor de decentrale wetgever een omgevingsvergunning verplicht wil stellen.

Een voorbeeld ter verduidelijking. Stel dat de gemeenteraad van 's-Hertogenbosch een verordening wil vaststellen met daarin het verbod om voor een project een terras te exploiteren zonder omgevingsvergunning. De gemeenteraad notificeert dat voornemen dan bij de centrale wetgever, die in de gelegenheid wordt gesteld om de activiteit 'het exploiteren van een terras' toe te voegen aan

104 PbEG 1998 L 204/37.

105 Zie ook de Interdepartementale Handleiding Notificatie van regels betreffende producten en elektronische diensten ICER, www.minbuza.nl/ecer/bijlagen/icer/handleidingen/icer-handl-notificatie.html, 16 maart 2010 . 
artikel 2.2 lid 1 Wabo. Maakt de centrale wetgever van die gelegenheid gebruik, dan wordt die mogelijkheid in de Wabo opgenomen voor alle gemeenten.

\subsubsection{Bundeling betreft niet alle regels ten aanzien van toestemmingsbesluiten ten aanzien van projecten}

Een wetssystematisch tekort van de Wabo is dat dit wetssysteem geen omgevingsvergunning eist voor bepaalde activiteiten binnen een project. Daarbij gaat het om plaatsgebonden activiteiten met gevolgen voor de fysieke leefomgeving die niet zijn aangewezen als omgevingsvergunningplichtige activiteit. Dat zal hierna met een aantal voorbeelden worden toegelicht. ${ }^{106}$

Belangrijke voorbeelden betreffen de activiteiten lozen op oppervlaktewateren ${ }^{107}$ of het infiltreren of onttrekken van grondwater ${ }^{108}$ waarvoor sinds 22 december $2009^{109}$ een watervergunning geldt op grond van de Waterwet. Het betreft hier een plaatsgebonden activiteiten met gevolgen voor de fysieke leefomgeving. Met name het in werking zijn van een inrichting waarvoor een omgevingsvergunning is vereist ${ }^{110}$ zal in veel gevallen samengaan met een of meer van de bedoelde activiteiten. ${ }^{111}$ Het feit dat voor genoemde activiteiten geen omgevingsvergunning geldt, maar een watervergunning strookt niet met het wetssystematische uitgangspunt dat het samenhangcriterium 'project' bepalend is voor de regels die in een wetssysteem moeten worden opgenomen.

De regering heeft dit wetssystematisch tekort overigens bewust aanvaard door te kiezen voor 'een stroomlijning binnen de Waterwet waarbij één zelfstandig vergunningstelsel voor water overblijft met voor directe lozingen behoud van de bevoegdheden van de waterbeheerder. Het betreft immers een kerntaak van de waterbeheerder, het in samenhang beoordelen van de effecten op het watersysteem. Deze beoordeling vergt, mede in het licht van internationale verplichtingen zoals de Kaderrichtlijn water, de nodige kennis en expertise over de chemische en ecologische aspecten van lozingen in relatie tot het watersysteem, die niet aanwezig is bij andere overheden dan waterbeheerders. ${ }^{112}$

106 Bregman noemt als ideaalmodel voor een gebruikersvriendelijk omgevingsrecht voor projectbesluitvorming een structuur van besluitvorming, waarbij omtrent de aanvaardbaarheid van een project, inclusief de planologische aspecten, middels één omgevingsrechtelijk besluit wordt besloten. De omgevingsvergunning voldoet volgens hem echter niet aan dit ideaalmodel in zoverre daarin niet alle voor de realisatie van een ruimtelijk project denkbare toestemmingsvereisten zijn geïntegreerd (Bregman, Naar een gebruikersvriendelijk omgevingsrecht 2010, p. 49).

107 Art. 6.2 Wtw.

108 Art. $6.4 \mathrm{Wtw}$

109 Stb. 2009, 107 en 549.

110 Art. 2.1 lid 1 aanhef en onder e Wabo.

111 Zie hierover Onrust, De relatie tussen Wabo en Waterwet 2010. Onrust gaat in op de relatie tussen de Wabo en de Waterwet, maar meer in het bijzonder de relatie tussen de omgevingsvergunning en watervergunning. Onrust inventariseert een aantal problemen die zich kunnen voordoen bij samenloop van de omgevingsvergunning en de watervergunning. Voor die problemen schetst zij mogelijke oplossing(srichting)en.

112 Kamerstukken II 2006/07, 30 844, nr. 3, p. 89. 
Uit een oogpunt van wetssystematiek kan het organisatorische argument mijns inziens niet doorslaggevend zijn. Aangenomen dat het beoordelen van een aanvraag om een watervergunning de nodige kennis en expertise vergt over de chemische en ecologische aspecten van lozingen in relatie tot het watersysteem, dan betekent dat nog niet dat het bevoegd gezag dat een aanvraag om een omgevingsvergunning moet beoordelen zich die kennis en expertise, mogelijk na een overgangstermijn, niet eigen zou kunnen maken. ${ }^{113}$ In de tweede plaats is het mogelijk om na bundeling van de watervergunning in de omgevingsvergunning gebruik te maken van die kennis en expertise zoals dat ook is gedaan bij de zogeheten indirecte lozingen. In die gevallen heeft de waterbeheerder een adviesrecht waarvan het bevoegd gezag in bepaalde gevallen niet mag afwijken. ${ }^{114}$ Ten slotte zij opgemerkt dat de regering het hier gebruikte organisatorische argument niet heeft gebruikt waar het betreft het opnemen van de bouwvergunning in de omgevingsvergunning. Tot 1 oktober 2010 waren uitsluitend burgemeester en wethouders bevoegd gezag voor wat betreft de bouwvergunning, doch onder de Wabo kunnen ook Gedeputeerde Staten of een minister bevoegd gezag zijn voor wat betreft een omgevingsvergunning voor bouwen. ${ }^{115}$ Hier is ervoor gekozen om de kennis en expertise van het voormalige bevoegd gezag - burgemeester en wethouders - te benutten. ${ }^{116}$

Het wetssystematische argument overtuigt evenmin. Het houdt in dat het een kerntaak van de waterbeheerder is om de effecten op het watersysteem in samenhang te beoordelen. Dat moge zo zijn, het verklaart nog niet waarom een dergelijke beoordeling niet mogelijk zou zijn in het kader van een omgevingsvergunning. Zulks temeer daar er in de Wabo voor is gekozen om het beoordelingskader per activiteit niet te laten afwijken van het beoordelingskader dat ten aanzien van een activiteit gold voor 1 oktober 2010. Activiteiten waarvoor een watervergunning nodig is, zouden in het kader van de omgevingsvergunning derhalve kunnen worden getoetst aan het toetsingskader dat geldt op basis van de Waterwet. In de tweede plaats erkent de regering dat er samenhang bestaat tussen de omgevingsvergunning en de watervergunning. Paragraaf 3.5 Wabo getuigt daarvan.

Wat daarvan ook zij, de wetgever heeft ervoor gekozen om de vergunningplicht voor de activiteiten lozen op oppervlaktewateren en infiltreren of onttrekken van grondwater te regelen in het wetssysteem van de Waterwet en niet in dat van de Wabo. Aangezien het systeem van de Waterwet wordt bepaald door het

113 Zelfs al hebben waterschappen in historisch perspectief hun sporen verdiend, zoals onder meer blijkt uit Havekes, Functioneel decentraal waterbestuur (diss.) 2009. Van den Berg meent dat 'het ideaal van een volledig geïntegreerd omgevingsrecht' zeker niet de prijs waard is van het ter discussie stellen van het stelsel van functioneel-gedecentraliseerd waterbeheer (Van den Berg, Waterschappen en de integratie van het omgevingsrecht 2011, p. 254). Groothuijse meent dat integratie van de watervergunning in de omgevingsvergunning mogelijk is, maar wel onder de strikte voorwaarde dat de watersysteembeheerder niet (of nauwelijks) inboet aan juridische mogelijkheden om handelingen in het watersysteem te reguleren. Hij kan zich onder voorwaarden ook voorstellen dat de watervergunning aanhaakt bij de omgevingsvergunning (Groothuijse, Water weren 2.02011 , p. 330 en 333).

114 Art. 2.26 Wabo.

115 Art. 2.1 lid 1 aanhef en onder a Wabo.

116 Art. 2.26 lid 4 Wabo. Van den Broek \& Dresden, De Wabo in de praktijk 2011, p. 97. 
op de echte werkelijkheid gebaseerde samenhangcriterium van watersystemen (object), moet die keus binnen het door mij gehanteerde theoretisch kader worden gerespecteerd. Die keus brengt echter wel het genoemde wetssystematisch tekort in de Wabo met zich. Vermelding verdient overigens dat door het reguleren van indirecte lozingen in de $\mathrm{Wabo}^{117}$ er een wetssystematisch tekort is ontstaan in de Waterwet. De geschetste wetssystematische tekorten kunnen overigens wel worden opgeheven als de Wabo en de Waterwet zouden worden opgenomen in het voorgenomen wetssysteem van de Omgevingswet. De regering heeft al aangekondigd, dat de omgevingsvergunning, de watervergunning, de Wabo en de Waterwet daarvan deel gaan uitmaken. ${ }^{118}$

Dat deze discussie niet nieuw is, leert ons onder meer Gilhuis die in 1986 gewag maakte van de integrale milieuvergunning, waarin geen van de destijds bestaande waterrechtelijke vergunningen zouden worden opgenomen. ${ }^{119}$ In 2006 beschrijft Backes twee elkaar overlappende samenhangen: het watersysteem en de inrichting. Backes meent dat het systematische argument pleit voor integratie in de omgevingsvergunning. Het perspectief van buiten, dus van de activiteit, respectievelijk het bedrijf kiezend, zou het opnemen van alle omgevingsgevolgen, dus ook van (alle) lozingen, in één vergunning consequenter zijn. Tegen integratie van ten minste de belangrijke (indirecte) lozingen in de omgevingsvergunning pleit volgens Backes dat het bestuursorgaan dat verantwoordelijk is voor een bepaald doel, ook de daartoe noodzakelijke instrumenten in huis moet hebben. Backes maakt nog geen keus; het staat volgens hem 2-2 en betrokkenen hebben evenveel argumenten in huis om in de eindfase van het spel nog te scoren. ${ }^{120}$ Van den Berg meent dat de mogelijke winst op het terrein van een zo integraal mogelijke omgevingsvergunning tegelijk ook een verlies betekent vanwege de inbreuk op de integraliteit van het waterbeheer. ${ }^{121}$

Wat Backes in 2006 nog niet kon weten was, dat ook in deze 'wedstrijd' zou gaan gelden 'Nach dem Spiel ist vor dem Spiel."122 Door samenvoeging van de ministeries van VROM en VenW in het Ministerie van IenM werd immers de mogelijkheid geopend om in het kader van de Omgevingswet de watervergunning op te nemen in de omgevingsvergunning. Begin 2012 schrijft de regering: 'In de Wet algemene bepalingen omgevingsrecht (Wabo) zijn reeds 26 vergunningstelsels gebundeld. Het voorstel voor de Wet natuurbescherming voegt daar de vergunningen voor natuur aan toe. Met de Omgevingswet wordt dit gecompleteerd met de nog resterende zelfstandige vergunningstelsels, zoals die voor water, ontgrondingen, archeologische rijksmonumenten en voor werkzaamheden aan en

117 Art. 2.26 lid 1 Wabo.

118 IenM, Kabinetsbrief stelselherziening omgevingsrecht 2012, p. 13.

119 Gilhuis, De verhouding van milieurecht tot waterrecht 1986, p. 287-288.

120 Backes, Watervergunning tegen Omgevingsvergunning 2006, p. 398 en 408.

121 Van den Berg, Waterschappen en de integratie van het omgevingsrecht 2011, p. 250.

122 Backes, Watervergunning tegen Omgevingsvergunning 2006, p. 390. 
rond spoor en wegen. Deze verdere integratie van vergunningstelsels geeft meer gebruiksgemak voor initiatiefnemers. ${ }^{, 23}$

Een tweede voorbeeld van een wetssystematisch tekort in de Wabo betreft de instemming met een saneringsplan. Wie voornemens is de bodem te saneren moet een saneringsplan indienen dat de instemming behoeft van het bevoegd gezag op basis van de Wet bodembescherming. ${ }^{24}$ Evenals in het hiervoor genoemde voorbeeld gaat het hier om een plaatsgebonden activiteit met gevolgen voor de fysieke leefomgeving die in de Wabo echter niet is aangewezen als omgevingsvergunningplichtige activiteit. Met name het in werking zijn van een inrichting waarvoor wel een omgevingsvergunning is vereist, ${ }^{125} \mathrm{zal}$ in veel gevallen samengaan met bedoelde activiteit. Het feit dat voor genoemde activiteiten geen omgevingsvergunning geldt, maar een instemming met een saneringsplan strookt niet met het wetssystematische uitgangspunt dat het samenhangcriterium project bepalend is voor de regels die in een wetssysteem moeten worden opgenomen.

Mij lijkt dat de wetgever dit wetssystematisch tekort eenvoudig kan opheffen door de bedoelde activiteiten alsnog op te nemen in artikel 2.1 lid 1 Wabo. De regering heeft aangekondigd, dat de Wet bodembescherming deel zal gaan uitmaken van de Omgevingswet, zij het pas na afronding van de lopende vernieuwing. ${ }^{126}$ Dat lijkt mij een geschikt moment om genoemd wetssystematisch tekort ongedaan te maken.

Een derde voorbeeld van een wetssystematisch tekort is de natuurbeschermingsvergunning, ${ }^{127}$ die niet is opgenomen in de omgevingsvergunning, maar daaraan kan worden aangehaakt. ${ }^{128}$

\subsubsection{Antwoord op toetsvraag 2}

De Wabo heeft het in paragraaf 4.3 beschreven wetssystematisch tekort weliswaar verminderd, maar niet geheel opgeheven. De vermindering van het wetssystematisch tekort is gerealiseerd door een groot aantal toestemmingsbesluiten voor een project in het wetssysteem van de Wabo op te nemen. Er is echter nog steeds sprake van wetssystematische tekorten, want de Wabo bevat niet alle regels ten aanzien van een project, noch alle

123 Ministerie van IenM, Kabinetsbrief stelselherziening omgevingsrecht 2012, p. 13

124 In beginsel GS, maar in een aantal gevallen zijn BenW aangewezen voor hun gemeente (art. $88 \mathrm{Wbb}$ ).

125 Art. 2.1 lid 1 aanhef en onder e Wabo.

126 IenM, Kabinetsbrief stelselherziening omgevingsrecht 2012, bijlage 1. Zie daarover P. Kiela, Wet bodembescherming verdwijnt 2011

127 Art. 19d lid $1 \mathrm{Nb}$-wet 1998

128 Voor een korte beschrijving van de aanhaakprocedure en een aantal aandachtspunten daarbij verwijs ik naar Verbeek, De natuur haakt aan bij de omgevingsvergunning, of toch niet? 2011. 
activiteiten binnen een project waarvoor een omgevingsvergunning is vereist. Ook eist de Wabo geen omgevingsvergunning voor een aantal activiteiten binnen een project. Daarmee is de tweede toetsvraag overwegend negatief beantwoord.

Voorts heb ik ten aanzien van een aantal wetssystematische tekorten voorstellen gedaan om die tekorten te verminderen.

\subsection{WETSSYSTEMATISCHE TEKORTEN VANWEGE TYPISCHE JURIDISCHE ORDENINGSCRITERIA}

\subsubsection{Algemeen}

In deze paragraaf zal de vraag worden beantwoord of het gebruik van typisch juridische ordeningscriteria in het wetssysteem van de Wabo heeft geleid tot wetssystematische tekorten en zo ja, of deze tekorten verdedigbaar zijn.

\subsubsection{Algemeen en bijzonder}

\subsubsection{Wetssystematische tekorten}

Het subwetssysteem van hoofdstuk 3 van de Wabo Voorbereidingsprocedures bevat regels over de voorbereiding van beschikkingen. In dat hoofdstuk is het typisch juridisch ordeningscriterium algemeen-bijzonder ${ }^{129}$ gebruikt.

Paragraaf 3.1 bevat algemene bepalingen over de totstandkoming van de beschikking op de aanvraag om omgevingsvergunning. Het gaat onder meer om regels inzake de indiening van de aanvraag, de ontvangstbevestiging, het bericht welke voorbereidingsprocedure volgens het bevoegd gezag geldt ${ }^{130}$ en de redenen voor aanhouding van de beslissing op een aanvraag. ${ }^{131}$

De paragrafen 3.2 en 3.3 bevatten bijzondere bepalingen over de totstandkoming van de beschikking op de aanvraag om een omgevingsvergunning. Paragraaf 3.2 bevat regels inzake de reguliere voorbereidingsprocedure. Paragraaf 3.3 bevat regels inzake de uitgebreide voorbereidingsprocedure. De reguliere procedure geldt tenzij de uitgebreide procedure expliciet van toepassing is verklaard. ${ }^{132}$

129 Par. 3.4.4.2.

130 Art. 3.1 Wabo.

131 Art. 3.3-3.6 Wabo. De bevoegdheid volgt uit de Wabo en het Bor zelf. Het bevoegd gezag kan mijns inziens daarom hooguit berichten dat het zich op basis van die bevoegdheidsregels bevoegd acht, niet dat het bevoegd is.

132 Art. 3.7 lid 1 jo 3.10 Wabo. 
Hier is sprake van een intern wetssystematisch tekort. ${ }^{133}$ De gebruiker van de Wabo is immers aangewezen op drie ${ }^{134}$ subwetssystemen $^{135}$ alvorens de in de Wabo opgenomen samenhangende regels inzake de voorbereiding van de beschikking op de aanvraag om een omgevingsvergunning voor hem kenbaar kunnen zijn.

Dit interne wetssystematisch tekort wordt bovendien nog gecombineerd met externe wetssystematische tekorten. ${ }^{136}$ Een groot aantal regels inzake de voorbereiding van de beschikking op de aanvraag om een omgevingsvergunning staat namelijk niet in de Wabo zelf, maar in de Awb. Hoofdstuk 3 Awb bevat algemene bepalingen over besluiten. In dit hoofdstuk staan in Afdeling 3.4 bepalingen over de uniforme openbare voorbereidingsprocedure. Hoofdstuk 4 Awb bevat bijzondere bepalingen over besluiten. De regels voor de reguliere voorbereidingsprocedure staan in Titel 4.1 Beschikkingen van de Awb.

In dit verband wordt overigens nog opgemerkt, dat de Awb de uniforme openbare voorbereidingsprocedure in hoofdstuk 3 Awb als de algemene regeling kent en de reguliere voorbereidingsprocedure in hoofdstuk 4 Awb als de bijzondere regeling, terwijl de Wabo juist de reguliere procedure in paragraaf 3.2 Wabo als de algemene regeling en de uitgebreide voorbereidingsprocedure in paragraaf 3.3 Wabo als de bijzondere regeling aanmerkt, namelijk als uitzondering op de reguliere voorbereidingsprocedure. ${ }^{137}$ Daarbij komt nog dat de uniforme openbare voorbereidingsprocedure in de Wabo wordt aangeduid als uitgebreide voorbereidingsprocedure. Dit alles komt de kenbaarheid niet ten goede.

Het ordeningscriterium algemeen-bijzonder komt dus driemaal voor:

- Awb (algemeen) - Wabo (bijzonder)

- Hoofdstuk 3 Awb (algemeen) - Hoofdstuk 4 Awb (bijzonder)

- Paragraaf 3.1 Wabo (algemeen) - paragrafen 3.1 en 3.2 Wabo (bijzonder)

Dit betekent dat de gebruiker van de Wabo, die wil weten wat rechtens is ten aanzien van de totstandkoming van de beschikking op de aanvraag om een omgevingsvergunning de wetssystemen van de Wabo en de Awb zal moeten raadplegen. Binnen die wetten dient hij vervolgens vijf (sub)wetssystemen te raadplegen.

Het gaat om de paragrafen 3.1, 3.2 en 3.3 Wabo, alsmede hoofdstukken 3 en 4 Awb. Indien bij de voorbereiding van de beslissing op de aanvraag om een omgevingsvergunning een milieueffectrapport moet worden gemaakt, is artikel 13.2 Wm van

133 Zie par. 3.4.4.1.

134 In vier wetssystemen als naast een omgevingsvergunning ook een watervergunning noodzakelijk is en par. 3.5 Wabo geldt (art. 3.16 Wabo).

135 Par. 3.1, 3.2 en 3.3 Wabo.

136 Zie par. 3.4.4.1.

137 Zie art. 3.7 lid 1 Wabo. 
toepassing (aldus art. 3.1 lid 5 Wabo), zodat alsdan ook het wetssysteem van de Wet milieubeheer moet worden geraadpleegd.

Het zou de kenbaarheid van de Wabo voor de gebruiker ten goede zijn gekomen, als de wetgever in de Wabo twee subwetssystemen zou hebben gecreëerd waarin alle regels zouden zijn opgenomen inzake de reguliere en de uitgebreide voorbereidingsprocedure. Wie een aanvraag zou indienen zou dan via een equivalent van artikel 3.7 lid 1 Wabo naar een van beide subwetssystemen worden verwezen waarin alle regels over de desbetreffende voorbereidingsprocedure zouden zijn opgenomen.

\subsubsection{Verdedigbaarheid wetssystematische tekorten}

Toch acht ik de gesignaleerde interne en externe wetssystematische tekorten op zichzelf wel verdedigbaar. Mij dunkt dat de uniformiteit van het bestuursrecht is gediend met het opnemen van uniforme regels inzake voorbereidingsprocedures in de Awb. Voorts hoeft de gebruiker van de Wabo niet zelf uit te zoeken in hoeverre bij de reguliere en de uitgebreide voorbereidingsprocedure sprake is van gelijke regels.

De gesignaleerde wetssystematische tekorten betekenen echter een aanzienlijk verlies aan kenbaarheid. ${ }^{138}$ Dat is het gevolg van het feit, dat van de gebruiker van het recht een specialistische juridische voorkennis wordt vereist, aangezien hij door de bepalingen in de paragrafen 3.1 , 3.2 en 3.3 Wabo niet attent wordt gemaakt op het drievoudig gebruik van het typisch juridisch ordeningscriterium algemeen-bijzonder. Wie de algemene bepalingen in paragraaf 3.1 Wabo leest, wordt door de wetgever niet op het spoor gezet van de bijzondere bepalingen in de paragrafen 3.2 en 3.3 Wabo; en vice versa. Wie de ten opzichte van de Awb bijzondere bepalingen in paragraaf 3.2 Wabo leest, wordt door de wetgever niet op het spoor gezet van de algemene bepalingen in hoofdstuk 4 Awb; en vice versa.

De wetgever zou de kenbaarheid van de regels inzake de totstandkoming van een beschikking op de aanvraag om een omgevingsvergunning aanzienlijk kunnen verbeteren door in de Wabo een leeswijzer op te nemen waarmee de gebruiker wel op het spoor wordt gezet van de geldende algemene en bijzondere bepalingen. Zo'n leeswijzer zou er als volgt uit kunnen zien.

Artikel x. Op de voorbereiding van een beschikking op de aanvraag om een omgevingsvergunning zijn de volgende bepalingen van toepassing:

a. de algemene bepalingen over besluiten als bedoeld in hoofdstuk 3 van de Awb;

138 Michiels c.s. merken ook op dat de Wabo voortdurend in samenhang met andere omgevingsrechtelijke wetten en de Awb moet worden gelezen waardoor de te boeken dereguleringswinst in dat opzicht gering is (Michiels/Nijmeijer \& Van der Velden, Het wetsvoorstel Wabo 2007, p. 141). 
b. de bijzondere bepalingen over beschikkingen als bedoeld in hoofdstuk 4 van de Awb;

c. de algemene bepalingen over de totstandkoming van de beschikking op aanvraag om een omgevingsvergunning als bedoeld in paragraaf 3.1 van de Wabo;

d. de bijzondere bepalingen over de totstandkoming van de beschikking op aanvraag om een omgevingsvergunning als bedoeld in paragraaf 3.2 van de Wabo als de beschikking moet worden voorbereid volgens de reguliere procedure dan wel paragraaf 3.3 van de Wabo als de beschikking moet worden voorbereid volgens de uitgebreide procedure.

Ten slotte merk ik nog op dat de hiervoor geschetste wetssystematische tekorten het gevolg zijn van het feit dat de wetgever twee voorbereidingsprocedures in het leven heeft geroepen en de regels daarvoor heeft verdeeld over nog meer wetssystemen. De vraag is of het noodzakelijk is voor de omgevingsvergunning twee voorbereidingsprocedures te hebben en zo ja, of die dan moeten worden geregeld in meer wetssystemen. Drupsteen merkt in verband met de twee voorbereidingsprocedures op: "Daaraan zijn we gewend en we ervaren dat ook niet als gek. Het is echter wel gek dat een omgevingsvergunning voor activiteiten de ene keer de ene en de andere keer de andere procedure moet volgen. Daar zou de wetgever een keus moeten maken." ${ }^{39}$ Ook Rademaker stelt zich de vraag of twee voorbereidingsprocedures wel noodzakelijk zijn. ${ }^{140}$ Mij lijkt dat de hiervoor besproken wetssystematische tekorten niet zouden bestaan als de wetgever voor de omgevingsvergunning kiest voor één voorbereidingsprocedure en die geheel regelt in het wetssysteem van de Awb. Met Rademaker ben ik het eens dat de wetgever daarover bij de Omgevingswet nog maar eens goed moet nadenken. ${ }^{141}$ Overigens wil ik daarbij niet op de uitkomst vooruitlopen. $\mathrm{Er}$ kunnen immers goede redenen zijn om, afhankelijk van de gevolgen van een project voor de fysieke leefomgeving, een lichtere of een zwaardere procedure te gebruiken. Daarbij kan ook een rol spelen of die gevolgen relatief veel personen kunnen raken, dan wel betrekking hebben op één of een beperkt aantal personen.

\section{5·3. Gelede normstelling}

\subsubsection{Algemeen}

In de Wabo is ook gebruik gemaakt van het typisch juridische ordeningscriterium van de gelede normstelling (zie par. 3.4.4.3). De Wabo bevat een groot aantal artikelen dat de basis vormt voor het stellen van uitvoeringsregels bij of krachtens algemene maatregel van bestuur. Het gaat daarbij om

139 Drupsteen, Interview 2012, bijl. 5.8, par. 3.4

140 Rademaker, Interview 2011, bijl. 5.2, par. 5.1.

141 Rademaker, Interview 2011, bijl. 5.2, par. 5.1. 
het Besluit omgevingsrecht (Bor) ${ }^{142}$ en de ministeriële Regeling omgevingsrecht (Mor). ${ }^{143}$

\subsubsection{Besluit omgevingsrecht}

Het Besluit omgevingsrecht kent dezelfde indeling als de Wabo. Na een algemeen hoofdstuk met definities, volgt de aanwijzing van categorieën inrichtingen, vergunningplichtige en vergunningvrije activiteiten en planologische gebruiksactiviteiten. Vervolgens vindt een nadere uitwerking plaats van welk bestuursorgaan bevoegd gezag is voor de omgevingsvergunningverlening. De daarna volgende hoofdstukken hebben betrekking op de aanvraag om een omgevingsvergunning, de inhoud daarvan en enkele procedurele zaken, zoals de aanwijzing van adviseurs en gevallen waarin er een verklaring van geen bedenkingen is vereist. Tot slot volgt een hoofdstuk over de kwaliteitseisen handhaving.

Het besluit kent drie bijlagen. Bijlage I wijst de categorieën inrichtingen aan en de vergunningplichtige inrichtingen. Ook wordt aangegeven in welke gevallen een ander bestuursorgaan dan BenW bevoegd gezag is. Bijlage II wijst de categorieën gevallen aan waarin voor bouwactiviteiten en planologische gebruiksactiviteiten geen omgevingsvergunning is vereist. Ook zijn categorieën gevallen aangewezen waarin voor planologische gebruiksactiviteiten een omgevingsvergunning kan worden verleend als bedoeld in artikel 2.12 lid 1 onder a onder $2^{\circ}$ Wabo. Bijlage III wijst de categorieën inrichtingen aan ten aanzien waarvan de inspecteur in de gelegenheid moet worden gesteld advies uit te brengen over het ontwerp van de beschikking op de aanvraag om een omgevingsvergunning.

\subsubsection{Regeling omgevingsrecht}

De ministeriële Regeling omgevingsrecht voorziet in nadere regels met betrekking tot bepaalde onderdelen van de Wabo en het Besluit omgevingsrecht. De Mor bestaat uit 11 hoofdstukken: algemene indieningsvereisten in verband met een aanvraag om een omgevingsvergunning, indieningsvereisten vanwege bouwactiviteiten, indieningsvereisten vanwege aanleg- of gebruiksactiviteiten, indieningsvereisten vanwege het oprichten, veranderen of in werking hebben van een inrichting of mijnbouwwerk, indieningsvereisten vanwege activiteiten met betrekking tot een beschermd monument, indieningsvereisten vanwege sloopactiviteiten, indieningsvereisten vanwege activiteiten krachtens een provinciale of gemeentelijke verordening, indieningsvereisten met betrekking tot de gebieds- en soortenbescherming, bijzondere gevallen van bestuurlijke verplichtingen (het verstrekken van gegevens aan de VROM-inspectie ${ }^{144}$ en

142 Stb. 2010, 143

143 Stcrt. 2010, 5162.

144 De VROM-Inspectie (VI) en de Inspectie Verkeer en Waterstaat (IVW) vormen vanaf 1 januari 2012 samen de Inspectie Leefomgeving en Transport (ILT) (http://www.ilent.nl/organisatie/veelgesteldevragenfusievrominspectieeniv.aspx). 
de aanwijzing van BBT-documenten), en kwaliteitscriteria voor de bestuursrechtelijke handhaving. Na het hoofdstuk met slotbepalingen volgt een bijlage met aanwijzing van BBT-documenten. ${ }^{145}$

\subsubsection{Verdedigbaarheid gelede normstelling}

Zoals uiteengezet in paragraaf 3.4 .5 .3 doorbreekt gelede normstelling het wetssystematische uitgangspunt dat alle regels in het omgevingsrecht die voldoen aan het samenhangcriterium in beginsel ook in hetzelfde wetssysteem moeten worden geregeld. In het geval van de Wabo bestaat die doorbreking erin dat de regels niet allemaal zijn opgenomen in de Wabo, doch verspreid staan over Wabo, Besluit omgevingsrecht en Regeling omgevingsrecht. De memorie van toelichting op de Wabo vermeldt slechts dat in uitvoeringsregelgeving wordt voorzien. ${ }^{146} \mathrm{Er}$ wordt niet gemotiveerd waarom voor gelede normstelling is gekozen, noch waarom is gekozen voor een driedeling, noch welke criteria gelden voor het opnemen van regels in Wabo, Bor en Mor. Ook de toelichting van de wetgever op Bor en Mor bevat eigenlijk niet meer dan een beschrijving van de inhoud van die regelingen.

Het is derhalve gissen of en zo ja welke van de door Veerman genoemde overwegingen $^{147}$ voor de wetgever aan de orde zijn geweest. Gelet op de inhoud van de bepalingen lijkt mij het meest voor de hand te liggen dat de wetgever van oordeel is dat het gaat om regels die snel moeten kunnen worden aangepast aan snel veranderende omstandigheden. Op zichzelf is dat in het algemeen wel verdedigbaar, zij het dat het van bepaalde onderdelen van beide regelingen niet direct aannemelijk is dat zij van de ene op de andere dag zullen worden aangepast. Te denken is bijvoorbeeld aan de in hoofdstuk 3 Bor opgenomen regels inzake het bevoegd gezag. Aangenomen mag toch worden dat een wijziging van bevoegd gezag voor het verlenen van de omgevingsvergunning goed zal worden voorbereid en dat het nieuwe bevoegd gezag de tijd en middelen zullen worden gegund om de nieuwe taken uit te voeren.

Het valt ook op dat de wetgever geen criteria noemt die gelden voor het opnemen van regels in Wabo, Bor en Mor. Dat zou zeker voor de hand

145 Beste Beschikbare Technieken: voor het bereiken van een hoog niveau van bescherming van het milieu meest doeltreffende technieken om de emissies en andere nadelige gevolgen voor het milieu, die een inrichting kan veroorzaken, te voorkomen of, indien dat niet mogelijk is, zoveel mogelijk te beperken, die - kosten en baten in aanmerking genomen - economisch en technisch haalbaar in de bedrijfstak waartoe de inrichting behoort, kunnen worden toegepast, en die voor degene die de inrichting drijft, redelijkerwijs in Nederland of daarbuiten te verkrijgen zijn; daarbij wordt onder technieken mede begrepen het ontwerp van de inrichting, de wijze waarop zij wordt gebouwd en onderhouden, alsmede de wijze van bedrijfsvoering en de wijze waarop de inrichting buiten gebruik wordt gesteld (art. 1.1 lid 1 Wabo).

146 Kamerstukken II 2006/07, 30 844, nr. 3, p. 60

147 Zie par. 3.4.4.3 
hebben gelegen nu de regels in Wabo, Bor en Mor voor 1 oktober 2010 veelal in andere wetten in formele zin, algemene maatregelen van bestuur of ministeriële regelingen stonden. Soms is een regel 'gedegradeerd' naar een lager wetgevingsniveau. Van de wetgever mag dan worden verwacht dat hij motiveert wat daarvan de reden is. Stond de regel voorheen op het verkeerde niveau en zo ja waarom dan? Het ontbreken van een duidelijke handleiding is de kenbaarheid van Wabo, Bor en Mor voor de praktijk niet ten goede gekomen. Het is mijn ervaring, dat gebruikers van de regels in het omgevingsrecht die zijn overgeheveld naar Wabo, Bor en Mor nu eenmaal min of meer verwachten dat zij de hen bekende regels terugvinden op hetzelfde wetgevingsniveau. Rademaker merkt in dit verband op dat er geen vaste regels golden om bepalingen op te nemen in Wabo, Bor of Mor. "Veelal werd gekeken naar een mogelijkheid om de Wabo zelf zo simpel mogelijk te houden." 148

Een voorbeeld van degradatie van een bepaling van wet in formele zin naar algemene maatregel van bestuur vinden we in artikel 2.4 Bor. Dit op artikel 2.1 lid 3 Wabo gebaseerde artikel bepaalt dat in bepaalde gevallen geen omgevingsvergunning is vereist. Tot 1 oktober 2010 stond die bepaling mutatis mutandis in artikel 8.1 lid 3 en $4 \mathrm{Wm}$. Het voordeel van artikel 8.1 Wm was bovendien dat in lid 1 het verbod stond om zonder vergunning een inrichting waartoe een gpbv-installatie behoort op te richten, te veranderen of de werking daarvan te veranderen of in werking te hebben. In de leden 3 en 4 stonden vervolgens meteen de twee gevallen waarin dat verbod niet van toepassing was.

Met ingang van 1 oktober 2010 staat in artikel 2.1 lid 1 aanhef en onder e Wabo het voorheen in artikel 8.1 lid $1 \mathrm{Wm}$ opgenomen verbod. De gebruiker van de Wabo moet vervolgens in artikel 2.1 lid 3 Wabo lezen dat bij algemene maatregel van bestuur kan worden bepaald in welke gevallen het genoemde verbod niet geldt. Hier is sprake van een wetssystematisch tekort dat het voor de gebruiker lastiger maakt een antwoord te vinden op de vraag of voor het oprichten van een inrichting al dan niet een omgevingsvergunning is vereist. Vanwege de genoemde kan-bepaling moet hij immers eerst uitzoeken of er een algemene maatregel van bestuur bestaat op basis van artikel 2.1 lid 3 Wabo. Als hij heeft gevonden dat zulks het geval is, moet hij nagaan om welke algemene maatregel van bestuur het gaat. Heeft hij gevonden dat het hier het Besluit omgevingsrecht betreft, dan dient hij in dat besluit de relevante artikelen te zoeken. De wetssystematiek van het Besluit omgevingsrecht is hem daarbij overigens wel behulpzaam vanwege het opschrift van paragraaf 2.2 Aanwijzing van categorieën gevallen waarin geen omgevingsvergunning is vereist.

Een voorbeeld van een bepaling in het omgevingsrecht die als gevolg van de Wabo is gedegradeerd van een algemene maatregel van bestuur naar een ministeriële regeling betreft artikel 9.2 Mor. Deze bepaling geeft aan met welke documenten het bevoegd gezag rekening moet houden bij het beoordelen van een aanvraag om omgevingsvergunning of watervergunning. Tot 1 oktober 2010 
was deze bepaling opgenomen in artikel 5 a.1 Inrichtingen- en vergunningenbesluit milieubeheer (Ivb). De wetgever heeft niet gemotiveerd waarom de desbetreffende bepaling is overgeheveld van genoemde algemene maatregel van bestuur (Ivb) naar de Mor.

Hiervoor heb ik reeds opgemerkt dat gelede normstelling in het kader van de Wabo verdedigbaar is in zoverre dat is gedaan om regels die regelmatig moeten worden gewijzigd ook snel te kunnen wijzigen. Een verdedigbaar motief voor gelede normstelling is ook, dat het opnemen van alle in Bor en Mor voorkomende uitvoeringsregels in de Wabo de overzichtelijkheid van dat laatste wetssysteem niet ten goede zou zijn gekomen.

Dat neemt echter niet weg dat de wetgever niet heeft gemotiveerd, waarom is gekozen voor een driedeling in Wabo, Bor en Mor. Vanuit een wetssystematisch oogpunt lijkt mij dat het de kenbaarheid ten goede zou kunnen komen om Bor en Mor samen te voegen, zodat de gebruiker van de Wabo voor het antwoord op een aantal vragen naast het wetssysteem van de Wabo nog slechts één uitvoeringswetssysteem behoeft te raadplegen.

\subsubsection{Europese richtlijnen en verordeningen}

\subsubsection{Wetssystematische tekorten}

Bij algemene maatregel van bestuur moeten categorieën inrichtingen worden aangewezen waarvan voor het oprichten, het veranderen of veranderen van de werking of het in werking hebben een omgevingsvergunning is vereist. ${ }^{149} \mathrm{De}$ genoemde algemene maatregel van bestuur is het Besluit omgevingsrecht. Daarin is bepaald dat als categorieën vergunningplichtige inrichtingen worden aangewezen (a) de categorieën inrichtingen waartoe een gpbv-installatie behoort en (b) de categorieën inrichtingen die als zodanig zijn aangewezen in bijlage 1, onderdeel B, en onderdeel C. Artikel 3.3 lid 1 Bor wijst Gedeputeerde Staten aan als bevoegd gezag voor bepaalde in bijlage 1, onderdeel C Bor aangewezen inrichtingen. Die aanwijzing geldt echter slechts voor activiteiten met betrekking tot een inrichting waartoe een gpbv-installatie behoort of waarop het Besluit risico's zware ongevallen 1999 van toepassing is. ${ }^{15^{\circ}}$ Onder een gpbv-installatie verstaat de Wabo een installatie als bedoeld in bijlage 1 bij richtlijn nr. 2008/1/EG van het Europees Parlement en de Raad van de Europese Unie van 15 januari 2008 inzake geïntegreerde preventie en bestrijding van verontreiniging $\left(P b E U\right.$ L 24) ${ }^{151}$

149 Als categorie moeten in ieder geval inrichtingen worden aangewezen waartoe een gpbv-installatie behoort (art. 1.1 lid 3 Wabo).

150 Dat dit in de praktijk tot misverstanden aanleiding kan geven, blijkt onder meer uit de uitspraak van de voorzieningenrechter Rechtbank 's-Hertogenbosch van 25 augustus 2011, M en R 2012/05, nr. 65 m.nt. Van den Broek.

151 Art. 1.1 lid 1 Wabo. De afkorting gpbv staat voor geïntegreerde preventie en bestrijding van verontreiniging. Zie par. 3.2.6.5. 
Het wetssystematisch tekort bestaat hierin, dat gebruikers van het wetssysteem van de Wabo om erachter te komen of Gedeputeerde Staten bevoegd gezag zijn zowel het wetssysteem van het Bor als dat van de genoemde IPPC-richtlijn ${ }^{152}$ moeten raadplegen.

\subsubsection{Verdedigbaarheid wetssystematisch tekort}

Het hiervoor genoemde wetssystematisch tekort acht ik in beginsel niet verdedigbaar. De wetgever kan immers eenvoudig een einde maken aan dit tekort door bijlage 1 van de IPPC-richtlijn op te nemen in de Wabo.

Een andere wijze om een einde te maken aan bedoeld wetssystematisch tekort zou zijn als de wetgever in het Besluit omgevingsrecht bij de aanwijzing van inrichtingen in ieder geval de in bijlage 1 van de IPPC-richtlijn genoemde activiteiten herkenbaar op zou nemen in bijlage 1, onderdeel C Bor. Alsdan zou de gebruiker immers niet verplicht zijn zelf onderzoek te doen in het wetssysteem van de IPPC-richtlijn om erachter te komen wat onder een gpbv-installatie dient te worden verstaan. ${ }^{153}$

\subsubsection{Antwoord op toetsvraag 3}

In de Wabo leidt het gebruik van typisch juridische ordeningscriteria als algemeen-bijzonder, gelede normstelling en de verwijzing naar de Europese IPPC-richtlijn tot het voortbestaan van wetssystematische tekorten. De gesignaleerde tekorten zijn in de meeste gevallen verdedigbaar, zij het dat de wetgever deze tekorten op een eenvoudige wijze kan verminderen. Daarmee is de derde toetsvraag overwegend positief beantwoord. Als antwoord op de derde deelvraag van dit onderzoek zijn per wetssystematisch tekort suggesties gedaan om dat op te heffen of te verminderen.

\subsection{WETSSYSTEMATISCHE TEKORTEN IN ANDERE WETSSYSTEMEN}

\subsubsection{Algemeen}

In deze paragraaf zal de vraag worden beantwoord of het wetssysteem van de Wabo heeft geleid tot het ontstaan of voortbestaan van wetssystematische tekorten in andere wetssystemen en zo ja, of dergelijke tekorten verdedigbaar zijn. In paragraaf 4.4 is het voortbestaan van wetssystematische tekorten binnen het door bundeling ontstane wetssysteem van de Wabo

152 Richtlijn 2008/1/EG van het Europees Parlement en de Raad van 15 januari 2008 inzake geïntegreerde preventie en bestrijding van verontreiniging, (PbEU $2008 \mathrm{~L} \mathrm{24/8).}$

153 Uiteraard is de gebruiker wel aangewezen op bijlage 1 van de IPPC-richtlijn als hij erachter wil komen of de Nederlandse wetgever die bijlage goed heeft verwerkt in bijlage 1 onderdeel C Bor. 
onderzocht. In paragraaf 4.6 gaat het om mogelijke wetssystematische tekorten buiten het door bundeling ontstane wetssysteem die in andere wetssystemen zijn ontstaan als gevolg van de bundeling.

\subsubsection{Wetssystematische tekorten}

De Wet milieubeheer regelt een aantal algemene onderwerpen op het gebied van de milieuhygiëne, aldus de intitulé van deze wet. ${ }^{154}$ Met de inwerkingtreding van de Wabo per 1 oktober 2010 is paragraaf $8.1 \mathrm{Wm}$ Inrichtingen vervallen. ${ }^{155}$

Kern van deze paragraaf was het verbod om zonder milieuvergunning een inrichting op te richten, te veranderen of de werking daarvan te veranderen, of in werking te hebben. ${ }^{156}$ Het verbod gold voor een inrichting waartoe een gpbv-installatie ${ }^{157}$ behoort of een in het Inrichtingen- en vergunningenbesluit milieubeheer aangewezen inrichting. ${ }^{158}$ Paragraaf $8.1 \mathrm{Wm}$ bevatte onder meer bepalingen inzake het bevoegd gezag ten aanzien van de inrichting, ${ }^{159}$ de vergunningaanvraag ${ }^{160}$ en de toetsingscriteria op basis waarvan het bevoegd gezag een aanvraag om milieuvergunning moest beoordelen. ${ }^{161}$ Per 1 oktober 2010 is voor het oprichten, het veranderen of veranderen van de werking of het in werking hebben van een inrichting niet langer een milieuvergunning vereist, maar een omgevingsvergunning. ${ }^{162} \mathrm{De}$ tot die datum in paragraaf $8.1 \mathrm{Wm}$ opgenomen bepalingen zijn nagenoeg gelijk overgenomen in Wabo, Bor en Mor. Paragraaf 8.1 Wm is dan ook terecht vervallen.

Als gevolg van de bundeling die tot het wetssysteem van de Wabo heeft geleid, is echter wel een wetssystematisch tekort ontstaan in de Wet milieubeheer. In deze laatste wet ontbreken per 1 oktober 2010 immers bepalingen inzake de vergunning voor inrichtingen. Daarbij zij vermeld, dat niet alle

154 Voor de ontstaansgeschiedenis van deze wet verwijs ik naar Hordijk, Een nieuwe wet voor het milieubeheer 1993, p. 66-74.

155 Art. 9.10 onder K Invoeringswet Wabo, Stb. 2010, 142

156 Art. 8.1 lid $1 \mathrm{Wm}$, zoals dat luidde tot 1 oktober 2010.

157 Gpbv staat voor geïntegreerde preventie en verontreiniging. Een gpbv-installatie is een installatie als bedoeld in bijlage 1 van de EG-richtlijn geïntegreerde preventie en bestrijding van verontreiniging (richtlijn 2008/1/EG van het Europees Parlement en de Raad van de Europese Unie van 15 januari 2008 inzake geïntegreerde preventie en bestrijding van verontreiniging ( $P b E U$ 2008 L 24/8)) (art. 1.1 lid $1 \mathrm{Wm}$ ). Zie par. 3.2.6.5.

158 Art. 8.1 lid 1 en $2 \mathrm{Wm}$, zoals dat luidde tot 1 oktober 2010. Het Inrichtingen- en vergunningenbesluit is per 1 oktober 2010 ingetrokken (art. 1.43 Invoeringsbesluit Wabo, Stb. 2010, 144).

159 Art. 8.2 Wm, zoals dat luidde tot 1 oktober 2010.

160 Art. $8.5 \mathrm{Wm}$, zoals dat luidde tot 1 oktober 2010.

161 Art. 8.8-8.10 Wm, zoals die luidden tot 1 oktober 2010.

162 Art. 2.1 lid 1 aanhef en onder e Wabo. 
regels die betrekking hebben op inrichtingen in de Wabo zijn ondergebracht. ${ }^{163}$ Zo bevat de Wet milieubeheer onder meer in:

a. paragraaf 8.1 Algemene regels de hoofdregel dat bij of krachtens algemene maatregel van bestuur regels worden gesteld, die nodig zijn ter bescherming van het milieu tegen de nadelige gevolgen die inrichtingen daarvoor kunnen veroorzaken; ${ }^{164}$

b. titel 12.2 Registratie gegevens externe veiligheid inrichtingen, transportroutes en buisleidingen de bepaling dat degene die een inrichting drijft waar gevaarlijke stoffen aanwezig zijn bepaalde gegevens moet verstrekken aan het bevoegd gezag;

c. hoofdstuk 14 Coördinatie onder meer regels over de gecoördineerde behandeling van aanvragen ten behoeve van eenzelfde inrichting;

d. hoofdstuk 16 Handel in broeikasgasemissierechten onder meer een verbod om zonder vergunning van het bestuur van de emissieautoriteit een inrichting in werking te hebben waarin zich een of meer broeikasgasinstallaties bevinden. ${ }^{165}$

Aldus is als gevolg van de bundeling die heeft geleid tot het wetssysteem van de Wabo een wetssystematisch tekort ontstaan in het wetssysteem van de Wet milieubeheer, aangezien in die wet niet langer alle bepalingen inzake inrichtingen voorkomen.

\subsubsection{Verdedigbaarheid wetssystematische tekorten}

Het hiervoor genoemde wetssystematisch tekort acht ik niet verdedigbaar. De wetgever heeft naar mijn oordeel geen goede gronden om de bepalingen inzake inrichtingen die tot 1 oktober 2010 samenhangend waren opgenomen in het wetssysteem van de Wet milieubeheer te regelen in de verschillende wetssystemen van Wabo en Wet milieubeheer. De wetgever zou eenvoudig een einde maken kunnen maken aan dit tekort door alle in het wetssysteem van de Wet milieubeheer opgenomen bepalingen inzake inrichtingen op te nemen in het wetssysteem van de Wabo.

Overigens is daarmee de kous nog niet af. Als alle bepalingen inzake inrichtingen van de Wet milieubeheer zouden worden overgeheveld naar de Wabo, zou dat leiden tot de situatie, dat de Wet milieubeheer geen bepalingen inzake inrichtingen meer zou bevatten. Dat betekent echter weer een ander wetssystematisch tekort in deze wet die beoogt een aantal algemene onderwerpen te regelen op het gebied van de milieuhygiëne. Aan een dergelijk wetssystematisch tekort zou mijns inziens wel een einde worden gemaakt door alle bepalingen in Wabo en Wet milieubeheer op te

163 Zie in dit verband ook par. 4.4.3.2.

164 Art. $8.40 \mathrm{Wm}$. Daarbij kan worden bepaald dat daarbij gestelde regels slechts gelden in daarbij aangegeven categorieën van gevallen.

165 Art. 16.2 en $16.3 \mathrm{Wm}$ 
nemen in een wetssysteem, dat wordt bepaald door het samenhangcriterium fysieke leefomgeving. De aangekondigde Omgevingswet zou dat wetssysteem kunnen zijn. ${ }^{166}$ Hier zien we een goed voorbeeld van de situatie die mij elders heeft geleid tot de verzuchting: 'Hier en daar wat juridisch sleutelen aan het huidige systeem biedt geen oplossing, maar is juist onderdeel van het probleem. ${ }^{167}$

\subsubsection{Antwoord op toetsvraag 4}

De bundeling die geleid heeft tot het wetssysteem van de Wabo heeft en passant geleid tot het ontstaan van wetssystematische tekorten in de Wet milieubeheer, aangezien belangrijke bepalingen inzake inrichtingen uit die wet zijn vervallen. Dit tekort is naar mijn oordeel niet verdedigbaar. Daarmee is de vierde toetsvraag positief beantwoord. Het genoemde tekort kan voor een deel worden verminderd door de in de Wet milieubeheer voorkomende bepalingen inzake inrichtingen op te nemen in de Wabo, maar een beklijvende oplossing zie ik slechts in een nieuw door het samenhangcriterium van de fysieke leefomgeving bepaald wetssysteem waarin de bepalingen van de Wabo en de Wet milieubeheer worden herschikt.

\subsection{WETSSYSTEEM TOEKOMSTBESTENDIG}

\subsubsection{Algemeen}

In deze paragraaf zal de vraag worden beantwoord of het wetssysteem van de Wabo toekomstbestendig is. In paragraaf 3.6 heb ik een wetssysteem toekomstbestendig genoemd als daarbinnen geen nieuwe - onverdedigbare wetssystematische tekorten ontstaan als gevolg van het feit dat de wetgever in belangrijke mate is gedwongen om een chronologische aanpak ${ }^{168}$ te hanteren. Daarbij heb ik vier wetgevingstechnieken aangegeven die al dan niet in samenhang gebruikt naar mijn oordeel tot een - meer - toekomstbestendig wetssysteem kunnen leiden. Hierna zal ik onderzoeken in hoeverre deze technieken zijn gebruikt in het kader van de bundeling die tot het wetssysteem van de Wabo heeft geleid, waarna ik zal aangeven of de Wabo toekomstbestendig mag worden genoemd.

\subsubsection{Op permanente opschoning gericht}

De wetgever heeft met de Wabo niet een wetssysteem beoogd dat de pretentie heeft het omgevingsrecht voor eens en voor altijd te codificeren. Veeleer is de Wabo een opschoning van het omgevingsrecht in de vorm van

166 Ministerie van IenM, Kabinetsbrief stelselherziening omgevingsrecht 2012.

167 Van den Broek, Omgevingsrecht doet recht aan integrale omgevingsbescherming 2010, p. 63

168 Zie par. 1.1 
een op permanente verandering toegesneden wetssystematiek, waarin nieuwe omgevingsregels van nationale of Europese oorsprong een plaats kunnen krijgen zonder nieuwe wetssystematische tekorten te veroorzaken. Dat volgt mijns inziens met name uit de in paragraaf 4.3.3.3 reeds besproken passages in de memorie van toelichting waarin een mogelijke verdere uitbouw van de Wabo wordt toegelicht.

\subsubsection{Aansluiten bij wetssystematische criteria en opbouw}

Het wetssysteem van de Wabo wordt bepaald door zakelijke en typisch juridische toekomstbestendige systeemordeningscriteria. ${ }^{169}$

Ten aanzien van de zakelijke ordeningscriteria wordt opgemerkt dat het wetssysteem van de Wabo wordt bepaald door het samenhangcriterium van 'een plaatsgebonden project dat bestaat uit één of meer activiteiten die van invloed zijn op de fysieke leefomgeving. ${ }^{170}$ Die activiteiten zijn thans aangewezen in de Wabo, het Besluit omgevingsrecht ${ }^{171}$ en verordeningen van gemeente, provincie of waterschap. ${ }^{172}$ Het betreft hier een open systeem in die zin dat het aantal activiteiten kan worden uitgebreid of beperkt al naar gelang de eisen van de tijd. Dat betekent dat nieuwe omgevingsregels van nationale of Europese oorsprong eenvoudig een plaats kunnen krijgen in het wetssysteem van de Wabo zonder dat zulks tot nieuwe wetssystematische tekorten leidt. Als de wetgever bijvoorbeeld zou besluiten om de omgevingsvergunning van toepassing te laten zijn op de activiteit lozen op oppervlaktewateren waarvoor thans een watervergunning is vereist, ${ }^{173}$ dan kan dat eenvoudig door aan artikel 2.1 lid 1 Wabo lozen op oppervlaktewateren als activiteit toe te voegen. ${ }^{174}$

Ten aanzien van de typisch juridische samenhangcriteria kan worden opgemerkt, dat ordeningscriteria als de omgevingsvergunning, voorbereidingsprocedures, financiële bepalingen, bestuursrechtelijke handhaving, inwerkingtreding beschikkingen en rechtsbescherming ${ }^{175}$ toekomstbestendig zijn, aangezien de wetgever bij mogelijke toekomstige wijzigingen van de

69 Zie par. 3.6.3.

170 Zie par. 4.3.3.1.

171 Art. 2.1 lid 1 aanhef en onder 1 Wabo jo. art. 2.2a Bor.

172 Art. 2.2 Wabo.

173 Art. $6.2 \mathrm{Wtw}$.

174 Uit de kabinetsbrief stelselherziening omgevingsrecht 2012 Omgevingsvergunning (Wabo) blijkt het voornemen om de volgende toestemmingen op te nemen in de Omgevingswet: watervergunning (Wtw), Ontgrondingenvergunning, Vergunning voor archeologische monumenten, Vergunning Wet beheer rijkswaterstaatswerken, Vergunning Spoorwegwet, Ontheffing Spoorwegwet, Ontheffing Spoorwegwet 1975.

Ontheffingen Wet bodembescherming, Ontheffingen hoofdstuk $10 \mathrm{Wm}$ (afvalstoffen) en overige vergunningen met betrekking tot de fysieke leefomgeving op basis van autonome verordening (Ministerie van IenM, Kabinetsbrief stelselherziening omgevingsrecht 2012, bijlage 1).

175 Deze ordeningscriteria bepalen achtereenvolgens hfds. 3-6 Wabo. 
Wabo kan aansluiten bij deze criteria zonder dat zulks tot nieuwe wetssystematische tekorten behoeft te leiden.

\subsubsection{Geen aanbouwwet}

De Wabo is geen aanbouwwet in de zin dat een wetssystematiek is geschapen, waarvan de diverse onderdelen nog moeten worden ingevuld.

\subsubsection{Antwoord op toetsvraag 5}

De Wabo pretendeert niet het omgevingsrecht voor eens en voor altijd vast te leggen, maar is juist gericht op permanente verandering. De toekomstbestendigheid wordt nog vergroot door het gebruik van toekomstbestendige zakelijke en typisch juridische systeemordeningscriteria, mits de wetgever bij toekomstige wijzigingen aansluit bij die criteria. Daarmee is de vijfde toetsvraag positief beantwoord.

\subsection{SAMENVATTING EN CONCLUSIE}

Op 1 oktober 2010 is de Wet algemene bepalingen omgevingsrecht (Wabo) in werking getreden. ${ }^{176}$ Hier is sprake van bundeling door herschikking. ${ }^{177}$ In hoofdstuk 4 is aan de hand van de in paragraaf 3.8 genoemde vijf toetsvragen onderzocht hoe deze bundeling van diverse regels in het omgevingsrecht in het wetssysteem van de Wabo zich verhoudt tot de in hoofdstuk 3 opgenomen criteria.

Het antwoord op de eerste toetsvraag ${ }^{178}$ is positief. Voor de inwerkingtreding van de Wabo was binnen het omgevingsrecht sprake van een wetssystematisch tekort omdat niet alle regels die volgens het op de echte werkelijkheid gebaseerde zakelijk samenhangcriterium een plaatsgebonden project dat bestaat uit één of meer activiteiten die van invloed zijn op de fysieke leefomgeving onderling samenhangen, deel uitmaakten van hetzelfde wetssysteem.

Het antwoord op de tweede toetsvraag is overwegend negatief. De Wabo heeft het hiervoor genoemde wetssystematisch tekort immers verminderd, zij het niet geheel opgeheven. De vermindering van het wetssystematisch tekort is gerealiseerd door een groot aantal toestemmingsbesluiten voor een project in het wetssysteem van de Wabo op te nemen. Er is echter nog steeds sprake van wetssystematische tekorten, want de Wabo bevat niet alle regels ten aanzien van een project, noch alle activiteiten binnen een project

176 Stb. 2008, 496 en Stb. 2010, 231

177 Zie par. 2.4.5.

178 Zie par. 3.8. 
waarvoor een omgevingsvergunning is vereist. Ook eist de Wabo geen omgevingsvergunning voor een aantal activiteiten binnen een project. Een aantal geconstateerde wetssystematische tekorten laat zich op relatief eenvoudige wijze oplossen.

Het antwoord op de derde toetsvraag is overwegend positief. In de Wabo leidt het gebruik van typisch juridische ordeningscriteria als algemeenbijzonder, gelede normstelling en de verwijzing naar de Europese IPPCrichtlijn tot het voortbestaan van wetssystematische tekorten, die in de meeste gevallen verdedigbaar zijn, doch door de wetgever veelal eenvoudig te verminderen zijn.

De vierde toetsvraag is positief beantwoord. De bundeling die geleid heeft tot het wetssysteem van de Wabo heeft en passant het ontstaan van wetssystematische tekorten in de Wet milieubeheer tot gevolg gehad, aangezien belangrijke bepalingen inzake inrichtingen uit die wet zijn vervallen. Het gesignaleerde tekort is naar mijn oordeel niet verdedigbaar en kan slechts gedeeltelijk worden verminderd door de in de Wet milieubeheer voorkomende bepalingen inzake inrichtingen op te nemen in de Wabo. Een echte oplossing zie ik eerst in een nieuw door het samenhangcriterium van de fysieke leefomgeving bepaald wetssysteem waarin de bepalingen van de Wabo en de Wet milieubeheer worden herschikt.

Toetsvraag vijf is positief beantwoord, aangezien de Wabo is gericht op permanente verandering. De toekomstbestendigheid wordt nog vergroot door het gebruik van toekomstbestendige zakelijke en typisch juridische systeemordeningscriteria, mits de wetgever bij toekomstige wijzigingen aansluit bij die criteria.

Het feit dat de toetsvragen 1 en 5 positief en toetsvraag 3 overwegend positief zijn beantwoord betekent dat de Wabo een belangrijke bijdrage heeft geleverd aan het ten dele verminderen van tot 1 oktober 2010 bestaande wetssystematische tekorten in het omgevingsrecht. Het overwegend negatieve antwoord op toetsvraag 2 en het positieve antwoord op toetsvraag 4 leidt in mijn toetsingskader desalniettemin tot de conclusie dat de bundeling die aanleiding is geweest voor het wetssysteem van de Wabo in de huidige vorm niet volledig verantwoord kan worden genoemd. In hoofdstuk 4 is een aantal suggesties gedaan tot verbetering. Als de wetgever er alsnog in zou slagen - in de Wabo of bijvoorbeeld in het kader van een nieuwe Omgevingswet - om de als gevolg van de bundeling in andere wetssystemen inzake het omgevingsrecht ontstane wetssystematische tekorten op te heffen, zou alsnog van een verantwoorde bundeling kunnen worden gesproken. 


\section{Integratie: Wet milieugevaarlijke stoffen in de Wet milieubeheer}

'Er is een verschil tussen de wereld gezien vanuit de torenflats in Den Haag en de maatschappelijke en ecologische realiteit. Daarom moet de wetgever van buiten naar binnen kijken en niet andersom.'

Gustaaf Biezeveld ${ }^{1}$

\subsection{INLEIDING}

Op 1 juni 2008 is de Wet milieugevaarlijke stoffen (Wms) als gevolg van codificerende bundeling door integratie ${ }^{2}$ opgenomen in de Wet milieubeheer $(\mathrm{Wm})$. Dat is het gevolg van de Uitvoeringswet EG-verordening registratie, evaluatie en autorisatie van chemische stoffen $(\mathrm{REACH}){ }^{3}$

Dat sprake is van codificatie volgt zowel uit een vergelijking van de wettekst van de Wms en de Wet milieubeheer, als uit de parlementaire geschiedenis. De wetsgeschiedenis bevat een aantal passages waaruit volgt dat met de integratie van de Wms in de Wet milieubeheer niet anders dan codificatie is beoogd. Zo is de wettekst van de artikelen $34 \mathrm{Wms}$ en 9.2.3.1 Wm nagenoeg gelijkluidend. Verder vermeldt de memorie van toelichting: 'Bepalingen van de Wms die niet behoeven te vervallen, worden één op één overgeheveld naar de Wet milieubeheer om een overzichtelijk geheel te behouden van de stoffenregelgeving. Het betreft hier bepalingen van de Wms die de basis bieden voor implementatie van een aantal andere Europese richtlijnen en verordeningen die naast REACH blijven bestaan, en die dienen te worden gehandhaafd teneinde de implementatie van die richtlijnen en verordeningen in stand te houden. (...) De overgehevelde bepalingen zijn uitsluitend waar nodig aan REACH of de Wet milieubeheer aangepast. Grote wijzigingen in de resterende bepalingen doen zich ten opzichte van de Wms niet voor. Hier en daar is enigszins archaïsch aandoend taalgebruik (zulks, regelen) redactioneel aangepast en zijn conform de Aanwijzingen voor de regelgeving zinsneden als bijvoorbeeld 'dient te geschieden' vervangen door 'geschiedt'. Voor zover er andersoortige wijzigingen zijn

\footnotetext{
Biezeveld, Duurzame milieuwetgeving 2002, p. 397.

Zie par. 2.4.4.

Stb. 2007, 181, art. IX (i.w.tr. Stb. 2007, 182), in hfds. 5 afgekort als: Uitvoeringswet EG-verordening REACH. Het Tijdschrift voor Milieu en Recht heeft een themanummer gewijd aan de inwerkingtreding van REACH op 1 juni 2007. Daarin onder meer bijdragen van Donkers, De nieuwe chemische stoffenwetgeving van de EU 2007 en Woldendorp, REACH doet stof opwaaien 2007.
} 
aangebracht wordt voor een toelichting hierop verwezen naar de artikelsgewijze toelichting bij het desbetreffende artikel." ${ }^{4}$

In dit hoofdstuk zal aan de hand van de in paragraaf 3.8 genoemde vijf toetsvragen worden onderzocht hoe deze bundeling van de Wms in de Wet milieubeheer zich verhoudt tot de in hoofdstuk 3 opgenomen criteria.

In paragraaf 5.2 zal een korte indruk worden gegeven van de Wms zoals die bestond tot 1 juni 2008, alsmede van de relevante bepalingen inzake stoffen in de Wet milieubeheer na bundeling. Vervolgens worden in de paragrafen 5.3 tot en met 5.7 de vijf genoemde toetsvragen beantwoord. Afgesloten zal worden met een korte samenvatting en conclusie in paragraaf 5.8.

\subsection{WMS EN WET MILIEUBEHEER IN HET KORT}

\subsubsection{Algemeen}

Alvorens in te gaan op de bundeling door integratie van de Wms in het wetssysteem van de Wet milieubeheer zal hierna een korte samenvatting worden gegeven van het wetssysteem van de Wms en de wijze waarop dat per 1 juni 2008 is geïntegreerd in de hoofdstukken 1, 9, 17, 21 en 22 Wm.

\subsubsection{De Wet milieugevaarlijke stoffen}

De Wms is op 1 februari 1986 in werking getreden ${ }^{5}$ en op 1 juni 2008 ingetrokken. ${ }^{6}$ Deze wet bevatte regels ter bescherming van mens en milieu tegen de gevolgen van gevaarlijke stoffen en preparaten. Op 31 mei 2008 kende de Wms 9 hoofdstukken, die hierna kort - en omwille van de leesbaarheid in de tegenwoordige tijd - worden toegelicht.

Hoofdstuk 1 Algemeen bevat definities en een zorgplicht. Zo worden onder stoffen verstaan chemische elementen en hun verbindingen, zoals deze voorkomen in de natuur of door toedoen van de mens worden voortgebracht. Preparaten zijn mengsels of oplossingen van stoffen. ${ }^{7}$ Onder stoffen worden niet begrepen voedings- en genotmiddelen, alsmede diervoeders. ${ }^{8} \mathrm{Bij}$ algemene maatregel van bestuur kunnen bepalingen van de Wms of onderdelen daarvan van toepassing worden verklaard op micro-organismen. ${ }^{9}$ De

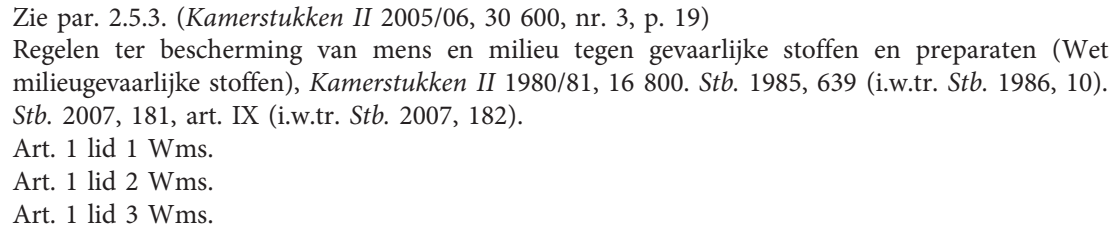


zorgplicht is gericht tot ieder die beroepshalve een stof of een preparaat vervaardigt, aan een ander ter beschikking stelt, dan wel in Nederland invoert of toepast. Wie weet of redelijkerwijs had kunnen vermoeden dat door die handelingen met die stof of dat preparaat gevaren kunnen optreden voor mens of milieu, is verplicht alle maatregelen te nemen die redelijkerwijs van hem kunnen worden gevergd, teneinde die gevaren zoveel mogelijk te beperken. ${ }^{10}$

Hoofdstuk 2 Kennisgeving bevat regels over de kennisgeving. Degene die voornemens is ertoe over te gaan een stof te vervaardigen of, al dan niet verwerkt in een preparaat, in Nederland in te voeren, is verplicht van dat voornemen schriftelijk kennis te geven aan de minister van VROM. ${ }^{11}$ Degene die de kennisgeving doet is verplicht daarbij bij algemene maatregel van bestuur aangewezen gegevens schriftelijk over te leggen met betrekking tot de mogelijke effecten van de stof op mens of milieu. ${ }^{12}$ Ook is hij verplicht voor het verkrijgen van die gegevens onderzoek te verrichten tenzij hij reeds op andere wijze over de vereiste gegevens kan beschikken. ${ }^{13}$ Het is verboden een stof te vervaardigen of, al dan niet verwerkt in een preparaat, in Nederland in te voeren zonder dat een kennisgeving is gedaan. ${ }^{14}$ Het is degene die een stof vervaardigt verboden die stof, al dan niet verwerkt in een preparaat, aan een ander ter beschikking te stellen zonder dat een kennisgeving is gedaan. ${ }^{15}$ Hoofdstuk 2 bevat voorts regels over de bekendmaking van de kennisgeving, aanvullende meldingen en onderzoeken en overige bepalingen, zoals de verplichting om de gegevens bij een kennisgeving ten minste 10 jaar te bewaren. ${ }^{16}$

Hoofdstuk 3 Onderzoek bevat onder meer regels over nieuwe kennis en belangrijke nieuwe toepassingen. Indien degene die beroepshalve stoffen of preparaten vervaardigt, in Nederland invoert, toepast of aan een ander ter beschikking stelt, met betrekking tot die stof of dat preparaat nieuwe kennis verkrijgt, waaruit ernstige gevaren voor mens of milieu blijken of redelijkerwijs kunnen worden afgeleid, moet hij dat aan de minister van VROM melden. ${ }^{17}$ Een soortgelijke verplichting bestaat als genoemde persoon kennis verkrijgt van een belangrijke nieuwe toepassing van een stof of preparaat. ${ }^{18}$ De minister van VROM stelt een lijst van aandachtsstoffen en -preparaten op. Met betrekking tot die stoffen is ieder die beroepshalve bepaalde handelingen verricht met een aandachtsstof of -preparaat zoals vervaardigen of invoeren - verplicht medewerking te verlenen aan

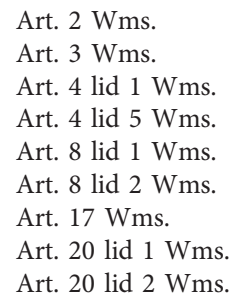


onderzoek naar het voorkomen, de toepassing en de verspreiding van die stoffen en preparaten in Nederland. ${ }^{19}$ In bepaalde gevallen kan de minister van VROM een opdracht geven om onderzoek te doen naar de gevaren van een stof of preparaat voor mens of milieu. ${ }^{20}$

Hoofdstuk 4 Maatregelen bevat de wettelijke grondslag voor het bij algemene maatregel van bestuur stellen van regels. Als een redelijk vermoeden is gerezen dat door handelingen met stoffen of preparaten ongewenste effecten zullen ontstaan voor mens of milieu, kunnen bij algemene maatregel van bestuur regels worden gesteld met betrekking tot het vervaardigen, in Nederland invoeren, toepassen, voorhanden hebben, aan een ander ter beschikking stellen, vervoeren, uitvoeren en zich ontdoen van deze stoffen en preparaten. Die regels kunnen onder meer een verbod betekenen om genoemde handelingen te verrichten. ${ }^{21}$ Hoofdstuk 4 bevat voorts regels omtrent verpakking, aanduiding en aanbeveling. Het gaat daarbij bijvoorbeeld om stoffen in de categorie ontplofbaar, zeer licht ontvlambaar, kankerverwekkend of mutageen. ${ }^{22}$ Ten slotte bevat hoofdstuk 4 regels inzake maatregelen in bijzondere omstandigheden.

Hoofdstuk 5 Financiële bepalingen, schadevergoeding en heffingen is reeds per 1 april 1988 vervallen. Hoofdstuk 6 Beroep op de administratieve rechter vermeldt slechts dat beroep openstaat overeenkomstig artikel 20 Wet milieubeheer. Hoofdstuk 7 Verdere bepalingen bevat onder meer een bijzondere regeling over geheimhouding van gegevens met het oog op de bescherming van bedrijfsgeheimen. ${ }^{23}$ Hoofdstuk 8 Handhaving verwijst naar de Wet milieubeheer. Hoofdstuk 9 bevat de gebruikelijke overgangs- en slotbepalingen, zoals de citeertitel ${ }^{24}$ en het moment van inwerkingtreding. ${ }^{25}$

\subsubsection{De Wet milieubeheer}

De bundeling is tot stand gekomen naar aanleiding van de Uitvoeringswet EG-verordening REACH. ${ }^{26}$

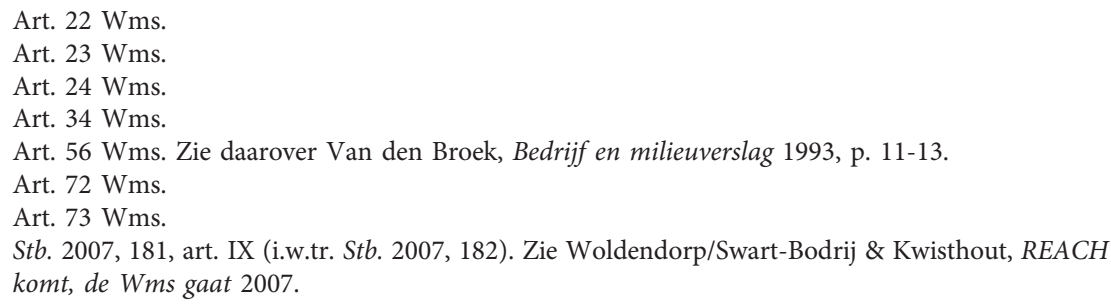


REACH legt producenten, importeurs en andere beroepsmatige en industriële gebruikers in de keten de verplichting op om informatie te verzamelen over de eigenschappen van een stof, de aan het gebruik verbonden risico's te beoordelen en de nodige maatregelen te nemen om de eventueel door hen geconstateerde risico's te beheersen. ${ }^{27} \mathrm{REACH}$ is een verordening en heeft dus rechtstreekse werking. Om REACH in de praktijk goed te laten werken zijn de lidstaten echter verplicht de daartoe noodzakelijke uitvoeringsregels vast te stellen. Deze uitvoeringsregels hebben met name betrekking op de strafbaarstelling van overtredingen van REACH, de aanwijzing van een nationale bevoegde instantie voor REACH, de regeling van het toezicht op de naleving van REACH, de mogelijkheid van bestuursrechtelijke handhaving van REACH en het opnemen van een rechtsgrondslag voor het stellen van regels die eventueel nodig zijn ter uitvoering van $\mathrm{REACH}{ }^{28}$

Voorts zijn de lidstaten verplicht met REACH overlappende of strijdige regels in de nationale wetgeving op stoffengebied in te trekken of aan te passen. Dat betrof in Nederland regels die waren gesteld bij of krachtens de Wms. ${ }^{29}$

De genoemde uitvoeringsregels of implementatiebepalingen zijn met name opgenomen in hoofdstuk $9 \mathrm{Wm}$. Door het gefaseerd gaan gelden van de verschillende bepalingen in REACH zijn de met REACH overlappende en strijdige bepalingen die bij of krachtens de Wms zijn gesteld, in twee fasen ingetrokken dan wel aangepast. Op 1 juni 2007, op het moment van inwerkingtreding van $\mathrm{REACH}$, de bepalingen ten aanzien van het veiligheidsinformatieblad. Op 1 juni 2008 de bepalingen ten aanzien van de kennisgeving van nieuwe stoffen. Gelijktijdig met laatstgenoemde aanpassing zijn de resterende bepalingen van de Wms overgeheveld naar (voornamelijk hoofdstuk 9 van) de Wet milieubeheer en is de Wms ingetrokken.

De bundeling betreft uitsluitend de overheveling van de op 1 juni 2008 nog resterende bepalingen in de Wms naar de Wet milieubeheer. De implementatie van REACH is geen bundeling, aangezien het niet gaat om het samenvoegen van twee of meer wetssystemen als gevolg waarvan een nieuw of vernieuwd wetssysteem ontstaat. ${ }^{30}$

Tot de inwerkingtreding van de Uitvoeringswet EG-verordening REACH bestond de Wet milieubeheer uit 22 hoofdstukken (zie overzicht 5.1) en twee bijlagen.

Kamerstukken II 2005/06, 30 600, nr. 3, p. 2.

Kamerstukken II 2005/06, 30 600, nr. 3, p. 3.

Kamerstukken II 2005/06, 30 600, nr. 3, p. 3.

Par. 2.5.1 


\section{Overzicht 5.1 Hoofdstukken Wet milieubeheer ten tijde van} integratie van de Wms in de in Wet milieubeheer

\begin{tabular}{|c|c|c|}
\hline 1. Algemeen & 10. Afvalstoffen & $\begin{array}{l}\text { 19. Openbaarheid van milieu- } \\
\text { informatie }\end{array}$ \\
\hline 2. Adviesorganen & 11. Andere handelingen & $\begin{array}{l}\text { 20. Beroep bij de } \\
\text { administratieve rechter }\end{array}$ \\
\hline $\begin{array}{l}\text { 3. Internationale } \\
\text { zaken }\end{array}$ & $\begin{array}{l}\text { 12. Verslag-, registratie- en } \\
\text { meetverplichtingen }\end{array}$ & 21. Verdere bepalingen \\
\hline 4. Plannen & $\begin{array}{l}\text { 13. Procedures voor } \\
\text { vergunningen en } \\
\text { ontheffingen }\end{array}$ & 22. Slotbepalingen \\
\hline $\begin{array}{l}\text { 5. Milieukwaliteitsei- } \\
\text { sen }\end{array}$ & 14. Coördinatie & \\
\hline 6. Milieuzonering & 15. Financiële bepalingen & Bijlage $1^{31}$ \\
\hline $\begin{array}{l}\text { 7. Milieueffect- } \\
\text { rapportage }\end{array}$ & 16. Handel in emissierechten & Bijlage $2^{32}$ \\
\hline 8. Inrichtingen & $\begin{array}{l}\text { 17. Maatregelen in } \\
\text { bijzondere } \\
\text { omstandigheden }\end{array}$ & \\
\hline $\begin{array}{l}\text { 9. Stoffen en } \\
\text { producten }\end{array}$ & 18. Handhaving & \\
\hline
\end{tabular}

Hoofdstuk 9 Wm kende op 31 mei 2007 nog geen enkele bepaling. De Uitvoeringswet EG-verordening REACH heeft ervoor gezorgd dat daarin op 1 juni 2007 Titel 9.3 De EG-verordening REACH is opgenomen en op 1 juni 2008 Titel 9.2 Stoffen, preparaten en genetisch gemodificeerde organismen. Als gevolg van die wet zijn de meeste bepalingen uit de Wms overgeheveld naar die titel ${ }^{33}$ en is de Wms per 1 juni 2008 ingetrokken. ${ }^{34}$

Op 1 januari 2012 bevatte het subwetssysteem van hoofdstuk 9 Wm bepalingen over stoffen, preparaten en producten, verdeeld over zeven titels, die hierna kort worden toegelicht.

Wetten, als bedoeld in art. 4.6 lid 3, 4.12 lid 3 en 4.19 lid 3 Wm.

Bijlage behorend bij art. 4.9, art. 8.40 en titel $5.2 \mathrm{Wm}$.

Art. I onder D Stb. 2007, 181.

Art. I onder X Stb. 2007, 181. 
Titel 9.1 Wm Algemeen. Per 1 januari 2012 is Titel 9.1 opgenomen, bedoeld voor bepalingen die gelden voor heel hoofdstuk $9 \mathrm{Wm} .{ }^{35}$

Titel 9.2 Wm bevat per 1 juni $2008^{36}$ met name een zorgplicht $^{37}$ en de basis voor algemene maatregelen van bestuur ${ }^{38}$ die tot 1 juni 2008 in de Wms waren opgenomen.

Titel 9.3 Wm bevat per 1 juni 2007 de implementatiebepalingen ${ }^{39}$ van de op die datum in werking getreden EG-verordening registratie, evaluatie en autorisatie van chemische stoffen (REACH) ${ }^{40}$

Titel 9.3A Wm is in werking getreden op 4 november 2009. ${ }^{41}$ Deze titel bevat de implementatiebepalingen van de EG-verordening indeling, etikettering en verpakking van stoffen en mengsels. ${ }^{42}$

Titel 9.4 Wm geeft per 24 oktober $2007^{43}$ uitvoering aan de EG-richtlijn ecologisch ontwerp energieverbruikende producten (Ecodesign). ${ }^{44}$

Titel 9.5 Wm betreft Overige bepalingen met betrekking tot stoffen, preparaten en producten. Deze titel is in werking getreden op 1 januari 2012. ${ }^{45}$

35 Dat is het gevolg van de Wet van 12 mei 2011 tot wijziging van de Wet milieubeheer en diverse aanverwante wetten (Verdere invulling van hoofdstuk 9), art. I onder C Stb. 2011, 269 en Stb. 2011, 374 (i.w.tr.). Daarbij is in Titel 9.1 als enig artikel opgenomen art. 9.1.1 luidende: 'Dit hoofdstuk en de daarop berustende bepalingen zijn mede van toepassing op handelingen verricht binnen de exclusieve economische zone, voor zover dat bij algemene maatregel van bestuur is bepaald.' Tot 1 januari 2012 was deze titel nog gereserveerd voor het initiatiefvoorstel Duurzaam geproduceerd hout (Kamerstukken I 1994/95, 23982 en 1999/2000, 26 998, alsmede Kamerstukken II 2002/03, 28 631). Het initiatiefwetsvoorstel zal naar verwachting in een andere titel van hfds. 9 Wm worden ondergebracht.

36 Stb. 2007, 181 (i.w.tr. Stb. 2007, 182).

37 Art. 9.2.1.2 Wm.

Art. 9.2.2.1 Wm.

Stb. 2007, 181 en 182

40 Verordening (EG) nr. 1907/2006 van het Europees Parlement en de Raad van 18 december 2006 inzake de registratie en beoordeling van en de autorisatie en beperkingen ten aanzien van chemische stoffen (REACH), tot oprichting van een Europees Agentschap voor chemische stoffen, houdende wijziging van Richtlijn 1999/45/EG en houdende intrekking van Verordening (EEG) nr. 793/93 van de Raad en Verordening (EG) nr. 1488/94 van de Commissie alsmede Richtlijn 76/ 769/EEG van de Raad en de Richtlijnen 91/155/EEG, 93/67/EEG, 93/105/EG en 2000/21/EG van de Commissie (PbEU 2006, L 396/1 met rectificatie in PbEU 2007 L 136/3) (art. $1.1 \mathrm{Wm}$ ).

41 Stb. 2009, 440

42 EG-verordening indeling, etikettering en verpakking van stoffen en mengsels: verordening (EG) nr. 1272/2008 van het Europees Parlement en de Raad van de Europese Unie van 16 december 2008 betreffende de indeling, etikettering en verpakking van stoffen en mengsels tot wijziging en intrekking van de Richtlijnen 67/548/EEG en 1999/45/EG en tot wijziging van Verordening (EG) nr. 1907/2006 (PbEU 2008 L 353) (art. 1.1 Wm).

43 Implementatiewet EG-richtlijn ecologisch ontwerp energieverbruikende producten, Stb. 2007, 383 (i.w.tr. Stb. 2007, 389)

44 EG-richtlijn ecologisch ontwerp energiegerelateerde producten: richtlijn nr. 2009/125/EG van het Europees Parlement en de Raad van de Europese Unie van 21 oktober 2009 betreffende de totstandbrenging van een kader voor het vaststellen van eisen inzake ecologisch ontwerp voor energiegerelateerde producten (herschikking) (PbEU 2009 L 285/10); (art. 9.4.1 lid 1 Wm).

Stb. 2011, 269 (i.w.tr. Stb. 2011, 347). 
Titel 9.6 Wm is op 9 april 2011 in werking getreden. ${ }^{46}$ Deze titel geeft uitvoering aan de EG-richtlijn ter bevordering van schone en energiezuinige wegvoertuigen. ${ }^{47}$

Op het moment voor integratie van de Wms in de Wet milieubeheer op 1 juni 2008 kende hoofdstuk 9 Wm nog slechts Titel 9.3 De EG-verordening REACH en Titel 9.4 De EG-richtlijn ecologisch ontwerp energiegerelateerde producten.

Een aantal artikelen in de Wms was ten tijde van de bundeling op 1 juni 2008 reeds vervallen. ${ }^{48}$ Omdat in de Wms voor een belangrijk deel dezelfde onderwerpen werden geregeld als in $\mathrm{REACH}$ zijn die artikelen ook vervallen. ${ }^{49}$

Het betreft onder meer de volgende artikelen:

- artikel 3-19 Wms: het kennisgevingsstelsel voor nieuwe stoffen is in REACH vervangen door een registratiesysteem; ${ }^{\circ}$

- artikel 22 Wms: REACH voorziet in een algemene wettelijke verplichting tot het melden van nieuwe toepassingen van stoffen en preparaten $;^{51}$

- artikel 23 Wms: REACH voorziet in de mogelijkheid tot het verstrekken van een onderzoeksopdracht..$^{2}$

De bepalingen van de Wms die niet zijn vervallen zijn één op één overgeheveld naar de Wet milieubeheer. Dat gebeurde volgens de memorie van toelichting bij de Uitvoeringswet EG-verordening REACH om een overzichtelijk geheel te behouden van de stoffenregelgeving. Het betreft hier bepalingen van de Wms die de basis bieden voor implementatie van een aantal andere Europese richtlijnen en verordeningen ${ }^{53}$ die naast REACH blijven bestaan. De overgehevelde bepalingen zijn volgens de regering uitsluitend waar nodig aan REACH of de Wet milieubeheer aangepast. De wetgever heeft daarbij gekozen voor overheveling van die bepalingen naar de hoofdstukken 1, 9, 17, 21 en 22 Wm 'naar gelang het onderwerp van de desbetreffende bepalingen'. ${ }^{54}$ Deze overheveling zal hierna kort worden toegelicht.

$46 \quad$ Stb. 2011, 163.

47 Richtlijn nr. 2009/33/EG van het Europees Parlement en de Raad van de Europese Unie van 23 april 2009 inzake de bevordering van schone en energiezuinige wegvoertuigen ( $P b E U 2009$ L 120/5) (art. 9.6.1 Wm).

48 Zo zijn de artikelen 41-54 per 1 april 1988 vervallen, art. 66 per 1 maart 1993 en de artikelen 57, 58 en 65 per 1 januari 1994 .

49 Kamerstukken II 2005/06, 30 600, nr. 3, p.18. Ook de op artikelen in de Wms gebaseerde lagere regelgeving is vervallen.

50 Titel II Registratie van stoffen (art. 5-24) REACH.

51 Art. 34 REACH.

Art. 39 lid 2 en 45 REACH.

Kamerstukken II 2005/06, 30 600, nr. 3, bijlage 2.

54 Kamerstukken II 2005/06, 30 600, nr. 3, p. 19. 
In hoofdstuk $1 \mathrm{Wm}$ zijn de meeste $\mathrm{e}^{55}$ definities uit de Wms opgenomen.

De meeste bepalingen uit de Wms zijn overgeheveld naar hoofdstuk $9 \mathrm{Wm}$. Het gaat onder meer het om regels inzake de zorgplicht (art. 2 Wms, art. 9.2.1.2 $\mathrm{Wm}$ ), informatieverstrekking (hfds. $3 \mathrm{Wms}$, art. 9.2.1.3 Wm), registratieverplichting (art. $32 \mathrm{Wms}$, art. 9.2.1.4 Wm), maatregelen (par. 4.1 Wms, par. 9.2.2 en art. 9.2.1.4 Wm) en indeling, verpakking, etikettering en aanbeveling (par. 4.2 Wms, art. 9.2.3.1-9.2.3.4 Wm).

Aan hoofdstuk $17 \mathrm{Wm}$ is artikel 17.6 toegevoegd. De kern van deze bepaling betreft de situatie dat stoffen, preparaten of ggo's dan wel handelingen daarmee naar het oordeel van de minister van VROM onduldbaar gevaar opleveren voor de gezondheid van de mens of voor het milieu. In dergelijke gevallen kan de minister van VROM, zo nodig met behulp van de sterke arm, alle maatregelen nemen die hij in het belang van de bescherming van de gezondheid van de mens en van het milieu noodzakelijk acht. ${ }^{56}$

Aan hoofdstuk $21 \mathrm{Wm}$ is onder meer artikel 21.4 Wm nieuw toegevoegd, luidende dat bij algemene maatregel van bestuur bepalingen van de Wet milieubeheer die betrekking hebben op stoffen, van toepassing kunnen worden verklaard op microorganismen, niet zijnde genetisch gemodificeerde organismen (ggo's).

In hoofdstuk $22 \mathrm{Wm}$ zijn aan artikel 22.1 Wm vier leden toegevoegd die bepalen dat titel 9.2 lid 4, 5, 6 en 7 Wm of artikel 9.3 lid 4 Wm in bepaalde gevallen niet van toepassing zijn.

\subsection{WETSSYSTEMATISCHE TEKORTEN}

\subsubsection{Algemeen}

In deze paragraaf zal de eerste toetsvraag worden beantwoord: is er binnen het omgevingsrecht sprake van een wetssystematisch tekort omdat niet alle regels die volgens een op de echte werkelijkheid gebaseerd zakelijk samenhangcriterium onderling samenhangen desalniettemin geen deel uitmaken van hetzelfde wetssysteem?

Om die vraag te beantwoorden zal ik in paragraaf 5.3.2 eerst nagaan welke aanleiding de regering noemt voor de bundeling die per 1 juni 2008 heeft geleid tot de integratie van de Wms in de Wet milieubeheer.

55 In art. 1 lid 2 Wms stond dat onder stoffen niet worden begrepen voedings- en genotmiddelen, alsmede diervoeders. Deze beperking staat per 1 juni 2008 in art. 9.2.1.1 Wm.

56 Op 1 april 2012 is art. $17.6 \mathrm{Wm}$ vernummerd tot art. 17.9 lid $1 \mathrm{Wm}$. 
In paragraaf 5.3.3 zal worden onderzocht of de regering in de memorie van toelichting op het wetsvoorstel Uitvoeringswet EG-verordening REACH ${ }^{57}$ een samenhangcriterium noemt, en zo ja welk, dat voor haar de aanleiding vormde tot bundeling. Daarbij neem ik het door de regering gekozen samenhangcriterium als uitgangspunt. Niet vanwege het feit dat dit het enige of beste criterium zou zijn - zoals eerder aangegeven kan een wetgever kiezen uit een schier oneindig aantal samenhangcriteria ${ }^{58}$ - maar vanwege het feit dat ik de vraag wil beantwoorden in hoeverre de integratie van de Wms in de Wet milieubeheer beantwoordt aan de in hoofdstuk 3 door mij ontwikkelde criteria voor bundeling. In paragraaf 5.3 .3 zal ook worden aangegeven of het aldus gevonden samenhangcriterium een op de echte werkelijkheid gebaseerd zakelijk samenhangcriterium betreft.

Mocht de vorige vraag bevestigend worden beantwoord, dan zal ik in paragraaf 5.3.4 vervolgens nagaan of sprake is van een of meer wetssystematische tekorten omdat niet alle regels die passen binnen het gevonden samenhangcriterium deel uitmaken van hetzelfde wetssysteem.

In paragraaf 5.3.5 zal de eerste toetsvraag worden beantwoord.

\subsubsection{Aanleiding voor bundeling}

Aanleiding voor de integratie van de Wms in de Wet milieubeheer was het feit dat als gevolg van de implementatie van REACH bepalingen over stoffen zowel in de Wms als in de Wet milieubeheer stonden. De overheveling van de bepalingen van de Wms naar de Wet milieubeheer gebeurde volgens de memorie van toelichting om een overzichtelijk geheel te behouden van de stoffenregelgeving. ${ }^{59}$

\subsubsection{Samenhangcriterium}

Hoofdstuk 9 Stoffen en produkten is in de Wet milieubeheer gekomen op 1 januari 1993. Uit de memorie van toelichting leid ik af dat de regering destijds geen precies omlijnd idee voor ogen lijkt te hebben gehad over wat de inhoud van hoofdstuk $9 \mathrm{Wm}$ zou moeten zijn.

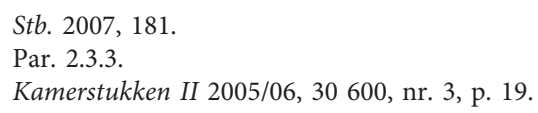


Het hoofdstuk was oorspronkelijk niet opgenomen in het wetsvoorstel Vergunningen en algemene regels (VAR), maar werd daaraan toegevoegd bij nota van wijziging. ${ }^{60}$ Ter toelichting vermeldt de regering slechts dat de wijziging van de hoofdstukindeling van de Wet milieubeheer al is aangekondigd in het NMPplus. ${ }^{61}$ Voorts wordt opgemerkt dat die indeling niet als een absoluut eindbeeld van de Wet milieubeheer moet worden beschouwd. Daarvoor zijn de onzekerheden ten aanzien van de verdere ontwikkeling van het instrumentarium voor het milieubeheer nog te groot. Zo kan niet worden uitgesloten dat zich in de toekomst nieuwe onderwerpen voor regeling in de wet aandienen. Ook is denkbaar dat ten aanzien van een bepaald onderwerp waarvoor nu ruimte wordt gereserveerd, uiteindelijk wordt geconcludeerd dat aan regeling ervan geen behoefte bestaat. $^{62}$

Duidelijk is echter wel dat de wetgever hoofdstuk $9 \mathrm{Wm}$ heeft bestemd voor bepalingen ten aanzien van stoffen en producten.

De memorie van toelichting bij de Uitvoeringswet EG-verordening REACH noemt weliswaar niet expliciet een bepaald samenhangcriterium, maar impliciet volgt uit die memorie van toelichting dat de regering de regels inzake stoffen op het oog heeft: 'Bepalingen van de Wms die niet hoeven te vervallen, worden één op één overgeheveld naar de Wet milieubeheer om een overzichtelijk geheel te behouden van de stoffenregelgeving. ${ }^{363}$

In hoofdstuk $9 \mathrm{Wm}$ is ervoor gekozen het begrippenkader, zoals dat in de Europese stoffen- en ggo-regelgeving is ontwikkeld over te nemen. Dit begrippenkader wordt ook gehanteerd in de REACH-verordening. De regering beoogt daarmee de eenheid van terminologie te behouden binnen de nationale en internationale stoffen- en ggo-regelgeving. ${ }^{64}$ Die eenheid van terminologie geldt volgens de regering niet alleen voor Titel 9.3 Wm waarin de REACH-verordening is geïmplementeerd, maar ook voor Titel $9.2 \mathrm{Wm}$. De reden daarvoor is dat voor de toekomst niet kan worden uitgesloten dat voor het uitoefenen van specifieke bevoegdheden op grond van REACH ook gebruik zal worden gemaakt van de artikelen uit Titel 9.2 Wm. ${ }^{65}$ Een reden

60 Uitbreiding en wijziging van de Wet algemene bepalingen milieuhygiëne en daarmee samenhangende wijzigingen van andere wetten (vergunningen en algemene regels voor inrichtingen; procedures voor vergunningen en ontheffingen; handhaving), Kamerstukken II 1989/90, 21 087, nr. 7, art. OOOO, p. 18.

61 Nationaal Milieubeleidsplan-plus, Kamerstukken II 1993-1994, 23 560, nr. 1-2.

62 Uitbreiding en wijziging van de Wet algemene bepalingen milieuhygiëne en daarmee samenhangende wijzigingen van andere wetten (vergunningen en algemene regels voor inrichtingen; procedures voor vergunningen en ontheffingen; handhaving), Kamerstukken II 1989/90, 21 087, nr. 7, art. OOOO, p. 30 .

63 Kamerstukken II 2005/06, 30 600, nr. 3, p. 19

64 Kamerstukken II 2005/06, 30 600, nr. 3, p. 22.

65 Kamerstukken II 2005/06, 30 600, nr. 3, p. 22. 
hiervoor kan zijn dat de uitvoeringsregels sterke samenhang vertonen met bestaande nationaal geïnspireerde regels. ${ }^{66}$ Het begrippenkader inzake stoffen in REACH, Titel 9.2 Wm en Titel 9.3 Wm komt dus overeen. Volgens de regering wordt hiermee ook de bestaande eenheid in terminologie gehandhaafd met andere regelgeving ter implementatie van de Europese stoffenregelgeving, zoals de Warenwet en Arbeidsomstandighedenwet. ${ }^{67}$

Onder stoffen worden verstaan: chemische elementen en de verbindingen ervan, zoals deze voorkomen in natuurlijke toestand of bij de vervaardiging ontstaan, met inbegrip van alle additieven die nodig zijn voor het behoud van de stabiliteit ervan en alle onzuiverheden ten gevolge van het toegepaste procedé, doch met uitzondering van elk oplosmiddel dat kan worden afgescheiden zonder dat de stabiliteit van de stof wordt aangetast of de samenstelling ervan kan worden gewijzigd. Deze aan REACH ontleende definitie van stoffen is op 1 juni 2007 in artikel 1.1 aanhef en onder 1 Wm geïntroduceerd.

In de Wms werd onder stoffen verstaan: chemische elementen en hun verbindingen, zoals deze voorkomen in de natuur of door toedoen van de mens worden voortgebracht. ${ }^{68}$ De memorie van toelichting bij de Uitvoeringswet EG-verordening REACH vermeldt echter dat met de integratie van de Wms in de Wet milieubeheer geen verandering van de reikwijdte van het begrip stoffen in de Wms is beoogd. ${ }^{69}$

Titel 9.2 Wm heeft niet alleen betrekking op stoffen, maar ook op preparaten en ggo's. Onder preparaten worden mengsels of oplossingen van twee of meer stoffen ${ }^{70}$ verstaan. Het gaat dus nog steeds om stoffen. Dat is ook het geval bij ggo's.

In de Wms werden ggo's niet genoemd als afzonderlijke categorie naast stoffen en preparaten. De reden was dat genetisch materiaal valt onder de definitie van stoffen, aangezien DNA en $\mathrm{RNA}^{71}$ chemische verbindingen zijn. In Titel 9.2 Wm zijn ggo's als stoffen behandeld, maar slechts voor de duidelijkheid afzonderlijk genoemd. De memorie van toelichting geeft aan dat hiermee alleen een verduidelijking is beoogd, die ten opzichte van de Wms niet leidt tot een verandering van de reikwijdte van Titel $9.2 \mathrm{Wm} .^{72}$

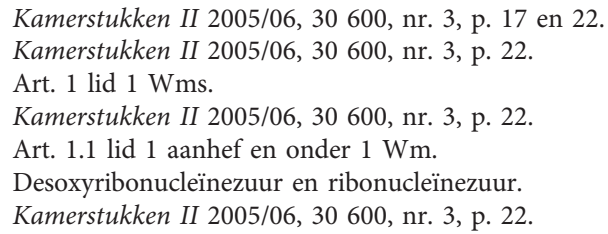


Gelet op hetgeen hiervoor is opgemerkt, worden de wetssystemen van REACH, Titel 9.2 Wm, Titel 9.3 Wm en de Wms dus in ieder geval mede bepaald door het samenhangcriterium stoffen.

Het gaat in Titel 9.2 Wm en Titel 9.3 Wm voorts om regels omtrent stoffen ter bescherming van mens en milieu. De omschrijving mens en milieu werd gebruikt in de Wms. Het onderdeel mens is in de Wet milieubeheer wel aangepast aan de wijze waarop dit in REACH wordt gebruikt en dus vervangen door de woorden gezondheid van de mens. De reikwijdte van Titels $9.2 \mathrm{Wm}$ en Titel $9.3 \mathrm{Wm}$ is daarmee ruimer dan de reikwijdte van andere onderdelen van de Wet milieubeheer, maar in vergelijking met de Wms is zij gelijk. Dat betekent dat zowel op basis van de Wms als op basis van Titel 9.2 Wm en Titel 9.3 Wm de mogelijkheid bestaat om aan handelingen voorschriften te verbinden uitsluitend in verband met de gezondheid van de mens of de arbeidsveiligheid, zonder dat het milieu verder in het geding is. Te denken valt aan etiketteringsvoorschriften, productiekennisgeving en veiligheidsinformatieblad. ${ }^{73}$

In de Wet milieubeheer worden onder gevolgen voor het milieu in ieder geval verstaan gevolgen voor het fysieke milieu, gezien vanuit het belang van de bescherming van mensen, dieren, planten en goederen, van water, bodem en lucht en van landschappelijke, natuurwetenschappelijke en cultuurhistorische waarden en van de beheersing van het klimaat, alsmede van de relaties daartussen. ${ }^{74}$

Onder gevolgen voor het milieu worden mede verstaan gevolgen die verband houden met een doelmatig beheer van afvalstoffen of een doelmatig beheer van afvalwater, gevolgen die verband houden met het verbruik van energie en grondstoffen, alsmede gevolgen die verband houden met het verkeer van personen of goederen van en naar de inrichting. ${ }^{75}$

Onder bescherming van het milieu wordt mede verstaan de verbetering van het milieu, de zorg voor een doelmatig beheer van afvalstoffen of een doelmatig beheer van afvalwater, de zorg voor een zuinig gebruik van energie en grondstoffen, alsmede de zorg voor de beperking van de nadelige gevolgen voor het milieu van het verkeer van personen of goederen van en naar de inrichting. ${ }^{76}$

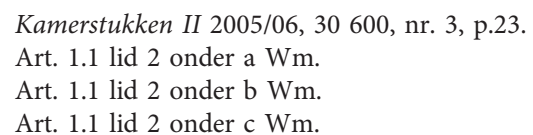


Gelet op het bovenstaande kom ik tot de conclusie dat Titel 9.2 Wm en Titel 9.3 Wm worden bepaald door de samenhangcriteria stoffen met gevolgen voor het milieu of de gezondheid van de mens. In dit hoofdstuk zal ik verder spreken over stoffen.

Het samenhangcriterium stoffen kan worden gekwalificeerd als een op de echte werkelijkheid gebaseerd samenhangcriterium. Dit samenhangcriterium combineert in wezen drie zakelijke samenhangcriteria: ${ }^{77}$ object (stoffen), fysieke leefomgeving (milieu) en gezondheid. Voor burgers, ondernemers en andere gebruikers van het omgevingsrecht zal aanstonds duidelijk zijn wat wordt bedoeld met stoffen.

Het samenhangcriterium stoffen bepaalt Titel 9.2 Wm en Titel 9.3 Wm. Hoofdstuk 9 Wm wordt echter ook bepaald door het samenhangcriterium producten. Op het moment van bundeling kende hoofdstuk 9 Wm Titel 9.4 met betrekking tot producten. In deze titel is per 24 oktober 2007 de EG-richtlijn ecologisch ontwerp energieverbruikende producten (Ecodesign $)^{78}$ geïmplementeerd. De regering heeft destijds gekozen voor implementatie van de richtlijn in de Wet milieubeheer vanwege het integrale karakter van die wet waardoor het in de richtlijn bedoelde kader in die wet kon worden neergelegd voor zowel milieu- als energienormering voor producten. Aangezien het zwaartepunt van de richtlijn producteisen op milieugebied betreft, is de richtlijn geïmplementeerd in hoofdstuk $9 \mathrm{Wm}$ dat gereserveerd is voor regels inzake stoffen en producten.

Hoewel de memorie van toelichting bij de Uitvoeringswet EG-verordening REACH. dat niet expliciet vermeldt, leid ik uit het voorgaande af, dat hoofdstuk 9 Wm mede wordt bepaald door het samenhangcriterium producten met gevolgen voor het milieu. Dat betekent dat bepalingen inzake de gevolgen van producten

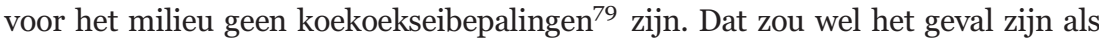
hoofdstuk 9 Wm slechts zou zijn bepaald door het samenhangcriterium stoffen.

Dat neemt echter niet weg, dat de vraag kan worden gesteld of de wetgever de kenbaarheid van de bepalingen inzake stoffen en producten wellicht groter had gemaakt als hij die in afzonderlijke hoofdstukken van de Wet milieubeheer zou hebben ondergebracht, te weten een hoofdstuk inzake Stoffen en een hoofdstuk inzake Producten. Het antwoord op die vraag is echter niet van belang voor de vraag die ons in hoofdstuk 5 bezig houdt, te weten of de integratie van de Wms in de Wet milieubeheer verantwoord kan worden genoemd. In het navolgende zal ik me dan ook beperken tot het samenhangcriterium stoffen.

77 Par. 3.3

78 EG-richtlijn ecologisch ontwerp energiegerelateerde producten: richtlijn nr. 2009/125/EG van het Europees Parlement en de Raad van de Europese Unie van 21 oktober 2009 betreffende de totstandbrenging van een kader voor het vaststellen van eisen inzake ecologisch ontwerp voor energiegerelateerde producten (herschikking) (PbEU 2009 L 285/10); (art. 9.4.1 lid 1 Wm). 


\subsubsection{Wetssystematisch tekort}

Vóór de integratie van de Wms in de Wet milieubeheer op 1 juni 2008 was binnen het omgevingsrecht sprake van een wetssystematisch tekort omdat niet alle regels die volgens het op de echte werkelijkheid gebaseerde zakelijke samenhangcriterium stoffen onderling samenhangen, deel uitmaakten van hetzelfde wetssysteem.

\subsubsection{Antwoord op toetsvraag 1}

Vóór de integratie van de Wms in de Wet milieubeheer op 1 juni 2008 was binnen het omgevingsrecht sprake van een wetssystematisch tekort omdat niet alle regels die volgens het op de echte werkelijkheid gebaseerde zakelijk samenhangcriterium stoffen onderling samenhangen, deel uitmaakten van hetzelfde wetssysteem. Onder stoffen worden verstaan chemische elementen en hun verbindingen, zoals deze voorkomen in de natuur of door toedoen van de mens worden voortgebracht met gevolgen voor het milieu of de gezondheid van de mens. Daarmee is de eerste toetsvraag positief beantwoord.

\subsection{WETSSYSTEMATISCHE TEKORTEN OPGEHEVEN OF VERMINDERD}

\subsubsection{Algemeen}

In deze paragraaf zal de vraag worden beantwoord of de integratie van de Wms in de Wet milieubeheer het wetssystematisch tekort heeft opgeheven of verminderd dat op het moment van die integratie bestond omdat niet alle regels inzake stoffen in hetzelfde wetssysteem waren opgenomen. Dat wetssystematisch tekort was op 1 juni 2007 ontstaan doordat de wetgever ervoor had gekozen REACH uit te voeren in de Wet milieubeheer en niet in de Wms.

Daarom laat zich daaraan voorafgaand de vraag stellen waarom de regering destijds niet heeft gekozen voor implementatie van REACH in de Wms. Het antwoord op die vraag heb ik niet gevonden in de memorie van toelichting bij de Uitvoeringswet EG-verordening REACH. ${ }^{80}$ Deze memorie van toelichting wekt veeleer de indruk dat de regering het vanzelfsprekend achtte dat de regels inzake stoffen een plaats zouden krijgen in de Wet milieubeheer.

In de Uitvoeringsnota $S O M S^{81}$ worden wel drie redenen genoemd om regels betreffende stoffen op te nemen in hoofdstuk $9 \mathrm{Wm}$. Het gaat om het behoud van de inzichtelijkheid van de stoffenwetgeving, een verdere integratie binnen

80 Kamerstukken II 2005/06, 30 600, nr. 3.

81 SOMS is een acroniem voor de Strategie Omgaan Met Stoffen d.d. 16 maart 2001. 
de milieuregelgeving en het beperken van administratieve lasten. Hierna volgt een korte toelichting op elk van die punten.

In de eerste plaats wordt opgemerkt, dat REACH rechtstreekse werking heeft, zodat vanuit formeel juridisch oogpunt Nederland daarom voor de implementatie kan volstaan met enkele uitvoeringsbesluiten op grond waarvan de strafbaarstelling, de handhavingsbevoegdheden en de aanwijzing van bevoegde autoriteiten worden geregeld. De rechtstreekse werking leidt er evenwel toe dat grote delen van de huidige Wms en de daarop gebaseerde uitvoeringsbesluiten buiten werking worden gesteld zodra REACH in werking treedt. Voor behoud van de inzichtelijkheid en toegankelijkheid van de stoffenwetgeving zijn daarom aanvullende activiteiten gewenst. ${ }^{82}$

In de tweede plaats was reeds het voornemen uitgesproken om, in het kader van een verdere integratie binnen de milieuregelgeving, de Wms te laten opgaan in hoofdstuk $9 \mathrm{Wm}$ Stoffen en producten. Genoemde uitvoeringsregelingen die voor de uitvoering van REACH noodzakelijk zijn, zullen derhalve worden gebaseerd op de Wet milieubeheer. Nu de Europese Commissie haar voorstel voor EU-stoffenregelgeving heeft gepubliceerd, wordt de voorbereiding van hoofdstuk $9 \mathrm{Wm}$ weer ter hand genomen. ${ }^{83}$

Het vormgeven van hoofdstuk $9 \mathrm{Wm}$ Stoffen en producten is ook een belangrijk voornemen in het kader van de herijking van de VROM-regelgeving. De totstandkoming van hoofdstuk $9 \mathrm{Wm}$ betekende voor de stoffenregelgeving dat een wet (de Wms) inclusief circa tachtig uitvoeringsregelingen zullen verdwijnen. Nederland zal bij deze herziening en stroomlijning van de stoffenregelgeving trachten de administratieve lasten voor het bedrijfsleven, die voortkomen uit REACH, zoveel als mogelijk is te beperken. ${ }^{84}$

Bij de eerste reden plaats ik de kanttekening dat ik niet vermag in te zien waarom de inzichtelijkheid en toegankelijkheid van de stoffenwetgeving per se beter gediend zou zijn met opname van de regels inzake stoffen in hoofdstuk 9 Wm dan in de Wms.

Woldendorp/Swart-Bodrij \& Kwisthout schrijven dat de inwerkingtreding van REACH het noodzakelijk maakte dat veel bepalingen van de Wms werden ingetrokken wegens overbodigheid of strijdigheid met REACH. Het was volgens hen al langer de bedoeling dat de Wms in de Wet milieubeheer zou worden geïntegreerd. Hiervoor was hoofdstuk 9 Wm Stoffen en producten volgens hen vrijgehouden. ${ }^{85}$ In 2002 was reeds aan de Tweede

VROM, Uitvoeringsnota SOMS 2004, p. 38.

VROM, Uitvoeringsnota SOMS 2004, p. 38.

VROM, Uitvoeringsnota SOMS 2004, p. 38.

Ik heb in de wetsgeschiedenis geen aanwijzingen gevonden voor de bewering dat hfds. $9 \mathrm{Wm}$ is 'vrijgehouden' om daarin de Wms op te nemen. Als zij juist is, dan komt het mij wel merkwaardig voor dat de wetgever pas 15 jaar na de inwerkingtreding van de Wm is overgegaan tot het integreren van de Wms in de Wm. 
Kamer een proeve van wetgeving toegezonden, waarin van het nieuwe hoofdstuk een eerste idee werd gegeven, gebaseerd op het Nederlandse beleidsvernieuwingsprogramma Strategie Omgaan Met Stoffen, maar deze proeve heeft geen vervolg meer gekregen omdat Europa intussen was begonnen met de voorbereiding van REACH. ${ }^{86}$

Woldendorp herhaalt dit op mijn vraag waarom de wetgever niet heeft gekozen voor het samenbrengen van regels over stoffen in de Wms. Vervolgens geeft hij een kijkje in de - zo blijkt - pragmatische wetgevingskeuken:

"Voor REACH was er al het idee in Nederland om het stoffenbeleid anders te organiseren (SOMS). Voordat de Wms in de Wet milieubeheer is geïntegreerd, is er al een proeve geweest voor een nieuwe Wms. Die is er niet gekomen omdat de nieuwe wet door REACH werd ingehaald. Toen REACH moest worden geïmplementeerd, werd in eerste instantie gedacht aan een uitvoering in het kader van de Wms. REACH regelde namelijk veel wat al in de Wms stond. Als gevolg van REACH, een rechtstreeks in de Nederlandse rechtsorde doorwerkende verordening, moest dubbele nationale regelgeving worden geschrapt. Je zou erg veel wettelijke regels moeten maken om dat te realiseren, zoals 'artikel $x$ vervalt, artikelen y en $\mathrm{z}$ worden samengevoegd, na '...' wordt een zinsnede ingevoegd, luidende ...., hoofdstuk 3 wordt vernummerd tot 2 en krijgt een andere titel.' Toen ik de opdracht kreeg om REACH uit te voeren, ging het eigenlijk alleen om het aanwijzen van het bevoegd gezag, het regelen van de strafbaarstelling en het schrappen van dubbelingen uit de Wms. Dat was voor de uitvoering van REACH voldoende. Ik schatte zo in dat het aanpassen van de Wms 95\% van het werk zou zijn. Voor de uitvoering van REACH waren maar drie artikelen nodig (art. 9.3.1, 9.3.2 en 9.3.3 Wm). Het was veel gemakkelijker om de restanten van de Wms te verplaatsen naar de Wet milieubeheer, dan kon je volstaan met één wijziging van de Wet milieubeheer dat er een paragraaf moest worden ingevoegd waarin alle resterende bepalingen van de voormalige Wms bij elkaar werden gezet. Dan zou ook meteen de politieke wens in vervulling gaan om de Wms in de Wet milieubeheer te integreren, al moeten we dat integreren dan wel met een korreltje zout nemen: dat is niet inhoudelijk integreren, maar alleen de boel bij elkaar zetten, in de volle kast erbij duwen, zeg maar. We hadden maar heel weinig tijd om REACH uit te voeren; 15 of 21 dagen en dan moest alles geregeld zijn. ${ }^{87} \mathrm{Er}$ werd dus voor gekozen om ons te beperken tot een simpele 'overplaatsing' van de Wms-bepalingen en om daarin geen verbeteringen aan te brengen. Een logische structuur zou zijn om REACH in elk geval een duidelijk zichtbare plaats in de Wet milieubeheer te geven. De Wms had verder weinig raakvlakken met de rest van de Wet milieubeheer, dus in feite gooiden we er alleen maar een bal in de ballenbak bij. Dat is ook geen probleem, als je dat maar erkent en niet net doet alsof er wel samenhang is. De implementatie van REACH had net zo goed in de Wms gekund, want de meerwaarde van integratie van de Wms in de Wet milieubeheer lijkt mij

86 Woldendorp/Swart-Bodrij \& Kwisthout, REACH komt, de Wms gaat 2007, p. 483.

87 De Verordening REACH stond overigens op 30 december 2006 in het Publikatieblad van de Europese Unie (PbEU L 396/1 en rectificatie in PbEU 2007 L 136/3) en trad in werking op 1 juni 2007 (art. 141 lid 1 Verordening REACH). 
beperkt, maar dan hadden we ook een nieuwe Wms moeten uitschrijven. Een essentieel onderdeel van deze operatie was dat er een brief aan de Tweede Kamer is gestuurd. ${ }^{8}$ Daarin is gezegd dat de implementatie alleen maar zou kunnen als er niet over de inhoud van REACH zou worden gesproken of over de Wms. Het minste risico op een verkeerde implementatie is dat er technisch wordt geïmplementeerd. Dit is puur pragmatiek. Er zitten geen verheven gedachten achter de structuur. Zelfs evidente verbeteringen waarvan we ons konden voorstellen dat die tot discussie zouden kunnen leiden, hebben we niet uit de Proeve overgenomen." 89

Wat er ook zij van het bovenstaande, feit is dat op 31 mei 2008 de situatie was ontstaan dat de regels inzake stoffen waren verspreid over de twee wetssystemen van Wms en Wet milieubeheer met het in paragraaf 5.3 beschreven wetssystematisch tekort tot gevolg. Hierna zal de vraag worden beantwoord of dat wetssystematisch tekort als gevolg van de integratie is opgeheven of verminderd.

\subsubsection{Opgeheven wetssystematische tekorten}

Op 1 juni 2007, het moment waarop REACH in werking trad en de implementatieregels in de Uitvoeringswet EG-verordening REACH, waren in het wetssysteem van de Wms reeds regels opgenomen ter bescherming van mens en milieu tegen stoffen. In hoofdstuk 9 Wm Stoffen en producten waren op dat moment vanaf de totstandkoming daarvan op 1 maart $1993^{90}$ geen bepalingen opgenomen. Hiervoor ${ }^{91}$ is al opgemerkt dat de regering het destijds denkbaar achtte dat ten aanzien van een bepaald onderwerp waarvoor ruimte werd gereserveerd, uiteindelijk wordt geconcludeerd dat aan regeling ervan geen behoefte bestaat.

Tot 1 juni 2007 bestond er dus geen wetssystematisch tekort, aangezien de regels inzake stoffen in het wetssysteem van de Wms waren ondergebracht. De regering heeft echter een wetssystematisch tekort in het leven geroepen door per 1 juni 2007 de implementatieregels betreffende REACH op te nemen in de Wet milieubeheer. Vanaf dat moment stonden de regels inzake stoffen verspreid over twee wetssystemen: de Wms en de Wet milieubeheer. De regering heeft dit tekort vervolgens op 1 juni 2008 weer opgeheven door integratie van de Wms in de Wet milieubeheer. Vanaf dat moment stonden de relevante regels inzake stoffen immers in het wetssysteem van de Wet milieubeheer.

88 Kamerstukken II 2006/07, 21 501-08, nr. 200. Bijlage 3 bij de brief waarin dit is verwoord, heeft bij de behandeling van het wetsvoorstel door de Tweede Kamer nauwelijks aandacht gekregen.

89 Woldendorp, Interview 2011, bijl. 5.1, par. 7.2

90 Stb. 1993, 59.

91 Par. 5.3.3. 


\subsubsection{Niet opgeheven wetssystematische tekorten}

Hiervoor is aangegeven dat de integratie van de Wms in de Wet milieubeheer op 1 juni 2008 het wetssystematisch tekort heeft opgeheven dat op 1 juni 2007 was ontstaan als gevolg van het feit dat regels inzake stoffen werden opgenomen in de Wet milieubeheer.

Dat wil echter niet zeggen, dat daarmee ook de wetssystematische tekorten zijn opgeheven, die op 31 mei 2007 reeds bestonden omdat een (groot) aantal regels inzake stoffen niet waren opgenomen in het wetssysteem van de Wms. Aan die situatie heeft de integratie van de Wms in de Wet milieubeheer immers niets veranderd.

In de memorie van toelichting bij de Wms is een kort overzicht gegeven van de wetten waarin in enige vorm een (gedeeltelijke) regeling was gegeven van de bescherming van mens en milieu tegen de mogelijke gevaren van chemische stoffen: ${ }^{92}$

- wetten gericht op stoffen en producten. Als expliciet stofgerichte wetten worden genoemd de Bestrijdingsmiddelenwet, ${ }^{93}$ de Wet op de geneesmiddelenvoorziening ${ }^{94}$ en enige besluiten op grond van de Warenwet;

- wetten die een onderdeel van de levensloop van een stof betreffen. De hierboven genoemde wetgeving is volgens de regering vooral gericht op de risico's die stoffen vanaf het moment van hun toepassing opleveren. Er zijn enkele wetten die nog nadrukkelijker betrekking hebben op bepaalde fasen in het leven van een stof: de Veiligheidswet ${ }^{95}$ (op het gebruik van stoffen in de arbeidssituatie), de Wet gevaarlijke stoffen ${ }^{96}$ (op het vervoer van gevaarlijke stoffen) en de - in 1994 vervallen $^{97}$ Wet chemische afvalstoffen (op stoffen in het afvalstadium);

92 Kamerstukken II 1980/81, 16 800, nr. 3, p. 8-10. Zie in dit verband ook Van den Berg, Milieurecht voor stoffen en produkten 1992, p. 195-196. Van den Berg noemt het juridische instrumentarium voor het stoffen- en produktenbeleid zeer breed. Hij onderscheid daarbij fysieke regulering (zoals de Wms), financiële instrumenten en civielrechtelijke mogelijkheden. Aan mogelijkheden tot fysieke regulering van stoffen en produkten heeft de milieuwetgeving geen gebrek, aldus Van den Berg.

93 Op 17 oktober 2007 vervallen met de inwerkingtreding van de Wet gewasbeschermingsmiddelen en biociden (Stb. 2007, 125 en 386). Zie art.139 Wgb.

94 Op 1 juli 2007 vervallen met de inwerkingtreding van de Geneesmiddelenwet (Stb. 2007, 93 en 227). Zie art. 132 van die wet.

95 Op 1 januari 1983 vervallen met inwerkingtreding van de Arbeidsomstandighedenwet (art. 46 lid 1 Arbeidsomstandighedenwet, St. 1980, 664)

96 Op 1 augustus 1995 vervallen met de inwerkingtreding van de Wet vervoer gevaarlijke stoffen (Stb 1995, 525 en Stb. 1996, 297). Zie art. 51 van die wet.

97 Art. V van de Wet van 2 juli 1992, tot uitbreiding en wijziging van de Wet algemene bepalingen milieuhygiëne (afvalstoffen), Stb. 1993, 283 en 769. 
- wetten gericht op één milieucompartiment. Een aantal wetten is bedoeld om lozingen van (milieugevaarlijke) stoffen in één bepaald milieucompartiment tegen te gaan. Genoemd worden de Wet inzake de luchtverontreiniging, de Wet verontreiniging oppervlaktewateren ${ }^{98}$ en de Wet verontreiniging zeewater; ${ }^{99}$

- andere wetten, zoals de Hinderwet ${ }^{100}$ en de Kernenergiewet.

Volgens de regering bestrijkt de genoemde wetgeving velerlei terreinen, maar kan niet worden gesproken van een samenhangend systeem van wetten dat de gevaren voor mens en milieu die chemische stoffen kunnen veroorzaken dekt. 'Geen van deze wetten biedt voldoende grondslag voor een samenhangend beleid gericht op het tegengaan van de ongecontroleerde blootstelling van mens en milieu aan chemische stoffen in het algemeen, en alle tezamen zijn ze dat evenmin.' Volgens de regering is er daarom behoefte aan een Wms die het mogelijk maakt inzicht te krijgen in de gevaren van stoffen voor mens en milieu, en wel voordat deze stoffen een aanzienlijke verspreiding hebben gekregen. De Wms moet het ook mogelijk maken de gevaren integraal aan te pakken. De regering realiseert zich dat 'een dergelijk breed opgezette' Wms 'onvermijdelijk een aantal raakvlakken heeft' met de hiervoor besproken wetgeving. ${ }^{101}$ Interessant voor mijn onderzoek is, dat de regering hierin echter geen aanleiding ziet tot het beantwoorden van de wetssystematische vraag of de genoemde wetten geheel of gedeeltelijk een plaats zouden moeten krijgen in de Wms.

Het gaat het bestek van mijn onderzoek te buiten om zelf een antwoord te geven op die vraag. Feit is wel dat als sprake mocht zijn van wetssystematische tekorten, die door de integratie van de Wms in de Wet milieubeheer op 31 mei 2008 niet zijn opgeheven.

De wetgever heeft die mogelijke wetssystematische tekorten zelfs uitdrukkelijk in stand gelaten door de volgende leden toe te voegen aan artikel 22.1 Wm:

a. Titel 9.2 Wm en Titel 9.3 Wm zijn niet van toepassing op gedragingen, voor zover daaromtrent regels zijn gesteld bij of krachtens de Wet op de geneesmiddelenvoorziening, de Bestrijdingsmiddelenwet 1962 of de Diergeneesmiddelenwet. ${ }^{102}$

98 Op 22 december 2009 vervallen met de inwerkingtreding van de Waterwet (art. 2.1 Invoeringswet Waterwet, Stb. 2009, 489 en 549).

99 Op 22 december 2009 vervallen met de inwerkingtreding van de Waterwet (art. 2.1 Invoeringswet Waterwet, Stb. 2009, 489 en 549).

100 Op 1 maart 1993 (Stb. 1993, 59) vervallen met inwerkingtreding van de Wet milieubeheer (art. XVIII Wet van 2 juli 1992, Stb. 1992, 414, tot uitbreiding en wijziging van de Wet algemene bepalingen milieuhygiëne en daarmee samenhangende wijzigingen van andere wetten (vergunningen en algemene regels voor inrichtingen; procedures voor vergunningen en ontheffingen; handhaving).

101 Kamerstukken II 1980/81, 16 800, nr. 3, p. 10-11.

102 Art. 22.1 lid 4 (oud) Wm. 
b. Titel $9.2 \mathrm{Wm}$ laat het met betrekking tot stoffen of preparaten bij of krachtens de Kernenergiewet bepaalde onverlet. ${ }^{103}$

c. Titel 9.2 Wm is niet van toepassing op het vervoeren, het ten vervoer aanbieden en het ten vervoer aannemen, het laden en het lossen en het nederleggen tijdens het vervoer van stoffen, preparaten of micro-organismen, alsmede op het laten staan en het laten liggen van een vervoermiddel waarin of waarop zich zodanige stoffen, preparaten of micro-organismen of resten daarvan bevinden, voorzover daaromtrent regels zijn gesteld bij of krachtens de Wet vervoer gevaarlijke stoffen of de Wet luchtvaart. In afwijking van de eerste volzin is titel 9.2 van toepassing met betrekking tot de verpakking van micro-organismen, zijnde genetisch gemodificeerde organismen, indien die organismen zich bij de handelingen, bedoeld in de eerste volzin, niet bevinden in een verpakking die voldoet aan de regels die terzake zijn gesteld bij of krachtens de Wet vervoer gevaarlijke stoffen of de Wet luchtvaart. ${ }^{104}$

d. Krachtens Titel 9.2 Wm worden geen regels gesteld met betrekking tot het zich ontdoen van stoffen en preparaten door het brengen daarvan in oppervlaktewateren, voor zover in het stellen van zodanige regels is voorzien door het vaststellen van grenswaarden krachtens artikel 1a van de Wet verontreiniging oppervlaktewateren of daarvoor een verbod geldt krachtens artikel 3 van de Wet verontreiniging zeewater. ${ }^{105}$

Deze bepalingen zijn per 1 januari 2012 mutatis mutandis ${ }^{106}$ nog steeds opgenomen in artikel $22.1 \mathrm{Wm}$.

\subsubsection{Antwoord op toetsvraag 2}

De integratie van de Wms in de Wet milieubeheer heeft het in paragraaf 5.3 beschreven wetssystematisch tekort opgeheven. Dit is gerealiseerd door alle bepalingen in de Wms die niet behoefden te vervallen op te nemen in de Wet milieubeheer. Daarmee is de tweede toetsvraag positief beantwoord. Daaraan doet niet af dat mogelijke andere ten tijde van de integratie bestaande wetssystematische tekorten niet zijn verminderd. Bij het gegeven antwoord past wel de belangrijke kanttekening dat het op 31 mei 2008 bestaande wetssystematisch tekort een jaar eerder door de wetgever zelf was geschapen door REACH niet in de Wms, doch in hoofdstuk $9 \mathrm{Wm}$ te implementeren. Hoewel daarvoor nader onderzoek nodig zou zijn, is het niet onwaarschijnlijk dat de uitvoering van REACH in de Wms niet zou hebben geleid tot het in paragraaf 5.3 geconstateerde wetssystematische tekort.

103 Art. 22.1 lid 5 (oud) Wm

104 Art. 22.1 lid 6 (oud) Wm

105 Art. 22.1 lid 7 (oud) Wm

106 Een aantal wetten is inmiddels vervangen; zo wordt in art. 22.1 lid 7 niet langer verwezen naar art. 3 Wet verontreiniging zeewater, maar naar art. 6.6 jo. 6.2 of $6.3 \mathrm{Wtw}$. 


\subsection{WETSSYSTEMATISCHE TEKORTEN VANWEGE TYPISCH JURIDISCHE ORDENINGSCRITERIA}

\subsubsection{Algemeen}

In deze paragraaf zal de vraag worden beantwoord of het gebruik van typisch juridische ordeningscriteria in de Wet milieubeheer heeft geleid tot wetssystematische tekorten en zo ja, of deze tekorten verdedigbaar zijn.

\subsubsection{Indeling ${ }^{107}$}

\subsubsection{Interne wetssystematische tekorten}

In paragraaf 5.2.3 is reeds toegelicht dat de bepalingen van de Wms die niet zijn vervallen als gevolg van de integratie van de Wms in de Wet milieubeheer op 1 juni 2008 zijn overgeheveld naar hoofdstuk 1 Algemeen, hoofdstuk 9 Stoffen en produkten, hoofdstuk 17 Maatregelen in bijzondere omstandigheden, hoofdstuk 21 Verdere bepalingen en hoofdstuk 22 Slotbepalingen van de Wet milieubeheer 'naar gelang het onderwerp van de desbetreffende bepalingen. ${ }^{108}$

Hier is sprake van een intern wetssystematisch tekort, aangezien de bepalingen inzake stoffen verspreid staan over vijf subwetssystemen binnen de Wet milieubeheer. $\mathrm{Nu}$ zou men wellicht kunnen tegenwerpen, dat de bepalingen in de Wms vóór de integratie ook verspreid stonden over de subwetssystemen van de hoofdstukken 1 Algemeen, 2 Kennisgeving, 3 Onderzoek, 4 Maatregelen, $6^{109}$ Beroep op de administratieve rechter, 7 Handhaving, 8 Verdere bepalingen en 9 Slotbepalingen van de Wet milieubeheer. Dat is juist, maar er is toch een belangrijk verschil. De bepalingen in die laatste subwetssystemen hadden immers allemaal uitsluitend betrekking op stoffen. Na integratie is de gebruiker gedwongen om de relevante bepalingen inzake stoffen te zoeken in subwetssystemen die ook betrekking hebben op stoffen. Dat is de kenbaarheid niet ten goede gekomen.

Ter illustratie noem ik artikel 17.19 Wm dat betrekking heeft op maatregelen bij gevaar door stoffen, preparaten of genetisch gemodificeerde organismen. Deze bepaling is op 1 januari 2008 als artikel $17.6 \mathrm{Wm}$ opgenomen als equivalent van met name artikel $40 \mathrm{Wms}$. Dat artikel vormde het enige artikel in paragraaf 4.3 Wm Maatregelen in bijzondere omstandigheden in hoofdstuk $4 \mathrm{Wms}$, dat uitsluitend van toepassing was op stoffen. Hoofdstuk $17 \mathrm{Wm}$ gaat ook over stoffen (Titel 17.3 Wm), maar bevat eveneens bepalingen inzake maatregelen bij

\footnotetext{
107 Par. 3.4.4.1

108 Kamerstukken II 2005/06, 30 600, nr. 3, p. 18.

109 Per 1 april 1988 is het enige artikel in hfds. 5 Wms vervallen.
} 
een ongewoon voorval (Titel 17.1 Wm), maatregelen betreffende afvalvoorzieningen (Titel 17.1A Wm) en maatregelen bij milieuschade of een onmiddellijke dreiging daarvan (Titel 17.2 Wm). Dat is zoals gezegd de kenbaarheid niet ten goede gekomen.

\subsubsection{Externe wetssystematische tekorten}

\section{Openbaarheidsregels}

Als gevolg van de integratie van de Wms in de Wet milieubeheer is artikel 56 Wms, dat een regeling gaf inzake de geheimhouding van bedrijfsgegevens die krachtens de Wms aan de overheid worden overgelegd, komen te vervallen. De regering rechtvaardigt dat door op te merken dat naast de Wet openbaarheid van bestuur ook hoofdstuk $19 \mathrm{Wm}$ van toepassing wordt op stoffen, preparaten en genetisch gemodificeerde organismen. ${ }^{110}$ Vanuit wetssystematisch oogpunt gezien is hier echter niet alleen sprake van een intern wetssystematisch tekort in de zin zoals hiervoor in paragraaf 5·5.2.1 besproken, maar eveneens van een extern wetssystematisch tekort, aangezien de regels inzake de openbaarheid inzake stoffen per 1 juni 2008 ook moeten worden gezocht in de Wet openbaarheid van bestuur.

\section{Economische delicten}

Een ander extern wetssystematisch tekort betreft het feit dat de regels inzake strafbedreiging bij overtreding van bepalingen die voor de integratie in de Wms stonden is geregeld in het wetssysteem van de Wet op de economische delicten. Dit extern wetssystematisch tekort is evenwel niet veroorzaakt door de integratie. De strafbedreiging van overtreding van bepalingen in de Wms vond tot het moment van integratie immers al plaats in de Wet op de economische delicten. ${ }^{111}$

\subsubsection{Verdedigbaarheid wetssystematische tekorten}

Mij lijkt dat het de kenbaarheid van regels inzake stoffen zou hebben vergroot als de integratie van de Wms geheel zou hebben plaatsgevonden in het subwetssysteem van hoofdstuk $9 \mathrm{Wm}$. Die situatie zou de wetssystematische situatie voorafgaande aan de integratie het meest hebben benaderd. Er is naar mijn oordeel geen logische aanleiding - en de regering noemt die ook niet in de memorie van toelichting bij de Uitvoeringswet EG-verordening REACH $^{112}$ - om de naar de hoofdstukken 17 en 22 overgehevelde bepalingen van de Wms niet op te nemen in hoofdstuk $9 \mathrm{Wm}$. Die bepalingen hebben

110 Kamerstukken II 2005/06, 30 600, nr. 3, p. 18

111 Art. 1a lid 1 onder $1^{\circ}$ en $2^{\circ}$ Wed.

112 Kamerstukken II 2005/06, 30 600, nr. 3. 
immers slechts betrekking op de materie die in hoofdstuk $9 \mathrm{Wm}$ is geregeld. Het lijkt mij voor de gebruiker van dat hoofdstuk bijvoorbeeld logischer als hij de regels inzake maatregelen bij gevaar door stoffen en de gevallen waarin onderdelen van hoofdstuk $9 \mathrm{Wm}$ niet van toepassing zijn leest in het subwetssysteem van hoofdstuk $9 \mathrm{Wm}$. De interne wetssystematische tekorten als gevolg van het overhevelen van bepalingen uit de Wms naar de hoofdstukken 17 en $22 \mathrm{Wm}$ acht ik derhalve niet verdedigbaar. De wetgever kan eenvoudig een einde maken aan die tekorten door de desbetreffende regels alsnog op te nemen in hoofdstuk $9 \mathrm{Wm}$.

De overige hiervoor gesignaleerde interne en externe wetssystematische tekorten acht ik echter wel verdedigbaar. Zo geldt de definitie van stoffen in hoofdstuk $1 \mathrm{Wm}$ niet slechts voor hoofdstuk $9 \mathrm{Wm}$. Ook de regels voor de totstandkoming van algemene maatregelen van bestuur en ministeriële regelingen (hoofdstuk $21 \mathrm{Wm}$ ) zijn niet beperkt tot hoofdstuk $9 \mathrm{Wm}$. Voorts is de uniformiteit van het recht gediend met een regeling als de Wet op de economische delicten en regels inzake openbaarheid in de Wet milieubeheer en de Wet openbaarheid van bestuur.

De verdedigbaarheid van genoemde wetssystematische tekorten wil echter niet zeggen dat de wetgever de kenbaarheid van hoofdstuk $9 \mathrm{Wm}$ niet zou kunnen verbeteren door daarin een leeswijzer op te nemen die de gebruiker van dit hoofdstuk op het spoor zet van de bepalingen in de Wet milieubeheer die betrekking hebben op stoffen waarover hoofdstuk $9 \mathrm{Wm}$ gaat. Zo'n leeswijzer zou er als volgt uit kunnen zien.

Artikel y. Ten aanzien van stoffen kunnen de volgende bepalingen van deze wet eveneens van toepassing zijn:

a. de van een * voorziene definities stoffen in hoofdstuk 1;

b. titel 17.3 Maatregelen bij gevaar door stoffen, preparaten of genetisch gemodificeerde organismen;

c. hoofdstuk 19 Openbaarheid van milieu-informatie;

d. artikel 22.1 lid 4-10.

\subsubsection{Algemeen en bijzonder}

\subsubsection{Algemeen}

In het subwetssysteem van Titel $9.2 \mathrm{Wm}$, waarin de meeste bepalingen van de Wms zijn overgeheveld, is het typisch juridisch ordeningscriterium algemeen-bijzonder ${ }^{113}$ gebruikt. 


\subsubsection{Wetssystematische tekorten}

Paragraaf 9.2.1 Wm bevat algemene bepalingen, paragraaf 9.2.2 Wm bijzondere bepalingen inzake maatregelen en paragraaf 9.2.3 Wm bijzondere bepalingen inzake verpakking, aanduiding en aanbeveling.

Hier is sprake van een intern wetssystematisch tekort. ${ }^{114}$ Zo moet degene die beroepshalve een stof, preparaat of genetisch gemodificeerd organisme aan een ander ter beschikking stelt drie subwetssystemen raadplegen om zijn rechten en plichten te kennen.

\footnotetext{
In het subwetssysteem van paragraaf 9.2.1 Wm geldt voor hem de in artikel 9.2.1.2 Wm opgenomen zorgplicht.

Het subwetssysteem van paragraaf 9.2.2 Wm dient hij te raadplegen om erachter te komen welke regels in een algemene maatregel van bestuur kunnen worden opgenomen.

Volgens het subwetssysteem van paragraaf 9.2.3 Wm gelden voor hem onder meer regels ten aanzien van de verpakking.
}

\subsubsection{Verdedigbaarheid wetssystematische tekorten}

Mij lijkt het hiervoor gesignaleerde wetssystematisch tekort niet verdedigbaar. In wezen bevat Titel $9.2 \mathrm{Wm}$ drie categorieën van bepalingen. In de eerste plaats gaat het om een bepaling als artikel 9.2.1.1 Wm die regelt in welke gevallen Titel $9.2 \mathrm{Wm}$ en de daarop berustende bepalingen niet van toepassing zijn. Het leeuwendeel van de bepalingen is gericht tot de overheid en betreft een algemene maatregel van bestuur, vrijstelling of ontheffing. Een bescheiden deel van de bepalingen richt zich tot burgers en bedrijven. Deze bepalingen staan echter verspreid over de drie paragrafen van Titel 9.2 Wm. Daarbij is niet altijd duidelijk waarom een bepaling is opgenomen in de ene of in een andere paragraaf.

Mij lijkt dat een andere indeling die niet loopt langs de lijnen van het ordeningscriterium algemeen-bijzonder de kenbaarheid ten goede zou komen. In paragraaf 9.2.1 Wm Reikwijdte zou artikel 9.2.1.1 Wm kunnen worden opgenomen. In paragraaf 9.2.2 Wm Handelingen met stoffen zouden bepalingen als artikel 9.2.1.2, 9.2.1.3 en 9.2.3.1 Wm een plaats kunnen krijgen. In paragraaf 9.2.3 Wm Uitvoeringsregels zouden dan alle bepalingen kunnen worden opgenomen die betrekking hebben op algemene maatregelen van bestuur. Met deze indeling zou een beroepsmatige gebruiker voor het antwoord op zijn vraag welke rechten en verplichtingen gelden zich veelal kunnen beperken tot het raadplegen van paragraaf 9.2.2 Handelingen met stoffen, dat een beperkt aantal artikelen zal bevatten. Uiteraard zal hij ook de relevante algemene maatregelen van bestuur dienen te raadplegen, maar in dat verband 
zal hij paragraaf 9.2.3 Wm Uitvoeringsregels slechts behoeven te raadplegen als hij meent dat een algemene maatregel van bestuur niet strookt met die paragraaf.

\subsubsection{Gelede normstelling}

\subsubsection{Algemeen}

In hoofdstuk $9 \mathrm{Wm}$ is ook gebruik gemaakt van het typisch juridische ordeningscriterium van de gelede normstelling. ${ }^{115}$ Dit hoofdstuk bevat een groot aantal artikelen dat de basis vormt voor het stellen van uitvoeringsregels bij of krachtens algemene maatregel van bestuur. Dat geldt ook voor Titel 9.2 Wm, die is ontstaan als gevolg van de integratie op 1 juni 2008. Hieronder een kort overzicht, waarbij gebruik is gemaakt van Titel $9.2 \mathrm{Wm}$ zoals die luidde op 1 juni 2008. ${ }^{116}$

Artikel 9.2.1.3 Wm bepaalt dat een ieder die beroepshalve een stof, preparaat of genetisch gemodificeerd organisme vervaardigt, in Nederland invoert, toepast, bewerkt, verwerkt of aan een ander ter beschikking stelt, desgevraagd aan Onze Minister gegevens verstrekt over die stof of dat preparaat of organisme waarover hij beschikt of redelijkerwijs kan beschikken (lid 1). Bij algemene maatregel van bestuur kunnen nadere regels worden gesteld met betrekking tot de in het eerste lid bedoelde gegevens (lid 2).

Artikel 9.2.1.4 Wm bepaalt dat bij algemene maatregel van bestuur kan worden bepaald dat degene die beroepshalve stoffen, preparaten of genetisch gemodificeerde organismen vervaardigt, in Nederland invoert, toepast, bewerkt of verwerkt, in daarbij aangegeven categorieën van gevallen een administratie bijhoudt van de hoeveelheden die hij daarvan heeft vervaardigd, in Nederland heeft ingevoerd, heeft toegepast, bewerkt of verwerkt of aan een ander ter beschikking heeft gesteld (lid 1). Bij of krachtens de maatregel worden regels gesteld met betrekking tot de wijze waarop de administratie wordt bijgehouden en kunnen andere gegevens worden aangewezen die in de administratie dienen te worden opgenomen (lid 2).

Artikel 9.2.1.5 Wm bepaalt dat bij algemene maatregel van bestuur in het belang van de landsverdediging vrijstelling kan worden verleend van de in de artikelen 9.2.3.1, 9.2.3.3, 9.3.3 of 9.3a.3 gestelde verplichtingen (lid 1).

Artikel 9.2.2.1 Wm bepaalt dat, indien een redelijk vermoeden is gerezen dat door handelingen met stoffen, preparaten of genetisch gemodificeerde organismen ongewenste effecten voor de gezondheid van de mens of voor het milieu zullen ontstaan, bij algemene maatregel van bestuur regels kunnen worden gesteld met betrekking tot het vervaardigen, in Nederland invoeren, toepassen,

115 Paragraaf 3.4.4.3.

116 Art. 9.2.2.6a Wm is daarin niet opgenomen, aangezien dat niet het gevolg is geweest van de integratie op 1 juni 2008. 
bewerken, verwerken, voorhanden hebben, aan een ander ter beschikking stellen, vervoeren, uitvoeren en zich ontdoen van deze stoffen, preparaten of organismen (lid 1). Onze Minister kan omtrent in een maatregel krachtens het eerste lid geregelde onderwerpen nadere regels stellen (lid 3).

Artikel 9.2.2.2 Wm bepaalt dat een algemene maatregel van bestuur waarbij toepassing is gegeven aan artikel 9.2.2.1, tweede lid, onder b, d, g, i, j, k, l of m, tevens de verplichting kan inhouden te voldoen aan door bestuursorganen die bij de maatregel zijn aangewezen, omtrent onderwerpen die in de maatregel zijn geregeld, gestelde nadere eisen.

Artikel 9.2.2.3 Wm bepaalt dat indien toepassing wordt gegeven aan artikel 9.2.2.1, tweede lid, onder c, tevens bij algemene maatregel van bestuur regels worden gesteld betreffende de wijze waarop de aanvraag om een vergunning geschiedt, en de gegevens die van de aanvrager kunnen worden verlangd (lid 1).

Artikel 9.2.2.4 Wm bepaalt dat indien toepassing wordt gegeven aan artikel 9.2.2.1, tweede lid, onder g, Onze Minister de instantie aanwijst, die de in die bepaling bedoelde keuring verricht. Bij de maatregel worden regels gesteld ten aanzien van de wijze waarop een zodanige keuring plaatsheeft.

Artikel 9.2.2.5 Wm bepaalt dat indien toepassing wordt gegeven aan artikel 9.2.2.1, tweede lid, onder $\mathrm{k}, \mathrm{l}$ of $\mathrm{m}$, tevens kan worden bepaald dat de schade, geleden door degene die de stoffen, preparaten, genetisch gemodificeerde organismen of producten moet terugzenden of afgeven, of de kosten, gemaakt door degene die is aangewezen om die stoffen, preparaten, organismen of producten in te zamelen, ten laste kunnen worden gebracht van degenen die deze stoffen, preparaten, organismen of producten hebben vervaardigd of in Nederland ingevoerd. Daarbij kunnen tevens regels worden gesteld inzake de berekening van die schade of kosten en de bepaling van degenen ten laste van wie die schade of kosten worden gebracht.

Artikel 9.2.2.6 Wm bepaalt dat indien de verwachte of gebleken effecten van stoffen, preparaten of genetisch gemodificeerde organismen op de gezondheid van de mens of op het milieu het stellen van regels als bedoeld in artikel 9.2.2.1, eerste lid, naar het oordeel van Onze Minister dringend noodzakelijk maken en naar zijn oordeel de totstandkoming van een algemene maatregel van bestuur krachtens dat artikel niet kan worden afgewacht, kan hij een besluit nemen van de in dat lid bedoelde strekking. Onze Minister neemt een zodanig besluit in overeenstemming met Onze Ministers wie het mede aangaat, tenzij de vereiste spoed zich daartegen naar zijn oordeel verzet. De artikelen 9.2.2.2 tot en met 9.2.2.5 zijn van overeenkomstige toepassing (lid 1). Een ministeriële regeling als bedoeld in het eerste lid vervalt een jaar nadat zij in werking is getreden of indien binnen die termijn een algemene maatregel van bestuur ter vervanging van die regeling in werking is getreden, op het tijdstip waarop die maatregel in werking treedt. De termijn kan bij ministeriële regeling eenmaal met ten hoogste een jaar worden verlengd (lid 2).

Artikel 9.2.3.1 Wm bepaalt dat degene die een preparaat aan een ander ter beschikking stelt of in Nederland invoert, behorende tot een of meer van de in het tweede lid aangewezen categorieën, er zorg voor draagt dat dat preparaat bij de aflevering en bij het ter aflevering voorhanden hebben is verpakt en op de 
verpakking is aangeduid overeenkomstig het bepaalde bij of krachtens de artikelen van deze paragraaf (lid 1). Lid 2 noemt als categorieën ontplofbaar, oxiderend, zeer licht ontvlambaar, licht ontvlambaar, ontvlambaar, zeer vergiftig, vergiftig, schadelijk, bijtend, irriterend, sensibiliserend, kankerverwekkend, mutagen, voor de voortplanting vergiftig en milieugevaarlijk. Bij of krachtens algemene maatregel van bestuur worden de criteria en methoden aangewezen volgens welke wordt bepaald of een stof of preparaat behoort tot een categorie als bedoeld in het tweede lid (lid 3). Bij of krachtens algemene maatregel van bestuur kunnen regels worden gesteld met betrekking tot de aanduiding van preparaten waarvan nog niet is bepaald in hoeverre zij behoren tot een of meer van de in het tweede lid bedoelde categorieën (lid 4).

Artikel 9.2.3.2 Wm bepaalt dat bij of krachtens algemene maatregel van bestuur regels kunnen worden gesteld met betrekking tot de aanduiding van preparaten waarin daarbij aangewezen stoffen voorkomen, alsmede met betrekking tot de aanduiding van producten waarin daarbij aangewezen stoffen of preparaten voorkomen. Daarbij kan worden bepaald dat die regels slechts gelden in daarbij aangewezen gevallen.

Artikel 9.2.3.3 Wm bepaalt dat bij of krachtens algemene maatregel van bestuur met betrekking tot de verpakking en sluiting regels kunnen worden gesteld. Daarbij kan worden bepaald dat die regels slechts gelden voor daarbij aangewezen preparaten of genetisch gemodificeerde organismen of categorieën daarvan of in daarbij aangewezen gevallen (lid 4).

Artikel 9.2.3.5 Wm bepaalt dat bij of krachtens algemene maatregel van bestuur kan worden bepaald dat in daarbij aangewezen gevallen de artikelen 9.2.3.1, 9.2.3.3 en 9.2.3.4 geheel of voor een daarbij te bepalen gedeelte niet van toepassing zijn: a. ter uitvoering van een krachtens het Verdrag betreffende de oprichting van de Europese Unie tot stand gekomen bindende regeling of b. indien het belang van de bescherming van de gezondheid van de mens en van het milieu zich daartegen niet verzet (lid 1). Bij of krachtens een maatregel als bedoeld in het eerste lid kunnen regels worden gesteld met betrekking tot de in de artikelen 9.2.3.1, 9.2.3.3 en 9.2.3.4 geregelde onderwerpen (lid 2).

\subsubsection{Algemene maatregelen van bestuur}

De hier geboden delegatiegrondslagen hebben niet in alle gevallen ${ }^{117}$ geleid tot algemene maatregelen van bestuur. Uit www.overheid.nl volgt op 20 november $2011^{118}$ het in overzicht 5.2 opgenomen overzicht van algemene maatregelen van bestuur. Een aantal algemene maatregelen van bestuur is gebaseerd op meer dan één delegatiebepaling. Waar geen algemene maatregel(en) van bestuur is/zijn vermeld, was op genoemde datum nog geen gebruik gemaakt van de delegatiegrondslag.

117 Op art. 9.2.1.3, 9.2.1.5, 9.2.2.4, 9.2.2.5, 9.2.2.6, 9.2.2.7 Wm waren op 20 november 2011 geen amvb's gebaseerd.

118 Om die reden is ook art. 9.2.2.6a Wm opgenomen. 
Overzicht 5.2 AMvB's op basis van artikelen in Titel 9.2 Wm

\begin{tabular}{|c|c|}
\hline Algemene maatregel van bestuur & $\begin{array}{l}\text { Delegatiegrondslag } \\
\text { (Wm) }\end{array}$ \\
\hline Aanpassingsbesluit veiligheidsregio's & $9.2 .2 .1,9.2 .2 .3,9.2 .3 .2$ \\
\hline Administratiebesluit milieugevaarlijke stoffen en preparaten & 9.2 .1 .4 \\
\hline Asbestverwijderingsbesluit 2005 & $9.2 .2 .1,9.2 .3 .2,9.2 .3 .3$ \\
\hline Besluit asbestwegen milieubeheer & 9.2 .2 .1 \\
\hline Besluit beheer elektrische en elektronische apparatuur & 9.2.2.1 \\
\hline Besluit beheer winningsafvalstoffen & 9.2.2.1 \\
\hline Besluit bodemkwaliteit & 9.2.2.1 \\
\hline Besluit brandstoffen luchtverontreiniging & $9.2 .2 .1,9.2 .3 .2,9.2 .2 .6 \mathrm{a}$ \\
\hline Besluit broeikasgassen in apparatuur op schepen Wms 2003 & 9.2 .2 .1 \\
\hline Besluit detergentia Wms & 9.2.2.1, 9.2.3.2 \\
\hline Besluit externe veiligheid buisleidingen & 9.2 .2 .1 \\
\hline Besluit gechloreerde paraffines milieubeheer & 9.2.2.1 \\
\hline Besluit gefluoreerde broeikasgassen Wms 2007 & $9.2 .2 .1,9.2 .3 .2$ \\
\hline Besluit genetisch gemodificeerde organismen Wms & $9.2 .2 .1,9.2 .2 .3,9.2 .3 .2$ \\
\hline Besluit gewasbeschermingsmiddelen en biociden & 9.2.2.1 \\
\hline Besluit hernieuwbare energie vervoer & 9.2.2.1, 9.2.2.6a \\
\hline Besluit kleiduivenschieten Wms & 9.2 .2 .1 \\
\hline Besluit kwik en kwikhoudende producten milieubeheer & 9.2.2.1 \\
\hline Besluit melden bedrijfsafvalstoffen en gevaarlijke afvalstoffen & 9.2 .2 .1 \\
\hline Besluit met arseenverbindingen behandeld hout milieubeheer & 9.2.2.1, 9.2.3.2 \\
\hline Besluit organisch-halogeengehalte van brandstoffen & 9.2 .2 .1 \\
\hline Besluit organische oplosmiddelen in verven en vernissen Wms & 9.2.2.1, 9.2.3.2 \\
\hline Besluit PAK-houdende coatings en producten Wms 2003 & $9.2 .2 .1,9.2 .3 .2$ \\
\hline $\begin{array}{l}\text { Besluit uitvoering verordening in- en uitvoer gevaarlijke che- } \\
\text { mische stoffen milieubeheer } 2008\end{array}$ & 9.2.2.1 \\
\hline $\begin{array}{l}\text { Besluit verpakking en aanduiding milieugevaarlijke stoffen en } \\
\text { preparaten }\end{array}$ & $\begin{array}{l}9.2 \cdot 3 \cdot 1,9.2 \cdot 3 \cdot 2,9.2 \cdot 3 \cdot 3 \\
9.2 \cdot 3 \cdot 5\end{array}$ \\
\hline POP-besluit Wms & 9.2 .2 .1 \\
\hline Productenbesluit asbest & 9.2.2.1, 9.2.3.2 \\
\hline Uitvoeringsbesluit EG-verordening ozonlaagafbrekende stoffen & 9.2 .2 .1 \\
\hline Vuurwerkbesluit & $9.2 .1 .4,9.2 .2 .1,9.2 .3 .2$ \\
\hline Warenwetbesluit drukverpakkingen & $\begin{array}{l}\text { 9.2.3.1, 9.2.3.2, 9.2.3.3, } \\
\text { 9.2.3.5 }\end{array}$ \\
\hline
\end{tabular}




\subsubsection{Ministeriële regelingen}

De hier geboden delegatiegrondslagen hebben niet in alle gevallen geleid tot ministeriële regelingen. Uit www.overheid.nl volgde op 20 november 2011 het in overzicht 5.3 opgenomen overzicht van ministeriële regelingen. Eén regeling is gebaseerd op drie delegatiebepalingen.

Overzicht 5.3 Ministeriële regelingen op basis van artikelen in Titel 9.2 Wm

\begin{tabular}{|l|l|}
\hline Regeling & $\begin{array}{l}\text { Delegatiegrondslag } \\
\text { (Wm) }\end{array}$ \\
\hline Regeling aanwijzing consumenten- en theatervuurwerk & 9.2 .2 .1 \\
\hline Regeling beheer batterijen en accu's 2008 & 9.2 .2 .1 \\
\hline Regeling genetisch gemodificeerde organismen & 9.2 .2 .1 \\
\hline Regeling kleiduivenschieten Wms & 9.2 .2 .1 \\
\hline Regeling melden bedrijfsafvalstoffen en gevaarlijke afvalstoffen & 9.2 .2 .1 \\
\hline Regeling overige pyrotechnische artikelen & $9.2 .2 .1,9.2 .2 .4,9.2 .3 .2$ \\
\hline
\end{tabular}

\subsubsection{Verdedigbaarheid gelede normstelling}

Zoals uiteengezet in paragraaf 3.4.4.3 doorbreekt gelede normstelling het wetssystematische uitgangspunt dat alle regels in het omgevingsrecht die voldoen aan het samenhangcriterium in beginsel ook in hetzelfde wetssysteem moeten worden geregeld. In het geval van Titel $9.2 \mathrm{Wm}$ bestaat die doorbreking erin dat de regels inzake de bescherming van mens en milieu tegen stoffen niet allemaal zijn opgenomen in Titel $9.2 \mathrm{Wm}$ doch verspreid staan over Titel $9.2 \mathrm{Wm}, 30$ algemene maatregelen van bestuur en zes ministeriële regelingen. Daarbij zij opgemerkt dat de Wms een nagenoeg gelijke regeling van gelede normstelling kende.

De memorie van toelichting op de Uitvoeringswet EG-verordening $\mathrm{REACH}^{119}$ motiveert niet waarom voor gelede normstelling is gekozen, noch waarom is gekozen voor een driedeling, noch welke criteria gelden voor het opnemen van regels in een algemene maatregel van bestuur dan wel een ministeriële regeling. In de artikelsgewijze toelichting op de desbetreffende algemene maatregelen van bestuur en ministeriële regelingen lees ik die motivering evenmin.

De memorie van toelichting op de Wms biedt echter wel tot op zekere hoogte een antwoord op de vraag of en zo ja welke van de door Veerman genoemde

119 Kamerstukken II 2005/06, 30 600, nr. 3. 
overwegingen ${ }^{120}$ voor de wetgever aan de orde zijn geweest. De regering merkt daarin op: 'Welke maatregelen in een concreet geval nodig zijn, kan nu nog niet met zekerheid vastgesteld worden. De omstandigheden waaronder de gevaren van een stof of preparaat zich kunnen manifesteren vragen om gerichte maatregelen die zo nodig snel aan veranderende omstandigheden of inzichten aangepast kunnen worden. Kenmerkend voor de problematiek van de milieugevaarlijke stoffen is, dat de gevaren voor mens en milieu zich op velerlei, vaak onverwachte wijze manifesteren. ${ }^{121}$

Op zichzelf laat de gelede normstelling zich op basis van de door de regering genoemde argumentatie wel verdedigen. Daarbij komt nog dat het opnemen van alle in algemene maatregelen van bestuur en ministeriële regelingen opgenomen uitvoeringsregels in Titel $9.2 \mathrm{Wm}$ de overzichtelijkheid van dat subwetssysteem niet ten goede zou komen.

Dat neemt echter niet weg dat de wetgever niet heeft gemotiveerd waarom is gekozen voor een driedeling in Wet milieubeheer, algemene maatregel van bestuur en ministeriële regeling. Zo lijkt het mij bijvoorbeeld verdedigbaar om de regels die thans in de Regeling kleiduivenschieten Wms (zes korte artikelen) ${ }^{122}$ zijn opgenomen te integreren in het Besluit kleiduivenschieten Wms (zes korte artikelen), ${ }^{123}$ zodat de gebruiker slechts de wetssystemen van Titel 9.2 Wm en het Besluit kleiduivenschieten Wms behoeft te raadplegen. De korte Regeling betreft een uitvoering van artikel 3 van het Besluit. ${ }^{124}$

\subsubsection{Antwoord op toetsvraag 3}

Bij de integratie van de Wms in de Wet milieubeheer is gebruik gemaakt van typisch juridische ordeningscriteria als indeling, algemeen-bijzonder en gelede normstelling. Dat heeft geleid tot het scheppen of laten voortduren van wetssystematische tekorten. De gesignaleerde tekorten zijn in de meeste gevallen verdedigbaar, zij het dat de wetgever een aantal tekorten op eenvoudige wijze zou kunnen verminderen. Daarmee is de derde toetsvraag overwegend positief beantwoord. Als antwoord op de derde deelvraag van dit onderzoek zijn per wetssystematisch tekort in een aantal gevallen suggesties gedaan om dat op te heffen of te verminderen.

120 Par. 3.4.4.3

121 Kamerstukken II 1980/81, 16 800, nr. 3, p. 50.

122 Stcrt. 2004, 237.

123 Stb. 2004, 237.

124 Art. 3 luidt als volgt: 1 . Het is verboden kleiduiven te gebruiken of voorhanden te hebben die bij regeling van Onze Minister aangewezen milieugevaarlijke stoffen bevatten in concentraties die de daarbij aangegeven waarden te boven gaan. 2. Bij de in het eerste lid bedoelde regeling worden tevens voorschriften gegeven voor het meten van de concentraties milieugevaarlijke stoffen. 


\subsection{WETSSYSTEMATISCHE TEKORTEN IN ANDERE WETSSYSTEMEN}

\subsubsection{Algemeen}

In paragraaf 5.4 is het voortbestaan van wetssystematische tekorten binnen het door integratie van de Wms in de Wet milieubeheer ontstane wetssysteem onderzocht. Daarnaast kan integratie in beginsel ook leiden tot wetssystematische tekorten die buiten het door bundeling ontstane wetssysteem zijn ontstaan als gevolg van de bundeling door integratie. $\mathrm{Nu}$ de bepalingen van de Wms, die niet behoefden te vervallen zijn overgenomen in de Wet milieubeheer is daarvan geen sprake.

Overigens is in dit verband nog wel interessant het antwoord van de regering op een op 16 februari 1978 - dus vóór de totstandkoming van de Wms - gestelde vraag van de vaste Commissie voor Milieuhygiëne welke grote praktische bezwaren er waren om te komen tot één breed opgezette wet voor alle gevaren in verband met chemische stoffen. ${ }^{125}$ De regering antwoordde dat in Nederland wel een wettelijk instrumentarium bestaat "waarmee ten aanzien van bepaalde aspecten, verbonden aan produktie en gebruik van chemische stoffen regelend kan worden opgetreden. (...) Het samenbrengen van al deze regelingen in slechts één breed opgezette wet voor alle gevaren in verband met chemische stoffen zou inhouden dat bestaande ministeriële verantwoordelijkheden, procedures, ambtelijke organisatiestructuren en dergelijke op ingrijpende wijze moeten veranderen. De systematiek van bestaande wetten, waaraan onderdelen die verband houden met een beleid inzake chemische stoffen worden onttrokken, kan verstoord raken. Het voordeel van samenbrengen enerzijds is noodzakelijkerwijs gekoppeld aan het bezwaar van verbrokkeling elders. ${ }^{\text {'126 }}$

\subsubsection{Antwoord op toetsvraag 4}

De integratie van de Wms in de Wet milieubeheer heeft niet geleid tot het ontstaan van wetssystematische tekorten buiten de Wet milieubeheer. Daarmee is de vierde toetsvraag positief beantwoord.

\subsection{WETSSYSTEEM TOEKOMSTBESTENDIG}

\subsubsection{Algemeen}

In deze paragraaf zal de vraag worden beantwoord of het wetssysteem van de Wet milieubeheer ten aanzien van stoffen na de integratie van de Wms daarin

125 Kamerstukken II 1977/78, 14800 XVII, nr. 12, p. 16.

126 Kamerstukken II 1977/78, 14800 XVII, nr. 14, p. 48. 
toekomstbestendig is. In paragraaf $3.6 \mathrm{heb} \mathrm{ik}$ een wetssysteem toekomstbestendig genoemd als daarbinnen geen nieuwe - onverdedigbare - wetssystematische tekorten ontstaan als gevolg van het feit dat de wetgever in belangrijke mate is gedwongen om een chronologische aanpak ${ }^{127}$ te hanteren.

Daarbij heb ik vier wetgevingstechnieken aangegeven die al dan niet in samenhang gebruikt naar mijn oordeel tot een - meer - toekomstbestendig wetssysteem kunnen leiden. Hierna zal ik onderzoeken in hoeverre deze technieken zijn gebruikt in het kader van de integratie van de Wms in de Wet milieubeheer, waarna ik zal aangeven of de Wet milieubeheer ten aanzien van stoffen toekomstbestendig mag worden genoemd.

\subsubsection{Op permanente opschoning gericht}

De wetgever heeft met de integratie van de Wms in de Wet milieubeheer niet een wetssysteem beoogd dat de pretentie heeft het omgevingsrecht ten aanzien van stoffen voor eens en altijd te codificeren. Veeleer is sprake van een opschoning van het omgevingsrecht in de vorm van een op permanente verandering toegesneden wetssystematiek, waarin nieuwe omgevingsregels van nationale of Europese oorsprong een plaats kunnen krijgen zonder nieuwe wetssystematische tekorten te veroorzaken. Een indicatie daarvoor zie ik met name in de in paragraaf 5.2.3 genoemde titels die na de integratie van de Wms in de Wet milieubeheer aan hoofdstuk 9 Wm zijn toegevoegd.

\subsubsection{Aansluiten bij wetssystematische criteria en opbouw}

Het subwetssysteem van hoofdstuk 9 Wm wordt bepaald door zakelijke en typisch juridische toekomstbestendige systeemordeningscriteria. ${ }^{128}$

Ten aanzien van de zakelijke ordeningscriteria wordt opgemerkt dat genoemd subwetssysteem wordt bepaald door het samenhangcriterium van 'stoffen met gevolgen voor het milieu of de gezondheid van de mens. ${ }^{129}$ Het betreft hier een open systeem in die zin dat nieuwe omgevingsregels van nationale of Europese oorsprong inzake stoffen eenvoudig een plaats kunnen krijgen in het wetssysteem van de Wet milieubeheer zonder dat zulks tot nieuwe wetssystematische tekorten leidt. Als gevolg van dit open systeem kon bijvoorbeeld per 4 november $2009^{130}$ Titel 9.3A Wm worden 
toegevoegd met daarin de implementatiebepalingen van de EG-verordening indeling, etikettering en verpakking van stoffen en mengsels. ${ }^{131}$ De wetssystematiek is daardoor niet gewijzigd.

Ten aanzien van de typisch juridische samenhangcriteria kan worden opgemerkt, dat de wetgever bij mogelijke toekomstige wijzigingen van hoofdstuk 9 Wm aan kan sluiten bij deze criteria zonder dat zulks tot nieuwe wetssystematische tekorten zal leiden.

\subsubsection{Geen aanbouwwetssysteem}

Hoofdstuk $9 \mathrm{Wm}$ is geen aanbouwwetssysteem in de zin dat een wetssystematiek is geschapen, waarvan de diverse onderdelen nog moeten worden ingevuld. Veeleer is, zoals hiervoor is opgemerkt, sprake van een open systeem waaraan de wetgever invulling kan geven. Uit de wetsgeschiedenis van de Wet milieubeheer blijkt ook dat zulks de bedoeling van de wetgever is geweest. In een nota van wijziging bij het wetsvoorstel Vergunningen en algemene regels (VAR) ${ }^{132}$ vermeldt de regering dat niet kan worden uitgesloten dat zich in de toekomst nieuwe onderwerpen voor regeling in de wet aandienen of dat ten aanzien van een bepaald onderwerp waarvoor nu ruimte wordt gereserveerd, uiteindelijk wordt geconcludeerd dat aan regeling ervan geen behoefte bestaat. ${ }^{133}$

\subsubsection{Antwoord op toetsvraag 5}

De integratie van de Wms in de Wet milieubeheer pretendeert niet het omgevingsrecht ten aanzien van stoffen voor eens en altijd vast te leggen, maar is juist gericht op permanente verandering. De toekomstbestendigheid wordt nog vergroot door het gebruik van toekomstbestendige zakelijke en typisch juridische systeemordeningscriteria, mits de wetgever bij toekomstige wijzigingen aansluit bij die criteria. Daarmee is de vijfde toetsvraag positief beantwoord.

131 EG-verordening indeling, etikettering en verpakking van stoffen en mengsels: verordening (EG) nr. 1272/2008 van het Europees Parlement en de Raad van de Europese Unie van 16 december 2008 betreffende de indeling, etikettering en verpakking van stoffen en mengsels tot wijziging en intrekking van de Richtlijnen 67/548/EEG en 1999/45/EG en tot wijziging van Verordening (EG) nr. 1907/2006 (PbEU 2008 L 353/1) (art. 1.1 Wm).

132 Uitbreiding en wijziging van de Wet algemene bepalingen milieuhygiëne en daarmee samenhangende wijzigingen van andere wetten (vergunningen en algemene regels voor inrichtingen; procedures voor vergunningen en ontheffingen; handhaving), Kamerstukken II 1989/90, 21 087, nr. 7, art. OOOO, p. 18.

133 Uitbreiding en wijziging van de Wet algemene bepalingen milieuhygiëne en daarmee samenhangende wijzigingen van andere wetten (vergunningen en algemene regels voor inrichtingen; procedures voor vergunningen en ontheffingen; handhaving), Kamerstukken II 1989/90, 21 087, nr. 7, art. OOOO, p. 30 . 


\subsection{SAMENVATting EN CONClUSie}

Per 1 juni 2008 is de Wms opgenomen in de Wet milieubeheer. ${ }^{134}$ Hier is sprake van bundeling door integratie. ${ }^{135}$ In hoofdstuk 5 is aan de hand van de in paragraaf 3.8 genoemde vijf toetsvragen onderzocht hoe deze bundeling zich verhoudt tot de in hoofdstuk 3 opgenomen wetenschappelijke criteria.

Het antwoord op de eerste toetsvraag is positief. Voor de integratie van de Wms in de Wet milieubeheer was binnen het omgevingsrecht sprake van een wetssystematisch tekort omdat niet alle regels die volgens het op de echte werkelijkheid gebaseerde zakelijk samenhangcriterium stoffen onderling samenhangen, deel uitmaakten van hetzelfde wetssysteem. Onder stoffen worden verstaan chemische elementen en hun verbindingen, zoals deze voorkomen in de natuur of door toedoen van de mens worden voortgebracht met gevolgen voor het milieu of de gezondheid van de mens.

Het antwoord op de tweede toetsvraag is eveneens positief. De integratie van de Wms in de Wet milieubeheer heeft het in paragraaf 5.3 beschreven wetssystematisch tekort opgeheven. Dit is gerealiseerd door alle bepalingen in de Wms die niet behoefden te vervallen op te nemen in de Wet milieubeheer. Daaraan doet niet af dat mogelijke andere wetssystematische tekorten ten tijde van de integratie onveranderd zijn gebleven. Bij het gegeven antwoord past wel de belangrijke kanttekening dat het op 31 mei 2008 bestaande wetssystematisch tekort een jaar eerder door de wetgever zelf was geschapen door REACH niet in de Wms, doch in hoofdstuk 9 van de Wet milieubeheer te implementeren. Hoewel daarvoor nader onderzoek nodig zou zijn, is het niet onwaarschijnlijk dat de uitvoering van REACH in de Wms niet zou hebben geleid tot het in paragraaf 5.3 geconstateerde wetssystematische tekort.

Het antwoord op de derde toetsvraag is overwegend positief. Bij de integratie van de Wms in de Wet milieubeheer is gebruik gemaakt van typisch juridische ordeningscriteria als indeling, algemeen-bijzonder en gelede normstelling. Dat heeft geleid tot het scheppen of laten voortduren van wetssystematische tekorten. De gesignaleerde tekorten zijn in de meeste gevallen verdedigbaar, zij het dat de wetgever een aantal tekorten op eenvoudige wijze zou kunnen opheffen of verminderen. Daarmee is de derde toetsvraag overwegend positief beantwoord. Als antwoord op de derde deelvraag van dit onderzoek zijn per wetssystematisch tekort in een aantal gevallen suggesties gedaan om dat op te heffen of te verminderen.

134 Stb. 2007, 181 en 182.

135 Zie par. 2.4.4. 
De vierde toetsvraag is negatief beantwoord, aangezien als gevolg van de integratie geen nieuwe wetssystematische tekorten zijn ontstaan buiten de Wet milieubeheer.

Toetsvraag vijf is positief beantwoord, aangezien de integratie van de Wms in de Wet milieubeheer niet pretendeert het omgevingsrecht ten aanzien van stoffen voor eens en altijd vast te leggen, maar juist is gericht op permanente verandering. De toekomstbestendigheid wordt nog vergroot door het gebruik van toekomstbestendige zakelijke en typisch juridische systeemordeningscriteria, mits de wetgever bij toekomstige wijzigingen aansluit bij die criteria.

Het feit dat de toetsvragen 1, 2 en 5 positief zijn beantwoord, toetsvraag 4 negatief en toetsvraag 3 overwegend positief, betekent dat de integratie van de Wms in de Wet milieubeheer een belangrijke bijdrage heeft geleverd aan het verminderen van tot 1 juni 2008 bestaande wetssystematische tekorten in het omgevingsrecht. Deze positieve antwoorden leiden in mijn toetsingskader tot de conclusie dat de integratie van de Wms in de Wet milieubeheer in de huidige vorm deels wel en deels niet voldoet aan de door mij ontwikkelde toetscriteria voor een verantwoorde bundeling. Dat betekent dat geen sprake is van een geheel verantwoorde bundeling. Verbeteringen zijn echter mogelijk, waarvoor in hoofdstuk 5 een aantal suggesties is gedaan. 


\section{$6 \quad$ Herschikking: Wet natuurbescherming}

'Toen moest er nog een hoofdstukje in over de Boswet. Toen ik dat allemaal had bekeken en zag hoe gedetailleerd het was, heb ik gezegd: daar heb ik geen zin in, zelfs al word ik ervoor betaald.'

Hans Woldendorp ${ }^{1}$

\subsection{INLEIDING}

Op 6 oktober 2011 is in het kader van een internetconsultatie een ontwerp gepubliceerd van een wetsvoorstel Regels over de bescherming van de natuur (Wet natuur) waarin de Natuurbeschermingswet 1998 (Nb-wet 1998), ${ }^{2}$ de Flora- en faunawet $(\mathrm{Ffw})^{3}$ en de Boswet (Bw) ${ }^{4}$ zijn opgenomen. ${ }^{5,6}$

In het kader van de internetconsultatie zijn als verwachte effecten van de regeling genoemd:

1. bescherming van de natuur, in overeenstemming met de Europese en internationale verplichtingen;

2. taken en verantwoordelijkheden uit het wetsvoorstel natuur worden dichter bij burger en ondernemer belegd (in principe bij de provincie);

Woldendorp, Interview 2011, bijl. 5.1, par. 8.1.

Wet van 25 mei 1998, houdende nieuwe regelen ter bescherming van natuur en landschap (Natuurbeschermingswet 1998), Stb. 1998, 403. Deze wet is gefaseerd in werking getreden, de eerste artikelen per 1 oktober 2005 (Stb. 2005, 473).

3 Wet van 25 mei 1998, houdende regels ter bescherming van in het wild levende planten- en diersoorten (Flora- en faunawet), Stb. 1998, 402. Deze wet is gefaseerd in werking getreden, de eerste artikelen op 2 juli 1999 (Stb. 1999, 264).

4 Wet van 20 juli 1961, houdende nieuwe bepalingen ter bewaring van bossen en andere houtopstanden (Stb. 1961, 256). Deze wet is in werking getreden op 1 juli 1962 (Stb. 1962, 193). www.internetconsultatie.nl/wetnatuur.

6 Zie voor een kritische bespreking van het ontwerp Wnb Kaajan, Gebiedsbescherming in het wetsvoorstel natuur 2011 en Meijer \& Zwier, Voorjaarsschoonmaak in het natuurbeschermingsrecht 2012. Volgens Kaajan is het ontwerp Wnb voor zover het de gebiedsbescherming betreft die voortvloeit uit de Vogelrichtlijn en de Habitatrichtlijn op papier een duidelijke vereenvoudiging en verbetering ten opzichte van de Nb-wet 1998. Meijer \& Zwier menen dat met het ontwerp Wnb een grote stap voorwaarts is gezet op het gebied van de leesbaarheid van de regelgeving ten opzichte van het huidige regime. 
3. onnodige belemmeringen voor economische en ruimtelijke ontwikkelingen worden opgeheven (programmatische aanpak) en

4. vermindering regeldruk voor burgers en bedrijven (met name vermindering administratieve lasten). ${ }^{7}$

Het betreft hier een voornemen tot modificerende ${ }^{8}$ bundeling door herschikking. ${ }^{9}$

Hoewel het ontwerp veel onderwerpen bestrijkt die nu reeds zijn geregeld in de Natuurbeschermingswet 1998, de Flora- en faunawet en de Boswet, ${ }^{10}$ is toch sprake van modificerende herschikking. Dat blijkt onder meer uit het vervallen van het in de Natuurbeschermingswet 1998 opgenomen beschermingsregime voor beschermde natuurmonumenten, uit het feit dat voor Natura 2000gebieden uitsluitend nog de instandhoudingsdoelstellingen gelden die voortvloeien uit de Vogelrichtlijn en de Habitatrichtlijn en het niet langer strafbaar stellen van niet-opzettelijke handelingen ten aanzien van soorten. ${ }^{11}$ Bij vogels zijn verstoringen bovendien niet langer strafbaar als de staat van instandhouding niet in gevaar komt. ${ }^{12}$

Het ontwerp beoogt samenhang te brengen door de wetssystemen van de Boswet, de Flora- en faunawet en de Natuurbeschermingswet 1998 geheel te laten opgaan in een nieuw wetssysteem (de Wet natuur), waarbij de drie genoemde wetssystemen worden ingetrokken. ${ }^{13}$ Inmiddels is uit contacten met het Ministerie van ELenI en de kabinetsbrief stelselwijziging omgevingsrecht duidelijk geworden dat het ontwerp is omgedoopt tot Wet natuurbescherming. Om die reden zal genoemd ontwerp in dit onderzoek als ontwerp Wet natuurbescherming (ontwerp Wnb) worden aangeduid. In hoofdstuk 6 zal aan de hand van de in paragraaf 3.8 genoemde vijf toetsvragen worden onderzocht hoe deze herschikking zich verhoudt tot de in hoofdstuk 3 opgenomen criteria.

Op 20 augustus 2012 is het wetsvoorstel Regels ter bescherming van de natuur (Wet natuurbescherming) aan de Tweede Kamer aangeboden. ${ }^{14}$ Het was in verband met de beschikbare tijd niet meer mogelijk hoofdstuk 6 op basis van dit wetsvoorstel geheel te herschrijven. Een vergelijking van het wetsvoorstel met het concept leert echter, dat de systematiek nagenoeg ongewijzigd is gebleven, zodat de conclusies in hoofdstuk 6 in belangrijke mate ook gelden voor het ingediende wetsvoorstel.

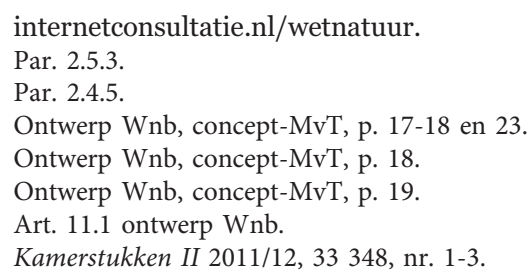


In paragraaf 6.2 zal eerst een korte indruk worden gegeven van elk van de drie te herschikken wetssystemen, alsmede van het ontwerp Wet natuurbescherming. Vervolgens worden in de paragrafen 6.3 tot en met 6.7 de vijf genoemde toetsvragen beantwoord. Afgesloten zal worden met een korte samenvatting en conclusie in paragraaf 6.8.

\subsection{DE NATUURWETGEVING IN HET KORT}

\subsubsection{Algemeen}

Hieronder volgt een korte beschrijving van elk van de drie te herschikken wetten $^{15}$ en van het ontwerp Wet natuurbescherming. Naar volledigheid is niet gestreefd. Het gaat er slechts om de lezer een globale indruk te geven van deze vier wetssystemen.

\subsubsection{Natuurbeschermingswet 1998}

De Natuurbeschermingswet 1998 bestaat uit de in overzicht 6.1 genoemde hoofdstukken.

\section{Overzicht 6.1 Hoofdstukken Natuurbeschermingswet 1998}

\begin{tabular}{|l|l|l|}
\hline I. $\begin{array}{l}\text { Inleidende } \\
\text { bepalingen }\end{array}$ & V. $\begin{array}{l}\text { Internationale } \\
\text { verplichtingen }\end{array}$ & IX. Omgevingsvergunning \\
\hline II. Natuurbeleidsplan & VI. Schadevergoeding & X. Toezicht \\
\hline $\begin{array}{l}\text { III. Beschermde } \\
\text { gebieden }\end{array}$ & VII. Beroep en \\
registratie & $\begin{array}{l}\text { XI. Slot- en overgangsbepa- } \\
\text { lingen }\end{array}$ \\
\hline $\begin{array}{l}\text { IV. Beschermde land- } \\
\text { schapsgezichten }\end{array}$ & $\begin{array}{l}\text { VIII. Procedure vergunning- } \\
\text { verlening }\end{array}$ & \\
\hline
\end{tabular}

De Natuurbeschermingswet 1998 is volledig in werking getreden op 1 oktober 2005.

De concept-MvT bij het ontwerp Wnb ${ }^{16}$ schetst de lange voorgeschiedenis en gefaseerde inwerkingtreding als volgt. Op 14 januari 1994 werd een wetsvoorstel aanhangig gemaakt ${ }^{17}$ dat heeft geresulteerd in de Natuurbeschermingswet 1998. Met het instrumentarium inzake de aanwijzing van natuurmonumenten en de daaraan gekoppelde rechtsgevolgen (vergunningplicht, beheerplannen) voorzag deze wet, aldus het toenmalige kabinet, ook in de gewenste basis voor implementatie van de Habitatrichtlijn (HR). Dit tezamen met ander bestaand

15 Daarbij is in enigszins verkorte vorm opgenomen de beschrijving op hoofdlijnen van die wetten in de concept-MvT bij het ontwerp Wnb, p. 37-41.

16 Concept-MvT bij het ontwerp Wnb, p. 37-38.

17 Kamerstukken II 1993/94, 23 580, nrs. 1-3. 
wettelijk instrumentarium, met name de toenmalige Wet op de ruimtelijke ordening en de Wet milieubeheer. Het bestendig beleid was om de bescherming van gebieden die worden aangewezen op grond van internationale verplichtingen, te regelen met toepassing van het bestaande wettelijke instrumentarium. Waar nodig zouden Habitatgebieden worden aangewezen als beschermde natuurmonumenten. ${ }^{18}$ Er was daardoor geen wettelijk onderscheid tussen gebieden van Europees belang en gebieden van nationaal belang. Naar aanleiding van een ingebrekestelling van 24 oktober 2000 door de Europese Commissie $^{19}$ inzake een onvolkomen implementatie van de HR moest de wet, alvorens zij verder in werking kon worden gesteld, worden aangepast. De totstandkoming van de wijzigingswet ${ }^{20}$ heeft geruime tijd gevergd als gevolg waarvan de Natuurbeschermingswet 1998 pas op 1 oktober 2005 volledig in werking getreden. Op dat moment is ook de toen nog vigerende eerdere Natuurbeschermingswet ingetrokken. De noodzaak voor deze wetswijziging werd onderstreept door het arrest van 14 april 2005 van het Europese Hof van Justitie, waarin het hof vaststelde dat de toen in Nederland geldende wettelijke en bestuursrechtelijke maatregelen een onvoldoende en deels onjuiste omzetting van de Vogel- en Habitatrichtlijnen omvatten. ${ }^{21}$ Later werd de aansluiting van de Natuurbeschermingswet 1998 op de HR nog iets verbeterd. ${ }^{22}$ Aanleiding was het feit dat door de Europese Commissie was geconstateerd dat Natura 2000-gebieden die wel al op de lijst van gebieden van communautair belang waren geplaatst, maar nog niet naar nationaal recht waren aangewezen, niet overeenkomstig artikel 4 lid 5 HR wettelijk waren beschermd door bepalingen die toepassing geven aan artikel 6 lid 2 en 3 HR. De op dit punt doorgevoerde wetswijziging was voor de Commissie aanleiding om de inmiddels gestarte inbreukprocedure te beëindigen. ${ }^{23}$

Daarmee kwam er volgens de regering in het stelsel van de natuurwetgeving voor het eerst een onderscheid tussen gebieden, aangewezen ter uitvoering van de Vogelrichtlijn ${ }^{24}$ en de Habitatrichtlijn, ${ }^{25}$ en andere gebieden. ${ }^{26}$ Eerder aangewezen gebieden die ook ter uitvoering van de richtlijnen moesten worden beschermd, waren niet langer een beschermd natuurmonument, maar een Natura 2000-gebied, met een separaat beschermingsregime. $^{27}$ Van de 189 gebieden die vroeger waren aangewezen als

Kamerstukken II 1996/97, 23 580, nr. 11.

Nr. SG(2000)D107813.

Wet van 20 januari 2005 tot wijziging van de Natuurbeschermingswet 1998 in verband met Europeesrechtelijke verplichtingen (Stb. 2005, 195)

21 Zaak C-441/03 (Commissie tegen Nederland).

22 Wet van 29 december 2008, houdende wijziging van de Natuurbeschermingswet 1998 in verband met de regulering van bestaand gebruik en enkele andere zaken (Stb. 2009, 18).

23 Concept-MvT bij het ontwerp Wnb, p. 37-38. Zie ook Backes \& Van den Broek, Gebiedsbescherming eindelijk geboden 2005.

24 Richtlijn 2009/147/EG van het Europees Parlement en de Raad van de Europese Unie van 30 november 2009 inzake het behoud van de vogelstand (PbEU 2010, L 20/7).

25 Richtlijn 92/43/EEG van de Raad van de Europese Gemeenschappen van 21 mei 1992 inzake de instandhouding van de natuurlijke habitats en de wilde flora en fauna (PbEG 1992 L 206/7).

26 Art. 15a lid $1 \mathrm{Nb}$-wet 1998.

27 Art. 15a lid 2 Nb-wet 1998. 
beschermd natuurmonument op basis van nationaal beleid, zijn 125 gebieden onderdeel geworden van het Europese Natura 2000-netwerk. De regimes voor de nationale natuurmonumenten en voor Europese Natura 2000-gebieden vormen het hoofdonderwerp van de wet, en zijn opgenomen in hoofdstuk III van de Natuurbeschermingswet 1998. De kern van de beschermingsregimes bestaat uit een vergunningensysteem voor mogelijk schadelijke activiteiten en - bij Natura 2000 - het beheerplan waarin de voor de gebieden noodzakelijke instandhoudingsmaatregelen zijn uitgewerkt. Voor de vergunningverlening zijn Gedeputeerde Staten van de provincies over het algemeen bevoegd gezag; dat geldt ook voor de beheerplannen, voor zover deze geen betrekking hebben op gebieden die onder de verantwoordelijkheid van het Rijk worden beheerd. Bij latere wijzigingen werd dit regime verder gedifferentieerd. Verder kent de wet een summier regime voor de bescherming van gebieden ter uitvoering van internationale verplichtingen. ${ }^{28}$ Dat was oorspronkelijk onder meer bedoeld als basis voor de uitvoering van de Habitatrichtlijn. ${ }^{29} \mathrm{Na}$ de totstandkoming van een specifieke regeling in de wet voor de bescherming van Natura 2000-gebieden is het oude regime zonder nadere toelichting gehandhaafd, onder uitsluiting van de Natura 2000-gebieden. ${ }^{30}$ Tevens voorziet de wet in de planologische bescherming van door de provincies daartoe aangewezen landschapsgezichten, ${ }^{31}$ in het bijzonder vanwege hun cultuurhistorische betekenis. ${ }^{32}$ Aan dit regime is nooit uitvoering gegeven. Bescherming van landschapsgezichten geschiedt door inzet van het reguliere instrumentarium van de Wet ruimtelijke ordening.

\subsubsection{Flora- en faunawet}

De Flora- en faunawet bestaat uit de in overzicht 6.2 genoemde hoofdstukken.

\section{Overzicht 6.2 Hoofdstukken Flora- en faunawet}

\begin{tabular}{|c|c|c|}
\hline $\begin{array}{l}\text { I. Algemene } \\
\text { bepalingen }\end{array}$ & $\begin{array}{l}\text { IV. Beschermde } \\
\text { leefomgeving }\end{array}$ & $\begin{array}{l}\text { VII. Overige } \\
\text { bepalingen }\end{array}$ \\
\hline $\begin{array}{l}\text { II. Aanwijzing van } \\
\text { beschermde soorten }\end{array}$ & $\begin{array}{l}\text { V. Bijzondere } \\
\text { bepalingen }\end{array}$ & $\begin{array}{l}\text { VIII. Toezicht, straf- en } \\
\text { dwangbepalingen }\end{array}$ \\
\hline $\begin{array}{l}\text { III. Algemene } \\
\text { verbodsbepalingen }\end{array}$ & VI. Het faunafonds & $\begin{array}{l}\text { IX. Overgangs- en } \\
\text { slotbepalingen }\end{array}$ \\
\hline
\end{tabular}

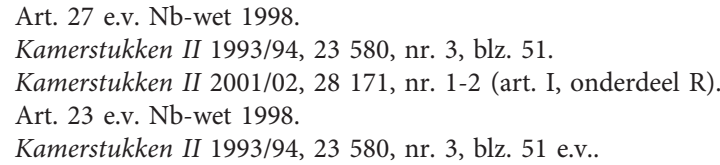


De Flora- en faunawet ${ }^{33}$ stelt regels met het oog op de bescherming en het behoud van de instandhouding van in het wild levende diersoorten en plantensoorten. Zij is grotendeels op 1 april 2002 in werking getreden, en verving de Vogelwet 1936, de Jachtwet, een deel van de oude Natuurbeschermingswet uit 1968, de Nuttige Dierenwet 1914 en de Wet bedreigde uitheemse dier- en plantensoorten. ${ }^{34}$ De wet gaat uit van het zogenoemde 'nee, tenzij-beginsel'. Handelingen met schadelijke gevolgen voor exemplaren van een beschermde diersoort zijn verboden, zoals het doden, verwonden, vangen, opzettelijk verontrusten, het beschadigen van rust- of verblijfplaatsen, alsook het verhandelen en het bezitten van exemplaren en producten daarvan. Ten aanzien van exemplaren van beschermde plantensoorten gelden gelijksoortige bepalingen. Van de verboden kan onder voorwaarden worden afgeweken, door het verlenen van ontheffing of vrijstelling. De bevoegdheid daartoe ligt ten dele bij de minister van ELenI, en ten dele - waar het gaat om ontheffingen en vrijstellingen in het kader van beheer en schadebestrijding - bij Gedeputeerde Staten van de provincies.

Er zijn veel diersoorten en plantensoorten aangewezen als beschermde inheemse soort. Overeenkomstig de Vogelrichtlijn zijn ook alle in Nederland van nature in het wild voorkomende Europese inheemse vogels beschermd, met uitzondering van gedomesticeerde individuen van de grauwe gans, de Europese kanarie, de rotsduif en de wilde eend. Verder zijn alle zoogdieren, met uitzondering van de zwarte rat, de bruine rat en de huismuis, beschermd, naast alle soorten amfibieën en reptielen, alsook de inheemse vissoorten. ${ }^{35}$ Voorts is een aantal vaatplantensoorten beschermd (waaronder orchideeën). Aan onder meer de CITES-verordening ${ }^{36}$ is uitvoering gegeven door diersoorten en plantensoorten aan te wijzen als beschermde uitheemse soort.

Voor de jacht en activiteiten die nodig zijn in het kader van beheer en schadebestrijding kent de wet verder afzonderlijke regimes. Ook voorziet de wet in de mogelijkheid voor provincies tot het aanwijzen van beschermde leefomgevingen. Hiermee kunnen kleinere afzonderlijke elementen veilig worden gesteld die van afzonderlijke betekenis zijn als de leefomgeving van een enkele planten- of diersoort. Van die bevoegdheid is nooit gebruik gemaakt, waar deze elementen grotendeels al binnen de ecologische hoofdstructuur (EHS) afdoende bescherming vinden of anderszins afdoende beschermd kunnen worden door inzet van het instrumentarium van de Wet ruimtelijke ordening.

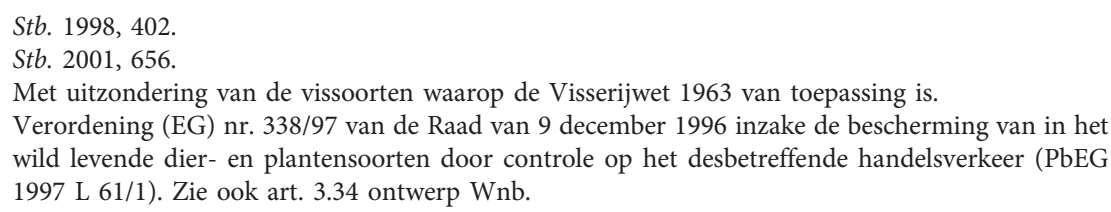


6.2.4. Boswet

De Boswet bestaat uit de in overzicht 6.3 genoemde hoofdstukken.

\section{Overzicht 6.3 Hoofdstukken Boswet}

\begin{tabular}{|c|c|c|c|c|}
\hline Afdeling I & $\begin{array}{l}\text { Algemene } \\
\text { bepalingen }\end{array}$ & Afdeling IV (vervallen) ${ }^{37}$ & Afdeling VII & $\begin{array}{l}\text { Voorzieningen door } \\
\text { andere openbare } \\
\text { lichamen }\end{array}$ \\
\hline Afdeling II & $\begin{array}{l}\text { Velling en } \\
\text { herplanting }\end{array}$ & Afdeling V (vervallen) ${ }^{38}$ & Afdeling VIII & $\begin{array}{l}\text { Straf-, slot- en over- } \\
\text { gangsbepalingen }^{39}\end{array}$ \\
\hline Afdeling III & Beroep & Afdeling VI Kapverbod & & \\
\hline
\end{tabular}

De Boswet heeft tot doel de instandhouding van het bosareaal (oppervlakte bos) in Nederland. Daartoe bevat de wet regels over de herbeplanting van gevelde houtopstanden buiten de bebouwde kom. ${ }^{40}$ Binnen de bebouwde kom is het aan gemeenten zelf om op basis van hun autonome bevoegdheid beleid te voeren. De Boswet is sinds haar inwerkingtreding in 1962 goeddeels onveranderd gebleven. Wel is de doelstelling van de bescherming van bos in de loop der jaren verschoven. Oorspronkelijk was zij - evenals haar voorganger de Boschwet 1922 - primair gericht op de belangen van de houtproductie, maar gaandeweg is de veelzijdige functie die bossen en houtopstanden hebben voor de samenleving (klimatologische, landschappelijke en recreatieve waarden) meer voor het voetlicht gekomen, zodat nu aan bossen ook een belangrijke betekenis wordt toegekend voor het behoud van de biodiversiteit, het gebruik van biomassa en de waterhuishouding.

De instandhouding van het bosareaal krijgt onder de Boswet vorm door de verplichting tot herbeplanting van een houtopstand die is geveld of anderszins is tenietgegaan. De eigenaar van de grond waarop de houtopstand zich bevond, moet die houtopstand binnen drie jaar herbeplanten. ${ }^{41}$ Voorafgaand aan het vellen dient het voornemen daartoe te worden gemeld aan de minister van ELenI, met het oog op effectief toezicht op de naleving van de herplantplicht. ${ }^{42}$ Verder kan deze minister voor telkens vijf jaar een kapverbod opleggen. Het opleggen van het kapverbod strekt ter bewaring van

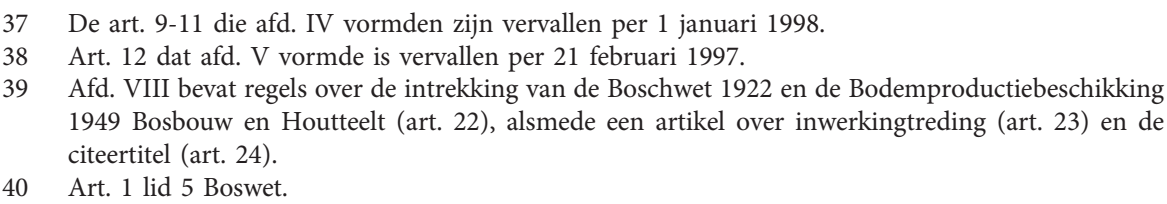


natuur- en landschapsschoon. ${ }^{43}$ Van deze bevoegdheid is zelden gebruik gemaakt.

\subsubsection{Ontwerp Wet natuurbescherming}

Het ontwerp Wet natuurbescherming bevat 11 hoofdstukken die in overzicht 6.4 zijn genoemd.

\section{Overzicht 6.4 Hoofdstukken ontwerp Wet natuurbescherming}

\begin{tabular}{|l|l|l|}
\hline $\begin{array}{c}1 \text { Algemene } \\
\text { bepalingen }\end{array}$ & $\begin{array}{c}5 \text { Vergunningen, ontheffingen en ver- } \\
\text { plichtingen }\end{array}$ & 9 Overgangsrecht \\
\hline 2 Gebieden & 6 Financiële bepalingen & $\begin{array}{c}10 \text { Wijziging } \\
\text { andere wetten }\end{array}$ \\
\hline 3 Soorten & 7 Handhaving & 11 Slotbepalingen \\
\hline 4 Houtopstanden & 8 Overig & \\
\hline
\end{tabular}

Hoofdstuk 1 Algemene bepalingen bevat onder meer begrippen ${ }^{44}$ en de regels over de vaststelling van de natuurvisie ${ }^{45}$ waarin de hoofdlijnen moeten worden opgenomen van het te voeren rijksbeleid met het oog op het behoud en duurzaam beheer van de biologische diversiteit, in samenhang met het economisch beleid van het Rijk. In het kader van algemene beschermingsmaatregelen geldt een zorgplicht ${ }^{46}$ en kan bij ministeriële regeling worden bepaald dat een verbeteringsprogramma wordt vastgesteld. ${ }^{47}$

Hoofdstuk 2 Gebieden geeft de minister van ELenI de bevoegdheid om Natura 2000-gebieden aan te wijzen als speciale beschermingszones ter uitvoering van artikel 3 lid 2 onderdeel a Vogelrichtlijn en artikel 4 lid 4 Habitatrichtlijn. Daarbij worden de instandhoudingsdoelstellingen aangewezen ten aanzien van de leefgebieden voor vogelsoorten of de natuurlijke habitats en habitats voor soorten. ${ }^{48}$ Gedeputeerde Staten moeten ervoor zorgen dat instandhoudingsmaatregelen en passende maatregelen worden getroffen die nodig zijn voor de Natura 2000-gebieden. ${ }^{49}$ Ook moeten zij voor elk Natura 2000-gebied een beheerplan vaststellen..$^{50}$ Het is verboden zonder vergunning van Gedeputeerde Staten een project te realiseren dat

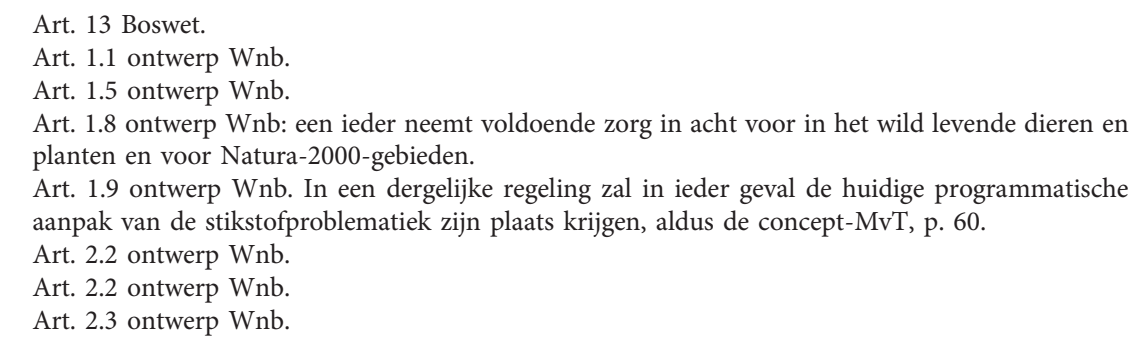


niet direct verband houdt met of nodig is voor het beheer van een Natura 200o-gebied en dat afzonderlijk of in combinatie met andere plannen of projecten significante gevolgen kan hebben voor een Natura 2000-gebied. Het verbod geldt niet als het gaat om een activiteit die kan worden aangemerkt als een project waarvoor een omgevingsvergunning op grond van de Wabo is vereist. ${ }^{51}$ Het verbod geldt niet als het gaat om een project dat is beschreven in en wordt gerealiseerd overeenkomstig een beheerplan..$^{52}$ Voor een plan of project moet een passende beoordeling worden gemaakt van de gevolgen voor het Natura 200o-gebied, rekening houdend met de instandhoudingsdoelstellingen van dat gebied. Het plan mag uitsluitend worden vastgesteld en voor het project mag uitsluitend een vergunning worden verleend als uit de passende beoordeling de zekerheid is verkregen dat het plan of het project de natuurlijke kenmerken van het gebied niet zal aantasten. Is de vereiste zekerheid niet verkregen, dan kan het plan toch worden vastgesteld of de vergunning worden verleend als er geen alternatieve oplossingen zijn, het plan of project nodig is om dwingende redenen van groot openbaar belang 53 en de nodige compenserende maatregelen worden getroffen om te waarborgen dat de algehele samenhang van Natura 2000 bewaard blijft. In geval het plan of project significante gevolgen kan hebben voor een prioritair type natuurlijke habitat of een prioritaire soort in een Natura 2000-gebied kan het plan worden vastgesteld of de vergunning worden verleend als de realisatie van het plan of project nodig is vanwege argumenten die verband houden met de menselijke gezondheid, de openbare veiligheid of met voor het milieu wezenlijk gunstige effecten, of andere dwingende redenen van openbaar belang na advies van de Europese Commissie. ${ }^{54}$

Hoofdstuk 3 Soorten kent een beschermingsregime voor vogels als bedoeld in de Vogelrichtlijn ${ }^{55,56}$ een beschermingsregime voor andere dieren en planten als bedoeld in de Habitatrichtlijn ${ }^{57}$ en een beschermingsregime voor andere soorten. ${ }^{58}$ Ten aanzien van vogels geldt ${ }^{59}$ onder meer dat het is verboden om opzettelijk vogels te doden of te vangen, opzettelijk nesten, rustplaatsen en eieren van vogels te vernielen of te beschadigen, of nesten van vogels weg te nemen, eieren van vogels te rapen en deze onder zich te hebben of vogels opzettelijk te storen. ${ }^{60}$ Ontheffing of vrijstelling is in

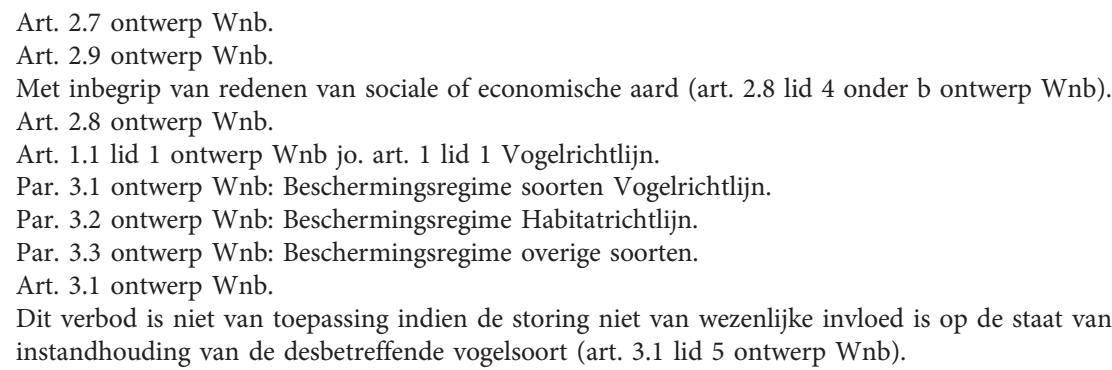


bepaalde gevallen mogelijk. ${ }^{61}$ Als het vangen of doden van vogels is toegestaan, stelt de wet regels over de middelen. ${ }^{62}$ Het is verboden om in het wild levende dieren ${ }^{63}$ in hun natuurlijk verspreidingsgebied opzettelijk te doden of te vangen, opzettelijk te verstoren, hun eieren in de natuur opzettelijk te vernielen of te rapen, en hun voortplantingsplaatsen of rustplaatsen te beschadigen of te vernielen. ${ }^{64}$ Het is verboden planten ${ }^{65}$ in hun natuurlijk verspreidingsgebied opzettelijk te plukken en te verzamelen, af te snijden, te ontwortelen of te vernielen. ${ }^{66}$ Voorts is het verboden aan de natuur onttrokken dieren of planten ${ }^{67}$ onder zich te hebben, te vervoeren, te verhandelen, te ruilen of te koop of te ruil aan te bieden. ${ }^{68}$ Ontheffing of vrijstelling is in bepaalde gevallen mogelijk. ${ }^{69}$ Als het vangen of doden van vogels is toegestaan, stelt de wet regels over de middelen. ${ }^{70}$ Een aantal van de genoemde bepalingen geldt ook ten aanzien van soorten die zijn aangewezen bij het Verdrag van Bern of het Verdrag van Bonn. ${ }^{71}$ Ten aanzien van de andere soorten geldt een verbod om in het wild levende zoogdieren, amfibieën of reptielen opzettelijk te doden. Op dit verbod bestaat een aantal uitzonderingen, onder meer voor de huismuis, verwilderde dieren en exoten. ${ }^{72}$ Hoofdstuk 3 bevat voorts regels inzake schadebestrijding en faunabeheer, ${ }^{73}$ jacht, ${ }^{74}$ toegestane middelen voor het vangen en doden van vogels en zoogdieren, ${ }^{75}$ overige bepalingen ten aanzien van in het wild levende dieren en planten ${ }^{76}$ en handel in en bezit van planten en dieren. ${ }^{77}$

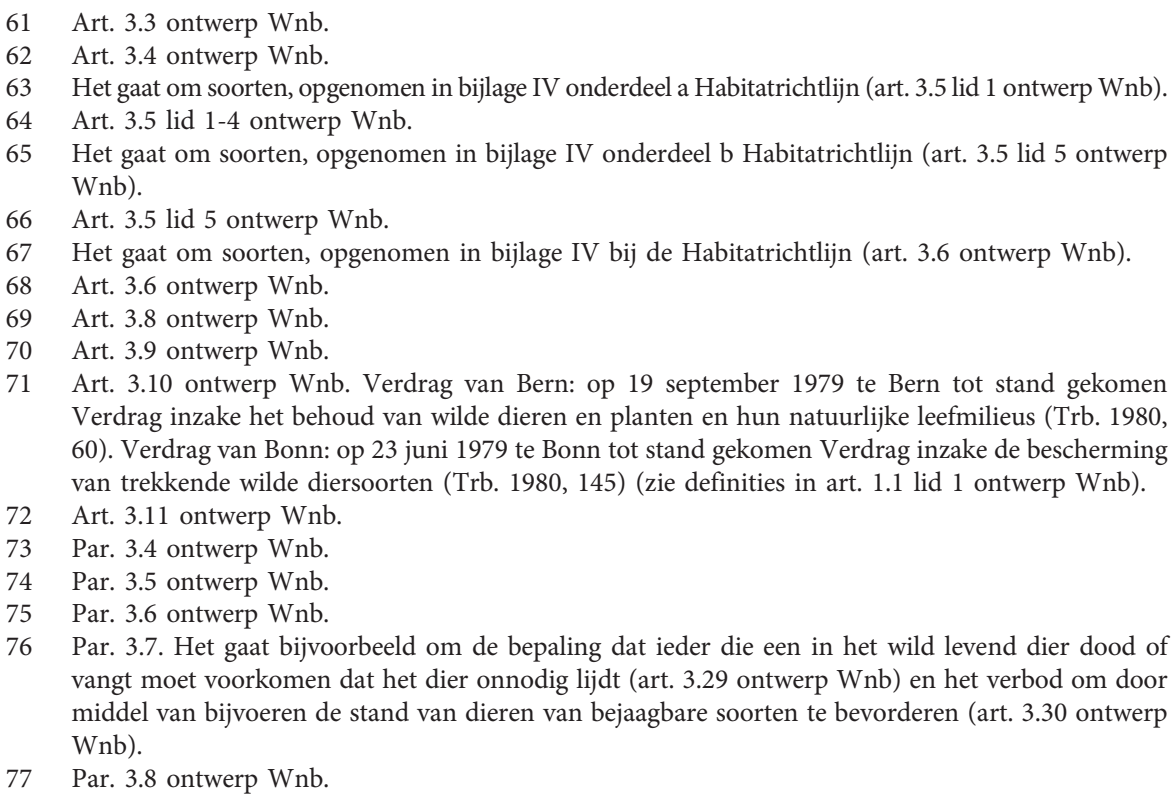


Hoofdstuk 4 Houtopstanden bepaalt dat het uitsluitend is toegestaan een houtopstand ${ }^{78}$ geheel of gedeeltelijk te vellen of te doen vellen, met uitzondering van dunnen, ${ }^{79}$ na voorafgaande melding daartoe bij Gedeputeerde Staten. Gedeputeerde Staten kunnen het vellen van houtopstanden telkens voor maximaal vijf jaar verbieden ter bescherming van bijzondere natuur- of landschapswaarden. ${ }^{80}$ De rechthebbende van de grond waarop de velling plaatsvindt, moet de houtopstand binnen drie jaren na het vellen herbeplanten op bosbouwkundig verantwoorde wijze op dezelfde grond als waarop de velling heeft plaatsgevonden. ${ }^{81}$ Hoofdstuk 4 bevat voorts bepalingen inzake invoer en op de markt brengen van hout en houtproducten. ${ }^{82}$

Hoofdstuk 5 Vergunningen, ontheffingen en verplichtingen kent een aantal procedurele bepalingen, zoals de beslistermijn op de aanvraag om een vergunning of ontheffing, en de gronden voor intrekking van een jachtakte. Hoofdstuk 6 Financiële bepalingen heeft betrekking op schadeloosstelling en leges. Hoofdstuk 7 Handhaving bevat regels inzake toezicht op de naleving, last onder dwangsom, last onder bestuursdwang, bijzondere sancties, bestuurlijke boete en uitwisseling van gegevens tussen toezichthouders. Hoofdstuk 8 Overig bevat een aantal procedurele bepalingen zoals de bepaling dat een belanghebbende beroep kan instellen tegen een op grond van de Wet natuurbescherming genomen besluit. ${ }^{83}$ Hoofdstuk 9 Overgangsrecht bevat overgangsrecht. Hoofdstuk 10 Wijziging andere wetten voegt onder meer de natuurbeschermingsvergunning toe aan de omgevingsvergunning door een wijziging van de Wabo. ${ }^{84}$ Hoofdstuk 11 Slotbepalingen bevat onder meer de intrekking van de Boswet, de Floraen faunawet en de Natuurbeschermingswet 1998.

\subsection{WETSSYSTEMATISCH TEKORT}

\subsubsection{Algemeen}

In deze paragraaf zal de eerste toetsuraag worden beantwoord: is er binnen het omgevingsrecht sprake van een wetssystematisch tekort omdat niet alle

78 Zelfstandige eenheid van bomen, boomvormers, struiken, hakhout of griend, die: a. een oppervlakte grond beslaat van tien are of meer, of b. bestaat uit een rijbeplanting die meer dan 20 bomen omvat, gerekend over het totaal aantal rijen (art. 1.1 lid 1 ontwerp Wnb). Het gaat in beginsel om houtopstanden buiten de bebouwde kom (art. 4.1 onder a ontwerp Wnb).

79 Vellen dat uitsluitend geschiedt ter verzorging of ontwikkeling van de overblijvende houtopstand (art. 1.1 lid 1 ontwerp Wnb).

Art. 4.2 ontwerp Wnb.

Art. 4.3 ontwerp Wnb.

Par. 4.2 ontwerp Wnb.

Met uitzondering van een besluit als bedoeld in artikel 7.5 ontwerp Wnb (art. 8.1 lid 1 ontwerp $\mathrm{Wnb}$ )

84 Art. 10.7 onder B ontwerp Wnb. 
regels die volgens een op de echte werkelijkheid gebaseerd zakelijk samenhangcriterium die onderling samenhangen desalniettemin geen deel uitmaken van hetzelfde wetssysteem?

Om die vraag te beantwoorden zal ik in paragraaf 6.3.2 eerst nagaan welke aanleiding de regering noemt voor bundeling van de Natuurbeschermingswet 1998, de Flora- en faunawet en de Boswet in het ontwerp Wet natuurbescherming.

In paragraaf 6.3.3 zal worden onderzocht of en zo ja welk samenhangcriterium de regering in de concept-memorie van toelichting op het ontwerp Wet natuurbescherming noemt dat voor haar de aanleiding vormt tot bundeling van de Natuurbeschermingswet 1998, de Flora- en faunawet en de Boswet in het ontwerp Wet natuurbescherming over te gaan. Daarbij neem ik het door de regering gekozen samenhangcriterium als uitgangspunt. Niet vanwege het feit dat dit het enige of beste criterium zou zijn - zoals eerder aangegeven kan een wetgever kiezen uit een schier oneindig aantal samenhangcriteria ${ }^{85}$ - maar vanwege het feit dat ik de vraag wil beantwoorden in hoeverre de door de regering met het ontwerp Wet natuurbescherming voorgestelde bundeling beantwoordt aan de in hoofdstuk 3 door mij ontwikkelde criteria. In paragraaf $6.3 .3 \mathrm{zal}$ ook worden aangegeven of het aldus gevonden samenhangcriterium een op de echte werkelijkheid gebaseerd zakelijk samenhangcriterium betreft.

Mocht de vorige vraag bevestigend worden beantwoord, dan zal ik in paragraaf 6.3.4 vervolgens nagaan of sprake is van een of meer wetssystematische tekorten omdat niet alle regels die passen binnen het gevonden samenhangcriterium deel uitmaken van hetzelfde wetssysteem.

In paragraaf 6.3 .5 zal de eerste toetsvraag worden beantwoord.

\subsubsection{Aanleiding voor bundeling}

Het ontwerp Wet natuurbescherming strekt volgens de regering 'tot vervanging van het huidige wettelijke stelsel voor de natuurbescherming, als neergelegd in de Natuurbeschermingswet 1998, de Flora- en faunawet en de Boswet'. Natuur vertegenwoordigt volgens het kabinet een grote waarde, niet alleen in zichzelf, maar ook vanwege alles wat zij de samenleving biedt. ${ }^{86}$ Voor het realiseren van de opgave waarvoor Nederland zich nationaal en internationaal ziet geplaatst om de biodiversiteitsdoelen te realiseren en tegelijk economische ontwikkeling te bevorderen, zullen het beleidsinstrumentarium en het wettelijk instrumentarium op orde moeten

85 Par. 2.3.3.

86 Ontwerp Wnb, concept-MvT, p. 6. 
zijn. Het wettelijk stelsel voor natuurbescherming, zoals neergelegd in de Natuurbeschermingswet 1998, de Flora- en faunawet en de Boswet is volgens de regering niet meer toegesneden op de behoeften van deze tijd. Daarbij verwijst zij onder meer naar de door het kabinet geformuleerde uitgangspunten voor de bundeling, vereenvoudiging, modernisering en versobering van het omgevingsrecht (een betere aansluiting op Europese wet- en regelgeving, ontwikkelingsgericht en integraal, en decentraal tenzij), alsook de daarvoor geformuleerde prioritaire thema's en transities (snellere en betere besluitvorming, integratie van plannen en toetsingskaders, vergroten bestuurlijke afwegingsruimte en doelmatig onderzoek). ${ }^{87}$

Het kabinet acht wijziging van het huidige stelsel van de natuurwetgeving in het bijzonder aangewezen om vier redenen:

1. De huidige wetgeving is nog te zeer opgezet vanuit het oorspronkelijke nationale wettelijke stelsel, dat primair diende voor de realisatie van nationale beleidsdoelstellingen op het vlak van de natuurbescherming. Dat stelsel is geleidelijk aangepast en uitgebreid om het in overeenstemming te brengen met de internationale verplichtingen, in het bijzonder die in de Vogelrichtlijn en de Habitatrichtlijn. Dat heeft het gecompliceerd en ontoegankelijk gemaakt. Gezien het sterk internationale karakter dat het biodiversiteitsbeleid in de loop der tijd heeft gekregen, ligt het volgens het kabinet thans in de rede om bij de opzet van het wettelijke stelsel het internationale recht als uitgangspunt te nemen. ${ }^{88}$

2. Gelet op de beperkte landoppervlakte van Nederland moeten wonen, bedrijvigheid, infrastructuur, recreatie en natuur worden gecombineerd. In de praktijk blijkt het soms moeilijk deze functies in te vullen op een wijze die recht doet aan de maatschappelijke en economische behoeften en die tegelijk het belang van natuur voor de langere termijn veilig stelt. Het wettelijk stelsel gaat gepaard met lasten voor onderzoek, vergunningen en beschermende maatregelen, in geval sprake is van activiteiten die nadelige gevolgen voor natuurwaarden zouden kunnen hebben. Er zijn binnen het wettelijke stelsel nog tal van verbeteringen denkbaar die positief zijn voor de gewenste economische en maatschappelijke ontwikkelingen. Het stelsel kan onder meer minder belastend worden door de wetgeving toegankelijker te maken en te bundelen. Daarbij is een betere aansluiting nodig van de natuurwetgeving op het omgevingsrecht. ${ }^{89}$

3. De bevoegdheidsverdeling in het huidige wettelijke systeem sluit niet optimaal aan bij de huidige inzichten over een doelmatig en doeltreffend bestuur..$^{90}$

\footnotetext{
87 Ministerie van IenM, Beleidsbrief Eenvoudig Beter 2011. Ontwerp Wnb, concept-MvT, p. 10.

88 Ontwerp Wnb, concept-MvT, p. 11

89 Ontwerp Wnb, concept-MvT, p. 11

90 Ontwerp Wnb, concept-MvT, p. 12
} 
4. Het handhavingsinstrumentarium kan op onderdelen worden versterkt, in het bijzonder waar het de handel in bedreigde diersoorten betreft, onder meer door ruimte te creëren voor uitwisseling van gegevens binnen de overheid en door de inzet van bestuurlijke boetes. ${ }^{91}$

In het licht van bovenstaande constateringen heeft het kabinet het bestaande wettelijke systeem als neergelegd in de Natuurbeschermingswet 1998, Flora- en faunawet en Boswet herijkt. Het voorontwerp bevat de weerslag daarvan. ${ }^{92}$

De door de regering genoemde redenen voor de wijziging van het huidige stelsel van de natuurwetgeving geven inzicht in de voorgestelde wijzigingen van de bepalingen in het voorontwerp ten opzichte van de bepalingen in de drie te bundelen wetssystemen, maar geven nog geen duidelijk antwoord op de vraag waarom bundeling daarvoor aangewezen is. Zo wordt geen antwoord gegeven op de vraag waarom bundeling noodzakelijk zou zijn als het er de wetgever om te doen is het internationaal recht als uitgangspunt te nemen. Hetzelfde geldt voor het optimaliseren van de bevoegdheidsverdeling en de versterking van het handhavingsinstrumentarium. Waarom is niet gekozen voor een aanpassing van de Natuurbeschermingswet 1998, de Flora- en faunawet en de Boswet? Wellicht moet het antwoord op de vraag waarom bundeling is aangewezen worden gezocht in de overweging van de regering dat het stelsel minder belastend kan worden 'door de wetgeving toegankelijker te maken en te bundelen, wat ook vorenbedoelde integratie bevordert. Een betere aansluiting van de natuurwetgeving op het omgevingsrecht is daarbij nodig. ${ }^{93}$ Deze overwegingen roepen echter eerder vragen op dan dat zij een helder antwoord geven op de vraag waarom bundeling van de drie natuurwetten aangewezen zou zijn.

Zo wordt niet duidelijk wat zou moeten worden verstaan onder een 'minder belastend' stelsel van natuurwetgeving. Ook is het kennelijk niet zo dat bundeling tot meer toegankelijkheid moet leiden, nu bundeling naast het toegankelijker maken wordt genoemd. Onduidelijk is ook waarnaar de 'vorenbedoelde integratie' verwijst. Naar het in de zinnen daarvoor genoemde integreren van plan- en besluitvormingsprocedures en het waar mogelijk integreren van toetsingskaders? Maar is een dergelijke integratie het gevolg van bundeling? De zin inzake de betere aansluiting bij het omgevingsrecht komt enigszins uit de lucht vallen. Waarom wil de regering dat? En waarom niet de natuurwetgeving volledig opnemen in de Omgevingswet?

Het vorenstaande leidt tot de conclusie dat de redenen die het kabinet geeft voor wijziging van het stelsel van de natuurwetgeving - wat daar ook van

91 Ontwerp Wnb, concept-MvT, p. 12.

92 Ontwerp Wnb, concept-MvT, p. 12.

93 Ontwerp Wnb, concept-MvT, p. 12. 
zij - op zichzelf wel een wijziging van de natuurwetgeving rechtvaardigen, maar geen antwoord geven op de vraag of bundeling daarvoor noodzakelijk is. Mijn aanbeveling aan de regering is om in de memorie van toelichting bij een wetsvoorstel Wet natuurbescherming alsnog helder aan te geven waarom bundeling is aangewezen.

Het bundelen van deze drie wetten wordt overigens niet door iedereen als vanzelfsprekend ervaren. Woldendorp merkt hierover op: "De Boswet heeft er eigenlijk niks mee te maken. Die wet gaat niet over natuur, maar gewoon over bomen die langs de wegen staan." 94 Drupsteen schrijft dat het natuurrecht is te vinden in de Natuurbeschermingswet 1998 en de Flora- en faunawet. ${ }^{95}$ Ik deel die mening niet. Zoals de regering terecht opmerkt, is de Boswet niet langer gericht op de belangen van de houtproductie, maar op de betekenis van bossen voor het behoud van biodiversiteit, het gebruik van biomassa en de waterhuishouding. ${ }^{96}$ In dat licht zou ik de Boswet toch wel willen zien als een wet die beantwoordt aan het samenhangcriterium 'natuur'.

\subsubsection{Samenhangcriterium}

Het ontwerp Wet natuurbescherming bevat 'regels over de bescherming van de natuur', aldus de titel van het ontwerp. Het ligt dus voor de hand om de natuur als samenhangcriterium te zien. Dat strookt ook met de inhoud van het ontwerp en de concept-memorie van toelichting waarin onder meer wordt opgemerkt dat het gaat om een wetsvoorstel 'houdende een nieuw integraal stelsel voor de bescherming van natuurgebieden, soorten en houtopstanden. ${ }^{97}$ Gelet op de titel van het voorontwerp, de inhoud daarvan en de memorie van toelichting kom ik tot de conclusie dat het kabinet kiest voor het op de echte werkelijkheid gebaseerd samenhangcriterium natuur.

De regering benoemt het samenhangcriterium echter niet als zodanig, waardoor niet precies duidelijk is of zij het samenhangcriterium wel voldoende scherp op het netvlies heeft. Ik zal dat illustreren aan de hand van twee voorbeelden.

In de eerste plaats vermeldt de aanhef dat het wenselijk is te komen tot een integraal en vereenvoudigd wettelijk kader voor het behoud en een duurzaam beheer van de biologische diversiteit en ter uitvoering van de Habitatrichtlijn, de Vogelrichtlijn en diverse verdragen inzake de biologische diversiteit. Mij lijkt dat alles wel te begrijpen onder het samenhangcriterium natuur, maar de vraagt rijst of daarmee precies hetzelfde wordt bedoeld als met bescherming van de natuur. Zou het samenhangcriterium bijvoorbeeld ruimer zijn, dan zou dat kunnen betekenen dat in het ontwerp Wet natuurbescherming geen bepalingen

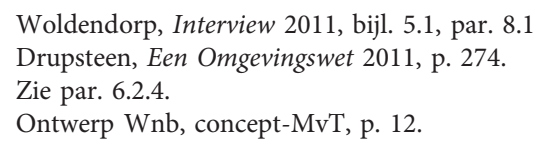


worden opgenomen, die wel de bescherming van de natuur betreffen maar niet het behoud en een duurzaam beheer van de biologische diversiteit, dan wel de uitvoering van genoemde richtlijnen en verdragen.

In de tweede plaats wordt in de concept-memorie van toelichting opgemerkt dat het ontwerp Wet natuurbescherming de onderwerpen betreft die nu worden geregeld in de Natuurbeschermingswet 1998, de Flora- en faunawet en de Boswet. ${ }^{98}$ Het is duidelijk dat het in die wetten gaat om regels die de natuur beschermen, maar als natuur het samenhangcriterium is, zou het kabinet zich ervan moeten vergewissen of die wetten alle regels over de bescherming van de natuur bevatten. Het samenhangcriterium bepaalt immers het wetssysteem van het ontwerp Wet natuurbescherming. De regering wekt nu de indruk alsof het bundelen van de drie genoemde wetten een doel op zich is, welke indruk wordt versterkt door de overweging 'dat de bescherming van de ecologische hoofdstructuur, die via bestemmingsplannen wordt verwezenlijkt, buiten dit wetsvoorstel valt. ${ }^{99}$

Het is uit een oogpunt van wetssystematiek onverstandig om geen helderheid te hebben omtrent het samenhangcriterium. Eerder in dit onderzoek heb ik het grote belang geschetst van samenhangcriteria voor een wetssysteem. ${ }^{100}$ Als de wetgever dat samenhangcriterium niet duidelijk voor ogen heeft, loopt hij het risico dat in het wetssysteem van het ontwerp Wet natuurbescherming regels zijn of worden opgenomen, die daarin niet thuis horen. Ook is er een kans op wetssystematische tekorten omdat regels die wel in het wetssysteem van het ontwerp Wet natuurbescherming thuis horen daarin niet zijn opgenomen. ${ }^{101}$

Dit risico zou actueel kunnen worden in het kader van de Omgevingswet. In de kabinetsbrief stelselherziening omgevingsrecht ${ }^{102}$ merkt het kabinet op dat het ontwerp Wet natuurbescherming vooruit loopt op de Omgevingswet, maar inhoudelijk al op de uitgangspunten van de Omgevingswet is afgestemd. De begrippen en definities in het ontwerp Wet natuurbescherming zullen volgens het kabinet 'maximaal aansluiten op de Omgevingswet zodat de ruimtelijk relevante onderdelen in een later stadium over kunnen naar de Omgevingswet. Dat geldt in ieder geval voor de natuurvisie, het natuurbeheerplan en de vergunningen. ${ }^{103} \mathrm{Om}$ te weten welke bepalingen in het wetssysteem van het Wet natuurbescherming een plaats dienen te krijgen, is het noodzakelijk dat het samenhangcriterium duidelijk is.

\footnotetext{
98 Ontwerp Wnb, concept-MvT, p. 23.

99 Ontwerp Wnb, concept-MvT, p. 23.

100 Zie par. 3.2.4.

101 Zie par. 6.4.

102 Ministerie van IenM, Kabinetsbrief stelselherziening omgevingsrecht 2011. Zie voor een samenvatting Van den Broek, Samenvatting kabinetsbrief stelselherziening omgevingsrecht 2012.

103 Ministerie van IenM, Kabinetsbrief stelselherziening omgevingsrecht 2011, p. 21
} 
Mijn aanbeveling aan de wetgever is dan ook om niet eerder tot bundeling van bepalingen in het ontwerp Wet natuurbescherming over te gaan dan nadat glashelder is welke samenhangcriteria het door bundeling te realiseren wetssysteem bepalen.

\subsubsection{Wetssystematisch tekort}

De regels inzake bescherming van de natuur zijn op dit moment in elk geval opgenomen in de Natuurbeschermingswet 1998, de Flora- en faunawet en de Boswet. Reeds om die reden is sprake van een wetssystematisch tekort, aangezien niet alle regels die zien op natuur zijn opgenomen in hetzelfde wetssysteem.

\subsubsection{Antwoord op toetsvraag 1}

Op dit moment is binnen het omgevingsrecht sprake van een wetssystematisch tekort omdat niet alle regels die volgens het op de echte werkelijkheid gebaseerde zakelijk samenhangcriterium natuur onderling samenhangen, deel uitmaken van hetzelfde wetssysteem. Daarmee is de eerste toets$\operatorname{vraag}^{104}$ positief beantwoord.

\subsection{WETSSYSTEMATISCH TEKORTEN OPGEHEVEN OF VERMINDERD}

\subsubsection{Algemeen}

In deze paragraaf zal de vraag worden beantwoord of bundeling van de Natuurbeschermingswet 1998, de Flora- en faunawet en de Boswet in het ontwerp Wet natuurbescherming het wetssystematisch tekort dat thans bestaat omdat niet alle regels inzake natuur in hetzelfde wetssysteem zijn opgenomen, zal opheffen of verminderen.

6.4.2. Wetssystematische tekorten gedeeltelijk opgeheven

In paragraaf 6.3 is geconcludeerd dat er sprake is van een wetssystematisch tekort dat daarin bestaat dat niet alle regels in het omgevingsrecht die betrekking hebben op bescherming van de natuur zijn opgenomen in hetzelfde wetssysteem dat wordt bepaald door het samenhangcriterium natuur.

Gelet op hetgeen hiervoor in paragraaf 6.2 is opgemerkt, is duidelijk dat de regering met de bundeling door herschikking in het ontwerp Wet natuurbescherming niet het oogmerk heeft om in het wetssysteem van het ontwerp

104 Vgl. par. 3.8. 
Wet natuurbescherming alle regels in het omgevingsrecht op te nemen die betrekking hebben op natuur. De regering heeft met bundeling uitsluitend het oog gehad op de bepalingen die thans zijn opgenomen in de Natuurbeschermingswet 1998, de Flora- en faunawet en de Boswet. Dat blijkt met name uit de concept-memorie van toelichting, waarin wordt gesteld: 'Het wetsvoorstel bestrijkt de onderwerpen die nu worden geregeld in de Natuurbeschermingswet 1998, de Flora- en faunawet en de Boswet.'

Aangezien deze drie wetten worden ingetrokken en de inhoud daarvan wordt opgenomen in het ontwerp Wet natuurbescherming concludeer ik dat de bundeling door herschikking het door de regering geconstateerde wetssystematische tekort zal opheffen.

\subsubsection{Wetssystematisch tekorten gedeeltelijk niet opgeheven}

\subsubsection{Algemeen}

Het ontwerp Wet natuurbescherming mag dan de wetssystematische tekorten opheffen die thans bestaan omdat de regels inzake natuur zijn opgenomen in de wetssystemen van de Wet natuurbescherming 1998, de Flora- en faunawet en de Boswet, daarmee is nog niet gezegd dat er na de bundeling geen wetssystematische tekorten zullen blijven bestaan. Het samenhangcriterium natuur dient immers het wetssysteem van het ontwerp Wet natuurbescherming te bepalen. Dat betekent onder meer dat in dat wetssysteem ook alle bepalingen moeten worden opgenomen die beantwoorden aan genoemd samenhangcriterium, maar niet in een van die drie wetten zijn opgenomen. Dat is alleen anders als verdedigbaar is dat zulks niet hoeft.

De concept-memorie van toelichting bij het ontwerp Wet natuurbescherming noemt verschillende wetssystemen die van belang zijn voor de bescherming van de natuur. Aan de orde komen onder meer regimes van algemene aard, generieke milieuwetgeving, de Wet grondslagen natuurbeheer en -bescherming BES, ${ }^{105}$ de Wet inrichting landelijk gebied, ${ }^{106}$ de Visserijwet $1963,{ }^{107}$ de Waterwet, ${ }^{108}$ de Natuurschoonwet $1928,{ }^{109}$ de Wet luchtvaart ${ }^{110}$ en de Gezondheids- en welzijnswet voor dieren. ${ }^{111}$

\footnotetext{
105 Stb. 2010, 565

106 Stb. 2006, 666.

107 Stb. 1963, 312

108 Stb. 2009, 107.

109 Stb. 1928, 63.

110 Stb. 1992, 368.

111 Stb. 1992, 585.
} 
Ten aanzien van elk van de genoemde wetssystemen geeft de regering summier aan in hoeverre het gaat om regels die bijdragen aan de bescherming van de natuur, alsmede waarom er niet voor is gekozen deze wetssystemen geheel of gedeeltelijk te bundelen in het ontwerp Wet natuurbescherming. Aangezien elk van de genoemde wetssystemen in elk geval deels bepalingen bevat die voldoen aan het samenhangcriterium natuur, aanvaardt de regering daarmee dus bewust mogelijke wetssystematische tekorten in het ontwerp Wet natuurbescherming. Hierna zal ik ten aanzien van de regimes van algemene aard en de door de regering genoemde wetssystemen aangeven of en zo ja in hoeverre de regering een verdedigbare argumentatie geeft om de bepalingen inzake natuur in die wetssystemen niet op te nemen in het ontwerp Wet natuurbescherming.

\subsubsection{2. $\quad$ Regimes van algemene aard}

De regering merkt in de concept-memorie van toelichting op dat regimes van algemene aard die eveneens van belang zijn voor de bescherming van de natuur, zoals de ruimtelijke ordening, buiten het ontwerp Wet natuurbescherming vallen. Als voorbeeld wordt de bescherming van de ecologische hoofdstructuur ${ }^{112}$ genoemd, die via het bestemmingsplan wordt verwezenlijkt. Die valt dus buiten het ontwerp. ${ }^{113}$

Backes c.s. menen dat het te overwegen zou zijn om de bescherming van de EHS onder te brengen in de Wet natuurbescherming en beter af te stemmen met of te integreren in de regeling met betrekking tot Natura 2000-gebieden. Zij stellen een duaal beschermingsregime voor. In de eerste plaats bescherming van nationale of regionale waarden en functies in Natura 2000-gebieden die niet samenhangen met de functie van een gebied voor het Europese Natura 2000-netwerk. In de tweede plaats bescherming van gebieden of elementen buiten Natura 2000gebieden die vanwege nationale of regionale waarden of vanwege hun functie als buffer- of verbindingszone voor het Natura 2000-netwerk moeten worden beschermd. Op deze wijze zou volgens de auteurs de complexiteit van het gebiedsbeschermingsrecht sterk afnemen en zouden nationale koppen duidelijk zichtbaar zijn en slechts daar worden toegepast waar dat nodig en zinvol is. ${ }^{114}$

Als ik het juist zie, geeft de regering voor het niet opnemen van de EHSregels geen andere motivering dan dat het ontwerp de onderwerpen bestrijkt die nu worden geregeld in de Natuurbeschermingswet 1998, de Flora- en faunawet en de Boswet. ${ }^{115}$ Wetssystematisch acht ik deze motivering onjuist.

112 De ecologische hoofdstructuur is een netwerk van ecologisch hoogwaardige natuurgebieden. De Natura 2000-gebieden zijn onderdeel van de ecologische hoofdstructuur. Het netwerk en zijn functies zijn planologisch beschermd (ontwerp Wnb, concept-MvT, p. 23-24). Zie uitgebreider Backes/Freriks \& Robbe, Hoofdlijnen natuurbeschermingsrecht 2009, hfds. 8.

113 Ontwerp Wnb, concept-MvT p. 23.

114 Backes/Poortinga \& Woldendorp, Natuurbescherming in de Natuuurwet: kop eraf? 2010, p. 36-37, 39-41.

115 Ontwerp Wnb, concept-MvT p. 23. 
Als het ontwerp wordt bepaald door het samenhangcriterium natuur dan dient dat criterium volgens mij ook het wetssysteem van het ontwerp te bepalen. ${ }^{116}$ Door daarvoor niet te kiezen aanvaardt de regering wetssystematische tekorten door regels die eveneens van belang zijn voor de bescherming van de natuur buiten het ontwerp te houden.

Dat kan wetssystematisch verdedigbaar zijn op basis van het wetssystematische argument dat het opnemen van dergelijke regels zou leiden tot een wetssystematisch tekort in het regime van algemene aard, zoals de Wet ruimtelijke ordening, welk wetssystematisch tekort minder wenselijk wordt geacht dan het bewust aanvaarde wetssystematisch tekort in het ontwerp Wet natuurbescherming. Eerder hebben we immers vastgesteld dat de wetgever veel keuzes heeft waar het gaat om samenhangcriteria en dat meer dan één keuze wetenschappelijk verdedigbaar is. ${ }^{117}$ De regering volgt echter niet de geschetste lijn om de verdedigbaarheid van de geconstateerde wetssystematische tekorten te verdedigen.

Wetssystematisch onverdedigbaar is het echter om - zoals de regering wil regels inzake bescherming van de natuur uit te sluiten van bundeling louter en alleen omdat ze thans niet zijn opgenomen in de Natuurbeschermingswet 1998, de Flora- en faunawet en de Boswet.

\subsubsection{Grondgebied BES-eilanden}

Het ontwerp Wet natuurbescherming is volgens de regering niet van toepassing op het grondgebied van de openbare lichamen Bonaire, SintEustasius en Saba (BES). Deze afwijking van het wetssystematisch uitgangspunt dat het samenhangcriterium natuur het wetssysteem van het ontwerp bepaalt, verdedigt de regering door aan te geven dat voor deze delen van Nederland de Wet grondslagen natuurbeheer en -bescherming $\mathrm{BES}^{118}$ geldt. Deze wet bevat de grondslagen voor de uitvoering van de verschillende natuurbeschermingsverdragen die op de eilanden gelden. Voor de handhaving van dit separate regime is gekozen omdat de flora en fauna op en rond de eilanden zeer verschillend zijn van die op het Europese grondgebied van Nederland en omdat de Vogelrichtlijn, de Habitatrichtlijn en de CITES-verordening ${ }^{119}$ niet op de eilanden van toepassing zijn. De eilanden maken immers geen deel uit van de Europese Unie. Voor de eilanden gelden voorts verschillende specifieke verdragen, zoals het Verdrag

116 Zie par. 3.2.4.2.

117 Zie par. 2.2.3.

118 Stb. 2010, 565.

119 Verordening (EG) nr. 338/97 van de Raad van 9 december 1996 inzake de bescherming van in het wild levende dier- en plantensoorten door controle op het desbetreffende handelsverkeer (PbEG 1997 L 61/1). Zie ook art. 3.34 ontwerp Wnb. 
inzake de bescherming en ontwikkeling van het mariene milieu in het Caraïbisch gebied ${ }^{120}$ en het SPAW-protocol bij dat verdrag. ${ }^{121}$

Op basis van deze argumentatie komt het mij verdedigbaar voor om het ontwerp Wet natuurbescherming niet van toepassing te laten zijn op het grondgebied van de BES-eilanden.

\subsubsection{Wet inrichting landelijk gebied}

In de derde plaats noemt de concept-memorie van toelichting de Wet inrichting landelijk gebied. Deze wet bevat onder meer een regeling van het investeringsbudget. Het gaat daarbij onder meer om subsidies voor natuurbeheer aan terrein beherende organisaties, particulieren en agrariërs. Ook bevat deze wet het wettelijk kader voor landinrichting, waarmee door provincies op dwingende wijze een herverkaveling van eigendomsrechten en gebruiksrechten ten aanzien van grond kan worden doorgevoerd. Daarmee kan volgens de regering een betere inrichting worden bereikt van het landelijk gebied in het licht van de daar aanwezige functies, zoals agrarische functies en natuur. ${ }^{122}$ Hoewel de regering het belang van deze wet noemt voor de bescherming van de natuur, geeft zij geen antwoord op de vraag of zelfs maar is overwogen om (onderdelen van) de Wet inrichting landelijk gebied op te nemen in de Wet Natuur. De memorie van toelichting vermeldt slechts: 'Dit instrumentarium blijft intact. ${ }^{123}$ Evenals dat bij de regels inzake ruimtelijke ordening het geval is, is het ook ten aanzien van de Wet inrichting landelijk gebied niet goed mogelijk om te beoordelen of deze afwijking van het genoemde wetssystematische uitgangspunt verdedigbaar is.

\subsubsection{Visserijwet}

In de vierde plaats noemt de concept-memorie van toelichting de Visserijwet. In die concept-memorie van toelichting wordt de volgende motivering gegeven van het niet opnemen van de Visserijwet in de Wet natuurbescherming: 'Het Europese visserijbeleid heeft onder meer als doelstelling de effecten van visserijactiviteiten op de mariene ecosystemen zo gering mogelijk te houden en maatregelen te nemen die erop zijn gericht de milieueffecten van visserij te beperken. In het kader van dat beleid zijn ook specifieke Europese maatregelen vastgesteld ter bescherming van gebieden en soorten. De Europese Commissie stelt zich op het standpunt dat de kaders van het gemeenschappelijke visserijbeleid ook de geëigende kaders zijn om in de mariene gebieden in de Exclusieve Economische Zone beperkingen te stellen aan visserijactiviteiten

120 Cartagena de Indias, 24 maart 1983, Trb. 1983, 152

121 Protocol betreffende speciaal beschermde gebieden en wilde dieren en planten; Kingston, 18 januari 1990, Kingston, Trb. 1990, 115.

122 MvT, p. 27

123 MvT, p. 27 
ter voldoening aan de Vogelrichtlijn en de Habitatrichtlijn. Voor de implementatie van maatregelen ter uitvoering van het gemeenschappelijk visserijbeleid biedt de Visserijwet 1963 het kader. Op grond van die wet kunnen regels ten aanzien van de zeevisserij worden gesteld in het belang van de natuurbescherming. In het wetsvoorstel strekkende tot wijziging van de Natuurbeschermingswet 1998 en de Flora- en faunawet in verband met de uitbreiding van beide wetten naar de exclusieve economische zone wordt de regulering van visserijactiviteiten dan ook buiten de reikwijdte van die wetten gehouden. Deze afbakening wordt ook in het onderhavige wetsvoorstel gevolgd.'

Wetssystematisch acht ik deze motivering onjuist. Het kabinet merkt immers op dat op basis van de Visserijwet regels kunnen worden gesteld in het belang van de natuurbescherming, met name, als ik het juist zie, ter uitvoering van de Vogelrichtlijn en de Habitatrichtlijn. Deze richtlijnen worden nu juist geïmplementeerd in de ontwerp Wet natuurbescherming. Ik kan het moeilijk anders zien, dan dat de Visserijwet derhalve ook regels bevat die voldoen aan het samenhangcriterium natuur. Het niet bundelen van de Visserijwet of onderdelen daarvan in de Wet natuurbescherming vormt daarom een afwijking van het wetssystematisch uitgangspunt dat het samenhangcriterium natuur het wetssysteem van het ontwerp bepaalt.

Dat kan wetssystematisch verdedigbaar zijn op basis van het wetssystematische argument dat het opnemen van dergelijke regels zou leiden tot een wetssystematisch tekort in de Visserijwet, welk wetssystematisch tekort minder wenselijk wordt geacht dan het bewust aanvaarde wetssystematisch tekort in het ontwerp Wet natuurbescherming. Eerder hebben we immers vastgesteld dat de wetgever veel keuzes heeft waar het gaat om samenhangcriteria en dat meer dan één keuze wetenschappelijk verdedigbaar is. ${ }^{124}$ De regering volgt echter niet de geschetste lijn om de verdedigbaarheid van het geconstateerde wetssystematisch tekort te verdedigen.

Wetssystematisch onverdedigbaar is het echter om - zoals het kabinet aangeeft - regels inzake de bescherming van de natuur uit te sluiten van bundeling louter en alleen omdat de relevante regels tot op heden steeds buiten de Natuurbeschermingswet 1998 en de Flora- en faunawet zijn gehouden.

\subsubsection{Waterwet}

In de concept-memorie van toelichting wordt opgemerkt dat de Waterwet de verantwoordelijkheid voor het voorkomen van schade aan de waterstaatswerken door muskus- en beverratten bij de waterschappen legt. 'De muskusrat en de beverrat worden beide beschouwd als invasieve exoot voor de 
bestrijding waarvan het concept-wetsvoorstel het juridisch instrumentarium zal bieden.' ${ }^{125}$

Ten aanzien van mogelijke verdere bundeling van de Waterwet of onderdelen daarvan in het ontwerp Wet natuurbescherming is het kabinet echter niet helder. In de concept memorie van toelichting wordt opgemerkt dat goed waterbeheer door de waterschappen bijdraagt 'aan de realisatie van de natuurdoelstellingen. Het gaat dan om keuzen ten aanzien van het waterpeil, afgestemd op de nattere dan wel juist drogere natuurdoeltypen, en om de kwaliteit van het oppervlaktewater. Daarbij ligt er ook een belangrijke relatie met de stroomgebiedsbeheerplannen en beheerplannen die op grond van de Waterwet ter uitvoering van de Kaderrichtlijn water worden vastgesteld. Ingevolge de Kaderrichtlijn water moeten de watercondities voor Natura 2000-gebieden ten laatste in 2027 op orde zijn.' Geeft het kabinet daarmee aan dat de Waterwet onderdelen bevat die voldoen aan het samenhangcriterium natuur? Zo ja, is het dan verdedigbaar dat die onderdelen niet worden opgenomen in het ontwerp Wet natuurbescherming? Zonder een antwoord op die vragen is het niet goed mogelijk om te beoordelen of deze mogelijke afwijking van het genoemde wetssystematische uitgangspunt verdedigbaar is.

\subsubsection{Natuurschoonwet 1928}

De Natuurschoonwet 1928 voorziet in fiscale faciliteiten voor landgoedeigenaren die hun landgoed ${ }^{126}$ als eenheid in stand houden en daarmee bijdragen aan het natuurschoon. Gezien het specifieke fiscale karakter van deze wet en het ontbreken van een directe samenhang met de beschermingsregimes in het ontwerp Wet natuurbescherming is ervan afgezien de Natuurschoonwet 1928 in dit ontwerp mee te nemen.

Wetssystematisch acht ik deze motivering onjuist. Als het ontwerp wordt bepaald door het samenhangcriterium natuur dan dient dat criterium volgens mij ook het wetssysteem van het ontwerp te bepalen. ${ }^{127}$ Door daarvoor niet te kiezen aanvaardt de regering wetssystematische tekorten door regels die eveneens van belang zijn voor de bescherming van de natuur buiten het ontwerp te houden.

Het specifieke fiscale karakter van de Natuurschoonwet 1928 betekent niet dat de in deze wet opgenomen bepalingen geen plaats zouden kunnen

125 Ontwerp Wnb, MvT p. 29.

126 Art. 1 lid 1 onder a Natuurschoonwet 1928 verstaat onder landgoed: een in Nederland gelegen, geheel of gedeeltelijk met natuurterreinen, bossen of andere houtopstanden bezette onroerende zaak - daaronder begrepen die waarop een buitenplaats of andere, bij het karakter van het landgoed passende, opstallen voorkomen - voor zover het blijven voortbestaan van die onroerende zaak in zijn karakteristieke verschijningsvorm voor het behoud van het natuurschoon wenselijk is.

127 Zie par. 3.2.4.2 
krijgen in het ontwerp Wet natuurbescherming. De Natuurschoonwet 1928 zelf toont aan dat een wetssysteem dat is bedoeld om natuurschoon te bevorderen specifieke fiscale bepalingen kan bevatten.

Ook het ontbreken van een directe samenhang met de beschermingsregimes in het ontwerp Wet natuurbescherming, wat daarvan ook zij, vormt een onvoldoende onderbouwing voor de verdedigbaarheid van het niet opnemen van de bepalingen in de Natuurschoonwet 1928 in het ontwerp. De vraag is immers niet of die bepalingen een directe samenhang vertonen met de beschermingsregimes in dat ontwerp, maar of die bepalingen beantwoorden aan het samenhangcriterium natuur. Mij lijkt dat bepalingen die beogen natuurschoon te bevorderen ook beantwoorden aan genoemd samenhangcriterium.

\subsubsection{Wet luchtvaart}

Ten aanzien van de Wet luchtvaart is de concept-memorie van toelichting zeer kort: 'Krachtens de Wet luchtvaart is een beperkingengebied vastgesteld ten behoeve van de luchtvaartveiligheid rond Schiphol. Binnen dat gebied mogen geen nieuwe vogelaantrekkende activiteiten worden ontplooid, waaronder de vestiging van vogel- of natuurreservaten. Gemeenten en provincies zullen daarmee rekening moeten houden bij de vaststelling van een bestemmingsplan of beheersverordening (art. 3.38 Wro). ${ }^{128}$

Op zichzelf kunnen er goede redenen zijn om regels in de Wet luchtvaart die van belang zijn voor de bescherming van de natuur niet op te nemen in de Wet natuurbescherming. De regering laat zich daarover echter niet uit. Het is daarom niet goed mogelijk om te beoordelen of deze afwijking van het genoemde wetssystematische uitgangspunt verdedigbaar is.

\subsubsection{Gezondheids- en welzijnswet voor dieren}

De Gezondheids- en welzijnswet voor dieren (GWWD) is het wettelijk kader voor voorschriften over het houden van dieren. Het concept Wet natuurbescherming ziet op in het wild levende dieren. In de regel zijn dat geen gehouden dieren, aangezien niemand feitelijke macht over het dier uitoefent. De concept-memorie van toelichting noemt echter wel verschillende raakvlakken met de Gezondheids- en welzijnswet voor dieren. ${ }^{129}$

Het in artikel 36 GWWD opgenomen verbod van dierenmishandeling is van toepassing zonder onderscheid naar gehouden en niet-gehouden dieren, en is dus van toepassing op in het wild levende dieren. Een tweede raakvlak is de dierziektebestrijding. De belangen van dier- of volksgezondheid kunnen vergen

128 Ontwerp Wnb, MvT, p. 30.

129 Volgens de concept-memorie van toelichting bij het ontwerp Wnb blijven deze raakvlakken hetzelfde wanneer de GWWD vervangen wordt door de Wet dieren. 
dat tegen in het wild levende dieren maatregelen worden getroffen ter voorkoming of bestrijding van besmettelijke dierziekten in afwijking van het bepaalde bij of krachtens dit wetsvoorstel. Ten slotte heeft het wetsvoorstel een raakvlak met de Gezondheids- en welzijnswet voor dieren wanneer dieren van onder dit wetsvoorstel beschermde soorten gehouden worden. In dat geval kunnen ook op grond van de Gezondheids- en welzijnswet voor dieren regels gelden ten aanzien van de wijze van houden, de verzorging, het vervoer of het verhandelen van die dieren of producten daarvan. Voorbeelden hiervan zijn het wildhygiënecertificaat waarover een jager moet beschikken als hij door hem geschoten wild op de markt wil brengen, en de voorschriften over huisvesting en verzorging van gehouden dieren die onder de bescherming van het CITES-verdrag vallen. ${ }^{130}$

Op zichzelf kunnen er goede redenen zijn om regels in de Gezondheids- en welzijnswet voor dieren die van belang zijn voor de bescherming van de natuur niet op te nemen in de Wet natuurbescherming. De regering laat zich daarover echter niet uit. Het is daarom niet goed mogelijk om te beoordelen of deze afwijking van het genoemde wetssystematische uitgangspunt verdedigbaar is.

\subsubsection{Omgevingswet}

Ten tijde van de internetconsultatie van het concept Wet natuurbescherming door het Ministerie van ELenI had het Ministerie van IenM reeds vergevorderde plannen voor een Omgevingswet. ${ }^{131}$ Aangezien deze wet het gehele omgevingsrecht, inclusief het natuurrecht, betreft lijkt het mij logisch dat het kabinet aangeeft waarom een Wet natuurbescherming nog nodig is naast een Omgevingswet. Daarvoor zouden goede - wellicht ook wetssystematische - redenen kunnen zijn, maar het kabinet houdt zelfs in de memorie van toelichting op het wetsvoorstel Wet natuurbescherming vast aan het uitgangspunt dat er een Wet natuurbescherming moet komen, die dan voor wat betreft 'relevante onderdelen' relatief eenvoudig kunnen worden ingepast in de Omgevingswet.

De concept-memorie van toelichting vermeldt: 'Het kabinet heeft vastgesteld dat het voorstel voor de Wet natuurbescherming voldoet aan de (...) uitgangspunten zoals deze in het kader van de herijking van het omgevingsrecht voor de toekomstige Omgevingswet zijn geformuleerd. Het voorstel draagt bij aan doelstellingen van de Omgevingswet en is afgestemd op de uitgangspunten daarvan. Er doen zich geen conflicten voor die aan een procedurele integratie van essentiële ruimtelijke afwegingen en aan het in een zo vroeg mogelijk stadium betrekken van de natuuraspecten bij gebiedsontwikkeling in de weg staan. Omdat de voorgestelde begrippen en definities aansluiten op de Omgevingswet, kunnen relevante onderdelen van het voorstel voor de Wet natuurbescherming relatief eenvoudig

130 Ontwerp Wnb, MvT, p. 30.

131 Ministerie van IenM, Beleidsbrief Eenvoudig Beter 2011. 
worden ingepast in de Omgevingswet. Dat wordt lopende het wetstraject van de Omgevingswet uitgewerkt. ${ }^{132}$

Wetssystematisch acht ik het onjuist en onverdedigbaar dat het kabinet vasthoudt aan twee bundelingsoperaties terwijl het zich realiseert dat de reikwijdte van het ene voorstel - de Omgevingswet - dat van het andere de Wet natuurbescherming - duidelijk overlapt. Daarmee neemt het kabinet het aanzienlijke risico dat onafhankelijk van elkaar twee wetssystemen door bundeling tot stand worden gebracht, waarin pas in een later stadium via een derde bundelingsoperatie samenhang zal moeten worden gebracht. Het kabinet verwacht dat de Wet natuurbescherming bijdraagt aan de doelstellingen van de Omgevingswet, is afgestemd op de uitgangspunten daarvan, dat zich geen conflicten voordoen die aan een procedurele integratie van essentiële ruimtelijke afwegingen en aan het in een zo vroeg mogelijk stadium betrekken van de natuuraspecten bij gebiedsontwikkeling in de weg staan, alsmede dat de voorgestelde begrippen en definities aansluiten op de Omgevingswet. Wat daarvan ook zij, zulks biedt op zichzelf nog geen garantie voor een succesvolle bundeling van natuurregels in de Omgevingswet. In elk geval kan men zich afvragen in hoeverre sprake kan zijn van een toekomstbestendige Omgevingswet en Wet natuurbescherming als reeds nu in statu nasciendi duidelijk is dat onderdelen van de laatste wet in de eerste zullen worden overgeheveld.

Mijn dringend advies aan het kabinet is dan ook om expliciet aan te geven welke samenhangcriteria de Omgevingswet zullen bepalen en aan de hand daarvan te beslissen in hoeverre de thans in het concept Wet natuurbescherming opgenomen regels in het wetssysteem van de Omgevingswet een plaats moeten krijgen.

\subsubsection{Antwoord op toetsvraag 2}

Het ontwerp Wet natuurbescherming zal het in paragraaf 6.3 beschreven wetssystematisch tekort opheffen door de bepalingen in de Natuurbeschermingswet 1998, de Flora- en faunawet en de Boswet te bundelen. De bundeling zal echter niet alle thans bestaande wetssystematische tekorten opheffen omdat in het ontwerp Wet natuurbescherming niet alle bepalingen zullen worden opgenomen die beantwoorden aan het samenhangcriterium natuur. In het geval van regimes van algemene aard, de Visserijwet, de Waterwet, de Natuurschoonwet 1928, de Wet luchtvaart en de Gezondheidsen welzijnswet voor dieren verzuimt de regering om een afdoende motivering te geven die deze wetssystematische tekorten kunnen verdedigen. Verder wordt nauwelijks ingegaan op de relatie met de Omgevingswet. ${ }^{133}$ Wel verdedigbaar is het niet van toepassing verklaren van het ontwerp op

132 Kamerstukken II 2011/12, 33 348, nr. 3, p. 23.

133 Zie hoofdstuk 7. 
het grondgebied van de openbare lichamen Bonaire, Sint-Eustasius en Saba (BES). Gelet op deze tekortkomingen beantwoord ik de tweede toetsvraag overwegend negatief.

\subsection{ANDERE SAMENHANGCRITERIA}

\subsubsection{Algemeen}

In deze paragraaf zal de vraag worden beantwoord of het gebruik van typisch juridische ordeningscriteria in het ontwerp Wet natuurbescherming zal leiden tot wetssystematische tekorten en zo ja, of deze tekorten verdedigbaar zijn.

\subsubsection{Typisch juridische begrippen}

\subsubsection{Interne wetssystematische tekorten}

Het wetssysteem van het ontwerp Natuurbeschermingswet bestaat uit de elf in overzicht 6.4 (par. 6.2.5) genoemde hoofdstukken, die vaak weer zijn onderverdeeld in subwetssystemen. De hoofdstukken 2, 3 en 4 ontwerp Wnb worden bepaald door de zakelijke samenhangcriteria van respectievelijk gebieden, soorten en houtopstanden. Voor de overige hoofdstukken en binnen de hoofdstukken 2, 3 en 4 ontwerp Wnb zijn typisch juridische samenhangcriteria gebruikt, die leiden tot interne wetssystematische tekorten. Dat heeft tot gevolg dat de gebruiker is gedwongen verschillende subwetssystemen binnen het ontwerp Natuurbeschermingswet te raadplegen om zijn rechten en plichten te kunnen kennen. Dat komt de kenbaarheid niet ten goede. Dat zal ik hierna illustreren met een voorbeeld.

Stel dat iemand het ontwerp raadpleegt om het antwoord te vinden op de vraag of het is toegestaan een bepaalde vogel, zoals de Gekraagde Roodstaart, ${ }^{134}$ te vangen. Het ontwerp kent geen subwetssysteem dat aansluit bij de echte werkelijkheid van het object 'vogel' of de activiteit 'vangen'. De gebruiker zal het antwoord op zijn vraag daarom dienen te zoeken in verschillende subwetssystemen.

In de eerste plaats bepaalt artikel 1.8 ontwerp Wnb in hoofdstuk 1 dat een ieder voldoende zorg in acht neemt voor in het wild levende dieren en planten en voor Natura 200o-gebieden. Deze algemene zorgplicht geldt ook ten aanzien van het vangen van vogels.

134 Terwijl ik dit buiten schrijf op het terras van een voormalige boswachterswoning van Staatsbosbeheer in Strijbeek zit er tegenover mij in een fruitboom een Phoenicurus phoenicurus te kwinkeleren. 
In de tweede plaats bepaalt artikel 2.1 lid 1 ontwerp Wnb dat de minister van ELenI gebieden aanwijst als speciale beschermingszones ${ }^{135}$ ter uitvoering van enige artikelen van de Vogelrichtlijn. Ook het vierde lid verwijst naar de Vogelrichtlijn door te bepalen dat het aanwijzingsbesluit de instandhoudingsdoelstellingen voor het gebied bevat ten aanzien van onder meer de leefgebieden voor vogelsoorten, voor zover nodig ter uitvoering van de Vogelrichtlijn. Het is niet uitgesloten dat de gebruiker het antwoord op zijn vraag in het subwetssysteem van hoofdstuk 2 ontwerp Wnb zal moeten zoeken, bijvoorbeeld als de vraag of het is toegestaan om een bepaalde vogel te vangen opkomt in het kader van de realisering van een project dat niet direct verband houdt met of nodig is voor het beheer van een Natura 2000-gebied. ${ }^{136}$

In de derde plaats zal de genoemde gebruiker voor het antwoord op zijn vraag het subwetssysteem van hoofdstuk 3 ontwerp Wnb Soorten van het ontwerp moeten raadplegen. Dat hoofdstuk is echter niet ingedeeld volgens zakelijke samenhangcriteria als vogels, categorieën van vogels of handelingen ten aanzien van vogels zoals het vangen van vogels. Hoofdstuk 3 ontwerp Wnb kent daarentegen acht paragrafen, waarvan het voor de gebruiker niet op voorhand duidelijk zal zijn of die - ook - betrekking hebben op vogels respectievelijk op de vogels waarvan hij zich afvraagt of hij die mag vangen.

Deze paragrafen zijn:

$\S 3.1$ Beschermingsregime soorten Vogelrichtlijn

§ 3.2 Beschermingsregime soorten Habitatrichtlijn

$\S 3.3$ Beschermingsregime andere soorten

$\S 3.4$ Schadebestrijding en faunabeheer

$\S 3.5$ Jacht

$\S$ 3.6 Middelen voor het vangen en doden van vogels en zoogdieren

$\S 3.7$ Overige bepalingen ten aanzien van in het wild levende dieren en planten $\S 3.8$ Handel in en bezit van planten en dieren

Paragraaf 3.1 regelt in artikel 3.1 lid 1 ontwerp Wnb het verbod om opzettelijk vogels te doden of te vangen. Daarmee is echter niet aanstonds duidelijk op welke vogels dit verbod ziet. Het antwoord op die vraag kan slechts worden gevonden door verschillende bepalingen te raadplegen in het subwetssysteem van paragraaf 3.1 ontwerp Wnb, het subwetssysteem van hoofdstuk 1 ontwerp Wnb en het wetssysteem van de Vogelrichtlijn. In het subwetssysteem van hoofdstuk 1 ontwerp Wnb is artikel 1.1 lid 1 opgenomen dat bepaalt dat onder vogels worden verstaan vogels van soorten als bedoeld in artikel 1 lid 1 Vogelrichtlijn. Dat laatste artikel bepaalt dat - het wetssysteem van - de Vogelrichtlijn betrekking heeft 'op de instandhouding van alle natuurlijk in het wild levende vogelsoorten op het Europese grondgebied van de Lid-Staten waarop het Verdrag van toepassing is'. In de tweede plaats bepaalt artikel 3.3 lid 2 ontwerp Wnb dat Provinciale Staten bij verordening vrijstelling kunnen verlenen van het verbod om vogels ten aanzien van daarbij aangewezen soorten te vangen. In de derde plaats bepaalt artikel 3.3 lid 6 ontwerp Wnb dat het verbod om vogels te vangen niet van toepassing is op

135 De term speciale beschermingszones is overigens niet in het hoofdstuk met begrippen gedefinieerd.

136 Art. 2.7 lid 2 ontwerp Wnb. 
handelingen waarvoor een omgevingsvergunning is vereist op basis van de Wabo. In de vierde plaats bepaalt artikel 3.3 lid 7 ontwerp Wnb dat het verbod om vogels te vangen niet van toepassing is op handelingen ten aanzien waarvan bij of krachtens enige wettelijke bepaling een besluit is vereist, indien bij of krachtens die wet is bepaald dat het vierde en vijfde lid van overeenkomstige toepassing zijn op dat besluit.

Paragraaf 3.2 ontwerp Wnb regelt in artikel 3.5 het verbod om in het wild levende dieren in hun natuurlijke verspreidingsgebied opzettelijk te doden of te vangen. Het moet daarbij gaan om in het wild levende dieren van soorten, opgenomen in bijlage IV onderdeel a bij de Habitatrichtlijn. De gebruiker zal de Habitatrichtlijn moeten raadplegen om erachter te komen dat genoemde bijlage geen vogels noemt. Paragraaf 3.2 ontwerp Wnb levert derhalve geen antwoord op de vraag van de gebruiker of het is toegestaan een bepaalde vogel te vangen.

Paragraaf 3.3 ontwerp Wnb bevat regels over het beschermingsregime van andere soorten en lijkt op het eerste gezicht ook betrekking te kunnen hebben op vogels. Deze paragraaf bevat echter geen regels over vogels, maar is beperkt tot in het wild levende zoogdieren, amfibieën en reptielen. ${ }^{137}$

Paragraaf 3.4 ontwerp Wnb bepaalt dat bij algemene maatregel van bestuur onder meer vogels kunnen worden aangewezen die niet in hun voortbestaan worden bedreigd of dat gevaar lopen, en in delen van het land schade aanrichten. ${ }^{138}$ Provinciale staten kunnen bij verordening toestaan dat de grondgebruiker handelingen als bedoeld in artikel 3.1 lid 1 Wnb verricht op door hem gebruikte gronden, dan wel in of aan door hem gebruikte opstallen, indien deze handelingen nodig zijn ter voorkoming van in het lopende of daarop volgende jaar dreigende schade binnen de grenzen van het werkgebied van de wildbeheereenheid waarin die gronden of opstallen zijn gelegen. De minister van ELenI kan invasieve exoten aanwijzen waarvan het noodzakelijk is dat de stand tot nul wordt teruggebracht.

Paragraaf 3.5 ontwerp Wnb inzake de jacht geldt eveneens voor vogels. Artikel 3.18 ontwerp Wnb bepaalt dat het de jachthouder en degenen in zijn gezelschap is toegestaan in zijn jachtveld bejaagbare soorten te vangen. Bejaagbare soorten zijn onder meer de volgende vogels: fazant, wilde eend, houtduif, grauwe gans, smient en kolgans.

Paragraaf 3.6 ontwerp Wnb geeft geen antwoord op de vraag of een bepaalde vogel mag worden gevangen, maar is wel van belang voor het antwoord op de vraag welke middelen daarbij zijn toegestaan.

In paragraaf 3.7 ontwerp Wnb bepaalt artikel 3.29 dat een ieder die een in het wild levend dier vangt voorkomt dat het dier onnodig lijdt. Dit geldt ook voor het vangen van vogels.

137 Art. 3.11 ontwerp Wnb.

138 Art. 3.12 ontwerp Wnb. 
Paragraaf 3.8 ontwerp Wnb gaat over de handel in en het bezit van planten en dieren en is dus niet direct relevant voor de vraag of een bepaalde vogel al dan niet mag worden gevangen.

Dit voorbeeld illustreert dat een gebruiker voor het antwoord op zijn tamelijk eenvoudige vraag 'wat zijn mijn rechten en plichten ten aanzien van het vangen van deze vogel,' niet alleen een aantal subwetssystemen binnen het wetssysteem van het ontwerp Wet natuurbescherming moet raadplegen, maar daarnaast nog andere wetssystemen: de Vogelrichtlijn, de Habitatrichtlijn, de Wabo, de in artikel 3.3 lid 7 ontwerp Wnb genoemde wettelijke bepaling(en), de - eventueel - op artikel 3.12 ontwerp Wnb gebaseerde algemene maatregel van bestuur de - eventueel - op artikel 3.16 ontwerp Wnb gebaseerde ministeriële aanwijzing en - eventueel - de op basis van artikel 3.3 lid 2 ontwerp Wnb relevante provinciale verordening. Het is deze wetssystematiek die het voor gebruikers moeilijk maakt om hun rechten en verplichtingen te kunnen kennen.

Maar zou het ook minder complex kunnen? Het komt mij voor dat de Vogelrichtlijn en de Habitatrichtlijn niet dwingen tot de in het ontwerp Wnb gekozen systematiek. En al zou dat wel zo zijn, dan biedt de nationale omzetting van die richtlijnen juist een kans om onvolkomenheden in de Europese wetssystematiek te mitigeren.

In dit verband is de volgende passage uit een publicatie van het Duitse Bundesministerium für Umwelt c.a. interessant: 'Das UGB macht das Umweltrecht europatauglich. Das Umweltgesetzbuch wird die Umsetzung europäischer Umweltrechtsakte in Deutschland wesentlich erleichtern. Auch das europäische Umweltrecht ist zunehmend fachübergreifend ausgerichtet, d.h. seine Anforderungen haben nicht nur den Schutz einzelner Umweltgüter, sondern die Umwelt insgesamt im Blick. Solche Regelungen der EU müssen im Rahmen eines UGB nicht mehr wie bisher getrennt und unter Auflösung bestehender Zusammenhänge in die verschiedenen Fachgesetze aufgenommen werden. Sie können vielmehr einheitlich in das Umweltgesetzbuch eingestellt werden. Dadurch kann die Umsetzung des europäischen Umweltrechts wesentlich schneller, unkomplizierter und europarechtsnäher erfolgen. Es gilt dann auch hier: Aufgabe der bisherigen Rechtszersplitterung, Regelungen aus einem Guss. Ein deutsches UGB kann aber auch zum Modell und Motor für eine europäische Umweltrechtsreform werden. Damit kann unser Land wieder an seine Vorreiterrolle im Umweltschutz in den 70er Jahren anknüpfen.'139

Mij lijkt het de moeite waard om te onderzoeken of het wetssysteem van het ontwerp Wnb aanzienlijk eenvoudiger zou kunnen worden voor de gebruiker door die niet in te richten op basis van drie beschermingsregimes, maar op basis van voor gebruikers kenbare activiteiten ten aanzien van soorten. Ook is het de vraag of het per se noodzakelijk is om drie regimes te gebruiken:

139 Bundesministerium für Umwelt c.a. 10 gute Gründe für ein Umweltgesetzbuch 2007, nr. 8. 
een algemene zorgplicht in hoofdstuk 1, een gebiedsregime in hoofdstuk 2 en een soortenregime in hoofdstuk 3. In de echte werkelijkheid gaat het immers in alle gevallen om activiteiten ten aanzien van planten, vogels en andere dieren. Het gaat het bestek van dit onderzoek te buiten om de hier gestelde vragen te beantwoorden.

\subsubsection{Externe wetssystematische tekorten}

\section{Algemene wet bestuursrecht}

Het subwetssysteem van hoofdstuk 5 ontwerp Wnb Vergunningen, ontheffingen en verplichtingen bepaalt onder meer dat op een aanvraag om een bij of krachtens het ontwerp Wnb vereiste vergunning of ontheffing binnen 13 weken na datum van ontvangst moet zijn beslist. Het bevoegd gezag kan de termijn eenmaal met 7 weken verlengen. ${ }^{140}$ Artikel 5.2 ontwerp Wnb bevat een uitzondering op de zogeheten lex silencio positivo (LSP). ${ }^{141}$ De Dienstenrichtlijn ${ }^{142}$ bepaalt dat een vergunning automatisch wordt verleend tenzij bij wettelijk voorschrift anders is bepaald. Deze bepaling is uitgewerkt in paragraaf 4.1.3.3 Awb. Artikel 4:20a lid 1 Awb bepaalt dat paragraaf 4.1.3.3 Awb van toepassing is indien dit bij wettelijk voorschrift is bepaald. Artikel 4:20b lid 1 Awb bepaalt dat indien niet tijdig op de aanvraag tot het geven van een beschikking is beslist, de gevraagde beschikking van rechtswege is gegeven.

Een groot aantal regels inzake de voorbereiding van de beschikking op een aanvraag om een bij of krachtens het ontwerp Wnb vereiste vergunning of ontheffing staat niet in het ontwerp, maar in de Awb. Dat betekent dat sprake is van handhaving van een reeds bestaand extern wetssystematisch tekort ${ }^{143}$ in het ontwerp. Dat betekent dat de gebruiker van het ontwerp, die wil weten wat rechtens is ten aanzien van de totstandkoming van de beschikking op een aanvraag de wetssystemen van het ontwerp en van de Awb zal moeten raadplegen.

140 Art. 5.1 lid 1 en 2 ontwerp Wnb. De regering onderbouwt niet waarom wordt afgeweken van de algemene beslistermijn van 8 weken in art. 4:13 Awb en de beslistermijnen van 8 respectievelijk 26 weken die de Wabo kent voor de omgevingsvergunning. Die laatste termijn geldt ook in geval van aanhaken van de $\mathrm{Nb}$-wetvergunning of de Ffw-ontheffing (par. 4.2).

141 In dit artikel is bepaald dat de LSP niet van toepassing is op een aanvraag om ontheffing van de handelsverboden in art. 3.2 en 3.6 en op een aanvraag om vergunning voor een project dat significante gevolgen kan hebben op een Natura 2000-gebied. De in art. 5.2 genoemde artikelen zijn gesteld ter uitvoering van Europeesrechtelijke verplichtingen. De Vogel- en Habitatrichtlijn verzetten zich tegen het toepassen van de LSP op deze vergunningstelsels, omdat de toets of geen afbreuk wordt gedaan aan natuurwaarden vooraf moet worden gedaan. Deze bepaling is in lijn met art. $75 \mathrm{f}$ van de Flora- en faunawet en art. 40 van de Natuurbeschermingswet 1998 (Ontwerp Wnb, concept-MvT p. 235)

142 Richtlijn nr. 2006/123/EG van het Europees Parlement en de Raad van de Europese Unie van 12 december 2006 betreffende de diensten op de interne markt, (PbEU 2006 L 276/36).

143 Zie par. 3.4.4.1 


\section{Economische delicten}

Een ander extern wetssystematisch tekort betreft het feit dat de regels inzake strafbedreiging bij overtreding van bepalingen die thans in de Natuurbeschermingswet 1998, de Flora- en faunawet en de Boswet staan en zullen worden gebundeld in het wetssysteem van het ontwerp Natuurbeschermingswet, is geregeld in het wetssysteem van de Wet op de economische delicten. Dit extern wetssystematisch tekort is evenwel niet veroorzaakt door de herschikking. De strafbedreiging van overtreding van bepalingen in de drie genoemde wetten vindt op dit moment al plaats in de Wet op de economische delicten. ${ }^{144}$

\subsubsection{Verdedigbaarheid wetssystematische tekorten}

Ten aanzien van de hiervoor gesignaleerde interne wetssystematische tekorten heb ik opgemerkt, dat onderzoek nodig is om te bepalen of een minder complex wetssysteem mogelijk is. Die tekorten acht ik vooralsnog op voorhand niet verdedigbaar. De gesignaleerde externe wetssystematische tekorten acht ik wel verdedigbaar, aangezien het recht is gediend met de door de Awb en de Wet op de economische delicten geboden uniformiteit.

De gevolgen van de wetssystematische tekorten ten aanzien van de Awb zouden wat betreft de artikelen 5.1 en 5.2 ontwerp Wnb overigens kunnen worden verminderd door ook voor de beslistermijnen aan te sluiten bij de Awb en de uitzonderingen op paragraaf 4.1.3.3 Awb in de Awb op te nemen. Het voordeel daarvan is dat de toepasselijke samenhangende regels in hetzelfde wetssysteem staan.

\subsubsection{Gelede normstelling}

\subsubsection{Wetssystematische tekorten}

In het ontwerp Wnb is ook gebruik gemaakt van het typisch juridische ordeningscriterium van de gelede normstelling. ${ }^{145}$ Het ontwerp bevat zoals dat ook het geval is met de Natuurbeschermingswet 1998, de Flora- en faunawet en de Boswet - veel artikelen die de basis vormen voor het stellen van uitvoeringsregels bij of krachtens algemene maatregel van bestuur. Aangezien de uitvoeringsregels op basis van het voorontwerp nog niet bekend zijn, kan daarop hier niet uitvoerig worden ingegaan. Volstaan wordt met een enkel voorbeeld ter illustratie.

Artikel 3.2 lid 1 ontwerp Wnb bevat het verbod om vogels dood of levend, of gemakkelijk herkenbare delen daarvan, of uit deze vogels verkregen producten te verkopen, te vervoeren voor verkoop, onder zich te hebben voor verkoop of

144 Art. 1a lid 1 onder $1^{\circ}$ en $2^{\circ}$ Wed.

145 Zie par. 3.4.4.3. 
ten verkoop aan te bieden. Teneinde zijn rechten en verplichtingen te kunnen kennen zijn in ieder geval ook de volgende bepalingen van belang:

a. het verbod is niet van toepassing ten aanzien van bij algemene maatregel van bestuur aangewezen vogels van vogelsoorten, opgenomen in bijlage III, deel B, bij de Vogelrichtlijn, die overeenkomstig het bepaalde bij of krachtens het ontwerp Wnb zijn gedood of gevangen, onderscheidenlijk verkregen, en delen of producten van die vogels; ${ }^{146}$

b. bij algemene maatregel van bestuur kunnen regels worden gesteld over de verkoop, het vervoer voor verkoop, het onder zich hebben voor verkoop of het ten verkoop aanbieden van vogels van vogelsoorten, aangewezen op grond van artikel 3.2 lid 3 ontwerp Wnb, en delen of producten van die vogels. ${ }^{147}$

Deze gelede normstelling doorbreekt het wetssysteem van het ontwerp Wnb, aangezien het verbod steeds zal moeten worden bezien in samenhang met de genoemde algemene maatregelen van bestuur.

\subsubsection{Verdedigbaarheid gelede normstelling}

De regering onderbouwt mijns inziens niet waarom gelede normstelling in het genoemde geval noodzakelijk is. De desbetreffende algemene maatregelen van bestuur zijn zoals gezegd nog niet bekend, dus is daarvan op dit moment niet te zeggen of die verdedigbaar zijn.

\subsubsection{Europese richtlijnen en verordeningen}

\subsubsection{Wetssystematische tekorten}

In het ontwerp Wnb wordt regelmatig verwezen naar Europese richtlijnen en verordeningen. Reeds eerder noemde ik als voorbeeld dat vogels worden gedefinieerd als vogels van soorten als bedoeld in artikel 1 lid 1 Vogelrichtlijn. ${ }^{148}$ Een ander voorbeeld betreft het verbod om in strijd te handelen met bij ministeriële regeling aangewezen voorschriften van EU-verordeningen als bedoeld in artikel 3.34 ontwerp Wnb. ${ }^{149}$ De wetssystematische tekorten bestaan hierin, dat gebruikers van het wetssysteem van het ontwerp Wnb

146 Art. 3.2 lid 3 ontwerp Wnb.

147 Art. 3.2 lid 4 ontwerp Wnb.

148 Art. 1.1 lid 1 ontwerp Wnb.

149 Art. 3.35 lid 1 Wnb. Het betreft a. verordening (EG) nr. 338/97 van de Raad van 9 december 1996 inzake de bescherming van in het wild levende dier- en plantensoorten door controle op het desbetreffende handelsverkeer (PbEG 1997 L 61/1); b. verordening (EG) nr. 1007/2009 van het Europees Parlement en de Raad van 16 september 2009 betreffende de handel in zeehondenproducten (PbEU 2009 L 286/36); c. verordeningen die berusten op de verordeningen, bedoeld in onderdelen a en b; d. bij algemene maatregel van bestuur aangewezen andere verordeningen en richtlijnen die geheel of gedeeltelijk berusten op de artikelen 114, 192, 207 of 352 van het Verdrag betreffende de werking van de Europese Unie, of op een andere bindende EU-rechtshandeling die op een of meer van die artikelen berusten en die betrekking hebben op de handel in uit de natuur onttrokken dieren en planten of producten daarvan (art. 3.34 Wnb). 
om erachter te komen wat hun rechten en verplichtingen zijn, zijn aangewezen op andere wetssystemen, te weten de genoemde Europese richtlijnen en verordeningen.

\subsubsection{Verdedigbaarheid wetssystematische tekorten}

Mij lijkt dat de hier bedoelde wetssystematische tekorten in elk geval niet in alle gevallen verdedigbaar zijn. Zo kan de wetgever het tekort dat ontstaat doordat de gebruiker kennis moet nemen van artikel 1.1 lid 1 Vogelrichtlijn eenvoudig oplossen door de relevante zinsnede van dat lid, dat het gaat om 'alle natuurlijk in het wild levende vogelsoorten op het Europese grondgebied van de Lid-Staten waarop het Verdrag van toepassing is,' in het ontwerp Wnb op te nemen.

Aangezien het niet mogelijk is om Europese verordeningen over te schrijven, kunnen in de in artikel 3.35 lid 1 ontwerp Wnb genoemde ministeriële regeling niet de aangewezen voorschriften in EU-verordeningen zelf worden opgenomen. ${ }^{150}$ In dat geval is de verwijzing dus wel verdedigbaar.

\subsubsection{Antwoord op toetsvraag 3}

In het ontwerp Wnb is gebruik gemaakt van typisch juridische ordeningscriteria als typisch juridische begrippen, gelede normstelling en verwijzing naar Europese richtlijnen en verordeningen. Dat zal leiden tot het scheppen of laten voortduren van wetssystematische tekorten. De gesignaleerde tekorten zijn in een aantal gevallen niet verdedigbaar en nopen tot nader onderzoek. Een aantal tekorten lijkt de wetgever op eenvoudige wijze te kunnen oplossen. Daarmee is de derde toetsvraag overwegend negatief beantwoord.

Als antwoord op de derde deelvraag van dit onderzoek zijn per wetssystematisch tekort in een aantal gevallen suggesties gedaan om dat op te heffen of te verminderen.

\subsection{WETSSYSTEMATISCHE TEKORTEN ELDERS}

\subsubsection{Algemeen}

In paragraaf 6.4 is het voortbestaan van wetssystematische tekorten binnen het door herschikking te realiseren wetssysteem van het ontwerp Wnb onderzocht. Daarnaast kan herschikking in beginsel ook leiden tot wetssystematische tekorten die buiten het door bundeling ontstane wetssysteem

150 Zie par. 3.4.5.4. 
zijn ontstaan als gevolg van de bundeling door herschikking. Nu de bepalingen van de Natuurbeschermingswet 1998, de Flora- en faunawet en de Boswet worden overgenomen in het ontwerp en die wetten zelf vervallen is daarvan geen sprake.

\subsubsection{Antwoord op toetsvraag 4}

De herschikking van de Natuurbeschermingswet 1998, de Flora- en faunawet en de Boswet zal niet leiden tot wetssystematische tekorten buiten het ontwerp Wnb. Daarmee is de vierde toetsvraag positief beantwoord.

\subsection{TOEKOMSTBESTENDIG}

\subsubsection{Algemeen}

In deze paragraaf zal de vraag worden beantwoord of het wetssysteem van het ontwerp Wnb ten aanzien van natuur na herschikking van de Natuurbeschermingswet 1998, de Flora- en faunawet en de Boswet toekomstbestendig zal zijn. In paragraaf 3.6 heb ik een wetssysteem toekomstbestendig genoemd als daarbinnen geen nieuwe - onverdedigbare - wetssystematische tekorten ontstaan als gevolg van het feit dat de wetgever in belangrijke mate is gedwongen om een chronologische aanpak ${ }^{151}$ te hanteren. Daarbij heb ik vier wetgevingstechnieken aangegeven die al dan niet in samenhang gebruikt naar mijn oordeel tot een - meer - toekomstbestendig wetssysteem kunnen leiden. Hierna zal ik onderzoeken in hoeverre deze technieken zijn gebruikt in het kader van de bedoelde herschikking, waarna ik zal aangeven of het ontwerp Wnb ten aanzien van natuur toekomstbestendig mag worden genoemd.

\subsubsection{Op permanente opschoning gericht}

De wetgever heeft met de herschikking niet een wetssysteem beoogd dat de pretentie heeft het omgevingsrecht ten aanzien van natuur voor eens en voor altijd te codificeren. Veeleer is sprake van een opschoning van het omgevingsrecht in de vorm van op permanente verandering toegesneden wetssystematiek, waarin nieuwe omgevingsregels van nationale of Europese oorsprong een plaats kunnen krijgen zonder nieuwe wetssystematische tekorten te veroorzaken.

De geschetste permanente verandering beperkt zich in eerste instantie tot de regels inzake de bescherming van de natuur die thans zijn opgenomen in de 
Natuurbeschermingswet 1998, de Flora- en faunawet en de Boswet. De permanente verandering richt zich echter ook op de Omgevingswet waarvan de regering begin 2012 de contouren heeft geschetst in de kabinetsbrief stelselherziening omgevingsrecht. ${ }^{152}$ In die brief wordt opgemerkt dat het ontwerp vooruitloopt op de Omgevingswet, maar inhoudelijk al op de uitgangspunten van de Omgevingswet is afgestemd. Het ontwerp neemt voor het samenhangende systeem voor de bescherming van dier- en plantensoorten de Europese regelgeving als uitgangspunt. De begrippen en definities in het ontwerp zullen verder maximaal aansluiten op de Omgevingswet zodat de ruimtelijk relevante onderdelen in een later stadium over kunnen naar de Omgevingswet. Dat geldt in ieder geval voor de natuurvisie, het natuurbeheerplan en de vergunningen. ${ }^{153}$ Zo worden de ruimtelijke aspecten van de natuurvisie geïntegreerd in de omgevingsvisie ${ }^{154}$ en wordt de natuurbeschermingsvergunning opgenomen in de omgevingsvergunning. ${ }^{155}$

\subsubsection{Aansluiten bij wetssystematische criteria en opbouw}

Het wetssysteem van het ontwerp Wnb wordt bepaald door zakelijke en typisch juridische toekomstbestendige systeemordeningscriteria. ${ }^{156}$

Ten aanzien van de zakelijke systeemordeningscriteria heb ik geconcludeerd dat genoemd wetssysteem wordt bepaald door het samenhangcriterium natuur. ${ }^{157}$ Het betreft hier een open systeem in die zin dat nieuwe omgevingsregels van nationale of Europese oorsprong inzake natuur eenvoudig een plaats kunnen krijgen in het wetssysteem van het ontwerp Wnb zonder dat zulks tot nieuwe wetssystematische tekorten leidt.

Ten aanzien van de typisch juridische ordeningscriteria kan worden opgemerkt, dat de wetgever bij mogelijke toekomstige wijzigingen van het ontwerp Wnb kan aansluiten bij deze criteria zonder dat zulks tot nieuwe wetssystematische tekorten zal leiden. Dat is met name het gevolg van het feit dat het ontwerp Wnb de Europese wetgeving als uitgangspunt neemt. Als wijziging van die wetgeving tot implementatie in het ontwerp Wnb aanleiding geeft, zal dat naar verwachting niet leiden tot nieuwe wetssystematische tekorten.

152 Ministerie van IenM, Kabinetsbrief stelselherziening omgevingsrecht 2012.

153 Ministerie van IenM, Kabinetsbrief stelselherziening omgevingsrecht 2012, p. 21.

154 Ministerie van IenM, Kabinetsbrief stelselherziening omgevingsrecht 2012, bijlage 1, onder 3.

155 Art. 10.7 onder B ontwerp Wnb.

156 Zie par. 3.6.3.

157 Zie par. 6.3.3 
Meijer \& Zwier menen overigens dat de wetgever minder goed is geslaagd in de opzet om nauwkeurig aan te sluiten bij internationale verplichtingen. Dat geldt volgens hen voor de aansluiting bij enkele soorten- en gebiedsbeschermingsbepalingen uit het Verdrag van Bern, maar ook voor verplichtingen die voortvloeien uit de Habitatrichtlijn en de Vogelrichtlijn. Zij bevelen de wetgever aan om het ontwerp Wnb nog eens onder de loep te nemen en de bepalingen die conflicteren met internationaal recht aan te passen. ${ }^{158}$

\subsubsection{Geen aanbouwwetssysteem}

Het ontwerp Wnb is geen aanbouwwetssysteem in die zin dat een wetssystematiek is geschapen, waarvan de diverse onderdelen nog moeten worden ingevuld.

\subsubsection{Antwoord op toetsvraag 5}

De herschikking van de Natuurbeschermingswet 1998, de Flora- en faunawet en de Boswet in het ontwerp Wnb pretendeert niet het omgevingsrecht ten aanzien van natuur voor eens en altijd vast te leggen, maar is gericht op permanente verandering waarbij reeds rekening is gehouden met de komst van een Omgevingswet. De toekomstbestendigheid wordt nog vergroot door het gebruik van toekomstbestendige zakelijke en typisch juridische systeemordeningscriteria, mits de wetgever bij toekomstige wijzigingen aansluit bij die criteria. Daarmee is de vijfde toetsvraag positief beantwoord.

\subsection{SAMENVATTING}

Op 6 oktober 2011 is een ontwerp gepubliceerd van een wetsvoorstel Regels over de bescherming van de natuur (Wet natuur) waarin de Natuurbeschermingswet 1998, ${ }^{159}$ de Flora- en faunawet ${ }^{160}$ en de Boswet ${ }^{161}$ zijn opgenomen. ${ }^{162}$ Dit ontwerp Wet natuurbescherming betreft een voornemen tot modificerende ${ }^{163}$ bundeling door herschikking. ${ }^{164}$ In hoofdstuk 6 is aan de

158 Meijer \& Zwier, Voorjaarsschoonmaak in het natuurbeschermingsrecht 2012, p. 171.

159 Wet van 25 mei 1998, houdende nieuwe regelen ter bescherming van natuur en landschap (Natuurbeschermingswet 1998), Stb. 1998, 403. Deze wet is gefaseerd in werking getreden, de eerste artikelen per 1 oktober 2005 (Stb. 2005, 473).

160 Wet van 25 mei 1998, houdende regels ter bescherming van in het wild levende planten- en diersoorten (Flora- en faunawet), Stb. 1998, 402. Deze wet is gefaseerd in werking getreden, de eerste artikelen op 2 juli 1999 (Stb. 1999, 264)

161 Wet van 20 juli 1961, houdende nieuwe bepalingen ter bewaring van bossen en andere houtopstanden (Stb. 1961, 256). Deze wet is in werking getreden op 1 juli 1962 (Stb. 1962, 193).

162 www.internetconsultatie.nl/wetnatuur.

163 Par. 2.5.3.

164 Par. 2.4.5 
hand van de in paragraaf 3.8 genoemde vijf toetsvragen onderzocht hoe deze bundeling zich verhoudt tot de in hoofdstuk 3 opgenomen criteria.

Het antwoord op de eerste toetsvraag ${ }^{165}$ is positief. Op dit moment is binnen het omgevingsrecht sprake van een wetssystematisch tekort omdat niet alle regels die volgens het op de echte werkelijkheid gebaseerde zakelijk samenhangcriterium natuur onderling samenhangen, deel uitmaken van hetzelfde wetssysteem.

Het antwoord op de tweede toetsvraag is overwegend negatief. De herschikking van de Natuurbeschermingswet 1998, de Flora- en faunawet en de Boswet in het ontwerp Wet natuurbescherming heeft het in paragraaf 6.3 beschreven wetssystematisch tekort opgeheven. Dit is gerealiseerd door alle bepalingen in de drie genoemde wetten die niet behoefden te vervallen op te nemen in het ontwerp en de drie wetten in te trekken. Daaraan doet echter niet af dat mogelijke andere bestaande wetssystematische tekorten onveranderd zullen blijven. De regering geeft echter geen afdoende motivering die deze wetssystematische tekorten zouden kunnen verdedigen.

Het antwoord op de derde toetsvraag is overwegend negatief. In het ontwerp Wnb is gebruik gemaakt van typisch juridische ordeningscriteria als typisch juridische begrippen, gelede normstelling en verwijzing naar Europese richtlijnen en verordeningen. Dat zal leiden tot het scheppen of laten voortduren van wetssystematische tekorten. De gesignaleerde tekorten zijn in een aantal gevallen niet verdedigbaar en nopen tot nader onderzoek. Een aantal tekorten lijkt de wetgever op eenvoudige wijze te kunnen oplossen.

De vierde toetsvraag is negatief beantwoord. Het overnemen van de bepalingen van de Natuurbeschermingswet 1998, de Flora- en faunawet en de Boswet in het ontwerp en het vervallen van die drie wetten zelf zal niet leiden tot wetssystematische tekorten als gevolg van de bundeling door herschikking.

Toetsvraag vijf is positief beantwoord, aangezien het ontwerp niet pretendeert het omgevingsrecht ten aanzien van natuur voor eens en altijd vast te leggen, maar juist is gericht op permanente verandering, waarbij reeds rekening is gehouden met de komst van een Omgevingswet. De toekomstbestendigheid wordt nog vergroot door het gebruik van toekomstbestendige zakelijke en typisch juridische systeemordeningscriteria, mits de wetgever bij toekomstige wijzigingen aansluit bij die criteria. 
Het feit dat de toetsvragen 1 en 5 positief zijn beantwoord, toetsvraag 4 negatief en de toetsvragen 2 en 3 overwegend negatief betekent dat de herschikking van de Natuurbeschermingswet 1998, de Flora- en faunawet en de Boswet in het ontwerp Natuurbeschermingswet weliswaar een belangrijke bijdrage zal leveren aan het verminderen van thans bestaande wetssystematische tekorten in het omgevingsrecht, doch dat het overwegend negatieve antwoord op de toetsvragen 2 en 3 in mijn toetsingskader moet leiden tot de conclusie dat de herschikking niet volledig verantwoord kan worden genoemd. Verbeteringen zijn mogelijk, waarvoor in hoofdstuk 6 een aantal suggesties is gedaan. Als de wetgever erin zou slagen zodanige wetssystematische verbeteringen aan te brengen in het ontwerp dat het antwoord op de tweede en derde toetsvraag positief zou kunnen luiden, zou het algehele oordeel in het voordeel van het ontwerp kunnen omslaan. 



\section{$7 \quad$ Herschikking: Omgevingswet}

'Gesetze haben in den meisten Fällen zum Ziel, eine große Anzahl von Sachverhalten und persönlichen Betroffenheiten zu regeln. Der Umfang der Regelungsgegenstände und die Allgemeinheit der Regelung machen es daher erforderlich, die vorhandene Regelungsmaterie zu ordnen und nach bestimmten Kriterien zu systematisieren. Erst diese Einteilung vermag eine gewisse geistige Beherrschung des Rechtsstoffes zu gewährleisten, erst durch sie werden aus Lebenssachverhalten rechtliche Tatbestände, mithin Recht.'

Hermann Hill

\subsection{INLEIDING}

Hiervoor is aan de hand van vijf toetsvragen onderzocht hoe de herschikking die heeft geleid tot de Wabo (hoofdstuk 4), de integratie van de Wms in de Wet milieubeheer (hoofdstuk 5) en de herschikking in het ontwerp Wet natuurbescherming zich verhouden tot de in hoofdstuk 3 ontwikkelde criteria voor bundeling van omgevingsrecht. Zulks is gebeurd aan de hand van concrete wettelijke bepalingen of - in het geval van het ontwerp - voorstellen daartoe.

In het regeerakkoord van het op 14 oktober 2010 aangetreden kabinet RutteVerhagen is aangekondigd dat het kabinet met voorstellen komt tot bundeling en vereenvoudiging van wet- en regelgeving op het gebied van het omgevingsrecht. $^{2}$ In een brief van 23 maart $2011^{3}$ schrijft dit kabinet te streven naar een Raamwet omgevingsrecht. Vervolgens heeft het kabinet in een beleidsbrief van 28 juni $2011^{4}$ aangekondigd dat begin 2012 een wetsvoorstel Omgevingswet zou worden gepresenteerd waarin 60 wetten op het gebied van het omgevingsrecht zouden moeten worden gebundeld. Op 9 maart 2012 heeft de minister van IenM ${ }^{5}$ in plaats van dat wetsvoorstel aan de Tweede Kamer een brief gestuurd waarin de contouren zijn geschetst van de door het kabinet beoogde herziening van het stelsel van omgevingsrecht. ${ }^{6}$

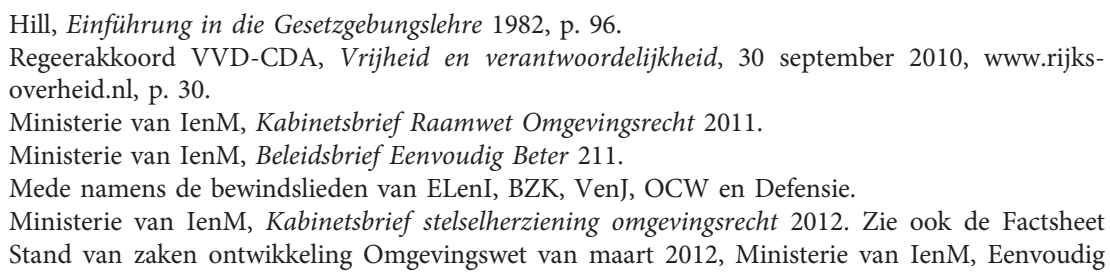


Het kabinet heeft de overtuiging dat het met een nieuw instrumentarium, verankerd in een integrale Omgevingswet, mogelijk is om sneller en beter besluiten te nemen en de juridische randvoorwaarden te scheppen voor een duurzame en doelmatige ontwikkeling van de leefomgeving. ${ }^{7}$ Op 11 april 2012 sloot de termijn voor de internetconsultatie over de kabinetsbrief van 9 maart 2012. ${ }^{8}$

In de brief wordt een concept-wetsvoorstel voor juni-september 2012 in het vooruitzicht gesteld. ${ }^{9}$ Ten tijde van het afsluiten van mijn onderzoek was dit concept-wetsvoorstel met concrete wettelijke bepalingen nog niet gepubliceerd. Dientengevolge was het niet goed mogelijk om aan de hand van de vijf toetsvragen te onderzoeken hoe de herschikking die zou moeten leiden tot een Omgevingswet zich verhoudt tot de in hoofdstuk 3 ontwikkelde criteria. Wel zal hierna in paragraaf 7.2 een korte indruk worden gegeven van de Omgevingswet zoals die op basis van de kabinetsbrief van 9 maart 2012 vorm zou kunnen worden gegeven. In de paragrafen 7.3 tot en met $7.7 \mathrm{zal}$ aan de hand daarvan een indicatie worden gegeven van de wijze waarop de vijf toetsvragen dienstig zouden kunnen zijn bij de beoordeling van de

Beter, https://omgevingswet.pleio.nl/pg/pages/view/361862/overige-dossiers. In het Themanummer Contouren van de Omgevingswet nader beschouwd (M en R 2012/6) is een samenvatting van de kabinetsvoornemens tot stelselwijziging opgenomen (Van den Broek, Samenvatting kabinetsbrief stelselherziening omgevingsrecht 2012). Uylenburg geeft een overzicht van de inhoud en plaatst enige kanttekeningen (Uylenburg, Kansen en kanttekeningen 2012). Het themanummer bevat voorts bijdragen uit wetenschap en praktijk over onderdelen van die voornemens. Arentz meent dat de Omgevingswet is gedoemd te mislukken als er niet iets wordt gedaan aan de lijstjesterreur (Arentz, De kop moet er (juist) op! 2012). Tolsma bespreekt het uitgangspunt om met de Omgevingswet beter aan te sluiten op Europese regelgeving en de betekenis van Europese regelgeving voor het streven naar meer flexibiliteit in de Omgevingswet (Tolsma, De Europese dimensie van de Omgevingswet 2012). Van Velsen belicht enkele ideeën van het kabinet met betrekking tot milieueffectrapportage (Van Velsen, De Europese m.e.r.-verplichtingen en de Omgevingswet 2012). Nijmeijer schrijft dat de naam bestemmingsplan misschien verdwijnt, maar de verschijningsvorm zeker niet (Nijmeijer, Van bestemmingsplan naar omgevingsverordening 2012). Groothuijse meent dat de Waterwet niet zal ontkomen aan integratie in de Omgevingswet, die sterke gelijkenis vertoont met de systematiek en de logische opbouw van de Waterwet (Groothuijse, Integratie van de Waterwet in de Omgevingswet 2012). Bregman geeft antwoord op de vraag in hoeverre de stroomlijning van het omgevingsrecht geschikt is voor een gebiedsgerichte aanpak (Bregman, Gebiedsontwikkeling met de Omgevingswet 2012). Volgens Van den Heuvel lijkt het erop, dat het bestaande stelsel van omgevingsrecht aan het einde van zijn latijn is en dat het beter is fundamenteel te vernieuwen in plaats van nog meer wijzigingen op wijzigingen te stapelen (Van den Heuvel, De flexibiliteit van de Omgevingswet 2012). Zie ook Van den Broek, Omgevingswet: de kers op de taart! 2012 en Backes c.s., Naar een nieuw omgevingsrecht 2012. Overigens is ook oudere literatuur nog steeds de moeite waard, zoals Michiels, De toekomst van de Omgevingswet 2002, die een aantal vragen formuleert die heden ten dage nog steeds relevant zijn voor het bundelen van omgevingsrecht, zoals 'Wat is het probleem?, 'Wat is omgevingsrecht?' en 'Betekent een integrale omgevingsrechtelijke kijk ook dat er een integrale wet moet komen?'

7 Ministerie van IenM, Kabinetsbrief stelselherziening omgevingsrecht 2012, p. 1. Het kabinet geeft helaas niet aan wat in dit verband precies onder duurzaamheid zou moeten worden verstaan.

8 www.internetconsultatie.nl/stelselwijziging_omgevingsrecht. Er zijn 76 openbare reacties ingekomen.

9 Ministerie van IenM, Kabinetsbrief stelselherziening omgevingsrecht 2012, p. 25. 
contouren van de Omgevingswet. Afgesloten zal worden met een korte samenvatting en conclusie in paragraaf 7.8.

In dit verband zij nog opgemerkt, dat het kabinet Rutte-Verhagen op 21 april 2012 weliswaar is gevallen, maar er zijn sterke aanwijzingen dat de plannen voor een Omgevingswet ook door een nieuw kabinet zullen worden voortgezet. $^{10}$ Zo gaat de ambtelijke voorbereiding naar verluidt onverminderd door en toonden de woordvoerders van PvdA, VVD, D66, CDA en SP zich tijdens het algemeen overleg van 6 augustus 2012 over de kabinetsbrief van 9 maart 2012 op hoofdlijnen positief over een Omgevingswet.

Kuiken (PvdA): 'Onze basishouding is dan ook positief, omdat wij nu een aantal knelpunten zien.' Houwers (VVD): 'De VVD juicht het dan ook toe dat de minister zo voortvarend aan de slag is gegaan met het ontwerpen van een nieuwe Omgevingswet.' Paulus Jansen (SP): '... kijken wij nu naar gestructureerde oplossingen voor de lange termijn. De SP-fractie is daarvan een groot voorstander, zij het dat wij ons in dit stadium wel afvragen of wij toewerken naar een gestructureerde oplossing.' Van Veldhoven (D66): 'D66 is voor versimpeling en grondige herziening van het omgevingsrecht, want alles is met alles gelinkt. Het zou prima zijn om dat in de wet beter tot uitdrukking te brengen.' De Rouwe (CDA): '... omdat het voor de CDA-fractie duidelijk is dat er een herziening moet komen. Het is duidelijk dat wij de minister steunen in haar ambitie. ${ }^{11}$

Bij de verkiezingen op 12 september 2012 behaalden VVD (41 zetels) en PvdA (38 zetels) een meerderheid in de Tweede Kamer. Hun verkiezingsprogramma's pleiten voor een Omgevingswet.

Het verkiezingsprogramma van de VVD vermeldt: 'De VVD wil het bestaande omgevingsrecht terugbrengen tot één basiswet. Deze Omgevingswet vervangt bestaande wetten, waaronder de Waterwet, de Crisis- en Herstelwet en de wet Ruimtelijke Ordening. Dit betekent: minder regels, kortere procedures, meer flexibiliteit en transparantie en minder onderzoek en kosten. ${ }^{12}$ Het verkiezingsprogramma van de PvdA vermeldt: 'Er moet één nieuwe Omgevingswet komen ter vervanging van tientallen andere wetten waarmee veel duidelijker wordt welke rol burgers in welke fase van planning en uitvoering kunnen spelen. ${ }^{13}$ Het Regeerakkoord VVD-PvdA van het kabinet Rutte II vermeldt: 'In 2013 komen we met een wetsvoorstel omgevingswet ter vervanging van onder meer de wet op de ruimtelijke ordening en de waterwet. ${ }^{14}$

10 In soortgelijke zin Sievers, Milieu-en omgevingsrecht: hoe meer integraal, hoe beter? 2012, p. 60 . Kamerstukken II 2011/12, 33 118, nr. 4.

Niet doorschuiven maar aanpakken, p. 36.

Nederland Sterker \& Socialer, p. 53.

Bruggen slaan, Regeerakkoord VVD-PvdA, 29 oktober 2012, p. 39 


\subsection{DE OMGEVINGSWET IN HET KORT}

\subsubsection{Betrokken wetten}

In de brief van 9 maart 2012 wordt voorgesteld in de Omgevingswet: ${ }^{15}$

- 15 wetten geheel te integreren: Belemmeringenwet Privaatrecht, Crisisen herstelwet, Interimwet stad-en-milieubenadering, Ontgrondingenwet, Planwet verkeer en vervoer, Spoedwet wegverbreding, Tracéwet, Waterwet, ${ }^{16}$ Wet algemene bepalingen omgevingsrecht, Wet beheer rijkswaterstaatswerken, Wet bodembescherming, Wet geluidhinder, Wet inzake de luchtverontreiniging, Wet milieubeheer en Wet ruimtelijke ordening;

- twee wetten volledig in te trekken: Wet ammoniak en veehouderij en Wet geurhinder en veehouderij;

- uit circa 25 andere wetten de omgevingsrechtelijke elementen over te nemen: Gaswet, Elektriciteitswet 1998, Lokaalspoor- en Tramwegwet/ Wet lokaal spoor, Monumentenwet 1988, Mijnbouwwet, Onteigeningswet, Spoorwegwet, Spoorwegwet 1875, Waterstaatswet 1900, Woningwet, Wegenwet, Wet aanvullende regels wegtunnels, Wet bereikbaarheid en mobiliteit, Wet voorkeursrecht gemeenten, Wet herverdeling wegenbeheer, Wet kabelbaaninstallaties, Wet kenbaarheid publiekrechtelijke beperkingen onroerende zaken, Wet luchtvaart, Wet natuurbescherming (Boswet, Flora- en faunawet, Natuurbeschermingswet 1998), Wet voorkoming verontreiniging door schepen, Wrakkenwet en Zwemwaterwet (Wet hygiëne veiligheid badinrichtingen en zwemgelegenheden).

Dit moet volgens het kabinet Rutte-Verhagen 'resulteren in een integrale wet, die een adequaat en toekomstbestendig instrumentarium biedt voor het aanpakken van de maatschappelijke opgaven op het brede gebied van de leefomgeving in Nederland. ${ }^{17}$

\subsubsection{Opbouw}

Het kabinet wil de Omgevingswet opbouwen rond een beheer- en ontwikkelcyclus voor de leefomgeving. ${ }^{18}$

Ministerie van IenM, Kabinetsbrief stelselherziening omgevingsrecht 2012, bijlage 1.

Zie Havekes, Governance 2011.

Ministerie van IenM, Kabinetsbrief stelselherziening omgevingsrecht 2012, p. 1. In de kabinetsbrief van 28 juni 2011 ging het overigens nog om 60 wetten. Dat aantal is ook overgenomen in de in noot 7 genoemde factsheet met een samenvatting van de kabinetsnotitie. De brief van 9 maart 2012 geeft geen verklaring voor het verschil. Een mogelijke verklaring zou kunnen zijn dat het Ministerie van IenM nog worstelt met de vraag wat precies onder omgevingsrecht moet worden verstaan.

18 Par. 7.2.3 is grotendeels ontleend aan Ministerie van IenM, Kabinetsbrief stelselherziening omgevingsrecht 2012, bijlage 2, par. 1.1. 
Die opbouw bestaat dan uit de volgende elementen:

- wettelijke normen vormen voor onderdelen van de leefomgeving het startpunt voor de zorg van de leefomgeving;

- feitelijke informatie over de toestand van de leefomgeving en de mate waarin aan de normen wordt voldaan (monitoring) is vereist ter uitvoering van deze zorg;

- een strategische, integrale omgevingsvisie is nodig om te bepalen op welke wijze de normen bereikt kunnen worden en om de verdere ambities van een bestuursorgaan voor de leefomgeving te formuleren;

- in programma's wordt deze visie uitgewerkt tot operationele beleidsvoornemens en maatregelen;

- algemene regels zijn het instrument om zoveel mogelijk vooraf in generieke zin duidelijkheid te geven over toelaatbaarheid van vaker voorkomende activiteiten;

- het projectbesluit is het instrument voor besluitvorming over projecten met een publiek doel;

- de omgevingsvergunning is het instrument voor besluitvorming over projecten en activiteiten die een voorafgaande toetsing of afweging door de overheid behoeven;

- sluitstuk van de cyclus wordt gevormd door toezicht en handhaving.

\subsubsection{Ontwerpprincipes van de Omgevingswet ${ }^{19}$}

De hoofddoelstelling van de Omgevingswet is volgens de kabinetsbrief een veilige en gezonde leefomgeving te bewerkstelligen en deze op een duurzame en doelmatige wijze te kunnen behouden, beheren, gebruiken en ontwikkelen. Met deze formulering wordt uitdrukking gegeven aan de inzet van het kabinet om de kwaliteit van de leefomgeving te waarborgen én de wens om alle relevante deelaspecten inzake de leefomgeving te betrekken bij beleids- en besluitvorming. De Omgevingswet moet daarbij zorgen voor stroomlijning van het totale complex aan wet- en regelgeving voor de fysieke leefomgeving, waardoor de inzichtelijkheid, voorspelbaarheid en het gebruiksgemak van het omgevingsrecht toenemen en de besluitvorming over projecten en activiteiten in de leefomgeving sneller en doelmatiger wordt.

Daartoe stelt het kabinet Rutte-Verhagen de volgende ontwerpprincipes voor:

- Gelijkwaardige bescherming. Uitgangspunt is het gelijkwaardig houden van het beschermingsniveau van de omgeving.

- Ontwikkelingsgericht en integraal. Daarbij staat de gebruiker centraal.

- Een betere aansluiting op Europese wet- en regelgeving. Het nieuwe stelsel moet qua werkwijze nauw aansluiten op Europese richtlijnen.

- Uitgaan van bestaande verantwoordelijkheidsverdeling.

- Vertrouwen als vertrekpunt. De vertrouwensbasis vergt wel een gedegen stelsel van toezicht en handhaving.

19 Ministerie van IenM, Kabinetsbrief stelselherziening omgevingsrecht 2012, p. 7-8. 


\subsubsection{Voorlopige inhoudsopgave}

De hiervoor genoemde opbouw en ontwerpprincipes moeten volgens het kabinet leiden tot een Omgevingswet met daarin de in overzicht 7.1 genoemde voorlopige indeling in hoofdstukken en paragrafen. ${ }^{20}$

\section{Overzicht 7.1 Voorlopige inhoudsopgave van de Omgevingswet}

\begin{tabular}{|c|c|}
\hline Hoofdstuk 1. Algemene bepalingen & $\begin{array}{c}\text { Hoofdstuk } 6 \text {. Voorbereiding, procedures en } \\
\text { rechtsbescherming }\end{array}$ \\
\hline 1.1 Begripsbepalingen & 6.1 Algemene bepalingen \\
\hline 1.2 Doelstelling en toepassingsgebied & 6.2 Elektronisch verkeer \\
\hline 1.3 Zorgplicht voor de leefomgeving & 6.3 Programma's \\
\hline 1.4 Experimenteerbepaling & 6.4 De omgevingsvergunning \\
\hline Hoofdstuk 2 De kwaliteit van de leefomgeving & 6.5 Projectprocedure \\
\hline 2.1 Algemene bepalingen & 6.6 Milieueffectrapportage (procedures) \\
\hline 2.2 Normen voor de leefomgeving & 6.7 Aanvullende procedurele bepalingen \\
\hline 2.3 Aanwijzing van gebieden en netwerken & $\begin{array}{l}\text { 6.8 Betrokkenheid andere bestuursorganen } \\
\text { bij besluitvorming }\end{array}$ \\
\hline 2.4 Het beheer van de leefomgeving & 6.9 Inwerkingtreding en rechtsbescherming \\
\hline 2.5 Informatie over de leefomgeving & Hoofdstuk 7 Milieueffectrapportage \\
\hline Hoofdstuk 3 Omgevingsvisies en programma's & 7.1 Algemene bepalingen \\
\hline 3.1 Algemene bepalingen & 7.2 Milieueffectrapportage voor plannen \\
\hline 3.2 Omgevingsvisies & 7.3 Milieueffectrapportage voor besluiten \\
\hline 3.3 Programma's & 7.4 Evaluatie \\
\hline $\begin{array}{c}\text { Hoofdstuk } 4 \text { Algemene regels voor activi- } \\
\text { teiten in de leefomgeving }\end{array}$ & $\begin{array}{l}\text { 7.5 De Commissie voor de milieueffect- } \\
\text { rapportage }\end{array}$ \\
\hline 4.1 Algemene bepalingen & Hoofdstuk 8-10 Gereserveerd \\
\hline 4.2 De omgevingsverordening & Hoofdstuk 11 Gedoogplichten \\
\hline $\begin{array}{l}\text { 4.3 Algemene regels ter bescherming van de } \\
\text { leefomgeving }\end{array}$ & $\begin{array}{l}\text { Hoofdstuk } 12 \text { Calamiteiten/Ongewone } \\
\text { voorvallen en sanering }\end{array}$ \\
\hline $\begin{array}{l}\text { 4.4 Algemene regels voor bepaalde onder- } \\
\text { delen van de leefomgeving }\end{array}$ & Hoofdstuk 13 Financiële bepalingen \\
\hline $\begin{array}{l}\text { Hoofdstuk } 5 \text { De omgevingsvergunning en } \\
\text { het projectbesluit }\end{array}$ & Hoofdstuk 14 Bestuursrechtelijke handhaving \\
\hline 5.1 Algemene bepalingen & Hoofdstuk 15 Verdere bepalingen \\
\hline 5.2 De omgevingsvergunning & Hoofdstuk 16 Slotbepalingen \\
\hline 5.3 Projectprocedure & \\
\hline
\end{tabular}

20 Ministerie van IenM, Kabinetsbrief stelselherziening omgevingsrecht 2012, bijlage 2 en bijlage 3 (Werking van het stelsel van de Omgevingswet). Par. 7.2.3 bevat een samenvatting van bijlage 3, par. 1.2. 
Hoofdstuk 1 Algemene bepalingen bevat definities, de doelstelling van de wet, een algemene zorgplicht en een experimenteerbepaling.

Bij de doelstelling wordt gedacht aan: 'Deze wet en de daarop berustende bepalingen zijn erop gericht een veilige en gezonde leefomgeving te bewerkstelligen en deze op een duurzame en doelmatige wijze te kunnen behouden, beheren, gebruiken en ontwikkelen.'

Bij de algemene zorgplicht gaat het om een verplichting voor eenieder om voldoende zorg voor de leefomgeving in acht te nemen. Dat houdt in ieder geval in dat een ieder die weet of redelijkerwijs kan vermoeden dat zijn activiteiten nadelige gevolgen voor de leefomgeving kunnen hebben dergelijke activiteiten achterwege laat dan wel maatregelen neemt om gevolgen te voorkomen, te beperken of ongedaan te maken.

Hoofdstuk 2 De kwaliteit van de leefomgeving bevat de grondslagen voor normen voor de leefomgeving. Deze normen geven primair de beleidsdoeleinden aan die richting gevend zijn voor de bestuursorganen bij de inzet van de bevoegdheden, die deze wet hen toekent en andere beleidsinstrumenten. Rijk en provincies kunnen (en voor een deel: moeten) normen stellen ter waarborging van kernwaarden als veiligheid, gezondheid, kwaliteit van ecosystemen, beschikbaarheid van hulpbronnen en behoud van cultureel erfgoed. Dit hoofdstuk bevat verder een regeling voor de aanwijzing van gebieden en netwerken, voor het beheer van specifieke onderdelen van de leefomgeving en voor verkrijgen van informatie over de leefomgeving (de monitoring) en het verstrekken van de aldus verkregen informatie aan andere overheidsinstanties en aan het publiek.

Hoofdstuk 3 Omgevingsvisies en programma's regelt de beleidsplanning door de overheid. Rijk en provincies moeten, gemeenten mogen elk één omgevingsvisie vaststellen, een integrale langetermijnvisie van een bestuursorgaan over de noodzakelijke en de gewenste ontwikkelingen in zijn bestuursgebied. De visievorming op verschillende terreinen zoals ruimtelijke ontwikkeling, verkeer en vervoer, water, milieu, ruimtelijke aspecten van natuurbeleid, gebruik van natuurlijke hulpbronnen en cultuurhistorie wordt in de omgevingsvisie niet slechts samengevoegd, maar ook met elkaar verbonden.

De visie biedt daarmee een beleidsmatige grondslag voor een samenhangende inzet van programma's, besluiten en andere beleidsinstrumenten. Het instrument komt in de plaats van gebiedsdekkende structuurvisies, de ruimtelijke aspecten van de natuurvisie, verkeers- en vervoerplannen, nationale en provinciale waterplannen en milieubeleidsplannen.

Het programma omvat concrete maatregelen voor behoud, beheer, gebruik en ontwikkeling van de leefomgeving. Het kan een sectoraal of gebiedsgericht karakter hebben en kan verschillende elementen bevatten. 
Het kan plannen bevatten voor uitvoering van projecten of maatregelen om sectorale doelen te verwezenlijken. Het kan ook kaders stellen voor de uitoefening van bevoegdheden door een bestuursorgaan dat het vaststelt. Voor enkele onderwerpen zijn programma's wettelijk voorgeschreven ter implementatie van Europese richtlijnen. Verder stelt een bestuursorgaan een programma op als de op grond van hoofdstuk 2 gestelde normen overschreden zijn of dreigen te worden. Rijk en provincie kunnen in een programma ook andere bestuursorganen betrekken. Verder is het mogelijk dat een programma wordt vastgesteld door meer dan één bestuursorgaan. In bijzondere situaties, in het bijzonder waar normen overschreden zijn of bijna overschreden worden, kan een programma ook worden gebruikt om regie te voeren op nog toe te laten projecten. Het programma omvat in dat geval zowel een uitgebalanceerd pakket van maatregelen teneinde het mogelijk maken de doelstellingen te halen (de zogenaamde programmatische aanpak). In dit geval is er strikte voortgangscontrole op het programma om het bereiken van de normen zeker te stellen.

Hoofdstuk 4 betreft Algemene regels voor activiteiten in de leefomgeving. Het merendeel van de activiteiten in de leefomgeving betreft initiatieven van burgers en bedrijven. Het in goede banen leiden van activiteiten gebeurt waar mogelijk met algemene regels. Elke gemeente, waterschap en provincie moet één gebiedsdekkende verordening voor de leefomgeving maken, waarin worden opgenomen alle geldende ruimtelijke regels, locatiegebonden regels en vergunningvereisten.

Hoofdstuk 5 bevat regels inzake de omgevingsvergunningen en het projectbesluit. De omgevingsvergunning is een generiek instrument voor de toetsing van bepaalde activiteiten met effecten op de leefomgeving. Het model van de Wabo is hierbij uitgangspunt. ${ }^{21}$ De toetsing blijft beperkt tot aspecten die betrekking hebben op de activiteiten waarvoor de vergunning is ingesteld. $\mathrm{Er}$ is dus in beginsel een sectorale en geen integrale toetsing, teneinde de toetsing van eenvoudige gevallen eenvoudig te houden. Het projectbesluit biedt een uniforme procedure voor gebiedsontwikkelingen en andere fysieke ontwikkelingen die voortvloeien uit de verantwoordelijkheid van een bestuursorgaan of andere publieke taken. Het projectbesluit kent een voorbereidingsprocedure die aansluit bij de adviezen van de Commissie Elverding.

Het projectbesluit vervangt het inpassingsplan uit de Wro en de coördinatieregelingen van de Wro, de Tracéwet, de Waterwet en de Ontgrondingenwet. Met het projectbesluit kan worden afgeweken van de omgevingsverordening. Het projectbesluit kan in de plaats treden van bepaalde, in dat besluit benoemde, omgevingsvergunningen. De toetsing aan de belangen die de omgevingsvergunning beoogt te beschermen vindt dan plaats in het kader van de vaststelling van het projectbesluit.

21 Zie hfds. 4. 
Hoofdstuk 6 Voorbereiding, procedures en rechtsbescherming bevat procedurele bepalingen voor de voorbereiding van plannen, omgevingsverordeningen, projectbesluiten en omgevingsvergunningen. Dit hoofdstuk bevat ook de specifieke bepalingen rond rechtsbescherming.

Hoofdstuk 7 Milieueffectrapportage dient ter implementatie van de m.e.r.richtlijn ${ }^{22}$ en de richtlijn strategische milieubeoordeling. ${ }^{23}$ Beide richtlijnen bepalen in welke gevallen een milieueffectrapportage (m.e.r.) respectievelijk plan-m.e.r. is vereist.

De hoofdstukken 8 tot en met 10 zijn gereserveerd voor niet-gebiedsgerichte onderwerpen uit met name de Wet milieubeheer.

Hoofdstuk 11 Gedoogplichten regelt gedoogplichten die noodzakelijk kunnen zijn voor het realiseren van werken van algemeen belang.

Hoofdstuk 12 Calamiteiten, ongewone voorvallen en sanering bundelt de regelingen voor buitengewone omstandigheden zoals die nu voorkomen in diverse wetten. Het betreft bijvoorbeeld bijzondere bevoegdheden in geval van (dreigende) calamiteiten. Daarnaast worden in dit hoofdstuk bijzondere bevoegdheden en verplichtingen rond sanering onderbracht (zoals (water)bodemsanering en wrakkenopruiming).

In hoofdstuk 13 Financiële bepalingen zullen de volgende soorten bepalingen uit bestaande omgevingswetten worden overgenomen en waar mogelijk geïntegreerd: financiële bepalingen met betrekking tot vergunningen, schaderegelingen, heffingen, kostenverhaal, leges en interbestuurlijke financiële regelingen. Op een later moment worden ook andere instrumenten bezien zoals tegemoetkomingen, fondsen, statiegeld, retourpremies en verzekeringen.

Hoofdstuk 14 Bestuursrechtelijke handhaving betekent een verdere integratie in de uitvoering: vergunningverlening, toezicht en handhaving. Het gaat daarbij om een intensivering van de afstemming van werkzaamheden, samenwerking en informatie-uitwisseling tussen overheden, al dan niet in het kader van de regionale uitvoeringsdiensten, en een uniforme borging van de uitvoeringskwaliteit in alle domeinen die onder de wet worden gebracht. De Omgevingswet biedt hiervoor de nodige wettelijke ankers.

22 Richtlijn 2011/92/EU van het Europees Parlement en de Raad van 13 december 2011 voor milieubeoordeling van bepaalde openbare en particuliere projecten (codificatie van de richtlijnen 85/337/EEG, 97/11/EG, 2003/35/EG en 2009/31/EG) (PbEU 2012 L 26/1).

23 Richtlijn 2001/42/EG van het Europees Parlement en de Raad van 27 juni 2001 betreffende de beoordeling van de gevolgen voor het milieu van bepaalde plannen en programma's ( $P b E G 2001$ L 197/30) 


\subsection{WETSSYSTEMATISCHE TEKORTEN}

De eerste toetsvraag luidt: is er binnen het omgevingsrecht sprake van een wetssystematisch tekort omdat niet alle regels die volgens een op de echte werkelijkheid gebaseerd zakelijk samenhangcriterium onderling samenhangen desalniettemin geen deel uitmaken van hetzelfde wetssysteem?

De aanleiding tot een herziening van het omgevingsrecht ligt volgens de kabinetsbrief in het feit dat huidige en toekomstige maatschappelijke opgaven in de leefomgeving zich minder effectief laten aanpakken met het huidige instrumentarium dat voortvloeit uit vele verschillende wettelijke regelingen. ${ }^{24}$ Elders in de kabinetsbrief wordt als rode draad genoemd: behoefte aan samenhang, flexibiliteit en maatwerk. ${ }^{25}$

De kabinetsbrief noemt echter geen duidelijk en eenduidig samenhangcriterium. De hoofddoelstelling van de Omgevingswet is een veilige en gezonde leefomgeving te bewerkstelligen en deze op een duurzame en doelmatige wijze te kunnen behouden, beheren, gebruiken en ontwikkelen. ${ }^{26}$ Het lijkt dan voor de hand te liggen dat als samenhangcriterium de fysieke leefomgeving geldt, maar de kabinetsbrief laat ons daarover in het ongewisse. Het ontbreken van een duidelijk samenhangcriterium wreekt zich reeds op de eerste bladzijde van genoemde brief, waarin wordt aangegeven dat 15 wetten in ieder geval geheel worden gebundeld, twee wetten worden ingetrokken en uit circa 25 wetten de omgevingsrechtelijke elementen worden overgenomen in de Omgevingswet. Door het ontbreken van een duidelijk samenhangcriterium blijft onduidelijk waarom juist deze wetten worden gebundeld en waarom andere wetten geen deel zullen uitmaken van de Omgevingswet. In dit verband breng ik in herinnering dat het samenhangcriterium bepalend is voor het wetssysteem van de Omgevingswet en dientengevolge ook voor wetssystematische tekorten, probleemstelling en oplossingen van dat wetssysteem. ${ }^{27}$ Zolang de regelgever de contouren van het te hanteren samenhangcriterium niet duidelijk voor ogen heeft, loopt hij onder meer het niet onaanzienlijke risico dat in het wetssysteem van de Omgevingswet regels worden opgenomen, die daarin niet thuis horen, ${ }^{28}$ dan wel wetssystematische tekorten bevat ${ }^{29}$ omdat regels die volgens het gekozen samenhangcriterium wel in de Omgevingswet thuis horen daarin niet zijn opgenomen. In overzicht 1.1 heb ik additioneel 15 wetten genoemd die naar mijn oordeel evenzeer recht doen aan het samenhangcriterium fysieke leefomgeving. ${ }^{30}$

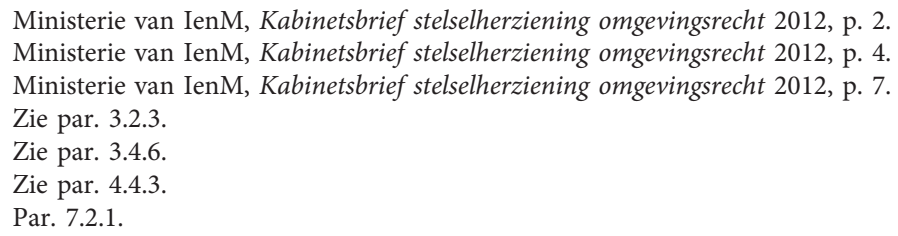


Volgens Boeve c.s. heeft de wetgever in de Wet milieubeheer geen definitie opgenomen van het begrip 'milieu' om toekomstige ontwikkelingen niet in de weg te staan. Zij pleiten niet voor het opnemen van een dergelijk begrip, maar menen dat zulks vanuit Europeesrechtelijk perspectief wel eens een vereiste zou kunnen zijn. ${ }^{31}$

In dit verband vraag ik onder meer aandacht voor Verschuuren, die in 2005 schreef: 'Dat natuur onderdeel uitmaakt van het milieu, of letterlijk vertaald, de omgeving, is voor gewone mensen ${ }^{32}$ een open deur. Juristen ${ }^{33}$ weten echter dat hoewel natuur formeel wel onderdeel uitmaakt van het milieubegrip van de Wet milieubeheer $(\mathrm{Wm})$, wet- en regelgeving en uitvoeringsorganisatie op het terrein van het natuurbeleid toch erg afwijken van die op het terrein van het milieubeleid. (...) De belangrijkste natuurbeschermingswetten zijn de Natuurbeschermingswet 1998 (NbW) en de Flora- en faunawet (Ffw).' Verschuuren meende destijds dat het op korte termijn noodzakelijk was om te komen tot een integratie en vereenvoudiging van de natuurbeschermingswetgeving, waarna integratie in de omgevingsvergunning kan worden aangepakt. ${ }^{34}$

Als inderdaad zou mogen worden uitgegaan van het samenhangcriterium fysieke leefomgeving dan lijkt het mij duidelijk dat sprake is van een wetssystematisch tekort aangezien niet alle regels volgens het op de echte werkelijkheid gebaseerde zakelijk samenhangcriterium fysieke leefomgeving onderling samenhangende regels deel uitmaken van hetzelfde wetssysteem. Het verdient daarom aanbeveling dat de wetgever reeds vanaf den beginne een duidelijk beeld schetst van de Omgevingswet, zoals dat in 1993 voor de Wet milieubeheer wel is gebeurd. ${ }^{35}$

\subsection{WETSSYSTEMATISCHE TEKORTEN OPGEHEVEN OF VERMINDERD}

Aangenomen dat het wetssysteem van de Omgevingswet zal worden bepaald door het samenhangcriterium fysieke leefomgeving, dan luidt de tweede toetsvraag: zal de bundeling die moet leiden tot het wetssysteem van de Omgevingswet het wetssystematisch tekort opheffen of verminderen dat

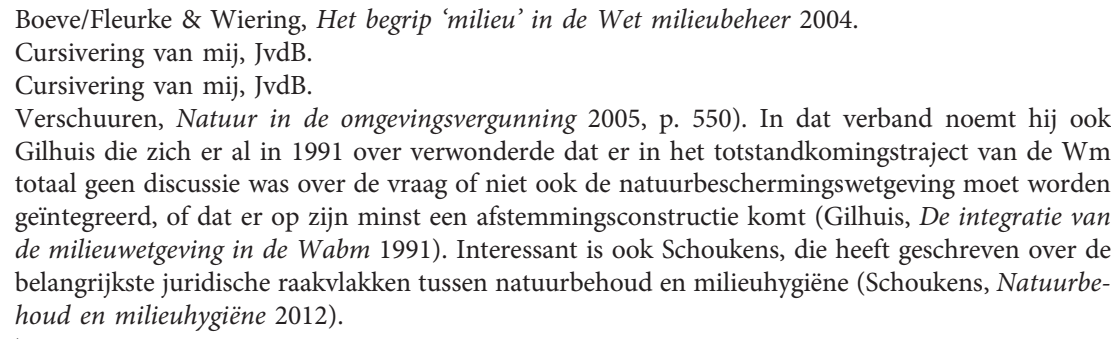


thans bestaat omdat niet alle regels inzake de fysieke leefomgeving in hetzelfde wetssysteem zijn opgenomen?

Het komt mij voor dat de voorgenomen Omgevingswet het hiervoor beschreven wetssystematisch tekort in elk geval zal verminderen door het bundelen van 15 wetssystemen, het laten vervallen van twee wetssystemen en het ten minste gedeeltelijk integreren van circa 25 wetssystemen op het gebied van het omgevingsrecht.

Er zijn echter twee belangrijke indicaties om aan te nemen dat het tekort niet geheel en wellicht zelfs in belangrijke mate niet zal worden opgeheven. In de eerste plaats wijs ik op de in overzicht 1.1 additioneel genoemde 15 wetssystemen die naar mijn oordeel evenzeer recht doen aan het samenhangcriterium fysieke leefomgeving. In dat verband merk ik op dat de regering Rutte-Verhagen in de beleidsbrief van 28 juni 2011 nog 60 wetten noemde, ${ }^{36}$ voor welk verschil met de 42 wetten in de kabinetsbrief van 9 maart $2012^{37}$ geen overtuigende verklaring wordt gegeven. In de tweede plaats kan het slechts gedeeltelijk bundelen van de 25 door de regering genoemde wetssystemen ertoe leiden dat in een of meer van die wetssystemen regels achterblijven, die wel voldoen aan genoemd samenhangcriterium.

\subsection{WETSSYSTEMATISCHE TEKORTEN VANWEGE TYPISCH JURIDISCHE ORDENINGSCRITERIA}

De vraag of het gebruik van typisch juridische ordeningscriteria in het wetssysteem van de Omgevingswet zal leiden tot wetssystematische tekorten en zo ja, of deze tekorten verdedigbaar zijn laat zich vanwege het ontbreken van een concreet wetsvoorstel moeilijk beantwoorden.

De voorlopige inhoudsopgave ${ }^{38}$ biedt overigens veeleer de indruk van het gebruik van typisch juridische ordeningscriteria dan van het gebruik van zakelijke ordeningscriteria. Die indruk wordt versterkt doordat de eerste vijf hoofdstukken uitdrukkelijk zijn bedoeld als een weerspiegeling van de beleidsmatige zorg van de overheid voor de kwaliteit van de leefomgeving. Normen, monitoring en beleidsplanning zijn volgens het kabinet bij uitstek overheidstaken. ${ }^{39}$ Hier lijkt het kabinet van binnen naar buiten te denken, hetgeen de kenbaarheid van de Omgevingswet voor burgers en bedrijven waarschijnlijk niet ten goede komt. Voor hoofdstuk 5 van de Omgevingswet vormt het model van de Wabo uitgangspunt,${ }^{40}$ hetgeen met zich zou kunnen

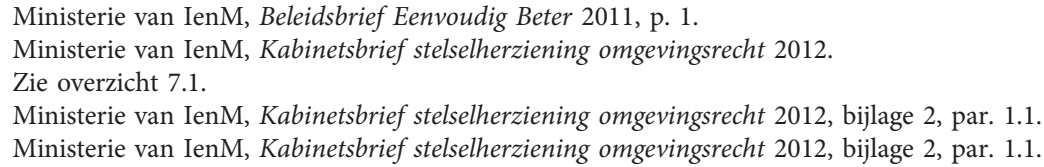


brengen dat daaraan dezelfde wetssystematische tekorten kleven die in paragraaf 4.5 van dit onderzoek zijn geconstateerd ten aanzien van de Wabo. Voorts lijkt het mij veilig om te veronderstellen dat in de voorgenomen Omgevingswet gebruik zal worden gemaakt van gelede normstelling hetgeen in beginsel leidt tot wetssystematische tekorten. ${ }^{41}$

Mijn voorlopige antwoord op de gestelde vraag is dan ook, dat de voorgenomen Omgevingswet wetssystematische tekorten zal bevatten als gevolg van het gebruik van typisch juridische ordeningscriteria, waarvan op voorhand niet is te zeggen of die verdedigbaar zijn.

\subsection{WETSSYSTEMATISCHE TEKORTEN IN ANDERE WETSSYSTEMEN}

Het lijkt niet ondenkbeeldig dat het wetssysteem van de voorgenomen Omgevingswet zal leiden tot het ontstaan of voortbestaan van wetssystematische tekorten in andere wetssystemen. Dat is alleen al te verwachten door het voornemen van het kabinet om circa 25 wetten niet geheel op te nemen in de Omgevingswet, maar slechts voor wat betreft de omgevingsrechtelijke elementen. ${ }^{42}$ Zonder concrete wettekst laat zich echter niet de vraag beantwoorden of dergelijke tekorten dan verdedigbaar zijn, temeer daar het kabinet niet aangeeft wat het precies verstaat onder 'omgevingsrechtelijke elementen'.

\subsection{WETSSYSTEEM TOEKOMSTBESTENDIG}

Ook de vraag of het wetssysteem van de Omgevingswet toekomstbestendig zal zijn, laat zich moeilijk beantwoorden zonder concrete wetteksten. In paragraaf 3.6 heb ik een wetssysteem toekomstbestendig genoemd als daarbinnen geen nieuwe - onverdedigbare - wetssystematische tekorten ontstaan als gevolg van het feit dat de wetgever in belangrijke mate is gedwongen om een chronologische aanpak ${ }^{43}$ te hanteren. Daarbij heb ik vier wetgevingstechnieken aangegeven die al dan niet in samenhang gebruikt naar mijn oordeel tot een - meer - toekomstbestendig wetssysteem kunnen leiden.

De kabinetsbrief geeft onvoldoende houvast om te kunnen beoordelen of de Omgevingswet de pretentie heeft het omgevingsrecht voor eens en voor altijd te codificeren.

41 Zie par. 3.4.5.3

42 Ministerie van IenM, Kabinetsbrief stelselherziening omgevingsrecht 2012, p. 1.

43 Zie par. 1.1 
Ten aanzien van het gebruik van toekomstbestendige samenhangcriteria verwijs ik graag naar paragraaf 3.6.3, waarin ik heb aangegeven dat daarvan in de Omgevingswet op verschillende wijzen gebruik wordt gemaakt. Zo zal de Omgevingswet onder meer voor wat betreft doelen, terminologie en instrumentarium nauw aansluiten bij de EU-regelgeving. ${ }^{44}$ Ook zullen de tientallen rechtsfiguren die het omgevingsrecht volgens het kabinet thans kent worden vervangen door zes rechtsfiguren. ${ }^{45}$

Gelet op de inhoudsopgave lijkt er een aanzet te worden gegeven voor een aanbouwwet, aangezien de hoofdstukken 8 tot en met 10 zijn gereserveerd, maar dat lijkt mij bij nadere bestudering niet het geval te zijn. Aanbouwwetgeving betekent immers dat de wetgever eerst de volledige voor het omgevingsrecht noodzakelijke wetssystematiek schept, waarna de diverse onderdelen van de wet weliswaar chronologisch tot stand komen, maar wel meteen op hun wetssystematisch juiste plaats kunnen worden gezet. Van een dergelijk aanbouwwetssysteem is geen sprake. Het lijkt er veeleer op dat het kabinet - vooralsnog - niet prijs wil geven - of bezwaarlijker: geen vastomlijnd idee heeft - hoe de Omgevingswet uiteindelijk zal worden ingevuld. Mij dunkt dat geen goede zaak, want als het wetssysteem niet duidelijk is, loopt de wetgever het risico dat de Omgevingswet niet de verwachte opschoning van het omgevingsrecht betekent.

Een voorbeeld betreft hoofdstuk 13 Financiële bepalingen waarin volgens het kabinet de volgende soorten bepalingen uit bestaande omgevingswetten worden overgenomen en waar mogelijk geïntegreerd: financiële bepalingen met betrekking tot vergunningen, schaderegelingen, heffingen, kostenverhaal, leges en interbestuurlijke financiële regelingen. Op een later moment worden ook andere instrumenten bezien zoals tegemoetkomingen, fondsen, statiegeld, retourpremies en verzekeringen. ${ }^{46}$ De vraag rijst dan welke criteria het kabinet hanteert om bepaalde financiële bepalingen wel en andere niet of nog niet in de Omgevingswet op te nemen. Het zou duidelijker zijn als het kabinet zich daarvan reeds nu een beeld vormt en voor de in de Omgevingswet op te nemen financiële bepalingen reeds een wetssystematisch plaats inruimt.

\subsection{SAMENVATTING EN CONCLUSIE}

Vanwege het ontbreken van een concreet wetsvoorstel is het niet mogelijk om aan de hand van de in paragraaf 3.8 genoemde vijf toetsvragen te onderzoeken hoe de herschikking die zou moeten leiden tot een Omgevingswet zich verhoudt tot de in hoofdstuk 3 ontwikkelde criteria. Wel is een

\footnotetext{
Ministerie van IenM, Kabinetsbrief stelselherziening omgevingsrecht 2012, p. 19.

Ministerie van IenM, Kabinetsbrief stelselherziening omgevingsrecht 2012, p. 10.

Ministerie van IenM, Kabinetsbrief stelselherziening omgevingsrecht 2012, bijlage 3, par. 1.2.
} 
indicatie gegeven van de wijze waarop de vijf toetsvragen dienstig kunnen zijn bij de beoordeling van de contouren van de Omgevingswet.

De hoofddoelstelling van de Omgevingswet is een veilige en gezonde leefomgeving te bewerkstelligen en deze op een duurzame en doelmatige wijze te kunnen behouden, beheren, gebruiken en ontwikkelen. Het lijkt dan voor de hand te liggen dat als samenhangcriterium de fysieke leefomgeving geldt, maar de kabinetsbrief laat ons daarover in het ongewisse. Door het ontbreken van een duidelijk samenhangcriterium blijft onduidelijk waarom juist de door het kabinet genoemde wetten geheel of gedeeltelijk worden gebundeld en waarom andere wetten geen deel zullen uitmaken van de Omgevingswet. Zolang de regelgever de contouren van het te hanteren samenhangcriterium niet duidelijk voor ogen heeft, loopt hij onder meer het niet onaanzienlijke risico dat in het wetssysteem van de Omgevingswet regels worden opgenomen, die daarin niet thuis horen, dan wel wetssystematische tekorten bevat omdat regels die volgens het gekozen samenhangcriterium wel in de Omgevingswet thuis horen daarin niet zijn opgenomen.

Als inderdaad zou mogen worden uitgegaan van het samenhangcriterium fysieke leefomgeving dan lijkt het mij duidelijk dat anno 2012 is van een wetssystematisch tekort aangezien niet alle regels volgens het op de echte werkelijkheid gebaseerde zakelijk samenhangcriterium fysieke leefomgeving onderling samenhangende regels deel uitmaken van hetzelfde wetssysteem.

Het komt mij voor dat de voorgenomen Omgevingswet het hiervoor beschreven wetssystematisch tekort in elk geval zal verminderen door het bundelen van 15 wetssystemen, het laten vervallen van twee wetssystemen en het ten minste gedeeltelijk integreren van circa 25 wetssystemen op het gebied van het omgevingsrecht. Verwacht mag echter worden dat het tekort niet geheel en wellicht zelfs in belangrijke mate niet zal worden opgeheven door het ontbreken van 15 wetssystemen die evenzeer recht doen aan het samenhangcriterium fysieke leefomgeving en het slechts gedeeltelijk bundelen van 25 wel genoemde wetssystemen.

De vraag of het gebruik van typisch juridische ordeningscriteria in het wetssysteem van de Omgevingswet zal leiden tot wetssystematische tekorten en zo ja, of deze tekorten verdedigbaar zijn laat zich vanwege het ontbreken van een concreet wetsvoorstel moeilijk beantwoorden. De voorlopige inhoudsopgave biedt veeleer de indruk van het gebruik van typisch juridische ordeningscriteria dan van het gebruik van zakelijke ordeningscriteria. Die indruk wordt versterkt doordat de eerste vijf hoofdstukken uitdrukkelijk zijn bedoeld als een weerspiegeling van de beleidsmatige zorg van de overheid voor de kwaliteit van de leefomgeving. Normen, monitoring en beleidsplanning zijn volgens het kabinet bij uitstek overheidstaken. Voor hoofdstuk 5 
van de Omgevingswet vormt het wetssysteem van de Wabo uitgangspunt, hetgeen met zich zou kunnen brengen dat daaraan dezelfde wetssystematische tekorten kleven als die in paragraaf 4.5 van dit onderzoek zijn geconstateerd. Voorts lijkt het mij veilig om te veronderstellen dat in de voorgenomen Omgevingswet gebruik zal worden gemaakt van gelede normstelling. Mijn voorlopige antwoord op de gestelde vraag is dan ook, dat de voorgenomen Omgevingswet wetssystematische tekorten zal bevatten, waarvan op voorhand niet is te zeggen of die verdedigbaar zijn.

Het lijkt niet ondenkbeeldig dat het wetssysteem van de voorgenomen Omgevingswet zal leiden tot het ontstaan of voortbestaan van wetssystematische tekorten in andere wetssystemen. De reden daarvoor is dat van volgens de kabinetsbrief circa 25 wetten slechts de omgevingsrechtelijke elementen zullen worden opgenomen in de Omgevingswet. Zonder concrete wettekst laat zich echter niet de vraag beantwoorden of dergelijke tekorten dan verdedigbaar zijn.

De vraag of het wetssysteem van de Omgevingswet toekomstbestendig zal zijn, laat zich moeilijk beantwoorden zonder concrete wetteksten. De kabinetsbrief geeft onvoldoende houvast om te kunnen beoordelen of de Omgevingswet de pretentie heeft het omgevingsrecht voor eens en voor altijd te codificeren. Wel is sprake van het gebruik van enige toekomstbestendige samenhangcriteria. Van aanbouwwetgeving is geen sprake omdat de wetgever niet eerst de volledige voor het omgevingsrecht noodzakelijke wetssystematiek schept, waarna de diverse onderdelen van de wet weliswaar chronologisch tot stand komen, maar wel meteen op hun wetssystematisch juiste plaats kunnen worden gezet. Het lijkt er veeleer op dat het kabinet - vooralsnog - niet prijs wil geven - of bezwaarlijker: geen vastomlijnd idee heeft - hoe de Omgevingswet uiteindelijk zal worden ingevuld.

Hoewel de toetsvragen bij gebreke van een concrete tekst van de Omgevingswet slechts indicatief kunnen worden beantwoord, zou ik toch voorzichtig willen concluderen, dat een Omgevingswet op basis van het samenhangcriterium fysieke leefomgeving een belangrijke bijdrage kan leveren aan het ten dele verminderen van de thans bestaande wetssystematische tekorten in het omgevingsrecht. De vraag in hoeverre de wetgever daarin concreet zal slagen, kan pas worden beantwoord aan de hand van een concreet wetsvoorstel.

Een dringend advies aan de wetgever is wel om bij een zo omvangrijke bundelingsoperatie in de memorie van toelichting op dat wetsvoorstel expliciet in te gaan op de gebruikte samenhangcriteria en de toekomstbestendigheid beter te waarborgen door gebruik te maken van de techniek van een aanbouwwet. 


\section{$8 \quad$ Samenvatting, conclusies en aanbevelingen}

'Die Gesetze so hoch aufhängen, wie Dionysios der Tyrann tat, daß sie kein Bürger lesen könnte, - oder aber sie in den weitläufigen Apparat von gelehrten Büchern, Sammlungen von Dezisionen abweichender Urteile und Meinungen, Gewohnheiten usf. und noch dazu in einer fremden Sprache vergraben, so da $\beta$ die Kenntnis des geltenden Rechts nur denen zugänglich ist, die sich gelehrt darauf legen, - ist ein und dasselbes Unrecht.'

Georg Wilhelm Friedrich Hegel ${ }^{1}$

\subsection{INLEIDING}

Het Nederlandse omgevingsrecht bestaat uit vele tientallen wetten in formele zin, algemene maatregelen van bestuur en ministeriële regelingen op het gebied van milieu, ruimtelijke ordening, water en natuur. In de afgelopen decennia is het aantal wettelijke regelingen verminderd door bundeling (zie bijlage 1). Zo zijn in 2008 elf algemene maatregelen van bestuur gebundeld in het Activiteitenbesluit en in 2009 acht wetten in formele zin in de Waterwet. Wetgevers beogen met bundeling diverse juridische, ecologische en/of economische voordelen. De aanleiding voor dit onderzoek vormt de vraag of het bij bundeling van omgevingsrecht gaat om een politieke keuze die nu eens in het voordeel dan weer in het nadeel van bundeling kan uitvallen, dan wel om een keuze die ook wetenschappelijk te verantwoorden is. Anders geformuleerd: bestaat er een wetenschappelijk gefundeerd kader of is een zodanig kader te ontwikkelen waaruit volgt in welk geval of in welke gevallen bundeling van omgevingsrecht al dan niet verantwoord is? Die vraag is niet alleen wetenschappelijk, maar ook maatschappelijk relevant, omdat de regering drie natuurwetten wil bundelen in een Wet natuurbescherming en 40 wetten in een Omgevingswet.

1 Georg Wilhelm Friedrich Hegel, Grundlinien der Philosophie des Rechts. Naturrecht und Staatswissenschaft, Herausgegeben und eingeleitet von Helmut Reichelt, Ullstein, Frankfurt am Main, 1972. Ook geciteerd door Hirsch Ballin, Architectuur van wetgeving 1984, p. 81. Naar verluidt bestrafte de tiran Dionysios van Syrakuse overtreding van zijn wetten die op borden waren geschreven die zo hoog waren opgehangen dat niemand die kon lezen (Clausdieter Schott, Gesetzesadressat und Begriffsvermogen, in: Gottfried Baumgärtel c.s. (red.), Festschrift für Heinz Hübner zum 70. Geburtstag am 7. November 1984, Berlin: Walter de Gruyter, p. 191). Van Gestel schrijft dat keizer Caligula soortgelijke bekendmakingsmethoden bezigde (Van Gestel, Eenieder wordt geacht de wet te kennen 1998, p. 78). 


\subsection{SAMENVATTING}

Hoofdstuk 1 bevat de centrale vraag van dit onderzoek: is bij de voornemens tot ordening van het omgevingsrecht door middel van bundeling (slechts) sprake van een politieke keuze, dan wel kan (ook) worden voldaan aan eisen die wetenschappelijk aan ordening van omgevingsrecht kunnen worden gesteld.

Om deze centrale vraag te beantwoorden is een antwoord gezocht op de volgende drie deelvragen:

1. Is er wetenschappelijk een toetsingskader (te ontwikkelen) waaruit volgt in welk geval of in welke gevallen bundeling van omgevingsrecht verantwoord is?

2. Hoe verhouden zich de bundeling door herschikking die in 2010 heeft geleid tot de Wet algemene bepalingen omgevingsrecht, de bundeling die in 2008 heeft geleid tot integratie van de Wet milieugevaarlijke stoffen in de Wet milieubeheer, de in 2010 voorgestelde bundeling door herschikking die moet leiden tot een Wet natuurbescherming en de contouren van de bundeling door herschikking die moet leiden tot een Omgevingswet tot dat (te ontwikkelen) toetsingskader?

3. Zijn er ten aanzien van de in deelvraag 2 genoemde bundelingsprojecten voorstellen te doen om de ordening van het omgevingsrecht beter te laten aansluiten bij de (te ontwikkelen) wetenschappelijke criteria voor bundeling van omgevingsrecht?

Bij de beantwoording van deze vragen heb ik mij beperkt tot mogelijke juridische criteria om over te gaan tot bundeling. Het toetsingskader is ontwikkeld na bestudering van 'klassieke' juridische bronnen, waaronder juridische literatuur en de geschiedenis van de totstandkoming van onderdelen van het omgevingsrecht waarbinnen bundeling van wetssystemen heeft plaatsgevonden. Daarnaast zijn ook interviews met een aantal wetgevingsjuristen en wetenschappers als onderzoeksmethode ingezet. Daarmee is getracht meer in de keuken van de wetgever te kijken teneinde de bevindingen uit de literatuur te toetsen aan de werkelijkheid, waarvan ook de departementale activiteiten deel uitmaken.

In hoofdstuk 2 is het begrippenkader ontwikkeld dat in dit onderzoek is gehanteerd. Centraal in dit onderzoek staan de begrippen wetssysteem en wetssystematisch tekort.

Onder een wetssysteem versta ik: volgens bepaalde criteria geordende, onderling samenhangende regels. Onderscheid kan worden gemaakt in formele en materiële aspecten van een wetssysteem. Bij de formele wetssystematiek ligt het accent op de uiterlijk zichtbare ordening. Bij de materiële wetssystematiek ligt het accent op de inhoudelijke systeemordeningscriteria en de onderlinge 
samenhang. Aangezien voor het antwoord op de vraag in welke gevallen bundeling van omgevingsrecht wetenschappelijk verantwoord is, van belang is de samenhang binnen een wetssysteem die aansluit bij de echte werkelijkheid zoals de gebruikers van een wetssysteem die ervaren, heb ik mij in dit onderzoek gericht op de materiële aspecten van wetssystemen.

Van een wetssystematisch tekort is sprake als bepaalde regels wel onderling samenhangen maar desalniettemin geen deel uitmaken van hetzelfde wetssysteem. Om in geval van wetssystematische tekorten alsnog samenhang tussen wetssystemen te scheppen kan de wetgever gebruik maken van de volgende instrumenten:

- coördinatie: tussen twee of meer wetssystemen wordt samenhang gebracht door een nieuwe wettelijke regeling waarbij de beide te coördineren wetssystemen blijven bestaan;

- harmonisatie: tussen twee of meer wetssystemen wordt samenhang gebracht door die wetssystemen als zodanig te laten bestaan, maar aan elkaar aan te passen;

- integratie: tussen twee of meer wetssystemen wordt samenhang gebracht door een wetssysteem geheel te laten opgaan in een ander wetssysteem, waarbij het geïntegreerde wetssysteem wordt ingetrokken;

- herschikking: tussen twee of meer wetssystemen wordt samenhang gebracht door die wetssystemen geheel te laten opgaan in een nieuw wetssysteem waarbij de herschikte wetssystemen worden ingetrokken;

- consolidatie: tussen een wetssysteem en alle daarop gevolgde in (deel) wetssystemen vervatte amendementen wordt samenhang gebracht door het oorspronkelijke wetssysteem en de amendementen ongewijzigd op te nemen in één wetssysteem.

Dit onderzoek beperkt zich tot het bundelen van omgevingsrecht: het samenvoegen van wetssystemen als gevolg waarvan een nieuw of vernieuwd wetssysteem ontstaat. Dat is uitsluitend het geval bij integratie en herschikking.

Bundeling kan plaatsvinden op verschillende regelingsniveaus: wet, algemene maatregel van bestuur en ministeriële regeling. Van horizontale bundeling is sprake als de bundeling beperkt blijft tot wetssystemen van hetzelfde regelingsniveau. Is dat (gedeeltelijk) niet het geval, dan is sprake van verticale bundeling.

Bundeling kan modificerend of codificerend zijn. Bij codificerende bundeling is niet beoogd de geldende rechtsopvattingen te wijzigen. Bij modificerende bundeling is dat wel beoogd. Van codificerende bundeling kan ook sprake zijn als de te bundelen regels niet exact hetzelfde, maar met enige puur redactionele wijzigingen in het gebundelde wetssysteem terugkomen. 
In hoofdstuk 3 is een wetenschappelijk kader ontwikkeld waaruit volgt in welke gevallen bundeling van omgevingsrecht al dan niet wetenschappelijk verantwoord is. Van een wetssysteem is pas sprake als er samenhangcriteria zijn. Die samenhangcriteria hebben drie belangrijke gevolgen: zij bepalen het wetssysteem, de wetssystematische tekorten en de oplossingen voor het probleem dat de wetgever met een wetssysteem wil regelen. Zolang geen sprake is van een iLawsysteem moet de wetgever een keus maken uit een in beginsel schier oneindig aantal ordeningscriteria om samenhang aan te brengen tussen regels in het omgevingsrecht. Daarbij kan het gaan om zakelijke ordeningscriteria en typisch juridische ordeningscriteria.

Onder een iLawsysteem versta ik een wetssysteem dat zodanig is vorm gegeven dat de gebruiker via een computerprogramma als het ware zijn eigen wetssysteem zou kunnen genereren op basis van een door hem zelf te kiezen, op dat moment voor hem relevant samenhangcriterium. Wie een woning wil bouwen en zich afvraagt welke regels in het omgevingsrecht daarop van toepassing zijn, zou dan bijvoorbeeld alle op het bouwen van een huis toepasselijke regels met een druk op de knop van zijn toetsenbord kunnen genereren als wetssysteem. Het gaat niet louter om het ontsluiten van omgevingsrecht door middel van digitale technieken, maar om het vorm geven aan omgevingsrecht in een naar de wens van de gebruiker te genereren wetssysteem op een wijze die verschillende samenhangen eenvoudig mogelijk maakt.

De keus voor een of meer samenhangcriteria is niet puur politiek bepaald, maar kan ook wetenschappelijk worden onderbouwd. Daarvoor dient in de eerste plaats te worden gekeken naar de belangrijkste functie van een wetssysteem: het vergemakkelijken van in het geschreven recht opgenomen informatie. Een wetssysteem is los van de inhoud van de daarvan deel uitmakende regels van belang voor de kenbaarheid van het omgevingsrecht. Een wetssysteem behoort bovendien probleemgeoriënteerd te zijn; dat betekent dat degene die het omgevingsrecht raadpleegt om een antwoord te vinden omtrent rechten en verplichtingen in het wetssysteem zelf al naar de plaats wordt geleid waar het antwoord is te vinden. Als gevolg van de kenbaarheid en de probleemgeoriënteerdheid zou de wetgever moeten kiezen voor samenhangcriteria die aansluiten bij de samenhangen die gebruikers van het omgevingsrecht in de echte werkelijkheid ervaren en zonder specialistische juridische voorkennis begrijpen. Dat betekent dat de wetgever moet kiezen voor zakelijke samenhangcriteria als subjecten, $o b$ jecten, activiteiten en fysieke leefomgeving. Dit is een belangrijke aan wetenschappelijk verantwoorde bundeling te stellen eis.

De keus voor een bepaald samenhangcriterium betekent echter per definitie dat bundeling elders in het omgevingsrecht wetssystematische tekorten laat 
bestaan of zelfs creëert. Daarbij laat zich een aantal categorieën onderscheiden:

- bundeling op basis van zakelijke samenhangcriteria kan betekenen dat bepaalde wetssystematische tekorten slechts gedeeltelijk worden opgeheven;

- bundeling op basis van zakelijke samenhangcriteria kan betekenen dat bepaalde wetssystematische tekorten geheel of gedeeltelijk worden opgeheven, doch dat daardoor wetssystematische tekorten in andere wetssystemen worden gecreëerd;

- bundeling op basis van typisch juridische samenhangcriteria kan betekenen dat wetssystematische tekorten worden gehandhaafd of gecreëerd in een door bundeling op basis van zakelijke samenhangcriteria bepaald wetssysteem. Het kan hier gaan om interne en externe wetssystematische tekorten. Een intern tekort kan zich voordoen als typisch juridische samenhangcriteria worden gebruikt binnen genoemd wetssysteem. Een extern tekort kan zich voordoen als typisch juridische samenhangcriteria tot gevolg hebben dat bepaalde regels geen deel uitmaken van dat wetssysteem.

Bundeling is niet wetenschappelijk verantwoord als het ontstaan of voortbestaan van deze wetssystematische tekorten niet verdedigbaar is.

Codificerende bundeling behoort uitgangspunt te zijn, aangezien bundeling zich in de eerste plaats moet richten op het opheffen of verminderen van wetssystematische tekorten in plaats van op de inhoud van de te bundelen regels zelf. Bundeling is echter ook dan verantwoord als kleine, maar ook als majeure modificaties worden aangebracht. In het laatste geval dient de wetgever zich er wel van te vergewissen, dat zulks kan betekenen dat de mogelijke voordelen van bundeling worden beperkt als gevolg van de modificatie. De wetgever loopt voorts het risico dat de maatschappelijke acceptatie van bundeling wordt verminderd of opgeheven door maatschappelijke weerstand tegen een of meer modificaties.

Ten slotte moet de wetgever zich ervan vergewissen of een door bundeling ontstaan wetssysteem toekomstbestendig is. Daarmee bedoel ik dat daarbinnen geen - onverdedigbare - wetssystematische tekorten ontstaan als gevolg van het feit dat de wetgever in belangrijke mate is gedwongen om de chronologische aanpak te hanteren. De wetgever kan deze toekomstbestendigheid bevorderen door niet te streven naar een wetssystematiek die de pretentie heeft het omgevingsrecht voor eens en voor altijd te codificeren, maar naar een op verandering en zo mogelijk op een iLawsysteem gericht wetssysteem. Voorts kan de toekomstbestendigheid worden vergroot door het gebruik van toekomstbestendige zakelijke of typisch juridische systeemordeningscriteria, waarvan mag worden verwacht, dat die niet alleen op dit moment, maar ook in de toekomst valide zijn. De wetgever moet ervoor 
zorgen dat nieuwe omgevingsregels die een bepaald probleem beogen te regelen aansluiten bij de gekozen wetssystematische ordeningscriteria waarop zij anders een inbreuk zouden vormen. Het gebruik van aanbouwwetgeving die voldoet aan de eisen die in dit hoofdstuk zijn gesteld aan de keuze voor wetssystematische ordeningscriteria kan eveneens bijdragen aan toekomstbestendigheid.

Op basis van het voorgaande heb ik het volgende toetsingskader ontwikkeld aan de hand waarvan de wetgever zich er door het beantwoorden van vijf vragen van kan vergewissen of sprake is van een verantwoorde bundeling van omgevingsrecht:

1. Is er binnen het omgevingsrecht sprake van een wetssystematisch tekort omdat niet alle regels die volgens een op de echte werkelijkheid gebaseerd zakelijk samenhangcriterium onderling samenhangen desalniettemin geen deel uitmaken van hetzelfde wetssysteem?

2. Zo ja, kan dat wetssystematisch tekort worden opgeheven of verminderd door middel van bundeling van wetssystemen door herschikking of integratie?

3. Leidt het gebruik van typisch juridische ordeningscriteria tot het ontstaan of voortbestaan van wetssystematische tekorten? Zo ja, zijn dergelijke tekorten verdedigbaar?

4. Leidt bundeling tot het ontstaan of voortbestaan van wetssystematische tekorten in andere wetssystemen? Zo ja, zijn dergelijke tekorten verdedigbaar?

5. Leidt de bundeling tot een toekomstbestendig wetssysteem?

Als het antwoord op de vragen 1, 2 en 5 bevestigend en op de vragen 3 en 4 ontkennend luidt, noem ik bundeling verantwoord. Als het antwoord op de vragen 3 en 4 bevestigend luidt, maar het antwoord ten aanzien van de verdedigbaarheid van de geconstateerde wetssystematische tekorten bevestigend, dan is bundeling eveneens verantwoord.

Per onderwerp zal moeten worden bekeken tot welke resultaten het toepassen van de genoemde toetsingscriteria leidt. De criteria zullen niet voor alle gevallen scherp omlijnd kunnen worden. Bij toepassing ervan kunnen de meningen mogelijk uiteenlopen. Maar we hebben nu tenminste een kompas, zodat we niet bij voorbaat het spoor bijster behoeven te raken.

Daarmee is het antwoord op de eerste deelvraag van dit onderzoek gegeven.

In hoofdstuk 4 is aan de hand van de vijf toetsvragen onderzocht hoe de herschikking die op 1 oktober 2010 heeft geleid tot de Wet algemene 
bepalingen omgevingsrecht (Wabo) zich verhoudt tot de in hoofdstuk 3 ontwikkelde criteria:

1. Voor de inwerkingtreding van de Wabo was binnen het omgevingsrecht sprake van een wetssystematisch tekort omdat niet alle regels die volgens het op de echte werkelijkheid gebaseerde zakelijk samenhangcriterium een plaatsgebonden project dat bestaat uit één of meer activiteiten die van invloed zijn op de fysieke leefomgeving onderling samenhangen, deel uitmaakten van hetzelfde wetssysteem. Het antwoord op de eerste toetsvraag luidt daarom positief.

2. De Wabo heeft dit wetssystematisch tekort verminderd, zij het niet geheel opgeheven. De vermindering van het wetssystematisch tekort is gerealiseerd door een groot aantal toestemmingsbesluiten voor een project in het wetssysteem van de Wabo op te nemen. Er is echter nog steeds sprake van wetssystematische tekorten, want de Wabo bevat niet alle regels ten aanzien van een project, noch alle activiteiten binnen een project waarvoor een omgevingsvergunning is vereist. Ook eist de Wabo geen omgevingsvergunning voor een aantal activiteiten binnen een project. Een aantal geconstateerde wetssystematische tekorten laat zich op relatief eenvoudige wijze oplossen. Het antwoord op de tweede toetsvraag luidt daarom overwegend negatief.

3. In de Wabo leidt het gebruik van typisch juridische ordeningscriteria als algemeen-bijzonder, gelede normstelling en de verwijzing naar de Europese IPPC-richtlijn tot het voortbestaan van wetssystematische tekorten, die in de meeste gevallen verdedigbaar zijn, doch door de wetgever veelal eenvoudig te verminderen. Het antwoord op de derde toetsvraag luidt overwegend positief.

4. De Wabo heeft en passant het ontstaan van wetssystematische tekorten in de Wet milieubeheer tot gevolg gehad, aangezien belangrijke bepalingen inzake inrichtingen uit die wet zijn vervallen. Het gesignaleerde tekort is naar mijn oordeel niet verdedigbaar en kan slechts gedeeltelijk worden verminderd door de in de Wet milieubeheer voorkomende bepalingen inzake inrichtingen op te nemen in de Wabo. Een echte oplossing zie ik eerst in een nieuw, door het samenhangcriterium van de fysieke leefomgeving bepaald wetssysteem waarin de bepalingen van de Wabo en de Wet milieubeheer worden herschikt. De vierde toetsvraag is daarmee positief beantwoord.

5. De Wabo is gericht op permanente verandering en de toekomstbestendigheid wordt nog vergroot door het gebruik van toekomstbestendige zakelijke en typisch juridische systeemordeningscriteria, mits de wetgever bij toekomstige wijzigingen aansluit bij die criteria. Daarmee is toetsvraag vijf positief beantwoord.

Deze antwoorden betekenen dat de Wabo weliswaar een belangrijke bijdrage heeft geleverd aan het verminderen van tot 1 oktober 2010 bestaande wetssystematische tekorten in het omgevingsrecht, maar dat de herschikking in de huidige vorm deels wel en deels niet voldoet aan de door mij ontwikkelde 
criteria voor een verantwoorde bundeling. Als de wetgever er alsnog in zou slagen - bijvoorbeeld in het kader van een nieuwe Omgevingswet - om de als gevolg van de bundeling in het wetssysteem van de Wabo en in andere wetssystemen zoals de Wet milieubeheer ontstane wetssystematische tekorten op te heffen, zou alsnog van een volledig wetenschappelijk verantwoorde bundeling kunnen worden gesproken. In hoofdstuk 4 is een aantal suggesties gedaan tot verbetering.

In hoofdstuk 5 is aan de hand van de vijf toetsvragen onderzocht hoe de integratie van de Wms in de Wet milieubeheer per 1 juni 2008 zich verhoudt tot de in hoofdstuk 3 ontwikkelde criteria:

1. Voor de integratie van de Wms in de Wet milieubeheer was binnen het omgevingsrecht sprake van een wetssystematisch tekort omdat niet alle regels die volgens het op de echte werkelijkheid gebaseerde zakelijk samenhangcriterium stoffen onderling samenhangen deel uitmaakten van hetzelfde wetssysteem. Onder stoffen worden verstaan chemische elementen en hun verbindingen, zoals deze voorkomen in de natuur of door toedoen van de mens worden voortgebracht met gevolgen voor het milieu of de gezondheid van de mens. Het antwoord op de eerste toetsvraag luidt daarom positief.

2. De integratie van de Wms in de Wet milieubeheer heeft dit wetssystematisch tekort opgeheven. Dit is gerealiseerd door alle bepalingen in de Wms die niet behoefden te vervallen op te nemen in de Wet milieubeheer. Daaraan doet niet af dat mogelijke andere wetssystematische tekorten ten tijde van de integratie onveranderd zijn gebleven. Het antwoord op de tweede toetsvraag luidt daarom eveneens positief. Bij het gegeven antwoord past wel de belangrijke kanttekening dat het op 31 mei 2008 bestaande wetssystematisch tekort een jaar eerder door de wetgever zelf was geschapen door de Europese verordening REACH niet in de Wms, doch in hoofdstuk 9 van de Wet milieubeheer te implementeren. Hoewel daarvoor nader onderzoek nodig zou zijn, is het niet onwaarschijnlijk dat de uitvoering van REACH in de Wms niet zou hebben geleid tot het wetssystematische tekort dat met integratie is opgeheven.

3. Bij de integratie van de Wms in de Wet milieubeheer is gebruik gemaakt van typisch juridische ordeningscriteria zoals typisch juridische begrippen, algemeen-bijzonder en gelede normstelling. Dat heeft geleid tot het scheppen of laten voortduren van wetssystematische tekorten. De gesignaleerde tekorten zijn in de meeste gevallen verdedigbaar, zij het dat de wetgever een aantal tekorten op eenvoudige wijze zou kunnen opheffen of verminderen. Daarmee is de derde toetsvraag overwegend positief beantwoord.

4. Als gevolg van de integratie zijn geen nieuwe wetssystematische tekorten ontstaan buiten de Wet milieubeheer, waarmee de vierde toetsvraag negatief is beantwoord.

5. De integratie van de Wms in de Wet milieubeheer pretendeert niet het omgevingsrecht ten aanzien van stoffen voor eens en voor altijd vast te 
leggen, maar is juist gericht op permanente verandering. De toekomstbestendigheid wordt nog vergroot door het gebruik van toekomstbestendige zakelijke en typisch juridische systeemordeningscriteria, mits de wetgever bij toekomstige wijzigingen aansluit bij die criteria. Toetsvraag vijf is daarmee positief beantwoord.

Deze antwoorden betekenen dat de integratie van de Wms in de Wet milieubeheer niet alleen een belangrijke bijdrage heeft geleverd aan het verminderen van tot 1 juni 2008 bestaande wetssystematische tekorten in het omgevingsrecht, maar dat de integratie van de Wms in de Wet milieubeheer in de huidige vorm deels wel en deels niet voldoet aan de door mij ontwikkelde toetsvragen voor een verantwoorde bundeling. Dat betekent dat geen sprake is van een geheel verantwoorde bundeling. Verbeteringen zijn echter mogelijk, waarvoor in hoofdstuk 5 een aantal suggesties is gedaan.

In hoofdstuk 6 is aan de hand van de vijf toetsvragen onderzocht hoe het op 6 oktober 2011 gepubliceerde ontwerp Wet natuurbescherming, dat herschikking beoogt van de Natuurbeschermingswet 1998, de Flora- en faunawet en de Boswet, zich verhoudt tot de in hoofdstuk 3 ontwikkelde criteria: 1. Op dit moment is binnen het omgevingsrecht sprake van een wetssystematisch tekort omdat niet alle regels die volgens het op de echte werkelijkheid gebaseerde zakelijk samenhangcriterium natuur onderling samenhangen, deel uitmaken van hetzelfde wetssysteem. Het antwoord op de eerste toetsvraag luidt daarom positief.

2. De herschikking van de Natuurbeschermingswet 1998, de Flora- en faunawet en de Boswet in het ontwerp Wet natuurbescherming heeft dit wetssystematisch tekort opgeheven. Dit is gerealiseerd door alle bepalingen in de drie genoemde wetten die niet behoefden te vervallen op te nemen in het ontwerp en de drie wetten in te trekken. De regering geeft echter geen afdoende motivering die bestaande wetssystematische tekorten zouden kunnen verdedigen. Het antwoord op de tweede toetsvraag is daarmee overwegend negatief.

3. In het ontwerp Wnb is gebruik gemaakt van typisch juridische ordeningscriteria als indeling, gelede normstelling en verwijzing naar Europese richtlijnen en verordeningen. Dat zal leiden tot het scheppen of laten voortduren van wetssystematische tekorten. De gesignaleerde tekorten zijn in een aantal gevallen niet verdedigbaar en nopen tot nader onderzoek. Een aantal tekorten lijkt de wetgever op eenvoudige wijze te kunnen oplossen. Het antwoord op de derde toetsvraag is overwegend negatief.

4. Het overnemen van de bepalingen van de Natuurbeschermingswet 1998, de Flora- en faunawet en de Boswet in het ontwerp en het vervallen van die drie wetten zelf zal niet leiden tot wetssystematische tekorten als gevolg van de bundeling door herschikking. De vierde toetsvraag is negatief beantwoord. 
5. Het ontwerp pretendeert niet het omgevingsrecht ten aanzien van natuur voor eens en voor altijd vast te leggen, maar is juist gericht op permanente verandering, waarbij reeds rekening is gehouden met de komst van een Omgevingswet. De toekomstbestendigheid wordt nog vergroot door het gebruik van toekomstbestendige zakelijke en typisch juridische systeemordeningscriteria, mits de wetgever bij toekomstige wijzigingen aansluit bij die criteria. Toetsvraag vijf is positief beantwoord.

Deze antwoorden betekenen dat de voorgenomen herschikking van de Natuurbeschermingswet 1998, de Flora- en faunawet en de Boswet in het ontwerp Wet natuurbescherming weliswaar een belangrijke bijdrage zal leveren aan het verminderen van thans bestaande wetssystematische tekorten in het omgevingsrecht, maar dat de herschikking in de huidige vorm deels wel en deels niet voldoet aan de door mij ontwikkelde criteria voor een volledig verantwoorde bundeling. Verbeteringen zijn echter mogelijk, waarvoor in hoofdstuk 6 een aantal suggesties is gedaan. Als de wetgever erin zou slagen zodanige wetssystematische verbeteringen aan te brengen in het ontwerp dat het antwoord op de derde toetsvraag positief zou komen te luiden, zou het algehele oordeel wellicht in het voordeel van het ontwerp kunnen omslaan.

In hoofdstuk 7 is onderzocht in hoeverre de vijf toetsvragen dienstig kunnen zijn bij de ontwikkeling van de herschikking die zou moeten leiden tot de Omgevingswet volgens de contouren in de kabinetsbrief van 19 maart 2012. De Omgevingswet moet 15 bestaande wetten geheel integreren, twee wetten volledig intrekken en uit circa 25 andere wetten de omgevingsrechtelijke elementen overnemen. Dat leverde het volgende op:

1. De hoofddoelstelling van de Omgevingswet is een veilige en gezonde leefomgeving te bewerkstelligen en deze op een duurzame en doelmatige wijze te kunnen behouden, beheren, gebruiken en ontwikkelen. Als zou mogen worden uitgegaan van het samenhangcriterium 'fysieke leefomgeving' dan lijkt het mij duidelijk dat anno 2012 sprake is van een wetssystematisch tekort aangezien niet alle regels volgens het op de echte werkelijkheid gebaseerde zakelijk samenhangcriterium fysieke leefomgeving onderling samenhangende regels deel uitmaken van hetzelfde wetssysteem.

2. Het komt mij voor dat de voorgenomen Omgevingswet het hiervoor beschreven wetssystematisch tekort in elk geval zal verminderen door het bundelen van 15 wetssystemen, het laten vervallen van twee wetssystemen en het ten minste gedeeltelijk integreren van circa 25 wetssystemen op het gebied van het omgevingsrecht. Of het tekort zal worden opgeheven hangt af van de wetssystemen die uiteindelijk bij de bundeling zullen worden betrokken. Verwacht mag echter worden dat het tekort niet geheel en wellicht zelfs in belangrijke mate niet zal worden opgeheven door het ontbreken van 15 wetssystemen die evenzeer recht 
doen aan het samenhangcriterium fysieke leefomgeving en het slechts gedeeltelijk bundelen van 25 wel genoemde wetssystemen.

3. Naar het zich laat aanzien zullen er in de Omgevingswet typisch juridische ordeningscriteria worden gebruikt. Dat zal leiden tot het scheppen of laten voortduren van wetssystematische tekorten. Vanwege het ontbreken van een concrete wettekst is niet op voorhand te zeggen of dergelijke tekorten verdedigbaar zijn.

4. Het lijkt niet ondenkbeeldig dat het wetssysteem van de voorgenomen Omgevingswet zal leiden tot het ontstaan of voortbestaan van wetssystematische tekorten in andere wetssystemen. De reden daarvoor is dat volgens de kabinetsbrief voor circa 25 wetten slechts de omgevingsrechtelijke elementen zullen worden opgenomen in de Omgevingswet. Zonder concrete wettekst laat zich echter niet de vraag beantwoorden of dergelijke tekorten dan verdedigbaar zijn.

5. Ook de vraag of het wetssysteem van de Omgevingswet toekomstbestendig zal zijn, laat zich moeilijk beantwoorden zonder concrete wetteksten. De kabinetsbrief geeft onvoldoende houvast om te kunnen beoordelen of de Omgevingswet de pretentie heeft het omgevingsrecht voor eens en voor altijd te codificeren. Wel is sprake van het gebruik van enige toekomstbestendige samenhangcriteria. Van aanbouwwetgeving is geen sprake omdat de wetgever niet eerst de volledige voor het omgevingsrecht noodzakelijke wetssystematiek schept, waarna de diverse onderdelen van de wet weliswaar chronologisch tot stand komen, maar wel meteen op hun wetssystematisch juiste plaats kunnen worden gezet. Het lijkt er veeleer op dat het kabinet - vooralsnog - niet prijs wil geven - of bezwaarlijker: geen vastomlijnd idee heeft - hoe de Omgevingswet uiteindelijk zal worden ingevuld.

Hoewel de vijf toetsvragen bij gebreke van een concrete tekst van de Omgevingswet slechts indicatief kunnen worden beantwoord, zou ik toch voorzichtig willen concluderen, dat een Omgevingswet op basis van het samenhangcriterium fysieke leefomgeving een belangrijke bijdrage kan leveren aan het ten dele verminderen van de thans bestaande wetssystematische tekorten in het omgevingsrecht. De vraag in hoeverre de wetgever daarin concreet zal slagen, kan pas worden beantwoord aan de hand van een concreet wetsvoorstel.

Een dringend advies aan de wetgever is wel om bij een zo omvangrijke bundelingsoperatie in de memorie van toelichting op dat wetsvoorstel expliciet in te gaan op de gebruikte samenhangcriteria en de toekomstbestendigheid beter te waarborgen door gebruik te maken van de techniek van een aanbouwwet. 


\subsection{CONCLUSIES}

Op basis van het voorgaande zijn de drie deelvragen als volgt beantwoord.

De eerste deelvraag luidt: Is er een wetenschappelijk toetsingskader (te ontwikkelen) waaruit volgt in welk geval of in welke gevallen bundeling van omgevingsrecht verantwoord is? Het antwoord op die vraag is dat ik in de door mij onderzochte bronnen geen toetsingskader heb gevonden dat bruikbaar is voor het beantwoorden van de vraag in welke gevallen bundeling verantwoord is. In hoofdstuk 3 heb ik daarom zelf een dergelijk toetsingskader ontwikkeld. Aan de hand van vijf toetsvragen kan worden vastgesteld of bundeling door herschikking of integratie verantwoord is.

De tweede deelvraag luidt: Hoe verhouden zich de bundeling door herschikking die in 2010 heeft geleid tot de Wabo, de bundeling die in 2008 heeft geleid tot integratie van de Wms in de Wet milieubeheer en de in 2010 door de regering voorgestelde bundeling door herschikking die moet leiden tot een Wet natuurbescherming en de contouren van de bundeling door herschikking die moet leiden tot een Omgevingswet, tot het naar aanleiding van dat (te ontwikkelen) toetsingskader? Deze vraag is beantwoord in de hoofdstukken 4, 5, 6 en 7. In deze vier gevallen heb ik geconcludeerd dat de bundeling deels wel en deels niet beantwoordt aan de door mij ontwikkelde criteria, zodat in de huidige vorm geen sprake is van een volledig verantwoorde bundeling.

De derde deelvraag luidt: Zijn er ten aanzien van de in deelvraag 2 genoemde bundelingsprojecten voorstellen te doen om de ordening van het omgevingsrecht beter te laten aansluiten bij de (te ontwikkelen) wetenschappelijke criteria voor bundeling van omgevingsrecht? Deze vraag is positief beantwoord door in de hoofdstukken 4, 5, 6 en 7 een aantal suggesties te doen. Als die suggesties alsnog worden gevolgd ten aanzien van de vier onderzochte bundelingsoperaties, dan zou dat ertoe leiden dat de onderzochte bundelingsoperaties beter aansluiten bij de ontwikkelde criteria.

Het antwoord op deze deelvragen stelt mij in staat een antwoord te formuleren op de centrale vraag van dit onderzoek: is bij de voornemens tot ordening van het omgevingsrecht door middel van bundeling sprake van een louter politieke keuze, dan wel kan (ook) worden voldaan aan eisen die wetenschappelijk aan ordening van omgevingsrecht kunnen worden gesteld. Dat antwoord luidt, dat bundeling van omgevingsrecht niet slechts een politieke keuze behoeft te zijn, maar kan voldoen aan daaraan te stellen wetenschappelijke eisen. Het feit dat de bundeling in de vier onderzochte gevallen niet heeft geleid tot een volledig verantwoorde bundeling wil niet zeggen dat het onmogelijk is aan die criteria te voldoen. Ten aanzien van elk van de vier bundelingsoperaties heb ik verbeteringsvoorstellen gedaan. 


\subsection{AANBEVELINGEN}

Mijn onderzoek en de gehouden interviews leiden tot een aantal aanbevelingen aan de wetgever en aan wetgevingsjuristen.

\subsubsection{Aanbevelingen aan de wetgever}

1. Ga niet eerder over tot bundeling dan na het benoemen en overtuigend motiveren van één of meer relevante samenhangcriteria. Als de samenhangcriteria niet duidelijk zijn, bestaat het risico dat in een wetssysteem regels worden opgenomen die daarin niet thuis horen dan wel dat er wetssystematische tekorten ontstaan of blijven bestaan doordat regels die wel in het wetssysteem horen daarin niet zijn opgenomen.

2. Kies omwille van de kenbaarheid en probleemgeoriënteerdheid van een wetssysteem waar mogelijk voor met de echte werkelijkheid samenhangende zakelijke samenhangcriteria.

3. Gebruik slechts typisch juridische ordeningscriteria als de daardoor ontstane wetssystematische tekorten verdedigbaar zijn.

4. Ga slechts over tot herschikking of integratie als de op basis van de gekozen samenhangcriteria geconstateerde wetssystematische tekorten daardoor worden opgeheven of verminderd.

5. Zorg ervoor dat bundeling niet leidt tot wetssystematische tekorten in andere wetssystemen, tenzij dat verdedigbaar is.

6. Laat nieuwe omgevingsregels omwille van de toekomstbestendigheid van een door bundeling verkregen wetssysteem consequent aansluiten bij de gekozen wetssystematische ordeningscriteria.

7. Voorkom het opnemen van koekoekseibepalingen in een wetssysteem.

8. Presenteer een overtuigende proef van een voorgenomen door bundeling te realiseren wetssysteem.

9. Kies in beginsel voor codificerende bundeling, maar maak tevens van de gelegenheid gebruik om slimme modificaties toe te passen. Wees er daarbij op bedacht dat juist modificaties de maatschappelijke acceptatie van bundeling kunnen beïnvloeden.

10. Onderzoek de mogelijkheden van iLawsystemen, maar zorg ervoor dat een wetssysteem zelfstandig kenbaar is en daarvoor niet afhankelijk is van ICT-toepassingen.

11. Geef in de Aanwijzingen voor de regelgeving aanwijzingen voor het bundelen van (omgevings)recht.

12. Ga over tot het periodiek opschonen en opnieuw vaststellen van geldende wetssystemen.

13. Laat de Raad van State bij elk wetsvoorstel in elk geval ook adviseren over de wijze waarop dat wetsvoorstel past in de geldende wetssystemen. 
8.4.2. Aanbevelingen aan wetgevingsjuristen

1. Zorg bij elke wetswijziging dat geen wetssystematische tekorten ontstaan. Dat speelt met name als het gaat om wetssystemen die zijn ontstaan door bundeling, aangezien anders het risico bestaat dat die wetssystemen niet toekomstbestendig zijn.

2. Realiseer $\mathrm{u}$ dat omgevingswetten weliswaar juridische documenten zijn, maar dat het de kenbaarheid ten goede komt als gebruikers hun rechten en verplichtingen zonder specialistische juridische voorkennis aan de hand van de wettekst zelf kunnen begrijpen. 


\section{$8 \quad$ Clustering of Environmental Law \\ Summary, Conclusions, and Recommendations}

'Die Gesetze so hoch aufhängen, wie Dionysios der Tyrann tat, daß sie kein Bürger lesen könnte, - oder aber sie in den weitläufigen Apparat von gelehrten Büchern, Sammlungen von Dezisionen abweichender Urteile und Meinungen, Gewohnheiten usf. und noch dazu in einer fremden Sprache vergraben, so daß die Kenntnis des geltenden Rechts nur denen zugänglich ist, die sich gelehrt darauf legen, - ist ein und dasselbes Unrecht.'

Georg Wilhelm Friedrich Hegel ${ }^{1}$

\subsection{INTRODUCTION}

Dutch environmental law consists of many dozens of statutes, orders in council, and ministerial regulations pertaining to the environment, urban and regional planning, water, and nature conservation. In the past few decades, the number of statutory provisions has been reduced as a result of clustering (see Appendix 1). For example, in 2008, eleven orders in council were clustered into the Activities Decree (Activiteitenbesluit) and in 2009 eight statutes were combined in the Water Act. Legislators pursue this clustering to achieve various legal, ecological, and/or economic benefits. This study was undertaken to answer the question of whether clustering of environmental law is inspired by a political choice that sometimes works out in favour of clustering and sometimes goes against it, or by a choice that can be scientifically underpinned. In other words: is there an assessment framework, or can such a framework be scientifically developed, which can predict in what case or cases clustering of environmental law is justified? This question is not only relevant scientifically but also socially, since the Netherlands government wants to cluster three nature conservation statutes into one Nature Protection Act (Wet natuurbescherming) and 40 other statutes - partly or entirely - into one Environmental Planning Act (Omgevingswet).

1 Georg Wilhelm Friedrich Hegel, Grundlinien der Philosophie des Rechts. Naturrecht und Staatswissenschaft, Herausgegeben und eingeleitet von Helmut Reichelt, Frankfurt am Main: Ullstein, 1972. 


\subsection{SUMMARY}

Chapter 1 contains the central question of this study: are the proposals to restructure the system of environmental law through clustering (merely) a political choice or does it also meet requirements that may be set scientifically for restructuring environmental law?

In order to answer this central question, answers were sought to the following three subquestions:

1. Is there, or is it possible to scientifically develop, an assessment framework which can predict in what case or cases clustering of environmental law is justified?

2. How does the clustering by rearrangement which, in 2010, led to the Environmental Permitting (General Provisions) Act (Wet algemene bepalingen omgevingsrecht), the clustering which, in 2008, led to the integration of the Chemical Substances Act (Wet milieugevaarlijke stoffen) into the Environmental Management Act (Wet milieubeheer), the clustering by rearrangement, proposed by the government in 2010, that is to result in a Nature Protection Act, and the proposed clustering by rearrangement that is to lead to the Environmental Planning Act (Omgevingswet) relate to this assessment framework?

3. As regards the clustering projects mentioned under subquestion 2, can proposals be made to the effect that the restructuring of environmental law links up better with the criteria (to be developed) for clustering environmental law?

In answering these questions, I have confined myself to possible legal criteria for a decision to proceed with clustering. The assessment framework was developed after studying 'classical' legal sources, including legal literature and the legislative history of those parts of environmental law in which law systems were clustered. In addition, the research method of interviewing a number of legislative drafters and scholars was used. In this way, I tried to take a better look behind the legislative scenes to test the results of the literature review against the reality of the legislative activities at the Ministries.

In Chapter 2, the conceptual framework used in this study is explored. Central to this study are the concepts of 'law system' and 'law system deficiency'.

I define a law system as: a consistent system of rules ordered on the basis of certain criteria. A distinction can be made between the procedural and substantive aspects of a law system. In a procedural approach to a law system, the focus is on the 'visible' aspects of the restructuring. In a substantive approach to a law system, the focus is on the content aspects of the restructuring criteria and the inner consistency. To answer the question of 
when clustering of environmental law is scientifically justified, it is important that the consistency within a law system links up with the reality as experienced by the users of the law system, so my research is focused on the substantive aspects of law systems.

A law system deficiency occurs if certain rules are consistent but nevertheless do not form part of the same law system. To create consistency between law systems, the legislator can use the following instruments:

- coordination: consistency between two or more law systems is created by means of a new legal arrangement whereby the two or more law systems continue to exist side by side;

- harmonisation: consistency between two or more law systems is created by allowing them to continue to exist as such while adapting them to each other;

- integration: consistency between two or more law systems is created by entirely integrating one law system into another and abrogating the system that has been integrated;

- rearrangement: consistency between two or more law systems is created by integrating those law systems into one new law system and subsequently abrogating (parts of) the constituting law systems;

- consolidation: consistency between a law system and all subsequent amendments in the form of (parts of) law systems by incorporating the original law system and its amendments unchanged into one single law system.

This study is confined to the clustering of environmental law: combining law systems resulting in a new law system. This is the case only with integration and rearrangement.

Clustering can take place at different legislative levels (i.e., statutes, orders in council, and ministerial regulations). Horizontal clustering is the clustering that is limited to law systems of the same level. If two or more levels are involved, I speak of vertical clustering.

Clustering can be modifying or codifying. The purpose of modifying clustering is to change the existing law. Codifying clustering is not aimed to change the law. Codifying clustering therefore may entail that the rules to be combined are not exactly the same but are incorporated into the new, clustered law system with a few purely editorial changes.

In Chapter 3, a scientific framework is developed that shows in what cases clustering of environmental law can be scientifically justified. A law system does not qualify as a law system unless it meets the consistency criteria. These criteria have three important effects: they determine the law system, the law system deficiencies, and the solutions to the problem that the 
legislator aims to remedy with a law system. Unless an iLawsystem is involved, the legislator must make a choice from among an almost unlimited number of restructuring criteria to achieve consistency of the rules in environmental law. Practical restructuring criteria and typically legal restructuring criteria may be involved.

I define an iLawsystem as a law system designed in such a way that the user, by means of a computer program, can generate his own law system as it were, on the basis of a consistency criterion that is relevant to him at that particular moment. For example, if a person wants to build a house and needs to know what environmental planning rules apply, it would be possible for him, at the press of a keyboard button, to access all the rules applicable to building and construction work as one law system. This is not merely about making environmental planning law available through digital technologies, but about making environmental planning law accessible in a way that enables the user to easily generate law systems on the basis of different criteria.

The choice for one or more consistency criteria is not purely politically determined, but may be scientifically underpinned. The first thing to be taken into account is the most important function of a law system: making the information contained in the written law accessible. Apart from the content of the constituting rules, a law system is important for the knowability of environmental law. Moreover, a law system must be problem-oriented; this means that a person who consults environmental law to find an answer concerning his rights and obligations is directed to the place in the law system itself where the answer can be found. To aid knowability and problemorientedness, the legislator should opt for consistency criteria that link up with the consistency experienced by the users of environmental law in the real world and that can be understood without any specific legal knowledge. This means that the legislator must opt for such reality-based, practical consistency criteria as subjects, objects, activities, and the physical living environment. This is a crucial requirement for scientifically justified clustering.

However, the choice for a particular consistency criterion entails by definition that clustering elsewhere in environmental law allows law system deficiencies to continue to exist; it may even create new deficiencies. The following categories of problems can be distinguished in this context:

- clustering on the basis of reality-based, practical consistency criteria can entail that certain law system deficiencies are only partly remedied;

- clustering on the basis of reality-based, practical consistency criteria can entail that certain law system deficiencies are partly or completely remedied, but that it creates deficiencies in other law systems;

- clustering on the basis of typically legal consistency criteria can entail that law system deficiencies are preserved or created in a certain law system that was clustered on the basis of reality-based, practical consistency criteria. This may involve internal and external law system deficiencies. 
An internal deficiency may arise if typically legal consistency criteria are used within the above-mentioned law system. An external deficiency may arise if the application of typically legal consistency criteria implies that certain rules are not part of that law system.

Clustering is not justified if the creation or continued existence of these law system deficiencies cannot be justified.

Codifying clustering ought to be the point of departure since clustering should be aimed first and foremost at the elimination or reduction of law system deficiencies rather than at the content of the rules to be clustered. However, clustering is also scientifically justified if small but also major modifications are made. In the latter case, the legislator must make sure that the effect may be that possible benefits of clustering are restricted as a result of the modification. Furthermore, the legislator runs the risk that the social acceptance of clustering is reduced or completely evaporates because of resistance to one or more modifications.

Finally, the legislator must make sure that a clustered law system is futureproof. By this I mean that no - unjustifiable - law system deficiencies arise because the legislator is largely forced to use a chronological approach. The legislator can make legislation more future-proof by striving for a law system that does not pretend to codify environmental law once and for all, and by aiming for a law system that is change-oriented and, if possible, iLawsystem-oriented. Rules can furthermore be made more future-proof by using future-proof, reality-based, practical or typically legal system restructuring criteria which may be expected to be valid also in the future. The legislator must take care that new environmental rules that are aimed to remedy a certain problem link up with the law system restructuring criteria chosen. The use of legislation in tranches (aanbouwwetgeving) that meets the requirements set in this Chapter for the choice of restructuring criteria may also contribute to a future-proof result.

Given the above, I have developed the following assessment framework. By answering the following five questions, the legislator can check whether the clustering of particular pieces of environmental law is justified.

1. Is there a law system deficiency within Dutch environmental law because some rules do not form part of the same law system even though they are consistent according to a reality-based, practical consistency criterion?

2. If so, can this law system deficiency be remedied or reduced by clustering law systems through rearrangement or integration?

3. Do law system deficiencies arise or continue to exist after the application of the typically legal restructuring criteria? If so, can these deficiencies be justified? 
4. Does clustering create law system deficiencies in other law systems or does it allow the deficiencies to continue to exist? If so, can these deficiencies be justified?

5. Does the clustering lead to a future-proof law system?

If the answer to questions 1,2 , and 5 is positive and to questions 3 and 4 negative, I consider clustering justified. If the answer to questions 3 and 4 is positive, but the answer as to the justifiability of the observed law system deficiencies is positive, then clustering is likewise justified.

It will be necessary to look at the results of application on a case-by-case basis. Moreover, I am aware of the fact that the criteria cannot be clearly defined in all cases. Opinions on their application may diverge considerably as a result. However, we now have a compass, so that we may avoid losing our way. This answers the first subquestion of this study.

The subject of Chapter 4 is how the rearrangement that led to the Environmental Permitting (General Provisions) Act (hence: Environmental Permitting Act) of 1 October 2010 relates to the criteria developed in Chapter 3. In this context, the five questions of the assessment framework mentioned above were answered as follows.

1. Before the Environmental Permitting Act came into operation, there was a law system deficiency within Dutch environmental law because not all rules formed part of the same law system even though they were consistent according to a reality-based, practical consistency criterion (viz., an area-specific project that consists of one or more activities that affect the physical living environment). The answer to the first assessment question is therefore positive.

2. The Environmental Permitting Act has reduced this law system deficiency, but failed to completely remedy it. This reduction was realised by incorporating a large number of authorization decisions for a project into the law system of the Environmental Permitting Act. There are still law system deficiencies because the Environmental Permitting Act does not contain all rules as regards a project or as regards all activities within a project that require an integrated environmental permit. Moreover, the Environmental Permitting Act does not require an integrated environmental permit for a number of activities within a project. Some of these deficiencies can be remedied relatively easily. The answer to the second assessment question is therefore mainly negative.

3. In the Environmental Permitting Act, the application of typically legal restructuring criteria like providing general as well as specific rules, setting standards in multiple phases, and referring to the European IPPC Directive ${ }^{2}$

2 Directive 2008/1/EC of the European Parliament and of the Council of 15 January 2008 concerning integrated pollution prevention and control, OJ L 24, 29 January 2008, pp. 8-29. 
maintains law system deficiencies, which are in most cases justifiable but may be easily reduced by the legislator. The answer to the third assessment question is mainly positive.

4. Law system deficiencies in the Environmental Management Act (Wet milieubeheer) have arisen as a side effect of the Environmental Permitting Act, since important provisions on establishments in the Environmental Management Act have ceased to apply. In my opinion, this deficiency is not justifiable and can only partly be remedied by incorporating the relevant provisions from the Environmental Management Act into the Environmental Permitting Act. A real solution, in my view, would require a new law system, on the basis of the 'physical living environment' consistency criterion, in which the provisions of the Environmental Permitting Act and the Environmental Management Act are rearranged. The answer to the fourth assessment question is therefore positive.

5. The Environmental Permitting Act is geared towards permanent change and its future-proofness is enhanced by the use of future-proof, practical and typically legal system restructuring criteria, provided that the legislator also follows these criteria when changes are made in the future. The answer to the fifth assessment question is positive.

It is true that the Environmental Permitting Act represents an important contribution to reducing the number of law system deficiencies in environmental law that had existed until 1 October 2010, but the above answers mean that the rearrangement in its present form only partly meets the criteria I developed for justified clustering. If - for example, in the framework of a new Environmental Planning Act (Omgevingswet) - the legislator succeeds in remedying the law system deficiencies resulting from the clustering in the law system of the Environmental Permitting Act and in other law systems such as the Environmental Management Act, the clustering could be fully justified after all. In Chapter 4, a number of suggestions for improvement were made.

In Chapter 5, the integration of the Chemical Substances Act (Wet milieugevaarlijke stoffen) into the Environmental Management Act on 1 June 2008 is discussed on the basis of the five assessment questions and tested against the criteria developed in Chapter 3 .

1. Before the integration of the Chemical Substances Act into the Environmental Management Act, there was a law system deficiency within Dutch environmental law because not all rules formed part of the same law system even though they were consistent according to a reality-based, practical consistency criterion (viz., substances). Substances are defined as 'chemical elements and their compounds in the natural state or obtained by any manufacturing process with an impact on the environment or human health'. The answer to the first assessment question is therefore positive. 
2. The integration of the Chemical Substances Act into the Environmental Management Act has remedied this law system deficiency. This was realised by incorporating all provisions from the Chemical Substances Act that did not need to be discontinued into the Environmental Management Act. Other law system deficiencies may have remained unchanged by the integration process. The answer to the second assessment question is therefore also positive. However, it must be noted here that the law system deficiency that existed on 31 May 2008 had been created a year earlier by the legislator itself because it had not implemented $\mathrm{REACH}^{3}$ into the Chemical Substances Act, but into Chapter 9 of the Environmental Management Act. Although it would require further research, it is very likely that implementation of REACH into the Chemical Substances Act would not have led to the law system deficiency that was remedied by means of the clustering by integration.

3. When the Chemical Substances Act was integrated into the Environmental Management Act, typically legal restructuring criteria were used, for example, typically legal concepts, providing general as well as specific rules, and setting standards in multiple phases. As a result, law system deficiencies were created or continued to exist. In most cases, the deficiencies identified can be justified, even though the legislator could easily have remedied or reduced a number of the deficiencies. Therefore, the answer to the third assessment question is mainly positive.

4. No new law system deficiencies have arisen outside the Environmental Management Act as a result of the integration. The answer to the fourth assessment question is therefore negative.

5. The integration of the Chemical Substances Act into the Environmental Management Act does not pretend to lay down the environmental law on substances once and for all but, on the contrary, is aimed at permanent change. The future-proofness is increased by the use of future-proof, practical and typically legal system restructuring criteria, that is, if the legislator continues to apply these criteria for future changes. Assessment question five is thus answered positively.

These answers imply that the integration of the Chemical Substances Act into the Environmental Management Act contributed to reducing the law system deficiencies that existed in environmental law until 1 June 2008. They also show that the integration of the Chemical Substances Act into the Environmental Management Act in its present form only partly meets the criteria I developed for justified clustering. This means that clustering

3 Regulation (EC) No 1907/2006 of the European Parliament and of the Council of 18 December 2006 concerning the Registration, Evaluation, Authorisation and Restriction of Chemicals (REACH), establishing a European Chemicals Agency, amending Directive 1999/45/EC and repealing Council Regulation (EEC) No 793/93 and Commission Regulation (EC) No 1488/94 as well as Council Directive 76/769/EEC and Commission Directives 91/155/EEC, 93/67/EEC, 93/105/EC and 2000/21/EC (OJ L 396, 30 December 2006, pp. 1-849). 
cannot be completely justified. There is room for improvement; a number of suggestions were explored in Chapter 5 .

In Chapter 6, the Nature Protection Bill (ontwerp Wet natuurbescherming), published on 6 October 2011, which is aimed to rearrange the legislation set out in the Nature Conservation Act 1998 (Natuurbeschermingswet 1998), the Flora and Fauna Act (Flora- en faunawet), and the Forestry Act (Boswet), is discussed on the basis of the five assessment questions and tested against the criteria developed in Chapter 3.

1. At the moment, there is a law system deficiency within Dutch environmental law because not all rules form part of the same law system even though they were consistent according to a reality-based, practical consistency criterion (viz., nature). The answer to the first assessment question is therefore positive.

2. The rearrangement of the Nature Conservation Act 1998, the Flora and Fauna Act, and the Forestry Act forming the Nature Protection Bill remedies this law system deficiency. This is achieved by incorporating all provisions of these three Acts that did not need to be discontinued into the Bill and abrogating these Acts. The answer to the second assessment question is therefore mainly positive.

3. In drafting the Nature Protection Bill, typically legal restructuring criteria were used, like structure, setting standards in multiple phases, and referring to European Directives and Regulations. As a result, law system deficiencies will be created or will continue to exist. A number of the deficiencies identified cannot be justified and require further research. The legislator will probably be able to remedy some of the deficiencies quite easily. The answer to the third assessment question is mainly negative.

4. Incorporating the provisions of the Nature Conservation Act 1998, the Flora and Fauna Act, and the Forestry Act into the Bill and abrogating those three Acts will not lead to law system deficiencies as a result of clustering through rearrangement. The fourth assessment question can thus be answered negatively.

5. The Nature Protection Bill is not meant to lay down the environmental law on nature once and for all but, on the contrary, is aimed at permanent change, already taking into account the anticipated Environmental Planning Act. Its future-proofness is increased by the use of future-proof, practical and typically legal system restructuring criteria, that is, if the legislator continues to apply these criteria for future changes. Assessment question five can be answered positively.

These answers imply that the proposed rearrangement of the Nature Conservation Act 1998, the Flora and Fauna Act, and the Forestry Act to form the new Nature Protection Bill will indeed contribute considerably to reducing the currently existing law system deficiencies in environmental law, but that the rearrangement in its present form only partly meets the 
criteria I developed for justified clustering. There is still room for improvement; suggestions to this effect were made in Chapter 6. If the legislator were to succeed in implementing such law system improvements in the Bill that the answer to the second and third assessment questions were positive, the overall judgment would possibly be in favour of the Bill.

The subject of Chapter 7 is to what extent the five assessment questions can be helpful in developing the rearrangement aimed to culminate in the Environmental Planning Act (Omgevingswet) outlined in the Cabinet letter dated 9 March 2012. ${ }^{4}$ The Environmental Planning Act will be the product of the full integration of fifteen existing statutes, the full abrogation of two statutes, and the incorporation of the environmental planning elements from approximately 25 other statutes. This exploration has led to the following results.

1. The main purpose of the Environmental Planning Act is to achieve a safe and healthy living environment and to maintain, manage, use, and develop it in an effective and sustainable way. If the consistency criterion physical living environment is taken as a point of departure, it seems to me that the effect will be a law system deficiency because not all rules form part of the same law system even though they are consistent according to a reality-based, practical consistency criterion (viz., physical living environment).

2. In my opinion, the proposed Environmental Planning Act will in any case reduce the law system deficiency described above by clustering the fifteen law systems, abrogating two law systems, and partially integrating approximately 25 law systems in the area of environmental law. Whether the deficiency will be remedied depends on the law systems that will ultimately be involved in the clustering operation. However, it may be expected that the deficiency will not be entirely remedied, and perhaps not even to a considerable extent, following the abrogation of fifteen law systems that also do justice to the consistency criterion physical living environment and the clustering of only parts of 25 named law systems.

3. So far, it seems that typically legal restructuring criteria will be used in the Environmental Planning Act. The effect will be that law systems deficiencies will be created or will continue to exist. Given the absence of the actual text of the law, it is not yet possible to say whether such deficiencies can be defended.

4. The law system of the proposed Environmental Planning Act may possibly generate law system deficiencies in other law systems or allow such deficiencies to continue to exist. The reason is that, according to the Cabinet letter, only the environmental planning elements of approximately 25 statutes will be incorporated into the Environmental Planning

4 Ministry of Infrastructure and the Environment, Kabinetsbrief stelselherziening omgevingsrecht, 9 maart 2012, Kamerstukken II 2011/12, 33 118, no. 3. 
Act. Given the absence of the actual text of the law, it is not yet possible to say whether such deficiencies can be defended.

5. The question of whether the law system of the Environmental Planning Act is future-proof is also hard to answer because the actual text of the statute is not available yet. The Cabinet letter provides too little information to be able to assess whether the Environmental Planning Act is aimed to codify environmental law once and for all. However, some future-proof consistency criteria have been applied. It is not a case of legislation in tranches: the legislator has not followed the route of first creating the full law system required by environmental law and then chronologically drafting the various parts of the law, putting them immediately in their correct place in the law system. It rather seems that the Cabinet does not wish to divulge - or, and this would be more of a problem: does not have a clearly defined idea - what the contents of the Environmental Planning Act will ultimately be.

In the absence of the actual text of the Environmental Planning Act, only an indication can be given as regards the answers to the five assessment questions. However, I venture the tentative conclusion that, on the basis of the consistency criterion physical living environment, an Environmental Planning Act could make an important contribution to partly reducing the currently existing law systems deficiencies in environmental law. The question to what extent the legislator will succeed in doing so in practical terms can only be answered on the basis of the actual text of the Bill.

My strong advice to the legislator in such an extensive clustering operation would be to explicitly comment on the consistency criteria in the explanatory memorandum to the Bill and to better safeguard the law's futureproofness by employing the technique of legislating in tranches.

\subsection{CONCLUSIONS}

Given the above, the three subquestions can be answered as follows.

The first subquestion was: Is there, or is it possible to scientifically develop, an assessment framework which can predict in what case or cases clustering of environmental law is justified? The answer to that question is that, in the sources consulted, I have not been able to find an assessment framework that can be used to determine in what cases clustering is justified. I therefore developed such a framework myself and explained it in Chapter 3. On the basis of five assessment questions, it can be determined whether clustering by means of rearrangement or integration can be justified. 
The second subquestion was: How does the clustering by rearrangement which, in 2010, led to the Environmental Permitting (General Provisions) Act (Wet algemene bepalingen omgevingsrecht), the clustering which, in 2008, led to the integration of the Chemical Substances Act (Wet milieugevaarlijke stoffen) into the Environmental Management Act (Wet milieubeheer), the clustering by rearrangement, proposed by the government in 2010, that is to result in a Nature Protection Act (Wet natuurbescherming), and the proposed clustering that should result in the Environmental Planning Act (Omgevingswet) relate to this scientific assessment framework? This question was answered in Chapters 4, 5, 6 and 7. On the basis of the four case studies dealt with in these chapters, I conclude that the clustering only partly meets the criteria I developed: in its present form, the clustering cannot be completely justified.

The third subquestion was: As regards the clustering projects mentioned under subquestion 2, can proposals be made to the effect that the restructuring of environmental law links up better with the scientific criteria (to be developed) for clustering environmental law? This question was answered positively in the sense that a number of suggestions could be made in Chapters 4, 5, 6 and 7. If these suggestions are implemented as regards the three clustering projects studied in this research, these clustering operations would link up better with the criteria developed.

The answers to these subquestions enable me to answer the central question of this study: are the proposals to restructure the system of environmental law through clustering (merely) a political choice or does it also meet the requirements that may be set scientifically for restructuring environmental law? The answer is that clustering of environmental law does not need to be merely a political choice but that it can meet scientific requirements. The fact that clustering in the four case studies did not lead to completely justified clustering does not mean that it is impossible to meet those criteria. I made suggestions for improvement as regards each of the four clustering operations.

\subsection{RECOMMENDATIONS}

My study as well as the interviews have led to a number of recommendations to the legislator and to legislative drafters.

\subsubsection{Recommendations to the legislator}

1. Do not undertake clustering until after identifying and convincingly motivating one or more relevant consistency criteria. If these criteria are not clear, there is a risk that rules are included in a law system that do 
not belong there, or that law system deficiencies are created or continue to exist because rules that do belong in the law system are not included.

2. For reasons of the knowability and problem-orientedness of a law system, opt for reality-based, practical consistency criteria wherever possible.

3. Only use typically legal restructuring criteria if the law system deficiencies created as a result can be justified.

4. Do not undertake rearrangement or integration unless the law system deficiencies identified on the basis of the chosen consistency criteria will be remedied or reduced as a result.

5. Make sure that clustering will not lead to law system deficiencies in other law systems, unless they can be defended.

6. For the benefit of the future-proofness of a law system created through clustering, make sure that new environmental law consistently meets the law system restructuring criteria.

7. Prevent the inclusion of cuckoo-in-the-nest provisions in a law system.

8. Present a convincing sample of a proposed law system to be realised by means of clustering.

9. In principle, opt for codifying clustering, but also use the opportunity to make shrewd modifications. Be aware that modifications may affect the social acceptance of clustering.

10. Explore the possibilities of iLawsystems, but make sure that a law system remains independently knowable and does not become dependent on ICT applications.

11. Include instructions for clustering environmental and other law in the Legislative Drafting Instructions (Aanwijzingen voor de regelgeving).

12. Take action to periodically tidy up and redefine applicable law systems.

13. When the Council of State (Raad van State) gives advice on a Bill, it should also advise on the way in which that Bill fits into the relevant law systems.

\subsubsection{Recommendations to legislative drafters}

1. Make sure with every change of law that no law system deficiencies arise. This is particularly important where law systems are concerned that are the result of clustering. Otherwise there is the risk that these law systems will not be future-proof.

2. Environmental laws are of course legal documents, but be aware of the fact that they will be more knowable if users can understand their rights and obligations on the basis of the legal text itself, without any specific previous legal knowledge. 



\title{
8 Bündelung von Umweltrecht \\ Zusammenfassung, Ergebnisse, Empfehlungen
}

\begin{abstract}
'Die Gesetze so hoch aufhängen, wie Dionysios der Tyrann tat, daß sie kein Bürger lesen könnte, - oder aber sie in den weitläufigen Apparat von gelehrten Büchern, Sammlungen von Dezisionen abweichender Urteile und Meinungen, Gewohnheiten usf. und noch dazu in einer fremden Sprache vergraben, so da $\beta$ die Kenntnis des geltenden Rechts nur denen zugänglich ist, die sich gelehrt darauf legen, - ist ein und dasselbes Unrecht.'

Georg Wilhelm Friedrich Hegel ${ }^{1}$
\end{abstract}

\subsection{EINLEITUNG}

Das niederländische Umweltrecht besteht aus dutzenden Gesetzen, allgemeinen Verwaltungsvorschriften und ministeriellen Erlassen auf den Gebieten Umwelt, Raumordnung, Wasser und Natur. In den vergangenen Jahrzehnten ist die Anzahl dieser gesetzlichen Regelungen unter dem Schlagwort „bundeling van omgevingsrecht” (Bündelung des Umweltrechts) verringert worden. Im Folgenden wird daher der Begriff „Bündelung” verwendet. Unter dem Begriff „Bündelung” wird die Systematisierung des Umweltrechts durch die „Neufassung” von Gesetzen („Bündeln durch Neufassung”), oder durch die „Integration” eines bestehenden Gesetzestexts in einen anderen („Bündeln durch Integration”) verstanden. ${ }^{2}$ So wurden im Jahr 2008 elf Allgemeine Verwaltungsvorschriften im Besluit algemene regels voor inrichtingen milieubeheer (Activiteitenbesluit) ${ }^{3}$ zusammengefasst und im Jahr 2009 acht

1 Georg Wilhelm Friedrich Hegel, Grundlinien der Philosophie des Rechts. Naturrecht und Staatswissenschaft, Herausgegeben und mit Einführung von Helmut Reichelt, Ullstein, Frankfurt am Main, 1972. Auch zitiert durch Hirsch Ballin, Architectuur van wetgeving 1984, S. 81. Wie es heißt, veröffentlichte der Tyrann Dionysios von Syrakus seine Gesetze auf Tafeln, die er so hoch aufhängen ließ, dass niemand sie lesen konnte. (Clausdieter Schott, Gesetzesadressat und Begriffsvermogen, in: Gottfried Baumgärtel c.s. (red.), Festschrift für Heinz Hübner zum 70. Geburtstag am 7. November 1984, Berlin: Walter de Gruyter, S. 191). Van Gestel schreibt, dass sich der Kaiser Caligula ähnlicher Methoden der Bekanntmachung bediente (Van Gestel, Eenieder wordt geacht de wet te kennen 1998, S. 78).

S. 8.2 .

3 Besluit algemene regels voor inrichtingen milieubeheer (Stb. 2007, 415) (Allgemeine Umweltrechtlichen Vorschriften für Anlagen): Der Activiteitenbesluit beinhaltet allgemeine Vorschriften für ca. 375.000 Anlagen, die sonst eine umweltrechtliche Genehmigung nötig hätten. 
Gesetze im Waterwet ${ }^{4}$ zusammengeführt. Der Gesetzgeber hat mit der Systematisierung der Vorschriften verschiedene rechtliche, ökologische und ökonomische Ziele verfolgt. Dieser Dissertation liegt die Frage zugrunde, ob es in den Niederlanden bei der Systematisierung des Umweltrechts um eine rein politische Entscheidung geht, die Vorteile oder Nachteile für die Gesetzessystematik mit sich bringen kann, oder ob es eine Entscheidung ist, die auch wissenschaftlich vertretbar ist. Anders formuliert: gibt es einen Prüfungsrahmen oder kann ein solcher Prüfungsrahmen wissenschaftlich entwickelt werden, aus dem abgeleitet werden kann, in welchem Fall die Bündelung von Gesetzestexten im Umweltrecht vertretbar ist? Diese Fragestellung ist nicht nur für die Rechtswissenschaft, sondern auch für die Gesellschaft von großer Relevanz, da die niederländische Regierung plant, drei Naturschutzgesetze $^{5}$ in einem einzigen Naturschutzgesetz (Wet natuurbescherming) und vierzig Gesetze in einem Umweltgesetz (Omgevingswet) zusammenzufassen.

\subsection{ZUSAMMENFASSUNG}

Kapitel 1 befasst sich mit der Hauptfrage der Dissertation: ist die Systematisierung des Umweltrechts durch „Bündelung” eine rein politische Entscheidung oder erfüllen die Vorhaben auch Forderungen, die von der Wissenschaft an die Ordnung des Umweltrechts gestellt werden können?

Die Hauptfrage gliedert sich in drei Unterfragen:

1. Kann wissenschaftlich ein Prüfungsrahmen entwickelt werden, aus dem ersichtlich ist, in welchem Fall die Bündelung des Umweltrechts vertretbar ist?

2. Wie verhalten sich die folgenden vier Systematisierungsprojekte zu diesem Prüfungsrahmen:

- die Bündelung, die 2010 zu einer Neufassung verschiedener Vorschriften im Wet algemene bepalingen omgevingsrecht (Wabo) ${ }^{6}$ führte;

4 Wet van 29 januari 2009, houdende regels met betrekking tot het beheer en gebruik van watersystemen (Stb. 2009, 490 (Tekstplaatsing)) (Gewässerschutzgesetz): Das Waterwet normiert die Verwaltung des Oberflächenwassers und des Grundwassers und verbessert die Zusammenarbeit zwischen Wasserpolitik und Raumordnung.

5 Wet van 25 mei 1998, houdende nieuwe regelen ter bescherming van natuur en landschap (Natuurbeschermingswet 1998) (Stb. 1998, 403); Wet van 25 mei 1998, houdende regels ter bescherming van in het wild levende planten-en diersoorten (Flora- en faunawet) (Stb. 1998, 402); Wet van 20 juli 1961, houdende nieuwe bepalingen ter bewaring van bossen en andere houtopstanden(Boswet) (Stb. 1961, 256).

6 Wet van 6 november 2008, houdende regels inzake een vergunningstelsel met betrekking to activiteiten die van invloed zijn op de fysieke leefomgeving en inzake handhaving van regelingen op het gebied van de fysieke leefomgeving (Wet algemene bepalingen omgevingsrecht) (Stb. 2008, 496) (Gesetz Allgemeine Vorschriften Umweltrecht): Hauptgegenstand dieses Gesetzes sind Bestimmungen zu umweltrechtlichen Genehmigungen für standortgebundene Projekte. 
- die Bündelung, die 2008 zur Integration des Wet milieuvaarlijke stoffen $(W m s)^{7}$ in das Wet milieubeheer $(W m)^{8}$ führte;

- die Bündelung, die zu einer Neufassung verschiedener Vorschriften im Wet natuurbescherming ${ }^{9}$ führen soll;

- die angestrebte Bündelung einer Vielzahl von Gesetzen im Omgevingswet. ${ }^{10}$

3. Müssen angesichts der in Unterfrage 2 genannten Systematisierungsprojekte Vorschläge erarbeitet werden, um die Ordnung des Umweltrechts besser an den (zu entwickelnden) Kriterien für die Systematisierung des Umweltrechts auszurichten?

Bei der Beantwortung dieser Fragen habe ich mich auf mögliche juristische Kriterien für die Bündelung beschränkt. Der Prüfungsrahmen wurde durch das Studium der „klassischen” juristischen Quellen, juristischer Literatur und der Gesetzesmaterialien entwickelt. Zudem wurden Interviews mit einigen Wissenschaftlern und Juristen geführt, die am Gesetzgebungsprozess beteiligt sind. Damit soll sichergestellt werden, dass die in der Literatur dargestellten Ansichten der Alltagspraxis entsprechen.

In Kapitel 2 wurden zentrale Begriffe der Dissertation definiert. Besonders wichtig sind die Begriffe des „Gesetzessystems” und des „systematischen Defizits".

Unter einem Gesetzessystem verstehe ich: nach bestimmten Kriterien geordnete, untereinander zusammenhängende Vorschriften. ${ }^{11}$ Hierbei kann zwischen formellen und materiellen Komponenten eines Gesetzessystems unterschieden werden. Bei der formellen Gesetzessystematik geht es um die nach außen hin sichtbare Ordnung. Bei der materiellen Gesetzessystematik handelt es sich um inhaltliche Ordnungskriterien und die gegenseitigen Beziehungen der Vorschriften untereinander. In welchen Fällen ist die Systematisierung wissenschaftlich nun vertretbar? Hinsichtlich dieser Frage ist der Zusammenhang innerhalb eines Gesetzessystems wichtig, das

$7 \quad$ Regelen ter bescherming van mens en milieu tegen gevaarlijke stoffen en preparaten (Wet milieugevaarlijke stoffen) (Stb. 1985, 639) (Gesetz zum Schutz vor schädlichen Stoffen): Dieses Gesetz beinhaltete Vorschriften zum Schutz des Menschen und der Umwelt vor schädlichen Stoffen.

8 Wet van 13 juni 1979, houdende regelen met betrekking tot een aantal algemene onderwerpen op het gebied van de milieuhygiene (Stb. 1992, 414 en 415, Stb. 1993, 31). Das Wet milieubeheer beinhaltet allgemeine Vorschriften zum Schutz der Umwelt.

9 Ontwerp Wet natuurbescherming (Gesetzentwurf Naturschutzgesetz): Dieses Gesetzentwurf beinhaltet Regelungen über den Naturschutz. Der Gesetzentwurf kann auf www.internetconsultatie.nl/ wetnatuur eingesehen werden. Mittlerweile wurde dieser Entwurf in modifizierter Form als Gesetzentwurf in die die Tweede Kamer eingebracht (Kamerstukken II 2011/12, 33 348, nr. 1-3).

10 Omgevingswet (Umweltgesetz): Das Omgevingswet, für das voraussichtlich Ende 2012 ein Gesetzesentwurf vorliegen wird, befasst sich mit dem Schutz der Umwelt, Raumordnung, Natur und Wasser; Ministerie van IenM, Kabinetsbrief stelselherziening omgevingsrecht, 9 maart 2012, Kamerstukken II 2011/12, 33 118, nr. 3.

11 In Anlehnung an Noll, Gesetzgebungslehre 1973, S. 205. 
sich an der Wirklichkeit orientiert, wie sie der Nutzer des Gesetzessystems erlebt. Deswegen ich mich in meiner Dissertation auf die materiellen Aspekte des Rechtssystems beschränke.

Ein systematisches Defizit liegt vor, wenn bestimmte Vorschriften zwar untereinander zusammenhängen, sie jedoch keinen Teil des gleichen Gesetzessystems bilden. Um solche systematischen Defizite zu beheben, kann sich der Gesetzgeber folgender Instrumente bedienen:

- Koordination: zwischen zwei oder mehr Gesetzessystemen wird durch eine neue gesetzliche Regelung ein Zusammenhang hergestellt, wobei beide ursprünglichen Gesetzestexte bestehen bleiben;

- Harmonisierung: zwischen zwei oder mehr Gesetzessystemen wird ein Zusammenhang hergestellt, indem die beiden Gesetzessysteme als solche zwar bestehen bleiben, sie jedoch aneinander angeglichen werden;

- Integration: zwischen zwei oder mehr Gesetzessystemen wird ein $\mathrm{Zu}$ sammenhang hergestellt, indem ein Gesetzessystem vollständig in ein anderes Gesetzessystem aufgenommen wird;

- Neufassung: zwischen zwei oder mehr Gesetzessystemen wird ein $\mathrm{Zu}-$ sammenhang hergestellt, indem die beiden Gesetzessysteme in einem neuen Gesetzessystem verschmelzen, wobei die beiden ursprünglichen Gesetzessysteme aufgehoben werden;

- Konsolidierung: zwischen einem Gesetzessystem und den darauf folgenden Abänderungsgesetzen wird ein Zusammenhang hergestellt, indem das ursprüngliche Gesetzessystem und die Änderungsgesetze unverändert in ein einziges Gesetzessystem aufgenommen werden.

Meine Dissertation befasst sich ausschließlich mit der „Bündelung durch Integration” und der „Bündelung durch Neufassung” von Gesetzessystemen.

Eine Bündelung von Gesetzestexten kann auf den verschiedenen Ebenen der Normenhierarchie vorgenommen werden (Gesetz, Allgemeine Verwaltungsvorschrift, Ministerieller Erlass). Horizontale Bündelung bezeichnet hierbei das Zusammenführen von Gesetzessystemen auf der gleichen Ebene der Normenhierarchie. Sind Gesetzessysteme verschiedener Ebenen betroffen, so wird dies als vertikale Bündelung bezeichnet.

Bündelung kann modifizierend oder kodifizierend sein. Bei der kodifizierenden Bündelung geht es nicht darum, die bestehende Rechtsauffassung zu verändern. Bei der modifizierenden Bündelung ist das hingegen der Fall. Von kodifizierender Bündelung kann mithin auch gesprochen werden, wenn die Vorschriften durch die Bündelung einige redaktionelle Änderungen erfahren.

In Kapitel 3 wurde ein wissenschaftlicher Prüfungsrahmen entwickelt, aus dem ersichtlich ist, in welchen Fällen die Bündelung des Umweltrechts 
vertretbar ist. Von einem Gesetzessystem kann erst dann gesprochen werden, wenn es bestimmte Systemkriterien ${ }^{12}$ enthält. Die Systemkriterien haben drei wichtige Aufgaben: sie bestimmen das Gesetzessystem und die systematischen Defizite und sie zeigen Lösungen für Probleme auf, die der Gesetzgeber mit dem System lösen will. Solange das niederländische Umweltrecht noch nicht in einem iLawsystem „gebündelt” ist, muss der Gesetzgeber aus einer großen Anzahl an Ordnungskriterien auswählen, um einen Zusammenhang zwischen den Vorschriften des Umweltrechts herzustellen. Dabei kann es um sachliche $^{13}$ und typisch juristische ${ }^{14}$ Ordnungskriterien gehen. Unter einem iLawsystem verstehe ich ein Gesetzessystem, das so gestaltet ist, dass der Nutzer mit einem Computerprogramm sein eigenes Gesetzessystem generieren kann und dafür ein von ihm selbst zu wählendes, zu diesem Zeitpunkt für ihn relevantes Systemkriterium bestimmt. Wer zum Beispiel ein Wohnhaus bauen will, und sich fragt, welche Vorschriften des Umweltrechts anzuwenden sind, sollte demnach sozusagen per Mausklick ein Gesetzessystem mit allen auf den Hausbau anwendbaren Vorschriften generieren können. Es geht hierbei nicht bloß darum, das Umweltrecht mit Hilfe digitaler Technik für jedermann zugänglich zu machen. Es geht vielmehr darum, dem Umweltrecht in einem flexiblen Gesetzessystem Form zu geben, das dem Wunsch des Benutzers entspricht und das Zusammenhänge zwischen den Vorschriften auf einfache Weise hergestellt.

Die Wahl für ein oder mehrere Systemkriterien ist nicht lediglich politisch zu treffen, sondern kann auch auf wissenschaftlichen Erwägungen fußen. Hierzu sollte man sich noch einmal die Hauptfunktion eines Gesetzessystems verdeutlichen: es geht meiner Meinung nach um die Vereinfachung der im geschriebenen Recht enthaltenen Informationen. Ein Gesetzessystem ist, unabhängig von den darin enthaltenen Regeln wichtig, um das Umweltrecht als solches zu erkennen. Ein Gesetzessystem sollte darüber hinaus problemorientiert sein. Das bedeutet, dass diejenigen, die das Umweltrecht zu Rate ziehen, selbständig darin eine Antwort finden sollten. Um sowohl die Erkennbarkeit als auch die Problemorientierung zu garantieren, sollte der Gesetzgeber Systemkriterien wählen, die unmittelbar an der Wirklichkeit anknüpfen, wie sie die Nutzer des Gesetzessystems erfahren, sodass das

12 Unter Systemkriterien werden solche Merkmale verstanden, die den Zusammenhang zwischen rechtlichen Vorschriften bestimmen.

13 Der Begriff „sachliche Ordnungskriterien” ist auf Peter Noll zurückzuführen: „Die wichtigste Rolle spielen im geltenden Rechtssystem die sachlichen Systemkriterien. Eine Ordnung nach der Regelungsmaterie zu dem, was Englisch das rein klassifikatorische System nennt. Da sie an sichtbare und im allgemeinen Vorverständnis als Einheiten betrachtete Gegebenheiten anknüpfen, an Erscheinungen wie Straßenverkehr, Landwirtschaft, Jagd, Schule, Kirche, einzelne Berufe, Landesverteidigung usw., eignen sie sich vorzüglich $\mathrm{zu}$ einer am Problem orientierten und vom Sachproblem her die Orientierung erleichternden, dem Problemimpuls und dem Problemanfall zugleich angepaßten Systematik der gesetzlichen Einzelwerken untereinander." (Noll, Gesetzgebungslehre 1973, S. 211).

14 Typisch juristische Ordnungskriterien sind solche, die sich von sachlichen Ordnungskriterien abgrenzen, indem sie von Juristen geschaffen und angewendet werden. 
System ohne spezielle juristische Vorkenntnis zu begreifen ist. Das bedeutet schließlich, dass sich der Gesetzgeber für sachliche Systemkriterien wie „Subjekte”, „Objekte”, „Aktivitäten” und „Umwelt”, entscheiden muss. Dies ist eine wichtige Anforderung, die die wissenschaftliche Systematisierung erfüllen muss.

Die Wahl eines bestimmten Systemkriteriums bedeutet jedoch auch, dass die Systematisierung an anderen Stellen systematische Defizite weiter bestehen oder entstehen lässt. Dabei lassen sich verschiedene Kategorien unterscheiden:

- die Bündelung auf der Grundlage von sachlichen Systemkriterien kann bedeuten, dass bestimmte systematische Defizite lediglich teilweise behoben werden;

- die Bündelung auf der Grundlage von sachlichen Systemkriterien kann bedeuten, dass bestimmte systematische Defizite ganz oder teilweise behoben werden, dass hierdurch jedoch systematische Defizite in anderen Gesetzessystem geschaffen werden;

- die Bündelung auf der Grundlage von typisch juristischen Systemkriterien kann bedeuten, dass systematische Defizite in einem durch die Systematisierung auf der Grundlage von sachlichen Systemkriterien entstandenen Gesetzessystem bestehen bleiben oder geschaffen werden. Hierbei kann es sich sowohl um interne als auch externe gesetzesssystematische Defizite handeln. Ein internes Defizit kann bei der Verwendung typisch juristischer Systemkriterien innerhalb des Gesetzessystems entstehen. Ein externes Defizit kann sich dadurch ergeben, dass typisch juristische Systemkriterien zur Folge haben, dass einige Vorschriften nicht in das Gesetzessystem aufgenommen werden.

Die Bündelung ist vertretbar, wenn das Entstehen oder Fortbestehen dieser systematischen Defizite vertretbar ist.

Grundsätzlich sollte die kodifizierende Bündelung den Ausgangspunkt bilden, da es bei der Zusammenführung von Gesetzessystemen hauptsächlich um die Behebung oder Verringerung systematischer Defizite gehen soll, und nicht um den Inhalt der zusammenzuführenden Regeln selbst. Die Bündelung ist jedoch auch dann vertretbar, wenn kleinere oder größere Änderungen vorgenommen werden. Hierbei sollte sich der Gesetzgeber jedoch dessen bewusst sein, dass die Folge einer solchen Veränderung die Vorteile der Bündelung einschränken kann. Des Weiteren läuft der Gesetzgeber hierbei Gefahr, dass die Akzeptanz der Systematisierung in der Gesellschaft verringert wird und dass sich Widerstand gegen eine oder mehrere Veränderungen formiert.

Schließlich muss der Gesetzgeber bei Bündelungsvorhaben für die Zukunftsfähigkeit des Gesetzessystems sorgen. Damit meine ich, dass innerhalb des neuen Systems keine - unvertretbaren- systematischen Defizite entstehen, 
wenn das System (in Zukunft) an neue Entwicklungen angepasst werden muss. Der Gesetzgeber kann diese Zukunftsfähigkeit erreichen, indem er nicht bestrebt ist, das Umweltrecht abschließend zu kodifizieren, sondern ein Gesetzessystem schafft, das auf Veränderungen reagieren kann und dies möglicherweise mithilfe eines iLawsystems realisiert. Zu diesem Zweck sollten juristische Ordnungskriterien gewählt werden, die nicht nur zum Zeitpunkt der Systematisierung, sondern aller Voraussicht nach auch in Zukunft Bestand haben. Der Gesetzgeber muss dafür Sorge tragen, dass neue umweltrechtliche Bestimmungen an den ausgewählten systematischen Ordnungskriterien ausgerichtet werden. Ferner können auch „Anbaugesetze", ${ }^{15}$ die den in diesem Kapitel genannten Forderungen nachkommen, zur Zukunftsfähigkeit des Gesetzessystems beitragen.

Auf Grundlage der vorhergehenden Ausführungen habe ich den folgenden Prüfungsrahmen entwickelt, anhand dessen sich der Gesetzgeber durch die Beantwortung von fünf Fragen entscheiden kann, ob es sich in einem konkreten Fall um eine vertretbare Bündelung des Umweltrechts handelt:

1. Gibt es innerhalb des Umweltrechts ein systematisches Defizit, weil nicht alle Vorschriften, die durch ein praxisnahes ${ }^{16}$ sachliches Systemkriterium untereinander zusammenhängen, Teil desselben Gesetzessystems sind?

2. Wenn Frage $1 \mathrm{zu}$ bejahen ist: kann dieses systematische Defizit durch die Bündelung (durch Neufassung oder Integration) verringert oder behoben werden?

3. Führt die Verwendung typisch juristischer Ordnungskriterien zur Entstehung oder dem Fortbestand systematischer Defizite? Wenn dies zu bejahen ist, sind diese Defizite vertretbar?

4. Führt die Bündelung zur Entstehung oder dem Fortbestand systematischer Defizite in anderen Gesetzessystemen? Wenn dies zu bejahen ist, sind diese Defizite vertretbar?

5. Stellt das neu geschaffene System ein anpassungs- und zukunftsfähiges Gesetzessystem dar?

Wenn Fragen 1, 2 und 5 bejaht werden können, während Fragen 3 und 4 verneint werden, nenne ich die Systematisierung vertretbar. Wenn die Fragen 3 und 4 in ihrem ersten Teil bejaht werden können, und die Antwort bezüglich der Vertretbarkeit der festgestellten systematischen Defizite ebenfalls bejaht werden kann, dann ist die Systematisierung ebenfalls vertretbar. Es muss je nach Thema gesehen werden, zu welchen Ergebnissen die Anwendung der Kriterien führt. Zugegebenermaßen können die Kriterien

15 Unter dem niederländischen Begriff „Aanbouwwetgeving” versteht man eine Gesetzgebungstechnik, bei der zuerst eine Gesetzessystematik geschaffen wird, die in zeitlich darauffolgenden Abständen durch ihre einzelnen Unterteile ergänzt wird, wobei die einzelnen Regeln ihren gesetzessystematisch „richtigen” Platz einnehmen.

16 Der Begriff „praxisnah“ bezieht sich auf die Wirklichkeit, wie sie die Nutzer eines Gesetzessystems erfahren. 
nicht immer genau definiert werden. Bei ihrer Anwendung können die Meinungen schnell auseinander gehen. Allerdings haben wir nun zumindest einen Kompass, sodass wir nicht schon im Voraus vom Weg abkommen. Somit ist die erste Forschungsfrage beantwortet.

In Kapitel 4 wurde anhand der fünf Fragen untersucht, wie sich die „Bündelung durch Neufassung” verschiedener Vorschriften im Wet algemene bepalingen omgevingsrecht (Wabo) vom 1. Oktober $2010 \mathrm{zu}$ dem in Kapitel 3 entwickelten Prüfungsrahmen verhält:

1. Bevor das Wabo in Kraft trat, gab es im Umweltrecht ein systematisches Defizit, da nicht alle Vorschriften, die durch das praxisnahe, sachliche Systemkriterium eines „standortspezifischen Projekts, das aus einem oder mehreren Aktivitäten besteht, die sich auf den natürliche Lebensraum auswirken" miteinander verknüpft sind, Teil desselben Gesetzessystems ausmachten. Somit ist die erste Frage mit ja zu beantworten.

2. Das Wabo hat dieses systematische Defizit zwar verringert, jedoch nicht gänzlich behoben. Die Verringerung des systematischen Defizits wurde hauptsächlich durch das Aufnehmen einer großen Anzahl von Vorschriften über Genehmigungsvorbehalte für Projekte erreicht. Allerdings bestehen auch weiterhin einige systematische Defizite, da das Wabo nicht alle Vorschriften, die sich auf ein „Projekt” beziehen, beinhaltet. Gleichermaßen umfasst es nicht alle Aktivitäten innerhalb eines Projekts, für die eine umweltrechtliche Genehmigung vorliegen muss. Das Wabo fordert auch keine umweltrechtliche Genehmigung für eine Anzahl von Aktivitäten innerhalb eines Projekts. Einige dieser Defizite ließen sich relativ problemlos beheben. Die zweite Frage ist somit prinzipiell mit nein zu beantworten.

3. Zur Bündelung der Vorschriften durch ihre Neufassung im Wabo wurden typisch juristische Ordnungskriterien verwendet. In erster Linie handelt es sich hierbei um die abgestufte Normenanordnung von allgemeinen zu spezialgesetzlichen Vorschriften und den Verweis auf die europäische IVU-Richtlinie. ${ }^{17}$ Dies hat zu einem Fortbestehen systematischer Defizite geführt, die in den meisten Fällen jedoch vertretbar sind. Die dritte Frage ist somit prinzipiell mit ja zu beantworten.

4. Die Bündelung der Vorschriften im Wabo rief systematische Defizite im Wet milieubeheer hervor, da wichtige Vorschriften, die für „Anlagen” gelten, aufgehoben wurden. Dieses Defizit ist meines Erachtens nicht vertretbar und kann nur teilweise dadurch verringert werden, dass die Vorschriften im Wet milieubeheer, die für „Anlagen” gelten, in das Wabo aufgenommen werden. Eine richtige Lösung kann meines Erachtens erst dann gefunden werden, wenn ein Gesetzessystem (durch Neufassung) geschaffen wird, das auf dem Systemkriterium des „natürlichen Lebensraums" basiert, und in das die Bestimmungen des Wabo und des Wet

17 Richtlinie 2008/1/EG des Europäischen Parlaments und des Rates vom 15. Januar 2008 über die integrierte Vermeidung und Verminderung der Umweltverschmutzung (IVU-Richtlinie)(ABl. L-24 vom 29. Januar 2008) 
milieubeheer aufgenommen werden. Die vierte Frage ist somit mit ja zu beantworten.

5. Das Wabo stellt ein anpassungs- und zukunftsfähiges Gesetzessystem dar, was besonders auf die Verwendung sachlicher und typisch juristischer Ordnungskriterien zurückzuführen ist. Damit ist die fünfte Frage mit ja zu beantworten.

Diese Antworten zeigen, dass das Wabo einen wichtigen Beitrag zur Verringerung systematischer Defizite geleistet hat, die bis zum 1. Oktober $2010 \mathrm{im}$ Umweltrecht bestanden. Allerdings erfüllt die Neufassung in der heutigen Form nur teilweise meine Kriterien für eine vertretbare Bündelung. Wenn es dem Gesetzgeber - z.B. im Rahmen eines neuen Umweltgesetzes - gelingen sollte, die durch die Systematisierung entstandenen Defizite im Wabo und in anderen Gesetzen, wie z.B. dem Wet milieubeheer, zu beheben, könnte im Ergebnis doch noch von einer vollständig vertretbaren Bündelung gesprochen werden. In Kapitel 4 werden einige Verbesserungsvorschläge angeführt.

In Kapitel 5 wird anhand des Fragenkatalogs untersucht, wie sich die Integration des Wet milieugevaarlijke stoffen (Wms) in das Wet milieubeheer (Wm) vom 1. Juni $2008 \mathrm{zu}$ den in Kapitel 3 entwickelten Kriterien verhält:

1. Vor der Integration des Wms in das $W m$ gab es im Umweltrecht systematische Defizite, da nicht alle Vorschriften, die durch das praxisnahe, sachliche Systemkriterium „Stoffe” zueinander in Beziehung standen, Teil desselben Gesetzessystems waren. Unter den Begriff „Stoffe” fallen „chemische Elemente und ihre Verbindungen, so wie sie in der Natur vorkommen oder durch das Zutun des Menschen entstehen mit Folgen für Umwelt und die Gesundheit des Menschen”. Die erste Frage ist somit mit ja zu beantworten.

2. Die Integration des $W m s$ in das $W m$ hat dieses systematische Defizit behoben. Dies konnte erreicht werden, weil alle Vorschriften des Wms, die nicht aufgehoben werden mussten, in das $W m$ aufgenommen wurden. Das ändert jedoch nichts an der Tatsache, dass andere systematische Defizite zur Zeit der Integration unverändert blieben. Die zweite Frage ist somit mit ja zu beantworten. An dieser Stelle sollte noch eine wichtige Anmerkung gemacht werden: das systematische Defizit, das am 31. Mai 2008 bestand, war ein Jahr zuvor durch den Gesetzgeber selbst verursacht worden, als er $\mathrm{REACH}^{18}$ nicht durch das $W m s$, sondern durch Kapitel 9 des $W m$ implementierte. Obwohl hier noch nähere Untersuchungen von

18 Verordnung 1907/2006/EG des Europäischen Parlaments und des Rates vom 18. Dezember 2006 zur Registrierung, Bewertung, Zulassung und Beschränkung chemischer Stoffe (REACH), zur Schaffung einer Europäischen Agentur für chemische Stoffe, zur Änderung der Richtlinie 1999/45/EG und zur Aufhebung der Verordnung (EWG) Nr. 793/93 des Rates, der Verordnung (EG) Nr. 1488/94 der Kommission, der Richtlinie 76/769/EWG des Rates sowie der Richtlinien 91/155/EWG, 93/67/EWG, 93/ 105/EG und 2000/21/EG der Kommission (ABl. L-396 vom 30. Dezember 2006 und ABl. 2007 L-136 vom 29. Mai 2007). 
Nöten sind, ist es nicht unwahrscheinlich, dass die Umsetzung von REACH im Wms nicht zu einem solchen Defizit geführt hätte, das mit der „Bündelung durch Integration” behoben wurde.

3. Bei der „Bündelung durch Integration” des Wms in das $W m$ wurden typisch juristische Ordnungskriterien verwendet. In erster Linie handelt es sich hierbei um den Gebrauch typisch juristischer Begriffe und die abgestufte Normenanordnung von allgemeinen zu spezialgesetzlichen Vorschriften. Dies hatte zur Folge, dass verschiedene systematische Defizite weiter fortbestanden oder neu entstanden sind. In den meisten Fällen sind diese Defizite vertretbar, auch wenn der Gesetzgeber relativ problemlos einige Defizite verringern oder beheben könnte. Damit ist die dritte Frage prinzipiell mit ja zu beantworten.

4. In Folge der „Bündelung durch Integration” sind keine neuen systematischen Defizite außerhalb des Wm entstanden. Somit ist die vierte Frage negativ zu beantworten.

5. Mit der „Bündelung durch Integration” des Wms in das Wm sollten die Vorschriften, die für „Stoffe” gelten, nicht ein für alle Mal geregelt werden. Stattdessen ist das neue Gesetzessystem auf stete Veränderungen ausgerichtet. Durch die Integration des Wms in das Wm wurde ein anpassungs- und zukunftsfähiges Gesetzessystem geschaffen, was besonders auf die Verwendung sachlicher und typisch juristischer Ordnungskriterien zurückzuführen ist. Damit ist die fünfte Frage mit ja zu beantworten.

Diese Antworten zeigen nicht nur, dass die Integration des $W m s$ in das $W m$ einen wichtigen Beitrag zur Verringerung der bis zum 1. Juni 2008 bestehenden systematischen Defizite im Umweltrecht geleistet hat, sondern auch, dass die Integration des Wms in das Wm in der heutigen Form nur teilweise den von mir entwickelten Kriterien für eine vertretbare Bündelung entspricht. Somit liegt keine vollständig vertretbare Bündelung vor. Dies schließt jedoch nicht aus, dass Verbesserungen möglich sind, wie sie in Kapitel 5 angeführt werden.

In Kapitel 6 wird anhand des Fragenkatalogs untersucht, wie sich der am 6. Oktober 2011 veröffentlichte Gesetzentwurf Wet natuurbescherming ${ }^{19}$ der $\mathrm{zu}$ einer Neufassung des Natuurbeschermingswet $1998,{ }^{20}$ des Flora- und

19 Ontwerp Wet natuurbescherming (Gesetzentwurf Umweltverwaltungsgesetz).

20 Natuurbeschermingswet 1998 (Naturschutzgesetz 1998): Das Natuurbeschermingswet 1998 ist ausschließlich auf Flächenschutz gerichtet. Das Gesetz regelt den Naturschutz von Naturdenkmälern (Nationalparke), Natura 2000-Gebieten und Feuchtgebieten (Schutzgebiete von europäischer, bzw. internationaler Bedeutung). 
faunawet $^{21}$ und des Boswet ${ }^{22}$ führen soll, zu den in Kapitel 3 entwickelten Kriterien verhält:

1. Zur Zeit (2012) besteht im Umweltrecht ein systematisches Defizit, da nicht alle Vorschriften, die durch das praxisnahe, sachliche Systemkriterium „Natur” in gegenseitigem Bezug stehen, Teil desselben Gesetzessystems sind. Die Antwort auf die erste Frage ist daher mit ja zu beantworten.

2. Die „Bündelung durch Neufassung” des Natuurbeschermingswet 1998, des Flora- und faunawet und des Boswet im Wet natuurbescherming wird dieses systematische Defizit beheben. Dies wurde durch die Aufnahme aller Vorschriften, die nicht aufgehoben werden mussten, erreicht. Dies hat zur Folge, dass verschiedene systematische Defizite weiter fortbestehen. Diese systematischen Defizite sind nicht vertretbar. Die Antwort auf die zweite Frage ist daher prinzipiell mit nein zu beantworten.

3. Im Gesetzentwurf Wet natuurbescherming werden typisch juristische Ordnungskriterien verwendet. In erster Linie handelt es sich hierbei um den Gebrauch von Gliederungen, der abgestuften Normenanordnung von allgemeinen zu spezialgesetzlichen Vorschriften und dem Verweis zu Europäischen Richtlinien und Verordnungen. Dies hat zur Folge, dass verschiedene systematische Defizite weiter fortbestehen. Diese systematischen Defizite sind nicht vertretbar und erfordern eine nähere Untersuchung. Einige Defizite können durch den Gesetzgeber relativ problemlos behoben werden. Die Antwort auf die dritte Frage ist daher prinzipiell mit nein zu beantworten.

4. Die Übernahme der Vorschriften aus dem Natuurbeschermingswet 1998, dem Flora- und faunawet und dem Boswet in den Gesetzentwurf Wet natuurbescherming und das Aufheben der ursprünglichen Gesetze wird an sich nicht zur Entstehung systematischer Defizite führen. Die vierte Frage ist somit mit nein zu beantworten.

5. Mit dem Gesetzentwurf sollen die umweltrechtlichen Vorschriften, die für das Systemkriterium „Natur” gelten, nicht ein für alle Mal geregelt werden. Stattdessen ist das neue Gesetzessystem auf stete Veränderung angelegt. Durch den Gesetzentwurf wird ein anpassungs- und zukunftsfähiges Gesetzessystem geschaffen. Dies ist besonders auf die Verwendung sachlicher und typisch juristischer Ordnungskriterien zurückzuführen. Damit ist die fünfte Frage mit ja zu beantworten.

21 Flora- en faunawet (Flora- und Faunagesetz): Das Flora- en Faunawet soll wildlebende Tier- und Pflanzenarten schützen. Das Gesetz umfasst Vorschriften über die Jagd und die allgemeine Schadensbekämpfung. Es beinhaltet auch Vorschriften über den Handel von Tieren und Pflanzen und den Besitz von bedrohten Tier- und Pflanzenarten. Tierarten, die unter das Gesetz fallen, dürfen nicht getötet, gefangen oder gestört werden.

22 Boswet (Waldschutzgesetz): Das Boswet regelt den Naturschutz von Wäldern, sodass niederländische Wälder erhalten bleiben und der Waldbestand ausgedehnt werden. 
Diese Antworten zeigen, dass die Neufassung des Nauurbeschermingswet 1998, des Flora-und faunawet und des Boswet in dem Gesetzentwurf Wet natuurbescherming einen wichtigen Beitrag zur Verringerung systematischer Defizite im Umweltrecht leisten kann. Allerdings erfüllt die Neufassung in der heutigen Form nur teilweise meine Kriterien für eine vertretbare Bündelung. Dies schließt jedoch nicht aus, dass Verbesserungen noch vorgenommen werden können. Hierzu habe ich in Kapitel 6 einige Vorschläge gemacht.

Wenn es dem Gesetzgeber gelingen würde, diese systematischen Verbesserungen in den Gesetzentwurf einzuarbeiten, sodass die 2. und 3. Frage mit ja beantwortet werden kann, könnte das Gesamturteil positiv ausfallen.

In Kapitel 7 wurde untersucht, wie der Prüfungsrahmen bei der Entwicklung eines neuen Gesetzessystems durch die „Bündelung durch Neufassung” im Omgevingswet (Umweltgesetz), ${ }^{23}$ behilflich sein kann. Das Omgevingswet muss fünfzehn bestehende Gesetze vollständig integrieren, zwei Gesetze vollständig aufheben und aus voraussichtlich 25 anderen Gesetzen die umweltrechtlichen Elemente übernehmen. Die Untersuchung führte zu folgenden Ergebnissen:

1. Das Hauptziel des Umweltrechts ist es - dem Kabinett Rütte-Verhagen zur Folge - einen sicheren und gesunden Lebensraum zu schaffen und diesen auf nachhaltige und zweckmäßige Weise zu erhalten, zu verwalten, zu nutzen und zu entwickeln. Wenn von dem Systemkriterium „natürlicher Lebensraum” ausgegangen wird, scheint es mir, dass 2012 ein systematisches Defizit besteht, da nicht alle Vorschriften, die durch das praxisnahe, sachliche Systemkriterium des "natürlichen Lebensraums" miteinander verknüpft sind, Teil desselben Gesetzessystems sind.

2. Ich habe den Eindruck, dass das geplante Umweltgesetz die beschriebenen systematischen Defizite in jedem Fall durch das Bündeln der 15 Gesetzessysteme, dem Aufheben von zwei Gesetzessystemen und der zumindest teilweisen Integration von 25 Gesetzessystemen auf dem Gebiet des Umweltrechts verringern wird. Ob das Defizit vollständig behoben wird, hängt von den Gesetzessystemen ab, die letztendlich von der Bündelung betroffen sein werden. Aller Voraussicht nach wird das Defizit nicht vollständig und vielleicht sogar nur in geringfügigem Maße behoben, da 15 Gesetzsysteme, die sich gleichermaßen unter das $\mathrm{Zu}$ sammenhangskriterium „natürlicher Lebensraum” fassen lassen, bei dem Bündelungsprojekt nicht berücksichtigt werden, und da die 25 genannten Gesetzessysteme nur teilweise „gebündelt” werden.

3. Wie es scheint, werden im Omgevingswet typisch juristische Ordnungskriterien verwendet. Dies hat zur Folge, dass verschiedene systematische

23 Mit dem Kabinetsbrief vom 9. März 2012 der Regierung Rutte-Verhagen wird der Grundriss des Omgevingswet dargestellt. Referenz: Ministerie van IenM, Kabinetsbrief stelselherziening omgevingsrecht, 9 maart 2012, Kamerstukken II 2011/12, 33 118, nr. 3. 
Defizite weiter fortbestehen oder geschaffen werden. In Ermangelung eines konkreten Gesetzentwurfs kann im Voraus nicht ermittelt werden, ob diese Defizite vertretbar sein werden.

4. Es scheint nicht unwahrscheinlich, dass das Gesetzessystem des geplanten Omgevingswet systematische Defizite bestehen lässt oder neu schafft. Der Grund hierfür ist, dass laut Kabinetsbrief vom 19 März 2012 von den etwa 25 Gesetzen nur die umweltrechtlichen Elemente in das Umweltgesetz übernommen werden sollen. Ohne Gesetzentwurf lässt sich jedoch nicht ermitteln, ob diese Defizite vertretbar sein werden.

5. Auch die Frage, ob das Gesetzessystem des Omgevingswet zukunftsfähig sein wird, lässt sich nicht ohne konkreten Gesetzestext bestimmen. Der Kabinetsbrief vom 19 März 2012 gibt nur unzureichende Anhaltspunkte für die Beurteilung, ob das Umweltrecht den Anspruch hat, das Umweltrecht ein für alle Mal zu kodifizieren. Jedoch werden zukunftsfähige Systemkriterien genannt. Von „Anbaugesetzgebung” kann jedoch keine Rede sein. Es wird keine „Anbaugesetzgebung” geben, da die Regierung für das Umweltrecht nicht erst die notwendige Gesetzessystematik schafft und in darauffolgenden Jahren die verschiedenen Unterteile des Gesetzes hinzufügt und sie im selben Zuge an ihre systematisch richtige Stelle platziert. Es scheint vielmehr, dass das Kabinett vorerst nicht offenlegen will, oder noch ärger, nicht genau weiß, wie das Omgevingswet eigentlich genau gestaltet werden soll.

Obwohl der Prüfungsrahmen mangels Gesetzestextes nur grob beantwortet werden kann, möchte ich doch vorsichtig zu dem Ergebnisse kommen, dass ein Omgevingswet auf der Grundlage des Systemkriteriums „natürlicher Lebensraum" einen wichtigen Beitrag zur teilweisen Verringerung gegenwärtiger systematischer Defizite im Umweltrecht liefern kann. Die Frage, in wie weit dies dem Gesetzgeber gelingen wird, kann nur durch einen Gesetzentwurf beantwortet werden. Dem Gesetzgeber wird dringend empfohlen, bei einem solch umfangreichen Bündelungsprojekt in der Memorie van Toelichting explizit auf die verwendeten Systemkriterien einzugehen und die Zukunftsbeständigkeit durch „Anbaugesetzgebung” besser zu garantieren.

\subsection{ERGEBNISSE}

Auf der Grundlage der vorhergehenden Ausführungen können die drei eingangs genannten Unterfragen wie folgt beantwortet werden:

Unterfrage 1: Kann wissenschaftlich ein Prüfungsrahmen entwickelt werden, aus dem ersichtlich ist, in welchem Fall die Bündelung des Umweltrechts vertretbar ist? In den von mir untersuchten Quellen konnte ich keinen eindeutigen Prüfungsrahmen finden, der für die Beantwortung der Frage, in welchen Fällen eine Systematisierung von Vorschriften vertretbar 
ist, geeignet wäre. Daher habe ich in Kapitel 3 selbst einen solchen Prüfungsrahmen entwickelt. Anhand von fünf Fragen kann nun festgestellt werden, ob die Bündelung durch die „Neufassung von Vorschriften” oder durch die „Integration von Vorschriften in Gesetzessysteme” vertretbar ist.

Unterfrage 2: Wie verhalten sich die folgenden vier Systematisierungsprojekte zu diesem Prüfungsrahmen:

- die Bündelung, die 2010 zu einer Neufassung verschiedener Vorschriften im Wet algemene bepalingen omgevingsrecht (Wabo) führte;

- die Bündelung, die 2008 zur Integration des Wet milieuvaarlijke stoffen $(W m s)$ in das Wet milieubeheer $(\mathrm{Wm})$ führte;

- die Bündelung, die zu einer Neufassung verschiedener Vorschriften im Wet natuurbescherming führen soll;

- die angestrebte Bündelung einer Vielzahl von Gesetzen im Omgevingswet. $^{24}$

Diese Frage wurde in den Kapiteln 4, 5, 6 und 7 erörtert. Ich bin zu dem Schluss gekommen, dass die Systematisierung nur teilweise die von mir entwickelten Kriterien erfüllt, sodass zum heutigen Zeitpunkt nicht von einer vollständig vertretbaren Systematisierung gesprochen werden kann.

Unterfrage 3: Müssen angesichts der in Unterfrage 2 genannten Systematisierungsprojekte Vorschläge erarbeitet werden, um die Ordnung des Umweltrechts besser an den (zu entwickelnden) wissenschaftlichen Kriterien für die Systematisierung des Umweltrechts auszurichten?

Diese Frage wurde in den Kapitel 4, 5, 6 und 7 bejaht und einige Verbesserungsvorschläge gemacht. Sollten diese Vorschläge in den vier untersuchten Systematisierungsprojekten doch noch berücksichtigt werden, würde dies dazu führen, dass die Projekte stärker an den von mir entwickelten Kriterien anknüpfen.

Nach der Beantwortung der drei Teilfragen ist es mir nun möglich, eine Antwort auf die Hauptfrage zu geben: ist die Systematisierung des Umweltrechts eine rein politische Entscheidung oder erfüllen die Vorhaben auch Forderungen, die von der Wissenschaft an die Ordnung des Umweltrechts gestellt werden? Ich bin zu dem Ergebnis gekommen, dass die Systematisierung des Umweltrechts auch wissenschaftliche Forderungen erfüllen kann. Auch wenn bei den vier untersuchten Systematisierungsprojekten keine vollständig vertretbare Systematisierung erreicht wurde, bedeutet dies

24 Omgevingswet (Umweltgesetz): Das Omgevingswet, für das voraussichtlich Ende 2012 ein Gesetzesentwurf vorliegen wird, befasst sich mit dem Schutz der Umwelt, Raumordnung, Natur und Wasser; Ministerie van IenM, Kabinetsbrief stelselherziening omgevingsrecht, 9 maart 2012, Kamerstukken II 2011/12, 33 118, nr. 3. 
nicht, dass es unmöglich ist, die Kriterien zu erfüllen. Ich habe jeweils Verbesserungsvorschläge gemacht.

\subsection{EMPFEHLUNGEN}

Auf der Grundlage meiner Dissertation und den Interviews, die ich während meiner Forschungsarbeiten führte, möchte dem Gesetzgeber und den Juristen, die in den Gesetzgebungsprozess eingebunden werden, einige Empfehlungen mit auf den Weg geben:

\subsubsection{Empfehlungen an den Gesetzgeber}

1. Bevor ein Systematisierungsprojekt beginnen kann, sollten (ein oder) mehrere Systemkriterien formuliert werden. Wenn die Systemkriterien nicht präzise sind, besteht das Risiko, dass entweder Vorschriften in ein Gesetzessystem aufgenommen werden, die dort eigentlich nicht hineingehören, oder dass Vorschriften, die in ein Gesetzessystem gehören würden, eben nicht darin aufgenommen werden, und dass somit systematische Defizite bestehen bleiben oder erst entstehen.

2. Es sollten möglichst praxisnahe, sachliche Systemkriterien ausgewählt werden, um sowohl die Erkennbarkeit, als auch Problemorientierung des Gesetzessystems zu garantieren.

3. Es sollten lediglich dann typisch juristische Ordnungskriterien verwendet werden, wenn die dadurch entstehenden gesetzesssystematischen Defizite vertretbar sind.

4. Eine „Bündelung durch Neufassung” oder „Integration” sollte nur dann erfolgen, wenn systematische Defizite, die auf der Grundlage von zu formulierenden Systemkriterien festgestellt wurden, behoben oder verringert werden können.

5. Die Bündelung sollte nicht zu systematischen Defiziten in anderen Gesetzessystemen führen, es sei denn dies ist vertretbar.

6. Um die Anpassungs- und Zukunftsfähigkeit eines Gesetzessystems zu garantieren, sollten Sie sich konsequent an die systematischen Ordnungskriterien halten.

7. Verhindern Sie, dass „Kuckuckseivorschriften” in ein Gesetzsystem aufgenommen werden.

8. Eine Sachverständigenkommission sollte einen überzeugenden Bündelungsentwurf erarbeiten.

9. Entscheiden Sie sich grundsätzlich für die kodifizierende Bündelung, wobei die Möglichkeit, kleinere Änderungen vorzunehmen, nicht ausgeschlossen werden muss. Dabei sollten Sie sich jedoch bewusst sein, dass gerade Veränderungen der Vorschriften oder des Systems die gesellschaftliche Akzeptanz des Systems beeinflussen können.

10. Die Schaffung von iLawsystemen sollte in Erwägung gezogen werden; hierbei muss jedoch dafür gesorgt werden, dass ein Gesetzessystem 
eindeutig erkennbar ist und dabei nicht von Anwendung von Computerprogrammen abhängig ist.

11. In den Aanwijzingen voor de regelgeving ${ }^{25}$ sollte konkret auf die Bündelung des Umweltrechts eingegangen werden.

12. Das Gesetzessystem muss in regelmäßigen Abständen überarbeitet werden.

13. Konsultieren Sie bei jedem Gesetzentwurf den Raad van State ${ }^{26}$ zur Kompatibilität des Gesetzentwurfes mit dem geltenden Gesetzessystem.

8.4.2 Empfehlungen für Juristen, die am Gesetzgebungsprozess beteiligt sind

1. Sorgen Sie dafür, dass bei Gesetzesänderungen keine systematischen Defizite entstehen. Das gilt besonders, wenn es sich um ein Gesetzessystem handelt, dass durch die Bündelung durch Neufassung oder Integration entstanden ist. Anderenfalls besteht das Risiko, dass das Gesetzessystem nicht zukunftsfähig ist.

2. Machen Sie sich bewusst, dass Umweltgesetze zwar juristische Dokumente sind, aber dass es der Erkennbarkeit und Deutlichkeit des Systems zu Gute kommt, wenn die Nutzer ihre Rechte und Pflichten auch ohne spezielle juristische Vorkenntnisse anhand des Gesetzestextes selbst ermitteln können.

Aanwijzingen voor de regelgeving (Anweisungen für die Gesetzgebung): Die Aanwijzingen voor de regelgeving sind ein verbindliches Rundschreiben des Minister-Präsidenten, das von Juristen, die am Gesetzgebungsprozess beteiligt sind als Nachschlagwerk genutzt wird. Bei der Gesetzgebung darf hiervon nur in Ausnahmefällen abgewichen werden.

26 Der Raad van State ist unabhängiger Berater der Regierung zur Gesetzgebung und der oberste Verwaltungsgerichtshof der Niederlande. Die Kompetenzen und Arbeitsweisen des Raad van State sind im Grondwet und dem Wet op de Raad van State normiert. 


\section{Literatuur}

Adviesgroepen Modernisering Omgevingsrecht, Gezamenlijk advies 2011

Door de minister van IenM ingestelde Adviesgroepen, Gezamenlijk advies 1 november 2011, https://omgevingswet.pleio.nl.

Adviesgroep Natuur, Borging, beweging en betrokkenheid 2011 Door de minister van IenM ingestelde Adviesgroep Natuur en Landelijk gebied o.l.v. prof. dr. P.C.E. van Wijmen, Advies Borging, beweging en betrokkenheid, 28 oktober 2011, https://omgevingswet.pleio.nl.

Adviesgroep Milieu, Energie en Duurzaamheid, Regels die helpen 2011

Door de minister van IenM ingestelde Adviesgroep Milieu, Energie en Duurzaamheid o.l.v. drs. E.H.T.M. Nijpels, Advies Regels die helpen, 4 november 2011, https://omgevingswet.pleio.nl.

Adviesgroep Verkeer en Vervoer, Voor een beter Nederland 2011 Door de minister van IenM ingestelde Adviesgroep Verkeer en Vervoer o.l.v. dr. J.C. Verdaas, Advies Voor een beter Nederland, 2 november 2011, https:// omgevingswet.pleio.nl.

Adviesgroep Water, Naar één ge(s)laagde Omgevingswet 2011 Door de minister van IenM ingestelde Adviesgroep Water o.l.v. Luc Kohsiek, Advies De kracht van water. Naar één ge(s)laagde Omgevingswet, november 2011, https://omgevingswet.pleio.nl.

\section{Adviesgroep Wonen en Cultuur, Naar een vereenvoudigd en} gebundeld Omgevingsrecht 2011

Door de minister van IenM ingestelde Adviesgroep Wonen en Cultuur o.l.v. Duco Stadig, Advies Naar een vereenvoudigd en gebundeld Omgevingsrecht, 1 november 2011, https://omgevingswet.pleio.nl.

\section{Amtenbrink \& Vedder, Recht van de Europese Unie 2008}

F. Amtenbrink \& H.H.B. Vedder, Recht van de Europese Unie, Den Haag: Boom Juridische Uitgevers 2008. 
Arentz \& Woldendorp, Soortenbescherming Ffw: complexiteit naar climax 2005

B. Arentz \& H.E. Woldendorp, 'Soortenbescherming Flora- en faunawet: complexiteit naar climax', $M$ en $R$ 2005, p. 202-212.

Arentz, De kop moet er (juist) op! 2012

B. Arentz, 'De kop moet er (juist) op!', $M$ en $R$ 2012/6, p. 398-399.

Backes \& Van den Broek, Gebiedsbescherming eindelijk geboden 2005

Ch.W. Backes \& J.H.G. van den Broek, 'Gebiedsbescherming eindelijk geboden. Herziene Natuurbeschermingswet 1998 in 2005 van kracht', $M$ en $R 2005 / 8$, p. 474 e.v.

Backes, Natuurbeschermingsrecht 2006

Ch.W. Backes, 'Natuurbeschermingsrecht', in: Ch.W. Backes, P.C. Gilhuis, N.S.J. Koeman, Milieurecht, Deventer: Kluwer 2006, p. 482-510.

Backes, Watervergunning tegen Omgevingsvergunning 2006

Ch.W. Backes, 'Watervergunning tegen Omgevingsvergunning - tussenstand 5:3 of 3:5', in: Th.G. Drupsteen, H.J.M. Havekes, H.F.M.W. van Rijswick (red.), Weids water. Opstellen over waterrecht, Ter ere van het afscheid van Alfred van Hall, Den Haag: Sdu Uitgevers 2006, p. 389-410.

Backes/Freriks \& Robbe, Hoofdlijnen natuurbeschermingsrecht 2009

Ch.W. Backes, A.A. Freriks, J. Robbe, Hoofdlijnen natuurbeschermingsrecht, Den Haag: Sdu 2009.

\section{Backes, Naar een integrale omgevingswet? 2010}

Ch.W. Backes, 'Naar een integrale omgevingswet?', in: Bezinning op het omgevingsrecht. Essays over de toekomst van het omgevingsrecht, Den Haag: Ministerie van IenM, oktober 2010, p. 2-17.

Backes/Poortinga \& Woldendorp, Natuurbescherming in de Natuurwet: Kop eraf? 2010

Ch.W. Backes, M.A. Poortinga \& H.E. Woldendorp, 'Natuurbescherming in de Natuurwet: Kop eraf?', in: Natuur(lijk) met recht beschermd: bouwstenen voor een effectieve en hanteerbare natuurbescherming, uitgave van de Vereniging voor Milieurecht, 2010-2, Den Haag: Boom Juridische Uitgevers 2010, p. 17-57.

Backes c.s., Naar een nieuw omgevingsrecht 2012

Ch.W. Backes, N.S.J. Koeman, F.C.M.A. Michiels, A.G.A. Nijmeijer, H.F.M.W. van Rijswick, B.J. Schueler, J. Struiksma \& R. Uylenburg, VBR Preadvies 
nr. 40, Naar een nieuw omgevingsrecht, Den Haag: Instituut voor Bouwrecht 2012.

Van den Berg, Milieurecht voor stoffen en produkten 1992

A.V. van den Berg, 'Milieurecht voor stoffen en produkten', $M$ en $R$ 1992/4, p. $194-206$.

Van den Berg, Waterschappen en de integratie omgevingsrecht 2011

J.T.K. van den Berg, Waterschappen en de integratie van het omgevingsrecht. Dreigt ontmanteling van onze oudste bestuursorganen?, in: Goed verdedigbaar. Vernieuwing van bestuursrecht en omgevingsrecht. Opstellen aangeboden aan prof. mr. P.J.J. van Buuren, Deventer: Kluwer 2011, p. 243-255.

Van den Berg, De paradox van de codificatie 2002

P.A.J. van den Berg, 'De paradox van de codificatie: over de gevolgen van codificatie in Europa voor de rechtsvinding', Rechtsgeleerd Magazijn Themis 163/4 (augustus 2002), 195-203.

\section{Biezeveld, De Wabm gaat veranderen 1989}

G.A. Biezeveld, 'De Wet algemene bepalingen milieuhygiëne gaat veranderen', $M$ en $R$ 1989/11, p. 442 e.v.

Biezeveld, Omgaan met samenhang bij integratie van milieuwetgeving en waterwetgeving 1990

G.A. Biezeveld, 'Omgaan met samenhangen bij integratie van milieuwetgeving en waterwetgeving', $M$ en $R$ 1990/5, p. 231 e.v.

Biezeveld, Duurzame milieuwetgeving (diss.) 2002

G.A. Biezeveld, Duurzame milieuwetgeving. Over wetgeving en bestuurlijke organisatie als instrument voor behoud en verandering, Den Haag: Boom Juridische Uitgevers 2002.

Blomberg/Michiels \& Nijmeijer, Vergunningverlening in het omgevingsrecht 2005

A.B. Blomberg, F.C.M.A. Michiels \& A.G.A. Nijmeijer, 'Vergunningverlening in het omgevingsrecht: naar stroomlijning of integratie?', TO 2005/1, p. 3-11.

Blomberg/Jongma/van 't Lam \& Michiels, De milieu-uitvoeringsregelingen op een A4-tje 2002

A.B. Blomberg, M.P. Jongma, V.M.Y. van 't Lam \& F.C.M.A. Michiels, De milieu-uitvoeringsregelingen op een A4-tje. Een onderzoek naar de noodzaak 
van en de mogelijkheden tot vereenvoudiging van VROM-uitvoeringsregelingen op het gebied van het milieubeheer, Centrum voor Omgevingsrecht en Beleid/NILOS, Universiteit Utrecht, Publicatiereeks Milieubeheer nr. 2002/ 13, januari 2002.

Bocken, Naar een algemeen kaderdecreet inzake milieuhygiëne? 1991

H. Bocken, 'Naar een algemeen kaderdecreet inzake milieuhygiëne? De werkzaamheden van de interuniversitaire commissie tot herziening van het milieurecht in het Vlaamse Gewest', Rechtskundig Weekblad 19901991/41, p. 1399-1402.

Boeve/Fleurke \& Wiering, Het begrip 'milieu' in de Wet milieubeheer 2004

M.N. Boeve, F.M. Fleurke \& M.A. Wiering, 'Het begrip 'milieu' in de Wet milieubeheer', $M$ en $R$ 2004/4, p. 221 e.v.

\section{Boeve/Groothuijse \& Van 't Lam, Omgevingsrecht 2009}

M.N. Boeve, F.A.G. Groothuijse \& V.M.Y. van 't Lam (red.), Omgevingsrecht, Groningen: Europa Law Publishing 2009.

Bonnes \& Florijn, Uitvoering van EG-verordeningen: overschrijven verboden 1995

J.M. Bonnes \& N. A. Florijn, 'Uitvoering van EG-verordeningen: overschrijven verboden', RegelMaat 1995, blz. 115-121.

Borgers \& Van der Heijden, Het recht op duurzame gebiedsexploitatie 2010

H.C. Borgers \& G.M.A. van der Heijden, 'Het recht op duurzame gebiedsexploitatie', in: Bezinning op het omgevingsrecht. Essays over de toekomst van het omgevingsrecht, Den Haag: Ministerie van IenM, oktober 2010, p. $30-45$.

Borgers \& Van der Heijden, Evenredig de ruimte 2011

H.C. Borgers \& G.M.A. van der Heijden, Evenredig de ruimte, Delft: Eburon 2011.

\section{Borman, Combineren van uitvoeringsregels 2010}

T.C. Borman, 'Alles ineen: het combineren van uitvoeringsregels', RegelMaat 2010 (25) 5, p. 275- 284.

Brans, Het gebiedsontwikkelingsplan 2011

M.C. Brans, 'Het gebiedsontwikkelingsplan; de nieuwe rekbaarheid in het milieurecht', in: Hoofdstuk 2 Crisis- en herstelwet, de experimenteerfase 
voorbij?, preadvies voor de Vereniging voor Bouwrecht, nr. 39, Den Haag: Instituut voor Bouwrecht 2011, p. 3-71.

Bregman, Naar een gebruikersvriendelijk omgevingsrecht 2010 A.G. Bregman, 'Naar een gebruikersvriendelijk omgevingsrecht', in: Bezinning op het omgevingsrecht. Essays over de toekomst van het omgevingsrecht, Den Haag: Ministerie van IenM, oktober 2010, p. 46-60.

Bregman, Gebiedsontwikkeling met de Omgevingswet 2012 A.G. Bregman, 'Gebiedsontwikkeling met de Omgevingswet', $M$ en $R$ 2012/ 6, p. 411-412.

Van den Broek/De Kok/Meulenberg \& Niezen, De Wet milieubeheer in bedrijf 1992

J.H.G. van den Broek, F.J.C.M. de Kok, A.P.M. Meulenberg en G.J. Niezen, De Wet milieubeheer in bedrijf. Een praktische handleiding voor ondernemer en adviseur, Deventer: Kluwer 1992.

Van den Broek, Bedrijf en milieuverslag 1993

J.H.G. van den Broek, 'Bedrijf en milieuverslag. Verantwoorde verantwoording', in: Publikaties van de VMR 1993-5, Openbaarheid van milieurelevante bedrijfsgegevens, Zwolle: WEJ Tjeenk Willink 1993.

Van den Broek /De Haas/De Kok \& Niezen, De Wet bodembescherming in bedrijf 1994

J.H.G. van den Broek, W.A. de Haas, F.J.C.M. de Kok, G.J. Niezen, De Wet bodembescherming in bedrijf, Deventer: Kluwer 1994.

Van den Broek, Integrale benadering verdient integrale milieuvergunning 1997

J.H.G. van den Broek, 'Integrale benadering verdient integrale milieuvergunning', in: Wetgever en gecoördineerde besluitvorming, Preadviezen Vereniging voor Wetgeving en Wetgevingsbeleid, Alphen aan den Rijn: Samsom H.D. Tjeenk WillInk 1997, p. 11-47.

Van den Broek, IPPC in werking getreden 1997

J.H.G. van den Broek, 'IPPC in werking getreden. Europa op weg naar een integrale milieuvergunning', $M$ en $R$ 1997/1, p. 7 e.v.

Van den Broek, Europese installatieproblemen 2003

J.H.G. van den Broek, 'Europese installatieproblemen. Eigenwijs op eigen wijze', $M$ en $R$ 2003/7-8, p. 206-212.

Van den Broek, Samenvatting herijkingsbrief 2004

J.H.G. van den Broek, 'Samenvatting herijkingsbrief', $M$ en $R$ 2004/1, p. 2. 
Van den Broek, Lex Dekker-Van Geel vergt politieke moed 2004 J.H.G. van den Broek, 'Lex Dekker-Van Geel vergt politieke moed', $M$ en $R$ 2004/1, p.12 e.v.

Van den Broek, Leden der Staten-Generaal! 2004

J.H.G. van den Broek, 'Leden der Staten-Generaal!', M en R 2004/7, p. 393.

Van den Broek \& Rutteman, Bedrijfsleven en milieubeweging steunen Wabo 2005

J.H.G. van den Broek \& J. Rutteman, 'Bedrijfsleven en milieubeweging steunen Wabo', $M$ en $R$ 2005/9, p. 546 e.v.

Van den Broek, Samenvatting Voorontwerp wetsvoorstel Wabo 2005

J.H.G. van den Broek, 'Wegwijzer Wabo. Samenvatting Voorontwerp wetsvoorstel algemene bepalingen omgevingsrecht', $M$ en $R$ 2005/9, p. 542 e.v.

Van den Broek, De Kroonjuwelen van VROM 2005

J.H.G. van den Broek, 'De Kroonjuwelen van VROM. Herijking, omgevingsvergunning en omgevingswetboek', NJB 2005, p. 578-584.

Van den Broek, Die Unvollendete 2005

J.H.G. van den Broek, 'Die Unvollendete', $M$ en $R$ 2005/9, p. 541.

Van den Broek, Kroonjuwelen met scherpe randjes 2006

J.H.G. van den Broek, 'Kroonjuwelen met scherpe randjes', TO 2006/4, p. 136 e.v.

Van den Broek, Dag van de Wabo 2008

J.H.G. van den Broek, 'Dag van de Wabo', $M$ en $R$ 2008/1, p.1.

Van den Broek, De bouw maakt het met Wabo en omgevingsvergunning 2008

J.H.G. van den Broek, 'De bouw maakt het met Wabo en omgevingsvergunning', $B R$ 2008, p. 157.

Van den Broek/Freriks \& Van Rijswick, Proefrechtszaak Kaderrichtlijn Water 2008

J.H.G. van den Broek, A.A. Freriks \& H.F.M.W. van Rijswick, 'Proefrechtszaak Kaderrichtlijn Water', $B R$ 2008, p. 720-726.

Van den Broek, Aan de slag met de Wabo 2010

J.H.G. van den Broek, 'Aan de slag met de Wabo, enige wijzigingen en verduidelijkingen belicht', $B R$ 2010, p. 405. 
Van den Broek \& Dresden, Parlementaire geschiedenis Wabo en omgevingsvergunning 2010

J.H.G. van den Broek \& J. Dresden, Parlementaire geschiedenis Wabo en omgevingsvergunning 2010, Alphen aan den Rijn: Kluwer 2010.

Van den Broek, Omgevingsrecht doet recht aan integrale omgevingsbescherming 2010

J.H.G. van den Broek, 'Omgevingswet doet recht aan integrale omgevingsbescherming', in: Bezinning op het omgevingsrecht. Essays over de toekomst van het omgevingsrecht, Den Haag: Ministerie van IenM, oktober 2010, p. 62.

Van den Broek, Omgevingswet, Offer you can't refuse 2011

J.H.G. van den Broek, 'Omgevingswet, Offer you can't refuse', TO, maart 2011, p. 1-2.

Van den Broek \& Dresden, De Wabo in de praktijk 2011

J.H.G. van den Broek \& M.J. Dresden, De Wabo in de praktijk. Juridische leidraad bij de Wet algemene bepalingen omgevingsrecht, Alphen aan den Rijn: Kluwer 2011.

Van den Broek, Wegwijzer toezicht en handhaving omgevingsrecht 2011

J.H.G. van den Broek, Wegwijzer Toezicht en handhaving omgevingsrecht, Alphen aan den Rijn: Kluwer 2010.

Van den Broek, Wegwijzer omgevingsrecht 2011

J.H.G. van den Broek, Wegwijzer Omgevingsrecht 2011, Alphen aan den Rijn: Kluwer 2011.

Van den Broek, Omgevingswet eenvoudig beter 2011

J.H.G. van den Broek, 'Omgevingswet eenvoudig beter', $M$ en $R$ 2011/6, p. 361.

Van den Broek \& Kortekaas, Wegwijzer Activiteitenbesluit en Landbouwbesluit 2011

J.H.G. van den Broek, S.C. Kortekaas, Wegwijzer Activiteitenbesluit en Landbouwbesluit 2012. Een praktische handleiding voor iedereen die met algemene regels voor bedrijven te maken heeft, Alphen aan den Rijn: Kluwer 2011.

Van den Broek, Wegwijzer Wabo 2012

J.H.G. van den Broek, Wegwijzer Wabo en omgevingsvergunning 2012, Alphen aan den Rijn: Kluwer 2011. 
Van den Broek, T\&C Wet bodembescherming 2012

J.H.G. van den Broek, 'Wet bodembescherming', in: Tekst en Commentaar Milieurecht (redactie: N.S.J. Koeman en R. Uylenburg), Deventer: Kluwer 2009, p. 977-1125.

Van den Broek, Samenvatting kabinetsbrief stelselherziening omgevingsrecht 2012

J.H.G. van den Broek, 'Kabinetsbrief stelselherziening omgevingsrecht', $M$ en $R$ 2012/ 6, p. 393-397.

Van den Broek, Omgevingswet: de kers op de taart! 2012

J.H.G. van den Broek, 'Omgevingswet: de kers op de taart!', TOO 2012/3, p. 124-125.

\section{Bundesministerium für Umwelt c.a., Umweltgesetzbuch} (UGB-KomE) 1998

Bundesministerium für Umwelt, Naturschutz und Reaktorsicherheit (Hrsg.), Umweltgesetzbuch (UGB-KomE). Entwurf der Unabhängigen Sachverständigenkommission zum Umweltgesetzbuch beim Bundesministerium für Umwelt, Naturschutz und Reaktorsicherheit, Berlin: Duncker \& Humblot 1998.

\section{Bundesministerium für Umwelt c.a., 10 gute Gründe für ein} Umweltgesetzbuch 2007

Bundesministerium für Umwelt, Naturschutz und Reaktorsicherheit, 10 gute Gründe für ein Umweltgesetzbuch, www.bmu.de/files/pdfs/allgemein/application/pdf/1ogute_gruende_ugb.pdf.

Van Buuren/De Gier/Nijmeijer \& Robbe, Hoofdlijnen ruimtelijk bestuursrecht 2010

P.J.J. van Buuren, A.A.J. de Gier, A.G.A. Nijmeijer \& J. Robbe, Hoofdlijnen ruimtelijk bestuursrecht, Deventer: Kluwer 2010.

Commissie van Advies Waterstaatswetgeving, Die op water is, moet varen ... 2002

Commissie van Advies inzake de Waterstaatswetgeving, Advies 'Die op water is, moet varen ... ,'2002, www.cawsw.nl.

\section{Commissie Bocken, Voorontwerp Decreet Milieubeleid 1995}

Interuniversitaire Commissie tot herziening van het milieurecht in het Vlaamse Gewest, Voorontwerp Decreet Milieubeleid, Brugge: die Keure, 1995 . 
Commissie Wetgevingsvraagstukken, Orde in de regelgeving 1985 Commissie Wetgevingsvraagstukken, Orde in de regelgeving, Eindrapport van 10 december 1985, Sdu, Den Haag.

Dhondt \& Uylenburg, Het beginsel van externe integratie 2001 Nele Dhondt en Rosa Uylenburg, Het beginsel van externe integratie, in: A.H.J. van den Biesen en P.C. Gilhuis (red.), Beginselen in het milieurecht, Deventer: Kluwer 2001, p. 89-111.

Dhondt, Integration of Environmental Protection into other EC Policies 2003

Nele Dhondt, Integration of Environmental Protection into other EC Policies, Groningen: Europa Law Publishing, 2003.

Donkers, De nieuwe chemische stoffenwetgeving van de EU 2007 R.H. Donkers, 'De nieuwe chemische stoffenwetgeving van de Europese Unie', $M$ en $R$ 2007/8, p. 467-474.

Driessen \& Schueler, Naar een integraler omgevingsbeleid 2011 P.P.J. Driessen \& B.J. Schueler, 'Naar een integraler omgevingsbeleid', in: Goed verdedigbaar. Vernieuwing van bestuursrecht en omgevingsrecht. Opstellen aangeboden aan prof. mr. P.J.J. van Buuren, Deventer: Kluwer 2011, p. 257-272.

Drupsteen, Ontwikkelingen in het milieurecht gedurende de jaren zeventig 1981

Th.G. Drupsteen, 'Ontwikkelingen in het milieurecht gedurende de jaren zeventig', NJB 1981, p. 879-889.

Drupsteen, Het milieubeleid geïntegreerd? 1983

Th.G. Drupsteen, 'Het milieubeleid geïntegreerd?', $M$ en R 1983/11, p. 313 e.v.

Drupsteen, De toekomst van de Wm 1998

Th.G. Drupsteen, 'De toekomst van de Wet milieubeheer. Hoofdlijnen van het onderzoek', in: De toekomst van de Wet milieubeheer, Deventer: Kluwer 1998, p. 1-32.

Drupsteen, Twintig jaar milieuwetgeving 1990

Th.G. Drupsteen, 'Twintig jaar milieuwetgeving: tijd voor bezinning', $M$ en $R$ 1990/5, p. 194 e.v.

Drupsteen, Relativiteit van integratie 1991

Th.G. Drupsteen, 'Relativiteit van integratie', in: Milieu als wetgevingsvraagstuk, Zwolle: WEJ Tjeenk Willlink 1991, p. 61 e.v. 
Drupsteen, Het specialiteitsbeginsel en de Waterwet 2006

Th.G. Drupsteen, 'Een brede kijk, het specialiteitsbeginsel en de Waterwet', in: Th.G. Drupsteen, H.J.M. Havekes, H.F.M.W. van Rijswick (red.), Weids water. Opstellen over waterrecht ter ere van het afscheid van Alfred van Hall, Den Haag: Sdu Uitgevers 2006, p. 285-303.

Drupsteen, Een Omgevingswet 2011

Th.G. Drupsteen, 'Een Omgevingswet', in: Goed verdedigbaar. Vernieuwing van bestuursrecht en omgevingsrecht. Opstellen aangeboden aan prof. mr. P.J.J. van Buuren, Deventer: Kluwer, 2011, p. 273-285.

ECWM, Buitenlandse inspiratie voor de Wm 2003

Evaluatiecommissie Wet milieubeheer, Buitenlandse inspiratie voor de Wet milieubeheer, Advies van de ECWM over een onderzoek naar integratie van milieuwetgeving in enkele andere EU-lidstaten en de inspiratie daaruit voor de Wet milieubeheer, ECWM 2003/17, http://rechten.uvt.nl/ecwm.

Van Eijkern, De macht van de zwoegers in het vooronder 1977

W.J. van Eijkern, 'De macht van de zwoegers in het vooronder. Rechtsvorming door juristen via het werk van de afdelingen wetgeving', in: De jurist-ambtenaar. Bundel opstellen opgedragen aan mr. J.M. Kan, Zwolle 1977, p. 39-48.

Eijlander, De verbindende wetgever (rede) 2000

Philips Eijlander, De verbindende wetgever. Over de verhouding tussen staat, markt en samenleving, Den Haag: Boom Juridische Uitgevers 2000.

Eijlander \& Voermans, Wetgevingsleer 2000

Philip Eijlander \& Wim Voermans, Wetgevingsleer, Den Haag: Boom Juridische uitgevers 2000.

Eijlander, De nota Met recht verantwoordelijk! 2001

Philip Eijlander, 'De nota Met recht verantwoordelijk! Naar een verantwoord en duurzaam wetgevingsbeleid ten aanzien van het milieu?', $M$ en $R$ 2001/11, p. 262-267.

Engish, Einführung in das juristische Denken 1956

Karl Engish, Einführung in das juristische Denken, herausgegeben und bearbeitet von Prof.Dr. Thomas Würtenberger und Dr. Dirk Otto, Stuttgart: Verlag W. Kohlhammer.

Faure, The Harmonization, Codification and Integration of Environmental Law: A Search for Definitions 2000

M.G. Faure, 'The Harmonization, Codification and Integration of Environmental Law: A Search for Definitions', European Environmental Law Review, June 2000, p. 174-182. 
Fleurke \& Michiels, Een digitale structuur voor het omgevingsrecht 2010

F.M. Fleurke en F.C.M.A. Michiels, 'Een digitale structuur voor het omgevingsrecht', in: Bezinning op het omgevingsrecht. Essays over de toekomst van het omgevingsrecht, Den Haag: Ministerie van IenM, oktober 2010, p. 104.

François, De Europese Richtlijn industriële emissies 2012

Filip François, 'De Europese Richtlijn industriële emissies', in: De Vlaamse Omgevingsvergunning, Brugge: Van den Broele 2012, p. 111-130.

\section{François, De BBT in Richtlijn IED 2012}

Filip François, 'De Beste Beschikbare Technieken (BBT) in Richtlijn 2010/ 75/EU inzake industriële emissies (IED)', in: L. Smorenburg-van Middelkoop \& R. Uylenburg (red.), De beste beschikbare technieken, van IPPC naar IED. Ontwikkeling, toepassing en toetsing van BBT, Amsterdam: Europa Law Publishing 2012, p. 29-44.

Geelhoed, Wetgeving en bestuur in de semi-soevereine staat 1996 L.A. Geelhoed, 'Wetgeving en bestuur in de semi-soevereine staat', in: L.A. Geelhoed en R.J. in 't Veld, Vervlechting en verschuivingen van wetgevingscomplexen aan het begin van de $21^{\text {ste }}$ eeuw, Zwolle: WEJ Tjeenk Willink 1996, p. 1-19.

\section{Geelhoed, Knoppen zonder draden 2006}

L.A. Geelhoed, 'Knoppen zonder draden', interview met M.G.W.M. Peeters en H.E. Woldendorp, $M$ en $R$ 2006/10, p. 590-596.

Van Gestel, Eenieder wordt geacht de wet te kennen 1998

R.A.J. van Gestel, 'Eenieder wordt geacht de wet te kennen, maar wie begrijpt er iets van?', Ars Aequi, 57(1), 78-80.

Van Gestel, Wetgeven is vooruitzien (rede) 2008

R.A.J. van Gestel, Wetgeven is vooruitzien, Tilburg 2008.

Van Gestel, Rol van de wetgevingsjurist 2011

R.A.J. van Gestel, 'Rol van de wetgevingsjurist: zwoegers in het vooronder of professionals in de frontlinie?', RegelMaat 2011/1, p. 3-6.

Gilhuis, De verhouding van milieurecht tot waterrecht 1986

P.C. Gilhuis, 'De verhouding van milieurecht tot waterrecht', Preadvies Vereniging voor Milieurecht, in: Waterbeheer en milieurecht, p. 1-50, Vereniging voor Milieurecht 19986-3, W.E.J. Tjeenk Willink, Zwolle, 1986. Ook opgenomen in: J.M. Verschuuren (red.), Fundament onder het omgevingsrecht. Een selectie uit het werk van prof. mr. P.C. Gilhuis, samengesteld en van een 
inleiding voorzien door J.M. Verschuuren, Nijmegen: Wolf Legal Publishers 2006, p. 265-300.

Gilhuis, Milieurecht op weg naar de jaren negentig (oratie) 1989 P.C. Gilhuis, Milieurecht op weg naar de jaren negentig (oratie Tilburg), Zwolle, W.E.J. Tjeenk Willink 1989. Ook opgenomen in: J.M. Verschuuren (red.), Fundament onder het omgevingsrecht. Een selectie uit het werk van prof. mr. P.C. Gilhuis, samengesteld en van een inleiding voorzien door J.M. Verschuuren, Nijmegen: Wolf Legal Publishers 2006, p. 11-32.

\section{Gilhuis, Over de verhouding van Wabm tot Awb 1990}

P.C. Gilhuis, 'Over de verhouding van de Wet algemene bepalingen milieuhygiëne tot de Algemene wet bestuursrecht', $M$ en $R$ 1990/5, p. 212-221.

Gilhuis, De integratie van de milieuwetgeving in de Wabm 1991 P.C. Gilhuis, 'De integratie van de milieuwetgeving in de Wabm: een zinvolle onderneming?' in: Milieu als wetgevingsuraagstuk, WEJ Tjeenk Willink, Zwolle 1991, p. 49 e.v.. Ook opgenomen in: J.M. Verschuuren (red.), Fundament onder het omgevingsrecht. Een selectie uit het werk van prof. mr. P.C. Gilhuis, samengesteld en van een inleiding voorzien door J.M. Verschuuren, Nijmegen: Wolf Legal Publishers 2006, p. 33-44.

\section{Gilhuis, Coördinatie bouw- en milieuvergunning 1992}

P.C. Gilhuis, 'Coördinatie bouw- en milieuvergunning', in: $M$ en $R$ 1992, p. 65. Ook opgenomen in: J.M. Verschuuren (red.), Fundament onder het omgevingsrecht. Een selectie uit het werk van prof. mr. P.C. Gilhuis, samengesteld en van een inleiding voorzien door J.M. Verschuuren, Nijmegen: Wolf Legal Publishers 2006, p. 337-338.

\section{Gilhuis, Met recht verantwoordelijk 2001}

P.C. Gilhuis, 'Met recht verantwoordelijk!', $M$ en $R$ 2001/11, p. 261. Ook opgenomen in: J.M. Verschuuren (red.), Fundament onder het omgevingsrecht. Een selectie uit het werk van prof. mr. P.C. Gilhuis, samengesteld en van een inleiding voorzien door J.M. Verschuuren, Nijmegen: Wolf Legal Publishers 2006, p. 179-180.

\section{Gilhuis \& Van Gestel, Hoe groen is de Wm? 2002}

P.C. Gilhuis \& R.A.J. van Gestel, 'Hoe groen is de Wet milieubeheer? Over sectoraal, nationaal en lokaal denken inzake natuurbescherming', $M$ en $R$ 2002, p. 248-255. Ook opgenomen in: J.M. Verschuuren (red.), Fundament onder het omgevingsrecht. Een selectie uit het werk van prof. mr. P.C. Gilhuis, samengesteld en van een inleiding voorzien door J.M. Verschuuren, Nijmegen: Wolf Legal Publishers 2006, p. 373-394. 
Gilhuis, Is er nog verschil en moet er nog verschil zijn? 2003

P.C. Gilhuis, 'Is er nog verschil en moet er nog verschil zijn?' in: Gilhuis, Verschuuren (red.), Is er nog verschil tussen Europees en Nederlands milieurecht?, Den Haag: Boom Juridische Uitgevers 2003, p. 125-133. Ook opgenomen in: J.M. Verschuuren (red.), Fundament onder het omgevingsrecht. Een selectie uit het werk van prof. mr. P.C. Gilhuis, samengesteld en van een inleiding voorzien door J.M. Verschuuren, Nijmegen: Wolf Legal Publishers 2006, p. 247-254.

\section{Gilhuis, Herijken 2004}

P.C. Gilhuis, 'Herijken', $M$ en $R$ 2004, p. 1. Ook opgenomen in: J.M. Verschuuren (red.), Fundament onder het omgevingsrecht. Een selectie uit het werk van prof. mr. P.C. Gilhuis, samengesteld en van een inleiding voorzien door J.M. Verschuuren, Nijmegen: Wolf Legal Publishers 2006, 191-192.

Gilhuis, Naar minder of naar betere regels in het milieurecht? 2004

P.C. Gilhuis, 'Naar minder of naar betere regels in het milieurecht? Over de herijking van VROM-regelgeving', TO 2004, p. 39-45. Ook opgenomen in: J.M. Verschuuren (red.), Fundament onder het omgevingsrecht. Een selectie uit het werk van prof. mr. P.C. Gilhuis, samengesteld en van een inleiding voorzien door J.M. Verschuuren, Nijmegen: Wolf Legal Publishers 2006, p. 193-204.

\section{Gilhuis, Over integraal besluiten 2004}

P.C. Gilhuis, 'Over integraal besluiten en de gemeente-ambtenaar in De Peel', in: Witteveen, Verschuuren (red.), De Fascinatie. Wat wetgevingsonderzoekers bezighoudt, Den Haag: Boom Juridische Uitgevers 2004, p. 119-124. Ook opgenomen in: J.M. Verschuuren (red.), Fundament onder het omgevingsrecht. Een selectie uit het werk van prof. mr. P.C. Gilhuis, samengesteld en van een inleiding voorzien door J.M. Verschuuren, Nijmegen: Wolf Legal Publishers 2006, p. 205-210.

\section{Groothuijse, Water weren 2.0 2011}

F.A.G. Groothuijse, 'Water weren 2.0: versnellen, vereenvoudigen, harmoniseren en integreren', in: Goed verdedigbaar. Vernieuwing van bestuursrecht en omgevingsrecht. Opstellen aangeboden aan prof. mr. P.J.J. van Buuren, Deventer: Kluwer 2011, p. 315-333.

Groothuijse, Integratie van de Waterwet in de Omgevingswet 2012

F.A.G. Groothuijse, 'Integratie van de Waterwet in de Omgevingswet. Geef waterschappen boter bij de vis!', $M$ en $R$ 2012/6, p. 408-410. 
Van Hall, Het specialiteitbeginsel in het waterstaatsrecht (oratie) 1995

A. van Hall, Het specialiteitbeginsel in het waterstaatsrecht. Over kringen van belangen, oratie, Zwolle: WEJ Tjeenk Willink 1995

Van Hall, Belangenafweging in de wet op de fysieke leefomgeving 2000

A. van Hall, 'Belangenafweging in de wet op de fysieke leefomgeving', in: A. Driesprong e.a. (red.), Lex Aquarum, Liber amicorum (Teulingsbundel), Den Haag: Ministerie van Verkeer en Waterstaat 2000, p. 138-159.

Van Hall, Het recht als waterdrager (rede) 2007

Alfred van Hall, Het recht als waterdrager, TO, september 2007/3, pp. 92-95.

Havekes, Het hete (hang)ijzer van de integrale Waterwet 1999

H.J.M. Havekes, 'Het hete (hang)ijzer van de integrale Waterwet', in: A. van Hall, Th.G. Drupsteen en H.J.M. Havekes (red.), De staat van water, Lelystad: Kon. Vermande 1999, p. 103-115.

Havekes, Wetgeving op de waterkwaliteit 2006.

H.J.M. Havekes, 'Wetgeving op de waterkwaliteit', in: Ch.W. Backes, P.C. Gilhuis, N.S.J. Koeman, Milieurecht, Deventer: Kluwer 2006, p. 332-365.

\section{Havekes, Functioneel decentraal waterbestuur (diss.) 2009}

H.J.M. Havekes, Functioneel decentraal waterbestuur: borging, bescherming en beweging, diss., 2009.

\section{Havekes, Governance 2011}

H.J.M. Havekes, 'Governance', $M$ en $R$ 2011/1, p. 1.

\section{Havekes, Waterwet en omgevingswet 2012}

H.J.M. Havekes, 'Waterwet en Omgevingswet', $M$ en $R$ 2012/3, p. 159.

\section{Havekes \& De Putter, Wegwijzer Waterwet 2009}

H.J.M. Havekes \& P.J. de Putter, Wegwijzer Waterwet. Een praktische handleiding voor iedereen die met de Waterwet te maken krijgt, Alphen aan den Rijn: Kluwer 2009.

Havekes \& Van Rijswick, Waterrecht 2010

H.J.M. Havekes \& H.F.M.W. van Rijswick, Waterrecht in Nederland, Alphen aan den Rijn: Kluwer 2010, hfds. 4 en 5.

Van den Heuvel, De flexibiliteit van de Omgevingswet 2012 J.H. van den Heuvel, 'De flexibiliteit van de Omgevingswet', $M$ en $R$ 2012/6, p. 413-414. 
Heuving \& Boere, De Aanwijzingen voor de regelgeving in de praktijk 2005

C.E.I. Heuving \& A.H.M. Boere, 'De Aanwijzingen voor de regelgeving in de praktijk: met enige suggesties voor verbetering', RegelMaat 2005/1, p. 14-22.

\section{Hill, Einführung in die Gesetzgebungslehre 1982}

Hermann Hill, Einführung in die Gesetzgebungslehre, Heidelberg: C.F. Müller Juristischer Verlag 1982.

\section{Hirsch Ballin, Architectuur van wetgeving 1984}

E.M.H. Hirsch Ballin, 'Architectuur van wetgeving', in: C. Fasseur, E.M.H. Hirsch Ballin, J.J. Wiarda en J.A.M. van Angeren (Redactiecommissie), Kracht van Wet. Opstellen publiekrechtelijke wetgeving, aangeboden aan Mr. W.J. van Eijkern bij zijn afscheid als hoofd van de Stafafdeling Wetgeving Publiekrecht van het Ministerie van Justitie, Zwolle: WEJ Tjeenk Willink 1984, p. 77 e.v.

\section{Hordijk, Een nieuwe wet voor het milieubeheer 1993}

M.G. Hordijk, 'Een nieuwe wet voor het milieubeheer', $M$ en $R$ 1993/2, p. 66-74.

\section{Kaajan, Gebiedsbescherming in het wetsvoorstel natuur 2011}

M.M. Kaajan, 'Gebiedsbescherming in het wetsvoorstel natuur: oude wijn in nieuwe zakken?', $M$ en $R$ 2011/10, p. 645-652.

Kiela, Wet bodembescherming verdwijnt 2011

P. Kiela, 'Wet bodembescherming verdwijnt', Bodem 2011/6, p. 6-7.

Kleijs-Wijnnobel \& De Leeuw, Interne integratie 1998

C.J. Kleijs-Wijnnobel \& S.D.M. de Leeuw, 'Interne integratie', in: Th.G. Drupsteen e.a., De toekomst van de Wet milieubeheer, Deventer: Kluwer 1998, hfds. 4, p. 135-166.

\section{Kleijs-Wijnnobel \& De Leeuw, Relatie Awb-Wm 1998}

C.J. Kleijs-Wijnnobel \& S.D.M. de Leeuw, 'Relatie Algemene wet bestuursrecht - Wet milieubeheer', in: Th.G. Drupsteen e.a., De toekomst van de Wet milieubeheer, Deventer: Kluwer 1998, hfds. 6, p. 185-215.

Kloepfer, Sinn und Gestalt des kommenden Umweltgesetzbuchs $\mathbf{2 0 0 7}$

Michael Kloepfer, 'Sinn und Gestalt des kommenden Umweltgesetzbuchs', UPR 2007/5, p. 161-170. 
Koeman, Integratie van milieudoelstellingen in de ruimtelijke ordening 1994

N.S.J. Koeman, 'Integratie van milieudoelstellingen in de ruimtelijke ordening', $M$ en $R$ 1994/11, p. 320-326.

\section{Koeman, Een wereld te winnen 2010}

N.S.J. Koeman, Een wereld te winnen. Enkele beschouwingen over de toekomst van het omgevingsrecht, oratie, Amsterdam: Vossiuspers UvA 2010.

Koeman, Kiezen en delen in het omgevingsrecht 2010

N.S.J. Koeman, 'Kiezen en delen in het omgevingsrecht', in: Bezinning op het omgevingsrecht. Essays over de toekomst van het omgevingsrecht, Ministerie van IenM, oktober 2010, p. 120-134.

\section{Koeman/Nijmeijer \& Uylenburg (red.), T\&C Wabo 2010}

N.S.J. Koeman, A.G.A. Nijmeijer, R. Uylenburg, Tekst \& Commentaar, Wet algemene bepalingen omgevingsrecht, Deventer: Kluwer 2010.

Konijnenbelt, Wetgevingskwaliteit in Frankrijk 2000

W. Konijnenbelt, 'Wetgevingskwaliteit in Frankrijk: codificatie en hercodificatie', RegelMaat 2000/5, p. 237-243.

\section{Kortmann, Ontregeling 1993}

C.A.J.M. Kortmann, ‘Ontregeling', NJB 1993, p. 1375-1380.

\section{Kramer, ICT en Milieuregelgeving 2009}

J. Kramer, 'ICT en Milieuregelgeving: moet de ondernemer de wet nog kennen?', $M$ en $R$ 2009/4, p. 202-208.

Kramer, Op naar een integrale benadering van het milieubeleid 2011

J. Kramer, 'Op naar een integrale benadering van het milieubeleid', $M$ en $R$ 2011/7, p. 437

\section{Kwisthout/Swart-Bodrij \& Woldendorp, De Uitvoeringswet} REACH 2004

J.K.B.H. Kwisthout, A.H. Swart-Bodrij \& H.E. Woldendorp, 'De Uitvoeringswet REACH: stof tot nadenken over de uitvoering van Europese verordeningen', NtER 2004, p. 131-150.

Larmuseau/De Smedt \& Roelandts, Vlaams omgevingsrecht 2010 Isabelle Larmuseau, Peter De Smedt \& Bert Roelandts, Vlaams omgevingsrecht, Groningen: Europa Law Publishing 2010. 
Larmuseau, Omgevingsrecht op z'n Vlaams 2011

I. Larmuseau, 'Omgevingsrecht op z'n Vlaams, Nederlandser kan niet?', in: Goed verdedigbaar. Vernieuwing van bestuursrecht en omgevingsrecht. Opstellen aangeboden aan prof. mr. P.J.J. van Buuren, Deventer: Kluwer 2011, p. 417-426.

Larmuseau/De Waele/Bernaert/Cabus \& De Smet, Wetboek Vlaams Omgevingsrecht 2012

Isabelle Larmuseau, Tom De Waele, Paul Bernaert, Peter Cabus \& Jochen De Smet (ed.), Wetboek Vlaams Omgevingsrecht, Brugge: Van den Broele 2012.

Lokin, Het op orde houden van het wettenbestand 2005

M.H.A.F. Lokin, 'Enkele suggesties voor het op orde houden van het wettenbestand', RegelMaat 2005/4, p. 155-156.

Von Meijenfeldt, De wettelijke regeling van de bodemsanering 1994

H.G. von Meijenfeldt, De wettelijke regeling van de bodemsanering, Lelystad 1994.

Meijer \& Zwier, Voorjaarsschoonmaak in het natuurbeschermingsrecht 2012

E.E. Meijer en W. Zwier, 'Voorjaarsschoonmaak in het natuurbeschermingsrecht: minder geld. Minder regels, minder bescherming', $M$ en $R$ 2012/3, p. $160-171$.

\section{Menninga, Integraal omgevingsbeleid? 1997}

H. Menninga, 'Integraal omgevingsbeleid?', $M$ en R 1997/1, p. 1.

$M$ en R, Externe integratie 1994

Milieu en recht, Themanummer: Externe integratie, $M$ en $R$ 1994/11.

Michiels, Kleur in het omgevingsrecht (rede) 2001

F.C.M.A. Michiels, Kleur in het omgevingsrecht, rede, Den Haag: Boom Juridische Uitgevers 2001.

Michiels, De toekomst van de Omgevingswet 2002

F.C.M.A. Michiels, 'De toekomst van de Omgevingswet', in: De grootste gemene deler. Opstellen aangeboden aan prof. mr. Th.G. Drupsteen ter gelegenheid van zijn afscheid van de Universiteit Leiden op 31 mei 2002, Deventer: Kluwer 2002, 307-320.

Michiels, De Wet milieubeheer 2003

F.C.M.A. Michiels, De Wet milieubeheer, Deventer: Kluwer 2003. 
Michiels, Het schijnvoordeel van integrale wetgeving 2004

F.C.M.A. Michiels, 'Het schijnvoordeel van integrale wetgeving', Stcrt. 16 december 2004, nr. 243, Bijlage VIII.

Michiels/Nijmeijer \& Van der Velden, Het wetsvoorstel Wabo 2007 F.C.M.A. Michiels, A.G.A. Nijmeijer \& J.A.M. van der Velden, Het wetsvoorstel Wabo, Preadviezen voor de Vereniging voor Bouwrecht, Den Haag: Vereniging voor Bouwrecht 2007.

Minister-President, Aanwijzingen voor de regelgeving 2012 Aanwijzingen voor de regelgeving, Circulaire van de Minister-President van 18 november 1992, daarna regelmatig aangepast; versie d.d. 18 januari 2012.

Ministerie van Financiën, Ruimte voor leven 2010

Ministerie van Financiën, Rapport brede heroverwegingen, Werkgroep Leefomgeving en natuur, Ruimte voor leven, april 2010.

Ministerie van IenM, Bezinning op het omgevingsrecht 2010 Ministerie van IenM, Bezinning op het omgevingsrecht. Essays over de toekomst van het omgevingsrecht, Den Haag: Ministerie van IenM, oktober 2010.

Ministerie van IenM, Beleidsbrief Infrastructuur en Milieu 2010 Ministerie van IenM, Beleidsbrief Infrastructuur en Milieu d.d. 26 november 2010 van de minister van IenM aan de Voorzitter van de Tweede Kamer, kenmerk IenM/BSK-2O 10/33455, Kamerstukken II 2010/11, 32500 A nr. 12.

Ministerie van IenM, Kabinetsbrief Raamwet Omgevingsrecht 2011

Ministerie van IenM, Kabinetsbrief Raamwet Omgevingsrecht, 23 maart 2011, Kamerstukken II 2010/11, 31 953, nr. 39.

Ministerie van IenM, Beleidsbrief Eenvoudig Beter 2011

Ministerie van IenM, Beleidsbrief Eenvoudig Beter, 28 juni 2011, Kamerstukken II 2010/11, 31 953, nr. 40.

Ministerie van IenM, Kabinetsbrief stelselherziening omgevingsrecht 2012

Ministerie van IenM, Kabinetsbrief stelselherziening omgevingsrecht, 9 maart 2012, Kamerstukken II 2011/12, 33 118, nr. 3.

Ministerie van Justitie, Nota Zicht op wetgeving 1991

Ministerie van Justitie, Nota Zicht op wetgeving, Kamerstukken II 1990/91, 22800. 
Ministerie van VenM, Urgentienota Milieuhygiëne 1972

Ministerie van Volksgezondheid en Milieuhygiëne, Urgentienota Milieuhygiëne Kamerstukken II 1971/7272, 11 906, nr. 2.

Ministerie van VROM, Met recht verantwoordelijk! 2001

Ministerie van Volkshuisvesting, Ruimtelijke Ordening en Milieubeheer, Met recht verantwoordelijk!. Discussienota over de toekomst van een op duurzame ontwikkeling gerichte milieuwetgeving in een verantwoordelijke samenleving, Kamerstukken II 2000/01, 27 664, nr. 1.

\section{Ministerie van VROM, Herijkingsbrief 2003}

Ministerie van Volkshuisvesting, Ruimtelijke Ordening en Milieubeheer, Brief van de minister en de staatssecretaris van VROM aan de voorzitter van de Tweede Kamer der Staten-Generaal (Herijkingsbrief), Kamerstukken II 2003/04, $29200 \mathrm{XI}, \mathrm{nr} .7$.

\section{Ministerie van VROM, Uitvoeringsnota SOMS 2004}

Ministerie van Volkshuisvesting, Ruimtelijke Ordening en Milieubeheer, Uitvoeringsnota SOMS. Nederlands stoffenbeleid in internationaal perspectief, vastgesteld door de ministerraad d.d. 23 april 2004.

\section{Ministerie van VROM, Opdracht essays 2010}

Ministerie van Volkshuisvesting, Ruimtelijke Ordening en Milieubeheer, Opdracht Essays bezinning op het stelsel van omgevingsrecht, Den Haag, 26 januari 2010.

\section{Munneke, Begrippen 2012}

S.A.J. Munneke, 'De bevoegdheid tot wetgeving bij de centrale overheid', in: Zijlstra (red.), T.C. Borman, S.A.J. Munneke, F.J. van Ommeren, A.E. Schilder \& E. Steyger, Wetgeven. Handboek voor de centrale en decentrale wetgever, Deventer: Kluwer 2012, p. 27-70.

\section{Munneke, De bevoegdheid tot wetgeving bij de centrale overheid 2012}

S.A.J. Munneke, 'De bevoegdheid tot wetgeving bij de centrale overheid', in: Zijlstra (red.), T.C. Borman, S.A.J. Munneke, F.J. van Ommeren, A.E. Schilder \& E. Steyger, Wetgeven. Handboek voor de centrale en decentrale wetgever, Deventer: Kluwer 2012, p. 239-262.

Nijmeijer/Hillegers \& Lam, Bouwen en ontwikkelen met de Wabo 2010

A.G.A. Nijmeijer, S. Hillegers \& T.E.P.A. Lam, Bouwen en ontwikkelen met de Wabo, Alphen aan den Rijn: Kluwer 2010. 
Nijmeijer \& Soppe, Alles draait om eenvoud 2011

A.G.A. Nijmeijer \& M.A.A. Soppe, 'Alles draait om eenvoud. De Omgevingswet tussen Haagse bluf en fata morgana?', in: Goed verdedigbaar. Vernieuwing van bestuursrecht en omgevingsrecht. Opstellen aangeboden aan prof. mr. P.J.J. van Buuren, Deventer: Kluwer 2011, p. 427-440.

\section{Nijmeijer, De Wet natuur versnippert 2011}

A.G.A. Nijmeijer, 'De Wet natuur versnippert', TBR 2011, p. 1056 e.v.

\section{Nijmeijer, Van bestemmingsplan naar omgevingsverordening} 2012

A.G.A. Nijmeijer, 'Van bestemmingsplan naar omgevingsverordening. Grijp kansen op het punt van de inhoud, wees verstandig op het punt van de rechtsbescherming!', $M$ en $R$ 2012/6, p. 405-407.

\section{Nijmeijer, IPPC-inrichting of installatie? 2012}

A.G.A. Nijmeijer, Implementatie van de Richtlijn industriële emissies ( $\mathrm{nr}$. 2010/75/EU): IPPC-inrichting of installatie?, Vereniging voor Milieurecht 2012.

Noll, Gesetzgebungslehre 1973

Peter Noll, Gesetzgebungslehre, Reinbek bei Hamburg, 1973.

Onrust, De relatie tussen Wabo en Waterwet 2010

F. Onrust, 'De relatie tussen Wabo en Waterwet', $B R$ 2010/6, p. 851-863.

Peeters, Elaborating on integration of environmental legislation: the case of Indonesia 2006

M.G.W.M. Peeters, 'Elaborating on integration of environmental legislation: the case of Indonesia' in: Environmental Law in Development, Edward Elgar, Cheltenham, UK, Northhampton, MA, USA, 2006

Van der Peppel/Hardenberg/Bröring \& Lambers, Afstemmingsregelingen in de Wm 1996

R.A. van der Peppel, E. Hardenberg, H.E. Bröring \& C. Lambers, Afstemmingsregelingen in de Wet milieubeheer, Achtergrondstudie nr. 27 voor de Evaluatiecommissie Wet milieubeheer, Groningen, februari 1996.

De Putter, Verdroging van natuurgebieden vraagt integrale aanpak 1995

Peter de Putter, 'Verdroging van natuurgebieden vraagt integrale aanpak', $M$ en $R$ 1995/11, p. 209 e.v. 
Rehbinder, Kodifikation des Umweltrechts in Europa 2010

Eckard Rehbinder, 'Kodifikation des Umweltrechts in Europa - Rechtsvergleichende Betrachtungen', in: Festschrift für Dieter Sellner zum 75. Geburtstag, Verfassung - Umwelt - Wirtschaft, Verlag C.H. Beck München 2010, p. 89-106.

Van Rijswick, De betekenis en vormgeving van waterkwaliteitseisen 2007

H.F.M.W. van Rijswick, 'De betekenis en vormgeving van waterkwaliteitseisen', $M$ en $R$ 2007/7, p. 395-406.

Robesin, Moderne milieuregels 2005

M.A. Robesin, 'Moderne milieuregels', RegelMaat 2005/6, p. 186-195.

Roos, Implementatie Richtlijn industriële emissies stroomlijnt emissieregelgeving 2012

P.C. Roos, 'Implementatie Richtlijn industriële emissies stroomlijnt emissieregelgeving', in: L. Smorenburg-van Middelkoop \& R. Uylenburg (red.), De beste beschikbare technieken, van IPPC naar IED. Ontwikkeling, toepassing en toetsing van BBT, Amsterdam: Europa Law Publishing 2012, p. 29-44.

\section{Scheltema, Van rechtsbescherming naar een volwaardig} bestuursrecht 1996

M. Scheltema, 'Van rechtsbescherming naar een volwaardig bestuursrecht', NJB 1996, p. 1355-1361.

\section{Schoukens, Natuurbehoud en milieuhygiëne 2012}

Hendrik Schoukens, 'Natuurbehoud en milieuhygiëne: een overzicht van de belangrijkste juridische raakvlakken', in: De Vlaamse Omgevingsvergunning, Brugge: Vanden Broele 2012, p. 1-74.

Schueler, Of heeft u liever negatieve onevenredigheid? 2012 B.J. Schueler, 'Of heeft u liever negatieve onevenredigheid?', $M$ en $R$ 2012/4, p. 241.

Schlössels, Het specialiteitsbeginsel (diss.) 1998

Schössels, Het specialiteitsbeginsel (diss.), Juridische Reeks Universiteit Maastricht, Den Haag: Sdu Uitgevers 1998.

\section{Sebus, Wetgevingstechniek en de toegankelijkheid van de wet} voor de burger 1984

G. Sebus, Wetgevingstechniek en de toegankelijkheid van de wet voor de burger, Post Scriptum Reeks, Zwolle: WEJ Tjeenk Willink 1984. 
Sievers, Milieu- en omgevingsrecht: hoe meer integraal, hoe beter? 2012

I. Sievers, 'Milieu- en omgevingsrecht: hoe meer integraal, hoe beter?', in: Milieurecht in ontwikkeling. Jubileumbundel 30 jaar VMR, Den Haag: Boom Juridische Uitgevers 2012, p. 59-61.

\section{Steyger, Implementatie van Europees recht 2012}

E. Steyger, 'Implementatie van Europees recht', in: S.E. Zijlstra (red.), T.C. Borman, S.A.J. Munneke, F.J. van Ommeren, A.E. Schilder \& E. Steyger, Wetgeven. Handboek voor de centrale en decentrale wetgever, Deventer: Kluwer 2012, p. 633-663.

Stoop, Nationale koppen op EU-regelgeving 2012

J. Stoop, 'Nationale koppen op EU-regelgeving; een relevante discussie?', NtEr 2012/6, p. 229-237.

Struiksma, Simpel toch? Een bezinning op het stelsel van het omgevingsrecht 2010

J. Struiksma, 'Simpel toch? Een bezinning op het stelsel van het omgevingsrecht', in: Bezinning op het omgevingsrecht. Essays over de toekomst van het omgevingsrecht, Den Haag: Ministerie van IenM, oktober 2010, p. 174-186.

Thijssen \& Woldendorp, Kaderrichtlijn water; waterkwaliteitseisen waterdicht geregeld 2009

M. Thijssen \& H.E. Woldendorp, 'Kaderrichtlijn water; waterkwaliteitseisen waterdicht geregeld', $M$ en $R$ 2009, p. 554.

Timmer, Wetgevingskwaliteit: een wereld te winnen 2005 W.W.Timmer, 'Wetgevingskwaliteit: een wereld te winnen', RegelMaat 2005/1, p. 35-38.

Tjeenk Willink, De mythe van het samenhangend overheidsbeleid 1984

H.D. Tjeenk Willink, De mythe van het samenhangend overheidsbeleid (oratie Tilburg), Zwolle, WEJ Tjeenk Willink 1984.

Tolsma, Omgevingsvergunning model 4 een stap dichterbij met de Omgevingswet? 2012

H.D. Tolsma, 'Omgevingsvergunning model 4 een stap dichterbij met de Omgevingswet?', $M$ en $R$ 2012/2, p. 82-89.

Tolsma, De Europese dimensie van de Omgevingswet 2012

H.D. Tolsma, 'De Europese dimensie van de Omgevingswet', $M$ en $R$ 2012/6, p. $400-401$. 
Tonnaer, Quo Vadis (oratie) 2011

F.P.C.L. Tonnaer, Quo Vadis? Over vertrouwen in het omgevingsrecht (oratie Heerlen), Amsterdam: Berghauser Pont Publishing 2011.

Uylenburg/Vogelezang-Stoute/Boeve/van der Grijp/Groothuijse/ Koeman/Smorenburg-van Middelkoop \& Peeters, De Wm als kader voor implementatie van Europese wetgeving 2010

R. Uylenburg, E.M. Vogelezang-Stoute, M.N. Boeve, N.M. van der Grijp, F.A.G. Groothuijse, N.S.J. Koeman, L. Smorenburg-van Middelkoop \& M.G.W.M. Peeters, 'De Wet milieubeheer als kader voor implementatie van Europese wetgeving', $M$ en $R$ 2010/7, 418-424.

Uylenburg, Het omgevingsrecht van de toekomst: kiezen en delen 2010

R. Uylenburg, 'Het omgevingsrecht van de toekomst: kiezen en delen', in: Bezinning op het omgevingsrecht. Essays over de toekomst van het omgevingsrecht, Den Haag: Ministerie van IenM, oktober 2010, p. 206.

Uylenburg, De richtlijn industriële emissies 2011

R. Uylenburg, 'De richtlijn industriële emissies en flexibiliteit in de milieuvergunning', in: Goed verdedigbaar. Vernieuwing van bestuursrecht en omgevingsrecht. Opstellen aangeboden aan prof. mr. P.J.J. van Buuren, Deventer: Kluwer 2011, p. 527-539.

Uylenburg, Kansen en kanttekeningen 2012

R. Uylenburg, 'Kansen en kanttekeningen', $M$ en $R$ 2012/6, p. 391-392.

Veerman, De wet als zinsbegoochelingstoestel over de kwaliteit van wetgeving (rede) 2004

G.J. Veerman, De wet als zinsbegoochelingstoestel. Over de kwaliteit van wetgeving (rede), Maastricht: Maastricht University 2004.

Veerman \& Hendriks-de Lange, Over wetgeving 2007

G.J. Veerman m.m.v. S.R. Hendriks-de Lange, Over wetgeving. Principes, paradoxen en praktische beschouwingen, Sdu Uitgevers, Den Haag 2007.

Van der Velden, Sneller is niet altijd beter 2012

J.A.M. van der Velden, 'Sneller is niet altijd beter', $M$ en $R$ 2012/2, p. 81.

Van Velsen, De Europese m.e.r.-verplichtingen en de Omgevingswet 2012

S.M. van Velsen, 'De Europese m.e.r.-verplichtingen en de Omgevingswet', $M$ en $R$ 2012/6, p. 402-403. 
Verbeek. De natuur haakt aan bij de omgevingsvergunning, of toch niet? 2011

J. Verbeek, 'De natuur haakt aan bij de omgevingsvergunning, of toch niet?', in: Goed verdedigbaar. Vernieuwing van bestuursrecht en omgevingsrecht. Opstellen aangeboden aan prof. mr. P.J.J. van Buuren, Deventer: Kluwer 2011, p. 541-551.

Verbraeken, Balkenende, Eén omgevingswet 2010

Hans Verbraeken, 'Balkenende: één omgevingswet', Het Financieele Dagblad, 20 januari 2010.

\section{Verschuuren, Codificatie van het milieurecht in het Vlaamse} Gewest 1996

J.M. Verschuuren, 'Codificatie van het milieurecht in het Vlaamse Gewest. Een bespreking van het Voorontwerp Decreet Milieubeleid', Tijdschrift voor Milieurecht 1996, p. 19-22.

\section{Verschuuren, Externe integratie 1998}

J.M. Verschuuren, 'Externe integratie', in: Th.G. Drupsteen e.a., De toekomst van de Wet milieubeheer, Deventer: Kluwer 1998, hfds. 5.

\section{Verschuuren, Natuur in de omgevingsvergunning 2005}

J.M. Verschuuren, 'Natuur in de omgevingsvergunning', $M$ en $R$ 2005/9, p. 550 e.v.

\section{Verschuuren, Fundament onder het omgevingsrecht 2006}

J.M. Verschuuren, 'Inleiding', in: J.M. Verschuuren (red.), Fundament onder het omgevingsrecht. Een selectie uit het werk van prof. mr. P.C. Gilhuis, samengesteld en van een inleiding voorzien door J.M. Verschuuren, Nijmegen: Wolf Legal Publishers 2006, p. 1-7.

Visser, Zorgplichtbepalingen in het strafrecht (diss.) 2001

M.J.C. Visser, Zorgplichtbepalingen in het strafrecht (diss.), Deventer: Gouda Quint 2001.

Van der Vlies, Handboek wetgeving 1991

I.C. van der Vlies, Handboek wetgeving, Zwolle: WEJ Tjeenk Willink 1991.

\section{VMR, Afstemmingsregelingen in de Wm 1996}

Vereniging voor Milieurecht, Afstemmingsregelingen in de Wet milieubeheer, 17 september 1996, Vereniging voor Milieurecht 1996-4.

Voermans, Het ontwerpen van wetten en systeemontwikkeling 1998 W.J.M. Voermans, 'Het ontwerpen van wetten en systeemontwikkeling, of ... alles moet anders', in: W.B.H.J. van de Donk en P.H. Frissen (red), Over 
bestuur, recht en informatisering. Opstellen aangeboden aan prof.dr.mr. I.Th.M. Snellen, Lelystad: Koninklijke Vermande 1998, p. 287-295.

Voermans, Weten van wetgeving 2004

W.J.M. Voermans, 'Weten van wetgeving', RegelMaat 2004/5, p. 155-160.

Voermans/Moll, Florijn \& Van Lochem, Codification and Consolidation in Europe as Means to Untie Red Tape 2008

Wim J.M. Voermans, C.P.P. Moll, Nico A. Florijn \& Peter J.P.M. van Lochem, Codification and Consolidation in Europe as Means to Untie Red Tape (March 1, 2008). Statute Law Review, Vol. 29, No. 2, pp. 65-81, 2008. Available at SSRN: http://ssrn.com/abstract=1113755

Voermans/Van Wijk \& Fokkema, Free the Legislative Process of its Paper Chains 2011

Wim J.M. Voermans, Remco van Wijk \& Welmoed Fokkema, Free the Legislative Process of its Paper Chains: IT-Inspired Redesign of the Legislative Procedure (May 30, 2011). Available at SSRN: http://ssrn. com/abstract $=1855595$ or doi:10.2139/ssrn.1855595.

Vogelezang-Stoute/Boeve/van der Grijp/Groothuijse/Koeman/ van Middelkoop/Peeters \& Uylenburg, De Wm als kader voor implementatie van Europese wetgeving 2009

E.M. Vogelezang-Stoute, M.N. Boeve, N.M. van der Grijp, F.A.G. Groothuijse, N.S.J. Koeman, L. van Middelkoop, M.G.W.M. Peeters \& R. Uylenburg, De Wet milieubeheer als kader voor implementatie van Europese wetgeving, een verkennende studie naar mogelijkheden en knelpunten voor een correcte implementatie, STEM-rapport 2009-02, p. 35.

De Vos, Coördinatie, integratie of beide? 2005

H.W. de Vos, Coördinatie, integratie of beide?, Den Haag: Ministerie van VROM.

De Vos, Een basis voor de toekomst: de Omgevingswet 2012

H.W. de Vos, 'Een basis voor de toekomst: de Omgevingswet', in: Milieurecht in ontwikkeling. Jubileumbundel 30 jaar VMR, Den Haag: Boom Juridische Uitgevers 2012, p. 71-73.

Witteveen, Nomoi. Utopia en de volmaakte wetskennis 2004 W.J. Witteveen, 'Utopia en de volmaakte wetskennis', RegelMaat 2004/5, p. 191-194. 
Van Wijk/Konijnenbelt/Van Male, Hoofdstukken van bestuursrecht 2008

H.D. van Wijk, Hoofdstukken van bestuursrecht, bewerkt door W. Konijnenbelt en R.M. van Male, Amsterdam: Reed Business 2008.

\section{Van Wijmen, Water en natuur 2006}

Peter van Wijmen, 'Water en natuur', in: Th.G. Drupsteen, H.J.M. Havekes, H.F.M.W. van Rijswick (red.), Weids water. Opstellen over waterrecht, Ter ere van het afscheid van Alfred van Hall, Den Haag: Sdu Uitgevers 2006, p. 353-369.

Van Wijmen, Integratie van natuurwetgeving; maar blijft er nog natuur over? 2011

P.C.E. van Wijmen, 'Integratie van natuurwetgeving; maar blijft er nog natuur over?', in: Goed verdedigbaar. Vernieuwing van bestuursrecht en omgevingsrecht. Opstellen aangeboden aan prof. mr. P.J.J. van Buuren, Deventer: Kluwer 2011, p. 571-582.

Woldendorp, Voor- en nadelen van een koppeling Wm-Meststoffenwet op wetsniveau 1994

H.E. Woldendorp, 'Voor- en nadelen van een koppeling Wet milieubeheerMeststoffenwet op wetsniveau', Agrarisch recht, 1994/2, p. 57 e.v.

Woldendorp/Swart-Bodrij \& Kwisthout, REACH komt, de Wms gaat 2007

H.E. Woldendorp, A. Swart-Bodrij, J.K. Kwisthout, 'REACH komt, de Wms gaat. De uitvoering van REACH in Nederland', $M$ en $R$ 2007/8, p. 479-486.

\section{Woldendorp, Een werker in het vooronder! 2006}

H.E. Woldendorp, 'Een werker in het vooronder! Interview met Hans Bierman ter gelegenheid van zijn vertrek bij VROM', $M$ en $R$ 2006, p. 2-7.

Woldendorp, Makkelijker kunnen we het niet maken, wel leuker? 2010

Hans Woldendorp, 'Makkelijker kunnen we het niet maken, wel leuker?', $M$ en $R$ 2010/7, p. 417.

Woldendorp, De sjoelbakmethode 2011

H.E. Woldendorp, 'De sjoelbakmethode', $M$ en $R$ 2011/8, p. 503.

Woldendorp, Teksten en toelichting Wetgeving natuurbescherming 2011

H.E. Woldendorp, Teksten en toelichting Wetgeving natuurbescherming, natuurbeschermingsaspecten van ruimtelijke ingrepen, Editie 2011, Den Haag: Sdu Uitgevers 2011. 
Woldendorp, REACH doet stof opwaaien 2007

H.E. Woldendorp, 'REACH doet stof opwaaien', $M$ en $R$ 2007/8, p. 465-466.

Zijlstra, Aanpak bij het opstellen van een wettelijke regeling 2012 S.E. Zijlstra, 'Aanpak bij het opstellen van een wettelijke regeling', in: S.E. Zijlstra (red.), T.C. Borman, S.A.J. Munneke, F.J. van Ommeren, A.E. Schilder \& E. Steyger, Wetgeven. Handboek voor de centrale en decentrale wetgever, Deventer: Kluwer 2012, p. 385-400.

Zijlstra, Opzet en indeling van een wettelijke regeling 2012

S.E. Zijlstra, 'Opzet en indeling van een wettelijke regeling', in: S.E. Zijlstra (red.), T.C. Borman, S.A.J. Munneke, F.J. van Ommeren, A.E. Schilder \& E. Steyger, Wetgeven. Handboek voor de centrale en decentrale wetgever, Deventer: Kluwer 2012, p. 533-550. 



\section{Bijlage 1: Omgevingsrecht 2002-2012}

\section{Verklaring kleuren}

\begin{tabular}{|l|l|}
\hline & Tussen 23 mei 2002 en 23 mei 2012 vervallen omgevingsrecht \\
\hline & Op 23 mei 2012 geldend omgevingsrecht, dat wordt geïntegreerd in de Omgevingswet \\
\hline $\begin{array}{l}\text { Op } 23 \text { mei } 2012 \text { geldend omgevingsrecht, dat gedeeltelijk, later of mogelijk wordt } \\
\text { geintegreerd in de Omgevingswet }\end{array}$ \\
\hline $\begin{array}{l}\text { Op } 23 \text { mei } 2012 \text { geldend omgevingsrecht dat niet is genoemd als te integreren omge- } \\
\text { vingsrecht in de Omgevingswet }\end{array}$ \\
\hline
\end{tabular}

\begin{tabular}{|c|c|c|c|c|}
\hline & \multicolumn{4}{|c|}{ Omgevingsrecht } \\
\hline $\begin{array}{l}\text { Jaar } \\
\text { i.w.tr. } \\
\text { (vervallen) }\end{array}$ & Milieu & $\begin{array}{l}\text { Ruimtelijke } \\
\text { ordening }\end{array}$ & Water & Natuur \\
\hline 1851 & & Onteigeningswet $^{1}$ & & \\
\hline 1876 & & $\begin{array}{l}\text { Spoorwegwet } \\
1875^{2}\end{array}$ & & \\
\hline 1902 & & & $\begin{array}{l}\text { Waterstaatswet } \\
1900^{3}\end{array}$ & \\
\hline 1902 & & $\begin{array}{l}\text { Lokaalspoor- en } \\
\text { Tramwegwet }^{4}\end{array}$ & & \\
\hline $\begin{array}{l}1904 \\
(2009)\end{array}$ & & & $\begin{array}{l}\text { Wet van } 14 \text { juli } \\
1904 \text { (Stb. 147), } \\
\text { houdende bepalin- } \\
\text { gen omtrent het } \\
\text { ondernemen van } \\
\text { droogmakerijen en } \\
\text { indijkingen }{ }^{5} \\
+22-12-2009^{6}\end{array}$ & \\
\hline
\end{tabular}

1 Wet van 28 augustus 1851, regelende de onteigening ten algemeenen nutte (Stb. 1851, 125), i.w.tr. 26 september 1851 (Stb. 1851, 125).

2 Wet van 9 april 1875, tot regeling van de dienst en het gebruik der spoorwegen, en zulks met intrekking der wet van 21 augustus 1859 (Staatsblad n. 98) (Stb. 1875, 67), i.w.tr. 15 oktober 1876 (Stb. 1876, 41).

3 Wet van 10 november 1900, houdende algemeene regels omtrent het waterstaatsbestuur (Stb. 1900, 176 en 1991, 444), i.w.tr. 15 juni 1902 (Stb. 1902, 75).

4 Wet van 9 juli 1900, houdende nadere regeling van den dienst en het gebruik van spoorwegen, waarop.

5 Wet van 14 juli 1904, houdende bepalingen omtrent het ondernemen van droogmakerijen en indijkingen (Stb. 1904, 104), i.w.tr. 9 september 1904 (Stb. 1904, 104).

6 Art. 2.1 Invoeringswet Waterwet (Stb. 2009, 489 en 549). 


\begin{tabular}{|l|l|l|l|l|}
\hline & \multicolumn{4}{|c|}{ Omgevingsrecht } \\
\hline $\begin{array}{l}\text { Jaar } \\
\text { i.w.tr. } \\
\text { (vervallen) }\end{array}$ & Milieu & $\begin{array}{l}\text { Ruimtelijke } \\
\text { ordening }\end{array}$ & Water & Natuur \\
\hline $\begin{array}{l}1906 \\
(2003)\end{array}$ & $\begin{array}{l}\text { Mijnwet } 1903^{7} \\
+1-1-2003^{8}\end{array}$ & & & \\
\hline $\begin{array}{l}1924 \\
(2003)\end{array}$ & & $\begin{array}{l}\text { Wet opsporing } \\
\text { delfstoffen } 1924^{9} \\
+1-1-2003^{10}\end{array}$ & & \\
\hline 1927 & & $\begin{array}{l}\text { Belemmeringen- } \\
\text { wet Privaatrecht }\end{array}$ & & \\
\hline 1928 & & & & $\begin{array}{l}\text { Natuurschoon- } \\
\text { wet }^{11}\end{array}$ \\
\hline $19328^{12}$
\end{tabular}

7 Wet van 27 april 1904, houdende nadere bepalingen betreffende de mijnontginning (Stb. 1904, 73) i.w.tr. 1 november 1906 (Stb. 1906, 249).

8 Art. 168 onder 1 Wet van 31 oktober 2002, houdende regels met betrekking tot het onderzoek naar en het winnen van delfstoffen en met betrekking tot met de mijnbouw verwante activiteiten (Mijnbouwwet) (Stb. 2002, 542 en 603).

9 Wet van 20 juni 1924, betreffende opsporing van delfstoffen (Stb. 1983, 683), i.w.tr. 27 juli 1924 (Stb. 1986, 191).

10 Art. 168 onder $\mathrm{h}$ Wet van 31 oktober 2002, houdende regels met betrekking tot het onderzoek naar en het winnen van delfstoffen en met betrekking tot met de mijnbouw verwante activiteiten (Mijnbouwwet) (Stb. 2002, 542 en 603).

11 Wet van 13 mei 1927, tot opheffing van privaatrechtelijke belemmeringen (Stb. 1927, 159), i.w.tr 14 juni 1927 (Stb. 1927, 159).

12 Wet van 15 maart 1928, houdende regeling van sommige van landgoederen geheven belastingen tot bevordering van behoud van natuurschoon (Stb. 1928, 63), i.w.tr. 1 januari 1928 (Stb. 1928, 63).

13 Wet van 31 juli 1930, houdende vaststelling van voorschriften omtrent openbare wegen (Stb. 1930, 342), i.w.tr. 1 oktober 1932 (Stb. 1932, 293)

14 Wet van 19 juli 1934, tot vaststelling van bepalingen omtrent de opruiming van vaartuigen en andere voorwerpen, in openbare wateren gestrand, gezonken of aan den grond geraakt of in waterkeeringen of andere waterstaatswerken vastgeraakt (Stb. 1934, 401), i.w.tr. 3 september 1934 (Stb. 1934, 401).

15 Wet van 19 april 1947, betreffende het nemen van maatregelen tot het tegengaan van bedrog in den handel in middelen ter bestrijding van verwekkers van plantenziekten (Stb. 1947, H123), i.w.tr. 5 juni 1947 (Stb. 1947, H123).

16 Art. XB Wet van 15 september 2005 tot wijziging van de Meststoffenwet (invoering gebruiksnormen) (Stb. 2005, 481 en 2007, 519).

17 Wet van 3 november 1954, houdende bepalingen betreffende de jacht (Stb. 1954, 523), i.w.tr 15 juni 1955 (Stb. 1955, 230).

18 Art. 123 lid 3 Wet van 25 mei 1998, houdende regels ter bescherming van in het wild levende planten- en diersoorten (Flora- en faunawet) (Stb. 1998, 402 en 2010, 3). 


\begin{tabular}{|l|l|l|l|l|}
\hline & \multicolumn{4}{|c|}{ Omgevingsrecht } \\
\hline $\begin{array}{l}\text { Jaar } \\
\text { i.w.tr. } \\
\text { (vervallen) }\end{array}$ & Milieu & $\begin{array}{l}\text { Ruimtelijke } \\
\text { ordening }\end{array}$ & Water & Natuur \\
\hline $\begin{array}{l}1957 \\
(2008)\end{array}$ & $\begin{array}{l}\text { Destructiewet } \\
+1-1-2008^{20}\end{array}$ & & & \\
\hline $\begin{array}{l}1958 \\
(2005)\end{array}$ & & & $\begin{array}{l}\text { Deltawet }^{21} \\
+28-09-2005^{22}\end{array}$ & \\
\hline 1959 & Luchtvaartwet $^{23}$ & & & \\
\hline $\begin{array}{l}1962 \\
(2007)\end{array}$ & $\begin{array}{l}\text { Bestrijdingsmiddelen- }_{\text {wet } 1962^{24}} \\
+17-10-2007^{25}\end{array}$ & & & \\
\hline 1962 & & & & \\
\hline 1963 & Kernenergiewet & & \\
\hline $\begin{array}{l}1964 \\
(2008)\end{array}$ & & $\begin{array}{l}\text { Woningwet } 1962^{28} \\
+1-7-2008^{29}\end{array}$ & & \\
\hline $\begin{array}{l}1965 \\
(2008)\end{array}$ & & $\begin{array}{l}\text { Wet op de Ruim- } \\
\text { telijke Ordening }^{20} \\
+1-7-2008^{31}\end{array}$ & & \\
\hline
\end{tabular}

19 Wet van 21 februari 1957, tot regeling van het door verwerking tot nuttige produkten onschadelijk maken van ondeugdelijk materiaal van dierlijke herkomst (Stb. 1957, 84), i.w.tr. 1 augustus 1957 (Stb. 1957, 260)

20 Art. IV Wet van 11 mei 2007, houdende wijziging van de voorschriften inzake niet voor menselijke consumptie bestemde dierlijke bijproducten (Stb. 2007, 224 en 528).

21 Wet van 8 mei 1958, houdende de afsluiting van de zeearmen tussen de Westerschelde en de Rotterdamsche Waterweg en de versterking van de hoogwaterkering ter beveiliging van het land tegen stormvloeden (Stb. 1958, 246), i.w.tr. 23 juni 1958 (Stb. 1958, 246).

22 Art. V Wet van 28 april 2005 tot wijziging van de Wet op de waterkering en intrekking van de Deltawet grote rivieren, de Deltawet, de Deltaschadewet, de Wet schade oesterkwekers, de Vergunningwet Westerschelde, de Zuiderzeewet en de Zuiderzeesteunwet, Stb. 2005, 275 en 461.

23 Wet van 15 januari 1958, houdende nieuwe regelen omtrent de luchtvaart (Stb. 1958, 47), i.w.tr. 1 oktober 1959 (Stb. 1959, 344).

24 Wet van 12 juli 1962, houdende vaststelling van nieuwe regelen met betrekking tot de handel in en het gebruik van bestrijdingsmiddelen (Stb. 1962, 288), i.w.tr. 1 september 1962 (Stb. 1962, 353).

25 Art. 139 onder a Wet van 17 februari 2007, houdende regeling voor de toelating, het op de markt brengen en het gebruik van gewasbeschermingmiddelen en biociden (Wet gewasbeschermingsmiddelen en biociden), Stb. 2007, 125 en 386.

26 Wet van 20 juli 1961, houdende nieuwe bepalingen ter bewaring van bossen en andere houtopstanden (Stb. 1961, 256), i.w.tr. 1 juli 1962 (Stb. 1962, 193).

27 Wet van 21 februari 1963, houdende regelen met betrekking tot de vrijmaking van kernenergie en de aanwending van radioactieve stoffen en ioniserende stralen uitzendende toestellen (Stb. 1963, 82), i.w.tr. 27 maart 1963 (Stb. 1963, 82).

28 Wet van 12 juli 1962 tot vaststelling van nieuwe voorschriften omtrent de volkshuisvesting (Stb. 1964, 220), i.w.tr. 8 juli 1964 (Stb. 1964, 220).

29 Art. 8.20 Invoeringswet Wet ruimtelijke ordening (Stb. 2008, 180 en 227).

30 Wet van 5 juli 1962, houdende vaststelling van nieuwe voorschriften omtrent de ruimtelijke ordening (Stb. 1962, 286), i.w.tr. 1 augustus 1965 (Stb. 1962, 340).

31 Art. 9.1.1 Invoeringswet Wet ruimtelijke ordening (Stb. 2008, 180 en 227) 


\begin{tabular}{|c|c|c|c|c|}
\hline & \multicolumn{4}{|c|}{ Omgevingsrecht } \\
\hline $\begin{array}{l}\text { Jaar } \\
\text { i.w.tr. } \\
\text { (vervallen) }\end{array}$ & Milieu & $\begin{array}{l}\text { Ruimtelijke } \\
\text { ordening }\end{array}$ & Water & Natuur \\
\hline $\begin{array}{l}1967 \\
(2003)\end{array}$ & $\begin{array}{l}\text { Mijnwet continentaal } \\
\text { plat }^{32} \\
+1-1-2003^{33}\end{array}$ & & & \\
\hline $\begin{array}{l}1967 \\
(2003)\end{array}$ & & $\begin{array}{l}\text { Wet opsporing } \\
\text { delfstoffen }{ }^{34} \\
+1-1-2003^{35}\end{array}$ & & \\
\hline $\begin{array}{l}1968 \\
(2005)\end{array}$ & & & & $\begin{array}{l}\text { Natuurbescher- } \\
\text { mingswet }{ }^{36} \\
+1-10-2005^{37}\end{array}$ \\
\hline $\begin{array}{l}1970 \\
(2009)\end{array}$ & & & $\begin{array}{l}\text { Wet verontreini- } \\
\text { ging oppervlakte- } \\
\text { wateren }^{38} \\
+22-12-2009^{39}\end{array}$ & \\
\hline 1970 & Wet luvo ${ }^{40}$ & & & \\
\hline $\begin{array}{l}1971 \\
(2005)\end{array}$ & & & $\begin{array}{l}\text { Deltaschadewet }^{41} \\
+28-09-2005^{42}\end{array}$ & \\
\hline 1971 & & $\begin{array}{l}\text { Ontgrondingen- } \\
\text { wet }^{43}\end{array}$ & & \\
\hline
\end{tabular}

32 Wet van 23 september 1965, houdende regelen ten aanzien van het onderzoek naar en de winning van delfstoffen in of op het onder de Noordzee gelegen deel van het continentaal plat (Stb. 1965, 428), i.w.tr. 1 maart 1967 (Stb. 1967, 73).

33 Art. 168 onder $\mathrm{m}$ Wet van 31 oktober 2002, houdende regels met betrekking tot het onderzoek naar en het winnen van delfstoffen en met betrekking tot met de mijnbouw verwante activiteiten (Mijnbouwwet) (Stb. 2002, 542 en 603).

34 Wet van 3 mei 1967, houdende regelen met betrekking tot de opsporing van delfstoffen door boringen (Stb. 1967, 258), i.w.tr. 24 mei 1967 (Stb. 1967, 258).

35 Art. 168 onder n Wet van 31 oktober 2002, houdende regels met betrekking tot het onderzoek naar en het winnen van delfstoffen en met betrekking tot met de mijnbouw verwante activiteiten (Mijnbouwwet) (Stb. 2002, 542 en 603).

36 Wet van 15 november 1967, houdende voorzieningen in het belang van de natuurbescherming (Stb. 1967, 572), i.w.tr. 1 januari 1968 (Stb. 1967, 572).

37 Art. 71 lid 2 Wet van 25 mei 1998, houdende nieuwe regelen ter bescherming van natuur en landschap (Natuurbeschermingswet 1998) (Stb. 1998, 403 en 2005, 473).

38 Wet van 13 november 1969, houdende regelen omtrent de verontreiniging van oppervlaktewateren (Stb. 1969, 536), i.w.tr. 1 december 1970 (Stb. 1970, 537).

39 Art. 2.1 Invoeringswet Waterwet (Stb. 2009, 489 en 549).

40 Wet van 26 november 1970, houdende regelen in het belang van het voorkomen of beperken van luchtverontreiniging (Stb. 1970, 580), i.w.tr. 29 december 1970 (Stb. 1970, 677).

41 Wet van 4 februari 1971, houdende tegemoetkoming voor anderen dan oesterkwekers in schade als bedoeld in artikel 8 van de Deltawet en tegemoetkoming in schade als gevolg van de afsluiting van de Lauwerszee, alsmede wijziging van de Deltawet en van de Wet van 16 september 1966 (Stb. 399) (Stb. 1971, 86), i.w.tr. 10 maart 1971 (Stb. 1971, 86).

42 Art. VI Wet van 28 april 2005 tot wijziging van de Wet op de waterkering en intrekking van de Deltawet grote rivieren, de Deltawet, de Deltaschadewet, de Wet schade oesterkwekers, de Vergunningwet Westerschelde, de Zuiderzeewet en de Zuiderzeesteunwet, Stb. 2005, 275 en 461.

43 Wet van 27 oktober 1965, houdende regelen omtrent de ontgrondingen (Stb. 1965, 509), i.w.tr. 1 september 1971 (Stb. 1971, 520). 


\begin{tabular}{|c|c|c|c|c|}
\hline & \multicolumn{4}{|c|}{ Omgevingsrecht } \\
\hline $\begin{array}{l}\text { Jaar } \\
\text { i.w.tr. } \\
\text { (vervallen) }\end{array}$ & Milieu & $\begin{array}{l}\text { Ruimtelijke } \\
\text { ordening }\end{array}$ & Water & Natuur \\
\hline $\begin{array}{l}1977 \\
(2009)\end{array}$ & & & $\begin{array}{l}\text { Wet verontreini- } \\
\text { ging zeewater } \\
+22-12-2009^{45} \\
\end{array}$ & \\
\hline 1980 & Wet geluidhinder ${ }^{46}$ & & & \\
\hline 1981 & & $\begin{array}{l}\text { Wet voorkeurs- } \\
\text { recht gemeen- } \\
\text { ten }^{47}\end{array}$ & & \\
\hline $\begin{array}{l}1982 \\
(2009)\end{array}$ & & & $\begin{array}{l}\text { Grondwaterwet }{ }^{48} \\
!+22-12-2009^{49}\end{array}$ & \\
\hline 1982 & & & $\begin{array}{l}\text { Wet schadefonds } \\
\text { olietankschepen }\end{array}$ & \\
\hline 1984 & & & $\begin{array}{l}\text { Wet hygiëne en } \\
\text { veiligheid badin- } \\
\text { richtingen en } \\
\text { zwemgelegenhe- } \\
\text { den }^{51}\end{array}$ & \\
\hline $\begin{array}{l}1985 \\
(2007)\end{array}$ & & $\begin{array}{l}\text { Landinrichtings- } \\
\text { wet }^{52} \\
+1-1-2007^{53}\end{array}$ & & \\
\hline $\begin{array}{l}1985 \\
(2008)\end{array}$ & & $\begin{array}{l}\text { Wet op de stads- } \\
\text { en dorpsvernieu- } \\
\text { wing } 54 \\
+1-7-2008^{55}\end{array}$ & & \\
\hline
\end{tabular}

44 Wet van 5 juni 1975, houdende voorschriften tot het voorkomen van de verontreiniging van de zee (Stb. 1975, 352), 1 januari 1977 (Stb. 1976, 628).

45 Art. 2.1 Invoeringswet Waterwet (Stb. 2009, 489 en 549).

46 Wet van 16 februari 1979, houdende regels inzake het voorkomen of beperken van geluidhinder (Stb. 1979, 99), i.w.tr. 1 februari 1980 (Stb. 1980, 41).

47 Wet van 22 april 1981, houdende regeling van een voorkeursrecht van gemeenten bij de verwerving van onroerende zaken (Stb. 1981, 319), i.w.tr. 6 juli 1981 (Stb. 1981, 319).

48 Wet van 22 mei 1981, houdende regelen inzake het onttrekken van grondwater en het kunstmatig infiltreren van water in de bodem (Stb. 1981, 392), i.w.tr. 1 juni 19821986 (Stb. 1981, 284).

49 Art. 2.1 Invoeringswet Waterwet (Stb. 2009, 489 en 549).

50 Wet van 14 mei 1981, houdende uitvoering van het op 18 december 1971 te Brussel tot stand gekomen Internationaal Verdrag ter oprichting van een internationaal fonds voor vergoeding van schade door verontreiniging door olie (Trb. 1973, 101) (Stb. 1981, 294), i.w.tr. 15 september 1982 (Stb. 1982, 510).

51 Wet van 2 juli 1969, houdende regelen nopens de hygiëne en de veiligheid in zweminrichtingen (Stb. 1969, 315), i.w.tr. 1 november 1984 (Stb. 1984, 470)

52 Wet van 9 mei 1985, houdende regelen met betrekking tot de inrichting van de landelijke gebieden (Stb. 1985, 299), i.w.tr. 15 oktober 1985 (Stb. 1985, 520).

53 Art. 95 lid 1 Wet van 7 december 2006, houdende regels inzake de inrichting van het landelijke gebied (Stb. 2006, 666 en 667).

54 Wet van 5 september 1984, houdende regelen ter bevordering van de stads- en dorpsvernieuwing (Stb. 1983, 683), i.w.tr. 15 april 1986 (Stb. 1986, 191).

55 Art. 9.2.1 Invoeringswet Wet ruimtelijke ordening (Stb. 2008, 180 en 227). 


\begin{tabular}{|c|c|c|c|c|}
\hline & \multicolumn{4}{|c|}{ Omgevingsrecht } \\
\hline $\begin{array}{l}\text { Jaar } \\
\text { i.w.tr. } \\
\text { (vervallen) }\end{array}$ & Milieu & $\begin{array}{l}\text { Ruimtelijke } \\
\text { ordening }\end{array}$ & Water & Natuur \\
\hline $\begin{array}{l}1986 \\
(2011)\end{array}$ & $\begin{array}{l}\text { Wet energiebesparing } \\
\text { toestellen }^{56} \\
+5-3-2011^{57} \\
\end{array}$ & & & \\
\hline $\begin{array}{l}1986 \\
(2008)\end{array}$ & $\begin{array}{l}\text { Wet milieugevaarlijke } \\
\text { stoffen }{ }^{8} \\
+1-6-2008^{59}\end{array}$ & & & \\
\hline 1986 & & & $\begin{array}{l}\text { Wet voorkoming } \\
\text { verontreiniging } \\
\text { door schepen }^{60}\end{array}$ & \\
\hline 1987 & $\begin{array}{l}\text { Wet bodembescher- } \\
\text { ming }{ }^{61}\end{array}$ & & & \\
\hline $\begin{array}{l}1989 \\
(2009)\end{array}$ & & & $\begin{array}{l}\text { Wet op de water- } \\
\text { huishouding } \\
+22-12-2009^{63}\end{array}$ & \\
\hline 1989 & & $\begin{array}{l}\text { Monumentenwet } \\
1988^{64}\end{array}$ & & \\
\hline 1992 & & $\begin{array}{l}\text { Wet herverdeling } \\
\text { wegenbeheer }\end{array}$ & & \\
\hline 1992 & & Woningwet $^{66}$ & & \\
\hline
\end{tabular}

56 Wet van 5 februari 1986, houdende regels ten aanzien van toestellen en installaties in het belang van de energiebesparing (Stb. 1986, 59), i.w.tr. 12 maart 1986 (Stb. 1986, 59).

57 Art. 38 Wet van 26 februari 2011, houdende regels omtrent energie-efficiëntie (Wet implementatie EG-richtlijnen energie-efficiëntie) (Stb. 2011, 114 en 117).

58 Wet van 5 december 1985, houdende regelen ter bescherming van mens en milieu tegen gevaarlijke stoffen en preparaten (Stb. 1985, 639), i.w.tr. 1 februari 1986 (Stb. 1986, 10).

59 Art. IX Wet van 16 mei 2007 tot uitbreiding en wijziging van de Wet milieubeheer in verband met de uitvoering van EG-verordening registratie, evaluatie en autorisatie van chemische stoffen $(\mathrm{REACH})$ en de overheveling van de bepalingen van de Wet milieugevaarlijke stoffen naar de Wet milieubeheer, alsmede daarmee samenhangende wijzigingen van andere wetten (Uitvoeringswet EG-verordening registratie, evaluatie en autorisatie van chemische stoffen (REACH)) (Stb. 2007, 181 en 182)

60 Wet van 14 december 1983, houdende regelen ter voorkoming van verontreiniging door schepen (Stb. 1983, 683), i.w.tr. 15 april 1986 (Stb. 1986, 191).

61 Wet van 3 juli 1986, houdende regelen inzake bescherming van de bodem (Stb. 1986, 374), i.w.tr. 1 januari 1987 (Stb. 1987, 404).

62 Wet van 14 juni 1989, houdende regelen inzake de waterhuishouding (Stb. 1989, 285), i.w.tr. 1 september 1989 (Stb. 1989, 339).

63 Art. 2.1 Invoeringswet Waterwet (Stb. 2009, 489 en 549).

64 Wet van 23 december 1988, tot vervanging van de Monumentenwet (Stb. 1988, 639), i.w.tr. 1 januari 1989 (Stb. 1988, 639).

65 Wet van 29 oktober 1992, tot herverdeling van het wegenbeheer over Rijk, provincies, gemeenten en waterschappen en daarmee samenhangende herziening van de financiering van de wegenzorg (Stb. 1992, 563), i.w.tr. 4 november 1992 (Stb. 1992, 563).

66 Wet van 29 augustus 1991 tot herziening van de Woningwet (Stb. 1991, 439), i.w.tr. 1 januari 1992 (Stb. 1991, 736). 


\begin{tabular}{|c|c|c|c|c|}
\hline & \multicolumn{4}{|c|}{ Omgevingsrecht } \\
\hline $\begin{array}{l}\text { Jaar } \\
\text { i.w.tr. } \\
\text { (vervallen) }\end{array}$ & Milieu & $\begin{array}{l}\text { Ruimtelijke } \\
\text { ordening }\end{array}$ & Water & Natuur \\
\hline 1993 & Wet milieubeheer ${ }^{67}$ & & & \\
\hline 1993 & Wet luchtvaart ${ }^{68}$ & & & \\
\hline 1994 & & Tracéwet $^{69}$ & & \\
\hline $\begin{array}{l}1994 \\
(2006)\end{array}$ & $\begin{array}{l}\text { Wet verplaatsing } \\
\text { mestproductie }^{70} \\
+1-1-2006^{71}\end{array}$ & & & \\
\hline 1995 & $\begin{array}{l}\text { Wet belastingen op } \\
\text { milieugrondslag }\end{array}$ & & & \\
\hline $\begin{array}{l}1995 \\
(2009)\end{array}$ & & & $\begin{array}{l}\text { Deltawet grote } \\
\text { rivieren } \\
+28-09-2005^{74}\end{array}$ & \\
\hline 1996 & Meststoffenwet ${ }^{75}$ & & & \\
\hline $\begin{array}{l}1996 \\
(2009)\end{array}$ & & & $\begin{array}{l}\text { Wet op de } \\
\text { waterkering }{ }^{76} \\
+22-12-2009^{77}\end{array}$ & \\
\hline
\end{tabular}

67 Wet van 13 juni 1979, houdende regelen met betrekking tot een aantal algemene onderwerpen op het gebied van de milieuhygiëne (Stb. 1992, 414 en 415, Stb. 1993, 31), i.w.tr. 1 maart 1993 (Stb. 1993, 59).

68 Wet van 18 juni 1992, houdende algemene regeling met betrekking tot het luchtverkeer (Stb. 1992, 368), i.w.tr. 1 januari 1993 (Stb. 1992, 726).

69 Wet van 16 september 1993, houdende regels voor de besluitvorming met betrekking tot de aanleg of wijziging van hoofdwegen, van landelijke railwegen en van hoofdvaarwegen (Stb. 1993, 582 en 690), i.w.tr. 1 januari 1994 (Stb. 1993, 614 en 693).

70 Wet van 2 december 1993, houdende regelen inzake het verplaatsen van de productie van dierlijke meststoffen (Stb. 1993, 686), i.w.tr. 1 januari 1994 (Stb. 1993, 771)

71 Art. III Wet van 15 september 2005 tot wijziging van de Meststoffenwet en intrekking van de Wet verplaatsing mestproductie en de Wet herstructurering varkenshouderij (vereenvoudiging productierechten) (Stb. 2005, 480 en 562).

72 Wet van 23 december 1994, houdende vaststelling van de Wet belastingen op milieugrondslag (Stb. 1994, 923), i.w.tr. 1 januari 1995 (Stb. 1994, 949).

73 Wet van 13 april 1995, houdende een bijzondere voorziening voor de versnelde uitvoering van werken tot versterking van enige dijkvakken langs de Rijn en zijn zijtakken en langs de bedijkte Maas, alsmede van werken tot aanleg van kaden langs de onbedijkte Maas en langs een gedeelte van de Rijksweg A2 (Stb. 1995, 210), i.w.tr. 21 april 1995 (Stb. 1995, 210).

74 Art. IV Wet van 28 april 2005 tot wijziging van de Wet op de waterkering en intrekking van de Deltawet grote rivieren, de Deltawet, de Deltaschadewet, de Wet schade oesterkwekers, de Vergunningwet Westerschelde, de Zuiderzeewet en de Zuiderzeesteunwet, Stb. 2005, 275 en 461.

75 Wet van 27 november 1986, houdende regelen inzake het verhandelen van meststoffen en de afvoer van mestoverschotten (Stb. 1986, 698), i.w.tr. 19 december 1986 (Stb. 1996, 520).

76 Wet van 21 december 1995, houdende algemene regels ter verzekering van de beveiliging door waterkeringen tegen overstromingen door het buitenwater en regeling van enkele daarmee verband houdende aangelegenheden (Stb. 1983, 683), i.w.tr. 15 januari 1996 (Stb. 1986, 191).

77 Art. 2.1 Invoeringswet Waterwet (Stb. 2009, 489 en 549). 


\begin{tabular}{|c|c|c|c|c|}
\hline & \multicolumn{4}{|c|}{ Omgevingsrecht } \\
\hline $\begin{array}{l}\text { Jaar } \\
\text { i.w.tr. } \\
\text { (vervallen) }\end{array}$ & Milieu & $\begin{array}{l}\text { Ruimtelijke } \\
\text { ordening }\end{array}$ & Water & Natuur \\
\hline 1996 & $\begin{array}{l}\text { Wet vervoer gevaar- } \\
\text { lijke stoffen }{ }^{78}\end{array}$ & & & \\
\hline $\begin{array}{l}1997 \\
(2012)\end{array}$ & $\begin{array}{l}\text { Wet op de VROM- } \\
\text { raad79 }^{79} \\
+11-2-2012^{80}\end{array}$ & & & \\
\hline $\begin{array}{l}1997 \\
(2012)\end{array}$ & & $\begin{array}{l}\text { Wet op de Raad } \\
\text { voor het landelijk } \\
\text { gebied }^{81} \\
+11-2-2012^{82}\end{array}$ & & \\
\hline 1997 & Wet op het RIVM ${ }^{83}$ & & & \\
\hline $\begin{array}{l}1997 \\
(2005)\end{array}$ & & & $\begin{array}{l}\text { Vergunningwet } \\
\text { Westerschelde }^{84} \\
+28-09-2005^{85}\end{array}$ & \\
\hline 1997 & & & $\begin{array}{l}\text { Wet beheer } \\
\text { rijkswaterstaats- } \\
\text { werken }^{86}\end{array}$ & \\
\hline $\begin{array}{l}1998 \\
(2006)\end{array}$ & $\begin{array}{l}\text { Wet herstructurering } \\
\text { varkenshouderij } \\
+1-1-2006^{88}\end{array}$ & & & \\
\hline
\end{tabular}

78 Wet van 12 oktober 1995, houdende regels voor het vervoer van gevaarlijke stoffen $($ Stb. 1995, 525), i.w.tr. 1 augustus 1996 (Stb. 1996, 297).

79 Wet van 10 oktober 1996 tot instelling van de Raad voor Volkshuisvesting, Ruimtelijke Ordening en Milieubeheer (Wet op de VROM-raad) (Stb. 1996, 551), i.w.tr. 1 januari 1997 (Stb. 1996, 551).

80 Art. 4 Wet van 19 januari 2012 inzake instelling van de Raad voor de leefomgeving en infrastructuur (Wet Raad voor de leefomgeving en infrastructuur) (Stb. 2012, 35).

81 Wet van 10 oktober 1996 tot instelling van een vast college van advies van het Rijk op het terrein van het landelijk gebied (Wet op de raad voor het landelijk gebied) (Stb. 1924, 307), i.w.tr. 1 januari 1997 (Stb. 1924, 307).

82 Art. 4 Wet van 19 januari 2012 inzake instelling van de Raad voor de leefomgeving en infrastructuur (Wet Raad voor de leefomgeving en infrastructuur) (Stb. 2012, 35).

83 Wet van 21 oktober 1996, houdende regeling van de takuitoefening door het RIVM (Wet op het RIVM) (Stb. 1996, 560), i.w.tr. 1 maart 1997 (Stb. 1997, 101).

84 Wet van 18 juni 1997, houdende bepalingen in verband met het uitvoeren van baggerwerken en het storten van baggerspecie voor de verruiming en het onderhoud van de vaarweg in de Westerschelde door het Vlaams Gewest (Vergunningwet Westerschelde) (Stb. 1997, 258), i.w.tr. 27 juni 1997 (Stb. 1997, 258).

85 Art. VIII Wet van 28 april 2005 tot wijziging van de Wet op de waterkering en intrekking van de Deltawet grote rivieren, de Deltawet, de Deltaschadewet, de Wet schade oesterkwekers, de Vergunningwet Westerschelde, de Zuiderzeewet en de Zuiderzeesteunwet, Stb. 2005, 275 en 461.

86 Wet van 14 november, houdende vaststelling van bepalingen betreffende waterstaatswerken in beheer bij het Rijk (Wet beheer rijkswaterstaatswerken) (Stb. 1996, 645), i.w.tr. 1 juli 1997 (Stb. 1996, 646).

87 Wet van 9 april 1998, houdende regels inzake een stelsel van varkensrechten en een heffing ter zake van het houden van varkens (Wet herstructurering varkenshouderij), (Stb. 1998, 236), i.w.tr. 1 september 1998 (Stb. 1998, 237).

88 Art. II Wet van 15 september 2005 tot wijziging van de Meststoffenwet en intrekking van de Wet verplaatsing mestproductie en de Wet herstructurering varkenshouderij (vereenvoudiging productierechten) (Stb. 2005, 480 en 562). 


\begin{tabular}{|c|c|c|c|c|}
\hline & \multicolumn{4}{|c|}{ Omgevingsrecht } \\
\hline $\begin{array}{l}\text { Jaar } \\
\text { i.w.tr. } \\
\text { (vervallen) }\end{array}$ & Milieu & $\begin{array}{l}\text { Ruimtelijke } \\
\text { ordening }\end{array}$ & Water & Natuur \\
\hline 1998 & & $\begin{array}{l}\text { Elektriciteitswet } \\
1998^{89}\end{array}$ & & \\
\hline 1998 & & $\begin{array}{l}\text { Planwet verkeer } \\
\text { en vervoer }{ }^{90}\end{array}$ & & \\
\hline 1998 & & & $\begin{array}{l}\text { Wet havenstaat- } \\
\text { controle }\end{array}$ & \\
\hline $\begin{array}{l}1999 \\
(2006)\end{array}$ & $\begin{array}{l}\text { Experimentenwet Stad } \\
\text { en Milieu }{ }^{92} \\
+1-2-2006^{93}\end{array}$ & & & \\
\hline 1999 & & & & $\begin{array}{l}\text { Flora- en } \\
\text { faunawet }^{94}\end{array}$ \\
\hline $\begin{array}{l}2000 \\
(2011)\end{array}$ & & $\begin{array}{l}\text { Wet stedelijke } \\
\text { vernieuwing }{ }^{95} \\
+28-04-2011 \text { met } \\
\text { terugwerkende } \\
\text { kracht tot en met } \\
1-1-2011^{96}\end{array}$ & & \\
\hline 2000 & & Gaswet $^{97}$ & & \\
\hline 2001 & & & & $\begin{array}{l}\text { Wet bescherming } \\
\text { Antarctica }^{98}\end{array}$ \\
\hline
\end{tabular}

89 Wet van 2 juli 1998, houdende regels met betrekking tot de productie, het transport en de levering van elektriciteit (Elektriciteitswet 1998) (Stb. 1998, 427), 2 juli 1998 (Stb. 1998, 427).

90 Wet van 25 mei 1998, houdende regels inzake plannen op het terrein van het verkeer en het vervoer (Planwet verkeer en vervoer) (Stb. 1998, 423), i.w.tr. 17 juli 1998 (Stb. 1998, 424).

91 Wet van 6 november 1997, houdende regels betreffende het toezicht aan boord van schepen onder buitenlandse vlag in Nederlandse havens op de naleving van internationale voorschriften op het gebied van de veiligheid, voorkoming van verontreiniging en leef- en werkomstandigheden (Wet havenstaatcontrole) (Stb. 1997, 557), i.w.tr. 1 juni 1998 (Stb. 1998, 296).

92 Wet van 26 november 1998, houdende regels over experimenten inzake zuinig en doelmatig ruimtegebruik en optimale leefkwaliteit in stedelijk gebied (Experimentenwet Stad en Milieu) (Stb. 1998, 684), i.w.tr. 1 januari 1999 (Stb. 1998, 732).

93 Art. 24 lid 1 Wet van 19 januari 2006, houdende regels met betrekking tot zuinig en doelmatig ruimtegebruik en optimale leefomgevingskwaliteit in stedelijk en landelijk gebied en met betrekking tot coördinatie van procedures (Stb. 2006, 37 en 38).

94 Wet van 25 mei 1998, houdende regels ter bescherming van in het wild levende planten- en diersoorten (Flora- en faunawet) (Stb. 1998, 402), i.w.tr. 2 juli 1999 (Stb. 1999, 264).

95 Wet van 15 november 2000 ter stimulering van integrale stedelijke vernieuwing (Wet stedelijke vernieuwing) (Stb. 2000, 504), i.w.tr. 1 december 2000 (Stb. 2000, 505).

96 Art. I Wet van 7 april 2011 tot intrekking van de Wet stedelijke vernieuwing in verband met de decentralisatie van het investeringsbudget stedelijke vernieuwing (Intrekkingswet Wet stedelijke vernieuwing) (Stb. 2011, 190).

97 Wet van 22 juni 2000, houdende regels omtrent het transport en de levering van gas (Gaswet) (Stb. 2000, 305), i.w.tr. 10 augustus 2000 (Stb. 2000, 318).

98 Wet van 5 maart 1998, houdende regels ter bescherming van het Antarctisch milieu ter uitvoering van het Protocol betreffende milieubescherming bij het Verdrag inzake Antarctica (Wet bescherming Antarctica) (Stb. 1993, 220), i.w.tr. 1 april 2001 (Stb. 2000, 444). 


\begin{tabular}{|c|c|c|c|c|}
\hline & \multicolumn{4}{|c|}{ Omgevingsrecht } \\
\hline $\begin{array}{l}\text { Jaar } \\
\text { i.w.tr. } \\
\text { (vervallen) }\end{array}$ & Milieu & $\begin{array}{l}\text { Ruimtelijke } \\
\text { ordening }\end{array}$ & Water & Natuur \\
\hline 2002 & $\begin{array}{l}\text { Wet ammoniak en } \\
\text { veehouderij }\end{array}$ & & & \\
\hline 2002 & & $\begin{array}{l}\text { Wet bereikbaar- } \\
\text { heid en mobili- } \\
\text { teit }^{100}\end{array}$ & & \\
\hline 2003 & & $\begin{array}{l}\text { Spoedwet wegver- } \\
\text { breding }^{101}\end{array}$ & & \\
\hline 2003 & Mijnbouwwet $^{102}$ & & & \\
\hline 2004 & & $\begin{array}{l}\text { Wet kabelbaanin- } \\
\text { stallaties }^{103}\end{array}$ & & \\
\hline 2004 & & Spoorwegwet ${ }^{104}$ & & \\
\hline 2005 & & & & $\begin{array}{l}\text { Natuurbescher- } \\
\text { mingswet } \\
1998^{105}\end{array}$ \\
\hline 2006 & $\begin{array}{l}\text { Interimwet stad- en } \\
\text { milieubenadering }{ }^{106}\end{array}$ & & & \\
\hline 2006 & & $\begin{array}{l}\text { Wet aanvullende } \\
\text { regels wegtun- } \\
\text { nels }^{107}\end{array}$ & & \\
\hline 2007 & & $\begin{array}{l}\text { Wet inrichting } \\
\text { landelijk gebied }^{108}\end{array}$ & & \\
\hline
\end{tabular}

99 Wet van 31 januari 2002, houdende regels inzake ammoniakemissie uit tot veehouderijen behorende dierenverblijven (Wet ammoniak en veehouderij) (Stb. 2002, 93), i.w.tr. 8 mei 2002 (Stb. 2002, 207).

100 Wet van 4 juli 2002, houdende regels voor het heffen van mobiliteitstarieven ter zake van het rijden op de weg met een motorrijtuig en de ondersteuning van regionale mobiliteitsfondsen (Wet bereikbaarheid en mobiliteit) (Stb. 2002, 406), i.w.tr. 1 november 2002 (Stb. 2002, 523).

101 Wet van 2 juni 2003, houdende regels ter bespoediging en vereenvoudiging van procedures met het oog op het zo spoedig mogelijk vergroten van de capaciteit van een aantal hoofdwegen door middel van een betere benutting en verbreding van die wegen (Spoedwet wegverbreding) (Stb. 2003, 256), i.w.tr. 25 juni 2003 (Stb. 2003, 256).

102 Wet van 31 oktober 2002, houdende regels met betrekking tot het onderzoek naar en het winnen van delfstoffen en met betrekking tot met de mijnbouw verwante activiteiten (Mijnbouwwet) (Stb. 2002, 542), i.w.tr. 1 januari 2003 (Stb. 2002, 603).

103 Wet van 5 februari 2004, houdende regels met betrekking tot de productie, de keuring en de exploitatie van kabelbaaninstallaties voor personenvervoer (Wet kabelbaaninstallaties) (Stb. 2004, 73), i.w.tr. 23 maart 2004 (Stb. 2004, 73).

104 Wet van 23 april 2003, houdende nieuwe algemene regels over de aanleg, het beheer, de toegankelijkheid en het gebruik van spoorwegen alsmede over het verkeer over spoorwegen (Spoorwegwet) (Stb. 2003, 264), i.w.tr. 31 december 2004 (Stb. 2004, 723).

105 Wet van 25 mei 1998, houdende nieuwe regelen ter bescherming van natuur en landschap (Natuurbeschermingswet 1998) (Stb. 1998, 403), gedeeltelijke i.w.tr. 22 januari 1999 (Stb. 1999, 15).

106 Wet van 19 januari 2006, houdende regels met betrekking tot zuinig en doelmatig ruimtegebruik en optimale leefomgevingskwaliteit in stedelijk en landelijk gebied en met betrekking tot coördinatie van procedures (Interimwet stad-en-milieubenadering) (Stb. 2006, 37), i.w.tr. 1 februari 2006 (Stb. 2006, 38). Deze wet zal op 1 januari 2014 vervallen (art. 3.4 onder H Stb. 2010, 135). 


\begin{tabular}{|c|c|c|c|c|}
\hline & \multicolumn{4}{|c|}{ Omgevingsrecht } \\
\hline $\begin{array}{l}\text { Jaar } \\
\text { i.w.tr. } \\
\text { (vervallen) }\end{array}$ & Milieu & $\begin{array}{l}\text { Ruimtelijke } \\
\text { ordening }\end{array}$ & Water & Natuur \\
\hline 2007 & & $\begin{array}{l}\text { Reconstructiewet } \\
\text { concentratiegebie- } \\
\text { den }^{109}\end{array}$ & & \\
\hline 2007 & $\begin{array}{l}\text { Wet geurhinder en } \\
\text { veehouderijij }{ }^{110}\end{array}$ & & & \\
\hline 2007 & $\begin{array}{l}\text { Wet kenbaarheid } \\
\text { publiekrechtelijke } \\
\text { beperkingen onroe- } \\
\text { rende zaken }{ }^{111}\end{array}$ & & & \\
\hline 2008 & & $\begin{array}{l}\text { Wet ruimtelijke } \\
\text { ordening }^{112}\end{array}$ & & \\
\hline 2009 & & & Waterwet ${ }^{113}$ & \\
\hline 2010 & Wabo ${ }^{114}$ & & & \\
\hline 2010 & & $\begin{array}{l}\text { Crisis- en } \\
\text { herstelwet }^{115}\end{array}$ & & \\
\hline 2010 & & & & $\begin{array}{l}\text { Wet grondslagen } \\
\text { natuurbeheer- en } \\
\text { bescherming } \\
\text { BES }^{116}\end{array}$ \\
\hline
\end{tabular}

107 Wet van 2 februari 2006, houdende regels met betrekking tot de veiligheid van voor het wegverkeer toegankelijke tunnels (Wet aanvullende regels veiligheid wegtunnels) (Stb. 2006, 134), i.w.tr. 25 mei 2006 (Stb. 2006, 249).

108 Wet van 7 december 2006, houdende regels inzake de inrichting van het landelijke gebied (Wet inrichting landelijk gebied) (Stb. 1983, 683), i.w.tr. 15 april 1986 (Stb. 1986, 191).

109 Wet van 31 januari 2002, houdende regels inzake de reconstructie van de concentratiegebieden (Reconstructiewet concentratiegebieden) (Stb. 2006, 666), i.w.tr. 1 juli 2007 (Stb. 2006, 667).

110 Wet van 5 oktober 2006, houdende regels inzake geurhinder vanwege tot veehouderijen behorende dierenverblijven (Wet geurhinder en veehouderij) (Stb. 2006, 531), i.w.tr. 1 januari 2007 (Stb. 2006 671).

111 Wet van 17 juni 2004, houdende regels ter vergroting van de kenbaarheid van publiekrechtelijke beperkingen ten aanzien van onroerende zaken (Wet kenbaarheid publiekrechtelijke beperkingen onroerende zaken) (Stb. 2004, 331), i.w.tr. 1 juli 2007 (Stb. 2007, 219).

112 Wet van 20 oktober 2006, houdende nieuwe regels omtrent de ruimtelijke ordening (Wet ruimtelijke ordening) (Stb. 2006, 566), i.w.tr. 1 juli 2008 (Stb. 2007, 227)

113 Wet van 29 januari 2009, houdende regels met betrekking tot het beheer en gebruik van watersystemen (Waterwet), Stb. 2009, 107, i.w.tr. 22 december 2009 (Stb. 2009, 549).

114 Wet van 6 november 2008, houdende regels inzake een vergunningstelsel met betrekking tot activiteiten die van invloed zijn op de fysieke leefomgeving en inzake handhaving van regelingen op het gebied van de fysieke leefomgeving (Wet algemene bepalingen omgevingsrecht) (Stb. 2008, 496), i.w.tr. 1 oktober 2010 (Stb. 2010, 231).

115 Wet van 18 maart 2010, houdende regels met betrekking tot versnelde ontwikkeling en verwezenlijking van ruimtelijke en infrastructurele projecten (Crisis- en herstelwet) (Stb. 2010, 135), i.w.tr. 31 maart 2010 (Stb. 2010, 135, 136 en 137).

116 Wet grondslagen natuurbeheer- en bescherming BES (Stb. 2010, 565), i.w.tr. 10 oktober 2010 (Stb. 2010, 389). 


\begin{tabular}{|c|c|c|c|c|}
\hline & \multicolumn{4}{|c|}{ Omgevingsrecht } \\
\hline $\begin{array}{l}\text { Jaar } \\
\text { i.w.tr. } \\
\text { (vervallen) }\end{array}$ & Milieu & $\begin{array}{l}\text { Ruimtelijke } \\
\text { ordening }\end{array}$ & Water & Natuur \\
\hline 2011 & $\begin{array}{l}\text { Wet implementatie } \\
\text { EG-richtlijnen } \\
\text { energie-efficiëntie }\end{array}$ & & & \\
\hline 2012 & & $\begin{array}{l}\text { Wet Raad voor de } \\
\text { leefomgeving en } \\
\text { infrastructuur }\end{array}$ & & \\
\hline
\end{tabular}

117 Wet van 26 februari 2011, houdende regels omtrent energie-efficiëntie (Wet implementatie EG-richtlijnen energie-efficiëntie) (Stb. 2011, 114), i.w.tr. 5 maart 2011 (Stb. 2011, 117).

118 Wet van 19 januari 2012 inzake instelling van de Raad voor de leefomgeving en infrastructuur (Wet Raad voor de leefomgeving en infrastructuur) (Stb. 2012, 35), i.w.tr. 11 februari 2012 (Stb. 35). 


\section{Bijlage 2 Inhoudstafel Voorontwerp Decreet Milieubeleid Vlaamse Gewest ${ }^{1}$}

\section{Deel 1. Inleidende bepalingen}

Titel 1. Toepassingsgebied en begrippen

Titel 2. Doelstellingen en beginselen van het milieubeleid

Deel 2. Besturen en adviesorganen betrokken bij het milieubeleid

Titel 1. Besturen ${ }^{2}$

Hoofdstuk 1. De Vlaamse Milieumaatschappij

Hoofdstuk 2. De openbare Afvalstoffenmaatschappij voor het Vlaamse Gewest

\section{Deel 3. Vrije toegang tot milieu-informatie}

Enige titel. Vrije toegang tot milieu-informatie

Hoofdstuk 1. Algemene bepalingen

Hoofdstuk 2. Passieve openbaarheid van milieu-informatie

Hoofdstuk 3. Slotbepalingen

\section{Deel 4. Besluitvorming}

Titel 1. Milieuplanning

Titel 2. Milieukwaliteitsnormen

Titel 3. Milieuhygiënische normen

Titel 4. Algemene, sectorale en integrale voorwaarden

Titel 5. Milieu-effect- en veiligheidsrapportage

Titel 6. Vergunningen en meldingsattesten

Titel 7. Milieubeleidsovereenkomsten

\section{Deel 5. Economische en financiële maatregelen}

Titel 1. Milieuheffingen

Titel 2. Milieusubsidies

\footnotetext{
Commissie Bocken, Voorontwerp Decreet Milieubeleid 1995, p. XIX-XXIV.

De delen $2,3,6,8,10,12$ en 13 omvatten slechts één titel. Teinde in die gevallen wat meer informatie over de inhoud van die delen te geven, zijn ook de hoofdstukken vermeld; deel 8 kent geen hoofdstuk(ken).
} 


\section{Deel 6. Bedrijfsinterne milieuzorg}

Enige titel. Bedrijfsinterne milieuzorg

Hoofdstuk 1. De milieucoördinator

Hoofdstuk 2. De milieu-audit

Hoofdstuk 3. Meet- en registratieverplichtingen

Hoofdstuk 4. Milieujaarverslag

Hoofdstuk 5. Bedrijfsbeleid ter voorkoming van zware ongevallen en ter beperking van de gevolgen ervan voor mens en milieu

\section{Deel 7. Handhaving}

Titel 1. Toezichtsbepalingen

Titel 2. Administratieve sancties

Titel 3. Strafsancties

Titel 4. Privaatrechtelijke verbodsactie

Titel 5. Saneringsprojecten

\section{Deel 8. Veiligheidsmaatregelen}

Enige titel. Veiligheidsmaatregelen

\section{Deel 9. Herstel van schade door milieuverontreiniging}

Titel 1. Aansprakelijkheid en financiële zekerheden

Titel 2. Vergoeding van schade door het Vlaamse Gewest ten laste van het Fonds voor preventie en sanering inzake leefmilieu en natuur

Titel 3. Borgsommen

Titel 4. Waarborgkas milieuschade

\section{Deel 10. Water}

Hoofdstuk 1. Inleidende bepalingen

Hoofdstuk 2. Toepassingsgebied

Hoofdstuk 3. Doelstelling

Hoofdstuk 4. Kwaliteit van de oppervlaktewateren

Hoofdstuk 5. Bescherming van de oppervlaktewateren tegen verontreiniging

Hoofdstuk 6. Gebruiksnormen

Hoofdstuk 7. Inleidende bepalingen

\section{Deel 11. Bodem}

Titel 1. Bodembescherming

Titel 2. Bodemsanering 
Deel 12. Afvalstoffen

Hoofdstuk 1. Inleidende bepalingen

Hoofdstuk 2. Doelstellingen van het afvalstoffenbeleid

Hoofdstuk 3. Preventie, vermindering, hergebruik en terugwinning van afvalstoffen

Hoofdstuk 4. Beheer en verwijdering van afvalstoffen

Hoofdstuk 5. Invoer en uitvoer van afvalstoffen

Hoofdstuk 6. Sectorale uitvoeringsplannen

\section{Deel 13. Geluid}

Hoofdstuk 1. Definities

Hoofdstuk 2. Doelstelling van het geluidhinderstelsel

Hoofdstuk 3. Milieukwaliteitsnormen

Hoofdstuk 4. Bronnencontrole 



\section{Bijlage 3 Inhaltsverzeichnis Umweltgesetz- buch (UGB-KomE) ${ }^{1}$}

\section{ALLGEMEINER TEIL}

\section{Kapittel: Algemeine Vorschriften}

1. Abschnitt: Zweck des Gesetzbuches, Begriffsbestimmungen

2. Abschnitt: Grundlagen des Umweltschutzes

3. Abschnitt: Recht- und Regelsetzung

4. Abschnitt: Beteiligung von Verbänden

5. Abschnitt: Rechtsschutz

6. Abschnitt: Unwelpflichtigkeit der öffentlichen Verwaltung

7. Abschnitt: Organisation und Zuständigkeiten

8. Abschnitt: Ordnungswidrigkeiten

\section{Kapittel: Planung}

1. Abschnitt: Algemeine Vorschrifte

2. Abschnitt: Umwelgrundlagenplanung

3. Abschnitt: Umweltverträglichkeitsprüfung bei Plänen und Programmen

\section{Kapittel: Vorhaben}

1. Abschnitt: Allgemeine Vorschriften

2. Abschnitt: Gebundene Vorhabengenehmigung

3. Abschnitt: Planerische Vorhabegenehmigung

4. Abschnitt: Einfache Vorhabengenehmigung

5. Abschnitt: Umweltverträglichkeitsprüfung bei vorgelagerten Verfahren und sonstigen Vorhaben

6. Abschnitt: Gemeinsame Vorschriften

\section{Kapittel: Produkte}

1. Abschnitt: Allgemeine Vorschriften

2. Abschnitt: Pflichten der Hersteller, Vertreiber und Verwender

3. Abschnitt: Umweltsiegel

4. Abschnitt: Ordnungswidrigkeiten

1 Bundesministerium für Umwelt c.a., Umweltgesetzbuch (UGB-KomE) 1998, p. 9-31. 


\section{Kapittel: Eingreifende Maßnahmen und Überwachung}

1. Abschnitt: Eingreifende Maßnahmen

2. Abschnitt: Überwachung

3. Abschnitt: Ordnungswidrigkeiten

6. Kapittel: Betrieblicher Umweltschutz, Umwelthaftung und sonstige ökonomische Instrumente

1. Abschnitt: Betrieblicher Umweltschutz

2. Abschnitt: Umwelthaftung

3. Abschnitt: Umweltabgaben

4. Abschnitt: Umweltsubventionen

5. Abschnitt: Kompensation, Benutzungsvorteile und Mitbenutzung

6. Abschnitt: Ordnungswidrigkeiten

\section{Kapittel: Umweltinformation}

1. Abschnitt: Staatliche Umweltinformation

2. Abschnitt: Zugang zu Umweltinformationen

3. Abschnitt: Geheimhaltung

4. Abschnitt: Kommissionen für den Informationszugang

\section{Kapittel: Grenzüberschreitender Umweltschutz}

1. Abschnitt: Allgemeine Vorschriften

2. Abschnitt: Verfahren bei grenzüberschreitenden Umweltauswirkungen

3. Abschnitt: Durchführung von Vorhaben außerhalb des Geltungsbereichs dieses Gesetzbuches

4. Abschnitt: Aus- und Einfuhr von Produkten

5. Abschnitt: Ordnungswidrigkeiten

\section{BESONDERER TEIL}

\section{Kapittel: Naturschutz, Landschaftspflege und Waldschutz}

1. Abschnitt: Allgemeine Vorschriften des Naturschutzes und der Landschaftspflege

2. Abschnitt: Allgemeiner Naturhaushaltsschutz

3. Abschnitt: Biotopschutz und Besonderer Flächenschutz

4. Abschnitt: Schutz wildlebender Tiere und Pflanzen

5. Abschnitt: Waldschutz

6. Abschnitt: Enteignung, Entschädigung und Härteausgleich

7. Abschnitt: Gemeinsame Vorschriften 


\section{Kapittel: Bodenschutz}

1. Abschnitt: Allgemeine Vorschriften

2. Abschnitt: Bodenertragsnutzung

3. Abschnitt: Abbau von Bodemschätzen

4. Abschnitt: Überwachung der Bodenbeschaffenheit und Vermeidiung von Bodenbeeinträchtigungen

5. Abschnitt: Sanierung von Bodenbelastungen und Rekultivierung

6. Abschnitt: Abschnitt: Ordnungswidrigkeiten

\section{Kapittel: Gewässerschutz}

1. Abschnitt: Allgemeine Vorschriften

2. Abschnitt: Genehmigung

3. Abschnitt: Oberirdische Gewässer

4. Abschnitt: Küstengewässer und Hohe See

5. Abschnitt: Grundwasser

6. Abschnitt: Gebietsbezogner Gewässerschutz

7. Abschnitt: Abwasserbeseitigung

8. Abschnitt: Anlagen zum Umgang mit wasser- und bodengefährdenden Stoffen

9. Abschnitt: Überwachung und Umweltbeauftragter

10. Abschnitt: Wassernutzungsabgaben

11. Abschnitt: Gemeinsame Vorschriften

\section{Kapittel: Immissionsschutz und Energieversorgung}

1. Abschnitt: Allgemeine Vorschriften zum Immissionsschutz

2. Abschnitt: Anlagenbezogener Immissionsschutz

3. Abschnitt: Verkehrsbezogener Immissionsschutz

4. Abschnitt: Gebietsbezogener Immissionsschutz

5. Abschnitt: Energieversorgung und Energienutzung

6. Abschnitt: Ordnungswidrigkeiten

\section{Kapittel: Kernenergie und Strahlenschutz}

1. Abschnitt: Allgemeine Vorschriften

2. Abschnitt: Genehmigung und Überwachung

3. Abschnitt: Strahlenschutz

4. Abschnitt: Haftung und Deckungsvorsorge

5. Abschnitt: Ordnungswidrigkeiten 


\section{Kapittel: Verkehrsanlagen und Leitungsanlagen}

1. Abschnitt: Verkehrsanlagen

2. Abschnitt: Leitungsanlagen

\section{Kapittel: Gentechnik und sonstige Biotechnik}

1. Abschnitt: Allgemeine Vorschriften zur Gentchnik

2. Abschnitt: Gentechnische Arbeiten im geschlossenen System

3. Abschnitt: Freisetzung von gentechnisch veränderten Organismen

4. Abschnitt: Inverkehrbringen von gentechnischen Produkten

5. Abschnitt: Anforderungen an sonstige Biotechnik

6. Abschnitt: Gemeinsame Vorschriften

\section{Kapittel: Gefährliche Stoffe}

1. Abschnitt: Allgemeine Vorschriften

2. Abschnitt: Anmeldung neuer Stoffe

3. Abschnitt: Einstufung, Verpackung und Kenzeichnung von gefährlichen Stoffen, Zubereitungen und Erzeugnissen

4. Abschnitt: Mitteilungspflichten

5. Abschnitt: Schutz von Beschäftigten

6. Abschnitt: Guter Laborpraxis

7. Abschnitt: Verfahren und Organisation

8. Abschnitt: Pflanzenschutzmittel

9. Abschnitt: Biozide

10. Abschnitt: Wasch- und Reinigungsmittel

11. Abschnitt: Düngemittel

12. Abschnitt: Beförderung gefährlicher Güter

13. Abschnitt: Ordnungswidrigkeiten

14. Abschnitt: Übergangsregelungen

\section{Kapittel: Abfallwirtschaft}

1. Abschnitt: Allgemeine Vorschriften

2. Abschnitt: Abfallwirtschaftliche Pflichten

3. Abschnitt: Ordnung und Planung der Entsorgung

4. Abschnitt: Genehmigung und Stillegung von Abfalldeponien

5. Abschnitt: Überwachung und Umweltbeauftragter

6. Abschnitt: Verbringung von Abfällen

7. Abschnitt: Abfallabgabe

8. Abschnitt: Gemeinsame Vorschriften 


\section{Bijlage 4: Bundeling in de Herijkingsbrief 2003}

De Herijkingsbrief ${ }^{1}$ bevat in het hoofdstuk Belangrijkste conclusies per deelterrein van het omgevingsrecht veel passages, die mijns inziens zien op herschikking van regelingen. Het gaat - niet limitatief - onder meer om de volgende onderdelen:

- 'Er is een proeve van een nieuw hoofdstuk 9 van de Wet milieubeheer opgesteld ter vervanging van de Wms en van bepalingen over toestellen uit andere wetten zoals de Wet inzake de luchtverontreiniging en de Wet geluidhinder.' 'Integratie van de Wms in de Wet milieubeheer wacht op de totstandkoming van de Europese wetgeving ... ${ }^{3}$

- 'In gevallen waarin regelingen betrekking hebben op dezelfde of vergelijkbare onderwerpen bevordert het samenvoegen ervan doorgaans de overzichtelijkheid en hanteerbaarheid voor de uitvoeringspraktijk (overheden, burger en bedrijf), ook wanneer er inhoudelijk weinig of niets verandert.' ${ }^{4}$

- 'Met betrekking tot houtverduurzamingsmiddelen zal één besluit worden opgesteld waarin naast het onderdeel creosoot van het besluit PAKhoudende coatings en het ontwerp-besluit koperhoudende houtverduurzamingsmiddelen, ook de bepalingen voor creosoot en carbolineum op grond van het Besluit implementatie EG-verbodsrichtlijn Wms 1998 worden meegenomen. ${ }^{5}$

- 'Het Besluit vluchtige organische stoffen en de daarbij behorende uitvoeringsregelingen zullen zo veel mogelijk worden vereenvoudigd en samengevoegd. ${ }^{6}$

- 'Met het Ministerie van VenW zal worden overlegd over de mogelijkheden tot integratie van de typekeuringsregelgeving voor motorvoertuigen, vervangingskatalysatoren en bromfietsen in het Voertuigreglement. Hiermee staan voor de gebruikers van de voorschriften (de fabrikanten en importeurs) alle voorschriften die aan voertuigen worden gesteld overzichtelijk op één plek."7

\footnotetext{
Zie ook Van den Broek, Samenvatting herijkingsbrief 2003

Ministerie van VROM, Herijkingsbrief 2003, p. 17.

Ministerie van VROM, Herijkingsbrief 2003, p. 17

Ministerie van VROM, Herijkingsbrief 2003, p. 17

Ministerie van VROM, Herijkingsbrief 2003, p. 17

Ministerie van VROM, Herijkingsbrief 2003, p. 18

Ministerie van VROM, Herijkingsbrief 2003, p. 18.
} 
- 'Daarnaast zullen verwante regelingen zo veel mogelijk worden samengevoegd om een hanteerbaarder situatie voor de uitvoeringspraktijk te krijgen. Voorbeelden daarvan zijn:

$\circ$ het samenvoegen van het Besluit in-, uit- en doorvoer radioactieve afvalstoffen en het Besluit vervoer splijtstoffen, ertsen en radioactieve stoffen, waarbij tevens wordt gekeken naar de consistentie en de toegankelijkheid van vooral het laatste besluit;

- het samenvoegen van de Regeling radionucliden bevattende aanwijsinstrumenten, de Regeling goedgekeurde ionisatie-rookmelders en de Regeling gebruiksartikelen stralingsbescherming."

- 'Bij andere mogelijkheden tot vereenvoudiging zal worden nagegaan of de daarvoor nodige tijdsinzet wel verantwoord is gezien de komende Europese regels in het kader van het nieuwe Europese stoffenbeleid.' Als voorbeeld wordt genoemd: 'het samenbrengen van verbodsregelingen met betrekking tot diverse stoffen in het Besluit implementatie EGverbodsrichtlijn Wms 1998 (...)'9

- 'De regelingen over logo's worden samengevoegd, evenals die over voertuigen. ${ }^{, 10}$

- 'De ongeveer 15 amvb's op grond van artikel $8.40 \mathrm{Wm}$ (die voor categorieën bedrijven de vergunningplicht vervangen en exploitatievoorschriften bevatten) worden alle of groepsgewijs samengevoegd. Hierdoor kan een betere afstemming tussen de amvb's worden bereikt. Bekeken wordt in hoeverre de voorschriften voor het lozen in de bodem uit het Lozingenbesluit bodembescherming ook in de geïntegreerde amvb('s) kunnen worden opgenomen. In overleg met het Ministerie van VenW zullen algemene regels op grond van de Wet verontreiniging oppervlaktewateren waar mogelijk en doelmatig in de nieuwe algemene regels worden opgenomen, zodat de ondernemer met nog minder regelingen wordt geconfronteerd. Integratie met behoud van bevoegdheden (zoals reeds bijvoorbeeld in het Besluit glastuinbouw heeft plaatsgevonden) is daarbij uitgangspunt. ${ }^{.11}$

- 'De 19 regelingen over grenswaarden voor emissies van diverse stoffen naar water en lucht die gebaseerd zijn op de verdragen van Oslo en Parijs (OSPAR) en op EG-richtlijnen zullen worden samengevoegd tot één ministeriële regeling. De huidige regelingen zijn door hun grote aantallen onvoldoende toegankelijk. Het onderbrengen van de regelingen in één parapluregeling zal het bedrijfsleven en de bevoegde instanties veel gezoek besparen. ${ }^{12}$

\footnotetext{
Ministerie van VROM, Herijkingsbrief 2003, p. 18 en 19

Ministerie van VROM, Herijkingsbrief 2003, p. 19.

Ministerie van VROM, Herijkingsbrief 2003, p. 22

Ministerie van VROM, Herijkingsbrief 2003, p. 25.

Ministerie van VROM, Herijkingsbrief 2003, p. 26.
} 
- 'De Wet inzake de luchtverontreiniging zal worden geïntegreerd in de Wet milieubeheer. ${ }^{13}$

- 'De Wet bodembescherming zal worden ingebouwd in de Wet milieubeheer.'14

- 'Het Lozingenbesluit bodembescherming zal worden gesplitst. Regels voor lozingen vanuit Wm-inrichtingen zullen in de in de 8.40/8.44amvb's worden opgenomen (...). Voor lozingen vanuit niet-inrichtingen (voornamelijk lozingen van huishoudelijk afvalwater en lozingen op landbouwgronden) zullen in overleg met het Ministerie van VenW waar mogelijk en doelmatig integrale algemene regels voor alle lozingen (riolering, oppervlaktewater, bodem) worden opgesteld, met behoud van bevoegdheden voor de waterbeheerder. Op deze manier kan het aantal regelingen verder worden beperkt. Zo geldt dan in plaats van de drie besluiten die op dit moment betrekking hebben op lozing van huishoudelijk afvalwater, nog slechts één besluit. ${ }^{15}$

- 'Vanwege de bijzondere problematiek en het feit dat het Besluit glastuinbouw mede op de Wet verontreiniging oppervlaktewateren en de Bestrijdingsmiddelenwet is gebaseerd, zal dit besluit niet worden geïntegreerd. ${ }^{16}$

- 'Om de overzichtelijkheid en consistentie te bevorderen zal een algehele integratie van alle toelatingscriteria voor zowel bestaande als nieuwe gewasbeschermingsmiddelen plaatsvinden door samenvoeging van het Besluit uniforme beginselen gewasbeschermingsmiddelen in één besluit (....). ${ }^{17}$

- 'De Wet geluidhinder en de uitvoeringsregelgeving worden vereenvoudigd. De wet zal daarbij op korte termijn worden ingebouwd in de Wet milieubeheer (landelijke grenswaarden en richtwaarden) en de Wro (lokale afweging en kwaliteitskeuze). Luchtvaartlawaai wordt geheel via de nieuwe Wet luchtvaart geregeld. ${ }^{18}$

- 'De regelingen voor meet- en rekenvoorschriften zullen in samenhang met de Europese standaardisatie worden gebundeld. ${ }^{19}$

- 'De toestellenregelingen zullen worden gebaseerd op het nieuwe hoofdstuk stoffen en producten van de Wet milieubeheer en de uitvoeringsregelingen zullen worden gebundeld. Overwogen wordt of opname in algemene waren- of consumentenwetgeving niet nog overzichtelijker is. ${ }^{20}$

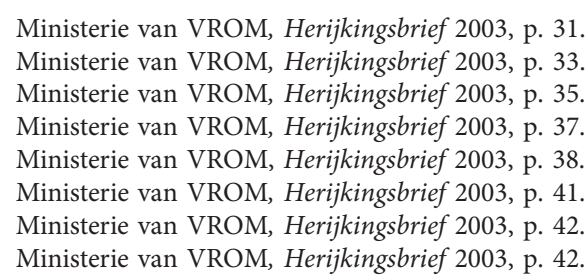


- 'Gestreefd zal worden naar overheveling van de typegoedkeuringsregelgeving voor motorvoertuigen, bromfietsen en uitlaatsystemen naar het op de Wegenverkeerswet 1994 gebaseerde Voertuigreglement, dit in samenhang met de typekeuringsregelgeving op basis van de Wet luchtverontreiniging. Op die manier zijn alle eisen voor motorvoertuigen, bromfietsen en uitlaatsystemen in één regeling voor voertuigen te vinden. ${ }^{21}$ 


\section{Bijlage 5: Interviews met wetgevingsdeskun- digen}

Functie: Wetgevingsjurist bij het Ministerie van Infrastructuur en Milieu (milieu) en juridisch adviseur bij het Instituut voor Infrastructuur, Milieu en Innovatie (IMI) te Brussel (natuur).

Relevante ervaring: Woldendorp heeft zich de afgelopen tien jaar onder meer als wetgevingsjurist bezig gehouden met de invoering van emissiehandel $\left(\mathrm{CO}_{2}\right.$ en $\mathrm{NO}_{\mathrm{x}}$ ), de implementatie van de Kaderrichtlijn water (milieukwaliteitseisen), de implementatie van REACH en de integratie van de Wet milieugevaarlijke stoffen (Wms) in de Wet milieubeheer (Wm). Bij het IMI heeft hij een ruime ervaring met de toepassing van de Vogel- en Habitatrichtlijnen bij grote infrastructuurprojecten in binnen- en buitenland. Hij heeft van 1999 tot 2001 bij de juridische afdeling van DG Milieu van de Europese Commissie gewerkt (inbreukprocedures op het terrein van milieu en natuur).

Datum interview: 15 december 2011

Interview geautoriseerd: 29 december 2011

\section{AlGEMEEN \\ 1.1. Bestaat er een opleiding voor wetgevingsjuristen?}

"Ja. Er bestaat een opleiding van twee jaar bij de Academie voor Wetgeving. Daar moeten alle nieuwe wetgevingsjuristen aan deelnemen. Men moet een praktijkopdracht maken - een regeling over een nieuw onderwerp - die dan wordt beoordeeld door mensen als Nico Verheij. De wetgevingsjuristen werken tegelijkertijd ook in de praktijk bij een van de ministeries. Ik heb zelf die opleiding niet gevolgd. Dat bestond nog niet toen ik als wetgevingsjurist werd aangesteld."

1.2. Geven de Aanwijzingen voor de regelgeving ook aanwijzingen voor bundeling van wetgeving en gelaagde wetgeving?

"Nee. De aanwijzingen geven geen antwoord op alle vragen. Zo geven ze geen antwoord op de vraag wanneer het verstandig is wetgeving te bundelen of hoe kan worden bepaald welk samenhangcriterium het beste kan worden gekozen. Dit moet de wetgevingsjurist naar eigen inzicht bepalen.” 


\section{SAMENHANG}

2.1. Heeft de wetgever veel mogelijkheden om samenhang tussen regels te creëren?

"Ja. De wetgever wil met wetgeving realiseren wat individuen elk voor zich niet zouden kunnen bereiken. De Europese wetgever kijkt wat er nodig is om bijvoorbeeld een goede toestand van de natuur of een goede watertoestand te bereiken, zoals monitoren van de huidige situatie, vaststellen van doelen waar je naartoe wilt en vervolgens het opstellen van een planmatige aanpak om de doelen te realiseren, wat dan ook weer moet worden gemonitord en geëvalueerd. Indien de doelen niet zijn gerealiseerd moeten in de volgende planperiode volgens dezelfde aanpak nieuwe maatregelen worden genomen. De richtlijn is een succes als het water uiteindelijke een goede kwaliteit heeft. In de Kaderrichtlijn water is regelgeving daarom gebundeld volgens het uiteindelijke beleidsdoel van een goede waterkwaliteit en de instrumenten die nodig zijn om dat doel te realiseren. Dat is een hele andere benadering dan de Nederlandse. Nederland heeft bijvoorbeeld bepaalde activiteiten als uitgangspunt voor regelgeving genomen. Het probleem bij milieuregelgeving is overigens dat er heel veel verschillende invalshoeken denkbaar zijn om regels te ordenen en dat vanuit al die invalshoeken ook regelgeving is opgesteld. Ik noem er een paar: Waar laten we onze afvalstoffen? Hoe beteugelen we nadelige gevolgen voor de omgeving van inrichtingen? Welke bouwstoffen mogen we toepassing in werken op de bodem? Hoe krijgen we ons water schoon? Welke eisen moeten we stellen aan het op markt brengen van chemische stoffen? Hoeveel geluid mogen bepaalde apparaten maken? Wie mogen bodemonderzoeken doen? Wanneer we vanuit al die invalshoeken naar onze omgeving kijken dan is het perspectief telkens totaal verschillend. We missen nu nog het panoramische uitzicht, dat de Omgevingswet ons hopelijk gaat bieden. Zoals we hierna nog wel zullen bespreken, zal dat naar mijn verwachting echter ook niet de Olympus worden, vanwaar af we onze omgeving kunnen aanschouwen."

\subsection{Bestaat er samenhang binnen het Europese recht?}

"Ik ben het niet eens met mensen die roepen dat de Brusselse wetgeving eigenlijk maar een ongestructureerd zootje is en dat men daar nog nooit van integratie heeft gehoord. De Europese wetgever kijkt meer per beleidsthema, zoals natuur en water of een eerlijke en vrije markt voor iedereen, en stelt daar doelen voor die moeten worden bereikt en hangt er dan vervolgens het benodigde instrumentarium aan. Voor die benadering voel ik veel. De overheid is er immers voor de burgers, om voor bepaalde zaken (beleidsthema's) te zorgen en bepaalde waarborgen voor de bescherming van de levenssfeer te bieden. Het lijkt me dan ook juist voorop te stellen wat de overheid op een bepaald terrein wil bereiken, en vervolgens aan te geven 
hoe dat moet gebeuren, om de overheid ten slotte op de bereikte en openbaar gemaakte resultaten af te rekenen."

\subsection{Is dat voor het Nederlandse recht dan anders?}

"De beleidsdoelen zijn in Nederland erg versnipperd over de verschillende wetten terechtgekomen en het is niet altijd duidelijk waar we het allemaal voor doen. Als je de regelgeving vooral op de bedrijven richt bijvoorbeeld, dan is op zich niet duidelijk wat je met de regelgeving überhaupt wilt bereiken. Wat de overheid doet, moet echter altijd door een herkenbaar doel worden gelegitimeerd, anders dient het ingrijpen achterwege te worden gelaten. Ik heb de indruk dat we in Nederland de kip en het ei wel eens verwarren. Dit blijft echter een lastig punt, want het is ook belangrijk dat de instrumenten die de overheid inzet, zijn gelegitimeerd. Niet elke methode is voor een gerechtvaardigd doel automatisch ook zelf gerechtvaardigd. Vaak zijn er in de regelgeving verschillende benaderingen denkbaar om ordening in de chaos aan te brengen. Uit het ei komt een kip, maar uit de kip komt weer een ei, dat is een beetje het probleem als we de zaken uit elkaar proberen te houden."

2.4. Krijgen we in Nederland vanwege die verschillende benadering dan geen problemen bij de omzetting van Europese regels, zoals de Kaderrichtlijn water?

"Voor oppervlaktewater valt het mee, vanwege de Waterwet, dat vind ik een mooie wet. Dat is anders voor grondwater. De overheid moet er volgens de Kaderrichtlijn water en de Grondwaterrichtlijn, een dochterrichtlijn van de Kaderrichtlijn water, voor zorgen dat het grondwater een goede kwaliteit heeft om allerlei functies te dienen en dat er ook voldoende van is. Er moet geen paalrot ontstaan, er moet drinkwater uit te winnen zijn, natuurgebieden mogen niet verdrogen, etcetera. Het Ministerie van VROM wist niet eens hoe het deze richtlijn zelf had geïmplementeerd. Er is een onderzoek uitbesteed om erachter te komen hoe dit was gedaan, want het was te veel werk om dat allemaal zelf te gaan uitzoeken. Toen kwamen er een heleboel wetten en enkele tientallen algemene maatregelen van bestuur en andere regelingen uit, die allemaal tot doel hadden bepaalde aspecten of activiteiten te reguleren, bijvoorbeeld het uitrijden van mest of het opslaan van olie in een ondergrondse tank. Daarin zat natuurlijk geen enkele samenhang. Het ministerie koerste dus niet recht op het beleidsdoel af en zat eigenlijk helemaal niet aan de knoppen van het eigen beleid. Daarentegen vereist de Kaderrichtlijn water een gestructureerde aanpak. Wat willen we met het grondwater, hoe ver zitten we nu van het doel af, als we wat moeten doen, wat gaan we dan doen en wie en hoe, werkt dat of moeten we nog wat extra doen?" 
2.5. Zoekt de Nederlandse wetgever de samenhang niet eerder in gebruikers van een wet?

"De nationale wetgever zoekt de samenhang inderdaad eerder in de gebruikers die met de wet moeten gaan werken, zoals bedrijven, en wil op hen een samenhangende benadering 'loslaten' van alles wat die van de overheid om wat voor reden ook moeten doen. Daarbij liggen dan, meer of minder zichtbaar, allerlei beleidsdoelen onzichtbaar achter de horizon verborgen, dat is vaak niet uit de wet af te lezen. Het staat natuurlijk wel in de toelichting, maar die leest na de vaststelling niemand meer. In het milieurecht is er om die reden eigenlijk altijd de kritiek geweest dat de wetten geen inhoud bevatten, er staat niet in wat het doel is van die wetten en wanneer het doel is gerealiseerd. Wat je verder ook van de Europese regelgeving vindt, dat staat er tenminste in, meteen al aan het begin."

\section{KENBAARHEID}

3.1. Moet de wetgever een eenvoudige en voor iedereen kenbare wet willen?

"Ik vraag me af of de wetgever wel een eenvoudige en voor iedereen kenbare wet wil en moet willen, omdat hij in de praktijk uiteindelijk vaak andere overwegingen toch zwaarder blijkt te wegen. Volgens mij is een wet een set van juridische afspraken over wat men in gezamenlijkheid wil, dus als daar niet iets eenvoudigs uitkomt wil men dat eigenlijk niet, even ervan uitgaande dat de wetgevingsjuristen hun vak verstaan. Dat laatste neem ik aan, bijvoorbeeld omdat ik laatst een uitspraak van hoogleraar wetgeving Wim Voermans las dat onze wetgevingsexpertise een uitstekend exportproduct zou zijn omdat Nederland daarmee internationaal veel aanzien geniet. De ingewikkeldheid is het resultaat van een wetgevingsproces waarin je met veel belangen rekening moet houden. De sociale complexiteit van het hele proces is voor het resultaat van dat proces veel bepalender dat het juridische vakwerk. Wetgeving is een enorm sociaal gebeuren. Daar is een prachtig proefschrift over verschenen, waarin dat allemaal heel overtuigend wordt uitgelegd. ${ }^{1}$ Bovendien laat de praktijk zich niet zo makkelijk in een hokje drukken, ik kom daar straks nog uitgebreider op terug. Ik ben het met je eens dat je wetgeving moet maken voor de werkelijkheid van de mensen waarvoor de wetgeving is bedoeld. En niet zoals vroeger, toen de wetten in

1 M. Hertogh en E. Westerveld, Playing with Complexity; management and organisation of large infrastructure projects, AT Osborne 2010. Woldendorp bespreekt L. Hermans en T. van der Lei, Actorenanalyses: Methoden voor een succesvol beleid of project, Amsterdam: Pearson Education Benelux 2011, waaruit volgens hem dezelfde conclusive wordt getrokken (Woldendorp, $M$ en $R$ 2012/46). 
elkaar zaten overeenkomstig de organisatie van de ministeries. Dat is niet het goede uitgangspunt. Van buiten naar binnen dus, niet andersom.”

\subsection{Kun je daar ook voorbeelden van noemen?}

"Met drie voorbeelden kan ik echter aangeven dat eenvoudige wetgeving toch vaak niet wordt gewenst, ook niet door de mensen voor wie zij is bedoeld en die natuurlijk liefst ook eenvoudige wetgeving willen. Uiteindelijk weegt voor hen toch zwaarder dat de wet voldoende rekening houdt met hun belangen en niet te veel hun vrijheid belemmert om naar eigen inzicht keuzes te maken die hen om wat voor reden ook het beste uitkomen. Dat is vaak passen en meten, omdat ze ook begrijpen dat de overheid bepaalde zaken wil realiseren en dus randvoorwaarden aan hun handelen stelt. Daar willen de meesten van ons zich ook best wel naar voegen, maar dan liefst wel op onze eigen manier, want wij hebben voor onszelf natuurlijk ook andere doelen dan alleen de beleidsdoelen van de overheid.

a. Mestboekhouding (MINAS). Dit werd super gedetailleerd geregeld. De veehouderijen realiseerden zich dat ze in het mestbeleid door de oude wetgeving werden afgerekend op forfaitaire eenheden fosfaat, zoals de hoeveelheid fosfaat die een koe per jaar uitpoept. Deze hoeveelheid was een beperkende factor voor het aantal dieren dat ze mochten houden. In werkelijkheid is de hoeveelheid fosfaat die in de mest terechtkomt, echter sterk afhankelijk van onder andere de kwaliteit veevoer en hangen de gevolgen van het mestgebruik sterk af van bijvoorbeeld de opnamecapaciteit voor fosfaat door het gewas dat wordt verbouwd. De boer kan hierdoor aan verschillende knoppen draaien om gunstiger uit te komen dan met de forfaitaire eenheden, zodat hij meer dieren kan houden zonder het milieu meer te belasten. Veel, maar niet alle, boeren wilden die mogelijkheden tot hun beschikking hebben in plaats van met forfaitaire eenheden te worden afgerekend. Dan moet natuurlijk ook wel heel precies worden nagegaan wat de balans is tussen de productie van fosfaat op het bedrijf en waar het bedrijf dat fosfaat uiteindelijk allemaal laat. Dat heette zelfs de verfijnde aanpak, waarvoor een gedetailleerde mestboekhouding moest worden bijgehouden. Dat moest natuurlijk ook allemaal 'verfijnd' worden geregeld. Uiteindelijk stond er zelfs in de wet hoeveel fosfaat er nog in een dode koe zit, die de mest nog niet heeft uitgepoept, en hoeveel fosfaat spruitjes opnemen. Ook een analyse van de kwaliteit van het gebruikte veevoer was belangrijk. Dat gaf ook allemaal aanleiding tot een uitgebreide administratie, zoals het bijhouden van alle aankoopbonnen voor het veevoer en de analyseresultaten. Maar er waren ook boeren die maar weinig dieren hadden of sowieso geen zin in een ingewikkelde boekhouding. Die wilden het bestaande eenvoudige systeem met forfaitaire eenheden houden, met als gevolg dat er uiteindelijk twee systemen in de wet stonden. Een eenvoudig systeem dat op aannames was gebaseerd (forfaitaire eenheden) en een verfijnd systeem dat zoveel mogelijk de 
werkelijkheid probeerde te benaderen. Heel ingewikkeld, maar wel tegemoetkomend aan de vraag uit de sector.

b. $\mathrm{CO}_{2}-$ en $\mathrm{NO}_{\mathrm{x}}$-emissiehandel. Een bijzondere situatie bestaat hier in de sfeer van handhaving. Gewoonlijk ga je een emissienorm van, laten we zeggen, 50, pas handhaven als je een vermoeden hebt dat er sprake is van 70 of zo. Dat is vaak niet al te ingewikkeld aan te tonen. Je hoeft niet aan te tonen dat het 50,5 is, maar dat het, alle onzekerheden in aanmerking nemend, hoe dan ook boven de 50 is. Maar bij $\mathrm{CO}_{2}$-emissiehandel is elke kilo $\mathrm{CO}_{2}$ geld waard omdat er voor alle bedrijven samen een hoeveelheid emissierechten beschikbaar is gesteld, die kleiner is dan de emissies die de bedrijven veroorzaken. Houdt een bedrijf rechten over, dan kan het die verkopen aan andere bedrijven, komt het daarentegen tekort, dan moet het rechten aankopen. Er moet dus heel precies worden vastgesteld hoeveel $\mathrm{CO}_{2}$-emissie een bedrijf heeft veroorzaakt, want dat moet allemaal door emissierechten worden gedekt. De concurrentieverhoudingen tussen de bedrijven zijn hierbij in het geding. Als bij bedrijven de indruk ontstaat dat andere bedrijven zitten te knoeien en onjuiste emissies opgeven, dan ligt al snel het hele systeem op zijn gat, want dat is gebaseerd op het vertrouwen dat het er allemaal eerlijk aan toe gaat. Bij het andere emissiehandelssysteem dat in Nederland bestaat, voor $\mathrm{NO}_{\mathrm{x}}$, is dat precies hetzelfde. Het handelssysteem voor $\mathrm{NO}_{\mathrm{x}}$ vergt 24 uur per dag monitoring om heel precies de $\mathrm{NO}_{\mathrm{x}}$-emissies vast te stellen. Dat vindt zijn weerslag in een ingewikkelde monitoringsregeling. Sowieso moest voor $\mathrm{NO}_{\mathrm{x}}$-emissiehandel met de monitoring een grote stap vooruit worden gezet, want zo precies en betrouwbaar de emissies van $\mathrm{NO}_{\mathrm{x}}$ monitoren als voor emissiehandel nodig is, dat konden we op dat moment nog helemaal niet. Het was niet nodig geweest om daar zulke hoge eisen aan te stellen. Bedrijven moeten nu uitgebreide monitoringsplannen opstellen die door het bevoegd gezag moeten worden goedgekeurd. Dat is allemaal heel gecompliceerd en gedetailleerd, dat snapt een gewoon mens echt niet. Bij het handelssysteem voor $\mathrm{CO}_{2}$ moesten juist de handelsaspecten uitgebreid worden geregeld, omdat dit systeem in de hele EU is ingevoerd en bedrijven dus overal onder dezelfde voorwaarden op de Europese markt rechten moeten kunnen kopen en verkopen. Een emissiehandelssysteem is dus alleen mogelijk met hoge uitvoeringskosten. Toch wilde de politiek dat, omdat de bedrijven dan hun eigen keuzes kunnen maken, bijvoorbeeld of zij op een bepaald moment in milieumaatregelen willen investeren om hun emissies te beperken, dan wel, al dan niet voorlopig, in plaats daarvan emissierechten willen aankopen. Uit studies was bovendien gebleken dat een emissiehandelssysteem tot de grootste emissiedaling zou leiden omdat de optimale milieu-investeringen worden gedaan. Dit betekent dus dat hier een gecompliceerd en gedetailleerd systeem met grote uitvoeringslasten wordt geaccepteerd, eenvoudigweg omdat men dit systeem politiek toch prefereert boven het bestaande systeem, dat minder flexibel voor bedrijven en minder effectief voor het milieu werd gevonden. 
c. Natuurwetgeving zou natuurlijk heel gemakkelijk kunnen zijn. De wetgever regelt gewoon dat er geen activiteiten plaats mogen vinden binnen een straal van $5 \mathrm{~km}$ vanaf een beschermd vogel- of habitatrichtlijngebied; geen wegen, geen bedrijven en al helemaal geen boerderijen. De grondwaterstand moet zijn natuurlijke peil hebben en emissies van schadelijke stoffen worden verre gehouden. Dat is heel gemakkelijk, maar alleen ... wil niemand dat. We zitten in een vol land. Dat is ook de reden dat het niet goed gaat met de natuur. Maar het is ook de reden dat we het ons niet kunnen permitteren om zoveel land rondom natuurgebieden ongebruikt te laten. We willen elke vierkante meter optimaal benutten en dat betekent dat alle wensen van potentiële gebruikers op elkaar moeten worden afgestemd, zodat het allemaal nog net kan. We willen het onderste uit de kan halen voor iedereen en dan ook nog een mooie natuur overhouden. Dan weet je al bij voorbaat - ongeacht het wetssysteem dat daarbij hoort - dat het moeilijk gaat worden. Want zelfs als de wet eenvoudig is, omdat je alleen een passende beoordeling moet maken, dan weet je dat het bij de uitvoering van de passende beoordeling passen en meten wordt. En niet alleen om alle functies überhaupt met elkaar te verenigen, maar vooral ook omdat de meningen over de feiten, de wensen, de achterliggende belangen en visies uiteenlopen. Daar moet je allemaal rekening mee houden en iedereen wil het volle pond krijgen in het eindresultaat, dus het is een ingewikkeld en tijdrovend proces om daar met z'n allen uit te komen. Niet alleen het resultaat is namelijk belangrijk, haast nog belangrijker is, zo blijkt uit onderzoek, ${ }^{2}$ het proces. Meestal lukt dat overigens nog heel aardig als je niet met $130 \mathrm{~km}$ per uur door de porseleinkast wilt razen. Ik vraag me wel eens af of de politiek dat voldoende in de gaten heeft, nu zo voortvarend allerlei grootscheepse wetgevingsoperaties worden opgetuigd om voortvarend besluiten in snel tempo te kunnen doordrukken. Dat gaat vermoed ik niet zo werken als men denkt, want uiteindelijk zal blijken dat men dat eigenlijk ook zelf niet wil. Of het gaat ertoe leiden dat bepaalde belangen of groepen worden achtergesteld.

Het is dus belangrijk wat je uitgangspunt is: kenbaarheid en eenvoud, of tegemoet komen aan in de maatschappij levende wensen, die daar vaak haaks op staan. Als het gaat om kenbaarheid is de vraag voor wie dat geldt. Voor elke persoon die je van de straat plukt? Maar ik kan me wel erin vinden dat je de kenbaarheid afmeet aan de personen die enige kennis van de wetgeving hebben.”

2 Wetenschappelijk Raad voor het Regeringsbeleid, De menselijke beslisser; over de psychologie van keuze en gedrag. W.L. Tiemeijer, Hoe mensen keuzes maken; De psychologie van het beslissen, Amsterdam University Press, ISBN 978908964302 5. Dit boek is ook te vinden op de website van de Wetenschappelijk Raad voor het Regeringsbeleid. 


\section{SAMENHANGCRITERIA}

4.1. Als met samenhang in wetssystemen wordt bedoeld: volgens bepaalde criteria geordende, met elkaar samenhangende regels, is de Wet milieubeheer dan samenhangend?

"Ik vind dat er nauwelijks samenhang is binnen de Wet milieubeheer. Er staan regels in die het milieu moeten beschermen, maar de samenhang tussen de diverse hoofdstukken is klein en vaak zelfs afwezig. Een bepaalde situatie valt nooit onder alle hoofdstukken tegelijk. Zelfs het begrippenkader is niet eens gelijk voor alle hoofdstukken, bijvoorbeeld het begrip milieu heeft een verschillende betekenis. Ik zeg altijd dat de Wet milieubeheer een ballenbak is. Daarmee bedoel ik dat alle onderwerpen die in de Wet milieubeheer worden geregeld, als losse ballen in dezelfde bak zijn gegooid. De Wet milieubeheer is de naam die als rand dient, zodat de ballen er niet uit rollen. Als je die rand weg zou nemen, zouden alle ballen zo over de vloer rollen, want niets houdt ze bij elkaar. Voor mij betekent dat dat er geen dwingende reden is om een milieuonderwerp in de Wet milieubeheer te zetten of juist niet. Als ik de Wet milieubeheer een ballenbak noem, dan kwalificeer ik het als een pragmatisch kader en niet als een dwingende ordening met interne logica."

\subsection{Is dat anders in de natuurbeschermingswetgeving?}

"Ook binnen de natuurwetgeving is er weinig samenhang. Zo staan er in de Flora- en faunawet regels over leefgebieden van beschermde dier- en plantensoorten, handel in beschermde soorten, jacht, toegestane lokmiddelen, het gebruik van een geweer, eendenkooien, het bestrijden van meeuwenoverlast, het prepareren van dieren, de gewenste wildstand en zo vallen er nog veel meer onderwerpen te noemen. Die hebben weinig met elkaar te maken, behalve dat ze over dieren gaan. Maar dan wel beschermde dieren, nuttige dieren, begeerde dieren en plaagdieren."

\subsection{Hoe komt dat?}

"Het is niet zo gemakkelijk om de zaken die geregeld moeten worden, te ordenen. Welke invalshoek kies je daarbij? Je kunt bijvoorbeeld uitgaan van de vraag of er op konijnen of vogels mag worden geschoten, dat kan dan mooi in de Flora- en faunawet worden geregeld. We hebben het er dan niet over dat je met een geweer wel op konijnen mag schieten, maar niet op mensen, dat laatste hoort duidelijk in een andere wet thuis dan de Flora- en faunawet. Het kan echter ook handig zijn om alles van het geweer in de wet bij elkaar te zetten, wie wanneer een geweer mag gebruiken, en dat kan dan beter in bijvoorbeeld de 'gewerenwet' staan. Daarin kun je dan ook regelen wie dat geweer mag kopen en waar, onder welke voorwaarden, welke 
opleiding je moet hebben om het geweer te mogen gebruiken, en alle mogelijke andere dingen waarbij het geweer centraal staat. We moeten daar dus een keuze maken hoe we het willen regelen en dan blijkt de juiste invalshoek vaak lastig te bepalen. Er wordt gewoonlijk gekeken naar de meest geschikte invalshoek, maar dat is natuurlijk een dooddoener. Bepalend is ook hoe het probleem waarvoor een regeling moet worden gemaakt, zich politiek aandient, en hoe uiteindelijk de opdracht om een regeling te gaan schrijven luidt, die bij mij op het bureau terecht komt."

4.4. Maar denkt de wetgevingsjurist er met een leeg blaadje voor zich überhaupt wel over na welk samenhangcriterium aansluit bij de werkelijkheid van de gebruiker?

"Het zou goed zijn vooraf te bedenken, welke wetgevingsjurist je bij het opstellen van wetgeving wilt betrekken en in welk stadium. Juristen verschillen en hebben ieder hun eigen (gebrek aan) capaciteiten, net als gewone mensen dus, je moet daar strategisch gebruik van maken en de aanwezige capaciteiten goed inzetten. Overigens gaat het niet alleen om juristen; bij Europese richtlijnen eigenlijk meestal niet. En waarom ook niet? Als iemand gestructureerd en logisch kan denken, is hij geschikt om mee te doen bij het opstellen van wetgeving, want juristen doen, als het goed is, ook niks anders. De een kijkt meer naar de details, de ander meer naar visie of structuur. Ik ben niet van de hemelbestormende visies, maar wel van de logische structuur.

Van belang is welk onderwerp de wetgevingsjurist krijgt. Je krijgt een bepaalde opdracht om een probleem te regelen. Het gaat mij om het bereiken van een duidelijk geformuleerd beleidsdoel. Wat is dat doel en hoe wil je dat realiseren en wat moeten de mensen doen, zowel aan de kant van de overheid als aan de kant van de burger. Meestal bedenk je niet zelf wat de reikwijdte van je wetgevingsproduct gaat worden, maar moet je het voorgelegde probleem oplossen. Er zijn al heel veel kaders gegeven, bijvoorbeeld de eisen die ter implementatie van Europese richtlijnen aan de wetgeving moeten worden gesteld, andere regels die er nu eenmaal gewoon al zijn en wat de minister wil, waarvan je ook niet zoveel hebt te vinden. De opdracht is niet om alle wetgeving in de gaten te houden en te kijken hoe de hele wetssystematiek er uit zou moeten zien nadat het nieuwe onderwerp geregeld is. Het ontbreekt gewoonlijk aan tijd om dat te doen. Het is ook niet de bedoeling om de opdracht groter te maken dan die is, zeker niet bij de implementatie van Europese richtlijnen. Je gaat niet de hele wereld er steeds bijhalen en ook niet het wiel opnieuw proberen uit te vinden."

\subsection{Waardoor wordt de aanvliegroute dan voornamelijk bepaald?}

"De opdracht bepaalt ook de aanvliegroute. Ik probeer wel veel tijd te investeren om na te denken over een logische aanvliegroute. Meestal is 
daar weinig tijd voor en dan wordt er eigenlijk in het wilde weg begonnen, heb ik wel eens de indruk. Vroeger had ik meer tijd om met anderen te praten hoe je zaken het beste zou kunnen regelen. Zo was er bij REACH eerst een idee om die verordening bij ministeriële regeling uit te voeren, want bij een verordening ligt alles toch al volledig vast en een regeling is dan op het eerste gezicht het snelst en het makkelijkst. Toen was de vraag of dat bij eerdere implementaties tot een goed resultaat had geleid. Dat bleek niet het geval, dus koos VROM toch voor een wet om het snelste resultaat te bereiken. Achteraf gezien is dat een goede keus geweest. Projecten zoals de poging van EZ om verordeningen bij ministeriële regeling uit te voeren en dit een plaatsje in de Postwet en de Elektriciteitswet te geven, ${ }^{3}$ zijn allemaal mislukt. Hoofdstuk 3 van de Wet milieubeheer over internationale zaken is er ook nooit gekomen. ${ }^{4}$ Allemaal om redenen die je in beeld zou hebben gehad als je tevoren interviews zou hebben gehouden, dan had je op je vingers kunnen natellen, dat dat niet zou gaan lukken. Dat wordt beschreven in het Tijdschrift voor Europees Recht. ${ }^{5}$ Maar dat betekent helemaal niet dat sindsdien iedereen het doet zoals wij dat bij REACH hebben gedaan. De daar gevolgde aanpak is natuurlijk ook maar in beperkte kring afgesproken. Alles heeft zijn beperkingen, je kunt niet bij alles wat je doet de hele wereld betrekken en tot een volledig afgestemde en gedragen aanpak komen. De praktisch gesproken noodzakelijkerwijs gefragmenteerde aanpak heeft zijn nadelen. Soms denk ik ook wel eens dat iedereen kennelijk het recht heeft zijn eigen wiel steeds opnieuw te mogen uitvinden."

4.6. Kun je een voorbeeld geven hoe het vinden van een aanvliegroute of samenhangcriterium werkt?

"Bij de Kaderrichtlijn water moest VROM ineens waterdoelen gaan stellen. Dat was de opdracht: implementeren van het onderdeel van de richtlijn over de vereiste waterkwaliteit. VROM was min of meer een nieuwe speler in de waterwereld, als dat ministerie zou gaan vertellen tegen Rijkswaterstaat en de waterschappen hoe het voortaan zou moeten, zou het vast helemaal fout gaan. VROM zou dan van buitenaf als een soort Marsmannetjes aan een parachute in de waterwereld dalen en daar de dienst gaan uitmaken, dat zou op enorm veel verzet gaan stuiten en leek niet de juiste weg om met z'n allen door dat ingewikkelde wetgevingsproces te komen, zeker niet omdat in dit geval ook de

3 Wijziging van de Elektriciteitsnet 1998 (... en enkele andere wetten) (Wet totstandkoming implementatie EG-besluiten op het terrein van de energie, post en telecommunicatie), Kamerstukken II 2003/04, 29 474, nrs. 1-3 en het advies van de Raad van State (Kamerstukken II 2003/04, 29 474, nrs. 4) en de reactie van de Tweede Kamer.

4 Wijziging van de Wet milieubeheer (toevoeging van bepalingen over internationale zaken), Kamerstukken II 1997/98, 25 991, nrs. 1-3.

5 Kwisthout/Swart-Bodrij \& Woldendorp, De Uitvoeringswet REACH: stof tot nadenken over de uitvoering van Europese verordeningen 2004. 
politiek er bovenop zat. Die wilde geen tweede luchtdossier en 'Nederland op slot' meer. We hebben dus eerst alle waterschappen en provincies afzonderlijk geraadpleegd door bij ze op bezoek te gaan. VROM wilde weten wat daar gebeurde en of de implementatie niet zou kunnen aansluiten bij hetgeen waarmee men al bezig was. De waterschappen bleken al bezig met waterplannen - ook een verplichting uit de Kaderrichtlijn water - en zo ontstond het idee om de waterkwaliteitseisen te koppelen aan de waterplannen. Dan krijg je een beeld van de logische structuur door bijvoorbeeld het waterplan centraal te stellen en de waterkwaliteitseisen geven dan aan wat je met de waterplannen moet bereiken.

De ervaringen met het luchtdossier, waarin we uiteraard ook hebben zitten neuzen, leerden dat ook heel belangrijk is wat je meet en hoe je meet. Getallen komen ergens vandaan en betekenen iets, als het goed is, want vaak leiden ze een eigen leven, dat was bij lucht het geval, daar moest de luchtkwaliteit zelfs in de berm van de snelweg worden gemeten waar nooit iemand komt. Aan dat soort informatie heb je niks en die zit je uiteindelijk ook vreselijk in de weg als je daar ook nog de vereiste kwaliteit moet zien te realiseren. Monitoring stond dus vanaf het begin centraal, want het gaat om de betekenis van de uiteindelijk alles bepalende getallen, daar moet je wel grip op houden zodat je geen onzin zit te doen. Bij veel onderzoeken is dat het geval, de Commissie Elverding spreekt in dit verband over een schijnwerkelijkheid die uit de onderzoeken oprijst en eigenlijk herkent iedereen zich wel in dat beeld. Dat moeten we dus niet doen, we moeten goed nadenken over wat die getallen (en andere onderzoeksgegevens) allemaal betekenen en welke rol we die geven. We moeten met een beroep op de getallen geen dingen gaan doen die weinig bijdragen aan de oplossing van het probleem, zeker niet als we daar wel veel last van hebben, maar we moeten na een analyse van de betekenis van de getallen aan de knoppen van de kritische succesfactoren voor de probleemoplossing gaan draaien. Overigens is het vaak een probleem dat de politiek dat helemaal niet wil, die wil de juiste toedracht van het probleem soms niet genadeloos door de brievenbus geschoven krijgen om er wat mee te moeten doen. In het geval van de Kaderrichtlijn water concludeerden we uiteindelijk dat de waterkwaliteit moet worden gemonitord op representatieve punten in de grotere wateren, de zogenaamde waterlichamen. De getallen deden dus een uitspraak over de waterkwaliteit in het algemeen en deze uitspraak kon bovendien niet op elk moment worden gedaan, er was een heel monitoringsprogramma voor nodig, waarbij op vaste punten geregeld voor verschillende kwaliteitselementen over langere tijd gemonitord wordt. De Kaderrichtlijn water bleek niet te eisen dat via monitoring op elk tijdstip op elk punt in elk water een uitspraak over de waterkwaliteit kan worden gedaan. Bij nader inzien heeft dat ook geen zin, want wanneer de waterstand door droogte laag is, zijn de concentraties van chemische stoffen veel hoger dan wanneer de waterstand juist zeer hoog is. Je moet dat dus over verschillende metingen uitmiddelen om een beeld te krijgen hoe de waterkwaliteit is, dat kan je niet zomaar elke 
dag zeggen en zeker niet naast een kwaliteitseis leggen. Dan ben je rare dingen aan het doen. Deze inzichten gaven ons ook een beter beeld wat eigenlijk het doel van de waterkwaliteitseisen is. Deze zijn bedoeld om het waterbeleid van de overheid op hoofdlijnen aan te sturen.

Dat leidde ons vervolgens weer naar de structurerende vraag wat de burger met de regulering van de waterkwaliteit te maken heeft. Heeft die recht op schoon water, overal en op elk moment? Kan hij met een emmertje water dat achter uit zijn sloot is geschept, naar het laboratorium stappen en dat daar laten analyseren en moet dat water dan aan de eisen voldoen? We zagen, met het luchtdossier in het achterhoofd, natuurlijk wel dat dit een cruciale vraag is om 'Nederland op slot' te voorkomen. De conclusie was dat de overheid weliswaar voor schoon water moet zorgen, maar dat de burger geen recht op schoon water heeft, wel op een serieuze aanpak van waterkwaliteitsproblemen. Je moet dan natuurlijk die uitspraak ook durven doen, dat schept ook duidelijkheid. Daar schrokken we eerst nog een beetje voor terug, maar uiteindelijk hebben we dat toch zo duidelijk gesteld.

Ik ga hier uitgebreid op in omdat ik uit wil leggen dat we ons in het waterkwaliteitsdossier eerst uitgebreid op onze omgeving hebben georiënteerd. Daar rees een heel ander beeld uit op dan we aan het begin hadden. Natuurlijk hebben we nog meer uitgezocht, met name wat de betekenis van die kwaliteitseisen is, of je er altijd aan vastzit of er onder bepaalde omstandigheden nog van kan afwijken, dat was de befaamde grens- en richtwaardendiscussie, ${ }^{6}$ en ook wat je eigenlijk met die eisen moet doen, daar kwam de zogenaamde koppeling om de hoek kijken. We konden daarna veel duidelijker zien waar het mis was gegaan in het luchtdossier en wat we vooral niet moesten doen, maar ook waar we juist wel aan vastzaten. Uiteindelijk werden de bevoegde bestuursorganen het doelwit van onze regeling. Die maken waterplannen en betrekken daarbij de burger. Het ging er bij het opstellen van de regelgeving dus voor ons uiteindelijk vooral om dat het bevoegd gezag begreep wat het te doen stond om de waterkwaliteit te verbeteren; als het bevoegd gezag dat zou snappen, vonden we het een goede regeling. De waterschappen herkenden zich in deze aanpak en zeiden dat ze van de extra regelgeving dan weinig last zouden hebben. Hierdoor kwamen we uit op een heel andere aanpak dan aanvankelijk in het luchtdossier, ons 'voorbeeld-dossier', was gekozen. Ik geef dit als voorbeeld hoe een wetgevingsjurist, samen met zijn projectteam, vooraf kan bedenken hoe hij de wetgevingsopdracht die hij heeft gekregen, wil gaan uitvoeren."

6 Zie daarover onder meer Thijssen \& Woldendorp, Kaderrichtlijn water; waterkwaliteitseisen waterdicht geregeld 2009, Van Rijswick, De betekenis en vormgeving van waterkwaliteitseisen 2007 en Van den Broek/Freriks \& Van Rijswick, Proefrechtszaak Kaderrichtlijn Water 2008. 
4.7. Houdt de wetgevingsjurist daarbij ook in de gaten hoe zijn wetgevingsopdracht past in het reeds bestaande wetssysteem?

"Ik probeer altijd de tijd te nemen om eerst goed na te denken hoe ik het probleem gestructureerd kan oplossen. Daarbij kijk ik niet zover dat ik het hele wetgevingsgebouw in de gaten houd. Dat gaat vaak de opdracht te buiten. De opdracht is het gegeven. Anders trek je er te veel dingen bij en dan krijg je de geest niet meer in de fles. Er zijn dan niet alleen te veel aspecten waarmee je rekening moet houden, maar er raken ook te veel mensen bij betrokken die allemaal willen meepraten en er ook iets van vinden, terwijl het eigenlijk niet meer gaat om de essentie van de opdracht die je hebt gekregen. Dit zie ik overigens als een risico van de steeds verdere integratie van het omgevingsrecht waarmee we nu bezig zijn. Ik ervaar het wetgevingsproces voor op zich kleine onderwerpen zoals het reguleren van warmte-koudeopslag, steeds meer als een reus op lemen voeten, die komt niet hard vooruit, en hij lijkt wel sterk, maar als actie wordt verlangd, heb je er niks aan."

4.8. Maar sommige wetgevingsjuristen denken minder aan de structuur?

"Er zijn ook wetgevingsjuristen die meer zijn van de wetgevingstechniek; dat verwijzingen goed kloppen bijvoorbeeld. Daar ben ik niet zo van. Het is ook maar net waar je goed in bent. Sommige wetgevingsjuristen laten het gewoon door het beleid opschrijven. Dan heb je dus helemaal geen greep op de structuur maar krijg je iets aangereikt, wat natuurlijk soms best goed in elkaar kan zitten. Ik kreeg zo laatst een ontwerp voor een wijziging van het Stortbesluit bodembescherming aangereikt. Mij was volstrekt niet duidelijk wat we nu waarom gingen regelen. Er moest een experiment worden uitgevoerd om te kijken of het wel nodig was na het einde van het gebruik van een stortplaats een bovenafdichting te hebben, zoals in het bestaande Stortbesluit wordt voorgeschreven. Dat is duur. Het gaat slecht met de sector dus kostenbesparing was nodig. Maar er was toch ook nog een milieudoel, dat ooit de reden van de verplichte bovenafdichting was geweest? Ik snapte verder niks van de aanpak van dit probleem. Het ontwerpbesluit was al voorgepubliceerd en in de voorhang geweest, de Tweede Kamer had er al een hele reeks vragen over gesteld want die begreep er ook niks van. Ik ben teruggegaan naar het beleid en heb gevraagd: Wat is het uiteindelijke beleidsdoel? Wat gaan we doen bij dat experiment? Waar is het op gericht? Wanneer is het een succes? Dat werd allemaal heel duidelijk uitgelegd in de koffiecorner. Toen heb ik gezegd: als jullie het zo duidelijk kunnen uitleggen, waarom schrijven wij dat dan niet gewoon ook zo op? En dat hebben we toen gedaan. Omdat een lijst van gestructureerde en logische vragen de aanpak ging bepalen, kwamen er nog een heleboel onontdekte en dus niet opgeloste problemen uit de kast rollen ook, dus het heeft ons nog heel wat hoofdbrekens gekost om te bepalen wat we nu uiteindelijk moesten gaan regelen en hoe. En dat doet het nog steeds trouwens, want het is nog niet af." 
4.9. Kun je een voorbeeld geven waartoe minder gestructureerd denken kan leiden?

"Om een voorbeeld te geven hoe ongestructureerd er soms te werk wordt gegaan. Pas helemaal aan het eind van het proces kwam de aap uit de mouw over welke onderwerpen het besluit nu eigenlijk ging. Het beleid wist dat natuurlijk wel, maar had het tegen niemand gezegd en ik vraag me af of ze het zelf ook wel op een rij hadden staan. De wetgevingsjuristen en Tweede Kamer begrepen het überhaupt niet en konden het ook niet zelf bedenken, dus iedereen zat gigantisch langs elkaar heen te praten. Helemaal aan het eind van het proces werd pas in de nota van toelichting een passage ingevoegd, waarin werd aangegeven wat nu eigenlijk de onderwerpen zijn die in dat besluit geregeld zouden worden:

1. Op pilotstortplaatsen wordt het experiment duurzaam stortbeheer uitgevoerd.

2. Stortplaatsen die bij een succesvol verloop van het experiment op de pilotstortplaatsen mogelijk in aanmerking komen voor duurzaam stortbeheer, krijgen nu eerst uitstel van de huidige verplichting om een bovenafdichting aan te brengen, want duurzaam stortbeheer is niet meer mogelijk als de, zeer dure, bovenafdichting al is aangebracht.

3. Indien uit lopend onderzoek blijkt dat de onderafdichting langer meegaat dan een periode van dertig jaar waarvan in het huidige Stortbesluit wordt uitgegaan, wordt de periode waarna een bovenafdichting moet worden aangebracht verlengd van dertig jaar tot ten hoogste vijftig jaar na het aanbrengen van de onderafdichting.

Van het laatste onderwerp is mij wel duidelijk dát de wens bestaat dat te regelen, maar toch is mij ook nu nog steeds niet helemáál duidelijk wat dat met het experiment te maken heeft, ergens gloort er wel een vaag besef dat dit zo is, dus het 'mag' van mij wel in het besluit, maar niemand heeft mij dat nog echt kunnen uitleggen. Dan komt het natuurlijk ook niet duidelijk in de toelichting terecht. Het zou natuurlijk mooi zijn voor de experimentenregeling als we dat nog in de toelichting duidelijk zouden kunnen maken, zodat iedereen een beetje de samenhang ziet tussen de drie onderwerpen die in het besluit geregeld worden en helder voor ogen staat hoe die met elkaar verband houden. Maar het is nu voor mij de vraag hoeveel tijd ik daar nu nog in ga steken en ook bij het beleid zitten ze nu wel een beetje aan hun tax, het was natuurlijk allemaal al lang met iedereen uitgebreid besproken voordat het tot die voorpublicatie en voorhang kwam, er was ergens overeenstemming over bereikt, en dan wil je dat proces ook niet allemaal met zijn allen nog eens gaan overdoen, als iedereen heeft geaccepteerd dat het derde onderwerp ook in de regeling staat, te meer omdat iedereen dat ook wil. Daar stuit mijn wens in de toelichting volledige duidelijkheid te geven dus op haar grenzen, waar ik me bij het beleid onmogelijk ga maken met mijn doorvragen." 
4.10. Wat is het belangrijkste aspect dat het samenhangcriterium bepaalt?

"De aanvliegroute wordt toch al met al vooral door de opdracht bepaald. Dat is wat de minister als wens van de Tweede Kamer te horen heeft gekregen. Dat is vaak weer wat de Tweede Kamer van organisaties als VNO-NCW heeft gehoord. Zoals het invoeren van het begrip installatie in plaats van inrichting. Dan maak je een wetsvoorstel om dat te bereiken. Er komt al zoveel bij kijken om zelfs de meest eenvoudige opdrachten uit te voeren, dat je de opdracht niet groter gaat maken dan die al is. Het Stortbesluit bodembescherming bijvoorbeeld is na al die jaren nu toch een beetje uit de tijd. Misschien kun je het beter nieuw opschrijven, maar daar is nu in het kader van de experimentenregeling geen tijd voor. Die hangt aan de Crisis- en herstelwet en de crisis wordt niet opgelost als we nu eerst eens het wetstechnisch ideale Stortbesluit gaan zitten maken."

\subsection{Maar kijkt de wetgever dan nooit naar het grote geheel?}

"De wetgevingsjurist heeft geen tijd, en eigenlijk ook geen zin, om steeds naar het grote geheel te kijken, want dan komt er niks meer uit zijn handen. Dat is anders bij de Omgevingswet, want daar is wel gelegenheid om naar de structuur te kijken, dat is immers juist de opdracht: één keer een goed gebouw ontwerpen, waar straks iedereen op een leuke manier met zijn spullen in terecht kan, zonder dat er buiten op het gras tenten moeten worden opgericht om iedereen te kunnen huisvesten, schuren met rotzooi worden vol geschoven waar vervolgens niemand meer bij kan of van weet wat daar eigenlijk ligt, of er ineens een geit in de woonkamer bivakkeert."

\section{WETSSYSTEMATISCH TEKORT}

5.1. Is het een goed idee om met gelaagde structuren te werken? Zorgen gelaagde structuren er niet voor dat de justitiabele in drie wetssystemen moet kijken wat zijn rechten en plichten zijn?

"Zoals, dacht ik, uit een STEM-advies blijkt maakt gelaagdheid wetgeving echt ingewikkeld. Een voorbeeld betreft Wabo, Bor en Mor. De trits Waterwet, Waterbesluit en Waterregeling laat door dezelfde indeling en nummering echter heel goed zien wat bij elkaar hoort, dus gelaagde regelgeving is niet altijd een onoverkomelijk probleem. Een ander voorbeeld staat in mijn boek over natuurbeschermingsrecht: de manier waarop beschermde dier- en plantensoorten zijn aangewezen. ${ }^{7}$ Als je ziet hoeveel lijsten met dieren er zijn. In de eerste plaats zijn er de richtlijnen waarnaar rechtstreeks wordt verwezen bij ministeriële regeling. Maar dan heb je verder nog aanwijzingen

7 Woldendorp, Teksten en toelichting Wetgeving natuurbescherming 2011, p. 27-35. 
bij wet, bij algemene maatregel van bestuur en nog een keer bij ministeriële regeling en daar komen dan nog verduidelijkende handleidingen met hun eigen lijsten bovenop om invulling te geven aan algemene aanduidingen in de regelgeving, zoals 'alle in Europa in het wild voorkomende vogelsoorten'. Als de Tweede Kamer zich destijds nou had kunnen beperken tot het formuleren van algemene aanwijzingscriteria in de wet en de aanwijzing verder aan de minister had overgelaten, dan was het volgens mij prima voor elkaar gekomen. Die criteria staan nu nota bene al geformuleerd in de wet, namelijk in art. 3, lid 1, van de Flora- en faunawet. Dat gebeurde echter niet. De Kamer wilde zich er ook mee gaan bemoeien, bijvoorbeeld met de aanwijzing van zoogdieren en andere dieren met een hoge aaibaarheidsfactor, maar dan weer met uitzondering van vervelende dieren als de huismuis en de bruine rat. Voor paddenstoelen hoefde dat natuurlijk sowieso niet, want die kent toch niemand en dat interesseerde de Tweede Kamer dus niet zo, evenmin als insecten, laat staan korstmossen en grassen; dat mag de minister allemaal uitzoeken zo lang we er maar niet te veel last van krijgen doordat de dieren ineens Nederland op slot blijken te hebben gedraaid. Er zijn dus al met al verschillende lijsten voor verschillende doelen: wat je niet mag bejagen, wat je wilt beschermen, wat je mag plukken, etcetera. In theorie zou de aanwijzing van soorten veel simpeler kunnen: één regeling met gewoon een paar lijsten, zoals in de voorlichtingsfolder, die het ministerie zelf had uitgegeven, met maar drie lijsten van diersoorten met daarbij behorend beschermingsregime.

Met Bart Arentz heb ik naar aanleiding van die voorlichtingsfolder een artikel geschreven. ${ }^{8}$ We hebben ons toen afgevraagd of de voorlichtingsfolder die immers zo duidelijk was, niet eenvoudig in de wet zou kunnen worden terugvertaald. Dan zouden we een eenvoudige en begrijpelijke wet hebben. Dat is echter niet de logica van de wetgeving. Je geeft eerst het beschermingsdoel aan, dan de hoofdregels, dan de uitzonderingen en dat leidt tot een ander resultaat. De wetgeving is een weerslag van denken in doelen en instrumenten en bevoegdhedenverdeling, de regels moeten volgens bepaalde uitgangspunten worden geordend. Een wet is niet een optelsom van instructies wat er in bepaalde situaties moet gebeuren. Dat zou zo ook niet door de Tweede Kamer komen, die wil het hoe en waarom van die instructies ook begrijpen en weten welke structurerende elementen daaraan ten grondslag liggen. Hans Bierman zei altijd dat de wet gewoon moet kloppen en dat de folder er is om het aan de mensen uit te leggen. ${ }^{. "}$

5.2. Welke redenen zijn er voor een gelaagde structuur?

"Een gelaagde structuur heeft praktische redenen. Wil je het eenvoudig houden, dan moet je een simpele wet maken, die niet te veel bij de Tweede

8 Arentz \& Woldendorp, Soortenbescherming Ffw: complexiteit naar climax 2005.

9 Zie ook Woldendorp, Een werker in het vooronder! 2006. 
Kamer legt. Wetgeving moet je tot de hoofdzaken beperken. Wat we niet weten of wat steeds verandert, dat proberen we in lagere wetgeving op te nemen. Anders moet je steeds terug naar de wetgever. Vaak wil de Tweede Kamer dat ook niet weten, omdat het te gedetailleerd is. Soms trouwens wel, zoals bij de aaibare dieren. Bij de aanwijzing van diersoorten vertrouwde de Tweede Kamer het kennelijk niet helemaal, zodat het deels in de wet kwam en deels ook niet en dus de totale regelgeving ingewikkeld werd. Ook bij milieukwaliteitseisen wil de Tweede Kamer zich ermee bemoeien en dus moest er een voor- én nahang in art. 21.6 van de Wet milieubeheer komen. Dat is bij wetgeving van Sociale Zaken bijvoorbeeld helemaal niet."

\section{TOEKOMSTBESTENDIG}

6.1. Is een wetssysteem toekomstbestendig te maken in die zin dat je een systeem ontwerpt dat vele decennia mee kan?

"Een wetssysteem is toekomstbestendig als je de juiste kapstokken kunt vinden om nieuwe regels aan op te hangen, volgens logische structuren die aansluiten bij je beleidsdoelen, de wensen vanuit de maatschappij of het EUrecht. Dan heeft een integrale wet wel meerwaarde. Voor de Omgevingswet zou ik dan tot de volgende globale gedachten komen:

- EU is een gegeven, hoe dan ook moeten we dat doen, inhoud en definities, alleen structuur staat dan juist nog vrij. Het Europese recht moet, ook in detail. Iedereen die naar de Europese richtlijnen kijkt, boeken vol, moet begrijpen dat er nooit een simpele Omgevingswet uit komt rollen, waarmee je kunt volstaan. Die illusie moeten we de mensen dan ook niet voorhouden.

- Als EU uitgangspunt is, ontstaan minder implementatieproblemen en ook is de EU- achtergrond van regels beter te herkennen, alsmede nationale toevoegingen. Dan kunnen we het ook beter over het nationale beleid hebben, of we dat willen of niet, want daar valt nu juist nog wel te kiezen. $\mathrm{Nu}$ kan vaak niemand vertellen waar en hoe EU-richtlijnen zijn geïmplementeerd en in hoeverre er in de nationale wetten nog wat te kiezen valt dan wel alles al vastligt omdat het moet van Europa. Aan het begin wordt er nog wel een transponeringstabel gemaakt om van de implementatie verantwoording af te leggen, vooral voor de Europese Commissie trouwens, maar niemand houdt die bij en na enkele jaren weet dus ook niemand nog hoe we dat hebben gedaan. We hebben bij VROM in mijn dossiers twee keer een onderzoek van 3 maanden uitbesteed om te laten uitzoeken hoe we de Grondwaterrichtlijn en de Richtlijn prioritaire stoffen hebben geïmplementeerd. Daar kwamen toen tientallen regelingen uitrollen. Het is zo ook nauwelijks te zeggen waar de nationale koppen zitten. En als je nationale recht gaat aanpassen, weet je vaak niet of nauwelijks of je intussen gaten schiet in de 
ooit eens kloppende implementatie, doordat de Europese achtergrond van een bepaling onbekend is. Allemaal voor het omgevingsrecht niet echt handig en pragmatisch. Ik zeg hier altijd over: als de richtlijnen in het Nederlands zijn geschreven, moet je ze bij de implementatie niet in het Chinees gaan vertalen, want dan snapt niemand er nog wat van. Dat is eigenlijk wat we vaak doen als we de richtlijnen in onze heel anders opgezette nationale regelgeving willen integreren.

- Zet pragmatisme voorop. Het kabinet wil geen nationale koppen ${ }^{10}$; dat is de kern van het milieubeleid. Dus regel hetgeen Europees moet worden geregeld en neem niet als uitgangspunt het nationale wat je juist niet wilt regelen, maar zet de nationale toevoegingen juist af tegen de kern van het Europese recht.

- Indien we de regelgeving op onze eigen wijze structureren, lopen we het risico dat de EU-wetgever met nieuwe regelgeving steeds gaat trekken aan willekeurige draden van de keurige bol waarin Nederland het omgevingsrecht heeft opgerold; het wordt al snel een rommeltje. We kunnen beter bij de structuur van de Europese wetgeving aansluiten, ook al is dat volgens Hans Bierman juist een gebrek aan structuur. Neem als voorbeeld het Verdrag van Aarhus. Dat verdrag maakte van de Wob een kind met een waterhoofd, of het waterhoofd moest elders, naar de Wet milieubeheer worden verplaatst. Het zag er keurig uit met de Wob, maar ineens niet meer. Dat Aarhus er zou komen, was voor Wob-makers moeilijk te voorspellen. Het is tijdens de totstandkoming van internationale regelgeving voor Nederland natuurlijk ook niet te doen die regelgeving conform de Wob vastgesteld te krijgen. Dus dat houd je altijd als je met integratie en implementatie begint, maar doe dat in elk geval niet met de dingen die je wel weet.

- Neem de naar verwachting permanente richtlijnen als uitgangspunt. Sommige richtlijnen zijn kaderrichtlijnen of bestaan sinds jaar en dag en die zijn blijvend structuurbepalend, in andere zit nog beweging. Structuurbepalend zijn onder meer de Richtlijn milieueffectrapportage, ${ }^{11}$ Kaderrichtlijn water, REACH, de IPPC-richtlijn en de Kaderrichtlijn afvalstoffen. ${ }^{12}$ Met die richtlijnen moet je in elk geval wat.

- Kijk welke instrumenten je nodig hebt. Als de Tweede Kamer en Eerste Kamer niet vergaand regelgevende bevoegdheid willen delegeren, dan wordt het niks met Eenvoudig Beter. Er moet hoe dan ook heel erg veel worden geregeld, dus dat moet je niet allemaal op wetsniveau willen doen. Dat betekent dat de TK en EK invloed moeten afstaan en vertrouwen moeten hebben in de lagere wetgever, of anders genoegen moeten nemen

10 Zie daarover Stoop, Nationale koppen op EU-regelgeving 2012.

11 Richtlijn 2011/92/EU van het Europees Parlement en de Raad van 13 december 2011 voor milieubeoordeling van bepaalde openbare en particuliere projecten (codificatie van de richtlijnen 85/337/EEG, 97/11/EG, 2003/35/EG en 2009/31/EG) (PbEU 2012 L 26/1).

12 Richtlijn 2008/98/EG van het Europees Parklement en de Raad van 19 november 2008 betreffende afvalstoffen en tot intrekking van een aantal richtlijnen (PbEU 2008 L 312/3). 
met een omvangrijke en moeilijke Omgevingswet. Dit dilemma moet vroeg op tafel worden gelegd, zodat de politiek op dit cruciale punt haar verantwoordelijkheid kan nemen.

- Wat de instrumentenkist betreft moet je eigenlijk van begin tot eind van de beleidscyclus van een onderwerp de stappen onderscheiden en daar de instrumenten bij bedenken. In veel richtlijnen moet de toestand van milieu of water worden vastgesteld door monitoring. Analyseer de toestand, identificeer de problemen en analyseer de oorzaken. Maak een plan waarin je de toestand beschrijft, de oorzaken en wat je er aan gaat doen in grote lijnen om het goed te krijgen of te houden. Maak een maatregelenprogramma met concrete maatregelen die je gaat nemen; daar moet ook bij hoe je dat gaat/kunt doen, of er geld, juridische instrumenten en technische kennis voor zijn, enzovoorts. Daarbij spelen ook grensoverschrijdende aspecten mee. De maatregelen moeten worden uitgevoerd, met of zonder medewerking van de burgers; dat vraagt op zichzelf al een hele instrumentenkist. Bestaande verontreiniging is doorgaans het probleem wanneer de milieukwaliteit nog niet goed is, niet de verontreiniging van activiteiten die er nog niet zijn en die je eventueel kunt tegenhouden. Dat laatste voorkomt weliswaar verdere verontreiniging, maar je bereikt niet dat het beter wordt, tenzij de techniek voortschrijdt of er varkenspest of zo uitbreekt. Dus wat ontbreekt in de instrumentenkist: instrumenten zoals nu in de Nb-wet 1998 al enigszins zitten, art. 19c en $21 \mathrm{Nb}$-wet 1998, plus veel dwingender instrumenten om bestaande activiteiten die legaal zijn, toch ambtshalve te gaan aanpakken. Daar moeten we nog eens goed over nadenken in de Omgevingswet, die instrumenten hebben we gewoon nodig en voor zover ze er nu al zijn, werken ze in de praktijk niet. Het resultaat van de maatregelen die in het programma zijn opgenomen, moet uiteraard ook worden geëvalueerd. Er moeten nieuwe maatregelen in het programma worden opgenomen als de milieukwaliteit nog niet goed is. Je zou de hiervoor benodigde instrumenten in de Omgevingswet kunnen opnemen. Die zijn dan gebaseerd op de kennis van wat je Europees gezien nodig hebt, maar toch als zodanig niet een letterlijke vertaling van het Europese recht. Je hebt dan ook goede kledinghaken om nieuwe regelgeving aan op te hangen, want het gaat altijd wel over plannen en programma's, monitoring en instrumenten om maatregelen te kunnen uitvoeren.

- Ik zou veel zaken die nu heel subtiel geregeld zijn, op een hoop gooien en alleen spreken van activiteiten, waaronder activiteiten die samenhangen en dus een project of inrichting zijn (dat kan dan op een lager niveau van regelgeving worden aangegeven), toestemmingen, (een vergunning, ontheffing enz., een beheerplan of een wet kan ook een toestemming zijn, voor het beheerplan is dat bijvoorbeeld al uitgemaakt door de rechter in het kader van de $\mathrm{Nb}$-wet 1998, een regeling dat je $130 \mathrm{~km}$ per uur mag rijden is ook een toestemming) en meldingen (administratieve formaliteit); 
- Begin eenvoudig: een gemakkelijk begin wordt altijd moeilijker, maar een moeilijk begin wordt nooit gemakkelijker. Dus begin niet meteen moeilijk te doen, want dan wordt dat alleen maar nóg moeilijker.”

6.2. Europese richtlijnen vormen dus een goed uitgangspunt voor een toekomstbestendige Omgevingswet?

"Wat je ook vindt van de Europese richtlijnen, het wordt alleen maar ingewikkelder als je het bij de implementatie anders doet. Tenzij je in die richtlijnen gemeenschappelijke factoren ontdekt, de rode draden. Als je die rode draden kunt implementeren dan blijven de richtlijnen herkenbaar. Zie ook mijn Opinie in Milieu en Recht. ${ }^{13}$ Ik vergelijk structureren wel met het opruimen van je kamer. Je bedenkt een mooi systeem voor je kasten met planken en vakken. Driekwart van de spullen past erin en is snel opgeruimd. Daarna word je afgeleid door de dingen die eigenlijk niet in het systeem passen. Het gaat je niet lukken om die op een goede plaats te krijgen, want de planken zijn eigenlijk al vol. Uiteindelijk wordt het toch proppen. De deur gaat dicht en dan moet je nog weten waar het ligt. Welke invalshoek je ook kiest - ook bij de nieuwe Omgevingswet met een Europese invalshoek - je blijft met rommeltjes zitten. Je kunt wel alle regels over de fysieke leefomgeving opnemen, maar dan blijft het voor een deel een ballenbak. Dat is op zichzelf voor de Omgevingswet ook wel acceptabel. Je moet niet streven naar $100 \%$ perfectie. Er komen straks allerlei zaken uit Europa of uit Kyoto en die passen dan niet in jouw systeem. Misschien kun je over 5 jaar een 8 bereiken, maar zou het wel 25 jaar kosten voordat het 10 wordt. Ondertussen heb je dan niets. Dat moet je zo niet doen.”

"Een bibliothecaris moet wel de goede etiketten kunnen plakken anders kan hij de zaken in zijn kast niet terugvinden. Een artikel met de titel 'Verwant zonder verband' was bijvoorbeeld niet duidelijk geëtiketteerd. De juridische bibliothecaris zal dit willen onderbrengen bij het personen- en familierecht (verwant) of bij het medische recht (verband). Het ging echter over de vraag of de milieu- en watervergunningen moeten worden gekoppeld. ${ }^{14}$ "

\section{WET MILIEUGEVAARLIJKE STOFFEN}

7.1. Waarom heeft de wetgever niet gekozen voor het samenbrengen van regels over stoffen in de Wet milieugevaarlijke stoffen?

"Voor REACH was er al het idee in Nederland om het stoffenbeleid anders te organiseren (SOMS). Voordat de Wms in de Wet milieubeheer is geïntegreerd,

13 Woldendorp, De sjoelbakmethode 2011.

14 "Dit voorbeeld is mij ooit verteld door Willem Bruil." 
is er al een proeve geweest voor een nieuwe Wms. Die is er niet gekomen omdat de nieuwe wet door REACH werd ingehaald."

\subsection{Kun je dat nader uitleggen?}

"Toen REACH moest worden geïmplementeerd, werd in eerste instantie gedacht aan een uitvoering in het kader van de Wms. REACH regelde namelijk veel wat al in de Wms stond. Als gevolg van REACH, een rechtstreeks in de Nederlandse rechtsorde doorwerkende verordening, moest dubbele nationale regelgeving worden geschrapt. Je zou erg veel wettelijke regels moeten maken om dat te realiseren, zoals 'artikel $\mathrm{x}$ vervalt, de artikelen y en z worden samengevoegd, na '...' wordt een zinsnede ingevoegd, luidende ....., hoofdstuk 3 wordt vernummerd tot 2 en krijgt een andere titel.' Toen ik de opdracht kreeg om REACH uit te voeren, ging het eigenlijk alleen om het aanwijzen van het bevoegd gezag, het regelen van de strafbaarstelling en het schrappen van dubbelingen uit de Wms. Dat was voor de uitvoering van REACH voldoende. Ik schatte zo in dat het aanpassen van de Wms 95\% van het werk zou zijn. Voor de uitvoering van REACH waren maar drie artikelen nodig (art. 9.3.1, 9.3.2 en 9.3.3 Wm). Het was veel gemakkelijker om de restanten van de Wms te verplaatsen naar de Wet milieubeheer, dan kon je volstaan met één wijziging van de Wet milieubeheer, dat er een paragraaf moest worden ingevoegd waarin alle resterende bepalingen van de voormalige Wms bij elkaar werden gezet. Dan zou ook meteen de politieke wens in vervulling gaan om de Wms in de Wet milieubeheer te integreren, al moeten we dat integreren dan wel met een korreltje zout nemen: dat is niet inhoudelijk integreren, maar alleen de boel bij elkaar zetten, in de volle kast erbij duwen, zeg maar. We hadden maar heel weinig tijd om REACH uit te voeren; 15 of 21 dagen en dan moest alles geregeld zijn. Er werd dus voor gekozen om ons te beperken tot een simpele 'overplaatsing' van de Wmsbepalingen en om daarin geen verbeteringen aan te brengen. Een logische structuur zou zijn om REACH in elk geval een duidelijk zichtbare plaats in de Wet milieubeheer te geven. De Wms had verder weinig raakvlakken met de rest van de Wet milieubeheer, dus in feite gooiden we er alleen maar een bal in de ballenbak bij. Dat is ook geen probleem, als je dat maar erkent en niet net doet alsof er wel samenhang is. De implementatie van REACH had net zo goed in de Wms gekund, want de meerwaarde van integratie van de Wms in de Wet milieubeheer lijkt mij beperkt, maar dan hadden we ook een nieuwe Wms moeten uitschrijven. Een essentieel onderdeel van deze operatie was dat er een brief aan de Tweede Kamer is gestuurd..$^{15}$ Daarin is gezegd dat de implementatie alleen maar zou kunnen als er niet over de inhoud van REACH zou worden gesproken of over de Wms. Het minste risico op een verkeerde implementatie is dat er technisch wordt geïmplementeerd. Dit is

15 Kamerstukken II 2006/07, 21 501-08, nr. 200. Bijlage 3 bij de brief waarin dit is verwoord, heeft bij de behandeling van het wetsvoorstel door de Tweede Kamer nauwelijks aandacht gekregen. 
puur pragmatiek. Er zitten geen verheven gedachten achter de structuur. Zelfs evidente verbeteringen waarvan we ons konden voorstellen dat die tot discussie zouden kunnen leiden, hebben we niet uit de Proeve overgenomen."

\section{WET NATUUR}

8.1. Wat zijn nu redenen om de Nb-wet 1998, de Ffw en de Boswet te bundelen in de Wet natuurbescherming?

"De Boswet heeft er eigenlijk helemaal niks mee te maken. Die wet gaat niet over natuur, maar gewoon over bomen die langs de wegen staan. Ik moest een keer voor Rijkswaterstaat een handleiding maken hoe je ecologisch onderzoek moest doen als er nieuwe wegen werden aangelegd. Het ging over soorten- en gebiedsbescherming. Toen moest er nog een hoofdstukje in over de Boswet. Toen ik dat allemaal had bekeken en zag hoe gedetailleerd dat was, heb ik gezegd: daar heb ik geen zin in, zelfs al word ik ervoor betaald."

8.2. Ken je voorbeelden waar milieu en natuur beter wel in hetzelfde wetssysteem een plaats kunnen krijgen?

"Ik heb ooit eens een vraag van de Tweede Kamer moeten beantwoorden wat voor veehouderijen het verschil is tussen de vergunningen van de toenmalige Natuurbeschermingswet en van de Wet milieubeheer. Het antwoord dat we gaven was dat die wetten verschillende doelen hebben. De ene beschermt natuurgebieden en de andere het milieu, waaronder de natuur. Nou, wie het verschil weet, mag het zeggen. Er worden ook geen andere toetsingskaders gehanteerd om te weten of een veehouderij mag of niet; de instrumenten zijn ook gelijk. Ik kon toen al niet uitleggen of het verschil uitmaakte of je twee vergunningen had of niet. $\mathrm{Nu}$ is dat wel een groot probleem, omdat veel veehouderijen wel een omgevingsvergunning hebben, afgegeven op basis van een natuurtoets (de oude milieuvergunning), maar geen natuurbeschermingsvergunning. Aan de omgevingsvergunning kon men volgens de Afdeling bestuursrecht eerst zelfs helemaal geen enkel recht ontlenen bij het aanvragen van een natuurbeschermingsvergunning. De veehouderij moet worden afgerekend op de huidige situatie, en met de bestaande hoge achtergronddepositie van stikstof in grote delen van het land kun je dan eigenlijk geen vergunning verlenen. Nu kun je in bepaalde gevallen bij het aanvragen van een natuurbeschermingsvergunning wel rechten aan je eerdere milieuvergunning ontlenen, maar dan weer niet altijd. Het is niet alleen een ongewenste verdubbeling, maar deze regeling heeft ook geleid tot verschillende wetswijzigingen omdat bestaand gebruik steeds anders werd geregeld, dit heeft voor veel onrust gezorgd. Ook de jurisprudentie is in de tussentijd nog een paar keer veranderd. Het is dus heel ingewikkeld 
geworden. Dit is dus een voorbeeld van twee wetten die nagenoeg hetzelfde regelen. Hierbij moet je ook bedenken: Achter deze wetgeving, daar zitten mensen, die door al dit ingewikkelde instrumentarium worden vermalen. Want de toekomst van hun bedrijven staat op het spel als er een vereiste vergunning ontbreekt, dat is nu dus vaak het geval omdat het bedrijf alleen de milieuvergunning heeft maar de natuurvergunning ontbreekt. Dan willen ook de banken niet meer investeren, die zien dat als een risico, zo'n 'illegaal' bedrijf, dat is een veel te groot risico, die banken willen dat tegenwoordig helemaal niet natuurlijk."

8.3. Maar moet voor de nieuwe Wet natuurbescherming het samenhangcriterium wel de natuur zijn?

"Er valt volgens mij nog heel wat op af te dingen of - bescherming van natuurwaarden wel het juiste samenhangcriterium is voor een Wet natuur. Waarbij de conclusie misschien nog wel hetzelfde kan zijn. Je hebt bescherming van soorten en habitattypen. Daarbij moeten vervolgens instrumenten worden gekozen. Kijken we alleen naar de soorten, dan is een van de instrumenten om soorten in een gunstige staat van instandhouding te brengen volgens de VR en de HR de aanwijzing van gebieden waar die soorten zitten. Het is dus een instrument van soortenbescherming. Er wordt vooral gekeken naar soorten die bij elkaar zitten. Er wordt gecontroleerd hoeveel procent van de populatie in die gebieden zit. Er zijn andere gebieden waar soorten niet bij elkaar zitten zoals vissen in de zee of trekvogels. Daarvoor hoef je geen gebieden aan te wijzen. Dat heeft namelijk geen zin. Dat moet je het met overal geldende verboden doen, zoals nu volgens de Flora- en faunawet. Het instrumentarium kan dus verschillen al naar gelang de soort. Voor de hamster geldt bijvoorbeeld geen gebiedsbescherming, maar wel soortenbescherming, want die hamsters zijn nogal opportunistisch en leiden een zwervend bestaan, dat zich bij voorkeur op en rond akkers afspeelt, dus buiten natuurgebieden. Maar dan natuurlijk geen gewone akkers, maar speciale akkers. Daar komt dan toch weer een soort leefgebiedenbenadering om de hoek kijken; het gaat om de juiste akkers die ook op juiste plaats liggen, waar bijvoorbeeld een voldoende dikke lösslaag is voor de hamster om zijn winterslaap te houden. De vraag is dus steeds: hoe moet je bepalen wat het samenhangcriterium is bij de bescherming van soorten en gebieden? Er zijn ook nog heel wat natuurbeschermingsonderwerpen, die helemaal geen samenhang met het omgevingsrecht vertonen, zoals de jacht, de internationale handel in beschermde soorten, schadebestrijding en beheer van de wildstand."

8.4. Maar is het dan geen goed idee om de Natuurbeschermingswet 1998 en de Flora- en faunawet samen te voegen?

"Ik wil eigenlijk liever kijken naar de beleidsdoelstellingen. Een betere natuur is het achterliggende doel. Vervolgens ga je kijken hoe dat moet. 
Dan kun je meteen al vaststellen dat vogels en andere dieren niet in twee richtlijnen terecht hadden moeten komen, de Vogelrichtlijn en de Habitatrichtlijn. Het is echter wel logisch dat het zo is gegaan, aangezien er over vogels veel meer kennis bestond en daar vrij eenvoudig een richtlijn over kon worden gemaakt. Bij de Habitatrichtlijn moest eerst nog worden uitgezocht welke soorten worden bedreigd en welke gebieden voor die soorten belangrijk zijn om te beschermen. Voor de bruine beer weet je dat wel, maar voor de zeggekorfslak kon je niet zeggen welke gebieden daarvoor nu de kerngebieden zijn in Nederland en of Nederland überhaupt een kerngebied is voor de instandhouding van de soort in de Europese Unie. Dat bleek uiteindelijk wel het geval te zijn. Maar toen vroeg men zich af of er in andere landen wel goed gekeken was. De grootste concentraties van die soort zaten dan weer in gebieden waarin de meeste 'liefhebbers' woonden om ze op te sporen en te tellen, want dat wil ook niet iedereen. Voor zover de Nb-wet 1998 en de Ffw zich op de omgeving richten, kunnen deze wetten zinnig worden samengevoegd, met het overige omgevingsrecht erbij trouwens. Maar het grootste deel van de Ffw gaat daar, zoals gezegd, helemaal niet over en dat hoeft dan van mij ook niet in de Wet natuur of de Omgevingswet."

8.5. Zie je vaker dat de wetgever twee wetten maakt omdat hij er niet meteen uitkomt?

"Iets dergelijks heeft zich ook voorgedaan bij de Kaderrichtlijn water (Krw). Daar kwam men niet uit de doelen voor grondwater. Men heeft toen gezegd dat de doelen voor grondwater later wel zouden komen. Met de prioritaire stoffen kwam men er ook niet uit, zodat er nu drie richtlijnen zijn: de Krw, ${ }^{16}$ de Grondwaterrichtlijn ${ }^{17}$ en de Richtlijn prioritaire stoffen. ${ }^{18}$ Die kunnen natuurlijk best worden geïntegreerd en horen ook bij elkaar, maar op het moment dat de Krw werd geschreven zei men toch 'Maar nu even niet ...'. Het is wel realistisch van de wetgever om dan niet te wachten. De wetgever is immers blij als het water wordt beschermd, ook al is het dan nog niet allemaal tot in de puntjes geregeld. Bovendien konden met de Krw veel richtlijnen worden ingetrokken en is er een vereenvoudigingsslag gemaakt. Dus al met al was de Krw die zich ging aftekenen, een heel mooi resultaat, ook al beantwoordde deze richtlijn niet aan het ideale eindplaatje. Het is

16 Richtlijn 2000/60/EG van het Europees Parlement en de Raad van 23 oktober 2000 tot vaststelling van een kader voor communautaire maatregelen betreffende het waterbeleid (PbEG 2000 L 327/1).

17 Richtlijn 2006/118/EG van het Europees Parlement en de Raad van 12 december 2006 betreffende de bescherming van het grondwater tegen verontreiniging en achteruitgang van de toestand $(P b E U$ 2006 L 372/19).

18 Richtlijn 2008/105/EG van het Europees Parlement en de Raad van 16 december 2008 inzake milieukwaliteitsnormen op het gebied van het waterbeleid tot wijziging en vervolgens intrekking van de Richtlijnen 82/176/EEG, 83/513/EEG, 84/156/EEG, 84/491/EEG en 86/280/EEG van de Raad, en tot wijziging van Richtlijn 2000/60/EG (PbEU 2008 L 348/84). 
goed dat de wetgever die Krw die al wel kon worden opgeschreven, toen eerst maar heeft vastgesteld, in afwachting van de rest."

\subsection{Maar zou een wetssysteem niet beter worden als de wetgever wacht tot hij meer weet?}

"De wetgever kan moeilijk wachten totdat hij alles weet. Bij elke nieuwe wet gaat het in het begin om boekenwijsheid. Daarna blijkt dat er in de harde werkelijkheid veel problemen zijn en vragen rijzen waarover nog niet veel kennis bestaat. Dan gaat de wereld er met die kennis in het achterhoofd gaandeweg toch weer anders uitzien dan het aanvankelijke beeld, dat soms achteraf bezien zelfs wel eens een beetje karikaturaal blijkt te zijn geweest. Dat zorgt weer voor een hoop extra wetgeving. De verdiepingsslag van je kennis over de werkelijkheid krijg je niet als je niet eerst gewoon eens begint met die wetgeving. Je moet ook echt niet verwachten dat je dat door inspraak en betrokkenheid van belangengroepen of zelfs praktijkmensen allemaal boven water krijgt. Die moeten ook eerst ervaren hoe de wetgeving gaat werken. Het is het lot van de wetgever dat er dan allemaal kritiek over hem wordt uitgestort, waar hij niet aan heeft gedacht, maar als hij zijn eigen wetten mag uitvoeren zou de wetgever dat natuurlijk zelf ook wel zien. Niemand heeft hem dat eerst verteld of kon hem dat zelfs vertellen, dus het is geen kwestie van niet luisteren of zo. Wetgeving vindt plaats op een hoog abstractieniveau, maar weinigen kunnen op dat niveau denken blijkt bij consultatie en inspraak steeds weer. De wet die op deze wijze is ontstaan wordt dan losgelaten in de praktijk, dat is eigenlijk net alsof je de kwetsbare orka Morgan in de wilde natuur loslaat."

"Vergelijk ook de ontwikkeling van betere milieutechnieken. Die komen er ook niet automatisch als je niet eerst eisen gaat stellen die het nodig maken om ze te gaan ontwikkelen. Je kunt beter dus maar gewoon beginnen met wat je al kunt bedenken. Je loopt dan vervolgens in de praktijk tegen de nodige problemen aan en die moet je dan weer met nieuwe wetgeving oplossen. Het is hierdoor toch vaak een incrementalistische aanpak, zoals ik in mijn studie leerde en dat sprak mij toen ook al aan als een realistische visie. Ook de wereld waarin de wetgeving terechtkomt, verandert voortdurend. Verder is er de uitdaging dat niet alles kan, omdat de middelen beperkt zijn. We hebben ook te maken met veel beperkingen van ons voorstellingsvermogen. Onze creativiteit om oplossingen te bedenken, of de tijd die we daarvoor krijgen, schiet vaak tekort. Daarom blijf je in de praktijk oplopen tegen de problemen die het gevolg zijn van die beperkingen. Je wordt ook pas vindingrijk als het geld op is, niet zolang er nog een heel pakhuis van Dagobert Duck is. De situatie waarin wetgeving geen vragen oproept en geen wensen onvervuld laat, is onbereikbaar.” 
8.7. Is het niet een risico om niet te wachten tot er voldoende kennis is alvorens een wet te maken?

"Soms worden er dingen over het hoofd gezien, waarvan je je later afvraagt waarom daaraan niet is gedacht. Over de Flora- en faunawet is destijds in de Tweede en Eerste Kamer 10 jaar gedaan. Terwijl het ging om een wet die voortkwam uit wetten die er al waren en waarmee men toch al enige ervaring had opgedaan of op had kunnen doen. De discussies gingen met name over de gevolgen voor de jacht en niet over onderwerpen die nu van belang zijn, zoals de gevolgen voor de infrastructuur of voor de veehouderij. Die problemen zijn toen helemaal niet aan bod geweest, eenvoudigweg omdat de eerdere wetgeving niet was toegepast en men tegen bepaalde problemen die zich dan onvermijdelijk zouden hebben voorgedaan, nog niet was opgelopen. De gevolgen van artikel $75 \mathrm{Ffw}$ voor infrastructuurwerken en bouwprojecten waren bijvoorbeeld helemaal geen onderwerp van bespreking, terwijl dit, toen de wet eenmaal in de uitvoeringsfase was beland, niet meer uit de krant was weg te branden. Onvoorstelbaar lijkt dat nu. Ieders fantasie om de komende problemen te bedenken was kennelijk tekort geschoten. Mijn stelling is dan ook dat als je niks van een wet hoort, dat niet betekent dat het een goede wet is, maar dat er in de praktijk niet mee wordt gewerkt. Want als je dat doet, komen de vragen en problemen vanzelf. De vergunningplicht voor veehouderijen is bijvoorbeeld nooit gehandhaafd en dan leer je ook niets. Vandaar de problemen, waarover we het al hebben gehad. Er is dus ook geen oplossing gezocht of gevonden voor het probleem van de veel te hoge stikstofdepositie die veehouderijen veroorzaken. Er is ook nog steeds een enorm gebrek aan kennis hoe de natuur precies werkt. De wetgever kan dus niet alles in één keer regelen, zelfs al zou hij dat willen. Ik heb overigens zelf niet zoveel op met hemelbestormende visies die voor alles een oplossing pretenderen, want die gedragen zich na verloop van tijd meestal als wereldvreemde dictators en blijken alleen maar zelf geformuleerde problemen op te lossen die niet bestaan en vooral zelf een reëel probleem te zijn."

"Ik kan trouwens nog een mooi voorbeeld noemen van voortschrijdend inzicht waardoor beleid veranderde. Aanvankelijk werd gedacht dat de instandhoudingsdoelstellingen per gebied zouden moeten worden bereikt, dat werd in elk geval in de wetenschappelijke literatuur verdedigd. Later vroeg men zich af of dat wel zo was en of niet ook naar de gunstige staat van instandhouding op nationaal niveau moest worden gekeken. Dat laatste werd toen uitgangspunt van het beleid van het ministerie. Dat dit zo kon, werd bevestigd door de Afdeling bestuursrechtspraak. Bij nader inzien is het zelfs een rare gedachte geweest om het vereiste van een gunstige staat van instandhouding op gebiedsniveau toe te passen, want je kunt ecologisch gezien de doelstellingen voor een habitattype of soort niet binnen één gebied realiseren. Het is eigenlijk raar dat men dat niet meteen al heeft bedacht. Maar nu heeft Chris Backes aangegeven dat het eigenlijk een Europese 
doelstelling is, op het niveau van het Natura 2000-netwerk als geheel. ${ }^{19}$ Dat lijkt mij op zichzelf een juiste gedachte, want het is een Europees netwerk. Het kabinet is daar onmiddellijk op ingesprongen, want dat zou kunnen betekenen dat Nederland bepaalde maatregelen helemaal niet hoeft te nemen, met als argument dat dit gemakkelijker en goedkoper in het buitenland kan gebeuren. Dat zou er dan toe kunnen leiden dat die natuurwaarden dan voor Nederland worden opgegeven. Ik denk niet dat Backes blij zal zijn met de draai die nu aan zijn conclusie wordt gegeven, want dat was vast de bedoeling niet. Het wordt dan al snel onduidelijk welke lidstaat waarvoor verantwoordelijk is, als het een beetje moeite kost zullen zij zich achter elkaar verschuilen en allemaal niks doen. Als het die kant op gaat, dan moet de Europese Commissie natuurlijk gaan nadenken hoe ze de lidstaten weer terug in hun hok krijgt. Zo wisselt gaandeweg de tijd het perspectief van de wetgever steeds weer. Wetgeving doet mij vaak denken aan een autorit door het hooggebergte, na elke S-bocht die je maakt ziet de wereld er weer heel anders uit."

8.8. Maar de vraag blijft waarom niet alles wat met natuur te maken heeft in de Wet natuurbescherming zou moeten worden geregeld? Waarom niet de Wet op de landinrichting of de EHS?

"Dat ben ik met je eens. We hebben dat ook zo opgeschreven in het onderzoek dat ik met Backes en Poortinga heb gedaan. ${ }^{20}$ De EHS is nodig om de Natura 2000-doelen te behalen. Die verbindingszones en dat netwerk heb je niet nodig als de afzonderlijke Natura 2000-gebieden zichzelf wel zouden kunnen redden. De gedachte achter Natura 2000 is juist dat je een netwerk moet hebben omdat al die gebieden zelf te klein zijn voor een duurzame instandhouding. Art. $10 \mathrm{HR}$ zegt dan ook dat je moet nadenken of je verbindingszones tussen de Natura 2000-gebieden moet aanleggen. Het mag ook wat anders zijn dan de EHS om een gunstige staat van instandhouding mee te bereiken, maar dat moet dan ook wel werken. Dat gebeurt nu niet, de verbindingszones worden simpelweg geschrapt en er komt agrarisch natuurbeheer waarvan uit alle onderzoeken blijkt dat het niet werkt."

19 Ch.W. Backes, A.A. Freriks en B.A. Beijen, Juridische ruimte in de implementatie van Natura 2000, in: Natura 2000 in Nederland. Juridische ruimte, natuurdoelen en beheerplannen, Planbureau voor de Leefomgeving, Den Haag, 2011, ISBN 978-90-78645-60-3, p. 24-76.

20 Backes/Poortinga \& Woldendorp, Natuurbescherming in de Natuurwet: Kop eraf? 2010. 


\subsection{Mr. ing. B. Rademaker}

Functie: Beleidscoördinator wetgeving bij het Ministerie van Infrastructuur en Milieu.

Relevante ervaring: Rademaker heeft als beleidsjurist onder meer meegewerkt aan het ontwerpen van teksten voor de Woningwet, de Wabo en de Wet ruimtelijke ordening. Het gaat daarbij met name om wetgevingstrajecten met een dereguleringsmotief om onderwerpen eenvoudiger en slimmer te regelen.

Datum interview: 28 december 2011

Interview geautoriseerd: 24 januari 2012

\section{SAMENHANG}

1.1. Kijken wetgevingsjuristen wel naar samenhang in omgevingswetgeving? En kijken ze daarbij ook naar wat voor burgers en bedrijven herkenbaar is?

"Toen ik bij het ministerie kwam, was het blikveld van de organisatie heel verkokerd. Elk departementsonderdeel zijn eigen beleidsveld, zijn eigen wet, zijn eigen vergunning en regeling. Dat werkte ook door naar provinciale en gemeentelijke overheden, met een afdeling bouw, ruimtelijke ordening, milieu, monumenten etcetera. Met de Wabo zijn eigenlijk voor het eerst diverse domeinen met elkaar te verbonden in één wet. De Wabo is eigenlijk ontstaan vanuit de behoefte om de bouwvergunningprocedure te versnellen. De mogelijkheden tot versnelling zaten niet zozeer in de Woningwet zelf. Daar zaten de problemen niet. Die zaten wel op het vlak van een bouwplan dat niet voldeed aan het bestemmingsplan. Dan moest je twee wetboeken openleggen (WRO en Woningwet) om voor één bouwplan twee aparte procedures te doorlopen. Een aanvraag om bouwvergunning op basis van de Woningwet wordt dan automatisch ook een aanvraag op basis van de Wro. De ene procedure moest vervlochten verlopen met de andere, terwijl het in de kern neerkwam op de vraag 'mag ik op die plek bouwen?' Zeker als er ook nog eens andere vergunningen nodig waren (zoals een milieuvergunning, monumentenvergunning, kapvergunning) werden de procedurele afstemmingsconstructies om de verschillen in bevoegd gezag, procedures van voorbereiding, rechtsbescherming en inwerkingtreding in goede banen te leiden, zo ingewikkeld dat ze eigenlijk niet meer waren uit te leggen. Niet echt handig voor burgers en bedrijven dus. Om dit te vereenvoudigen werd aanvankelijk eerst gedacht aan coördinatieregelingen om diverse procedures op elkaar af te stemmen. In de Woningwet zaten die al (art. 52 en 52a Wow), maar dergelijke regelingen worden naar mijn mening nooit eenvoudig." 
"De stomste fout die de wetgever ooit heeft gemaakt is het lostrekken van de ruimtelijke ordening uit de Woningwet in 1965 . Het bouwen is achtergebleven in de Woningwet terwijl de ontwikkeling van de ruimtelijke ordeningswetgeving in een aparte wet werd opgenomen. Daar is het denk ik fout gegaan." Waarom? "De bouwvergunning en de bouwverordening bleven in de Woningwet. In de bouwverordening stond een stedenbouwkundige regeling: een uitbreidingsplan in hoofdzaken, eigenlijk een stratenplan om te voorkomen dat je op de straat zou kunnen bouwen. In 1932 is de Woningwet van 1901 gaan gelden voor andere gebouwen dan woningen. Na WO II kreeg je de Wederopbouwwet. Het bouwen als zodanig is zo verweven met ruimtelijke ordening, zodat het achteraf niet goed is te begrijpen dat je die onderwerpen los van elkaar in afzonderlijke wetten regelt! Ik denk dat we geen discussie over een Wabo hadden gehad als destijds was gekozen voor bouwen en ruimtelijke ordening in één wet. Dan was het logisch om in dezelfde wet te regelen dat je zou mogen bouwen in afwijking van een bestemmingsplan. Het was misschien al wel denkbaar geweest dat de milieuwetgeving zich ook vanuit die wet zou hebben ontwikkeld, maar dat weet ik niet zeker."

"De aanleiding voor de Wabo was eigenlijk het samenvoegen van toestemmingen op ruimtelijk gebied met de bouwvergunning. Ook allemaal toestemmingen die door de gemeente werden verleend. De milieuvergunning is er later pas bijgekomen. Dat was de wens van minister Dekker. Goed voor burgers en bedrijven. Maar ingewikkelder voor overheden. Daarmee kwam namelijk ook een ander bevoegd gezag in beeld: Gedeputeerde Staten.”

1.2. Wordt het wel eenvoudiger door bundeling?

"Ja, maar moeilijke onderwerpen worden inhoudelijk niet eenvoudiger door te bundelen. Maar een Omgevingswet dwingt, net als de Wabo, tot intensievere samenwerking. Van samenwerking word je slimmer en daardoor kun je wellicht ook de materiële wetgeving eenvoudiger maken doordat er diverse expertises bezig zijn met hetzelfde besluit. Die boodschap draag ik overal uit. Er zijn wel vereenvoudigingsslagen te maken, maar het uitsluitend verhangen van regelingen maakt het op zichzelf niet eenvoudiger."

1.3. Is een apart projectbesluit naast de omgevingsvergunning dan een goed idee?

"We moeten ons goed afvragen of zo'n aparte figuur naast de omgevingsvergunning wel echt nodig is. Hoe minder juridische figuren hoe eenvoudiger. Minder instrumenten, meer mogelijkheden zou mijn motto zijn. Waarom zouden we niet gewoon de omgevingsvergunning gebruiken, ook voor grote projecten met een voorbereidingsprocedure gebaseerd op de adviezen van de commissie Elverding? De omgevingsvergunning is tenslotte 
een vergunning voor het uitvoeren van een project en is niet naar boven toe afgebakend tot een bepaalde reikwijdte of begrenzing."

"De Wro lijkt eenvoudig: er is een bestemmingsplan dat moet voldoen aan een goede ruimtelijke ordening. Je staat soms een afwijking van het bestemmingsplan toe met een omgevingsvergunning en op termijn pas je in het reguliere actualiseringsritme de vergunning in in het bestemmingsplan. Lijkt eenvoudig. Maar ... er is een grote hoeveelheid van vrij niet transparante en versnipperde wetgeving waarin staat waarmee je allemaal rekening moet houden bij het nemen van ruimtelijke besluiten, zoals het Bevi, de Wet geluidhinder, archeologie, waterkwaliteit, lozingen, geurregels, vaak met zoneringen. Die regels waarmee je rekening moet houden staan niet in de Wro of het Bro maar elders. Daar zou in de Omgevingswet meer samenhang gevonden kunnen worden."

1.4. Hoe zou je tot een betere inhoudelijke samenhang kunnen komen?

"Door niet elk motief apart in een afzonderlijke wet te regelen, maar meer aan te sluiten bij de werkelijkheid van een project. Zo zou je welstandstoezicht, nu nog geregeld in aparte welstandsnota's, de stedenbouwkundige regeling in de bouwverordening en de lokale monumentenverordening kunnen integreren met het bestemmingsplan of de beheersverordening en bij elkaar kunnen plaatsen in een omgevingsverordening. Dan heb je ook inhoudelijke vereenvoudiging en samenhang bereikt.”

\subsection{Is dat niet ook een soort verhangen?}

"Niet per se. In het bestemmingsplan staat nu wat je waar wel en niet mag bouwen en gebruiken. In de bouwverordening is een stedenbouwkundige paragraaf opgenomen waarin is bepaald wat je wel en niet mag bouwen ten opzichte van stedenbouwkundige rooilijnbepalingen. Die regeling is veel globaler dan het bestemmingsplan en werkt aanvullend op het bestemmingsplan. Dat is het gevolg van het feit dat er eigenlijk twee wetten deels over hetzelfde onderwerp gaan: Woningwet en Wro. Leg daarnaast de welstandsnota. Die gaat ook over waar je wat en hoe mag bouwen. Dat is dus ook een soortgelijke regeling als in het bestemmingsplan. Die dingen horen bij elkaar; dat moet je niet loskoppelen. Iets dergelijks heb je bij de monumentenregels. Daar worden panden aangewezen als monument en dan is er ook een vergunningplicht voor slopen en wijzigen nodig. Dat lijkt veel op de bouwvergunningplicht. Waarom moet dat allemaal in vier verschillende boekjes staan? Als burger moet je dus telkens vier boekjes raadplegen. Als je dat bij elkaar zou zetten in een omgevingsverordening, dan mag je verwachten dat er veel meer inhoudelijke samenhang zal gaan bestaan tussen hetgeen is geregeld. De overlap tussen bestemmingsplan en welstandstoets leidt nu nog wel eens tot achterhoedegevechten in de pikorde tussen welstand en de ambtelijke organisatie van gemeenten. Bij meer samenhang in het regelen, verdwijnen de 
kunstmatige begrenzingen tussen welstand, bestemmingsplan, bouwverordening en cultuurhistorie en wordt het vanzelf transparanter."

1.6. Is het een goed idee om milieuaspecten daaraan toe te voegen?

"Op zichzelf kunnen geur, geluid en andere milieuaspecten ook in die verordening, maar echt integreren zie ik dat niet. Die aspecten zijn veelal ook op rijksniveau geregeld. Je kunt het wel in één wet zetten, want dan heb je alles transparant bij elkaar wat ruimtelijke consequenties heeft. Maar grote inhoudelijke integratievoordelen (anders dan procedureel) zie ik zo niet heel direct."

1.7. Waarom gekozen voor ruimtelijke consequenties?

"Bij projecten komen alle ruimtelijke consequenties samen, terwijl de wetgeving daarover tamelijk versnipperd is. Het zou best kunnen dat er ook andere samenhangcriteria zijn, zodat ook stoffen en producten in de Omgevingswet moeten. Ik zie niet meteen grote winst daar. Als je alles op het gebied van milieu, natuur, water en ruimtelijke ordening bij elkaar kunt zetten, is dat op zichzelf mooi. Een bijbel voor alles wat met omgevingsrecht te maken heeft. Maar het lijkt mij bijvoorbeeld niet echt nodig om regels over het vangen van walvissen op zee in de Omgevingswet te zetten. Ik ben niet op voorhand tegen, maar het blijven dan waarschijnlijk wel losse onderdeeltjes in een omvangrijkere wet, zonder dat er echte integratievoordelen ontstaan."

\subsection{Speelt de taakverdeling tussen departementen hier nog een rol?}

"Dat ligt voor de hand. Als alle omgevingsregels in één wet staan, is er een kans dat op termijn ook het beleid en de zeggenschap bij hetzelfde departement komt. Waarom ligt het primaat met betrekking tot monumenten nog bij OCW? Het is toch niet alleen cultuur, maar ook erg ruimtelijk? Waarom bouwen bij BZK en niet bij IenM? Bouwen is immers altijd een hard onderdeel geweest van VROM-beleid. Natuur heeft veel ruimtelijke consequenties. Zoals ook Biezeveld, Geelhoed en Woldendorp hebben gezegd moet de overheid niet van binnen naar buiten maar andersom denken en organiseren. Een voorbeeld is ook water. Ik heb wel horen zeggen dat het kwartet van de Waterwet niet meer compleet zou zijn als de lozingsvergunning onderdeel wordt van de integrale omgevingsvergunning. Tja, wat is integraal? Voor burgers en bedrijven lijkt het me juist handig dat ze via één aanvraag voor een project vergunning kunnen vragen en dat de overheid achter het loket alle inhoudelijke aspecten van een project in samenhang beoordeelt. Een Wabo dus." 


\section{KENBAARHEID}

2.1. Kijkt de wetgevingsjurist ook naar meer kenbaarheid of voorspelbaarheid?

"Dat zou wel zo moeten zijn. Hoe duidelijker een regel is hoe liever. Daarmee wordt ook de naleving gemakkelijker. Maar dat is niet altijd mogelijk. Bij ruimtelijke ordening bijvoorbeeld gaat het niet alleen over harde grenswaarden maar ook over appreciatie en goede smaak. Je zou de ruimtelijke ordening eigenlijk in een NEN-norm moeten kunnen vangen. Maar dat is een illusie, het zou de voorspelbaarheid echter wel ten goede komen."

\section{SAMENHANGCRITERIA}

\subsection{Wat was het samenhangcriterium dan voor de Wabo?}

"Over een inhoudelijk samenhangcriterium hebben we niet echt nagedacht geloof ik. De Wabo was bedoeld om procedures te integreren in één procedure. De Wabo was niet bedoeld om inhoudelijke wetgeving te vereenvoudigen. Er waren immers al de nodige dereguleringsoperaties doorgevoerd. Op korte termijn bleek vooral winst te behalen in de aanpak van de verbrokkelde procedurele wetgeving. Daar zagen we nog relatief eenvoudige mogelijkheden om tot een vereenvoudigingsslag te komen."

3.2. Dat verklaart dan ook dat de wetgever in de memorie van toelichting bij de Wabo opschrijft dat het gaat om het samenvoegen van toestemmingsvereisten voor een Wabo-project?

"Ja. Het wordt namelijk inhoudelijk niet eenvoudiger als je het Bouwbesluit onder de Wabo hangt in plaats van onder de Woningwet. Je kunt dus best de grondslag voor het Bouwbesluit verhangen naar de Wabo of de Omgevingswet, maar het Bouwbesluit wordt daar zelf niet eenvoudiger van. De sterkteberekeningen blijven zoals ze zijn en daar kan de wetgever niet veel vereenvoudigen. Je kunt wel materiële wetgeving schrappen, maar dat gaat direct ten koste van de beschermingsniveaus. Zo kun je het Bouwbesluit afschaffen, maar dan gaan verzekeraars direct zaken regelen, zoals in Frankrijk het geval is. Dat is natuurlijk ook niet echt deregulering. Bovendien is er dan geen sprake meer van overheidswetgeving en dan is er geen inspraak meer mogelijk. Bovendien wordt het daar ook niet gemakkelijker van.” 
3.3 De wetgever moet aansluiten bij de echte werkelijkheid van burgers en bedrijven?

"Daarvan ben ik heilig van overtuigd. Voor hen is de werkelijkheid dat zij iets op een bepaalde plaats willen realiseren en gebruiken. Hun eigendom bijvoorbeeld. Zij gaan echt niet denken vanuit een watersysteembenadering. Het grote voordeel van een wet die mensen begrijpen is ook dat de kans groter wordt dat men zich eraan houdt. De wetgever moet dus op zijn minst datgene wat je van burgers en bedrijven verlangt (dat ze zich houden aan een aantal regeltjes op het terrein van het omgevingsrecht) transparant en samenhangend regelen. Als je vindt dat iemand ergens een bouwproject ontwikkelt, dan moet je hetgeen je regelt niet versnipperen over verschillende wetten. Dat geldt overigens ook voor ambtenaren die in de ruimtelijke ordening bestemmingsplannen moeten maken. Als je al ziet hoe lastig het soms is om op te zoeken waar wat staat en hoe je het moet lezen, dan vraag je om fouten in de naleving."

3.4. Waarom is in de Wabo niet gekozen voor het integreren van de watervergunning in de omgevingsvergunning?

"Tja. De Waterwet werd in een eigen traject ontwikkeld bijna tegelijkertijd met het traject van de Wabo. Er was denk ik ambtelijk en politiek onvoldoende draagvlak om direct in het 'diepe' te springen van de Wabo. Bedenk daarbij dat de Wabo internationaal gezien nieuw en heel vooruitstrevend is. Zowel binnen als buiten ons departement waren er bij velen tot het einde twijfels of het idee van een integrale vergunning in het echt wel zou kunnen werken. Eerst zien, dan geloven!"

3.5. En waarom niet de terrasvergunning, de exploitatievergunning en de drank- en horecavergunning opgenomen in de Wabo?

"Dat zou inderdaad wellicht logisch zijn geweest, maar eigenlijk gaat het dan om persoonsgebonden vergunningen, terwijl de vergunningen in de Wabo allemaal projectgebonden zijn. Voor de terrasvergunning geldt dat niet, maar die is weer meer op openbare orde gericht. Er is eigenlijk meer gekeken naar de bouwvergunning en wat daarmee samenhangt. De milieuvergunning is er ook later pas bij gekomen. Dat wilde minister Dekker. Zij was ook geen voorstander van tranches. Met de milieuvergunning haalde je ook de ingewikkelde bevoegdheidsdiscussie binnen. Dat is wel gebleken. Bij de verdere doorontwikkeling van de omgevingsvergunning in de Omgevingswet komen alle mogelijkheden natuurlijk weer in beeld."

\subsection{En de ontgrondingenvergunning?}

"Daarvan was van meet af aan duidelijk dat die in de Wabo zou moeten. Het voorstel daartoe lag eigenlijk al klaar. Er waren nog wel wat uitzoekpunten. De vraag was zelfs of er überhaupt nog wel een ontgrondingenvergunning 
zou moeten blijven. In de snelheid van het wetstraject van de Wabo (waarbij we overigens nog genoeg andere discussie- en uitzoekpunten hadden) kon het om die reden niet direct meegenomen worden."

4.1. Is het een goed idee om met gelaagde structuren te werken? Zorgen gelaagde structuren er niet voor dat de justitiabele in drie wetssystemen moet kijken wat zijn rechten en plichten zijn?

"Daar is wel over nagedacht. Een wet moet langs het parlement. Een algemene maatregel van bestuur alleen in geval er een voor- en/of nahangprocedure is voorgeschreven. Een ministeriële regeling is nog weer sneller. Eigenlijk is het een algemeen criterium dat de echt belangrijke dingen in de wet zelf staan en de uitvoeringsaspecten in de onderliggende regelingen." "Het nadeel is wel dat je voor sommige zaken in drie regelingen moet kijken. Maar alles regelen op wetsniveau maakt een wet ook wel erg dik en ondoorgrondelijk. Bovendien zou voor wijzigingen op bijzaken een compleet wetstraject nodig zijn.”

4.2. Bij de Wabo zijn regels van wet naar Bor of Mor gegaan. Welke criteria golden?

"Tja, daar golden niet echt vaste regels voor. Veelal werd gekeken naar een mogelijkheid om de Wabo zelf zo simpel mogelijk te houden. We zijn bijvoorbeeld niet op alle fronten slim genoeg om een kort en eenvoudig criterium te bedenken wat wel en niet met vergunning mag worden gebouwd. Dus is op die onderdelen vaak een uitwerking nodig, zoals bij vergunningvrije bouwwerken. Dit kan beter op amvb-niveau. Dat is flexibeler. Met digitale technieken is wel inzicht te geven in uitgebreide amvb-regels."

4.3. Is ook nagedacht over de gevolgen van het schrappen van hoofdstuk IV van de Woningwet en het grootste deel van hoofdstuk 8 van de Wet milieubeheer door de Wabo?

"Iedereen was wel gebaat bij het schrappen van de bouwvergunningregels uit de Woningwet. De Woningwet zou aanvankelijk eigenlijk opgedeeld worden in een Woonwet en een Bouwwet. Er was al een wetsontwerp gemaakt voor een Woonwet, die eigenlijk de regels over corporaties zou bevatten. Wat er over zou blijven, zou in een Bouwwet moeten landen. Remkes heeft dat in 1999 al aan de Tweede Kamer geschreven. In de Bouwwet zou er al een bredere bouwgerelateerde vergunning komen voor bouwen en ontheffingen van bestemmingsplan etcetera. Dat idee is vervolgens verder verbreed door ook de milieuvergunning toe te voegen. Toen werd het geen Bouwwet maar een Wabo." 
4.4 Waarom zijn regels over procedures en handhaving niet in de Awb gebleven?

"Die zijn in de Awb gebleven, maar soms moet je aanvullend regelen wat er wel of niet geldt van de Awb. En er zijn natuurlijk ook wel een paar regels in de Wabo opgenomen die afwijken van de Awb."

\section{GEEN NIEUWE WETTELIJKE OPLOSSINGEN}

5.1. Is het een goed idee om nieuwe wettelijke oplossingen te creëren bij het bundelen van omgevingsrecht?

"Ja, uiteraard. Sommige dingen kunnen beter en eenvoudiger. Maar er is niet voor elke vereenvoudiging voldoende draagvlak. Zo is de gemeente niet altijd voor alle vergunningen bevoegd. Zo zijn er nog steeds twee procedurevarianten in de Wabo (regulier en uitgebreid). Ook bestaan in de Wabo de figuren van advies, verplicht advies en verklaring van geen bedenkingen. $\mathrm{Al}$ die variaties zijn soms vanuit een bepaalde optiek wenselijk, maar maken een wet wel ingewikkelder. Daarover moet de wetgever bij de Omgevingswet ook nog eens goed nadenken. De kunst is om ingewikkeld makende compromissen te voorkomen."

\section{TOEKOMSTBESTENDIG}

6.1. Hoe voorkom je dat je een Omgevingswet maakt die over drie jaar weer fundamenteel anders moet?

"Ik denk wel dat we de Omgevingswet nu voor langere tijd maken. Uiteraard moet zich dat doorontwikkelen. De structuur moet dan wel eenvoudiger worden. Je moet eigenlijk iets verzinnen dat in zijn opzet en structuur niet zo snel zal veranderen.”

\subsection{De echte werkelijkheid?}

"Dat zou je zo kunnen noemen. Kijk, een bouwproject blijf je houden. Een vergunning daarvoor verzin je ook niet zomaar weg. Als je een omgevingsvergunning hebt met daarin ook de watervergunning en natuurvergunning, een integrale omgevingsverordening en één bevoegd gezag, dan maak je denk ik een eenvoudig systeem dat over vele jaren nog kan werken." 


\subsection{Mr. T.C. Borman}

Functie: coördinerend raadadviseur bestuursrecht

Relevante ervaring: de heer Borman heeft als wetgevingsjurist vele jaren ervaring met bestuursrecht (bij het Ministerie van Veiligheid en Justitie).

Datum interview: 17 januari $2012^{21}$

Interview geautoriseerd: 25 januari 2012

\section{$5.4 \quad$ Mr. J.F.L. Roording}

Functie: coördinerend raadadviseur wetgevingskwaliteitsbeleid

Relevante ervaring: de heer Roording heeft als wetgevingsjurist vele jaren ervaring met (nationale en internationale) wetgeving op het terrein van het strafrecht (bij het Ministerie van Veiligheid en Justitie) en de natuurwetgeving (bij het toenmalige Ministerie van Landbouw, Natuur en Voedselkwaliteit).

Datum interview: 17 januari 2012

Interview geautoriseerd: 25 januari 2012

\section{SAMENHANG}

1.1. Wordt bij nieuwe wetgeving steeds naar de inpassing in het gehele systeem gekeken?

Borman: "De politiek wil constant allerlei zaken regelen met wetgeving. Als er een probleem moet worden aangepakt en er is wetgeving nodig, dan moet er gewoon iets geregeld worden. De eerste reflex is dan niet om te kijken of er samenhang bestaat met andere onderdelen van het recht. Het in elkaar schuiven van wetgeving gebeurt in mijn perceptie eigenlijk pas als men waarneemt dat voor verschillende compartimenten of beleidsterreinen regels zijn gemaakt die enige of soms wel 100 procent gelijkenis vertonen en denkt dat dat eenvoudiger zou kunnen door er één wet van te maken. Daarvan zijn allerlei voorbeelden te geven, zoals de Awb en de Waterwet. Dat zal allemaal verschillende redenen hebben. Het is niet gezegd dat dat altijd iets oplost. Het zou in bepaalde gevallen ook slechts een cosmetische operatie kunnen zijn. Maar bundeling is niet iets dat meteen op het netvlies staat van wetgevingsjuristen.”

Roording: "We hebben bij het Ministerie van Veiligheid en Justitie natuurlijk een aantal algemene wetten, zoals de Awb, maar nog ouder het Burgerlijk Wetboek, het Wetboek van Strafrecht en het Wetboek van Strafvordering. Dan

21 De heren Borman en Roording zijn gezamenlijk geïnterviewd. 
is de reflex natuurlijk snel, dat we kijken of we iets in die algemene wetten kunnen regelen. Er is dan eerder een natuurlijke aandrang tot systematiseren in die algemene wetten. In die zin heeft Justitie het dan misschien ook wat gemakkelijker dan vakdepartementen die zo'n algemene wet niet hebben." "Op het terrein van het strafrecht zag je overigens ook dat de neiging bestond om elke Europese regeling (kaderbesluit of richtlijn) in een aparte wet te regelen. Zo is er voor het Europees aanhoudingsbevel een aparte Overleveringswet ${ }^{22}$ gemaakt. Zo zijn er nog een paar gevolgd. Een enkele keer is weer wel gekozen voor omzetting in het Wetboek van Strafvordering. Ik kan me echter voorstellen dat je dan op een gegeven moment een soort fragmentatie ziet, waardoor de behoefte bestaat om die wetten ineen te schuiven."

1.2. Bestaat er een soort handboek voor bundeling?

Borman: "Nee, dat bestaat er niet. De Aanwijzingen voor de regelgeving en de literatuur gaan er ook niet zo expliciet op in.”

1.3. Van wie komt het initiatief tot bundeling?

Roording: "De oorsprong zal nogal eens bij de rechtspraktijk liggen als daar wordt geconstateerd dat wetten niet consistent zijn en langs elkaar heen schuren. De rechtspraktijk zal gewoonlijk echter niet pleiten voor een nieuwe integrale wet omdat men in die praktijk vaak juist huiverig is voor vernieuwingen. Maar in de praktijk kan wel blijken dat wetscomplexen niet goed op elkaar zijn afgestemd. Voor een departement of wetgevingsafdeling kan dat een reden zijn om die wetten in elkaar te schuiven, maar er moet dan wel een politieke basis voor zijn. We zitten tenslotte niet om werk verlegen en er is niet echt mee te scoren. Die politieke prikkel is dus heel belangrijk."

Borman: "In de sociale verzekeringswetgeving, zoals de Algemene kinderbijslagwet en de Algemene nabestaandenwet, zie je veel gelijksoortige bepalingen staan. Veel bepalingen zijn zelfs letterlijk hetzelfde. Ik denk dat die regels wel een keer zullen worden samengevoegd. Het lost misschien in de werkelijkheid niet veel op, maar het kan toch voordelen hebben om in één wet te kunnen kijken. Het lijkt heel basaal, maar ik denk dat als je het tien wetgevingsjuristen zou vragen, ze alle tien wel op de gedachte zouden komen van samenvoeging."

Borman: "Met de Awb hebben we in de derde tranche ${ }^{23}$ allerlei toezichthoudende bevoegdheden uit de bijzondere wetten gehaald en in hoofdstuk 5

22 Wet van 29 april 2004 tot implementatie van het kaderbesluit van de Raad van de Europese Unie betreffende het Europees aanhoudingsbevel en de procedures van overlevering tussen de lidstaten van de Europese Unie (Overleveringswet) (Stb. 2004, 195).

23 Kamerstukken II 1994/95, 23 700, Aanvulling van de Algemene wet bestuursrecht (Derde tranche Algemene wet bestuursrecht). 
opgeschreven. Het ging om honderden bepalingen in tientallen verschillende wetten met steeds verschillende formuleringen. Voor iedere wet afzonderlijk werkte dat wel, maar toch kwam de vraag op of de betekenis in de ene wet nu anders was dan in de andere vanwege het verschil in woordgebruik. Daar kan een algemene wet wat aan doen door een uniforme bepaling die voor alle gebieden geldt. De werkelijkheid verandert er volgens mij niet veel mee, maar de toepassing van de wet wordt wel gemakkelijker uiteindelijk."

\subsection{Maar gebruikers worden wel gedwongen om in twee wetten te kijken?}

Borman: "Dat klopt. Een veel gehoorde klacht van gebruikers is dat zij niet alleen in de bijzondere wet moeten kijken, maar ook in de Awb. Vroeger stond dat van a tot $\mathrm{z}$ in 'hun eigen' wet. Maar je moet toch al vaak in meer dan één wet kijken, zoals in het Wetboek van Strafrecht en het Wetboek van Strafvordering. Als je dat wilt voorkomen, moet je heel veel dubbel regelen en regels uit die wetboeken overschrijven. Bij de Awb is harmonisatie van wetgeving een officiële doelstelling: het bundelen van wetgeving om onnodige verschillen te voorkomen. Dat gebeurde in de derde tranche ook."

1.5. Waarom is het niet te vermijden dat gebruikers in verschillende wetten moeten kijken om hun rechten en plichten te kennen?

Borman: "Stel dat je de Awb niet zou hebben. Dan heb je de situatie van vóór die wet. Elke bijzondere wet regelt dan eigen toezichtsbevoegdheden, voorbereidingsprocedures, bezwaar, beroep, termijnen voor bezwaar en beroep, etcetera. Voor een advocaat en rechter is het wel gemakkelijk dat regels over procedures in het bestuursrecht bij elkaar staan in één wet en altijd gelijk zijn." "Als je ondernemer bent, eigenaar van een vervoersbedrijf bijvoorbeeld, dan kan ik me er iets meer bij voorstellen. Die ondernemer hoeft alleen maar te kijken naar de inhoudelijke normen die op zijn bedrijf van toepassing zijn, zoals de Wet Personenvervoer. Maar dat is niet het hele verhaal. Want ook die komt wel met andere wetten in aanraking. Het is voor de ondernemer toch ook handig te weten dat toezichthouders in alle gevallen hetzelfde mogen en dat een beroepstermijn in alle gevallen 6 weken bedraagt. Technisch is het wel mogelijk om die regels over te schrijven in een bijzondere wet. Dat is vroeger wel eens gebeurd en er is nog steeds discussie over. Tegenwoordig is die discussie snel afgelopen, want de lijn is duidelijk: niet herhalen." "Een belangrijk nadeel van herhaling is, dat er bij verandering dan in heel veel wetten tegelijk iets moet worden veranderd en ook dat iedere wetgever dan weer zelf kan bepalen om het weer net iets anders te doen. Dat bevordert de overzichtelijkheid en voorspelbaarheid van het recht niet. Nu wil ik niet zeggen dat uniformiteit altijd het hoogste doel moet zijn, maar vanuit de Awb is dat wel uitgangspunt. Stel dat je de beroepstermijn niet uniformeert in de Awb, maar in alle wetten die het 
aangaat 6 weken regelt. Dan weet ik zeker dat na vijf jaar in 10 wetten er 8 weken van is gemaakt en in tien andere wetten 2 weken. Dat is uit een oogpunt van eenduidige wetgeving geen goed idee." "In de Aanwijzingen voor de regelgeving kun je wel aangeven dat dat niet mag, maar de Aanwijzingen zijn in vergelijking tot echte wetgeving een redelijk zwak instrument."

Roording: "Het scheelt wetgevingsjuristen ook heel veel werk om niet steeds weer alles opnieuw te moeten regelen. Het brengt ook focus aan in wetsvoorstellen. Als je namelijk naast hetgeen in de kern geregeld moet worden ook nog allerlei andere zaken moet regelen, dan heb je kans dat ook daarover weer discussie gaat ontstaan. De Awb is in Den Haag bij de departementen wel geliefd, omdat veel zaken vastliggen. Dat geldt waarschijnlijk ook voor de rechtspraktijk van rechters en advocaten. Voor hen is het in elk geval handiger dan elke keer een aparte wet te moeten raadplegen. De vraag is of burgers en ondernemers nu zo vaak in de wet kijken. Of het voor hen nu zo erg is dat ze in twee wetten zouden moeten kijken."

Borman: "In de toelichting moet ook worden uitgelegd wat er niet in de wet staat. Zo kan daar worden uitgelegd hoe de rechtsbescherming in elkaar zit. Want de burger die een wettekst leest en daarin geen regels over beroep ziet staan, zou kunnen denken dat er helemaal geen beroep mogelijk is. Die regels staan echter in de Awb en die gelden als er niets anders is geregeld in bijzondere wetten.”

1.6. De indruk bestaat soms dat met name wordt gekeken naar de getallen. Elke wet minder lijkt dan goed te zijn?

Borman: "Het is heel onzuiver, maar die puur getalsmatige benadering speelt soms inderdaad wel een rol. Een paar jaar geleden is er een regelgevingsmonitor opgericht. Daar zit best wel wat in, want het is best interessant om te weten hoeveel regels en artikelen er zijn. Maar we moeten wel goed in het achterhoofd houden dat dat uiteindelijk niets zegt over regeldruk. Terwijl dat in de politiek wel gemakkelijk wordt gedacht. Dan wordt het getalsmatig al snel aantrekkelijk gezien om wetten in te trekken en samen te voegen."

Borman: "De Wet natuur is daar een goed voorbeeld van. Van drie naar één wet schijnt volgens sommigen al winst te zijn. De Boswet kun je natuurlijk net zo goed apart laten. Die is eigenlijk alleen maar een apart hoofdstuk geworden. Misschien dat je nog iets met harmoniseren van begrippen kunt in die zin dat voor de Boswet dezelfde begrippen gelden als voor de Natuurbeschermingswet 1998 en voor de Flora- en faunawet, maar dan heb je het ook wel gehad. Als het alleen maar betekent dat drie wetten in drie hoofdstukken zijn weergegeven, dan is het eigenlijk slechts een cosmetische operatie. Maar toch zie je dat dat door de politiek wel als winst wordt gezien." 
Roording: "En toch kan dat eenvoudig in elkaar schuiven al leiden tot een zekere stroomlijning. De operatie kan ertoe leiden dat je nog eens goed nadenkt over het systeem en dat je inconsistenties, die dan vanzelf aan het licht treden, wegneemt.”

\section{KENBAARHEID}

2.1. Kijkt de wetgevingsjurist ook naar meer kenbaarheid of voorspelbaarheid?

Borman: "Intelligent overschrijven kan een voordeel hebben, omdat het begrippenkader dan gelijk blijft en de praktijk niet steeds hoeft te veranderen. Wetgevers hebben een tamelijk conservatieve houding: zoveel mogelijk aanhaken bij wat er al is. Dat is voor de praktijk niet slecht."

Roording: "De wetgevingsjurist zal vaak zoeken naar soortgelijke bepalingen en formuleringen. Het is niet nodig om steeds weer het wiel uit te vinden. Dat is niet alleen gemakkelijk, maar ook goed uit een oogpunt van consistentie."

Borman: "Wetgeving blijft natuurlijk een juridisch document, dat niet kan worden opgesteld in Jip-en-Janneketaal. Daarvoor is de spreektaal te weinig precies en te multi-interpretabel. Het aantal rechterlijke procedures zou vertienvoudigen als we dat wel zouden doen. Je kunt vaak wel eenvoudig uitleggen wat er in de wet staat, maar dat kan zo niet worden opgeschreven."

2.2. Wordt de wetgeving dan wel ooit echt eenvoudig?

Roording: "Eigenlijk weet je het pas als je het hebt geprobeerd en je weet welk dor hout je kunt snoeien. De Omgevingswet is qua gedachte wel de moeite waard, maar ik moet eerst de tekst zien voor een echt oordeel. Ik denk dat het opnieuw overdenken tot vereenvoudigingen kan leiden.”

\section{SAMENHANGCRITERIA}

3.1. Bestaan er regels voor het kiezen voor een samenhangcriterium?

Borman: "Daar bestaan geen regels voor. Vaak is er eigenlijk ook geen tijd om daar uitgebreid onderzoek naar te doen. Laten we wel zijn, het gaat bij wetgeving om juridische documenten. Die zullen in de praktijk in de voorlichting vertaald moeten worden. Het is een illusie te denken dat burgers en ondernemers die teksten zonder gedegen voorkennis zouden kunnen begrijpen." "Het criterium zal moeten zijn dat er wel samenhang 
moet zijn. Als twee wetten niets met elkaar te maken hebben, lijkt er geen reden tot samenvoeging."

3.2. Voor wie maakt de wetgever wetten dan?

Borman: "De geadresseerde is wel vaak een burger of bedrijf, maar het gaat om juridische documenten. Die worden eerder geschreven voor een rechter dan voor de burger. Dat geldt zeker voor regels als de Awb. De burger zal die wetteksten niet integraal gaan lezen."

Roording: "Of voor de uitvoerende ambtenaren."

Borman: "In de Awb staat natuurlijk wel veel waarmee burgers en ondernemers wel te maken hebben. Denk aan de aanvraag en de voorbereiding van vergunningen. Het verhaal in bijzondere wetten is dus behoorlijk incompleet. Maar dat is een keus die welbewust is gemaakt omwille van de harmonisatie van bestuurswetgeving in de Awb. De ondernemer zal daar wellicht dagelijks mee te maken hebben."

Roording: "Die keuze tussen algemeen regelen in de Awb of sectoraal in bijvoorbeeld de Omgevingswet is elke keer weer relevant."

\subsection{Wie beslist nu wat het samenhangcriterium zal zijn?}

Borman: "De vraag is eigenlijk wanneer iets zich leent voor algemene regels. Vaak zijn de wetgevingsjuristen de mensen die daar een belangrijke stem in hebben. Beleid en politiek zijn niet zozeer geïnteresseerd in samenhangvragen. Dat vindt men te technisch en overziet men niet. Het initiatief voor oplossingsrichtingen moet gewoonlijk van juristen komen."

Roording: "Bij de Omgevingswet is het Ministerie van Veiligheid en Justitie ook betrokken, maar wel enigszins op afstand. De discussie welke onderwerpen precies vanuit welk samenhangcriterium worden opgenomen is meer een discussie binnen de beleidsdepartementen. Of stoffenregels al dan niet in de Omgevingswet moeten is meer een kwestie van wat de beleidsdepartementen op een gegeven moment handig vinden. Daar heeft Justitie geen strong feelings over."

3.4. Wetgevingsjuristen lijken geneigd voor typisch juridische samenhangcriteria te kiezen zoals het verschil tussen publiek- en privaatrecht, en algemene en bijzondere bepalingen. Zou het voor de kenbaarheid van het recht niet beter zijn als zou worden gekozen voor criteria die de gebruiker in de werkelijkheid ervaart?

Borman: "Ik zie dat niet meteen als een tegenstelling." 
Roording: "Bundeling van wetgeving is gewoonlijk beleidsmatig geïnitieerd. De ordening binnen een wet is vaak niet opgebouwd aan de hand van criteria als de ondernemer, de belastingplichtige of de fysieke leefomgeving. Er wordt vaak doorgebouwd op wetgeving die haar nut bewezen heeft. Die is weer een vertaling van politieke wensen. Zelfs de verboden in het Wetboek van Strafrecht zijn strikt genomen niet tot de burger gericht. Er staat namelijk niet dat het verboden is iemand te vermoorden. Artikel 289 is eerder gericht tot de rechter: 'Hij die opzettelijk en met voorbedachten rade een ander van het leven berooft, wordt, als schuldig aan moord, gestraft met levenslange gevangenisstraf of tijdelijke van ten hoogste dertig jaren of geldboete van de vijfde categorie."

3.5. Wat is eigenlijk het samenhangcriterium voor de Awb?

Borman: "De invalshoek is dat in de Awb bestuursrechtelijke regels worden opgeschreven die anders in veel bijzondere wetten verschillend zouden worden geregeld. Ook codificatie van hetgeen in de jurisprudentie naar voren komt. Het moet ook wetsoverstijgend zijn. Iets wat alleen in één bijzondere wet voorkomt, past niet in de Awb."

\section{WETSSYSTEMATISCH TEKORT}

4.1. Is het een goed idee om met gelaagde structuren te werken? Zorgen gelaagde structuren er niet voor dat de justitiabele in drie wetssystemen moet kijken wat zijn rechten en plichten zijn?

Borman: "Het is vooral bij instrumentele wetgeving ondoenlijk om alle normen in regels op wetsniveau vast te leggen. Daarvoor zijn allerlei redenen. Het is wellicht niet overzienbaar wat er precies moet worden geregeld op het moment dat de wet wordt geschreven. Ook omdat wijziging veel moeilijker is in het traject van formele wetgeving. Delegatie van regelgevende bevoegdheid gebeurt standaard bij de wetgeving van vakdepartementen." "Er bestaat wel een tendens om die uitvoeringsregels zoveel mogelijk te bundelen. Ik heb daarover geschreven in RegelMaat. ${ }^{24}$ Bundelen bevordert overzichtelijkheid, consistentie en één begrippenkader. Alles ineen. Voor de werkelijkheid maakt het verder natuurlijk niet veel uit.”

Roording: "Dat staat zelfs in de Aanwijzingen voor de regelgeving ${ }^{25}$ en wordt door de Raad van State ook geadviseerd. Bij de nog niet in werking

24 T.C. Borman, Combineren van uitvoeringsregels 2010.
25 Na de negende wijziging van de Aanwijzingen: Aanwijzing 104 
getreden Wet dieren wordt de normadressaat zoals de dierenarts zelfs gebruikt als ordeningscriterium voor algemene maatregelen van bestuur. ${ }^{26}$,

Borman: "De gelaagde structuur heeft te maken met de architectuur van wetgeving. Hirsch Ballin heeft daarover ooit een interessant artikel geschreven. ${ }^{27} \mathrm{Hij}$ noemt verschillende vormen van opbouw en systematiek. Van algemeen naar bijzonder of chronologie van handelingsverloop. Daarbij gaat het uiteindelijk om Fingerspitzengefühl, dat een goede wetgevingsjurist in de loop der jaren ontwikkelt. Aan de gelaagde structuur in de Awb ligt een erudiete gedachte ten grondslag, maar je merkt wel dat sommigen dit juist complex vinden, terwijl het juist was bedoeld om het gemakkelijker te maken. Je hoeft de algemene zaken namelijk niet weer opnieuw op te schrijven. Je moet het systeem wel kennen en het is misschien wel iets te juridisch-technisch voor burgers en bedrijven."

\section{GEEN NIEUWE WETTELIJKE OPLOSSINGEN}

5.1. Is het een goed idee om nieuwe wettelijke oplossingen te creëren bij het bundelen van omgevingsrecht?

Roording: "Het gaat daarbij om een politieke of beleidsmatige keuze."

Borman: "Klopt. Ik heb me zelf bezig gehouden met de voorbereidingsprocedures in de Awb. De uitgebreide voorbereidingsprocedure kwam uit de Wet algemene bepalingen milieuhygiëne (Wabm). Die was nog veel uitgebreider dan de uitgebreide procedure die uiteindelijk in de Awb is gekomen. Justitie wilde, anders dan VROM, dat de uitgebreide procedure niet zou worden vervuild met allerlei details uit de Wabm en heeft zich er toen sterk voor gemaakt om de procedure te ontdoen van allerlei details."

1. Indien een regeling voorziet in de verplichting of de bevoegdheid tot het vaststellen van uitvoeringsregelingen, wordt ter uitvoering van de hogere regeling zo mogelijk één algemene maatregel van bestuur of ministeriële regeling vastgesteld.

2. In een uitvoeringsregeling worden zo mogelijk de indeling en volgorde van de onderdelen, de opschriften van die onderdelen, de wijze van nummering van de artikelen en de volgorde van de artikelen van de hogere regeling in acht genomen.

Voorbeeld

Vreemdelingenwet 2000 en Vreemdelingenbesluit 2000.

26 Ik zie dat wel in de wet, maar niet in een algemene maatregel van bestuur. Roording: "Die algemene maatregelen van bestuur zijn kennelijk nog niet tot stand gebracht. Je zou daarvoor bij ELenI moeten informeren".

27 Hirsch Ballin, Architectuur van wetgeving 1984. 


\section{TOEKOMSTBESTENDIG}

6.1. Hoe voorkom je dat je een Omgevingswet maakt die over drie jaar weer fundamenteel anders moet?

Borman: "Dat is een terechte vraag."

Roording: "Het is onvermijdelijk dat de Omgevingswet toch weer zal uitdijen. De omgeving verandert, er zullen nieuwe incidenten komen en de politiek zal nieuwe wensen hebben. Neem de Wet op het financieel toezicht van het Ministerie van Financiën. Die is in 2006 begonnen als een mooie systematische wet, maar die is inmiddels weer uitgedijd. Het Ministerie van Veiligheid en Justitie zal dat wel proberen te bewaken, maar als een vakminister politieke wensen heeft, dan zal de wet toch weer veranderen."

Borman: "Het klinkt misschien gek, maar wetgevingsjuristen zijn juist geneigd om zaken ongeregeld te laten. Het is vaak de politiek die zorgt voor een kerstboom. Wetgevingsjuristen zijn zich ervan bewust, dat wetgeving niet almachtig is. De Tweede Kamer wil echter vaak juist zoveel mogelijk details regelen. Van het toevoegen van een voorhangprocedure heeft de burger op zichzelf geen last, maar dat brengt wel weer veel bureaucratie, procedurelasten en vertraging met zich." 
Functie: hoogleraar staats- en bestuursrecht bij de Afdeling staats- en bestuursrecht van de Faculteit rechtsgeleerdheid van de Universiteit Leiden en wetenschappelijk directeur van het Instituut Publiekrecht.

Relevante ervaring: het huidige onderwijs en onderzoek van de heer Voermans richten zich zowel op het nationale staatsrecht, als het Europese constitutionele recht. Daarbinnen ligt het accent op (Europese) wetgevingsvraagstukken (kwaliteit van EU-wetgeving, deregulering, vereenvoudiging en terugdringen van administratieve lasten, wetgevingsprocedures (met name de rol van het (Europees) parlement), openbaarheid en transparantie, de relaties tussen de wetgevende instellingen, decentralisatie, omzetting en uitvoering van EG-wetgeving, naleving, toezicht en handhaving, wetgevingtechniek en wetsevaluatie). ${ }^{28}$

Datum interview: 19 januari 2012

Interview geautoriseerd: 28 augustus 2012

\section{SAMENHANG}

1.1. Waarom gaat de wetgever over tot bundeling, bijvoorbeeld door in de Wet natuur de Natuurbeschermingswet 1998, de Flora- en faunawet en de Boswet te bundelen?

"De kabinetten Balkenende zijn een operatie begonnen om administratieve lasten te verlichten. Die operatie is eigenlijk best een groot succes geweest. Een onderdeel van die operatie is dat er systematisch is gezocht naar minder regels. Wat een beetje een gekke categorie is. En toen zijn we gaan tellen. Er is een monitor, waarover Tim Borman heeft geschreven in RegelMaat. ${ }^{29} \mathrm{Hij}$ schrijft over verzamelbesluiten: algemene maatregelen van bestuur, die kunstmatig in elkaar zijn gedrukt, want dan tellen ze als minder. De departementen hebben onder de vorige kabinetten afgesproken dat a) er regelgevingsplafonds zouden komen en b) - wat een beetje een domme afspraak is - dat als je een regel maakt, er ook één af moet."

1.2. Boekhouden dus?

"Ja. Dat geeft opwaartse druk aan bundeling. Dan gooien we maar alles in één regeling, want dan telt die als één.”

28 www.law.leidenuniv.nl/org/publiekrecht/sbrecht/medewerkers/wim-voermans.html.

29 Borman, Combineren van uitvoeringsregels 2010 
1.3. Waarom is dat tellen niet zo'n goed idee?

"Bij deregulering gaat het er eigenlijk om dat je probeert om de intensiteit van overheidsinterventie voor bedrijven en burgers te verminderen. Of die overheidsinterventie nu in 1001 wetten zit of in één, dat maakt niet uit. Maar in de politieke discussie ligt dat anders. Daar is het aangrijpingspunt om serieus om te gaan met deregulering. Het is niet effectief om te zeggen dat ministers moeten ophouden met interveniëren. Elke minister wil een eigen monumentje in wetgeving achterlaten. Het is veel effectiever om ze af te pakken waar ze mee spelen: een imprint in het Staatsblad. Je zegt dan dus dat er geen nieuwe regel meer mag komen als je niet een oude wegdoet. Dat is in wezen op meta-niveau grote onzin omdat het niets afdoet aan de mate van overheidsinterventie. Maar voor het gesprek tussen de bewindslieden in de ministerraad kapt het wel één route af, namelijk dat een minister probeert een politiek feit te maken door een voetafdruk in het Staatsblad. Dat is het enige wat je ermee bezweert, maar dat is intern en indirect." "Door het schrappen van de Crisis- en herstelwet en gelijktijdig opnemen van de regels daarin in andere wetten, blijft de overheidsinterventie natuurlijk hetzelfde, maar de politiek zal zeggen dat er weer een wet minder is."

1.4. Kleven er ook nadelen aan het intrekken van regels?

"Dat kan zich voordoen. Bij het intrekken van regels krijg je gedurende een bepaalde periode ingewikkelde invoerings- en overgangsregels." "Een groot probleem, nog niet echt goed beschreven, is dat het intrekken van regels voor bijvoorbeeld bedrijven niet betekent dat die bedrijven geen waarborgen willen voor de kwaliteit van diensten en producten. Als de overheid dat niet meer doet, gaan ze het mooi zelf doen. Er is echter niets zo verdrukkend als regels die in zelfregulering worden vastgesteld. Die zijn zo gedetailleerd en eigenlijk is er alleen sprake van verplaatsing van regels."

\subsection{Bestaan er wel goede redenen voor bundeling?}

"Ja. Er zit ook wel een andere reden achter bundelen van regels, namelijk om een geïntegreerd kader te hebben. Dat is natuurlijk geen slechte reden. Het is weinig politiek omdat je probeert wat bij elkaar hoort ook zoveel mogelijk in één wet bij elkaar te zetten. Dat is gewoon een goed structureringsprincipe. De toegankelijkheid van de wet is beter, de kenbaarheid natuurlijk ook en je ziet beter wat je coördinatieproblemen zijn als het gaat om uitvoeringsbeslissingen waaronder beschikkingen."

1.6. Stelt dat ook eisen aan de te bundelen regels?

"Het is best mogelijk om een geïntegreerd kader te hebben met heel verschillende wetten. Dat hoeft niet één op één te lopen." 
1.7. Zoals de Wet milieubeheer?

"Ja, die heeft dat." "Het is dus een goede reden om ervoor te zorgen dat iemand die te maken heeft met regels op een bepaald terrein bij één wet te rade moet. Dat is het externe perspectief. Gebruiksgemak en kenbaarheid voor burgers die de regels willen kennen, maar ook voor overheden die de regels uit moeten voeren. Wie regels gaat integreren kan soms synergie gebruiken. Waarom zou je de regels voor de afgifte van een omgevingsvergunning niet allemaal op één plaats zetten?" "In Europa hebben we een aantal richtlijnen gehad over douanerechten. Op dit moment is er nog maar één. Dat werkt veel handiger voor iedereen die ermee te maken heeft.”

"Er is ook een intern perspectief. In Europa zie je dat het allerbeste. Je moet bij wetgeven het ritme volgen van 'de slagen nemen zoals je kunt'. Er wordt eerst in een eerste tranche gewerkt, waarbij bijvoorbeeld de telecommunicatiediensten op elkaar worden afgestemd. Daarna volgt de infrastructuur. Op een bepaald moment heb je zoveel onderdelen in kleine richtlijnen geregeld, maar daarna komt er een moment waarop wordt nagedacht om alles vanuit een bepaalde gedachte weer bij elkaar te zetten en op elkaar af te stemmen." "Dat gebeurt in Nederland ook. De wetgevingscomplexen groeien in lagen in de tijd. Na enige tijd wordt het van belang om te harmoniseren en te codificeren. De Awb is daarvan een goed voorbeeld. Men wist al vanaf het begin dat het niet allemaal in één keer kon. De wetgeving evolueert dus in de tijd en op een bepaald moment wil men toch tot een samenhangend geheel komen.”

\subsection{Waarom schrijf je de wet niet in één keer goed op?}

"Soms kan dat helemaal niet." "Neem ons Burgerlijk Wetboek. Daar denken we al tweeduizend jaar over na. Waarom hebben we dat in 1860 niet in één keer goed opgeschreven? Waarom kwam er in het midden van de vorige eeuw een nieuw Burgerlijk Wetboek? Welnu, de omstandigheden veranderen. De eisen die wij stellen veranderen. Dat geldt ook op het gebied van het omgevingsrecht. Zo stellen we op dit moment andere eisen aan de bestuurlijke leefomgeving, de grondstoffen die we daarbij gebruiken, de wijze waarop de economie zich ontwikkelt, de aanspraken op de openbare ruimte, onze woonsituatie en de werksituatie. De werkelijkheid evolueert. Ik zou niet graag nog moeten werken met het ruimtelijke ordeningsrecht van de jaren zestig." "Neem als voorbeeld de bestemmingsplannen voor het buitengebied. Die zijn nooit verplicht geweest. Waarom niet? Dat was niet nodig. De markt deed daar gewoon haar werk. En het was bijna allemaal agrarisch. Waarom zou je dat allemaal gaan bestemmen? Wie zou er nu komen met een plan voor een woningboulevard in een kleine landelijke gemeente? Totdat zich ineens van alles ging ontwikkelen. Dan moet je de wetgeving opnieuw doordenken." "De wetgeving op het gebied van ruimtelijke ordening was in de jaren zestig betrekkelijk kaal. Een vrij centrale aansturing. De eerste aanzetten tot 
inrichting van het land. Er waren geen milieuvergunningen. Denk aan het arrest van de Hoge Raad inzake Lekkerkerker/Vermeulen; ${ }^{30}$ schade werd via het burgerlijk recht geregeld. Op een gegeven moment is dat niet meer haalbaar en komen milieu- en bouwvergunningen op. Het platteland wordt helemaal gebruikt, dus komen er ook regels voor de woonboulevard in het buitengebied van een kleine gemeente." "Later in de tijd wordt eerst binnen de kolommen milieu en ruimtelijke ordening een reactie gezocht, maar op een gegeven moment daagt het inzicht van samenhang en wordt er gedacht aan integreren. De beslissingen zitten gewoon aan elkaar vast. Het inzicht kan dus gewoon groeien.”

\section{KENBAARHEID}

2.1. Kijkt de wetgevingsjurist ook naar meer kenbaarheid of voorspelbaarheid?

"Ja, zij het dat hij de kenbaarheid eerder zoekt voor juridische gebruikers. Het gaat immers om wetgeving. Voor andere gebruikers kun je wellicht ook beter andere wegen bewandelen, zoals ICT. Ik kom daar nog op."

2.2. Is vereenvoudiging goed als het gaat om de kenbaarheid van het recht in de zin dat rechten en plichten gemakkelijk kunnen worden gekend?

"Vereenvoudigen is een goed principe, want complexiteit verhoogt foutgevoeligheid bij bestuur en burger. Je kunt daar eigenlijk niet tegen zijn. Een waarheid als een koe."

\section{SAMENHANGCRITERIA}

3.1. De wetgever is geneigd typische juridische indelingscriteria te gebruiken. Wat is er voor gebruikers zo handig aan het regelen volgens een algemeen en een bijzonder deel?

"Dan hoef je niet te herhalen voor de bijzondere delen wat je in het algemeen deel al hebt geregeld."

3.2. Maar voor wie is dat dan zo handig?

"Vanuit wetgevingssystematiek is dat handig voor juristen, maar ook voor andere gebruikers." 
3.3. Begrijpt de gemiddelde burger de gelaagde structuur van de Awb dan?

"Ik denk dat die wel weet dat het verschil maakt of er sprake is van een besluit of een beschikking en welke voorbereidingsprocedure geldt. Dat staat er vrij kloek in het begin in."

3.4. Maar loopt de wetgever niet het risico dat burgers en bedrijven regels missen omdat ze niet weten op welke plaatsen ze moeten kijken, als ze al in de wet kijken?

"Nou, over de invulling van de bestuurlijke afweging staat in hoofdstuk 2 niets anders dan in hoofdstuk 4. Je moet natuurlijk wel enige voorkennis hebben. In een ver verleden moest je alles wat nu in de Awb staat in handboeken bij elkaar zoeken. Ten opzichte van die situatie is de Awb wel een verbetering."

3.5. Welke overwegingen liggen voor de wetgever ten grondslag aan het bundelen van wetten en regelingen?

"Er is mij eigenlijk nauwelijks literatuur bekend die specifiek gaat over de vraag wanneer je omgevingswetten zou kunnen bundelen. Peter Noll (Gesetzgebungslehre ${ }^{31}$ ) schrijft erover en op onderdelen ook Hermann Hill (Einführung in die Gesetzgebungslehre ${ }^{32}$ ). Voor wat betreft de vraag hoe je bij elkaar kunt zetten wat bij elkaar hoort, is een publicatie van Gwen Sebus ${ }^{33}$ wellicht nuttig. Ik heb zelf daarover geschreven in Codification and Consolidation in Europe as a Means to Untie Redtape. ${ }^{34}$ " "De kunst is om het juiste gezichtspunt te kiezen. Er zijn veel mogelijkheden, maar je moet consistent zijn. Te denken is aan het beschermd rechtsgoed. Zo is het Wetboek van Strafrecht opgebouwd. Het verschil tussen overtredingen en misdrijven gaat daarover. Een ander uitgangspunt is rechtsbetrekkingen dat in Boek 2 van het BW wordt gehanteerd. Chronologie is het meest gebruikt; in de Awb wordt de chronologie van besluitvorming gehanteerd: aanvraag, voorbereiding etc.." "Sebus heeft daar aanwijzingen voor gegeven in 1984 en in ons boek Wetgevingsleer ${ }^{35}$ hebben wij in hoofdstuk 9 ook de mogelijkheden proberen bij elkaar te zetten. Maar dat gaat meer over de techniek."

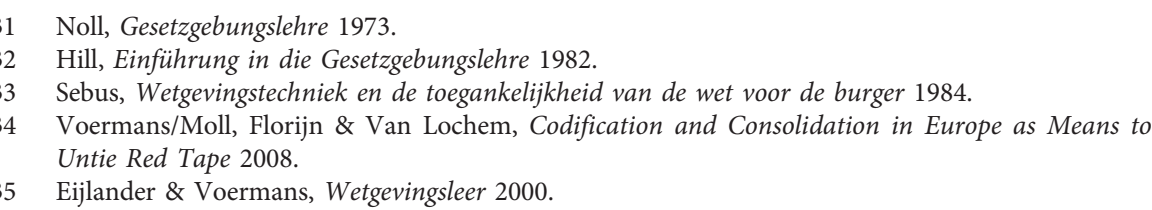


3.6. Hoe is een keuze te verantwoorden?

"Wij zeggen in Wetgevingsleer dat het slechtste wat je kunt hebben is, dat je een indelingscriterium kiest en dat verlaat voor een ander. Dan is de wet niet meer te volgen. Consistentie is heel belangrijk. Van chronologisch naar rechtsbetrekkingen is een slecht idee. Hoofdstuk 9 van Wetgevingsleer gaat om het structureren van de vormgeving."

\section{WETSSYSTEMATISCH TEKORT}

4.1. Is het een goed idee om met gelaagde structuren te werken?

Zorgen gelaagde structuren er niet voor dat de justitiabele in drie wetssystemen moet kijken wat zijn rechten en plichten zijn? Bijvoorbeeld in Wabo, Bor en Mor.

"De wetgever kiest voor delegatie vanwege de flexibiliteit. In kunnen spelen op een situatie. Gemakkelijker wijzigen. Beter maatwerk. Meer deskundigheid bundelen."

4.2. Maar heeft de wetgever dan ook wel aan de gebruiker gedacht?

"Voor de blote gebruiker is het inderdaad niet gemakkelijk. De gespecialiseerde gebruiker kan zo het Activiteitenbesluit citeren. Het gaat om het structureren van wetten met het oog op de toegankelijkheid. Hoofdstuk 9 van Wetgevingsleer ${ }^{36}$ geeft aan hoe je een regeling structureert en dat onderdeel staat nog wel. Welke gezichtspunten zijn er? Er staat nog niet op welke manier je toegang zou kunnen verschaffen tot moderne wetgeving. Daarover heb ik wel geschreven in Weten van wetgeving. ${ }^{37}$ Als voorbeeld noem ik de belastingwetgeving. Het gaat om een lappendeken van wetten die stuk voor stuk ontzettend ingewikkeld zijn. Als je vijf jaar fiscaal recht hebt gestudeerd, begrijp je het wellicht op hoofdlijnen. De Belastingdienst heeft niet gekozen voor een integratie van al die wetten in een belastingwetboek, maar een ICT-tool ontwikkeld. Daarbij wordt helemaal vanuit de gebruikers gedacht. Die gebruikers zijn heel divers: burgers in loondienst, zzp'ers, bedrijven, noem maar op. Heel divers. Er komt een website waarop wordt vertaald wat de gebruiker moet doen om de uitvoering van al die ingewikkelde wetten op gang te brengen. Ga naar de website van de belastingdienst. Gemakkelijker kunnen we het niet maken, eenvoudiger wel. Bent u burger? Ja. In loondienst? Ja. Etcetera. Dan bent u waarschijnlijk een zodanige gebruiker en moet u waarschijnlijk dit en dit invullen. Er staat geen snipper wettekst en toch, een hogere mate van integratie zou je

Eijlander \& Voermans, Wetgevingsleer 2000.

Voermans, Weten van wetgeving 2004. 
niet voor elkaar kunnen krijgen door het sleutelen aan de belastingwetgeving zelf. Want iedereen snapt wat zijn eigen situatie is."

4.3. In wat ik de echte werkelijkheid noem?

"Ja." "Dit zou je ook kunnen doen in andere wetgevingscomplexen. Niet langer uitgaan van de gebruiker die zich in een wettekst verdiept, maar probleemgestuurd: $u$ wilt iets van de overheid. Dan is de gelaagdheid niet meer zo belangrijk. Het maakt dan niet meer uit of zijn rechten en plichten zijn neergelegd in bijvoorbeeld Wabo, Bor of Mor. Of je nu door de kat of door de hond wordt gebeten. Dat is meer van belang voor de parlementaire inbreng." 38

\section{GEEN NIEUWE WETTELIJKE OPLOSSINGEN}

5.1. $\quad$ Is het een goed idee om nieuwe wettelijke oplossingen te creëren bij het bundelen van omgevingsrecht?

"Koopmans heeft destijds gezegd dat we over wetgeving denken als codificatie-instrument. Onder codificatie versta ik dan dat wat niet is geschreven in de wet wordt opgeschreven. Als het gaat om het bijeenbrengen van wat is geschreven, dan noem ik dat assembleren. Maar de moderne wetgever wil juist modificeren. De meeste sturing in dit land is tegenwoordig in wetten in brede zin neergelegd. Als we wetten bij elkaar vegen, dan zit daar ook wel de gedachte achter om nieuwe interventies te plegen. Je ziet dat bij de Crisisen herstelwet en in het omgevingsrecht. Die wetten proberen slagvaardiger bestuur mogelijk te maken. Bij grote infrastructurele projecten lukt dat niet altijd meer vanwege de rechtsbescherming die daar op de huidige wijze eigenlijk niet voor is geschreven." "Er is niets op tegen om tegelijk te assembleren en te modificeren."

"Je modificeert al snel. Als vereenvoudigen betekent lasten verminderen, dan verander je dat al. Voor departementale wetgevingsambtenaren geldt de politiek vaak als de storende factor die hun heilige wetgevingsideeën komt bezoedelen. Maar politiek moet uitgangspunt zijn bij wetgeving. Er moet ook iets te veranderen zijn in de loop der tijd. Dat is uitgangspunt van onze manier van wetten maken. De belangrijkste afspraken worden door de wetgever in de wet neergelegd. Politiek is goed als het op wetten aankomt. Dat willen we zo. Als de wetgever iets wil, dan is dat degene die het te bepalen heeft. De voorgenomen Omgevingswet is een vorm, een vehikel, een verpakking van een inhoudelijke beslissing, niet iets in zichzelf. De politieke 
beslissing kan niet afhankelijk zijn van het vehikel. De automobilist onderhandelt ook niet met zijn auto."

\section{TOEKOMSTBESTENDIG}

6.1. Hoe voorkom je dat je een Omgevingswet maakt die over drie jaar weer fundamenteel anders moet?

"Ik denk dat het nooit kan."

6.2. Kun je ook niet wetssystematisch voor toekomstbestendigheid zorgen? Bijvoorbeeld door een soort aanbouwwetgeving?

"Dat hoop je dan maar. De wetgever kan de toekomst niet voorspellen. Er zijn wel wetgevingscomplexen die geraffineerd in elkaar zitten omdat ze bijvoorbeeld techniek-onafhankelijk zijn opgesteld. Het Burgerlijk Wetboek regelt een verbintenis. Dat concept kun je op van alles loslaten. Dat is slim. Het maakt niet uit of het een schriftelijk contract is of wat anders. Voor de voorzienbare toekomst blijft het kader staan. Maar zelfs van het Burgerlijk Wetboek durf ik niet te zeggen of het er over 50 jaar nog hetzelfde uit zal zien. Dat weet je gewoonweg niet. Samenlevingen ontwikkelen zich zo snel. Nederland verandert met lichtsnelheid sociaal, demografisch, economisch, qua ruimtegebruik. De wetgever kan wel proberen om de zon boven Gideon stil te zetten en een kader maken dat de werkelijkheid fixeert. De BWwetgever heeft het daarbij nog gemakkelijk. Het omgevingsrecht verandert echter zo snel. Je kunt wel een aantal valkuilen omzeilen door met generiekere concepten te werken: algemenere vergunningen, algemene regels... In het milieurecht heeft men op een gegeven moment het algemene alara-beginsel ${ }^{39}$ en het voorzorgbeginsel geintroduceerd."

\subsection{Helpt een aanbouwwet?}

"Dat is heel formele oplossing. Je kijkt dan naar de structuur. Na de Wet algemene bepalingen milieuhygiëne is de Wet milieubeheer gekomen met een geïntegreerd kader. Het is moeilijk het succes daarvan vast te stellen. Ik zie wel de technische handigheid van de wetgever om het zo te doen. Van de andere kant wordt bijvoorbeeld niet handig gebruik gemaakt van een algemeen deel en een bijzonder deel (zie hiervoor). Je ziet dat aanbouwwetgeving ook weer bezwaren heeft. Sommige hoofdstukken zijn eigenlijk alleen maar de implementatie van een Europese richtlijn. Het is zo'n letterdoos geworden.”

39 As low as reasonably achievable. 
Functie: coördinerend wetgevingsjurist bij het Ministerie van Infrastructuur en Milieu.

Relevante ervaring: mevrouw Molenaars heeft als wetgevingsjurist bij het voormalig Ministerie van VROM respectievelijk Ministerie van Verkeer en Waterstaat en het huidige Ministerie van Infrastructuur en Milieu vele jaren ervaring met het opstellen van wetgeving op het brede terrein van het omgevingsrecht. Op het moment van het interview hield zij zich als coördinerend wetgevingsjurist bezig met de totstandkoming van de nieuwe Omgevingswet.

Datum interview: 26 januari $2012^{40}$

Interview geautoriseerd: 16 februari 2012

\subsection{Mr. H.W. de Vos}

Functie: coördinerend wetgevingsjurist bij het Ministerie van Infrastructuur en Milieu.

Relevante ervaring: de heer de Vos heeft als wetgevingsjurist bij het voormalig Ministerie van VROM respectievelijk Ministerie van Verkeer en Waterstaat en het huidige Ministerie van Infrastructuur en Milieu vele jaren ervaring met het opstellen van wetgeving op het brede terrein van het omgevingsrecht. Op dit moment houdt hij zich als coördinerend wetgevingsjurist bezig met de totstandkoming van de nieuwe Omgevingswet. ${ }^{41}$

Datum interview: 26 januari 2012

Interview geautoriseerd: 16 februari 2012

\section{SAMENHANG}

1.1. Hoe bepaal je samenhang tussen wetssystemen?

Molenaars: "De eerste vraag die een wetgevingsjurist zich dient te stellen is welk doel de nieuwe wet zou moeten dienen. Het antwoord op die vraag bepaalt namelijk het perspectief van waaruit je een wettelijk systeem ontwerpt. Dat doel kan bijvoorbeeld zijn: vereenvoudiging van de regelgeving en verbetering van de toepasbaarheid daarvan in de praktijk voor de gebruikers of voor een bepaalde groep van gebruikers. Een ander doel kan bijvoorbeeld zijn de door de jaren heen opgebouwde sectorale wetgeving te bundelen of verdergaand te integreren. Ook het willen realiseren van nieuwe of aangepaste beleidsdoelen kan aanleiding zijn voor het opstellen van wetgeving."

40 Mevrouw Molenaars en de heer de Vos zijn gezamenlijk geïnterviewd.

41 Hij is onder meer de auteur van De Vos, Coördinatie, integratie of beide? 2005 en van De Vos, Een basis voor de toekomst: de Omgevingswet 2012. 


\subsection{Wat betekent dat toegespitst op de Omgevingswet?}

Molenaars: "Een belangrijk doel van de Omgevingswet is in elk geval het bundelen, vereenvoudigen en uniformeren van sectoraal opgebouwde wetgeving op het gebied van de leefomgeving en het komen tot een nieuw wettelijk stelsel dat een daarop toegesneden instrumentarium bevat. Dat betekent dat in die hoek ook het 'samenhangcriterium' moet worden gezocht. Over wat dat betekent voor de scope van de Omgevingswet kun je uiteraard discussiëren. De bestaande sectoraal opgebouwde stelsels zijn vanuit verschillende motieven ontstaan. Als we het hebben over integratie van het omgevingsrecht dan is mogelijk dat daarmee wel heel erg veel regels onder de Omgevingswet gaan vallen. Als dat om bepaalde redenen niet gewenst of haalbaar wordt geacht, is het ook mogelijk om meer focus aan te brengen en te kiezen voor die regels die primair te maken hebben met ruimtelijke ontwikkeling, laten we zeggen het gebiedsgerichte deel van het omgevingsrecht. Maar een bredere aanpak laat zich ook voorstellen. Die keuze kan van juridische aard zijn, maar zal vaker voortkomen uit een politieke of beleidsmatige wens." "Een politieke of beleidsmatige overweging komt veelal weer voort uit het feit dat er in de praktijk een probleem wordt gesignaleerd dat de wetgever moet of wil oplossen."

De Vos: "Samenhang heeft ook te maken met een combinatie van het te regelen onderwerp en het motief voor het stellen van regels" "De leefomgeving is het onderwerp. Daarin zit een bepaalde samenhang. Daarnaast vloeit uit de combinatie met het motief (de achterliggende reden of het doel waarvoor de regels worden gesteld) een bepaalde samenhang voort.

Zo kunnen vanuit verschillende motieven regels over de leefomgeving worden gesteld. Een motief kan zijn de bescherming van de leefomgeving. Regels die vanuit dat motief zijn gesteld kunnen bijvoorbeeld worden onderscheiden van regels voor de leefomgeving die zijn gesteld vanuit een marktgerichte ordening. Het gaat dan bijvoorbeeld om wetgeving over stoffen en producten die zich richt tot de producenten en importeurs. Een ander motief kan openbare orde zijn."

Molenaars: "Vaak vormen Europese regels het motief of de context voor wat je moet regelen binnen bestaande kaders of waarvoor je nieuwe regels moet maken. Europese regels laten soms wel, soms geen ruimte voor samenhang."

\section{KENBAARHEID}

2.1. Wordt er gekeken naar een betere aansluiting bij de echte werkelijkheid van burgers en ondernemers?

De Vos: “Ja, daar zijn we wel mee bezig. Zo is de vraag of we moeten uitgaan van het begrip inrichting, terwijl een ondernemer zijn bedrijf nooit zo zal 
noemen. Wellicht is het beter om uit te gaan van waarmee iemand daadwerkelijk bezig is: de activiteit. We zijn nadrukkelijk op zoek om in terminologie en aangrijpingspunt voor de normstelling om beter aan te sluiten bij de fysieke wereld en wie zich daarin bezig houden. De Omgevingswet gaat immers over de leefomgeving zelf en over activiteiten die daarvoor gevolgen kunnen hebben. Daarin moeten de gebruikers van het recht zich kunnen herkennen. Als de wetgever daarvan sterk afwijkt, werpt hij een drempel op, ook voor de naleving." "De wetgever moet aansluiten bij het rechtsgevoel. Regels moeten niet te ver afstaan van de beleving."

\section{SAMENHANGCRITERIA}

3.1. Leidt samenhang tot een bepaald samenhangcriterium?

De Vos: "Het is niet zo gemakkelijk om te bepalen wat wel en niet in een Omgevingswet geregeld zou moeten worden. Met name omdat veel sectorale wetten verschillende onderwerpen vanuit verschillende motieven regelen. Bepaalde onderdelen passen dan wel, andere niet in de Omgevingswet. Zo bevat de Mijnbouwwet verdelingsdoelen naast het regelen van effecten voor de leefomgeving van bepaalde activiteiten." "Bij de Omgevingswet wordt gekozen voor een nieuw samenhangcriterium. Je moet je dan steeds afvragen of het mogelijk of zinvol is om een bepaalde wet of onderdeel daarvan te bundelen."

Molenaars: "Bij de Omgevingswet wordt gekozen voor een nieuw perspectief, een nieuw uitgangspunt, een samenhangcriterium. Als je probeert daaraan verschillende wetssystemen op te hangen, dan moet steeds de vraag worden beantwoord of je bepaalde regels wilt bundelen onder dat nieuwe criterium en zo ja of dat ook kan, welke gevolgen dat voor de praktijk heeft en welke 'winst' daarmee geboekt wordt. Dat is voor ons een dagelijkse uitdaging."

De Vos: "Het gaat erom wat de meerwaarde is van het onderbrengen van regels in het nieuwe kader. Want integratie in het ene kader kan leiden tot desintegratie in een ander kader. Het gaat erom welk integratiekader uit een oogpunt van efficiency, het bereiken van je doelen, het meest geëigende integratiekader is. Liefst - in verband met de bestendigheid van wetgeving voor een langere periode."

Molenaars: "Een goed samenhangcriterium is belangrijk. Maar soms zijn er meerdere criteria, die naast elkaar kunnen worden gebruikt. Bij de Waterwet is integraal waterbeheer de kerngedachte, maar binnen de wet valt het criterium uiteen in onder meer waterveiligheid, chemische en ecologische kwaliteit en maatschappelijke functies. De Omgevingswet is groter qua 
omvang en scope, zodat het lastiger is om een samenhangcriterium te kiezen. De bescherming van de leefomgeving is het criterium dat ons nu voor ogen staat. Daarbij is het beoogde doel van de wet het bewerkstelligen van een veilige, gezonde en duurzame leefomgeving. Daarbij onderscheiden wij behoud, beheer, gebruik en ontwikkeling van de leefomgeving."

\section{WETSSYSTEMATISCH TEKORT}

\subsection{Hoe voorkom je desintegratie?}

De Vos: "Het betekent in elk geval dat je moet nadenken over de grenzen en wat zich juist daarbuiten afspeelt. Je kunt elementen uit bestaande wetten halen, maar hetgeen overblijft moet ook een samenhangend geheel zijn. Anders heb je een prachtig nieuw bouwwerk, maar ligt er een veld van puin omheen. Dat is zeker niet de bedoeling van de Omgevingswet.

Het zit soms ook wel in de ontwikkeling van wetgeving. Een concreet probleem wordt vaak aangepakt met sectorale wetgeving. Daarin wordt een instrument gezocht dat functioneel is voor het oplossen van dat probleem. Op een bepaald moment ebt dat concrete probleem, zoals bodemverontreiniging, weg en ontstaat de behoefte aan een wetssysteem dat een groter geheel regelt in plaats van het geïsoleerde probleem." "Een wet met een integrale benadering waarbij er een overkoepelende benadering of evenwicht kan worden gezocht. In elk geval moet er dan een geharmoniseerd instrumentarium zijn. Soms leent een specifiek instrument zich voor verbreding zoals bij de programmatische aanpak. Soms zie je dat op deelterreinen hetzelfde is uitgevonden. Zoals bij de coördinatieregeling. Een andere manier om tot harmonisatie te komen is door codificatie van jurisprudentie. Wat zich op een deelterrein heeft voorgedaan veralgemeniseer je in de wet. Daarmee dien je ook de rechtszekerheid."

Molenaars: "Een ander belangrijk motief om te komen tot een Omgevingswet is dat je een systeem wilt ontwerpen dat robuust genoeg is om toekomstige maatschappelijke ontwikkelingen en trends (denk aan klimaatveranderingen, krimpregio's, energietransitie, etcetera) te kunnen opvangen en dat een instrumentarium wordt geïntroduceerd dat mede geschikt is voor die opgaven." "Je ziet dat bijvoorbeeld ook bij bodemwetgeving. De sanering van verontreinigde bodem is wel zo'n beetje afgerond en nu ontstaat er een beweging naar nieuw beleid voor het gebruik van de ondergrond." "We willen incidentenwetgeving, waarbij een acuut, concreet, geïsoleerd probleem met wetgeving wordt aangepakt, zoveel mogelijk voorkomen." 
4.2. Is het een goed idee om met gelaagde structuren te werken? Zorgen gelaagde structuren er niet voor dat de justitiabele in drie wetssystemen moet kijken wat zijn rechten en plichten zijn?

De Vos: "Het zou mooi zijn als we een soort wetgevingsapp zouden kunnen maken. Je vult in wie je bent en wat je doet, waarna www.overheid.nl alle regels genereert die op jouw situatie van toepassing zijn. Ontsluiten van wetgeving is voor een deel een functie van de wetgever zelf. Maar omdat elke situatie weer anders is, kan niet voor elke persoon of activiteit een regeling worden gemaakt. Die ontsluiting is echter wel van belang. In het Activiteitenbesluit zie je dat de wetgever heeft gekozen voor de activiteit als integratiekader. Voorheen was de regelgeving toegespitst op categorieën van bedrijven. Keuzes kunnen dus veranderen. Van belang is wel dat regels vindbaar zijn; het helpt als die in een beperkt aantal regelingen zijn geconcentreerd."

Molenaars: "Er bestaat soms wel spanning tussen wat je direct in de wet en elders in een algemene maatregel van bestuur of ministeriële regeling opschrijft. Als je bijvoorbeeld een lijst opneemt van vergunningplichtige activiteiten, ontleend aan de bestaande wetten, dan wordt de Omgevingswet op dat onderdeel wel erg uitgebreid. We horen ook wel eens dat er veel te veel delegatiebepalingen in de Omgevingswet komen, maar daartegenover staat dat dit ook zijn nuttige functie kan hebben, omdat op specifieke onderdelen dan de toepasselijke regels mooi bij elkaar staan in één algemene maatregel van bestuur. Daarmee wordt de wet zelf eenvoudiger en beter toegankelijk voor hen die niet met die specifieke regels te maken hebben." "Het maakt het ook niet eenvoudiger om in de wet een artikel met daarin de vergunningplicht op te nemen en vervolgens in een algemene maatregel van bestuur alle gevallen te regelen waarin er geen vergunningplicht is."

\subsection{Waarom niet?}

Molenaars: "De wet wordt niet overzichtelijker door het opnemen van grote delen uitvoeringsregels. Maar de keus is best wel eens arbitrair. Er is daarvoor geen handboek met spelregels." "Wel is het zo dat een van de uitgangspunten bij het opstellen van de Omgevingswet is dat we rekening houden met aspecten als toegankelijkheid en leesbaarheid van de wet en onderliggende regelgeving. Dat maakt onderdeel uit van het wetgevingsproces en de wetgevingsarchitectuur."

De Vos: "Het is inderdaad handig om regels zoveel mogelijk bij elkaar in dezelfde laag te hebben. Je ziet nu de vergunningplicht voor een inrichting in de wet. Dan denk je dat je weet waar je aan toe bent. Maar nee, het gaat om een bij algemene maatregel van bestuur aangewezen inrichting. Je moet dus toch in die algemene maatregel van bestuur kijken." "Bij bouwen doet 
zich iets soortgelijks voor maar dan omgekeerd. Het lijkt dat alles bouwvergunningplichtig is, maar dan blijkt in het Besluit omgevingsrecht een enorme lijst van bouwwerken voor te komen die niet vergunningplichtig zijn. Het zou mooi zijn om alle regels en uitzonderingen op hetzelfde niveau te regelen. Het zou te veel zijn om alles bij wet te regelen, dat kan een motief zijn om die zaken in de algemene maatregel van bestuur bij elkaar te zetten."

4.4. Maar moet het dan in drie delen: wet, algemene maatregel van bestuur en ministeriële regeling?

Molenaars: "Als je zeker weet dat je iets wilt regelen op het niveau van een ministeriële regeling, dan is het tegenwoordig wetgevingsbeleid om in de wet direct een basis voor die ministeriële regeling op te nemen, en niet gebruik te maken van de formulering 'bij of krachtens algemene maatregel van bestuur. Denk bijvoorbeeld aan meet- en rekenmethodes. De keuze voor wet, algemene maatregel van bestuur regeling moet per geval worden gemaakt."

De Vos: "Als je Europese regels strikt moet implementeren, dan is er minder beleidsvrijheid en kan dat ook meteen op lager niveau. Daardoor wijkt het niveau van implementatieregelgeving soms af van nationale wetgeving."

4.5. Waarom worden regels die al in de Awb staan nog herhaald in de Omgevingswet?

Molenaars: "Uitgangspunt voor de Omgevingswet is aansluiten bij de Awb waar dat kan. Maar soms willen beleid of politiek wat anders."

De Vos: "De algemene systematiek is dat we algemeen en bijzonder bestuursrecht hebben. Uitgangspunt is dat we zo weinig mogelijk afwijken, maar het kan nodig zijn om dat wel te doen. Dat doe je dan in de bijzondere wet, anders zou je de algemene wet vervuilen.”

\subsection{Waarom niet algemene en bijzondere regels bij elkaar zetten?}

De Vos: "Dan maak je één wet voor het bestuursrecht. Dat zou je kunnen doen, maar of het daarvan eenvoudiger wordt?"

Molenaars: "Omgekeerd: Als een regeling in de praktijk alleen toegepast wordt binnen het omgevingsrecht en niet op andere beleidsterreinen daarbuiten dan zou het vreemd zijn om die regeling niet op te nemen in de Omgevingswet." 


\section{GEEN NIEUWE WETTELIJKE OPLOSSINGEN}

5.1. Is het een goed idee om nieuwe wettelijke oplossingen te creëren bij het bundelen van omgevingsrecht?

Molenaars: "Bij het opstellen van een nieuwe wet kom je gewoonlijk ook tot wijzigingen van bestaande systemen en tot nieuwe oplossingen. Dat kan het gevolg zijn van politieke wensen of wensen vanuit het beleid. Soms wil je ook vanuit wetgevingstechnisch oogpunt zaken anders regelen. Uitgangspunt bij de Omgevingswet is het ontwerpen van een nieuw systeem, waarbij ook oog is voor het behoud van het 'goede' uit de bestaande systemen."

\section{TOEKOMSTBESTENDIG}

6.1. Hoe voorkom je dat je een Omgevingswet maakt die over drie jaar weer fundamenteel anders moet?

Molenaars: "De Omgevingswet moet bij voorkeur wel decennia mee kunnen. Dat betekent dat er een voldoende robuust maar ook flexibel wetssysteem moet worden ontworpen met een instrumentarium dat daarop is berekend. Dat kan bijvoorbeeld door op onderdelen in de wet haakjes op te nemen om daaraan in de toekomst nieuwe wetgeving op te hangen. Het is daarvoor niet per se nodig dat je precies weet welk probleem zich gaat voordoen en welk nieuw beleid er komt." "Als men klimaatveranderingen verwacht moet bijvoorbeeld de opslag van $\mathrm{CO}_{2}$ kunnen worden geregeld in de Omgevingswet." "Je kunt het ook zoeken in het instrumentarium dat je ontwerpt. Bijvoorbeeld een omgevingsvergunning kun je algemeen regelen. Als in een latere fase blijkt dat het noodzakelijk is om een vergunning te eisen voor een bepaalde activiteit, dan kun je dat instrument ook daarvoor gebruiken. Het is dan een kwestie van een nieuwe activiteit opnemen in het lijstje van activiteiten waarvoor al een omgevingsvergunning is vereist."

De Vos: "Het is de kunst om flexibiliteit in te bouwen in het systeem, aangezien je weet dat er zich situaties gaan voordoen die je niet kunt voorspellen. In het nieuwe systeem mogen ook best specifieke regels voorkomen, mits de basis maar bestendig is en zich bewezen heeft. Als er nieuwe regels nodig zijn, is er dan geen nieuw systeem nodig. Er kan dan op de basis worden voortgebouwd.”

De Vos: "Bestendigheid creëer je ook door de basisinstrumenten te verankeren. Die kunnen voor verschillende onderwerpen worden ingezet. Een vergunning kan zo'n basisinstrument zijn. Die rechtsfiguur gaat al lang mee. Het is redelijk te veronderstellen dat je ook in de toekomst een vergunningstelsel nodig hebt. Dat kan ook gelden voor beginselen, zoals de vervuiler 
betaalt. Die kunnen betekenis hebben voor toekomstige zaken die je nu nog niet kunt voorspellen. De Omgevingswet regelt de basisinstrumenten om de doelen van de wet te kunnen bereiken."

Molenaars: "De Omgevingswet beoogt aan te sluiten bij de beleidscyclus (doelstellingen, monitoring, maatregelen)." 


\subsection{Mr. Th.G. Drupsteen}

Functie: staatsraad en voorheen hoogleraar milieurecht aan de Universiteit Leiden

Relevante ervaring: de heer Drupsteen is een autoriteit op het gebied van het omgevingsrecht en heeft daarover veel gepubliceerd. ${ }^{42}$

Datum interview: 13 februari 2012

Interview geautoriseerd: 16 februari 2012

\section{SAMENHANG}

1.1. Centraal in mijn onderzoek staan wetssystemen: volgens bepaalde criteria geordende, onderling samenhangende regels. Kan de wetgever objectief bepalen wat samenhangt?

"Nee. Er zal niemand zijn die bijvoorbeeld de Wet inkomen en arbeid zal willen samenvoegen met de Wet algemene bepalingen omgevingsrecht. De regels binnen die wetten hebben immers niets met elkaar te maken, vertonen geen samenhang."

"De samenhang leg je er voor een deel zelf in. En als je daar te ver in gaat, dan krijg je als reactie de vraag wat het met elkaar te maken heeft. Je kunt de gelovigen eigenlijk nooit echt overtuigen. De mensen van het water zullen altijd geneigd zijn te zeggen dat de regels over het water bij elkaar moeten blijven. Dat hangt samen. Dat is tot op zekere hoogte ook zo. De mensen die naar een Omgevingswet toe willen, zullen zeggen dat water in die wet moet worden geregeld. Het is sterk afhankelijk van de invalshoek en het abstractieniveau dat je kiest."

1.2. Is samenvoegen van wetssystemen dan wel een goed idee?

"In het algemeen ben ik wel voorstander van het samenvoegen van wetssystemen. Het dwingt je namelijk om na te denken over wat je wilt regelen en wat je vindt dat bij elkaar hoort, samenhangt. Als je dat goed opzet, dan snoei je meestal ook een hoop dor hout wat in de loop der tijd in de samen te voegen wetten is blijven staan, maar waarvan niemand ooit de moeite heeft genomen het weg te halen. Vaak heeft dat niet veel prioriteit. Als je het goed doet, kun je een wetssysteem dan opnieuw, systematischer, eenvoudiger soms, opzetten. Bij de Waterwet is dat vrij goed gelukt. Dat is een betrekkelijk eenvoudige, goed leesbare wet. Bij de Wabo is dat om de een of andere reden minder goed gelukt.”

42 Zie literatuurlijst. 


\subsection{Hoe komt dat?}

"De Wabo is een ingewikkelde wet die niet gemakkelijk leesbaar is. En dan spreek ik nog niet eens over de toepassing. De Waterwet is vergeleken met de Wabo een wonder van eenvoud. Bij sommige wetten is het gemakkelijk om je weg te vinden, maar bij de Wabo is het lastig om te weten waar iets is geregeld. Ook al omdat de regels zijn verdeeld over Wabo, Bor en Mor. De moeilijkheid is, dat de praktijk op een gegeven moment gewend is geraakt aan bepaalde wetgeving. Ik was op 1 oktober 2010 gewend aan de Wet milieubeheer en wat oudere gebruikers wellicht zelfs aan de Hinderwet. Daarin weet je de weg dan, zodat die wet voor je gevoel ook toegankelijk is. Als je dan over moet naar een ander systeem zoals het Activiteitenbesluit en de Wabo, dan is dat lastiger. Dat had je destijds bij de Wet milieubeheer vermoedelijk ook al."

\section{KENBAARHEID}

2.1. Kijkt de wetgevingsjurist ook naar meer kenbaarheid of voorspelbaarheid voor burgers en ondernemers?

"Ik denk dat dat niet de eerste insteek zal zijn, als het al een aandachtspunt is."

2.2. Maar moet de wetgever dan niet wat meer moeite doen om de gebruiker van een wetssysteem meer kenbaarheid te geven?

"Ondernemers hebben wel wat anders te doen dan wetten te lezen. Burgers en ondernemers lezen de wetssystemen niet. Maar als een gebruiker, zoals een ondernemer, aanloopt tegen problemen die te maken hebben met de inrichting van wetssystemen, dan moet je kijken of daaraan iets te doen is. Zo liepen ondernemers voor de Wabo aan tegen het probleem dat ze veel verschillende vergunningen moesten aanvragen voor een activiteit. Daaraan is wat gedaan met de Wabo. Dat wordt meer geredeneerd vanuit het voorkomen van onnodige verschillen, valkuilen en moeilijkheden. Er wordt dus niet beredeneerd vanuit de gedachte dat wetssystemen voor iedereen leesbaar moeten zijn, zodat de ondernemer na zijn dagtaak denkt: 'Kom, ik ga nog eens een stukje wetgeving lezen."

2.3. Maar iedereen wordt toch geacht de wet te kennen?

"Dat zijn van die stomme verhalen. Dat hoeft helemaal niet. Je gaat alleen niet vrijuit als je de wet niet kent. Dat is de enige functie. Voor de rest niet." 
2.4. Kijken wetgevingsjuristen naar de wetssystematiek?

"Wie een proefschrift schrijft, zoekt naar houvast. De wetgevingsleer van Peter Noll levert dat houvast. Maar als je een wetgevingsjurist vraagt of hij daaraan denkt, mag je het antwoord verwachten: 'Hoe bedoelt u?'”

\subsection{Is dat niet vreemd?}

"Nee. Wetgevingsjuristen zijn over het algemeen cynische lieden, die al veel hebben meegemaakt. Die hebben al veel opgeschreven, waarvan ze denken: 'Als ik het zelf voor het zeggen had, dan was dit het laatste dat ik zou hebben opgeschreven. Maar laten we maar kijken hoe we de schade zo beperkt mogelijk kunnen houden.' Dat moet je wel in de gaten houden. Je moet je realiseren dat initiatieven voor wetgeving op allerlei wonderlijke manieren tot stand komen. De politiek roept wat en de minister heeft het zwaar voor zijn kiezen gehad in de Tweede Kamer; hij roept dan dat het afgelopen moet zijn. Jullie moeten aan de slag en dit en dat doen."

\subsection{Maar zit er dan helemaal geen systeem in?}

"Toch wel. Kijk eens naar het Ministerie van Financiën. Daar is een enorme wetgevingsoperatie geweest om de oude toezichtwetten te vervangen. Met die oude wetten kon men niet goed uit de voeten. Maar zelfs als je begint om een wet systematisch te ontwerpen, dan lopen er andere dingen dwars doorheen. Dat zag je ook vaak met de Awb. Dan moet er opeens een kleinigheid worden geregeld. Maar of dat nu past in het systeem van de Awb ... Toch maar doen. Dus dat hele wetgevingsproces is een mengeling van rationaliteit en irrationaliteit. Een wetgevingsjurist die opstaat en zegt, wacht even want we moeten de leer van Noll toepassen, die wordt neergesabeld."

\subsection{Altijd?}

"Nee, soms komt er wel eens een stuk theorie naar voren. Op een gegeven moment moesten we reflexief wetgeven. Dat was het gedachtegoed van Gunther Teubner. ${ }^{43}$ Die bracht naar voren dat overheidssystemen de neiging hebben zich af te schermen voor de buitenwacht en met een eigen interne dynamiek gaan reageren. Gesloten en afgesloten systemen. Dat moest anders. Mensen van justitie hadden het daar ook over. Als je dan vervolgens vroeg wat men anders ging doen, dan riep dat in het algemeen tamelijk grote verwarring op. Er komt dus wel een idee uit de theorie naar voren en daar weet men wel een zekere toepassing aan te geven, maar dat waait over. Niemand heeft het nog over reflexief wetgeven. Als je dat noemt,

43 Zie onder meer G. Teubner (1992), Reflexief recht: de kracht van niet-statelijk recht, in: N.J.H. Huls en H.D. Stout (red.), Reflecties op reflexief recht, Zwolle: Tjeenk Willink, p. 71-84. 
dan vraagt men je of je de laatste vijftien jaar nog wel iets hebt gelezen. Met theorievorming kom je in de wereld van wetgevingsjuristen niet erg ver."

\subsection{Hoe komt dat?}

"Dat komt omdat wetgeving een raar vak is. Het is een mengeling van conceptueel kunnen denken en de techniek onder de knie hebben. Een wetgevingsjurist moet het allebei kunnen, ook al is de een beter in het ene en de ander in het andere. Je moet ergens een regeling voor maken en het moet tot je doordringen hoe die regeling moet worden opgezet. Hoe dat gaat, dat weet ik eigenlijk niet. Wellicht hetzelfde als wanneer je een artikel moet schrijven voor een vaktijdschrift. Je loopt er een tijdje over te denken. Opeens ben je wat anders aan het doen en dan ontstaat er een opzet voor een wet. Zo gaat het waarschijnlijk ook met wetgevingsjuristen. Al werkend ontstaat een opzet. Dat wordt naar mijn gevoel maar weinig door de theorie gestuurd. Wel vakmatig; een oudere wetgevingsjurist die tegen een jongere zegt dat het op een andere manier eenvoudiger is; dat soort zaken. Alles wat wij in Tilburg en Leiden bedachten, dat landt eigenlijk niet bij departementen. Daar denkt men wellicht: 'Het zijn aardige jongens, maar die hebben zelf nog nooit een regeling gemaakt.' Dat is het probleem als je een boek schrijft over wetssystemen. Dan moet je houvast hebben. Maar of de wetgever zich erdoor laat beïnvloeden? Ik denk maar in heel beperkte mate."

\section{SAMENHANGCRITERIA}

3.1. $\quad$ De wetgever is geneigd typische juridische indelingscriteria te gebruiken. Maar zou de wetgever vanwege de kenbaarheid van het omgevingsrecht niet beter kunnen aansluiten bij wat iemand in de werkelijkheid als samenhangend ervaart?

"Ja, maar dan moet er wel overeenstemming zijn wat iemand in de werkelijkheid als eenheid ervaart. In theorie kun je wel uitgaan van rechtssubjecten of -objecten, zoals een ondernemer of een fabriek. Toch geloof ik hier niet in. Die discussie hadden we ook in de Commissie Scheltema. Stel dat iemand invalide wordt. Hij krijgt een invaliditeitsuitkering. Hij wil ook een invalideparkeerplaats hebben. Hij moet een aangepaste auto hebben. En subsidie daarvoor. Eigenlijk moet hij omgeschoold worden, dus moet daarbij worden geholpen. En eigenlijk moet hij van twee hoog naar een andere woning, dus die parkeerplaats laten we maar even zitten. Je moet dan een regeling zien te maken die al die aspecten aan elkaar verbindt. Misschien niet op wetsniveau, maar wel met een systeempje waarin je na het invoeren van het woord invalide ook alle regels tevoorschijn haalt. Maar dat is niet nodig op het niveau van wetgeving." 
3.2. Waarom niet als je het voor de invalide gemakkelijker wilt maken de wet te kennen?

"Met wetgeving probeer je regels te stellen en normen te geven. Je bent juridisch bezig. Een juridische indeling en juridische opbouw beklijven daarom langer. Is meer toekomstbestendig. In feite is de Wet milieubeheer ook zo opgebouwd. Het vanuit de werkelijkheid opereren betekent dat je overeenstemming moet hebben over de beelden die iedereen heeft van de werkelijkheid. Dat is een geweldige exercitie waarvan ik me afvraag waarom je dat zou doen. Als je er maar voor zorgt dat bijvoorbeeld de ondernemer bij het overheidsloket alles kan worden geboden waaraan hij behoefte heeft. Dat is op zichzelf al een geweldige opgave, die we volgens de Dienstenrichtlijn ook voor elkaar moeten krijgen. En dat moet je dan ook nog zo doen dat je niet een deel vergeet, zodat de ondernemer na het verlaten van het loket nog regels niet mee heeft gekregen. Die informatie moet ook actueel zijn.”

3.3. Voor wie is de Awb kenbaar? Voor juristen of ook voor burgers en ondernemers?

"Met name voor juristen. Ook wel voor burgers en ondernemers. Die kunnen weten dat er bijvoorbeeld altijd een beroepstermijn van 6 weken bestaat. Zelfs al kun je die niet vinden in de Awb. In die zin zijn er vereenvoudigingen bereikt."

\subsection{Kan het nog eenvoudiger?}

"Ja. We hebben nog twee voorbereidingsprocedures. Daaraan zijn we gewend en we ervaren dat ook niet als gek. Het is echter wel gek dat een omgevingsvergunning voor activiteiten de ene keer de ene en de andere keer de andere procedure moet volgen. Daar zou de wetgever een keus moeten maken."

3.5. Wat is er voor gebruikers zo handig aan het regelen volgens een algemeen en een bijzonder deel?

"De gemiddelde burger zal dat niet begrijpen, maar het is de vraag of dat wel hoeft. Ik denk dat er bij de totstandkoming van de eerste tranche van de Awb erg is gekeken naar het systeem van het Burgerlijk Wetboek, waar dat ook in zit. Men dacht, dat dat systematisch wel mooi is: eerst algemeen en dan bijzonder. Voor wetgevingsjuristen en andere juristen die ermee werken is het een logisch en begrijpelijk systeem. Of het de toegankelijkheid ten goede komt, is de vraag. Ik heb zelf nog wel eens bij de Awb de vraag waar een regel staat. De Awb is als zodanig niet erg toegankelijk. Voor burgers en ondernemers is de gelaagde structuur niet handig, denk ik. In het Burgerlijk Wetboek ben ik ook oneindig aan het zoeken." 
3.6. Hoe is een keuze te verantwoorden?

"Het zal vaak gaan om de keus van een wetgevingsjurist. Er zijn bij mijn weten geen objectieve regels die daarbij behulpzaam kunnen zijn.”

\section{WETSSYSTEMATISCH TEKORT}

4.1. Is het een goed idee om al het omgevingsrecht in één Omgevingswet te regelen?

"Daar is op zichzelf niets tegen, maar al het omgevingsrecht hoeft er wat mij betreft niet per se in. Je kunt best accepteren dat er delen buiten blijven. Uit een oogpunt van wetssystematiek en kenbaarheid is dat allemaal prachtig, maar de vraag ik of het ook voor de toepassing van het omgevingsrecht noodzakelijk is. Maar als het politieke besluit is genomen dat alles bij elkaar gaat komen, dan zou dat moeten gaan gebeuren. Ik moet het nog zien.”

4.2 Zijn er goede redenen om regels buiten een wetssysteem te laten terwijl die daarmee toch samenhangen?

"Ja. Dat zou bijvoorbeeld kunnen gelden voor de regels in de Awb. Daarmee hebben we een systeem dat redelijk functioneert en waar iedereen redelijk tevreden over is. Niet iedereen in de samenleving is gelukkig als gevolg van de Awb, maar als wet is het een redelijk systeem van wetgeving waarop niet al te veel kritiek is. Dan moet je oppassen dat je bij het opzetten van een nieuw systeem een bestaand systeem, zoals de Awb dat redelijk functioneert, niet gaat uithollen, door het allemaal in een nieuw wetssysteem op te nemen."

4.3. Is het een goed idee om met gelaagde structuren te werken?

Zorgen gelaagde structuren er niet voor dat de gebruiker in drie wetssystemen moet kijken wat zijn rechten en plichten zijn? Bijvoorbeeld in Wabo, Bor en Mor.

"Het feit dat je op drie plaatsen moet zoeken maakt het ingewikkeld. Het betekent ook dat je er lang over doet om te weten waar iets staat. Ik begrijp wel dat je niet allerlei details in de wet in formele zin opneemt. In het Bor staan echter in onze ogen belangrijke regelingen die daarvoor in de Wet milieubeheer stonden. Het zou niet vreemd zijn geweest om bepaalde regelingen in de Wabo zelf op te nemen. Er zit wel een zeker systeem in; alles wat met de vergunning samenhangt moet in het Bor. Maar of het nu nodig was om een onderscheid te maken tussen Bor en Mor? Misschien vond men het ook gewoon gemakkelijk; dat kunnen we allemaal zelf doen. Misschien ben ik daar te cynisch over, maar alle grote verhalen die daarover verteld worden, neem ik met een korreltje zout." 
"Er is wel iets voor te zeggen om in de wet zelf te lezen voor welke activiteiten een omgevingsvergunning nodig is. Behalve als de insteek van de minister is dat de wet kort moet zijn. Dat kan als je veel verhangt naar een algemene maatregel van bestuur. Het is overigens ook nog wel een mogelijkheid om zowel de vergunningplichtige activiteiten als de uitzonderingen in het Bor bij elkaar te zetten. Dan blijft de samenhang behouden."

\section{GEEN NIEUWE WETTELIJKE OPLOSSINGEN}

5.1. Is het een goed idee om nieuwe wettelijke oplossingen te creëren bij het bundelen van omgevingsrecht?

"Jawel. Ik denk dat je als je bezig bent toch veranderingen aanbrengt. Het zou ook jammer zijn om de gelegenheid niet te baat te nemen. Je weet van bepaalde regelingen dat ze niet goed functioneren. Of dat het beter zou kunnen. Daarover bestaan soms ook wel ideeën. Neem dat meteen mee. Je moet wel oppassen dat je het wetsvoorstel wel overzichtelijk houdt. Je moet aangeven wat je gaat doen. Als je te veel modificaties aanbrengt kan dat ertoe leiden dat het overzicht verdwijnt. Maar als je al weet dat een regeling niet optimaal is en je hebt een idee hoe het beter kan, dan zou ik het onverstandig vinden om dat niet mee te nemen bij een bundelingsoperatie."

\subsection{Geldt dat ook voor de voorgestelde Wet natuur?}

"Ja. Bij de Wet natuur moet je welhaast modificeren. De bestaande wet is zo ingewikkeld en moeilijk leesbaar, dat er sprake zou zijn van een halfbakken operatie als je niet ook zou modificeren. Maar of je het zo ingrijpend zou moeten doen dat je beschermde natuurmonumenten weghaalt, dat weet ik niet. Men valt van het ene uiterste in het andere. We gaan alleen doen wat Europa voorstelt. Dat is geen gekke benadering. Als je in korte tijd kans ziet om de Europese richtlijnen om te zetten in Nederlands recht, dan heb je heel wat bereikt. Die omzetting gaat nog steeds niet heel goed. Men heeft de omzettingstermijn vaak heel hard nodig en dan is er vaak nog wel iets fout. Maar je krijgt niet de indruk dat er een inventarisatie heeft plaatsgevonden waarbij is gekeken of bepaalde natuurmonumenten tot Natura 2000-gebied zouden moeten worden verheven. Ik weet niet of dat zo is. We moeten natuurlijk ook oppassen, dat niet alleen wordt geklaagd dat er zoveel biodiversiteit verdwijnt, terwijl er de afgelopen jaren ook heel veel natuur is bijgekomen." 


\section{TOEKOMSTBESTENDIG}

6.1. Kun je voorkomen dat je een Omgevingswet maakt die over drie jaar weer fundamenteel anders moet?

"Nee. Je kunt wel iets bedenken, maar wetgeving verandert permanent. Dat zie je zelfs bij een grote en gegeven eenheid als het Burgerlijk Wetboek. Daaraan wordt in de loop der jaren gesleuteld. Daaraan worden regels toegevoegd. Bij bestuurswetgeving blijf je dat houden, ook omdat ik niet verwacht dat we erin zullen slagen om die Omgevingswet helemaal voor elkaar te krijgen."

\subsection{Waarom niet?}

"We hebben het met de Wet milieubeheer niet voor elkaar weten te krijgen. Men zag geen kans om de Wet geluidhinder en de Wet bodembescherming goed te integreren. De Omgevingswet is een geweldig project, waar we een jaar of tien voor nodig hebben, en waar geen prioriteiten worden gesteld. Als je begint met een aantal quick wins die niet al te ingewikkeld en controversieel zijn, dan heb je het voordeel dat je binnen afzienbare tijd al wat bereikt hebt. Dan kan de wetgever al wat laten zien. Dat houdt er de moed een beetje in. Ik verwacht dan ook dat men wel prioriteiten gaat stellen, tenzij ik de mensen geweldig onderschat. Ik houd er rekening mee dat het project niet afkomt. Als dat wel gebeurt, dan is er een kans dat iedereen amechtig achterover hangt en voorlopig niets meer wil. Maar ook dan houd je nieuwe richtlijnen en problemen, die tot nieuwe regelgeving nopen. Het is een illusie dat je op een gegeven moment klaar bent."

6.3. Kun je niet wetssystematisch voor toekomstbestendigheid zorgen? Bijvoorbeeld door een soort aanbouwwetgeving?

"In het BW en in de Awb is de wetssystematiek nog ongeveer hetzelfde. Dat kun je ook bedenken voor de Omgevingswet. Eenzelfde soort stramien als is gekozen in de Waterwet. De wet is opgezet naar onderdelen van het beleid en de beleidsstructuur. Dat zou voor de Omgevingswet ook kunnen. Dan krijg je een hoofdstuk Plannen, Normen, Instrumenten, Vergunningen, Omgevingseffectrapportage etcetera. Dat zou een redelijk stabiel systeem kunnen opleveren, waarmee je wel uit de voeten kunt. Je moet wel een beetje opportunistisch zijn, zoals je ziet in hoofdstuk 4 van de Awb. Daar staan ook regels in waarvan je je kunt afvragen of die daar wel in thuis horen. Maar dat is niet altijd zo belangrijk. Er is dus wel een tamelijk stabiel wetssysteem te bedenken voor de Omgevingswet." 


\section{Namenregister}

(verwezen wordt naar paragrafen, tenzij wordt aangegeven dat naar een hoofdstuk of bijlage wordt verwezen)

A

Amtenbrink, F.

Arentz, B.

\section{B}

Backes, Ch.W.

Balkenende, J.P.

Van den Berg, A.V.

Van den Berg, J.T.K.

Van den Berg, P.A.J.

Bernaert, P.

Biezeveld, G.A.

Blomberg, A.B.

Bocken, $\mathrm{H}$.

Boere, A.H.M.

Boeve, M.N.

Bonnes, J.M.

Borgers, H.C.

Borman, T.C.

Brans, M.C.

Bregman, A.G.

Van den Broek, J.H.G.

Bröring, H.E.

Van Buuren, P.J.J.

\section{C}

Cabus, P.

D

Dekker, S.M.

Dhondt, N.
$3 \cdot 4 \cdot 5 \cdot 4$

3.4.5.3, 7.1, Bijlage 5.1-5.1

1.1, 3.2.5.1, 3.2.6.3, 3.3.6.5, 3.5.3, 3.7, 4.4.3.4 6.4.3.2, Bijlage 5.1-8.7

1.1, 1.2, 1.3.6, Bijlage 5.5-1.1

$5 \cdot 4 \cdot 3$

$2.2,4.4 \cdot 3.4$

3.6.2

2.2

1.1, 3.2.4.2, 3.2.6.3, hfds.5

1.4

1.1, 1.2.2.1, 1.2.2.2, 1.3.1.7, Bijlage 2

$3.2 .5 \cdot 1,3.4 .5 \cdot 3$

$3 \cdot 4 \cdot 4 \cdot 5,7 \cdot 3$

$3 \cdot 4 \cdot 5 \cdot 4$

$1.2,3 \cdot 3.6 .5$

1.4, 3.2.6.1, 3.4.4.2, 3.4.5.3, 3.5.2, 3.6.4,

Bijlage $5 \cdot 3$, Bijlage 5·3-1.1

3.3.6.6

$3.2 .5 .1,4.4 .3 .4,7.1$

$1.1,1.2,1.3 .6,3.2 .2 .3,3.2 .5 .1,3.2 .5 .3,3.3 .5$,

$3.3 .6 .5,3.3 .7,3.5 .2,3.7,4.1,4.3 .3 .3,4.4 .3 .4$ 4.5.4.1, 4.6.3, 5.2.2, 6.3.3, 7.1, Bijlage 5.1-4.6

$1.1,2.4 .2$

1.1

2.2

1.2, Bijlage 5.2-1.1, $3 \cdot 5$

3.3.6.2 
Dresden, M.J.

Driessen, P.P.J.

Drupsteen, Th.G.

\section{$\mathbf{E}$}

Van Eijkern, W.J.

Eijlander, P.

Elverding, $\mathrm{P}$.

\section{F}

Faure, M.G.

Fleurke, F.M.

Florijn, N.A.

Fokkema, W.

François, F.

Freriks, A.A.

\section{G}

Van Geel, P.L.B.A.

Geelhoed, L.A.

Van Gestel, R.A.J.

De Gier, A.A.J.

Gilhuis, P.C.

Goddijn, S.

Van der Grijp, N.M.

Groothuijse, F.A.G.

\section{H-I}

De Haas, W.A.

Van Hall, A.

Hardenberg, E.

Havekes, H.J.M.

Van der Heijden, G.M.A.

Hegel, G.W.F.

Hendriks-de Lange, S.R.

Van den Heuvel, J.H.

Heuving, C.E.I.

Hill, $\mathrm{H}$.

Hilligers, S.

Hirsch Ballin, E.M.H.
3.2.5.1, 4.1, 4.4.3.4

$3 \cdot 3 \cdot 5,3 \cdot 3.6 .5$

1.1, 1.2, 2.2, 3.2.4.2, 3.2.5.1, 3.2.6.1, 3.3.1, 3.3.6.2, $3.3 .6 .5,3.3 .6 .6,3.4 .4 .1,3.4 .4 .5,3.4 .6,3.5 .2,3.5 \cdot 3$, 3.6.4, 4.5.2.2, 6.4.3.2, Bijlage 5.8

1.5

$1.1,1.2,2.3 .2,2.3 .3,2.4 .1,3.2 .2 .3,3.2 .5 .2,3.3 .6 .4$, 3.6.1, 4.2

7.2 .4

$2.1,2.2,2.3 .1,2.4 .2,2.4 .3,2.4 .4,2.4 .5,2.5 .3$, $3 \cdot 3 \cdot 6.2$

$3 \cdot 3 \cdot 5,3 \cdot 7,7 \cdot 3$

1.4, 2.4.6, 3.4.5.4, Bijlage 5.5-3.5

3.2.2.3, Bijlage $5 \cdot 5-4 \cdot 3$

3.2.6.5

6.4.3.2, Bijlage 5.1-4.6

1.2

$1.2,3.2 .6 .3,3.3 .6 .4,3 \cdot 3.6 .5$

$1.2,1.5,3.2 .5 .1,3.2 .6 .1,3.3 .6 .3$, hfds.8

1.1

$1.2,1.3 .3,2.4 .2,3.2 .4 .2,3.3 .6 .3,3.3 .6 .4,3.6 .3$, $3.6 .5,3.8$, hfds. $4,4.4 .3 .4,7.3$

$3 \cdot 2.5 \cdot 1$

$3 \cdot 4 \cdot 4 \cdot 5$

$3.4 .4 .5,4.4 .3 .4,7.1$

1.1

$3 \cdot 3.5,3.3 .6 .5,3.7$

$1.1,2.4 .2$

$1.1,1.2,2.1,2.3 .1,3.3 .5,4.4 .3 .4,7.2 .1$

$1.2,3 \cdot 3.6 .5$

hfds. 8

$3 \cdot 2.5 \cdot 1,3 \cdot 4 \cdot 5 \cdot 3$

7.1

$3 \cdot 2.5 \cdot 1,3 \cdot 4 \cdot 5 \cdot 3$

1.1, 2.4.1, 2.3.3, 3.2.5.1, 3.4.7, hfds. 7 ,

Bijlage 5.5-3.5

3.3.1, 4.1

2.3.1, 2.3.3, 3.3.2, 3.4.4.2, 3.6.1, 3.6.5, 3.7, hfds.8, Bijlage 5.3-4.1 
Van Horen, F.

Hordijk, M.G.

Houwers, J.

\section{J}

Jansen, P.F.C.

Jongma. M.P.

\section{$\mathbf{K}$}

Kaajan, M.M.

Kiela, P.

Kleijs-Wijnnobel, C.J.

Koeman, N.S.J.

Kloepfer, M.

Kohsiek, L.

De Kok, F.J.C.M.

Konijnenbelt, W.

Kortmann, C.A.J.M.

Kramer, J.

Kuiken, A.H.

Kwisthout, J.K.B.H.

L

Lam, T.E.P.A.

Van 't Lam, V.M.Y.

Lambers, C.

Larmuseau, I.

Leenders, I.

De Leeuw, S.D.M

Van Lochem, P.J.P.M.

Lokin, M.H.A.F.

\section{M}

Van Male, R.M.

Von Meijenfeldt, H.G.

Meulenberg, A.P.M.

Michiels, F.C.M.A.

Molenaars, M.D.A.

Moll, C.P.P.

Munneke, S.A.J.

\section{$\mathbf{N}$}

Niezen, G.J.

Noll, P.
3.2.5.1

$4.6 .2,3.3 .5$

7.1

7.1

1.4

6.1

$1.1,4 \cdot 4 \cdot 3 \cdot 4$

$1.1,3.2 .4 .2,3.3 .5,3.3 .6 .2$

$2.2,3.3 .6 .2,3.3 .6 .6,3.4 .4 .1,3.4 .4 .5,3.7,4.1$

1.3 .8

1.3 .6

1.1, 1.2

$3 \cdot 3.1,3.4 .4 \cdot 3$

1.2

3.3.6.1

7.1

5.2.3, 5.4.1, Bijlage 5.1-4.5

$3.3 .1,4.1$

1.4

$1.1,2.4 .2$

2.2

3.2.5.1

$1.1,3.2 .4 .2,3.3 .5,3.3 .6 .2$

1.4, 2.4.6, Bijlage 5.5-3.5

3.2.6.1

$3 \cdot 4 \cdot 4 \cdot 3$

1.1

1.2

1.2, 2.2, 2.4.2, 3.2.4.4, 3.3.5, 3.3.6.5,

$3.6 .5,3.7,4.1$

3.2.6.1, 3.3.5, 3.3.7, 3.4.4.1, 3.5.3, 3.6.2, 3.6.3,

Bijlage 5.6

1.4, 2.4.6, Bijlage 5.5-3.5

$1.1,1.5,2.3 .1,2.3 .2$

$1.1,1.2$

$1.1,2.3 .1,2.3 .2,2.4 .6,3.2 .1,3.2 .2 .3,3.2 .4 .4$, $3.2 .5 .1,3.2 .5 .2,3.2 .6 .1,3.2 .6 .3,3.3 .1,3.4 .4 .1$, 3.4.4.2, 3.4.4.3, 3.4.4.4, 3.4.7, 3.5.1, 3.5.3, 3.5.2, 3.6.2, 3.6.4, 3.7, Bijlage 5.5-3.5 
Nijmeijer, A.G.A.

Nijpels, E.H.Th.M.

\section{$\mathbf{O}$}

Van Ommeren, F.J.

\section{P-Q}

Peeters, M.G.W.M.

Van der Peppel, R.A.

De Putter, P.J.

\section{$\mathbf{R}$}

Rademaker, B.

Rehbinder, E.

Robbe, J.

Robesin, M.A.

Roelandts, B.

Roording, J.F.L.

De Rouwe, S.

Rutte-Verhagen (kabinet)

Rutte II (kabinet)

Rutteman, J.

Van Rijswick, H.F.M.W.

\section{S}

Scheltema, M.

Schlössels, R.J.N.

Schmidt, A.M.G.

Schott, C.

Schoukens, H.

Schueler, B.J.

Sebus, G.

Sievers, I.

De Smedt, $P$.

De Smet, J.

Smorenburg-van Middelkoop, L.

Soppe, M.A.A.

Stadig, D.

Steyger, E.

Stoop, J.

Struiksma, J

Stuyt, L.B.J.

Swart-Bodrij, A.H.

\section{$\mathbf{T}$}

Thijssen, M.

Timmer, W.W

Tjeenk Willink, H.D.
$1.1,1.2,3.3 .1,3.2 .6 .5,3.3 .6 .5,3.5 \cdot 3,4.1,7.1$

1.3.6

1.5

$1.2,3 \cdot 4 \cdot 4 \cdot 5$

$1.1,2.4 .2$

$1.2,2.1,3.3 .5,3.3 .6 .2$

1.2, 2.4.2, 3.2.6.1, 3.4.4.3, 3.5.2, 4.5.2.2, 4.5.3.4, Bijlage 5.2

$1.2,1.3 .1,2.2,3.4 \cdot 3$

$1.1,6.4 \cdot 3.2$

$3 \cdot 3.6 .6,4 \cdot 3 \cdot 3.2$

2.2

1.4, 3.4.5.3, Bijlage $5 \cdot 4$

7.1

$1.1,1.2,7.1,7.2 .1,7.8$

$7 \cdot 1$

3.3.6.6

1.1, 3.3.6.5, Bijlage 5.1-4.6

3.2.6.3, 3.3.6.4, 3.7, Bijlage 5.8-3.1

3.3 .6 .4

3.2 .5 .1

hfds. 8

$7 \cdot 3$

$3 \cdot 3 \cdot 5,3 \cdot 3.6 .5,3 \cdot 3.6 .6$

1.1, 2.4.1, 3.2.5.1, 3.2.5.2, 3.4.4.4, Bijlage 5.5-3.5

7.1

2.2

2.2

3.4.4.5

$1.2,3 \cdot 3.6 .5$

1.3.6

3.4.5.4

Bijlage 5.1-6.1

3.3.6.5

1.1

5.2.3, 5.4.1, Bijlage 5.1-4.5

Bijlage 3.1-4.6

3.4.4.1

1.5, 3.2.6.3, Bijlage 5.8-2.7 
Tolsma, H.D.

Tonnaer, F.P.C.L.

$\mathbf{U}$

Uylenburg, R.

\section{V}

Vedder, H.H.B.

Veerman, G.J.

Van der Velden, J.A.M.

Van Veldhoven, S.

Van Velsen, S.

Verbauwen, E.

Verbraeken, H.

Verdaas, J.C.

Verheugen, G.

Verschuuren, J.M.

Visser, M.J.C.

Van der Vlies, I.C.

Voermans, W.J.M.

Vogelezang-Stoute, E.M. De Vos, H.W.

\section{W-Y}

De Waele, T.

Wagner, R.

Wiering, M.A.

Witteveen, W.J.

Woldendorp, H.E.

Van Wijk, H.D.

Van Wijk, R.

Van Wijmen, P.C.E.

\section{$\mathbf{Z}$}

Zijlstra, S.E.

Zwier, W.
$3 \cdot 3.6 .6,7.1$

1.1

$3.3 .6 .2,3.3 .6 .3,3.3 .6 .5,3.4 .4 .5,4.1$

$3 \cdot 4 \cdot 5 \cdot 4$

$3 \cdot 2.6 .1,3 \cdot 4 \cdot 4 \cdot 3,3 \cdot 4 \cdot 5 \cdot 3$

$1.2,4.1$

7.1

7.1

1.1

1.3 .6

1.3 .6

1.2

$2.2,3 \cdot 3.6 .2,3.6 .3,7 \cdot 3$

$3.2 .5 .1,3.2 .6 .3$

$2.5 \cdot 3$

$1.1,1.4,2.3 .2,2.3 .3,2.4 .1,2.4 .5,2.4 .6,2.5 .3$, 3.2.2.3, 3.2.5.1, 3.2.5.2, 3.2.6.1, 3.4.4.2, 3.4.7, 3.5.3, Bijlage 5.5, Bijlage 5.5-3.5, 4.2, $4 \cdot 3$

3.4.4.5

3.2.6.1, 3.6.2, 3.6.3, 4.4.3.3, Bijlage $5 \cdot 7$

2.2

$3.2 .2 .1,3.2 .2 .2$

7.3

3.2.6.1

1.5, 2.3.2, 3.4.2.1, 3.2.6.1, 3.3.1, 3.3.6.5, 3.3.7, $3.4 .5 .3,3.4 .6,3.6 .4,3.6 .5,5.2 .3,5.4 .1$, hfds.6, $6.4 \cdot 3.2$, Bijlage 5.1

$3 \cdot 4 \cdot 4 \cdot 3$

3.2.2.3, Bijlage $5.5-4.3$

1.3.6, 3.3.6.5

$3.2 .5 .1,3 \cdot 4 \cdot 5 \cdot 4$

$6.1,6.7 .3$ 



\title{
Trefwoordenregister
}

(verwezen wordt naar paragrafen, tenzij wordt aangegeven dat naar een hoofdstuk of bijlage wordt verwezen; de lezer wordt geadviseerd eerst de vet opgenomen paragraaf te raadplegen)

A

Aanbevelingen

- aan de wetgever

- aan wetgevingsjuristen

Aanbouwwetssysteem

Aanleiding onderzoek

Activiteitenbesluit

Awb

\author{
8.4 \\ 8.4 .1 \\ 8.4 .2 \\ 3.6.5, $4.7 .4,5.7 .4,6.7 .4,7.7$ \\ hfds. 1 \\ 1.2, 1.3.1.2, 3.2.2.3, 3.2.3, 3.2.6.4, 3.3.4, 3.3.7, \\ $3 \cdot 4 \cdot 5 \cdot 3,4.4 \cdot 3.2$ \\ $2.3 .3,3.2 .2 .3,3.2 .4 .2,3.2 .5 .3,3.3 .6 .5,3.3 .6 .6$, \\ $3.4 .4 .1,3.4 .4 .2,3.5 .2,3.6 .5,3.7,3.8$, hfds. $4,4.2$, \\ 4.3.3.1, 4.5.2.1, 4.5.2.2, 6.5.2.2, 6.5.2.3, Bijlage \\ $5 \cdot 3-1.1,1.3,1.4,1.5,3.2,3.5,4.1,5.1$, Bijlage $5.4-$ \\ $1.1,1.5,3.2$, Bijlage $5.5-1.7,3.3,3.4,3.5$, \\ Bijlage 3.6-4.5, Bijlage 5.8-2.6, 3.3, 3.5, 4.2, 6.3
}

\section{B}

Bes-eilanden

$6.4 \cdot 4 \cdot 3$

Besluit omgevingsrecht (Bor)

$2.4 .5,2.5 .2 .3,3.4 .4 .3,4.2,4.4 .3 .2,4.4 .3 .3,4.5 \cdot 3.1$, 4.5.3.2, 4.5.3.4, 4.5.4.1, 4.5.4.2, 4.7.3, 7.7.3, Bijlage $5 \cdot 7-4 \cdot 3$

Begrippen

hfds. 2

Boswet

1.1, 1.2, 1.3.5, 2.2, 3.3.5, 3.9, hfds. 6, 6.1, 6.2.4, $6.2 .5,6.3 .1,6.3 .2,6.3 .3,6.3 .4,6.4 .1,6.4 .2$, 6.4.3.1, 6.4.3.2, 6.4.4, 6.5.5.2, 6.5.3.1, 6.6.1, 6.6.2, 6.7.1, 6.7.2, 6.7.6, 6.8, 7.2.1, 8.2, Bijlage 1, Bijlage 5.1-8.1, Bijlage 5.3-1.6, Bijlage 5.5-1.1

Bundeling $1.2,1.3,1.4,1.5,2.1,2.3 .1,2.4 .2,2.5, \mathbf{2 . 5 . 1}, 2.6$, 3.1, 3.4.1, 3.4.2, 3.4.3, 3.8, hfds. 8, Bijlage 5.21.2, Bijlage 5.2-1.1, 1.2, 1.3, Bijlage 5.4-1.3.3.4, Bijlage 5.5-1.1, 1.2, 1.5, Bijlage 5.8, 5.1

- Activiteitenbesluit

1.3.1.2

- indelingsniveau

2.5.2

- codificerend

$\mathbf{2 . 5 . 3}, 3.5 .1$

- Duitsland

1.2.2.3, 1.3.1.8

- ecologische voordelen

$1.3,1.3 .2$

- economische voordelen

$1.3,1.3 .2$ 
- Europese Unie

- herschikking

- horizontaal

- integratie

- juridische voordelen

- modificerend

- Nederland

- Omgevingswet

- proeve

- redenen

- Richtlijn industriële emissies

- toekomstbestendig

- toetsvragen

- verticaal

- Vlaanderen

- Wabo

- Waterwet

- ontwerp Wet natuurbeschermin

- Wms

\section{C}

Codificatie

- uitgangspunt bundeling

Chronologische aanpak

Coördinatie

Conclusies onderzoek

Consolidatie

D

Decreet Milieubeleid

(Voorontwerp)

$\mathbf{E}$

Echte werkelijkheid
1.2.2.4, 1.3.1.9

2.4.5, hfds. 4 , hfds. 6 , hfds. 7

2.5.2.2

2.4.4, hfds. 5

$1.3,1.3 .3$

$\mathbf{2 . 5 . 3}, 3.5 .3$

$1.2 .3,1.3 .1 .2,1.3 .1 .3,1.3 .1 .4,1.3 .1 .5,1.3 .1 .6$

1.3.1.6, hfds. 7

3.7

1.3

1.3.1.9

3.6

3.8

2.5.2.3

1.2.2.2, 1.3.1.7, Bijlage 2

1.3.1.4, hfds. 4

1.3.1.3

hfds. 6

hfds. 5

$2.5 \cdot 3$

$3 \cdot 5 \cdot 1$

1.1, 3.3.7, 3.4.4.1, 3.6.4, 3.6.6, 3.8, 4.7.1, 5.7.1, 6.7.1, 8.2

2.4.2

8.3

2.4.6

- Aanwijzingen voor de regelgeving

- beleidsstukken

2.3.3, 2.4.2, 2.6, 3.2.6, 3.3.1, 3.3.5, 3.3.7, 3.4.4.1, 3.4.5.1, 3.4.5.3, 3.6.3, 3.8, 4.3.1, 4.3.3.1, 4.3.5, 4.4.3.4, 4.8, 5.3.1, 5.3.3, 5.3.4, 5.3.5, 5.8, 6.3.1, $6.3 .3,6.3 .5,6.5 .2 .1,6.8,7.3 .1,7.3 .5,7.8,8.2$, 8.4.1, Bijlage $5.2-3.3,6.2$, Bijlage $5.5-4.3$, Bijlage 5.6-2.1, Bijlage 5.7-2.1

- literatuur 3.2.6.2

3.2 .6 .3

- toelichting op wetgeving $\quad 3.2 .6 .5$

F

Flora- en faunawet

$1.1,1.2,1.3 .5,2.2,2.3 .1,2.4 .3,3.3 .5,3.8,4.2$, $4.3 .3 .3,4.4 .3 .3,6.1,6.2 .3,6.3 .1,6.3 .2,6.3 .3$, $6.4 .1,6.4 .2,6.4 .3 .1,6.4 .3 .2,6.4 .4,6.5 .2 .2$, 
Fysieke leefomgeving

- externe integratie

- interne integratie

- integrale afweging van omgevingsbelangen

- samenhangcriterium

- specialiteitsbeginsel

- toetsingscriterium

- (geen) uitruil

\section{G}

Gelede normstelling

Gezondheids- en welzijnswet voor dieren

\section{H}

Harmonisatie

Herijkingsbrief

Herschikking

\section{I}

iLawsysteem

- iLawsysteembesluit

- iLawsysteem Tankstations

- iLawsysteem Bakkerij met winkel

Integrale afweging

- externe integratie

- interne integratie

- integrale afweging omgevingsbelangen

Integratie

Interimwet bodemsanering

Interviews

- Borman, T.C.

- Drupsteen, Th.G.

- Molenaars, M.D.A

- Rademaker, B.

- Roording, J.F.L.

- Voermans, W.J.M.

- De Vos, H.W.

- Woldendorp, H.E.

IPPC

iTunes
6.5.3.1, 6.6.1, 6.6.2, 6.7.1, 6.7.2, 6.7.4, 6.8, 8.2, Bijlage 1, Bijlage 5.1-4.2, 4.3, 5.1, 8.3, 8.7, Bijlage $5 \cdot 3-1.6$, Bijlage $5 \cdot 5-1.1$

1.3.6, 2.2, 3.2.5.1, 3.2.6.5, 3.3.5, 3.3.6, 3.7, 3.8, $4.1,4.3 \cdot 3.3,4.7 .3,7.1,7.7 \cdot 3$, Bijlage 1

$3 \cdot 3 \cdot 6.2$

$3 \cdot 3.6 .2$

$3 \cdot 3.6 .3,3 \cdot 3.6 .5$

$3 \cdot 3 \cdot 5$

$3 \cdot 3.6 .4$

3.3 .6

$3 \cdot 3 \cdot 6.6$

$\mathbf{3 \cdot 4 \cdot 5 \cdot 3}, 3 \cdot 4 \cdot 5 \cdot 3,4.5 \cdot 3,5 \cdot 5 \cdot 4,6.5 \cdot 3$

$6.4 \cdot 3 \cdot 9$

2.4.3

1.2, 1.3.1, 2.4.2, 3.2.6.4, Bijlage 4

2.4.5, hfds.4, hfds.6

$3.2 .2 .3,3.2 .3,3.2 .4 .1,3.4 .1,3.6 .2,3.6 .6,3.8,8.2$

3.2.3.1

$3 \cdot 2 \cdot 3 \cdot 3$

$3 \cdot 2 \cdot 3 \cdot 4$

3.3.6.3

$3 \cdot 3.6 .2$

$3 \cdot 3 \cdot 6.2$

3.3.6.3

2.4.4, hfds.5

1.1

Bijlage 5

Bijlage $5 \cdot 3$

Bijlage 5.8

Bijlage 5.6

Bijlage 5.2

Bijlage 5.4

Bijlage 5.5

Bijlage 5.7

Bijlage 5.1

1.3.9

$3.2 .2 .1,3.2 .2 .2,3.3 .2 .4,3.2 .6 .6$ 


\section{J}

Juridische ordeningscriteria

(typisch)

- algemeen-bijzonder

- chronologisch

- Europese richtlijnen en verordeningen

- gelede normstelling

$\mathbf{K}$

Kenbaarheid

Koekoekseibepaling(en)

L

Legitimiteitsperspectief

\section{M}

Modificatie

- modificerende bundeling

- slimme aanpassingen

\section{$\mathbf{N}$}

Natuurbeschermingswet 1998

Natuurschoonwet 1928

$\mathbf{O}$

Omgevingsrecht

- overzicht

Omgevingswet (contouren)

- toekomstbestendig

- typisch juridische ordeningscriteria

- wetssystematische tekorten buiten Wabo

- wetssystematische tekorten in Wabo

- wetssystematische tekorten verminderd

Onderzoeksmethoden

Onderzoeksvragen

- antwoorden

- vragen

Opzet onderzoek

P-Q

Permanente opschoning

Probleemstelling
$3.4 \cdot 4$

$3 \cdot 4 \cdot 4.2$

3.4 .4 .4

$3 \cdot 4 \cdot 5 \cdot 4$

$3 \cdot 4 \cdot 4 \cdot 3$

3.2.4.1, 3.2.4.3, 3.2.5.6

$2.4 .3, \mathbf{3 . 4 . 6}, 4.3 .3 .3,5.3 .3,8.4 .1$

$3 \cdot 3.6 .4,3.3 .6 .5$

$3 \cdot 5 \cdot 3$

$3 \cdot 5 \cdot 3$

$3 \cdot 5 \cdot 2$

1.1, 1.2, 1.3.5, 2.3.1, 6.2.2, Bijlage 1

$6.4 \cdot 3 \cdot 7$

2.2

1.1, Bijlage 4

1.2.3, 1.3.1.6, 6.4.3.10, hfds. 7

$7 \cdot 7$

$7 \cdot 5$

7.6

$7 \cdot 3$

$7 \cdot 4$

1.5

1.4

8.3

1.4

1.5

3.6.2, 4.7.2, 5.7.2, 6.7.2

hfds. 1 
Producten

Project

Probleemgeoriënteerdheid

- Wet bodembescherming

\section{$\mathbf{R}$}

REACH

Regeling omgevingsrecht (Mor)

Richtlijn industriële emissies

\section{$\mathbf{S}$}

Samenhangcriteria

- iTunes

- oplossingen

- problemen

- uitgangspunt

- wetssysteem

- wetssystematisch tekort

Samenvatting

- Duits

- Engels

- Nederlands

Specialiteitsbeginsel

- besluitvormingsperspectief

- democratisch perspectief

- doelmatigheidsperspectief

- legitimiteitsperspectief

- organisatieperspectief

- rechtsbeschermingsperspectief

Stoffen

Summary

- conclusions

- introduction

- recommendations

- summary

Systeemordeningscriteria

- chronologisch

- Europese richtlijnen en verordeningen

- typisch juridisch

- zakelijk

\section{$\mathbf{T}$}

Toekomstbestendig

- aanbouwwetssysteem
1.1, 3.3.2, 4.4.3.3, 5.2.3, 5.3.3, 5.4.1, 5.4.2, .4.3, 5.5.4.1, 5.5.4.2, 6.2.3, 6.2.5, 6.5.3.1, Bijlage 4, Bijlage 5.2-1.7, Bijlage 3.5-1.4, Bijlage 5.6-1.2

$4 \cdot 3$

3.2.4.2

$3 \cdot 2.5 \cdot 3$

$1.1,5 \cdot 2.3$

$4 \cdot 5 \cdot 3 \cdot 3$

$1.2 .2 .4,1.3 .1 .9$

3.2.2.1, 3.2.2.2, 3.3.2.4, 3.2.6.6

3.2 .4 .4

$3 \cdot 2.4 \cdot 4$

3.2.4.5

3.2.2.3, 3.2.4.2

$3 \cdot 2 \cdot 4 \cdot 3$

hfds. 8

hfds. 8

hfds. 8

3.3.6.4

$3 \cdot 3.6 .4$

$3 \cdot 3.6 .4$

$3 \cdot 3 \cdot 6.4$

$3 \cdot 3 \cdot 6.4$

$3 \cdot 3.6 .4$

3.3.6.4

1.1, 1.2, 2.4, 3.3.2, 3.4.4.5, 4.2, 4.7.3, hfds. 5, $\mathbf{5 \cdot 3 \cdot 3}$, Bijlage 1

hfds. 8

8.3

8.1

8.4

8.2

$3 \cdot 3$

$3 \cdot 4 \cdot 4 \cdot 4$

$3 \cdot 4 \cdot 4 \cdot 5$

$3 \cdot 4 \cdot 4$

$3 \cdot 3$

3.6, $4.7,5.7,6.7,7.7$

3.6 .5 
$\begin{array}{ll}\text { - consequent wetssystematisch } & \\ \text { plaatsen } & 3.6 .4 \\ \text { - permanente verandering } & 3.6 .2 \\ \text { - samenhangcriteria } & 3.6 .3 \\ \text { Toetsvragen } & \mathbf{3 . 8}\end{array}$

$\mathbf{U}$

Uitruil

Umweltgesetzbuch

- Inhaltsverzeichnis

- voordelen

$3 \cdot 3 \cdot 6.6$

1.2.2.3, 1.3.1.8

Bijlage 3

1.3.1.8

$6.4 \cdot 3 \cdot 5$

Visserijwet

Voorontwerp Decreet Milieubeleid

Vlaams Gewest

- inhoudstafel

1.2.2.2, 1.3.1.7

- voordelen

Bijlage 2

1.3.1.7

Voorontwerp Wet inzake de

Bodemverontreiniging

W

Wabo

- toekomstbestendig

- typisch juridische ordeningscriteria

- wetssystematische tekorten buiten Wabo

- wetssystematische tekorten in Wabo

- wetssystematische tekorten verminderd

Waterwet

Wet bodembescherming

Wet inrichtin g landelijk gebied

Wet inzake de luchtverontreinigin

Wet luchtvaart

Wet milieubeheer

Wet milieugevaarlijke stoffen

- toekomstbestendig

- typisch juridische ordeningscriteria

- wetssystematische tekorten buiten Wabo

4.7

$4 \cdot 5$

4.6

$4 \cdot 3$

4.4

1.1, 1.3.3, 6.4.3.6, Bijlage 1

1.1, 3.2.5.3, Bijlage 1

6.4.3.4

1.1, Bijlage 1

6.4.3.8

1.1, Bijlage 1

1.1, 5.2.2, Bijlage 1

5.7

$5 \cdot 5$

5.6

$5 \cdot 3$ in Wabo

- wetssystematische tekorten verminderd 
Wet natuurbescherming (ontwerp) 1.1, hfds. 6, Bijlage 1

- toekomstbestendig

6.7

- typisch juridische ordeningscriteria

6.5

- wetssystematische tekorten buiten Wabo

6.6

- wetssystematische tekorten in Wabo

- wetssystematische tekorten verminderd

6.4

Wet op de economische

delicten (Wed)

Wetssysteem

$3 \cdot 4 \cdot 4 \cdot 1$

- formeel

2.3

- materieel

2.3.1, 2.3 .2

- Wet bodembescherming

2.3.1, 2.3.3

Wetssystematisch tekort

- algemeen en bijzonder

- Europese richtlijnen en verordeningen

$3 \cdot 2 \cdot 5 \cdot 3$

2.4.1, 2.5.1, 3.2.3.3, 3.4, 4.3, 4.4, 4.5, 4.6, 5.3, $5.4,5.5,5.6,6.3,6.4,6.5,6.6,6.3,6.4,7.3,7.4$, $7 \cdot 5$

$3 \cdot 4 \cdot 4 \cdot 2,3 \cdot 4 \cdot 5 \cdot 2$

- extern

- gelede normstelling

- intern

- opgeheven of verminderd

$3 \cdot 4 \cdot 4 \cdot 5,3 \cdot 4 \cdot 5 \cdot 4$

3.4.4.1, $5 \cdot 5 \cdot 2.1,6.5 \cdot 2.1$

$3 \cdot 4 \cdot 4 \cdot 3,3.4 \cdot 5 \cdot 3$

3.4.4.1, $5 \cdot 5 \cdot 2.2,6.5 \cdot 2.2$

$4.4,5.4,6.4$

- verdedigbaarheid

3.4.5, 4.5.2.2, 4.5.4.2, 4.6.3, 5.3, 5.5.2.3, 5.5.3.3, $5.5 .4 .4,5.6 .1,6.3,6.4,6.5 .2 .3,6.5 .3 .2,6.5 .4 .2$

$\mathbf{X}-\mathbf{Z}$

Zakelijke systeemordeningscriteria 3.3

- activiteiten

- fysieke leefomgeving

- object

$3 \cdot 3 \cdot 3$

- subject

3.3 .2

Zusammenfassung

hfds. 8

- Einleitung

8.1

- Empfehlungen

8.4

- Ergebnisse

Zusammenfassung

8.3

8.2 



\section{Curriculum Vitae}

Jan van den Broek, geboren in Den Dungen (Noord-Brabant) op de dag dat Laika de ruimte vond, is getrouwd met José Pennings met wie hij de kinderen Inge, Marleen en Jaap heeft. In 1976 behaalde hij het diploma gymnasium- $\beta$ aan Gymnasium Bernrode te Heeswijk-Dinther en studeerde vervolgens Nederlands recht aan de Katholieke Universiteit Nijmegen. In 1981 studeerde hij af als meester in het staats- en bestuursrecht. Hij werkte achtereenvolgens als juridisch beleidsmedewerker op de afdeling Algemene Zaken en Kabinet van de gemeente Uden (1981-1984) en als advocaat en procureur bij Ruijgrok, Van Iersel \& Luchtman in Uden (1984-1989). Op 1 november 1989 trad hij in dienst van het Nederlands Christelijk Werkgeversverbond te Den Haag als secretaris Energie, milieu en kwaliteitszorg. Dat dienstverband werd gecontinueerd na de fusie tussen VNO en NCW. Thans is hij als Senior Legal Counsel verbonden aan VNO-NCW en MKB Nederland te Den Haag. Van zijn hand zijn diverse boeken en wetenschappelijke publicaties op het gebied van omgevings- en bestuursrecht, waaronder de Wegwijzer Wabo, de Parlementaire geschiedenis van de Wabo en de Wegwijzer Activiteitenbesluit. Voor zijn inzet voor de Wabo kreeg hij uit handen van minister Jacqueline Cramer van VROM de prijs Wabo-er 2008. Hij is onder meer voorzitter van de redactie van het Tijdschrift voor Milieu en Recht, lid van de redactieadviesraad van het Tijdschrift voor Bouwrecht, lid van de Wetenschappelijke Raad van de Universiteit van Amsterdam, lid van het redactieteam van het Vlaamse Tijdschrift voor Omgevingsrecht en Omgevingsbeleid, rechter-plaatsvervanger in de sector bestuursrecht van de rechtbank 's-Hertogenbosch, hoofddocent bij de postacademische Beroepsopleiding Bedrijfsjuristen en lid van de door de minister van Infrastructuur en Milieu in het kader van de Omgevingswet ingestelde Adviesgroep Milieu, Energie en Duurzaamheid o.l.v. oudmilieuminister Ed Nijpels. 


\section{Overzicht 1.1 Omgevingsrecht 1851-2012}

\begin{tabular}{|c|c|c|c|c|}
\hline & Omgevingsr & & & \\
\hline $\begin{array}{l}\text { Jaar } \\
\text { i.w.tr. } \\
\text { (verv.) }\end{array}$ & Milieu & $\begin{array}{l}\text { Ruimtelijke } \\
\text { ordening }\end{array}$ & Water & Natuur \\
\hline 1851 & & Onteigeningswet & & \\
\hline 1876 & & Spoorwegwet 1875 & & \\
\hline 1902 & & & Waterstaatswet 1900 & \\
\hline 1902 & & $\begin{array}{l}\text { Lokaalspoor- en } \\
\text { Tramwegwet }\end{array}$ & & \\
\hline $\begin{array}{l}1904 \\
(2009)\end{array}$ & & & $\begin{array}{l}\text { Wet van } 14 \text { juli } 1904 \\
\text { (Stb. 147), houdende } \\
\text { bepalingen omtrent } \\
\text { het ondernemen van } \\
\text { droogmakerijen en } \\
\text { indijkingen }\end{array}$ & \\
\hline $\begin{array}{l}1906 \\
(2003)\end{array}$ & $\begin{array}{l}\text { Mijnwet } \\
1903\end{array}$ & & & \\
\hline $\begin{array}{l}1924 \\
(2003) \\
\end{array}$ & & $\begin{array}{l}\text { Wet opsporing delf- } \\
\text { stoffen } 1924\end{array}$ & & \\
\hline 1927 & & $\begin{array}{l}\text { Belemmeringenwet } \\
\text { Privaatrecht }\end{array}$ & & \\
\hline 1928 & & & & $\begin{array}{l}\text { Natuurschoon- } \\
\text { wet } 1928\end{array}$ \\
\hline 1932 & & Wegenwet & & \\
\hline 1934 & & & Wrakkenwet & \\
\hline $\begin{array}{l}1947 \\
(2008)\end{array}$ & $\begin{array}{l}\text { Meststoffen- } \\
\text { wet } 1947\end{array}$ & & & \\
\hline $\begin{array}{l}1955 \\
(2010)\end{array}$ & & & & Jachtwet \\
\hline $\begin{array}{l}1957 \\
(2008)\end{array}$ & $\begin{array}{l}\text { Destructie- } \\
\text { wet }\end{array}$ & & & \\
\hline $\begin{array}{l}1958 \\
(2005)\end{array}$ & & & Deltawet & \\
\hline 1959 & $\begin{array}{l}\text { Luchtvaart- } \\
\text { wet }\end{array}$ & & & \\
\hline $\begin{array}{l}1962 \\
(2007)\end{array}$ & $\begin{array}{l}\text { Bestrijdings- } \\
\text { middelenwet } \\
1962\end{array}$ & & & \\
\hline 1962 & & & & Boswet \\
\hline 1963 & $\begin{array}{l}\text { Kernenergie- } \\
\text { wet }\end{array}$ & & & \\
\hline $\begin{array}{l}1964 \\
(2008)\end{array}$ & & Woningwet 1962 & & \\
\hline $\begin{array}{l}1965 \\
(2008)\end{array}$ & & $\begin{array}{l}\text { Wet op de Ruimte- } \\
\text { lijke Ordening }\end{array}$ & & \\
\hline
\end{tabular}

